
федеральный университет

имени первого Президента России Б.Н.Ельцина

Уральский гуманитарный институт

\title{
ПСИХОЛОГИЯ ОБРАЗОВАНИЯ: СОВРЕМЕННЫЙ ВЕКТОР РАЗВИТИЯ
}



МИНИСТЕРСТВО НАУКИ И ВЫСШЕГО ОБРАЗОВАНИЯ РОССИЙСКОЙ ФЕДЕРАЦИИ

УРАЛЬСКИЙ ФЕДЕРАЛЬНЫЙ УНИВЕРСИТЕТ

ИМЕНИ ПЕРВОГО ПРЕЗИДЕНТА РОССИИ Б. Н. ЕЛЬЦИНА

\section{ПСИХОЛОГИЯ ОБРАЗОВАНИЯ: СОВРЕМЕННЫЙ ВЕКТОР РАЗВИТИЯ}

Екатеринбург

Издательство Уральского университета 
УДК $159.953: 37.01$

ББК Ю93

П863

Р е ц е з ен ты:

И. В. Дубровина, доктор психологических наук, профессор, академик РАО

(Психологический институт РАО, Москва);

С. А. Новоселов, доктор педагогических наук, профессор

(Уральский государственный педагогический университет, Екатеринбург)

Научные редакторы:

С. Б. Мальх, доктор психологических наук, профессор, академик РАО

(Психологический институт РАО, Москва);

T. Н. Тихомирова, доктор психологических наук, член-корреспондент РАО

(Психологический институт РАО, Москва)

О тветственны й редактор

И. А. Ершова, кандидат философских наук, доцент

(Уральский федеральный университет, Екатеринбург)

Психология образования: современный вектор развития : [монограП863 фия] / науч. ред. С.Б. Малых, Т.И. Тихомирова ; отв. ред. И. А. Ершова ; Министерство науки и высшего образования Российской Федерации, Уральский федеральный университет. - Екатеринбург : Изд-во Урал. ун-та, 2020. - 790 с. : ил. - ISBN 978-5-7996-3101-7. - DOI 10.15826/B 978-5-7996-3101-7. - Текст : электронный.

\section{ISBN 978-5-7996-3101-7}

DOI 10.15826/B978-5-7996-3101-7

В монографии представлены результаты теоретических и эмпирических исследований в области психологии образования, систематизированные по основным актуальным вопросам, с которыми сталкивается система образования на современном этапе ее развития. Рассмотрены вопросы, связанные с методологическими аспектами психологии образования, психологической безопасностью и психологическим благополучием субъектов образования, особое внимание уделено проблемам реализации инклюзивного образования, особенностям профессионального развития педагога и междисциплинарным исследованиям современного детства.

Монография будет интересна всем, кто занимается научной и практической психологией, а также студентам и аспирантам психологических факультетов.

УДК 159.953:37.01

ББК Ю93

Издание осуществлено при финансовой поддержке гранта РФФИ № 20-013-20024

по итогам проведения Всероссийского форума

с международным участием психологов образования

«Психология образования: современный вектор развития» 


\section{ПРЕДИСЛОВИЕ}

На сегодняшний день круг психолого-педагогических исследований вышел далеко за рамки школы/вуза и уже не ограничивается проблемами обучения и воспитания, традиционно входящими в сферу компетенции педагогической психологии. Современный лозунг «Образование через всю жизнь» определил перспективы новых исследований, фокусирующих внимание на всем многообразии (личностном, межличностном, когнитивном, реабилитационном и т. д.) происходящих изменений в жизни человека при его включении в сферу образования.

Это вполне закономерно привело к тому, что в последнее десятилетие наблюдается активное развитие новой для отечественной психологии отрасли - психологии образования, исторические корни которой прослеживаются в таких отраслях, как педагогическая психология, психология развития, психология труда, а также в практической деятельности психологов образования.

Вполне закономерно возникает ряд вопросов: чем обусловлено появление новой отрасли? В чем отличия психологии образования от педагогической психологии? Ответ на них можно найти в тех изменениях, которые произошли и происходят в системе образования в настоящее время.

Современные реалии таковы, что за последние несколько лет достаточно серьезно изменились представления об образовательной системе, оформились понятия, которые до этого в данном контексте не рассматривались (например, образовательный маршрут, образовательная среда, поликультурное образовательное пространство, инклюзивное образование и т.п.). Проблемы, с которыми приходится сталкиваться всем участникам образовательных отношений, серьезны и важны, поэтому требуют глубокого анализа, обсуждения и принятия своевременных решений.

Отправной точкой зарождения психологии образования принято считать момент, когда наряду с понятием «педагогический процесс» стало использоваться понятие «образовательный процесс» 
и наметился переход от организации образовательного процесса на основе построения субъект-объектных отношений к субъектсубъектным.

Следует отметить, что педагогическая психология и психология образования отличаются прежде всего областью научного знания, вокруг которой сконцентрированы интересы исследователей. Если педагогическая психология традиционно сосредоточена на изучении конкретных явлений, имеющих педагогическую составляющую (порождаемых педагогической практикой, принадлежащих ей, обладающих свойствами педагогической деятельности и ее педагогического влияния на человека), то психология образования изначально сосредоточена на изучении вопросов, возникающих у отдельных людей и их объединений в сфере образования и направлена на изучение психологических механизмов и закономерностей развития, поведения и деятельности человека в образовательном процессе под влиянием образовательной среды в границах конкретного образовательного пространства.

Психология образования сегодня - это направление фундаментальных исследований, а также активно развивающаяся отрасль прикладной психологии. На примере данной отрасли отчетливо можно проследить, как происходит объединение теоретических и практических знаний.

Как направление фундаментальных исследований, психология образования определяет закономерности развития и функционирования социума и личности, взаимосвязи природного, социального, культурного и индивидуального в становлении человеческого в человеке, механизмов, средств и путей преобразования развития в саморазвитие. Она раскрывает значимые вопросы культурного становления человека в онтогенезе, психологические механизмы и процессы развития высших психических функций, когнитивных способностей, личностных потенциалов и способностей.

Активно развивающаяся сегодня психология образования позволяет, базируясь на понимании закономерностей психического развития и личностного становления человека, выстраивать адекватные модели образовательных систем с целью эффективной социализации человека через приобщение его к духовному богатству 
культуры и выведение на активную позицию субъекта творческой деятельности. По сути, психология образования определяет и фундаментальные психологические основы непрерывного образования (Е. И. Исаев, В. И. Слободчиков, С. Н. Костромина, В. А. Бородина и др.). Поэтому психология образования является одним из приоритетных научных направлений мировой науки.

Вместе с тем психология образования имеет большое прикладное значение. В последнее время на новый виток развития вышла деятельность психологической службы в системе образования. Подтверждением тому является, в частности, разработка и утверждение Концепции развития психологической службы в системе образования и создание Федерального ресурсного центра по развитию психологической службы в системе образования.

Сегодня психология образования в своем прикладном направлении решает задачи по психологическому сопровождению учителя и ученика в ситуации их взаимодействия в процессе обучения и воспитания, способствует созданию эффективных условий психического и физического развития учащихся с учетом возрастных и личностных особенностей, позволяет наиболее эффективно и продуктивно выстроить образовательный процесс, индивидуальную образовательную траекторию.

При решении фундаментальных и прикладных задач становится важным определение направлений и методологических основ современных исследований. Безусловно, фундаментальный подход к исследованию проблем психологии образования является важной предпосылкой для дальнейшего развития исследований.

В монографии представлены результаты теоретических и практических исследований современной психологии образования, которые обсуждались на Всероссийском форуме с международным участием психологов образования «Психология образования: современный вектор развития». Форум организован при активном участии преподавателей кафедры педагогики и психологии образования департамента психологии Уральского федерального университета.

В качестве ключевых для обсуждения был выделен ряд важнейших актуальных проблем в рамках современного проблемно- 
предметного поля психологии образования, в соответствии с которыми были выделены разделы в монографии.

Первый раздел посвящен рассмотрению вопросов, связанных с методологическими аспектами психологии образования. Вопросы методологии являются основой развития любой отрасли знаний. Учитывая молодой возраст психологии образования, они приобретают особое значение. В данном разделе представлены различные теоретические подходы к изучению системы образования и психолого-педагогического взаимодействия. Особое внимание уделено рассмотрению вопросов, связанных с построением современных психологических исследований, в том числе имеющих междисциплинарный характер, а также методологическим основаниям внедрения цифровых технологий в образовательную практику и их влияния на развитие обучающегося.

Во втором разделе рассматриваются различные аспекты психологического благополучия в образовательной среде. В условиях постоянных изменений и увеличения неопределенности особенно актуальным становится определение его предикторов применительно ко всем ступеням образования. Особое значение это приобретает в подростковом и студенческом возрасте, когда происходит активная перестройка социальной и образовательной ситуации развития. В разделе акцент сделан на таких предикторах психологического благополучия, как личностные характеристики обучающихся и условия образовательной среды.

Третий раздел посвящен рассмотрению психологии профессионального развития педагога. В нем отражены различные аспекты профессионального развития и саморазвития, рассмотрены особенности формирования профессионализма педагога, специфика развития профессиональной компетентности и карьерных стратегий учителя. Также уделено внимание рассмотрению деструктивных вариантов профессионального развития, в частности, актуальным в современных условиях вопросам саморазвития педагогов с профессиональными деформациями и развития кризиса утраты профессии педагогом в период поздней зрелости.

В четвертом разделе обсуждаются проблемы психологической безопасности образовательной среды. Современные условия ха- 
рактеризуются тем, что количество факторов, негативно влияющих на обучающихся и угрожающих психологической безопасности личности, постоянно увеличивается, причем они начинают приобретать особую специфику. Среди наиболее актуальных сегодня выделяются вопросы жестокого обращения с детьми, просоциального поведения, буллинга. Особое внимание уделено рассмотрению такого вида буллинга, как кибербуллинг, в связи с тем, что вынужденная самоизоляция привела к активному переходу в онлайн-пространство, что обусловило трансформацию травли из офлайн-пространства - в онлайн.

В пятом разделе представлены междисциплинарные исследования детства. Такие исследования для системы образования являются новыми, так как переход к междисциплинарности наметился сравнительно недавно. Но данный переход является вполне закономерным. Для того чтобы понять всю специфику функционирования когнитивных процессов, личностных особенностей зачастую только знаний психологии недостаточно. Важно рассматривать изучаемый феномен с позиции разных наук, для формирования всестороннего и целостного представления о нем.

В шестом разделе рассматриваются психологические аспекты реализации инклюзивного образования. Основное внимание уделено различным аспектам инклюзивного образовательного пространства, а также практической работе с детьми-инвалидами и имеющими ограниченные возможности здоровья (проблемы интеграции ребенка с ОВ3 в образовательный процесс, специфика коррекционно-развивающих занятий с данной категорией детей, создание комфортной образовательной среды для детей с ОВ3 и детей-инвалидов).

Следует отметить, что в монографии отражены только те аспекты, которые вызывают наибольший исследовательский и практический интерес в настоящее время. Конечно, круг вопросов, рассматриваемых в рамках психологии образования, гораздо шире. Более того он будет постоянно меняться, в связи с изменениями, происходящими в системе образования. Ведь образование, несмотря на то, что это система, а для любой системы характерна в определенной степени стабильность и постоянство, все же очень 
гибко реагирует на вызовы времени. А современные реалии таковы, что в условиях значительных внешних преобразований педагоги вынуждены внедрять активные цифровые методы обучения, разрабатывать новые методики обучения, осваивать новые технологии. Для этого важно понимать, как все эти новшества скажутся на развитии личности, когнитивных процессах, эмоционально-волевой сфере и т.д. обучающихся. Соответственно, это приведет к новым научным исследованиям и практическим разработкам.

Надеемся, что представленные в монографии результаты теоретических и эмпирических исследований внесут вклад в развитие психологии образования, вызовут исследовательский и практический интерес у всех, кому не безразлична психология образования.

А. А. Печеркина 


\section{Раздел 1 \\ МЕТОДОЛОГИЧЕСКИЕ АСПЕКТЫ \\ ПСИХОЛОГИИ ОБРАЗОВАНИЯ}

\section{РАЗВИТИЕ САМОСОЗНАНИЯ И ФОРМИРОВАНИЕ СОЦИАЛЬНО ЗРЕЛОЙ ЛИЧНОСТИ КАК ПРОБЛЕМА ПСИХОЛОГИИ ОБРАЗОВАНИЯ}

Б. Ю. Берзин

B. A. Архипова

В разные исторические периоды для каждого человека был важен вопрос «Кто Я?», но иногда этот вопрос становился особенно острым, что могло быть связано с проблемами личной и групповой идентификации или с уровнем личной ответственности индивида за происходящие события. Однако всегда это являлось проблемой внутреннего бытия человека, его активности или пассивности, способности к самораскрытию или, наоборот, стремления уйти, спрятаться, закрыться. Сегодня, по нашему мнению, как раз наступило время осознания обществом необходимости отрефлексировать сложившееся положение дел и предпринять усилия для предотвращения нарушения равновесия в отношениях между странами, народами и отдельными людьми. Сознание людей в подобном случае становится мощным фактором, нацеливающим их «практическую энергию» в том или ином направлении.

Именно поэтому, рассматривая сознание как «осознанное бытие» [1, с. 25], а реальную жизнь как общественно-историческую практику, К. Маркс объясняет сознание, исходя из противоречий

* Исследование выполнено при финансовой поддержке РФФИ в рамках научного проекта 19-29-07016 «Трансфер человеческого капитала образовательных общностей: от неуспешности к успешности».

() Берзин Б. Ю., Архипова В. А., 2020 
человеческой деятельности, а его изменения - как результат изменения самой этой деятельности.

Способность человека как носителя сознания отражать реальный мир проявляется, как правило, в виде двух взаимосвязанных и взаимообусловленных сторон отражения: отражение внешнего мира, назовем его предметным сознанием, и самоотражение (самосознание) - как некая самотождественность (тождественность самому себе), идентичность с самим собой.

При этом самосознание (самоотражение) можно охарактеризовать как восприятие, фиксацию, сохранение и изменение состояний организма личности и ее внутреннего жизненного мира. Это отношение субъекта к своим особенностям: физиологическим, психологическим и социальным - к собственной самооценке, социальному статусу и социальной роли. Можно говорить о системной реакции индивида и одновременно о представлении своего физического и духовного «Я».

Однако имея общие признаки, самоотражение и самосознание различаются как род и вид, форма и содержание. Самоотражение, как более широкое понятие, может характеризовать и человека, и животное.

Для животного самоотражение и есть сама жизнедеятельность, оно самотождественно, а для человека жизнедеятельность носит опосредованный сознанием характер [2, с. 93].

Самоотражению присущи спонтанность, непроизвольность. Самосознание, как правило, наоборот, произвольно, т.е. предполагает волевые усилия со стороны субъекта. Самоотражение отличается и временем возникновения - оно присуще индивиду с момента возникновения жизни. Время возникновения самосознания предмет научной дискуссии: это и досознательный период, и время отделения ребенка от матери, и момент осознания своей самостоятельности («я сам» - говорит ребенок), и готовность к переносу знаний о другом человеке на самого себя; чаще всего связывают зарождение самосознания с подростковым возрастом [3, с. 8-11].

Представляется, что разноуровневое выделение особенностей самосознания свидетельствует, прежде всего, о динамичном характере самосознания, его можно рассматривать и как процесс смены состояний, и как результат развития личности в тот или 
иной период жизни. Поэтому в качестве основы для понимания времени возникновения самосознания мы принимаем утверждение Л. С. Выготского, согласно которому это момент появления способности человека к осознанию и обобщению психических процессов, проникновение в их сущность, овладение ими [4, с. 220].

Рассматривая самосознание как сознание, обращенное во внутрь индивида, мы обычно подчеркиваем общие характеристики сознания: субъективность и творческую активность, благодаря чему происходит овладение идеальным, тождество объекта и субъекта познания, отношения и действия. Предметом интереса субъекта становится его собственная личность: чувства и желания, мысли и действия становятся объектом исследования. При этом снимается противопоставление субъекта и объекта, субъективной и объективной реальности. Сущность самосознания раскрывается во взаимодействии субъекта и объекта, приобретая социальный характер.

Субъективность самосознания, его пристрастность находит свое проявление в придании определенного значения, прежде всего «личностного смысла», любому факту, явлению [5, с. 149-158]. Благодаря этому человек отражает свое внутреннее бытие строго определенным, присущим только ему образом - через осознание своих особенностей, отношение к ним, а также степень саморегуляции. Эта субъективность проявляется в представлениях, чувствах, оценках и в способности к самореализации (самоосуществлению).

По И.Г. Фихте, активное творческое «Я» - единство «Я» и «Не-Я» («без субъекта нет объекта, без объекта нет субъекта») [6, с. 160]. Активность самосознания, согласно Гегелю, проявляется через осознание самого себя, которое достигается благодаря «практической деятельности» - через изменения внешних предметов посредством воздействия своей «внутренней жизни» и нахождения в них самого себя [7, с. 33].

Активность самосознания заключается, прежде всего, в стремлении овладеть своей субъективной реальностью, так как она выступает инструментом познания и преобразования объективной реальности. Источники активности самосознания находятся как внутри субъекта, так и во вне его. Прежде всего, это потребности, интересы, ценностные ориентации и социальные установки. Бла- 
годаря активности и происходит развитие самосознания человека как все большее овладение своей самостью.

Развитие, характеризуя не только количественные, но и, самое главное, качественные изменения субъекта - носителя самосознания, позволяет описывать динамику состояний внутреннего мира индивида - его упрощение или усложнение, появление новых качеств или свойств. Основой развития выступает приобретенный человеком жизненный опыт, который опирается на первоначально сформированный образ предметного мира и представление о самом себе. Современные концепции развития связаны, прежде всего, с пониманием его системной противоречивости, подчас нелинейного характера. Нелинейность обусловлена незавершенностью системы, которая развивается и одновременно является тождественной и нетождественной самой себе, устойчивой и изменяющейся [8, с. 577-578].

Развитие каждой системы имеет свою специфику, и самосознание личности не является исключением. Мы исходим из положения, высказанного А. Н. Леонтьевым в работе «Проблемы развития психики» [9, с. 184-185]. Он отмечал, что развитие человеческих способностей, всех его психических функций является особым, совершенно иным от других процессов, в том числе отличным от развертывания генетически обусловленного поведения или приобретения индивидом жизненного опыта.

Этот процесс происходит сугубо специфически, свойственным только человеку способом - через «осознание и произвольность» [4, с. 214]. При этом «изменение функционального строения сознания составляет главное и центральное содержание всего психического развития» [Там же, с. 217].

В ходе своего развития человек, осознавая и осваивая окружающий его предметный мир, не только приспосабливается к нему, но и «присваивает» его [9, с. 535]: осваивает, осознает и присваивает внешние предметы и свой внутренний жизненный мир в форме совместной деятельности, прямо или опосредовано.

При этом происходит разрешение противоречий, возникающих при взаимодействии с другими людьми, появляются изменения, которые преобразуются в те или иные черты, особенности сознания конкретного субъекта. Подобный процесс происходит непрерывно, 
и появляется некая «спираль развития», основывающаяся на системе сложившихся отношений и ее противоречиях со способами деятельности, реализуемыми в определенных ситуациях взаимодействия.

Именно разрешение противоречий в той или иной форме способствует развитию личности и является основой для периодизации происходящих в ней изменений [10, с. 65].

При анализе этапов развития самосознания личности обычно исходят из периодизации, принятой в возрастной психологии. Выделяются, как некие уровни, младенческий возраст (1), раннее детство (2), дошкольный (3), младший школьный (4) возраст, подростковый (5) и старший школьный (6) возраст. На первых двух этапах возникает осознание границ тела и появляется своя собственная самооценка.

Затем в дошкольном возрасте продолжается формирование самооценки, происходит осознание своих переживаний и себя во времени.

В младшем школьном возрасте самооценки становятся все более объективными и соотносятся с другими людьми.

В подростковом возрасте самосознание становится все более целостным, возникает несколько образов своего «Я», отличающихся как по времени, так и по степени реальности. Появляется чувство взрослости [11, с. 84-83].

При этом на всех этапах познание себя происходит в зависимости от познания других людей и их отношения к себе. В процессе познания других у индивида формируется оценка самого себя, при этом чем глубже познание других людей, тем адекватнее становится самооценка [12, с. 59].

Следует отметить, что развитие самосознания продолжается и на следующих этапах жизни человека: мы можем говорить о развитии зрелой личности (юность, молодость, зрелость - 30-70 лет) и поздней зрелости (после 60-70 лет). И даже если изменения в этот период незначительны, они существуют, а иногда могут носить и принципиальный характер [13, с. 341-343].

Примерно так же, по схожей схеме можно анализировать становление социально зрелой личности. Однако следует иметь в виду, что понятие «зрелость» характеризует определенный этап разви- 
тия самосознания, причем, пусть это будут несколько абстрактно, в зависимости от возрастного периода происходит то соединение, то разделение на различные сущности: на социальную и личностную зрелость. Разумеется, каждый человек достигает определенной зрелости. По А. Адлеру, ребенок с малых лет включается в борьбу за свое развитие, может быть, с неосознанной целью достичь совершенства, могущества, превосходить других людей [14, с. 18]. А. Адлер считает, что в индивиде одновременно сочетается единство личности (как совокупности определенных характеристик) и неповторимого стиля выражения этого единства. Каждый формирует свой внутренний мир в соответствии с его индивидуальным видением, но под влиянием окружающей реальности [Там же, с. 19]. Именно неповторимое сочетание внутренних и внешних факторов позволяет выделить личностную и социальную зрелость. При этом, на наш взгляд, каждый индивид осознает свою личностную зрелость при достижении какой-то цели либо под влиянием какого-то внешнего, очень значимого для него события. Этот момент можно обозначить как инициацию. Социальную же зрелость можно обозначить как факт признания окружающими личной зрелости индивида, его идентичности (профессиональной, возрастной и т.п.).

Единство личностной и социальной зрелости показывает уровень развития самосознания в конкретный период времени. По нашему мнению, А. Адлер в своих работах заложил по крайней мере две важнейшие тенденции в анализе зрелости: первая - это выделение психологического и социологического подходов; вторая многокомпонентный анализ зрелости. В частности, он выделил, как признаки зрелости, отношение к другому полу, умение распоряжаться своей жизнью и отношение к общественному бытию [Там же, c. 26-29], а также профессиональное самоопределение, активность, наличие социального чувства, мужества, сознательности, целенаправленности. Зрелый человек - это прежде всего «социально полезный тип». Если продолжить анализировать вклад психологов в исследование зрелости, то необходимо отметить работы К. Рождерса и А. Маслоу, в которых высокий уровень зрелости ассоциируется с самоактуализацией, стремлением к развитию и поиску нового. 
А. Маслоу, например, отождествляет зрелого человека с самоактуализирующейся личностью, в основе которой лежит преданность какому-то делу, служению «ценностям бытия» [15, с. 55].

Ценности бытия А. Маслоу называет мегапотребностями, которых насчитывает более 10 , - среди них потребность справедливости, красота, совершенство и т. п. При этом он особо подчеркивает необходимость осознания самого себя - без этого невозможно понять сущность самоактуализированности личности. Из перечня черт зрелой личности А. Маслоу выделяет готовность к творчеству, наличие креативности, принятие ответственности за свои решения [Там же, с. 61].

Создатель концепции черт личности Г. Олпорт считал зрелыми только «психически здоровых людей», которые способны усваивать социальный опыт и перенимать новое, совершенствоваться в течение всей жизни, изменять окружающую реальность. Он отмечал, что в научной литературе присутствует 6 согласованных критериев зрелой личности:

- сильное «Я»,

- дружелюбие,

- самопринятие,

- активность и адекватность восприятия реальности и действия,

- способность к самовыражению,

- жизнь в гармонии с окружающим [16, с. 353-354].

Отечественные психологи также выделили в своих работах показатели зрелости. Б. Г. Ананьев рассматривал зрелость как некий интегрированный признак, включающий в себя физические и умственные параметры, трудовую деятельность и гражданскую активность [17]. Для Л.И. Божович зрелость - это показатель уровня развития психических и социальных качеств [18].

Один из основателей современной российской социальной психологии Г. М. Андреева считала, что зрелость личности зависит от процессов социализации и ее становление связано с такими сферами, как деятельность, общение и самосознание личности, с ее социальной идентичностью. При этом она придерживалась концеп- 
ции восьми стадий развития личности Э. Эриксона [19, с. 196-197]. Близкую позицию занимает и Л. И. Анцыферова [20].

Начало современного этапа социологического анализа социальной зрелости личности связано с именами И.С. Кона и Л.Н. Когана, известных советских и российских социологов.

И.С. Кон в работе «Социология личности» пишет, что следующий этап за юностью - это зрелость, когда главным для человека становится трудовая деятельность и он осваивает целостную систему социальных ролей. Зрелость, в отличие от юности, это, прежде всего, определенность и ответственность, уход от иллюзий юности, жизнь не будущим, а настоящим. Но люди при этом отличаются друг от друга применением различных стратегий поведения - либо пассивной адаптации, приспособления к жизни, либо активного воздействия на окружающую реальность, ее изменение. В любом случае зрелость И.С. Кон рассматривал как движение, как динамичный процесс [21, с. 181-184].

Анализируя особенности социальной зрелости, И. С. Кон ссылается на ее определение, данное Гордоном Олпортом, известным американским психологом. Для Г. Олпорта зрелая личность гармонично сочетает в себе психические и социальные характеристики, адекватно воспринимая себя и действительность, активно взаимодействует с окружающими ее людьми [22, p. 277].

Если И.С. Кон акцент делал на социально-психологические характеристики зрелой личности, то известный уральский социолог Л.Н. Коган в своей книге «Человек и его судьба» утверждает, что понятие «социальная зрелость» является обобщенной характеристикой личности. При этом он считает некорректным сведение наступления социальной зрелости к времени исполнения гражданских обязанностей (вступление в брак, служба в армии и т. п. - это, скорее, характеристика возраста «зрелости»). Л.Н. Коган считает зрелость характеристикой уровня развития личности и предлагает ряд критериев. Исходя из понимания личности как сложной социальной системы, первой характеристикой зрелости является целостность как некое состояние, результат взаимодействия ее элементов. Важнейшим из них выступает соответствие личности главным социальным критериям, присущим данной исторической 
эпохе (доминирующий тип личности, идентичность ее с конкретной социальной группой, типичный образ и стиль жизни).

В качестве антитезы зрелости Л.Н. Коган приводит такую характеристику, как инфантильность, которая наделяется лишь отрицательными свойствами: отсутствие у человека социально признанной общественной и нравственной позиции, самостоятельности, низкая ответственность за свои поступки, нежелание профессионально самоопределяться, готовность жить на иждивении у близких людей.

Противоположные качества формируются у зрелой личности, и критерием развития выступает опыт социальной практики. Главным, определяющим компонентом служит мировоззрение, основы которого закладываются школой.

Основываясь на этом, Л.Н. Коган выделяет политическую, нравственную и профессиональную зрелость [23, с. 190-194].

Таким образом, и психологическая, и социологическая традиция в понимании феномена «зрелость» исходят из некоего набора характеристик, которые и дают новое качество, уровень в развитии личности, именуемый зрелостью, позволяют судить о ее успешности. Одним из совпадающих элементов в концепциях названных авторов является утверждение о существенной роли социальной среды в формировании человека, об определяющем влиянии внешних факторов, понимаемых в широком смысле слова как социализация и более предметно - как воспитание.

Воспитание связано с целенаправленным воздействием на человека общества в целом, семьи и специально созданных структур для приобщения личности к социокультурным ценностям, нормам, образцам и правилам поведения в соответствии с существующими идеалами.

Воспитание призвано воздействовать на сознание человека в целом и благодаря осознанию им себя через предметный мир и других людей оказывает влияние и на развитие самосознания, формирование зрелой личности во всем многообразии форм проявления.

Воспитание влияет на самосознание человека косвенным образом, через вхождение его в окружающий мир, но главным образом в ранний период формирования личности. 
В предшествующих нынешнему столетиях это воздействие осуществлялось, прежде всего, благодаря обучению детей в школах. Однако в последние годы число акторов, влияющих на развитие, резко увеличилось. И школа в лице учителей потеряла монопольное положение, но осталась как важнейший фактор.

Однако вместо стремления реформировать свою воспитательную роль или хотя бы приблизиться к прошлому статусу школа предпочла уйти в сторону и в результате этого практически полностью утратила свою прежнюю идентичность. Это относится, в первую очередь, к основному общему и среднему образованию.

Среди ученых уже второе десятилетие бытует мнение, что отсутствие государственной идеологии, целей общественного развития создает вакуум в сознании людей, который впоследствии заполняется отнюдь не общезначимыми идеалами. Сегодня уже даже подсчитано количество угроз существующей системе воспитания подрастающего поколения [24, с. 8-13].

Помимо единой идеологической платформы воспитания, ученые называют многовекторность, неконтролируемое обществом информационное воздействие на молодежь (пропаганда насилия, наркомании, суицида, уголовной культуры), равнодушие к проблемам воспитания детей среди значительной части российских писателей, художников, артистов и музыкантов. В основу искусства положено только получение удовольствия и прибыли. Средства массовой информации широко транслируют любую критику в адрес учителей. Проведенные нами опросы среди учителей, родителей учащихся и выпускников школ свидетельствуют о негативной роли СМИ в формировании имиджа учителя.

Мы согласны с позицией Н. Ф. Головановой, критикующей отождествление социализации и воспитания, так как социализация более широкое понятие, включающее как элементы стихийного, так и целенаправленного воздействия. Воспитание всегда имеет определенную цель, пути движения к ней, сформированный идеал. Благодаря воспитанию целенаправленно передается опыт поколений, система общественных ценностей, моральные нормы и образцы поведения [25, с. 25-32]. 
То, что подход к постановке воспитательной работы, например, в школе, должен быть пересмотрен, не вызывает сомнений. Происходящие в мире изменения, носящие многомерный характер, нелинейное развитие требуют новых подходов к обучению и воспитанию, формированию принципиально иных теоретических знаний и практических навыков [26, с. 5-15]. Цифровые технологии, дистанционное обучение поставили перед необходимостью изменения привычного хода событий, поиска решений ранее неизвестных проблем.

В 2019 г. для выявления реальных оценок состояния воспитательной работы в современной школе был проведен с участием одного из авторов онлайн-опрос выпускников школ, поступивших на первый курс ряда вузов г. Екатеринбурга ( $n=1085$ чел., жители г. Екатеринбурга - 425 чел., иногородние, в том числе из других регионов России, - 660 чел.). Абсолютное большинство (96\% опрошенных) считают необходимым внести изменения в существующую систему образования (причем 30 \% из них - за радикальные преобразования).

В целом положительно оценили состояние воспитательной работы две трети респондентов, каждый третий поставил оценку «плохо» и «очень плохо». Особенно низких оценок удостоились организация досуга и свободного времени школьников (индекс удовлетворенности 0,05 при шкале от -1 до +1 ); вовлечение в волонтерскую деятельность (индекс удовлетворенности 0,01), при этом опрошенные отмечают, что участие в волонтерском движение развивает уверенность в себе, общительность, эмпатию $(76,1 \%)$, формирует умение работать в команде $(65,9 \%)$ - вспомним движение тимуровцев; различные формы эстетического воспитания (индекс удовлетворенности 0,003).

Положительно оценено правовое и нравственное воспитание. Определенные затруднения вызывал вопрос о влиянии на учебновоспитательный процесс представления о системе образования как о сфере оказания услуг. Каждый третий не смог на него ответить. Негативно высказался по этому поводу каждый четвертый опрошенный, при этом 22,9 \% считают, что такой подход разрушает учебно-воспитательный процесс. 
Одной из форм воспитания является профориентационная деятельность школы. Каждый второй опрошенный считает, что эту работу надо проводить с 7-8-х классов. При этом больше привлекает практически-ориентированный показ профессий - экскурсии на предприятия и в вузы (73,8 \% опрошенных), специальные уроки, посвященные конкретным профессиям (56,1%), включение рассказов о профессиях при изучении отдельных предметов (53,6 \%).

Исследование показало, что выпускники школ видят связь между эффективностью проведения уроков и нравственным воспитанием (коэффициент корреляции ГАММА - 0,604), нравственное воспитание зависит от использования индивидуального подхода $(0,57)$, от отношений с учителями $(0,46)$, от отношений с другими учениками $(0,27)$. Выпускники наиболее высоко оценили такие качества формирования личности, как толерантность, ответственность, логичность мышления, честность и воспитанность.

Однако, например, чуткость оказалась на 11-м месте из 16 предложенных характеристик, трудолюбие - на 12-м месте. Доброту назвал только 1 человек из 1085, столько же выборов получили любовь к людям, инициативность, целеустремленность, искренность.

Приведенные примеры показывают, что система образования утратила лидерские позиции в целенаправленном формировании подрастающего поколения, а следовательно, мы можем получить и определенные деформации в развитии личности.

Самосознание, становление социально зрелой личности находится в прямой зависимости от условий жизнедеятельности конкретных индивидов, и непрерывное их изменение, усложнение и отнюдь нелинейный характер требуют усиления воздействия на формирующуюся личность во избежание в будущем необходимости каких-то радикальных мер. В этом сегодня, на наш взгляд, состоит одна из важнейших задач психологии образования, всего образовательного и воспитательного комплекса страны.

Необходимость реформирования существующей сегодня системы образования отчетливо представляет и руководство страны. Вносятся изменения в Федеральный закон «Об образовании в Российской Федерации» (например, с 1 сентября 2020 г. вступают в силу поправки, предусматривающие обязательное включение в образовательные 
программы воспитательных проектов и календарных планов, создание в школах советов по воспитательной работе); дается определение что следует понимать под воспитанием [27]). В 2018 г. принят национальный проект «Образование», ведущее место среди 10 федеральных программ занимает программа «Современная школа» - ей отводится почти 40 \% всех выделяемых на национальный проект средств [28].

Подобные меры дают надежду, что проблемы, стоящие перед российской системой образования, будут решены.

1. Маркс К., Энгельс Ф. Сочинения. 2-е изд. М. : Госполитиздат, 1955. T. $3.630 \mathrm{c}$.

2. Маркс К., Энгельс Ф. Сочинения. 2-е изд. М. : Изд-во полит. лит., 1974. T. 42.514 c.

3. Столин В. В. Самосознание личности. М. : Изд-во Моск. ун-та, 1983. 284 c.

4. Выготский Л. С. Собрание сочинений : в 6 т. Т. 2 : Проблемы общей психологии / под ред. В.В.Давыдова. М. : Педагогика, 1982. 504 с.

5. Леонтьев А. Н. Деятельность. Сознание. Личность. М. : Политиздат, $1975.304 \mathrm{c}$.

6. Фихте И. Г. Избранные сочинения / под ред. кн. Е. Трубецкого. М. : Путь, 1916. Т. $1.521 \mathrm{c.}$

7. Гегель Г. В. Ф. Сочинения. М. : Полиграфкнига, 1938. Т. 12. 494 с.

8. Кемеров В.Е. Развитие // Современный философский словарь / под ред. проф. В.Е. Кемерова. 3-е изд., испр. и доп. М. : Акад. проект, 2004. 864 с.

9. Леонтьев А. Н. Проблемы развития психики. 3-е изд. М. : Изд-во Моск. ун-та, 1972. 576 с.

10. Нечаев Н.Н. Категория развития как основа психологопедагогических исследований образования // Культурно-историческая психология. 2018. Т. 14, № 3. С. 57-66.

11. Кулагина И. Ю., Колюцкий В. Н. Возрастная психология: полный жизненный цикл развития человека : учеб. пособие для студентов высш. учеб. заведений. М. : Сфера, 2001. 464 с.

12. Чеснокова И. И. Проблема самосознания в психологии. М. : Наука, 1977. 144 c.

13. Ананьев Б. Г. О проблемах современного человекознания. М. : Наука, 1977. 380 с. 
14. Адлер А. Воспитание детей. Взаимодействие полов / пер с англ. А. А. Валеева и Р. А. Валеевой (The Education of Children. Gateway Editions, Ltd South Bend Indiana, 1978). Ростов н/Д : Феникс, 1998. 448 с.

15. Маслоу А. Г. Дальние пределы человеческой психики / пер. с англ. А. М. Татлыбаевой. СПб. : Евразия, 1999. 432 с.

16. Олпорт Г. Становление личности : избр. тр. М. : Смысл, 2002. 462 с.

17. Ананьев Б. Г. Человек как предмет познания. 3-е изд. М. : Питер, 2010. 282 c.

18. Божович Л. И. Проблемы формирования личности : избр. психол. тр. / под ред. Д. И. Фельдштейна ; Рос. акад. образования, Моск. психол.соц. ин-т. 3-е изд. М. : МПСИ, 2001. 349 с.

19. Андреева Г. М. Психология социального познания : учеб. пособие для студентов высш. учеб. заведений. 3-е изд., перераб. и доп. М. : Аспект Пресс, 2005. 303 с.

20. Анцыферова Л. И. Развитие личности и проблемы геронтопсихологии : монография. М. : Ин-т психологии РАН, 2006. 512 с.

21. Кон И. С. Социология личности. М. : Политиздат, 1967. 383 с.

22. Allport G. W. Pattern and growth in personality. N. Y., NY : Holt, Rinehart and Winston, 1961. $593 \mathrm{p}$.

23. Коган Л. Н. Человек и его судьба. М. : Мысль, 1988. 284 с.

24. Нечаев М.П., Петренко А. И. Риски и угрозы в системе воспитания подрастающего поколения // Воспитание школьников. 2018. № 8. С. 8-13.

25. Голованова Н. Ф. Воспитание: убедительные декларации и противоречивая теория // Педагогика. 2017. № 6. С. 25-32.

26. Берулава Г.А., Берулава М. Н. Российская система высшего образования и новая теоретическая платформа развития личности // Педагогика. 2019. № 7. C. 5-15.

27. О внесении изменений в Федеральный закон «Об образовании в Российской Федерации» по вопросам воспитания обучающихся : Федер. закон от 31 июля 2020 г. № 304-Ф3 [Электронный ресурc]. URL: https://www. garant.ru/products/ipo/prime/doc/74351950/ (дата обращения: 10.09.2020).

28. Паспорт национального проекта «Образование» : утв. Президиумом Совета при Президенте Российской Федерации по стратегическому развитию и национальным проектам (протокол от 24 декабря 2018 г. № 16) [Электронный ресурс]. URL: http://government.ru/info/35566/ (дата обращения: 10.09.2020). 


\title{
НЕПРЕРЫВНОЕ ОБРАЗОВАНИЕ: ВОЗРАСТНОЙ АСПЕКТ ПРОЯВЛЕНИЙ «Я» (САМООЦЕНКА, САМООТНОШЕНИЕ, САМОАКТУАЛИЗАЦИЯ)*
}

\author{
Н. С. Глуханюк \\ М. Н. Юртаева
}

Специфика современного экономического и социального развития предполагает особые изменения в сфере образования. Прежде всего это формирование развернутых систем обучения, охватывающих широкие слои населения. Второе направление изменений связано со сменой акцентов образовательной системы, основным параметром которой становится обучение в течение всей жизни, а центром этой системы - человек. Третий вектор изменений связан с активным отношением субъекта к саморазвитию и изменению себя. Современному человеку необходимо не только иметь достаточный запас профессиональных знаний и умений, но и уметь выстраивать стратегию собственной жизни, адаптироваться к изменениям, интегрироваться в различные сообщества, самостоятельно определять внутренний потенциал развития.

Основным инструментом, сопровождающим необходимые изменения, может выступить система непрерывного образования в течение жизни и образования взрослых, как наиболее значимая его часть. Непрерывное образование способно укрепить и социальные связи человека, особенно ослабевающие в позднем периоде жизни, выполняя важные социальные и психологические функции [1].

Образование взрослых является ареной интенсивного научного поиска и психолого-педагогических экспериментов. За последние десятилетия сформировалась новая сфера - дополнительное образование взрослых, и, что важно, не только с профессиональной направленностью. Ориентация на потребителя, гибкость в новых условиях относительной свободы, применение не только педаго-

Исследование выполнено при финансовой поддержке РФФИ в рамках научного проекта № 19-013-00431 «Личностная мобильность как предиктор сохранения профессионального здоровья в пожилом возрасте».

(อ) Глуханюк Н. С., Юртаева М.Н., 2020 
гических, но и социальных и психологических технологий - все это стало отличительной особенностью программ для взрослого населения страны. Данный вид образования ориентирован не только на передачу новых знаний, но и на сохранение психической и социальной активности, что является необходимым условием достижения успешности, благополучия человека в динамично меняющейся социально-профессиональной среде. В собирательном смысле их можно обозначить как когнитивные ресурсы и потенциал личности $[2,3]$.

Особые ожидания от образования взрослых детерминированы проникновением цифровизации, различных видов коммуникации в повседневную жизнь человека, что требует от взрослых людей постоянного освоения новых умений, связанных с информационными технологиями, иностранными языкам, предпринимательством и психологической культурой.

Образование взрослых отличает ведущая роль обучающегося на всех этапах обучения: планировании, реализации и оценке программ и методов. Психологам необходимо переосмыслить сущность образования взрослых, отведя в нем значимое место самообразованию человека. Психологические характеристики взрослого обучающегося группируются по типу влияния на процесс обучения. К позитивным относятся стремление к самореализации; ведущая роль в процессе обучения; обладание жизненным (обыденным, социальным, профессиональным) опытом, который может быть использован в качестве источника обучения. К негативным - такие, как устаревшие представления об учебе, сформированная структура комплексов, определенный дефицитарный тип обработки информации (фильтры восприятия), ментальные проявления, механизмы сопротивления, в основе которых лежат психологические барьеры и защиты, интолерантность к неопределенности в познавательной сфере.

Таким образом, мы полагаем, что современное образование взрослых - это не только и не столько традиционный процесс формирования профессиональных компетенций, но прежде всего работа с когнитивными ресурсами, потенциалом личности и возможностью реализовать себя. 
Осознание и развитие человеком собственного потенциала позволяет эффективно воплощать свои способности, ощущать удовлетворение от собственных достижений. Активное отношение субъекта к саморазвитию и изменению себя является и условием, и результатом непрерывного образования. В данном контексте особого внимания заслуживает изучение проявлений Я (самооценки, самоотношения и самоактуализации) взрослого человека и создание специфических образовательных сред, форм и технологий самостоятельного управления данными характеристиками.

Исследование проводилось в группе взрослых людей, самостоятельно выбравших программу дополнительного непрофессионального образования, которая была анонсирована как тренинг личностного роста. Использовались известные стандартизованные методики. Целью было установление изменений самооценки, самоотношения и самоактуализации в процессе прохождения образовательной программы. Участвовало 102 человека, возраст от 45 до 60 лет (средний возраст 52,5 года), 47 \% мужчин и 53 \% женщин. Показатели измерялись до и после прохождения программы, анализировались значимые достоверные различия в выраженности показателей, а также корреляционные связи между параметрами Я.

Методики. Особенности самооценки анализировались с помощью методики «Опросник шкалы самооценки» (ОШсо). Специфика самоотношения изучалась с помощью методики исследования самоотношения (МИС), разработанной С. Р. Пантилеевым. Изучение особенностей самоактуализации осуществлялось с помощью методики POI Э. Шострома в русскоязычной модификации (Ю. Е. Алешина, Л. Я. Гозман, М. В. Загика, М. В. Кроз) $[4,5,6]$.

\section{Обсуждение результатов}

Теоретический анализ и систематизация научного опыта позволили сформулировать следующее теоретическое предположение: самооценка, самоотношение и самоактуализация доступны преднамеренному воздействию и целенаправленному изменению, что позволяет прогнозировать варианты перехода к самообразованию взрослых обучающихся. 
Проверке этого предположения посвящена эмпирическая часть настоящего исследования. Нами были определены следующие эмпирические задачи: 1) выявить психологические особенности самооценки, самоотношения и самоактуализации участников до реализации образовательной программы; 2) исследовать изменения показателей самооценки, самоотношения и самоактуализации участников в результате проведения программы.

Измерение различных аспектов самооценки участников до занятий позволило установить, что показатель глобальной самооценки имеет уровень выраженности выше среднего, т. е. большинство участников имеют явное преобладание высоких значений общей самооценки над низкими. Полученный результат свидетельствует о том, что участникам свойственны позитивные чувства по отношению к себе, выражающиеся в высоком самоуважении, самоэффективности и чувстве личностного контроля.

Сравнение негативного и позитивного аспектов самооценки выявило явное доминирование последнего, а также их отрицательную корреляционную сопряженность друг с другом. Таким образом, чем менее свойственна участникам склонность к самообесцениванию и чувство собственной неполноценности, тем большим самоуважением и позитивным акцентированием своего Я они обладают.

Такие чувства в адрес своего Я, как оптимистичность ожиданий по поводу своей компетентности и совокупный личностный контроль, выражены у большинства участников в пределах среднего уровня. Однако если по показателю «оптимистические ожидания» участники достаточно похожи между собой, то по показателю «личностный контроль» они существенно отличаются друг от друга. То есть преобладающее большинство участников испытывает оптимистичные чувства по поводу своей действенности и компетентности («я могу, я способен»), однако причины своих успехов и неудач (личностный контроль) склонны приписывать как самим себе (интернальный контроль, «причина произошедшего во мне»), так и внешним обстоятельствам (экстернальный контроль, «произошедшее от меня не зависит»).

В факторной модели самоотношения, предложенной С. Р. Пантилеевым, содержание данного феномена, понимаемое как обобщенное 
чувство человека в адрес собственного Я, представлено девятью показателями. Они, в свою очередь, факторизованы в три фактора: самоуважение, аутосимпатия, самоуничижение. В рамках авторской модели мы сочли целесообразным интерпретировать результаты по трем обобщенным факторам самоотношения. Изучение специфики самоотношения участников до занятий в рамках программы позволило получить следующие результаты. Наиболее выражен в сравнении с другими фактор самоуважения, включающий показатели закрытости, самоуважения, саморуководства, отраженного самоотношения. Вторым по уровню выраженности выступил фактор аутосимпатии, описываемый показателями самоценности, самопринятия, самопривязанности. И третий - фактор «самоуничижения», раскрываемый такими показателями негативного самоотношения, как внутренняя конфликтность и самообвинение.

Содержательным основанием фактора «самоуважение» выступает то, что вошедшие в него показатели выражают оценку человеком собственного Я по отношению к социально-нормативным критериям: целеустремленности, воле, успешности, моральности, социальному одобрению и т. п. Это обобщенное измерение самоотношения близко по содержанию к тому аспекту глобальной самооценки, который в литературе принято обозначать как чувство компетентности, эффективности, инструментальности Я. В качестве основной особенности данного аспекта самоотношения большинством исследователей подчеркивается его оценочный характер. Самоуважение предполагает оценку себя по сравнению с некоторыми социально значимыми критериями и эталонами: представлениями о благополучном и успешном человеке, заложенными в идеальный образ Я. В этом отношении характерна тесная связь данного фактора со шкалой закрытости, большую часть содержания которой составляет тенденция к соответствию человека социально-желательному образу.

Самоуважение будущих участников тренинга, превышающее среднестатистический уровень, свидетельствует о достаточно психологически комфортной оценке испытуемыми своего реального Я в сравнении с собственным идеальным образом. В представлениях о себе они соответствуют определенным, ими же самими установ- 
ленным социально значимым критериям успеха, что свидетельствуют о высокой самооценке участников исследования.

Дифференцированный анализ по показателям, входящим в шкалу самоуважения (закрытость, самоуверенность, саморуководство, отраженное отношение), указывает на то, что все ее аспекты имеют у частников исследования тенденцию к более высоким результатам, нежели к низким. Саморуководство интерпретируется как представление о том, что основным источником активности и результатов, касающихся как деятельности, так и собственной личности человека, является он сам. Конструкт, лежащий в основе этого измерения, близок по содержанию к такой психологической переменной, как локус контроля. В нашей работе локус опосредованно измерялся с помощью показателя «оптимистичные ожидания по поводу своей компетентности». Корреляционный анализ показал высоковероятную значимую прямо пропорциональную (положительную) взаимосвязь между показателями саморуководства и оптимистичных ожиданий участников. Тем не менее содержание феномена саморуководства имеет специфику по отношению к локусу контроля. Если последний выражает представление об управляемости и предсказуемости мира и результатов деятельности самого субъекта, то саморуководство отражает чувство человека по поводу управляемости и предсказуемости собственного Я. Высокое саморуководство, свойственное участникам исследования, выражается в представлении, что их Я выступает как внутренний стержень, интегрирующий и организующий их личность, деятельность и общение; что их судьба находится в их собственных руках. Кроме этого высокое саморуководство отражает мнение участников о способности эффективно справляться с эмоциями и переживаниями по поводу самого себя.

Самоуверенность и отраженное отношение также обнаруживают тенденцию к преобладанию высоких показателей. То есть большинство участников оценивает себя как уверенных и самостоятельных людей; ощущают силу своего Я, веру в свои возможности и компетентность. Также им свойственно представление о том, что и у других людей их личность, характер и деятельность способны вызывать уважение, симпатию, одобрение, понимание, т. е. благоприятно предвосхищаемое отраженное отношение других. 
Интересные факты установлены в отношении показателя «закрытость», или «внутренняя честность». Выявлено сходство будущих участников тренинга между собой с преобладанием высоких значений данного показателя. Утверждения, вошедшие в данный показатель, по замыслу С. Р. Пантилеева, формулировались так, чтобы в них содержались некоторые качества (в первую очередь негативные с точки зрения обыденной морали), в определенной степени присущие каждому человеку, но требующие достаточных навыков рефлексии и обладания определенной внутренней честностью для их признания. Отсюда ответы на данные пункты опросника определяются преобладанием одной из двух тенденций: либо критичностью, глубоким осознанием себя, внутренней честностью и открытостью (внутренняя честность), либо конформностью или выраженной мотивацией социального одобрения (закрытость). Соответственно этот показатель самоотношения измеряет осознанность Я и описывает глубокое или поверхностное проникновение в себя, открытое или закрытое (защитное) отношение к себе. Можно заключить, что преобладающему большинству участников свойственно скорее защитное, нежели рефлексивное отношение к себе, и внутренняя честность. Данный факт соотносится с представлениями о психологических особенностях взрослых, участвующих в каких-либо образовательных программах.

Таким образом, участникам свойственно позитивное самоуважение, имеющее психологически комфортный высокий уровень выраженности. Высокая оценка собственной компетентности и эффективности Я, вера в способность успешно управлять и справляться с эмоциями и переживаниями по поводу самого себя, сила Я и представление о позитивном восприятии себя другими людьми. Однако ресурсное обеспечение подобной саморегуляции является слабым и нестабильным. Более вероятно наше предположение, что описанное выше высокое самоуважение - это скорее следствие стремления соответствовать социально-желательному образу Я; это проявление закрытого, защитного отношения к себе, нежели результат глубокой и «честной» саморефлексии.

Во второй обобщенный фактор самоотношения - аутосимпатию входят шкалы «самоценность», «самопринятие», «самопривя- 
занность». В отличие от предыдущего фактора, тесно связанного с процессами самооценивания, аутосимпатия включает, в первую очередь, показатели, выражающие те или иные чувства или переживания в адрес собственного Я. В данном факторе фиксируется содержание, которое называют самоотношением на основе эмоционального чувства привязанности и расположенности к себе. Чувства привязанности и принятия себя не предполагают сравнения и сопоставления с какими-либо социально заданными и индивидуально усвоенными нормами-эталонами. Если фактор самоуважения связан со стремлением к социально-желательному образу Я, то аутосимпатия не предполагает этой связи. Даже наоборот, за счет положительного эмоционального отношения человек может относиться к себе более честно и открыто. В основе фактора лежит некоторое обобщенное чувство симпатии, которое может существовать наряду и даже вопреки той или иной обобщенной самооценке, выражающейся в переживании самоуважения. Об этом свидетельствует и то, что фактор аутосимпатии относительно независим от фактора самоуважения.

Установлено, что участникам исследования свойственна высокая аутосимпатия, т. е. позитивные чувства и переживания в адрес собственного Я. Однако дифференцированный анализ чувств разной модальности (самоценность, самопринятие, самопривязанность) показывает их различную выраженность в сравнении друг с другом. Так, показатель «самоценность» отражает эмоциональную оценку себя по внутренним критериям духовности, богатства внутреннего мира, способности вызывать в других глубокие чувства. По показателю самоценности выявлено сходство будущих участников между собой, с преобладанием высоких значений. Данный факт свидетельствует о том, что участникам свойственно переживать ощущение ценности собственной личности и одновременно предполагаемую ценность своего Я для других. Им не свойственны отстраненность и безразличие к себе, потеря интереса к своему внутреннему миру. Показатель «самопринятие» обнаруживают тенденцию к преобладанию средних значений, т. е. участники переживают чувство симпатии к себе и принимают себя такими, как есть, пусть даже с некоторыми недостатками. 
Интересны результаты по показателю «самопривязанность», трактуемому как желание или нежелание изменяться по отношению к наличному состоянию. Анализ показал, что участникам свойственно преобладание средних значений данного показателя. Так, для 15 \% из них характерна низкая самопривязанность, т. е. стремление к преднамеренному самоизменению в соответствии с идеальными представлениями о себе. Для 12,3 \% - высокая самопривязанность, которая отражает некоторую ригидность Я-концепции, консервативную самодостаточность, отрицание возможности и желательности развития собственного Я. Отсюда следует, что участники проявляют амбивалентные чувства в отношении готовности к изменениям своего Я.

Третий обобщенный фактор - «самоуничижение» составили такие показатели, как внутренняя конфликтность и самообвинение, которые объединяет наличие негативного эмоционального тона по отношению к себе. Данные показатели обнаруживают тенденцию к явному преобладанию средних значений. Выявление средневыраженного чувства антипатии к себе, по нашему предположению, скорее характеризует не наличие отрицательных чувств к своему Я, а актуальное действие защитных механизмов от отрицательных эмоций для поддержания общего самоуважения на относительно постоянном уровне. Действие этого защитного механизма направлено в первую очередь на блокировку антипатии к себе, чтобы уменьшение симпатии не приводило к нарастанию антипатии. Суть действия данного защитного механизма проясняют корреляционные зависимости показателей конфликтности и самообвинения и показателей саморуководства и личностного контроля по методике обобщенной самаооценки. Факт интерпретируется следующим образом: чем более выражено чувство уничижения и обвинения себя, тем меньше представлено стремление нести ответственность за свои действия, поведение (экстернальный локус контроля). Отсюда самоуничижение предполагает позицию Я, с помощью которой человек снимает с себя ответственность за свои дела и поступки, фактически перекладывая ее на других людей или внешние обстоятельства, что как раз и является определяющим моментом действия защитного механизма. Установлено, что участникам исследования 
более свойственна высокая, нежели низкая аутосимпатия. Однако дифференцированный анализ чувств (самоценность, самопринятие, самопривязанность) показывает их различное проявление в сравнении друг с другом.

Анализ психологических особенностей проявления самоактуализации у участников программы до занятий позволил установить, что все показатели имеют среднестатистический уровень выраженности. Полученные результаты свидетельствуют о том, что участники характеризуются, во-первых, достаточно оформленным, свойственным большинству людей стремлением к актуализации своего потенциала, во-вторых, не обнаруживают яркого своеобразия в стремлении к личностному росту в фиксируемых методикой основных жизненных сферах. Отсюда следует, что участникам свойственна средняя по количеству степень присвоения поведенческих и ценностных индикаторов, которые характеризуют самоактуализирующуюся личность.

Меры изменчивости индивидуальных результатов показали, что участники достаточно похожи между собой в выраженности потенциала самоактуализации. Исключение из этой тенденции составляет высокий уровень выраженности показателя «самоуважение», что трактуется как высокое стремление ценить свои достоинства, уважать себя за них. Однако сравнение самоуважения и самопринятия показывает достоверные различия в их выраженности. Отсюда стремление участников высоко себя ценить не находит поддержки в их реальном поведении и принятии себя такими как есть.

Попарное сравнение показателей самоактуализации по блокам также показало достоверные различия в выраженности между показателями ценностей. Большинство участников разделяют и принимают ценности, свойственные самоактуализирующейся личности, однако демонстрируют неготовность реализовать их в собственном поведении. Декларируемая и действительная стороны ценностной регуляции поведения не совпадают.

Детальный анализ разброса индивидуальных значений позволил зафиксировать следующие результаты. По показателю «поддержка/ независимость» обнаружено, что низкие значения свойственны 27 \% участников, а высокие - 31 \%. Анализ мер изменчивости показал 
широкий диапазон разброса индивидуальных значений. Отсюда следует, что на программу приходят достаточно непохожие люди в отношении присущего им локуса контроля своего поведения, как «извне», так и «изнутри» направляемые личности. Установлено, что низкие значения по показателю «ориентация во времени» свойственны 37 \% участников исследования, а высокие - 8 \%. Более чем треть участников обнаруживает дискретное восприятие своего жизненного пути, ориентируясь лишь на один из отрезков временной шкалы. И лишь десятая часть участников проявляет психологическое восприятие времени, присущее самоактуализирующимся личностям.

Таким образом, группу участников, самостоятельно выбравших программу, характеризуют: высокая глобальная самооценка; позитивные чувства по отношению к себе, при этом чем менее выражены склонность к самообесцениванию и чувство собственной неполноценности, тем большим самоуважением и позитивным акцентированием своего Я они обладают; оптимистичные чувства по поводу своей действенности и компетентности, однако, причины своих успехов и неудач они склонны приписывать как себе, так и внешним обстоятельствам. Участникам свойственно позитивное самоуважение; вера в способность успешно управлять и справляться с эмоциями. Однако ресурсное обеспечение является слабым и нестабильным; высокое самоуважение - это следствие стремления соответствовать социально-желательному образу, проявление закрытого, защитного отношения к себе вследствие низкой саморефлексии. Показатели самоактуализации выражены средне, при этом имеется явный диссонанс между желаемым уровнем (да, я разделяю ценности актуализации и хотел бы раскрыть свой потенциал) и объективной выраженностью показателей. Декларируемая и действительная стороны поведения не совпадают.

Вторая эмпирическая задача заключалась в исследовании возможности изменения самооценки, самоотношения, самоактуализации участников программы. Анализ динамики осуществлялся посредством измерения и сравнения выраженности показателей Я до и после прохождения программы (период ретеста составил 4 недели). Изучение динамики показателей проводилось с помощью 
Т-критерия Вилкоксона для зависимых выборок, а также коэффициентов ранговой корреляции Спирмена путем анализа значимых связей. Основанием для суждений о выраженности показателей выступили меры центральной тенденции: средние значения и мода.

Сравнительный анализ изменений в процессе прохождения образовательной программы самооценки позволил прийти к следующим результатам. Все аспекты глобальной самооценки, измеряемые с помощью методики «Общая шкала самооценки», проявили чувствительность к образовательному воздействию.

Установлены достоверные сдвиги всех показателей самооценки, зафиксированные в измерении после окончания программы. Отсюда следует, что глобальная самооценка и ее различные аспекты доступны для психолого-педагогического воздействия и коррекции с помощью определенных психотехник в рамках образовательной программы с использованием техник интенсивной групповой подготовки.

Таким образом, в результате воздействия общая самооценка как проявление общего уважения к себе, а также оптимистичность ожиданий по поводу своей действенности достоверно возросли. Данный факт свидетельствует об увеличении позитивного отношения к себе у участников программы, оптимистичности в оценке своих возможностей и прояснении представлений о доступности личного контроля собственных поступков, отношений, деятельности.

Негативный аспект самооценки достоверно уменьшился. Сепаратная позиция негативной самооценки в общей структуре глобальной самооценки рассматривается как индикатор напряженности защитных механизмов личности в адрес своего Я. Отсюда сдвиг негативной самооценки в сторону уменьшения ее выраженности трактуется как снижение напряженности, связанной с необходимостью защиты отношения к себе от различных дестабилизирующих его угроз.

Сравнительный анализ дифференцированных показателей самоотношения, измеренных с помощью методики С.Р. Пантилеева у участников до и после прохождения программы, позволил прийти к следующим результатам. Общие тенденции в его проявлении сохраняются до и после прохождения программы, т. е. траектории 
профилей до и после воздействия совпадают. Однако статистически достоверно зафиксированы изменения (уменьшение или увеличение) значений показателей самоотношения.

Анализ сдвигов по вторичным факторам самоотношения (самоуважение, аутосимпатия и самоуничижение) показывает, что наибольшую чувствительность к воздействию проявили факторы «самоуважение» и «самоуничижение». По фактору «аутосимпатия» не обнаружено достоверно значимых сдвигов. Значения показателей закрытости, самоуважения, саморуководства, входящих в первый фактор, выражены достоверно выше у участников после воздействия. Исключение составляет показатель отраженного самоотношения, по которому не было обнаружено достоверных сдвигов.

Полученные результаты свидетельствуют о том, что в процессе воздействия у участников достоверно возросла оценка собственного Я по отношению к социально-нормативным критериям: целеустремленности, воли, успешности, моральности, социального одобрения, т. е. чувство уверенности в собственной компетентности и эффективности стало более интенсивным. Показатель ожидаемого положительного отношения других людей к себе не изменился, что свидетельствует о преобладании ориентации на внутренний локус при оценке самоэффективности, нежели ориентация на оценки и мнения других людей.

Значения показателей, входящих в фактор «самоуничижение» (внутренняя конфликтность, самообвинение), выражены достоверно ниже. Соответственно негативный эмоциональный тон в отношении как оценок своего Я, так и чувств к себе после программы у участников стал менее выраженным и интенсивным. Важно учитывать и тот факт, что обособленная позиция фактора «самоуничижение» в структуре самоотношения выполняет защитную функцию самоподдержания. Суть защитного механизма проясняют отрицательные корреляции внутренней конфликтности и интернальности в области неудач. Можно предположить, что в процессе интенсивной групповой коммуникации у участников снижается защитное отношения к себе, которое проявляется как перекладывание ответственности за свои неудачи на других или внешние обстоятельства. Возможна и другая интерпретация обнаруженных связей. Высокая 
интернальность сопряжена с собственной виной за неудачи, что усиливает защитные механизмы Я. По всей видимости, программа способствовала принятию себя, снижала гипертрофированные идеалистические установки в отношении Я, способствовала смене позиции Я в области контроля неудач, активизировала «рабочую» позицию на изменение.

Таким образом, был зафиксирован факт того, что программа способствует снятию внутренних барьеров к изменениям в Я, активизируя готовность к ним. Но насколько глубоки и устойчивы будут эти изменения - зависит от самой личности, ее когнитивнорефлексивного опыта.

Интересен факт отсутствия достоверных сдвигов в значениях таких показателей фактора «аутосимпатия», как самоценность, самопринятие, самопривязанность. Данный факт свидетельствует о том, что позитивные чувства в адрес своего Я не изменяют своей модальности и не становятся более интенсивными в ходе программы, т. е. являются более устойчивыми к какому-либо воздействию, что, вероятнее всего, связано с возрастным аспектом.

Таким образом, в процессе интенсивной групповой подготовки возрастает оценочный аспект отношения к своему Я (вера в себя), не изменяется эмоциональное отношение к себе (чувство симпатииантипатии) и существенно уменьшается внутренняя конфликтность в представлениях о себе, чувство самообвинения и, как следствие, защитное поведение в отношении Я. Это указывает на чувствительность данной образовательной программы к процессам самопознания Я как источнику самодетерминации. Но что мы будем иметь на выходе? Аттитюд, который будет «включаться» в специфическом контексте тренинговой группы, или устойчивую внутреннюю потребность, обеспечивающую истинную интринсивную мотивацию поведения? Пожалуй, ответ на этот вопрос будет зависеть от степени включенности личности в процессы непрерывной трансформации, реконструкции, консолидации, рефлексии личностного и когнитивного опыта, предпосылкой которых и выступает непрерывное образование.

Анализ динамики стремления к самоактуализации в процессе прохождения образовательной программы, измеренного с помо- 
щью методики «Самоактуализационный тест», показал следующие результаты.

Траектории профилей самоактуализации до и после прохождения программы показывают совпадающие тенденции в выраженности показателей. Однако статистически достоверно зафиксирован сдвиг уровня выраженности показателей самоактуализации. Достоверно установлен рост всех значений показателей самоактуализации при повторном измерении после прохождения образовательной программы. Исключение составил показатель «контактность» из блока межличностной чувствительности как области самореализации.

Предваряя интерпретацию полученных эмпирических фактов, обозначим понимание феномена самоактуализации, заложенное в основу измерения. В русле экзистенциально-гуманистического подхода феномен трактуется как стремление к самоосуществлению, точнее, тенденция актуализировать то, что содержится в качестве потенций. Эту тенденцию можно назвать стремлением человека стать тем, кем он способен стать. Отсюда следует, что образовательная программа инициировала стремление ее участников к реализации своего потенциала. Сущностной особенностью этого инициированного стремления выступило не просто принятие участниками ценностей самоактуализации, но и готовность реализовать эти ценности в поведении. Результат сравнения свидетельствует о том, что стремление к самоосуществлению у участников программы выражено гораздо интенсивнее, нежели готовность реализовать его в собственном поведении, отношениях, деятельности.

Наибольшее увеличение значений зафиксировано в таких сфеpax, как чувства (сензитивность к себе и спонтанность), самовосприятие (самоуважение и самопринятие) и отношение к познанию (познавательные потребности и креативность). То есть воздействие привело к изменениям в сфере рефлексии Я, точности и тонкости самопонимания, уважению себя и стремлению к приобретению новых знаний. Высокозначимые сдвиги зафиксированы также в значениях базовых показателей - компетентности во времени и независимости, что свидетельствует о более гармоничном восприятии времени и проживании собственной жизни, а также о независимости своих ценностей от окружающего влияния. 
Сравнение изменений корреляционных связей до и после программы осуществлялось между показателями Я. Установлена высокая плотность значимых и сильных по тесноте прямо пропорциональных взаимосвязей между показателями самооценки, самоотношения и самоактуализации. На наш взгляд, полученный результат проясняет природу феномена самоактуализции, свидетельствуя о том, что стремление человека к самоосуществлению тесно связано с его представлениями о себе, положительными оценками и чувством симпатии в адрес своего Я, а также с отсутствием внутренней конфликтности, напряженности и несклонностью к самоуничижению.

Эмпирически выявленные нами взаимосвязи позволяют прояснить представления о природе самоактуализации. Предположительно, именно чувство адекватно высокого самоуважения и сниженное стремление к самобичеванию выступают психологическими (внутренне детерминированными) условиями реализации человеком своего потенциала.

Ядерными показателями самоотношения и самооценки, т.е. сопряженными с наибольшим количеством показателей самоактуализации, в период начала тренинга выступили общая самооценка и ее позитивный компонент, личностный контроль, внутренняя конфликтность и самообвинение. Последние два показателя обнаружили значимую обратно пропорциональную (отрицательную) взаимосвязь с самоактуализацией.

Показателями-аутсайдерами, т. е. обнаружившими слабую, единичную сопряженность с другими показателями самоактуализации, выступили самопринятие, самопривязанность, закрытость и принятие агрессии. Данные факты свидетельствуют о том, что стремление человека к реализации своего потенциала в большей степени обеспечивается его адекватно высокой положительной самооценкой, чувством собственной эффективности и личностного контроля и умеренно сниженным защитным поведением в адрес своего Я, а также стремление к самоактуализации не связано с чувством аутосимпатии и желанием-нежеланием изменяться по отношению к наличному состоянию, т. е. ригидностью Я-концепции (показатель самопривязанности). Последний факт можно объяснить с позиций 
действия защитного механизма. Также это можно объяснить сложностью проявлений Я.

Анализ динамики установленных корреляционных взаимосвязей позволил сделать следующие выводы. По завершении программы установлено существенное увеличение плотности корреляций между всеми показателями Я. Характер обнаруженных корреляционных зависимостей сохранил основные особенности, которые были получены до программы. Наиболее сильную, практически тотальную взаимосвязь с самоактуализацией по окончании программы обнаружили показатели самооценки, а не показатели самоотношения.

Изучение взаимосвязей между показателями Я до и после программы и анализ их изменений позволил прийти к следующим заключениям. Самоактуализация как стремление к самоосуществлению тесно связана с представлениями человека о себе, положительными оценками и чувством симпатии в адрес своего Я, а также с отсутствием внутренней конфликтности, напряженности и несклонностью к самоуничижению. Предположительно, именно чувство адекватно высокого самоуважения, отсутствие внутриличностной конфликтности и склонности к самобичеванию выступают психологическими условиями реализации человеком своего потенциала.

Чувства аутосимпатии, а также отсутствие стремления к самоизменению (самопривязанность) не обнаружили связи с самоактуализацией, что отчасти объяснимо защитным поведением. Анализ изменений корреляционных взаимосвязей позволил сделать следующие выводы: психотехнология, заложенная в основу программы для взрослых, способна инициировать стремление человека к самоактуализации; механизмом данного инициирования выступают, с одной стороны, рост адекватной положительной самооценки и самоуважения, который основан на рефлексивности, внутренней «честности» и осознанности по отношению к себе, с другой - снижение напряженности защитного поведения в адрес Я. Результаты исследования подтверждают представления о том, что самооценка, уважение и самоактуализация доступны психологическому воздействию в процессе реализации образовательных программ для взрослых. 
Предпринятая попытка определить уровень самооценки, самоотношения и самоактуализации взрослых людей, ищущих возможность развития и реализации себя средствами дополнительного образования, позволяет сделать следующие выводы. Поиск образовательных возможностей личностного развития осуществляют люди с высокими потребностями в подтверждении своих потенциальных (скрытых) личностных качеств. Уровень генерализованности показателей самоактуализации по всем блокам превышает уровень их выраженности. Желание актуализировать резервы есть, но в реальном поведении это не проявляется. Именно данный результат свидетельствует в пользу принятия решения об участии в образовательной программе.

Остается открытым вопрос об устойчивости достигнутых результатов. Возможно ли длительное сохранение высоких показателей самооценки и самоотношения, лежащих в основе раскрытия потенциальных возможностей человека, после окончания программы и вне группы? Будет ли полученный результат не только приводить к актуализации личности, но и создавать предпосылки для самообразования, поскольку краткосрочное интенсивное воздействие в специфическом контексте групповой работы скорее активизирует установки, а не формирует устойчивую внутреннюю потребность, обеспечивающую мотивацию поведения? Ответы на эти вопросы будут зависеть от степени включенности личности в процессы рефлексии личностного и когнитивного опыта, предпосылкой которых и выступает непрерывное образование.

Поэтому задачей психологического сопровождения образования взрослых является разработка таких инструментов активизации и поддержки Я, которые можно включать в самые разнообразные образовательные программы.

Резюме. Пути развития образования взрослых как фактора интеграции в современную действительность неразрывно связаны с выявлением и активизацией потенциальных ресурсов и возможностей взрослых и моделированием современных образовательных сред, адекватно обеспечивающих запуск механизмов саморазвития. Увеличение адаптационных возможностей взрослого человека, обеспечение конструктивного реагирования на социокультурные 
изменения можно осуществить посредством продвижения новых моделей образования через всю жизнь.

1. Вельтер С. Образование взрослых как ресурс развития социальных структур: международные тенденции // Новые знания. 2002. № 2. С. 28-29.

2. Вершловский С. Г. Ценность образования на разных этапах жизни // Новые знания. 2008. № 4. С. 27-32.

3. Merriam S. B., Kee Y. Promoting community wellbeing: The case for lifelong learning for older adults // Adult Education Quarterly. 2014. Vol. 64 (2). P. $128-144$.

4. Глуханюк Н. С., Дьяченко Е. В. Я в профессии и профессиональное Я: результаты исследований. Екатеринбург : Изд-во Рос. гос. проф.-пед. ун-та, 2005.

5. Пантилеев С. Р. Методика исследования самоотношения. М. : Смысл, 1993. 32 c.

6. Самоактуализационный тест / Ю. Е. Алешина, Л. Я. Гозман, М. В. Загика, М. В. Кроз. М. : Рос. пед. агентство, 1995. 42 с. 


\section{ПСИХОЛОГИЧЕСКИЕ ХАРАКТЕРИСТИКИ ТРАНСПРОФЕССИОНАЛЬНЫХ КОМПЕТЕНЦИЙ СПЕЦИАЛИСТОВ (НА ПРИМЕРЕ МАГИСТРАНТОВ - ПРЕДСТАВИТЕЛЕЙ СОЦИОНОМИЧЕСКИХ И ТЕХНОНОМИЧЕСКИХ ГРУПП ПРОФЕССИЙ)}

\section{Э. Ф. Зеep}

М. В.Зиннатова

Т.Д. Буковей

В настоящее время в мире профессий происходят множественные изменения: одни профессии уходят с рынка труда, другие - подвергаются трансформации, третьи - возникают впервые. Совершенно очевидно, что профессии, которые будут трансформироваться или появляться в ближайшие годы, потребуют от нынешних специалистов абсолютно новых транспрофессиональных компетенций, которые будут востребованы цифровой экономикой, отвечать на вызовы постиндустриального общества, цифровой индустриализации и находиться на стыке нескольких отраслей. В то же время возникнет необходимость в непрерывном и опережающем образовании, в ходе которого субъект профессиональной деятельности будет наращивать данные компетенции.

Утверждение шестого технологического уклада, глобальная цифровизация, роботизация и трансформации рынка труда порождают потребность в специалистах нового уровня - транспрофессионалах, обладающих интегративными метапрофессиональными компетенциями и готовыми к преодолению вызовов цифровой экономики и цифровой индустриализации. Стоит отметить, что в современной социально-экономической ситуации важное значение отводится формированию в ходе профессионально-образовательной подготовки soft skills (гибких, сквозных навыков), позволяющих человеку быть успешным независимо от специфики деятельности и направления работы.

Исследование выполнено при финансовой поддержке РФФИ, проект № 18-013-01147 «Социально-гуманитарная парадигма формирования транспрофессионализма субъектов социономических профессий». 
Обобщая вышеизложенное, можно сделать вывод об актуальности исследуемой проблемы. Современному специалисту недостаточно быть профессионалом и обладать профессиональной компетентностью, в условиях изменчивости и развития современных технологий он должен быть способен к преадаптации, отличаться эмоциональным интеллектом, толерантностью к неопределенности, быть мобильным и отвечать предъявляемым требованиям, обладая при этом новой для профессионального общества характеристикой - транспрофессионализмом. Следует отметить, что нынешняя профессионально-образовательная подготовка на уровне и бакалавриата, и магистратуры ориентирована на массового обучающегося, тогда как формирование транспрофессионализма, по нашему мнению, всегда сопряжено с индивидуально выстраиваемой траекторией. Реализуемые сегодня подходы к построению профессиональных образовательных программ, учебных планов ориентированы на прошлое и пока не учитывают новых требований цифровой экономики и цифрового общества.

Понятие «транспрофессионализм» раскрывается в трудах П. Малиновского [1]. Согласно его научным изысканиям, транспрофессионализм можно описать как «коллективно-распределенную способность рефлексивно связывать и соорганизовывать представителей различных профессий для решения комплексных проблем» [Там же]. Ученый также предлагает понятие базовых транспрофессиональных компетенций, которые подразумевают «узкую специализацию в какой-то профессии, способности к межпрофессиональной коммуникации и трансдисциплинарному синтезу знаний, ориентацию на сочетание фундаментальных исследований с практическим решением проблем, навыки командной работы, постоянное саморазвитие и самосовершенствование, реальное и виртуальное вхождение в... профессиональные и транспрофессиональные сети» [2].

Сходное понимание феномена транспрофессионализма встречается в работах Г. Перкина [3], посвященных рассмотрению и анализу профессиональных революций. По мнению ученого, транспрофессионалы являются индикатором новой эпохи профессионализма, характеризующейся готовностью и способностью к работе в межпрофессиональных средах. При этом Г. Перкин считает, что 
транспрофессионалу не важна роль, которую он занимает в организационной структуре, самое главное для него - реализация поставленных задач. Также автор отмечает, что транспрофессионал не пользуется готовым алгоритмом действий или утвержденными стандартами, он свободно выбирает методы и техники, направленные на реализацию поставленных задач, а также максимально полно использует свое мышление, творческий потенциал.

Таким образом, П. Малиновский и Г. Перкин рассматривают транспрофессионализм как способность создавать, организовывать трансдисциплинарные команды с целью решения межотраслевых проблем.

Э. Ф. Зеер и Э.Э. Сыманюк определяют транспрофессионализм как «интегральное качество специалиста, характеризующее способность осваивать и выполнять деятельность из различных видов и групп профессий» [4, с. 13]. Следовательно, транспрофессионализм характеризуется непрерывным взаимопереходом из одного вида профессиональной деятельности в другой, из одной профессии в другую.

По мнению Е. А. Максимовой, транспрофессионал - это «специалист, готовый действовать на стыке профессиональных областей» [5, с. 83]. Таким образом, автор подчеркивает трансдисциплинарную направленность данного феномена.

Определение транспрофессиональной компетенции, отличное от предыдущих, представлено в работах И. Н. Лазаревой и Э. М. Габитовой, которые акцентируют внимание на образовательной подготовке транспрофессионала. Так, по мнению И.Н. Лазаревой, под транспрофессиональной компетенцией следует понимать «наличие знаний, умений и личностных качеств, способствующих выполнению профессиональной деятельности в различных отраслях» [6, с. 519].

Таким образом, транспрофессионализм можно определить как комплексную характеристику специалиста, означающую способность и готовность выполнять деятельность на стыке профессиональных областей, трансдисциплинарно рассматривать производственные проблемы, строить эффективную коммуникацию и междисциплинарное взаимодействие, осуществлять собственную 
профессиональную деятельность в быстро изменяющихся условиях внешней и внутренней среды организации.

В зависимости от методологических оснований и специфики профессиональной среды разные исследователи предлагают различные структуры и модели транспрофессионализма.

Так, Э. Ф. Зеер и Э.Э. Сыманюк, основываясь на концепции конвергенции технологий, на междисциплинарной основе и методологическом многомерном подходе, разработали логико-смысловую модель транспрофессионализма, состоящую из пяти компонентов $[7$, с. 73-75]:

1. Трансфессиональная направленность, ориентированная на освоение деятельности различных профессиональных областей и осуществление полученных знаний на практике. Данный компонент модели транспрофессиональной компетенции включает «Я-концепцию», социально-профессиональную адаптивность, многомерную идентичность, трансфессиональные ценностные ориентации, мотивацию профессиональной деятельности.

2. Регулятивный компонент представляет собой психологические ресурсы личности, связанные с организацией и регуляцией своей деятельности. Содержательными аспектами данного компонента являются самоорганизация, самоактуализация, самоэффективность, автономность и регуляция психических состояний.

3. Информационно-коммуникативный компонент рассматривает способность личности ориентироваться в информационной профессиональной среде и содержит такие характеристики специалиста, как социально-коммуникативная и профессиональная мобильность, толерантность к неопределенности, рефлексивность, перцептивная адекватность (аутокомпетентность).

4. Гуманитарно-технологический компонент обеспечивает синтез знаний из множества профессиональных областей и способствует построению индивидуальной траектории транспрофессионального развития; включает в себя социокультурную компетентность, трансдисциплинарные знания, когнитивные способности, социальный интеллект и рефлексивно-оценочную активность.

5. Межпрофессионально-образовательный компонент демонстрирует многомерность специалиста как необходимое качество 
транспрофессионала. Данный компонент представлен междисциплинарной компетентностью, метапрофессиональными качествами и ключевыми компетенциями (hard-soft-digital-competence). При этом авторы подчеркивают, что формирование soft-skills является приоритетным для развития транспрофессионализма.

Таким образом, данная логико-смысловая модель транспрофессионализма отражает существенные характеристики представленного понятия и позволяет не только оценить сформированность транспрофессионализма, но и разработать индивидуальную траекторию развития специалиста как транспрофессионала.

В научных изысканиях Э.Ф. Зеера, М. В. Зиннатовой, В. С. Третьяковой, Д. П. Заводчикова предлагается перечень транспрофессиональных компетенций и его последующая экспертная оценка. На основании теоретического анализа ФГОС 3++ программ магистратуры по разным направлениям профессиональной подготовки, Атласа новых профессий (Сколково), логико-смысловой модели транспрофессионализма субъекта профессиональной деятельности (Э.Ф. Зеер), целевой модели компетенций в цифровой экономике (М.В. Полевая), представлений о навыках и умениях будущего был сформирован перечень из 14 транспрофессиональных компетенций [8, с. 190-191]:

1. Способен осуществлять критический анализ проблемных ситуаций (ТК-1).

2. Способен применять системный подход к анализу объектов и ситуаций (ТК-2).

3. Способен управлять проектами и процессами (ТК-3).

4. Способен организовывать и руководить работой команды, вырабатывая командную стратегию для достижения поставленной цели (ТК-4).

5. Способен работать с коллективами, группами и отдельными людьми, выстраивать эффективное межличностное взаимодействие и общение (ТК-5).

6. Способен понимать и управлять своими эмоциями, определять эмоции других людей и влиять на них (ТК-6).

7. Способен управлять людьми, проявлять лидерские качества, принимать решения и нести ответственность за них (ТК-7). 
8. Способен анализировать и учитывать разнообразие культур в процессе межкультурного взаимодействия (ТК-8).

9. Способен к самоорганизации и саморазвитию, способен ставить цели и достигать их, способен к рефлексии (ТК-9).

10. Способен работать в режиме высокой неопределенности и быстрой смены условий задач (ТК-10).

11. Способен применять инновационные технологии (информационно-коммуникационные, программные средства, цифровые, коммуникативные) для профессионального взаимодействия (ТК-11).

12. Способен и мотивирован продолжать обучение в течение всей жизни, самостоятельно осваивать новые профессиональные знания и навыки (ТК-12).

13. Способен мыслить нестандартно и продуцировать новое, реализовать творческий подход к решению профессиональных задач (ТК-13).

14. Способен эффективно работать в условиях стресса и адаптироваться к изменениям (ТК-14).

На основе сформированных авторами транспрофессиональных компетенций можно выделить психологические факторы - компоненты транспрофессионализма, лежащие в его основе.

\section{Эмоциональный фактор:}

- способен осуществлять критический анализ проблемных ситуаций (ТК-1).

- способен понимать и управлять своими эмоциями, определять эмоции других людей и влиять на них (ТК-6).

\section{Регулятивный фактор:}

- современный специалист способен работать в режиме высокой неопределенности и быстрой смены условий задач (ТК-10);

- способен и мотивирован продолжать обучение в течение всей жизни, самостоятельно осваивать новые профессиональные знания и навыки (ТК-12);

- способен эффективно работать в условиях стресса и адаптироваться к изменениям (ТК-14).

\section{Лидерский фактор:}

- способен управлять проектами и процессами (ТК-3); 
- способен организовывать и руководить работой команды, вырабатывая командную стратегию для достижения поставленной цели (ТК-4);

- способен управлять людьми, проявлять лидерские качества, принимать решения и нести ответственность за них (ТК-7).

Коммуникативный фактор:

- способен работать с коллективами, группами и отдельными людьми, выстраивать эффективное межличностное взаимодействие и общение (ТК-5);

- способен анализировать и учитывать разнообразие культур в процессе межкультурного взаимодействия (ТК-8).

\section{Социально-профессиональный фактор:}

- способен применять системный подход к анализу объектов и ситуаций (ТК-2);

- способен к самоорганизации и саморазвитию, способен ставить цели и достигать их, способен к рефлексии (ТК-9);

- способен работать в режиме высокой неопределенности и быстрой смены условий задач (ТК-10);

- способен применять инновационные технологии (информационно-коммуникационные, программные средства, цифровые, коммуникативные) для профессионального взаимодействия (ТК-11);

- способен мыслить нестандартно и продуцировать новое, реализовать творческий подход к решению профессиональных задач (ТК-13);

- способен эффективно работать в условиях стресса и адаптироваться к изменениям (ТК-14).

В итоге выделим сущностные признаки транспрофессионализма:

- психологическая природа - индивидуально-психологические особенности личности, благодаря которым личность эффективно осуществляет свою деятельность;

- функциональный признак - транспрофессионализм позволяет сорганизовать специалисту имеющиеся у него междисциплинарные знания, а также сорганизовывать деятельность специалистов других областей посредством такого личностного качества, как лидерство; 
- результативный признак - транспрофессионализм проявляется в решении комплексных проблем, требующих знаний, умений и навыков специалистов различных областей.

Проведенный теоретический анализ позволил определить цель исследования, представляемого в данной статье: выявление и описание психологических характеристик транспрофессиональных компетенций специалистов. Фокус исследования был смещен на ТК-4, ТК-5, ТК-6, ТК-7, ТК-9, ТК-10, ТК-14.

Объект исследования: транспрофессионализм.

Предмет исследования: транспрофессиональные компетенции как составляющие транспрофессионализма.

Изначально была выдвинута гипотеза, заключающаяся в том, что статистически значимых различий в уровне выраженности транспрофессиональных компетенций, как составляющих транспрофессионализма, у работников социономических и технономических профессий не существует.

Теоретико-методологическая основа исследования: методологические основания исследования транспрофессионализма (Э. Ф. Зеер, П. В. Малиновский, Э.Э. Сыманюк и др.) и транспрофессиональных компетенций (Э. М. Габитова, Э. В. Галажинский, Э. Ф. Зеер, М.В. Зиннатова, В.С. Третьякова), концепции профессионального становления личности и личностно-ориентированного профессионального образования (Э.Ф. Зеер, Е. А. Климов, А. К. Маркова, Э.Э. Сыманюк), исследования психологии профессионализма (Т. Ю. Базаров, М. А. Дмитриева, С. А. Дружилов, В. П. Малиновский), подход к классификации профессий (В.Е. Гаврилов), деятельностный подход (А.Н. Леонтьев).

Методы исследования: теоретический анализ, опросный метод, методы математико-статистического анализа (описательный анализ, сравнительный анализ), методы интерпретации. Для упорядочения и сортировки данных использовалась программа Excel, для количественной обработки данных - программа SPSS 22.

Исследование проводилось во ФГАОУ ВО «Российский государственный профессионально-педагогический университет» и ФГАОУ ВО «Уральский федеральный университет имени первого Президента России Б. Н. Ельцина». Эмпирическую выборку составили 
студенты-магистранты, представители социономических (29 человек) и технономических (45 человек) групп профессий, обучающиеся по направлениям 44.04.02 «Психолого-педагогическое образование» (14 человек), 37.04.01 «Психология» (15 человек), 13.04.02 «Электроэнергетика и электротехника» (45 человек), в возрасте от 22 до 54 лет. Совокупная выборка исследования составила 74 человека.

Участникам предлагались следующие методики:

1. Тест на самооценку стрессоустойчивости личности (Н. В. Киршева, Н. В. Рябчикова).

2. Опросник эмоционального интеллекта «ЭМИН» (Д.В. Люсин).

3. Методика «Диагностика лидерских качеств» (Е. Жариков, Е. Крушельницкий).

4. Методика «Коммуникативные и организаторские склонности» (В. В. Синявский, В. А. Федорошин).

5. Диагностика рефлексивности (А. В. Карпов).

6. Тест «Командные роли» (Р. М. Белбин).

7. Опросник толерантности-интолерантности к неопределенности (Т. В. Корнилова).

8. Многоуровневый личностный опросник «Адаптивность» (А. Г. Маклаков, С. В. Чермянин).

9. Опросник самоорганизации деятельности (Е. Ю. Мандрикова).

В результате оценки показателей асимметрии и эксцесса в подвыборках выявлено, что распределение эмпирических показателей отличается от нормального. Следовательно, с целью подтверждения/ опровержения исследовательской гипотезы, в ходе сравнения двух независимых выборок использовался непараметрический $U$-критерий Манна - Уитни.

Для изучения транспрофессионализма был проведен сравнительный анализ выраженности транспрофессиональных компетенций специалистов по разным группам профессий (социономические и технономические), по результатам которого не обнаружилось ни одного значимого различия (уровень значимости показателей (p) по всем шкалам применяемых методик в пределах 0,604-0,973).

Данный результат подтверждает теоретические изыскания ученых в области транспрофессионализма. Так, к примеру, согласно 
В.С. Третьяковой, транспрофессиональные компетенции обладают рядом существенных характеристик:

«- являются базовыми для любых видов профессии;

- обеспечивают продуктивность различных видов деятельности независимо от сферы профессиональных интересов;

- обеспечивают такие качества специалиста, как многофункциональность, многозадачность, социально-профессиональная мобильность, синергичность;

- включают широкий спектр аналитических, коммуникативных, прогностических способностей;

- позволяют успешно адаптироваться в разных социальных и профессиональных сообществах;

- задают вектор для определения специальных компетенций» [9, с. 289].

Следовательно, транспрофессиональные компетенции не должны отличаться у представителей разных групп профессий.

Таким образом, гипотеза о том, что статистически значимых различий в уровне выраженности транспрофессиональных компетенций, как составляющих транспрофессионализма, у работников социономических и технономических профессий не существует, подтвердилась.

На основе результата сравнительного анализа при описании психологических характеристик транспрофессиональных компетенций были использованы данные совокупной выборки без разделения участников на представителей социономических и технономических профессий.

Исходя из результатов дескриптивной статистики, можно констатировать, что у большинства респондентов лидерские качества выражены достаточно сильно $\left(\bar{x}=39,43, M o=28 ; m_{e}=28\right)$. Это значит, что участники исследования готовы брать на себя ответственность за принятие групповых решений и проявлять активность и инициативность в профессиональной деятельности.

По результатам описательной статистики (тест «Командные роли») установлено следующее (рис. 1):

- для большинства участников исследования характерна командная роль «Председатель» $\left(\bar{x}=11,88 ;\right.$ Mo $\left.=14 ; m_{e}=12\right)$ : они спо- 
собны ясно формулировать цели, продвигать решения, делегировать полномочия, способны организовать работу команды и использовать ресурсы в соответствии с групповыми целями;

- также отмечается приверженность командной роли «Доводчик» $\left(\bar{x}=11,20 ; M o=10 ; m_{e}=10\right)$ : участники ориентированы на выполнение обязательств и меньше интересуются эффектным и громким успехом; склонны к достижению совершенства во всем, за что они берутся, и непреклонны в достижении намеченного. К слабым сторонам данной роли следует отнести недостаточную гибкость, в результате чего порой тратится слишком много сил на достижение поставленных целей, которые при изменившихся обстоятельствах оказываются недостижимыми;

- у наименьшего количества участников исследования выражена командная роль «Мыслитель» $\left(\bar{x}=3,7 ; M o=4 ; m_{e}=3\right)$. Данная роль характеризуется интровертированностью. Это яркие представители интеллектуалов-одиночек, и они часто воспринимаются членами команды как не слишком коммуникабельные. Мыслители чаще встречаются в новых, только формирующихся компаниях, поскольку по складу своему они скорее предприниматели, чем менеджеры.

Для большинства респондентов характерен средний уровень стрессоустойчивости $\left(\bar{x}=11,20 ; M o=10 ; m_{e}=10\right)$ : участники способны управлять своими эмоциями, сохраняя при этом высокую работоспособность.

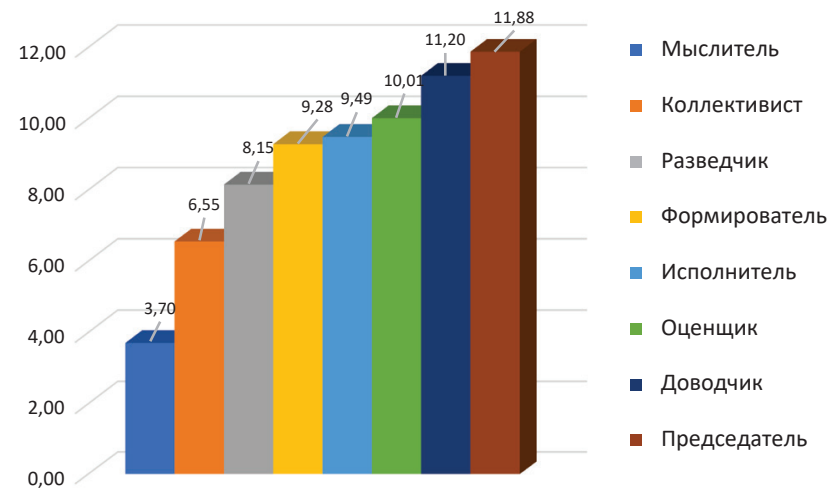

Рис. 1. Гистограмма выраженности командных ролей $(\bar{x})$ 
Рефлексивность $\left(\bar{x}=5,6 ; M o=5 ; m_{e}=5,5\right)$ у большинства респондентов находится на среднем уровне выраженности: участники склонны к самоанализу в профессиональной деятельности, мобилизации личностных ресурсов.

У большинства участников преобладает способность понимать эмоциональное состояние другого человека на основе внешних проявлений (жесты, мимика, тембр голоса), они умеют вызывать у других людей те или иные эмоции, снижать интенсивность нежелательных эмоций (межличностный эмоциональный интеллект: $\bar{x}=51,4$; $\left.M o=51 ; m_{e}=51\right)$; также в достаточной степени участники способны к осознанию своих эмоций, поддержанию желательных и контролю нежелательных эмоций, управлению внешними проявлениями своих эмоций (внутриличностный эмоциональный интеллект: $\bar{x}=47,68$; $\left.M o=47 ; m_{e}=47\right)$. Данные результаты отражены на рис. 2 .

У большинства участников толерантность к неопределенности выражена на уровне выше среднего $\left(\bar{x}=57,58 ; M o=55 ; m_{e}=54\right)$, что указывает на их готовность действовать в ситуации отсутствия четких ориентиров, способность учитывать влияние разных факторов в процессе выполнения деятельности, готовность к творчеству, импровизации и экспериментам. Закономерно, что участники исследования показали низкий уровень интолерантности к неопреде-

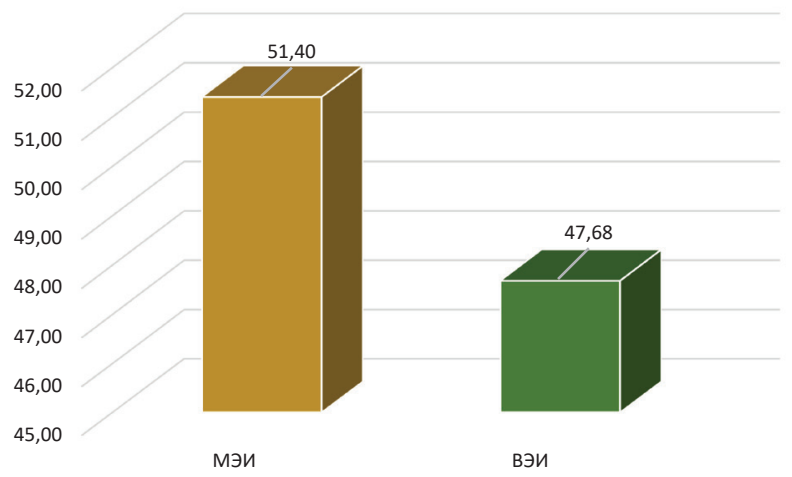

Рис. 2. Гистограмма выраженности эмоционального интеллекта:

МЭИ - межличностный эмоциональный интеллект;

ВЭИ — внутриличностный эмоциональный интеллект $(\bar{x})$ 
ленности $\left(\bar{x}=39,22 ; M o=40 ; m_{e}=39\right)$, аналогично и межличностная интолерантность к неопределенности слабо выражена $(\bar{x}=22,00$; $\left.M o=23 ; m_{e}=22\right)$. Данные результаты отражены на рис. 3 .

Большинство респондентов стараются не ограничивать круг знакомых людей, в процессе общения отстаивают свою позицию, им свойственны коллективизм, коммуникативная активность $(\bar{x}=10,50$; $\left.M o=4 ; m_{e}=11\right)$. Средние значения организаторских склонностей большинства участников $\left(\bar{x}=12,27 ; M o=13 ; m_{e}=13\right)$ указывают на то, что они способны вовлекать членов команды в процесс принятия решения, делегировать полномочия и определять зону ответственности своей команды. Описанные результаты отражены на рис. 4.

Дескриптивный анализ данных адаптивности продемонстрировал следующие результаты:

- у участников исследования высокий уровень нервно-психической устойчивости и поведенческой регуляции, для них характерна высокая адекватная самооценка, реальное восприятие действительности и устойчивое эмоциональное состояние (нервнопсихическая устойчивость: $\left.\bar{x}=30,99 ; M o=12 ; m_{e}=34\right)$;

- респонденты не ограничивают круг знакомых людей, в процессе общения отстаивают свою позицию, им свойственны коллек-

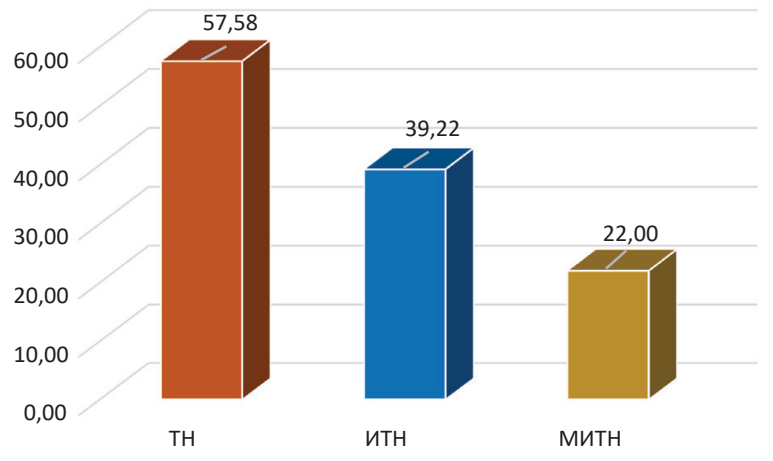

Рис. 3. Гистограмма выраженности

толерантности-интолерантности к неопределенности $(\bar{x})$ : ТН - толерантность к неопределенности; ИТН - интолерантность к неопределенности; МИТН - межличностная интолерантность к неопределенности 
тивизм, коммуникативная активность (коммуникативные особенности: $\left.\bar{x}=14,22 ; M o=13 ; m_{e}=14,50\right)$;

- участники вполне реально оценивают свою роль в коллективе, ориентируется на соблюдение общепринятых норм поведения, что является весьма важным компонентом для продуктивной деятельности и межличностного общения (моральная нормативность: $\left.\bar{x}=8,96 ; M o=10 ; m_{e}=9\right)$;

- адаптивные способности у большинства участников на среднем уровне выраженности $\left(\bar{x}=54,16 ; M o=31 ; m_{e}=58,50\right)$, и успех адаптации специалиста может зависеть от внешних условий окружающей среды.

Результаты представлены на рис. 5.

Результаты анализа самоорганизации деятельности показывают, что большинство участников имеет высокие и средние баллы (рис. 6). Высокий общий суммарный балл характеризует респондентов как способных видеть и ставить цели, планировать свою деятельность, в том числе с помощью внешних средств, и, проявляя волевые качества и настойчивость, идти к ее достижению, что иногда может приводить к негибкости и «зацикленности» на структурированности и организованности.

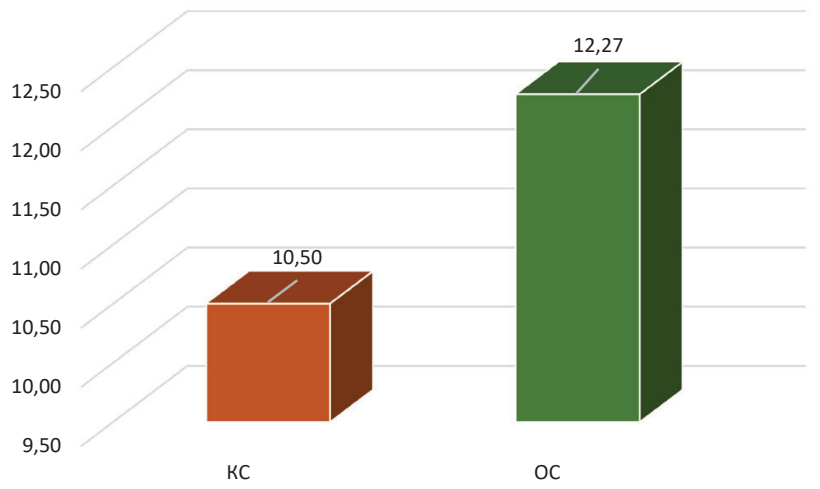

Рис. 4. Гистограмма выраженности коммуникативных и организаторских склонностей $(\bar{x})$ :

КС - коммуникативные склонности; ОС - организаторские склонности 
Эмпирические результаты позволяют составить обобщенную актуальную психологическую характеристику транспрофессиональных компетенций специалистов (см. таблицу).

Подводя итоги, следует заметить, что у большинства участников исследования в отношении развития транспрофессиональных

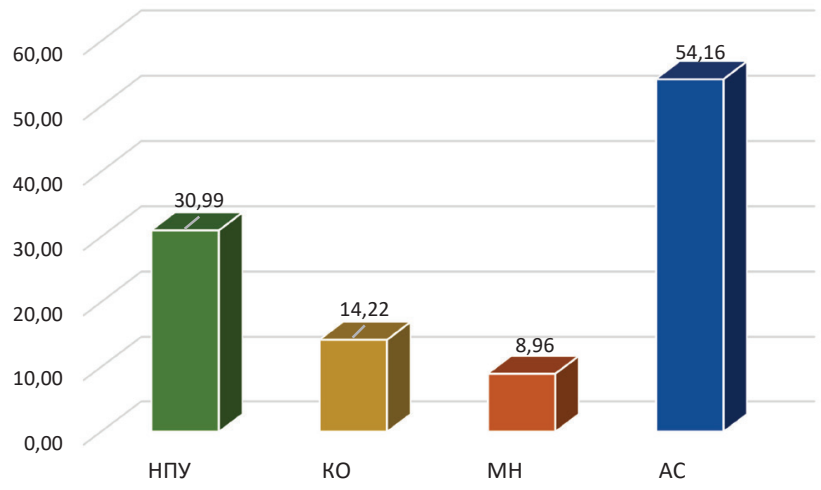

Рис. 5. Гистограмма выраженности адаптивных способностей $(\bar{x})$ :

НПУ - нервно-психическая устойчивость; КО - коммуникативные особенности; МН - моральная нормативность; АС - адаптивные способности

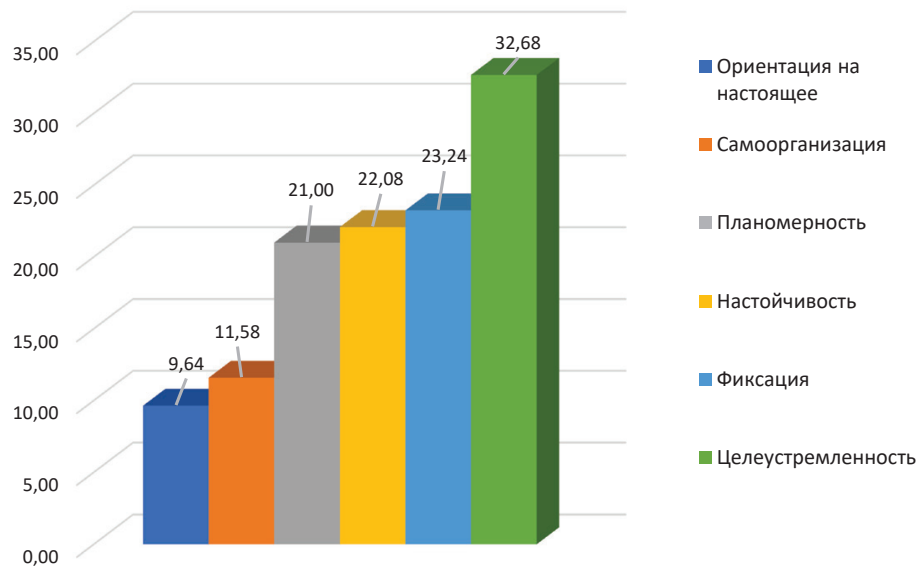

Рис. 6. Гистограмма выраженности самоорганизации деятельности $(\bar{x})$ 
компетенций достаточно благоприятная ситуация. Возможно, стоит предпринять усилия для повышения уровня развития таких компетенций, как ТК-5, ТК-9, ТК-14. Однако данные показатели являются, на наш взгляд, не результатом реализации специальным образом выстроенных образовательных программ магистратуры, a, скорее, были сформированы субъектами в процессе выполнения профессиональной деятельности.

Психологическая характеристика транспрофессиональных компетенций специалистов (на примере магистрантов - представителей социономических и технономических групп профессий)

\begin{tabular}{|c|c|c|}
\hline № & $\begin{array}{c}\text { Транспрофессиональная } \\
\text { компетенция }\end{array}$ & $\begin{array}{l}\text { Психологическая характеристи- } \\
\text { ка участников исследования }(\bar{x})\end{array}$ \\
\hline \multicolumn{3}{|c|}{ Эмоциональный фактор } \\
\hline TK-6 & $\begin{array}{l}\text { Способен понимать и управлять } \\
\text { своими эмоциями, определять } \\
\text { эмоции других людей и влиять } \\
\text { на них }\end{array}$ & $\begin{array}{l}\text { Развитый межличностный } \\
\text { и внутриличностный эмоцио- } \\
\text { нальный интеллект }\end{array}$ \\
\hline \multicolumn{3}{|c|}{ Регулятивный фактор } \\
\hline TK-10 & $\begin{array}{l}\text { Способен работать в режиме } \\
\text { высокой неопределенности } \\
\text { и быстрой смены условий задач }\end{array}$ & $\begin{array}{l}\text { Выраженная толерантность } \\
\text { к неопределенности }\end{array}$ \\
\hline ТК-14 & $\begin{array}{l}\text { Способен эффективно работать } \\
\text { в условиях стресса и адаптиро- } \\
\text { ваться к изменениям }\end{array}$ & Средний уровень адаптивности \\
\hline \multicolumn{3}{|c|}{ Лидерский фактор } \\
\hline TK-4 & $\begin{array}{l}\text { Способен организовывать } \\
\text { и руководить работой команды, } \\
\text { вырабатывая командную стра- } \\
\text { тегию для достижения постав- } \\
\text { ленной цели }\end{array}$ & $\begin{array}{l}\text { Ориентация на командную } \\
\text { работу, выполнение взятых } \\
\text { обязательств и достижение } \\
\text { цели; умеренная степень выра- } \\
\text { женности коммуникативной } \\
\text { активности и организаторских } \\
\text { склонностей }\end{array}$ \\
\hline ТК-7 & $\begin{array}{l}\text { Способен управлять людьми, } \\
\text { проявлять лидерские качества, } \\
\text { принимать решения и нести } \\
\text { ответственность за них }\end{array}$ & $\begin{array}{l}\text { Выраженные лидерские каче- } \\
\text { ства }\end{array}$ \\
\hline
\end{tabular}


Окончание табл.

\begin{tabular}{|c|c|c|}
\hline № & $\begin{array}{c}\text { Транспрофессиональная } \\
\text { компетенция }\end{array}$ & $\begin{array}{l}\text { Психологическая характеристи- } \\
\text { ка участников исследования }(\bar{x})\end{array}$ \\
\hline \multicolumn{3}{|c|}{ Коммуникативный фактор } \\
\hline TK-5 & $\begin{array}{l}\text { Способен работать с коллекти- } \\
\text { вами, группами и отдельными } \\
\text { людьми, выстраивать эффек- } \\
\text { тивное межличностное взаимо- } \\
\text { действие и общение }\end{array}$ & $\begin{array}{l}\text { Умеренная степень выра- } \\
\text { женности коммуникативной } \\
\text { активности и организаторских } \\
\text { склонностей }\end{array}$ \\
\hline \multicolumn{3}{|c|}{ Социально-профессиональный фактор } \\
\hline TK-9 & $\begin{array}{l}\text { Способен к самоорганизации } \\
\text { и саморазвитию, способен } \\
\text { ставить цели и достигать их, } \\
\text { способен к рефлексии }\end{array}$ & $\begin{array}{l}\text { Высокий уровень самооргани- } \\
\text { зации при средней выраженно- } \\
\text { сти рефлексивности }\end{array}$ \\
\hline TK-10 & $\begin{array}{l}\text { Способен работать в режиме } \\
\text { высокой неопределенности } \\
\text { и быстрой смены условий задач }\end{array}$ & $\begin{array}{l}\text { Выраженная толерантность } \\
\text { к неопределенности }\end{array}$ \\
\hline TK-14 & $\begin{array}{l}\text { Способен эффективно работать } \\
\text { в условиях стресса и адаптиро- } \\
\text { ваться к изменениям }\end{array}$ & $\begin{array}{l}\text { Умеренно выраженные стрессо- } \\
\text { устойчивость и адаптивность }\end{array}$ \\
\hline
\end{tabular}

Полученные результаты могут стать основой для разработки инновационных программ магистерской подготовки, модернизации непрерывного и внедрения опережающего образования, организации психолого-педагогического сопровождения профессиональнообразовательного процесса в условиях становления цифровой экономики и цифровой индустриализации России.

Вместе с тем проведенное исследование имеет ограничения: анализ усредненных значений индикаторов транспрофессиональных компетенций, возможно, привел к исключению из исследования «крайних случаев». Также фокус исследования был смещен на компетенции ТК-4, ТК-5, ТК-6, ТК-7, ТК-9, ТК-10, ТК-14. Однако данные условия не снижают значимости исследования, представленного в статье, и существенно обогащают научные данные о способах определения выраженности транспрофессиональных компетенций, факторах транспрофессионализма личности, о психологической сущности транспрофессиональных компетенций. 
1. Малиновский П. Вызовы глобальной профессиональной революции на рубеже тысячелетий [Электронный ресурс] // Российское экспертное обозрение. 2007. № 3. URL: http://www.protown.ru/information/articles/3344. html (дата обращения: 28.08.2020).

2. Малиновский П. Транспрофессионализм как критерий эффективности управления человеческим потенциалом [Электронный ресурc]. URL: http://www.shkp.ru/lib/actions/ss/malinovsky/publications/1 (дата обращения: 28.08.2020).

3. Авраамова Е. М., Верлаховская Ю. Б. Работодатели и выпускники вузов на рынке труда: взаимные ожидания // Социол. исслед. 2006. № 4. C. 37-46.

4. Зеер Э. Ф., Сыманюк Э. Э. Методологические ориентиры развития педагогов профессионального образования // Образование и наука. 2017. 19 (8). C. 9-28.

5. Максимова Е. А. Холдинг-современная утопия в профессиональном образовании? // Наука и общество. 2014. № 7 (16). С. 80-85.

6. Лазарева И.Н. Транспрофессиональные компетенции в иноязычном образовании: от идеи к технологии // Современные наукоемкие технологии. 2015. № 12 (3). С. 517-520.

7. Зеер Э. Ф., Сыманюк Э. Э. Психология развития транспрофессионализма : монография. Екатеринбург : Юника, 219. 174 с.

8. Зеер Э. Ф., Зиннатова М.В., Третьякова В. С., Заводчиков Д. П. Исследование состава и содержания транспрофессиональных компетенций субъектов социономических профессий [Электронный ресурс] // Мир образования - Образование в мире. 2019. № 4 (76). С. 181-199. URL: https:// www.mpsu.ru/upload/iblock/1ea/1 eacla1d1cbb39f62317e0506c38a418.pdf\#2 (дата обращения: 28.08.2020).

9. Третьякова В.С. Транспрофессионализм: проблемы и пути решения // Транспрофессионализм как предиктор социально-профессиональной мобильности молодежи : материалы Всерос. (с междунар. участием) науч.практ. конф. Н. Тагил, 2019. С. 287-291. 


\section{ПОСТНЕКЛАССИЧЕСКАЯ ПАРАДИГМА В ОБРАЗОВАНИИ: ВОЗМОЖНОСТИ И ОГРАНИЧЕНИЯ}

Л. В. Карапетян

Инновационный путь развития современного общества задает траекторию поступательного движения во всех отраслях науки, но в первую очередь в тех, которые связаны с изучением человека и социума. Смена парадигмы в педагогике, появление новых информационных и телекоммуникационных технологий, повышение требований к профессиональному и личностному потенциалу человека, его адаптивности, мобильности, жизнестойкости, скорости усвоения информации неизбежно сказываются на функционировании системы образования. В связи с этим новые идеи, прогрессивные проекты и новации, внедряемые в образовании, проходят серьезнейшую научную экспертизу, являются результатом интеграции теории и практики, основываются на прочном фундаменте мировой науки с учетом актуального этапа ее развития.

В своей периодизации развития науки В.С. Степин выделяет три этапа, соответствующие трем видам рациональности: классический, неклассический и постнеклассический $[1,2]$. При этом автор отмечает, что возникновение нового типа рациональности и нового образа науки не приводит к полному исчезновению представлений и методологических установок предшествующего этапа: «Напротив, между ними существует преемственность. Неклассическая наука вовсе не уничтожила классическую рациональность, а только ограничила сферу ее действия. При решении ряда задач неклассические представления о мире и познании оказывались избыточными, и исследователь мог ориентироваться на традиционно классические образцы (например, при решении ряда задач небесной механики не требовалось привлекать нормы квантово-релятивистского описания, а достаточно было ограничиться классическими нормативами исследования). Точно так же становление постнеклассической науки не приводит к уничтожению всех представлений и познавательных установок неклассического и классического исследования. Они будут использоваться в некоторых познавательных ситуациях, 
но только утратят статус доминирующих и определяющих облик науки» [2, с. 334]. И все же отметим принципиальные различия, характерные для каждого этапа науки и соответствующего ему вида рациональности.

Классическая рациональность, возникнув благодаря промышленному перевороту и как результат успехов в области естествознания, ориентирована на получение обезличенных знаний, представлений о реальной картине окружающей действительности, получаемых при помощи объективных методов. Классический тип научной рациональности выделяет и исследует простые объекты, центрируя внимание на получении объективно-истинного знания о мире. Цели и приоритеты науки при этом обусловлены доминирующими в культуре мировоззрением и ценностями. Но классическая наука, концентрируясь на результатах, не рефлексирует эти детерминации. Образование в период классического развития ориентировано на развитие классического мышления, которое понимается как линейная цепочка рассуждений, как дедуктивноаксиоматический метод изложения.

Особенностями неклассической рациональности стали персонифицированное знание, осознание детерминации результатов методом их получения, стремление преодолеть разделение категорий «объект» и «субъект», понимание исторической каузальности науки. В отличие от классической науки, изучающей простые системы, неклассическая наука ориентирована на постижение сложных, саморегулирующихся систем. На неклассической стадии своего становления образование расценивается как процесс, направленный на развитие обучающегося как индивидуальности, творческой, уникальной личности. Неклассическая наука оценивает универсальные образовательные системы как неэффективные и основное внимание учителей направляет на разработку педагогических приемов, позволяющих учитывать самобытность личности каждого обучающегося и особенности социокультурного контекста, что приводит к отождествлению обучения и воспитания. Неклассическая рациональность диктует необходимость перестройки образования таким образом, чтобы оно соответствовало актуальным интересам социума и человека, чтобы создавало условия для построения каждым 
обучающимся жизненной перспективы, нахождения своего места в планируемой реальности, которое в максимально возможной степени отвечало бы его потребностям, способностям и возможностям. В рамках неклассической педагогики обучающийся уже не рассматривается исключительно как объект педагогического воздействия со стороны преподавателя, отношения в этой диаде выстраиваются как сотрудничество, взаимодействие, диалог и полилог. При этом ученик из пассивного объекта педагогического воздействия становится активным участником образовательного процесса, имеющим свою систему установок, интересов и направленностей. Знание, приобретаемое в процессе образования, не просто усваивается, а присваивается, становится «личностным», продуманным и прочувствованным, соотнесенным с приоритетами обучающегося, с его представлениями о возможности применения полученного знания для себя, других людей, природы, общества, государства, всего мира.

А. Г. Маджуга, И. А. Синицина подчеркивают, что «...радикальное различие между классической и неклассической наукой заключается в убеждении первой, что изучаемые явления суть фрагменты “самого мира”. В то же время неклассическая наука отдает себе отчет в том, что исследование (эмпирическое или теоретическое) всегда имеет дело не с “самим миром”, а с его моделированным отражением в сознании и акцентирует внимание на рефлексивной реконструкции предпосылок полученной модели» [3, с. 13].

Принципиально иная картина мира открывается при восприятии реальности на постнеклассическом этапе развития науки. М. С. Гусельцева отмечает, что при этом «...постнеклассическая “парадигма” не вытесняет неклассическую, а находит ей достойное место в сети знания. Более того, вряд ли возможно найти неклассическую и постнеклассическую рациональность в психологических концепциях в чистом виде: это скорее “идеальные типы”, нежели реальности» $[16$, с. 12]. Тем не менее проанализируем специфические особенности поснеклассического типа рациональности.

Поскольку постнеклассическая рациональность проявляет себя во всех сферах жизнедеятельности - в области экономики, политики, права, в искусстве, религии и т.д., постнеклассический период развития науки связан с критическим переосмыслением конкретных 
областей знания и научных дисциплин, поиском их места в целостной картине научного мира, в научно-практическом ландшафте, постижением новых смыслов, обнаружением иных возможностей толкования и интерпретации имеющихся фактов и результатов исследования. Поэтому постнеклассический этап особо важен для наук, связанных с изучением человека. В настоящее время неклассическая методология еще не исчерпала свой потенциал и эффективность в пределах своей научной рациональности, и новая постнеклассическая методология, безусловно, учитывает ее определенные регулятивы, но вместе с тем отличается от нее по двум основным параметрам: объекту и типу рациональности. В отношении объекта постнеклассическая наука отличается тем, что ориентирована на исследование не только сложноорганизованных систем, но в качестве приоритетного направления постулирует сверхсложные многомерные открытые системы, способные к самоорганизации. В отношении второго параметра постнеклассическая наука отличается от неклассической тем, что соотносит знания об объекте не только с методами его познания, но и с ценностно-целевыми компонентами деятельности по его познанию $[1,2]$. То есть признание влияния ценностных факторов на получаемые в процессе познания результаты, на специфику сконструированных объяснительных моделей - еще один важный признак постнеклассической науки. Безусловно, этот признак относится и к психологии: «...внесение ценностного компонента в психологические теории отражает не столько специфику гуманитарной парадигмы в психологии, сколько связь их с общим изменением подходов к пониманию человека и его места в мире в период постнеклассической науки...» [4, с. 429-430].

В области педагогики классический и неклассический методологические подходы, безусловно, продолжают сохранять свои позиции, однако постнеклассический подход получает все большее развитие. Ориентация педагогики на постнеклассическую рациональность диктует необходимость обратить внимание руководителей всех уровней системы образования и рядовых педагогов не только на изменения, касающиеся внешнего функционирования человека и общества, но и на более глубинные трансформации, относящиеся к личностному развитию обучающихся. 
В первую очередь изменения касаются ценностно-смысловой cøеры. Поскольку на сегодняшний день размыты базовые ценности, утрачена точка отсчета, задающая ценностно-смысловые ориентиры, критерии оценки правильности или неправильности ценностей, в обществе возрастает плюрализм, инакомыслие, критичность. То, что раньше расценивалось как незыблемое, единственно правильное и непреложное, сегодня оспаривается и ставится под сомнение. Это проявляется как на уровне общества в целом, так и на уровне отдельного человека. Все большее количество людей характеризуется несформированностью системы ценностей, ее нестабильностью, непредсказуемостью, стихийностью, дезинтеграцией, утратой смысла жизни, потерей ориентиров, подверженностью случайным влияниям. У многих современных школьников сформированы ошибочные представления о допустимом и недопустимом, нравственности и безнравственности, корысти и безвозмездной помощи, добре и зле, милосердии и жестокости, прощении и наказании, правде и лжи и т. д. Вместе с тем именно образовательная среда в лице педагогов с их личной системой ценностно-смысловых ориентаций, мировоззрением, нравственными ориентирами способна оказывать значительное позитивное воздействие на процесс формирования ценностно-смысловой сферы всех субъектов системы образования.

Также претерпели изменения все аспекты мотивационной сбеpы учащихся, в том числе и их познавательная мотивация. Именно мотивы ученые считают побудительным стимулом осуществления любой деятельности, в том числе и учебной. И если при классической и неклассической модели образования функцию формирования положительной мотивации к обучению выполнял педагог, то постнеклассическая модель предполагает в качестве движущих факторов учебной деятельности умение самих обучающихся учиться, находить, обрабатывать и интерпретировать информацию, наличие у них навыков осознанного и целенаправленного обучения, сформированность познавательной активности, т.е. развитую самомотивацию. Функцией педагога при этом является создание условий для развития у обучающихся самомотивации, осознанной саморегуляции учебной деятельности, увлеченности учебным про- 
цессом, стремления к познанию нового, получения опыта освоения многообразной событийно-познавательной образовательной среды, опыта достижения учебных и личных задач. Создание таких условий позволит обеспечить не только соответствующую современным вызовам целостную и непротиворечивую мотивационную структуру учащихся, но и их психологическое благополучие в образовательной среде.

Пристальное внимание ученых вызывают изменения, коснувшиеся интеллектуальной сферь, поскольку именно интеллектуально развитые граждане, создатели и носители новой уникальной информации, способны обеспечить конкурентоспособность государства. Интеллектуальное саморазвитие учащихся, формирование нестандартного, индивидуального образа мышления становятся одной из актуальных проблем образования, педагогической науки и практики на постнеклассическом этапе развития науки. Интеллектуальное саморазвитие ученые считают одним из приоритетных процессов учебной деятельности, признают неоспоримость его влияния на повышение качества образования. К сожалению, в системе традиционного образования школьников линия, направленная на интеллектуальное саморазвитие, не просматривается, возможно, в силу того, что педагогами эта линия понимается как передача ответственности за успеваемость школьникам и их родителям.

Существенные изменения произошли в структуре волевой сферы субъектов образовательной среды. В связи с увеличением направлений деятельности, эффективность которых определяет постоянная изменчивость, спонтанность человека, быстрота его реакций, вовлеченность, эмерджентность, несовпадение с традициями и стереотипами, необходимость в волевой саморегуляции и способность к ней отходят на второй план. Тогда как именно в образовательном пространстве необходимо создавать условия для формирования личностно-регуляторных структур обучающихся, обеспечивающих повышение личностной активности и ответственности в учебной и социальной видах деятельности. Целенаправленное систематическое позитивное воздействие на компоненты волевой сферы учащихся детерминирует формирование у них готовности и умения ставить цели и проектировать пути их достижения, брать на себя 
ответственность за результаты собственной деятельности, изживать установку на беспомощность и виктимность, распознавать и преодолевать конформизм, прокрастинацию, проявлять инициативу в принятии личностно важных решений, использовать конструктивные стратегии самоутверждения, не бояться выходить из зоны комфорта.

Эмоциональную сферу современного человека, в том числе и как субъекта образовательного процесса, характеризует преобладание тревожности, депрессивности, апатии. В образовательной среде должны быть заложены условия для оптимального развития эмоциональной сферы, что является непременным условием психологического здоровья всех участников образовательного процесса и обеспечения их психологической безопасности. Тогда как зачастую психологические риски образовательной среды (со стороны педагогов: низкая мотивация к профессиональной деятельности, профессиональное выгорание, недостаточный уровень психологической культуры и грамотности, использование неэффективных и опасных психолого-педагогических технологий, со стороны сверстников: преобладание неэффективных стилей межличностного взаимодействия, повышенная конфликтность, булинг; со стороны родителей: применение неэффективных стилей взаимодействия, игнорирование возрастных закономерностей развития и др.) оказывают отрицательное воздействие на внутреннее благополучие обучающихся, приводят к преобладанию негативных переживаний в их эмоциональной структуре, к оценке образовательной среды как небезопасной, разрушают сохранность и целостность их психической организации.

Изменения коснулись и соииальной сферь. Это изменения в содержании, характере общения, в процессе построения отношений между людьми и структуре их взаимодействия, что проявляется в нарастании отчужденности, изолированности, дистанцировании, безучастности людей, их равнодушии друг к другу, снижении уровня межличностной эмпатии при общей формализации отношений. Существенно изменилось и положение человека в семье. С одной стороны, семья перестала восприниматься как место психологической безопасности. С другой стороны, изменилась роль и функции 
семьи. Снизилась ее значимость как социальной ценности и социального института. Произошло перекладывание полномочий воспитания и социализирующего предназначения семьи на государство и систему образования. Однако необходимо помнить, что именно интеграция образовательной среды и института семьи способна обеспечить формирование необходимых социально-личностных компетенций обучающихся. Важно также отметить, что образовательная система придает большое значение в получении результатов образовательного процесса активности самих обучающихся. В ее тезарус прочно вошли такие понятия, как «межличностное взаимодействие», «субъект образования», «обучающийся», которые подчеркивают личностное развитие учащихся как основную функцию системы образования, а общение, взаимодействие, совместную деятельность всех субъектов образования как основной инструмент реализации данной функции.

Для системы образования свойственны изменения не только общего характера (касающиеся людей в целом), но и специфические, касающиеся непосредственно субъектов образовательного процесса. Так, в последнее время существенно возрос объем информации, необходимой для усвоения учебных программ, при этом намного увеличилась доступность информации. Это привело к потере школой роли монополиста как источника знаний и постепенной утрате роли посредника в передаче информации. Консервативность, ригидность и маломобильность системы образования детерминируют тот неоспоримый факт, что знания и разрабатываемые технологии стремительно устаревают, теряют актуальность, иногда это происходит раньше, чем педагоги успевают их не только внедрить в профессиональную деятельность, но даже апробировать. Более того, образование стремительно теряет позиции в плане формирования и поддержания мотивации к учению. Социальные сети, видеосервисы, игры выступают мощным конкурентом привлечения внимания учащегося. Сегодня средства обучения, предлагаемые интернетом, для ребенка зачастую интереснее, чем обучение в школе. Образование, конечно, уже реагирует на требования окружающей действительности и меняется, становится более интерактивным, использует интернет-технологии, видео, игровые технологии, но все 
равно отстает как минимум на шаг, поскольку педагог в школе не готов быть проводником в мире информации, комментатором, помогающим обучающимся систематизировать уже полученную ими информацию. Вызов постнеклассической педагогики состоит в том, что учитель должен выступать как транслятор, посредник между человеком и культурой, понимающий свою посредническую миссию: «Тенденция развития педагогической мысли, определяющей практику образования, проходит по линии: “трансляционная педагогика” - “осмысленное учение” - “смысловая педагогика” “онтопедагогика”. За этой логикой развития скрывается смена “внутренних форм”, организующих мышление психологов и педагогов» [5, с. 12]. К сожалению, значительная часть современных педагогов по-прежнему претендует на то положение, которое сформировалось у них на этапах классического и неклассического развития педагогики, к которому привыкли, с которым сжились, срослись. А тем временем доверие к достоверности знания, получаемого от учителя, снижается, непреложные истины подвергаются сомнению - то, что сегодня ребенок читает в интернете, зачастую не совпадает с тем, что он слышит от учителя. Мало того, объем информации, предоставляемый интернетом, значительно превышает информационное поле, освоенное педагогом, и вопросы, задаваемые обучающимися, могут находиться вне зоны его информационной осведомленности. Это, безусловно, подрывает авторитет педагогов и не может не отражаться на взаимоотношениях учителя и ученика как субъектов образовательного процесса.

Вышеперечисленные трансформации привели, во-первых, к изменениям индивидуальных и психологических особенностей индивидов, включенных в систему образования (изменились процессы восприятия и осмысления информации, структура и соотношение внешней и внутренней речи, система ценностей, эмоциональная сфера, структура социальных отношений, волевая саморегуляция и т.д.), а во-вторых, к усилению в отечественной педагогике и психологии интереса к осмыслению методологических основ системы образования, поскольку без переосмысления методологических принципов и ценностно-целевых установок невозможно влиять на динамику вышеперечисленных особен- 
ностей и организовать эффективное функционирование системы образования в новых условиях. В новых исторических условиях перед педагогикой как наукой вновь достаточно остро встают задачи методологической рефлексии, осмысления собственного парадигмального статуса.

По мнению ряда ученых, современная педагогика уже не первый год переживает методологический кризис [6-8] Авторы особо акцентируют внимание на том, что отечественная педагогическая наука ориентирована на заимствование сомнительных западных идей, теряет свои критериальные функции по отношению к педагогической практике и не справляется с прогностическими задачами [7]. В педагогическом сообществе разворачиваются дискуссии вокруг процесса воспитания, в частности, вокруг таких его проблем, как соотношение теории и практики воспитания, определение зоны ответственности образовательного учреждения в воспитательном процессе, миссия и цель современного воспитания, необходимость и возможность нравственного воспитания и формирования активной гражданской позиции, целесообразность построения воспитательного процесса с учетом детской и молодежной субкультуры. Организация процесса обучения также втянута в научный дискурс: оцениваются предлагаемые способы повышения качества обучения, анализируется сложившаяся практика подготовки педагогических кадров, обсуждаются границы образовательных возможностей, идет осмысление новаций в образовательной сфере, прогнозируются их результаты и последствия. Особое внимание отводится обсуждению того, что образование получило статус услуги. К числу негативных последствий этого изменения педагоги относят формирование потребительского отношения к школе, падение авторитета учителя и статуса профессии. При этом разнообразные технологии обучения и воспитания, многочисленные образовательные программы, инновационные идеи и стратегии не вносят кардинальных позитивных изменений в педагогическую реальность.

Решение этих и других не менее актуальных вопросов невозможно без серьезной научной проработки, без определения фундаментальной основы развития системы образования, осознания возможностей и ограничений этой основы. 
Образование в данном исследовании рассматривается как сложно организованная система, требующая изучения с позиции системного подхода [9-13] и постнеклассической методологии [14-20]. Однако позиции постнеклассического подхода в педагогике на современном этапе явно не отличаются особой прочностью и масштабом распространения. В своей работе мы исходим из того, что ориентация на характерные для постнеклассического типа рациональности признаки, такие, как полипарадигмальность и трансдисциплинарность, сочетание естественно-научного и гуманитарного походов, сочетание номотетических и идеографических, количественных и качественных методов исследования [1], могут использоваться при решении сложных педагогических проблем.

Опора педагогики на постнеклассическую методологию допускает множественность подходов к организации системы образования, что позволяет, с одной стороны, более многопланово и всесторонне организовать функционирование данной системы, а с другой - дает возможность педагогу проявить инициативу, продемонстрировать активную профессиональную позицию, реализовать творческий подход.

Кроме этого для постнеклассического подхода характерна междисциплинарность, что в педагогике допускает создание комплексных исследовательских программ с привлечением специалистов различных областей знаний: педагогов, психологов, социологов, экологов и т. д. Создание таких программ позволит выявить имеющиеся в образовательной системе не только локальные проблемы и организовать масштабную многовекторную работу по их решению.

На постнеклассическом этапе развития науки в соответствии с мультипарадигмальным подходом [14, 21] единого общепризнанного вектора анализа систем не существует, а потому ученые, работающие в той же проблемной области, должны иметь возможность опираться на разные концептуальные подходы и приходить к разным, подчас взаимоисключающим выводам, которые могут становиться предметом профессиональных дискуссий, дебатов, а могут ложиться в основу разнонаправленных педагогических траекторий. 
М.С. Гусельцева в своих работах $[16,17]$ формулирует основные признаки постнеклассической науки, которая допускает выбор методологии в зависимости от задач и личных предпочтений специалиста; предполагает открытость знания новому опыту и междисциплинарный дискурс; развивает идеи о социальном конструировании реальности и особой креативности субъективного опыта; связана с ситуативным детерминизмом; развивается в контексте информационного общества и постмодернистской культуры; использует способность критического самоосмысления в меняющихся исследовательских контекстах [16, с. 9]. Автор отмечает, что «эгоцентризм научных концепций, свойственный классической и неклассической рациональности, сменяется в постнеклассической рациональности установкой на коммуникативность» [16, с. 10].

С точки зрения постнеклассического подхода процесс обучения как главный компонент образовательной системы представляет собой «комплексную динамическую систему» [19, с. 14], особенности которой в систематизированном виде изложены А.Н. Поддьяковым [Там же]. А.Н. Поддьяков понимает комплексную динамическую систему как «черный ящик», который в принципе не может быть описан в полной мере в силу своей «непрозрачности». Такая система требует «множества описаний, отличающихся друг от друга и дополняющих друг друга», а также характеризуется «внутренней динамикой существенного» [Там же, с. 14]. Исходя из этих посылок, характеризующих сложно организованную комплексную динамическую систему, А.Н. Поддьяков называет несколько существенных следствий, среди которых - отсутствие универсальных правил исследования сложных систем; необходимость и эффективность использования в качестве орудий познания сложных систем не только теоретических, но и эмпирических обобщений; правомерность использования индукции и абдукции; получение новых эмпирических фактов в результате разнообразных поисковых проб; множественное целеполагание при исследовании сложных систем и др. [Там же, c. 15-16]. Обучающийся представляет собой в некотором смысле «черный ящик». Результаты обучения могут быть обусловлены как его внутренней умственной деятельностью, системой мотивов и психоэмоциональным состоянием, ценностно-смысловыми 
ориентациями и установками, так и внешними факторами образовательной среды. И нельзя однозначно утверждать, что оказало более сильное влияние. Однако построение процесса обучения должно быть основано на необходимости максимального познания личности каждого учащегося для обеспечения психологической безопасности и минимизации риска неэффективного и нерационального педагогического воздействия, которое может привести к появлению дидактоневроза, снижению уровня психологического благополучия и другим негативным последствиям.

Основываясь на том, что объектами постнеклассической науки выступают сложные, развивающиеся системы, характеризующиеся открытостью и способностью к саморазвитию, может быть выдвинута новая цель образовательной системы: создание условий для формирования разновекторного многомерного мира учащихся, заинтересованных в самоизменении и саморазвитии, способных к самодисциплине, самоуправлению и саморегуляции. При этом основная функция педагога будет заключаться в организации возможностей для выбора учащимися значимой информации, соответствующей ценностно-смысловым ориентирам их картины мира, для расширения и упорядочивания этой картины.

Очевидно, что современное состояние теории и практики педагогической науки, уровень психологического развития учащихся, позиция родителей по отношению к школе, уровень профессиональной подготовки педагогов, сокращение числа образовательных учреждений и нехватка квалифицированных кадров свидетельствуют о невысокой готовности системы образования к идеологическим трансформациям, к реализации представленной выше цели и соответствующей ей педагогической функции. Тем не менее постнеклассическое понимание мира открывает для педагогики новые возможности, а именно:

- позволяет наметить векторы трансформаций в области образования, соответствующие современным реалиям;

- дает возможность понимать усложнения мировосприятия и миропонимания и создавать условия для развития многомерного мира учащегося; 
- предоставляет обучающимся возможности для развития не только логического, но и инновационного и критического мышления;

- вводит в педагогический процесс субъектно-диалоговое начало, субъект-субъектные образовательные отношения, важной характеристикой которых является диалог во взаимодействии учителя и ученика, что расширяет их социальную компетентность, снимает барьеры при познании объективной реальности;

- обеспечивает возможности самореализации творческим педагогам и прогрессивно мыслящим управленцам в сфере образования;

- обеспечивает приоритет универсальных знаний перед локальными, предметными знаниями.

Вместе с тем постнеклассическая парадигма имеет определенные ограничения, которые ставят под угрозу эффективность функционирования образовательной системы:

- происходит «засорение» педагогической науки разнообразными псевдонаучными знаниями, технологиями, которые подаются «под соусом» полипарадигмальности;

- утрачивается либо игнорируется потенциал большинства известных педагогических концепций;

- идея бифуркации снимает с педагогов ответственность за результаты их профессиональных действий;

- затрудняется реализация индивидуального и дифференцированного подхода к обучению и воспитанию;

- требуются изменения в подготовке педагогических кадров: налицо необходимость в подготовке высококвалифицированного педагога, заинтересованного в самоизменении, способного к реализации творческого подхода в преподавании учебной дисциплины, готового к личностному росту и профессиональной. самореализации.

Таким образом, общая задача государства и общества сегодня сохранить то положительное, что накоплено бесценным опытом развития национальной системы образования, ее возможностей как важнейшего института формирования интеллекта, морали, нравственности, человеческих ценностей и обеспечить ресурсы для 
ее дальнейшего развития. При этом постнеклассическая парадигма может являться как трамплином для стремительного взлета системы образования, так и тормозом для ее движения вперед. Что перевесит, пока трудно сказать. Поскольку парадигма - инструмент, все зависит от того, кто будет на нем играть и какие произведения будут исполнены. Вопрос о том, кто будет определять жизнеспособность, целесообразность постнеклассической методологии, траекторию ее развития, средства реализации и парадигмальные границы, остается открытым. Государство, ученые, педагоги, родители? Однозначного ответа нет, поскольку современная ситуация в образовании характеризуется противостоянием государственных и общественных интересов, несовместимостью стратегий развития образовательных систем, рассогласованием общечеловеческих установок, уклонением от ответственности за процесс и результаты обучения и воспитания и многими другими аспектами, которые порой не просто носят острый дискуссионный характер, а в ряде случаев выходят за рамки морали и нравственного поведения. А вопрос-то действительно важный, ведь речь идет не только о будущем страны, но и о жизни конкретных детей.

1. Степин В.С. О философских основаниях синергетики // Синергетическая парадигма. Синергетика образования. М. : Прогресс-Традиция, 2007. С. 97-102.

2. Степин В. С. Теоретическое знание: структура, историческая эволюция. М. : Прогресс-Традиция, 2000. 743 с.

3. Маджуга А. Г., Синицина И. А. Здоровьесозидающая педагогика: теория, методология, опыт, перспективы развития. М. : Логос, 2014. 508 с.

4. Корнилова Т. В., Смирнов С. Д. Методологические основы психологии. М. : Юрайт, 2011. 483 с.

5. Клочко В. Е. Онтопедагогика: психологические основы и гуманитарный потенциал // Проблемы целеполагания в психологических и педагогических исследованиях : материалы II Забайкальской межрегион. школы молодых ученых. Чита : Изд-во ЗабГПУ, 2003. С. 3-14.

6. Голованова Н. Ф. Теория воспитания в поисках методологических ориентиров // Изв. ВГПУ. 2016. № 5 (109). С. 23-26. 
7. Пичугина В. К., Сериков В. В. Гуманитарная парадигма как перспектива преодоления методологического кризиса в педагогике // Педагогика. 2016. № 1. С. 19-30.

8. Садовская И. Л. Методологический кризис дидактики и его последствия // Вестн. КГПУ им. В. П. Астафьева. 2012. № 4. С. 46-56.

9. Абульханова-Славская К.А. Субъект и субъектность: проблема определения качества // Развитие психологии в системе комплексного человекознания. М. : Ин-т психологии РАН, 2012. С. 49-62.

10. Брушлинский А. В. Проблемы психологии субъекта. М. : Ин-т психологии РАН. - 1994. 109 с.

11. Знаков В. В. Теоретические основания психологии человеческого бытия // Психол. журн. 2013. Т. 34, № 2. С. 29-38.

12. Ломов Б. Ф. Системный подход и проблема детерминизма в психологии // Психол. журн. 1989. Т. 10, № 4. С. 19-33.

13. Слободчиков В. И. Антропология образования - как предчувствие смысла // Наука и школа. 2015. № 6. С. 138-142.

14. Аллахвердов В. М. Опыт теоретической психологии (в жанре научной революции). СПб. : Печатный двор, 1993. 325 с.

15. Аллахвердов В. М. Вечно зеленеющий предмет психологии на фоне сухой теории // Методология и история психологии. 2006. Т. 1, вып. 1. C. 100-104.

16. Гусельцева М. С. Методологические кризисы и типы рациональности в психологии // Вопр. психологии. 2006. № 1. С. 3-15.

17. Гусельцева М. С. Культурно-историческая психология в свете постнеклассической рациональности // Современная социальная психология: теоретические подходы и прикладные исследования. 2013. № 1. С. 5-32.

18. Зинченко Ю. П. Становление постнеклассического проекта в психологии // Философские науки. 2014. № 12. С. 26-40.

19. Поддьяков А.Н. Исследовательское поведение. Стратегии познания, помощь, противодействие, конфликт. М. : ПЕР СЭ-Пресс, 2006. 240 с.

20. Степин В.С. Особенности научного познания и критерии типов научной рациональности // Эмистемология и философия науки. 2013. T. 26, № 2. С. 78-91.

21. Смит Н. Современные системы психологии / пер. с англ. под общ. ред. А. А. Алексеева. СПб. : ПРАЙМ-ЕВРОЗНАК, 2003. 384 с. 


\section{ОНЛАЙН-ФОРМАТ И ТРАДИЦИОННОЕ ОБУЧЕНИЕ: СРАВНИТЕЛЬНЫЙ АНАЛИЗ ПСИХОЛОГИЧЕСКИХ ПРЕДИКТОРОВ УСПЕШНОСТИ СТУДЕНТОВ}

М. В. Клименских

Ю. В. Лебедева

А. В. Мальцев

В.В. Савельев

Альтернативное традиционному формату онлайн-обучение стремительно завоевывает образовательное пространство. Его элементы активно внедряются в системы среднего, высшего и дополнительного образования по всему миру. В нашей стране количество пользователей различными образовательными интернет-площадками, такими, например, как «Открытое образование», «Coursera», EdX и др., также заметно увеличилось и продолжает неуклонно расти. Их гуманитарная миссия очевидна - они расширяют границы доступности знаний и делают получение образования экономичным, но в то же время и ставят множество вопросов психологического характера, которые требуют подробных исследований.

В настоящий момент онлайн-курсы, применявшиеся в основном в сфере дополнительного и заочного образования, активно используются и в системе высшего образования. Традиционно в России деятельность в системе образования регламентируется нормативными правовыми актами, содержащими государственные нормативные требования, не является исключением и электронное обучение. В Федеральном законе «О внесении изменений в Закон Российской Федерации “Об образовании” в части применения электронного обучения, дистанционных образовательных технологий» «...под электронным обучением понимается организация образовательного процесса с применением содержащейся в базах данных и используемой при реализации образовательных программ информации

Работа выполнена при поддержке РФФИ в рамках научного проекта № 17-36-01069 «Исследование психологических предикторов эффективности дистанционного обучения». 
и обеспечивающих ее обработку информационных технологий, технических средств, а также информационно-телекоммуникационных сетей, обеспечивающих передачу по линиям связи указанной информации, взаимодействие участников образовательного процесса. Под дистанционными образовательными технологиями понимаются образовательные технологии, реализуемые в основном с применением информационно-телекоммуникационных сетей при опосредованном (на расстоянии) взаимодействии обучающихся и педагогических работников» [1].

Широкое внедрение цифровизации в образовательный процесс уже на данном, начальном этапе ее освоения позволяет говорить как о ее достоинствах, так и о проблемах, возникающих при данном формате обучения. С одной стороны, онлайн-обучение делает знания доступнее, а с другой - рискует обезличить педагогику и убрать из фокуса ее внимания индивидуально-психологические особенности обучающихся. Это вызывает неоднозначное отношение педагогов, студентов, а также их родителей. Считается, что главным ограничением такого формата обучения является вытеснение зарекомендовавших себя педагогических технологий, прежде всего минимизация или даже отсутствие педагогического общения [2].

Оставив в стороне социально-экономические предпосылки для утверждения «онлайна» в высшей школе, а также дискуссию, развернувшуюся вокруг этого процесса, сфокусируемся на выявлении базовых психолого-педагогических идей, лежащих в его основе. Анализ теоретических и эмпирических исследований как отечественных, так и зарубежных авторов показывает, что в педагогической теории и практике пока еще нет однозначного ответа на вопрос о том, как соотносятся специфика онлайн-формата с классическими психолого-педагогическими подходами к обучению, разработанными в свое время для традиционной face-to-face формы $[3,4]$.

Этот вывод сделан нами на основании того, что системно, целостно онлайн-обучение и все его факторы пока не собраны психологами и педагогами в какую-либо принципиально новую теоретико-методологическую концепцию. Вероятно, это связано с тем, что методологическая концепция онлайн-обучения как инновационного педагогического феномена со специальным диагности- 
ческим и квалиметрическим инструментарием, а также отличными от традиционных технологиями организации образовательных интервенций в настоящий момент в разработке или, точнее, на этапе накопления и обработки эмпирических данных. Его психологическая составляющая представлена рядом отечественных и зарубежных исследований [5-7]. Большинство из них реализовывались или продолжают осуществляться с опорой на концепцию адаптивного обучения, которая, по мнению ряда исследователей, а также практикующих специалистов является единственно возможным будущим для онлайн-обучения.

Представленное исследование логично вписывается в этот ряд. Его цель - выявление взаимосвязей между психологическими качествами учащихся и показателями результативности в онлайни традиционном обучении, а также построение прогностической педагогической модели, с помощью которой можно корректировать дидактические решения при разработке, организации и реализации занятий для студентов в формате онлайн.

Авторы и разработчики представленного в данной статье исследовательского проекта исходили из того, что в сравнении с лекциями и семинарами онлайн-курс как форма обучения имеет свою специфику, а значит, и базовые элементы структуры учебной деятельности - мотивация, задача, контроль-оценка в онлайн-обучении приобретают особые черты и требуют от слушателей особых психологических компетенций, прежде всего высокого уровня рефлексии, осознанности и самоменеджмента. Именно это предположение стало концептуальной основой дизайна психодиагностического исследования, которое проводилось в течение трех лет.

\section{Выборка и методы исследования}

Исследование было проведено в Институте радиоэлектроники и информационных технологий Уральского федерального университета (УрФУ) в 2018-2019 гг. Выборку составили 138 студентов, из них 56 девушек и 82 юноши. Возраст учащихся - от 17 до 23 лет, средний возраст - 18,7 лет, обучаются на 1-2-х курсах. Число первокурсников составило 84 человека, а соответственно опрошенных студентов второго курса было 54 человека. Вошедшие в выборку 
студенты слушали онлайн-курсы из общеобразовательного цикла дисциплин: «Философия», «История», «Русский язык». Треть студентов (44 человека) впервые получили опыт прохождения онлайнкурса в вузе, остальные (94 человека) изучали дистанционно от 2 до 4 предметов. Небольшой перечень дисциплин и ограниченная по направлению подготовки выборка позволили получить более надежные данные о связи результатов онлайн-обучения с предикторами его успешности.

Успешность прохождения онлайн- и очных курсов оценивалась с точки зрения показателей результативности (т.е. степени достижения педагогических результатов). В качестве объективного показателя результативности нами были взяты средние оценки по онлайн- и очным курсам по 100-балльной шкале в соответствии с балльно-рейтинговой системой. Мониторинг уровня учебных достижений респондентов был проведен посредством тестирования на специальном внутривузовском ресурсе, разработанном на базе платформы Moodle, информация была предоставлена администрацией института. При этом сведения об успеваемости студентов были собраны за две сессии по всем предметам, изучаемым в традиционной форме и в режиме онлайн.

В качестве дополнительных показателей для онлайн-курсов были взяты субъективные оценки учащихся полезности и изменений в основных знаниях умениях и навыках. Эти показатели были получены путем анкетирования, в котором испытуемым предлагалось оценить каждый из курсов по 10-балльной шкале.

В качестве методов оценки психологических качеств нами были использованы короткий портретный опросник большой пятерки (Б5-10) М. С. Егоровой и О.В. Паршиковой, шкала академической мотивации Т. О. Гордеевой, методика «Ведущий канал восприятия» С. Ефремцевой, шкала самоконтроля Т. О. Гордеевой и тест интеллекта Равена.

Обработка производилась путем корреляционного анализа Пирсона с последующим построением моделей методом множественной линейной регрессии с использованием метода пошагового исключения. Для расчетов использовался статистический язык программирования R. 


\section{Результаты исследования}

В табл. 1 представлены значимые корреляции психологических качеств со средней оценкой по онлайн-курсам.

Таблица 1

Значимые корреляции психологических качеств со средним баллом по онлайн-курсам

\begin{tabular}{c|c}
\hline Психологическое качество & Средний балл по онлайн-курсам \\
\hline Добросовестность & $0,27^{* *}$ \\
\hline Визуальная модальность & $-0,21^{*}$ \\
\hline
\end{tabular}

* - значимо на уровне 0,05 . ** - значимо на уровне 0,01 .

Для начала отметим, что здесь и далее все представленные корреляции являются крайне слабыми несмотря на статистическую значимость.

Как мы можем увидеть, только два психологических качества демонстрируют корреляции с успеваемостью по онлайн-курсам на уровне статистической значимости. Учащиеся, имеющие более высокий балл по шкале «добросовестность» и более низкий балл по шкале «визуальная модальность», демонстрируют лучшую успеваемость. Регрессионная модель успеваемости по онлайн-курсам представлена в табл. 2.

Таблица 2

Регрессионная модель успеваемости по онлайн-курсам

\begin{tabular}{l|c|c|c}
\hline \multicolumn{1}{c|}{ Переменная } & Коэффициент & $\begin{array}{c}\text { Стандартная ошиб- } \\
\text { ка коэффициента }\end{array}$ & р-значение \\
\hline (Intercept) & 72,86 & 4,69 & 0,00 \\
\hline Добросовестность & 1,91 & 0,49 & 0,00 \\
\hline $\begin{array}{l}\text { Визуальная модаль- } \\
\text { ность }\end{array}$ & $-1,59$ & 0,50 & 0,00 \\
\hline
\end{tabular}

Обе переменные, представленные в табл. 1, вошли в регрессионную модель. Коэффициент детерминации данной модели равен 0,14. Таким образом, данная модель объясняет лишь 14 \% наблюдаемой дисперсии успеваемости по онлайн-курсам.

Значимые корреляции успеваемости по очным курсам представлены в табл. 3. 
Значимые корреляции психологических качеств со средним баллом по очным курсам

\begin{tabular}{c|c}
\hline Психологическое качество & Средний балл по очным курсам \\
\hline Добросовестность & $0,28^{\star}$ \\
\hline
\end{tabular}

* - значимо на уровне 0,01 .

Как мы можем увидеть, только добросовестность значимо коррелирует с успеваемостью по очным курсам. Эта переменная и попала в регрессионную модель (табл. 4).

Таблица 4

Регрессионная модель успеваемости по очным курсам

\begin{tabular}{l|c|c|c}
\hline \multicolumn{1}{c|}{ Переменная } & $\begin{array}{c}\text { Коэффици- } \\
\text { ент }\end{array}$ & $\begin{array}{c}\text { Стандартная } \\
\text { ошибка коэффи- } \\
\text { циента }\end{array}$ & $p$-значение \\
\hline (Intercept) & 51,81 & 4,64 & 0,00 \\
\hline Добросовестность & 1,69 & 0,50 & 0,00 \\
\hline
\end{tabular}

Данная модель объясняет лишь 8 \% наблюдаемой дисперсии.

В табл. 5 мы можем наблюдать положительные корреляции между субъективной оценкой изменения в знаниях и психологическими качествами.

Таблица 5

Значимые корреляции психологических качеств с субъективной оценкой изменений знаний по результатам онлайн-курса

\begin{tabular}{l|c}
\hline \multicolumn{1}{c|}{ Психологическое качество } & Оценка изменений в знаниях \\
\hline Добросовестность & $0,21^{*}$ \\
\hline Познавательная мотивация & $0,20^{*}$ \\
\hline Мотивация достижения & $0,19^{*}$ \\
\hline
\end{tabular}

* - значимо на уровне 0,05 .

Как мы можем увидеть, с субъективной оценкой изменений знаний по онлайн-курсам положительно коррелируют такие качества, как добросовестность, познавательная мотивация и мотивация достижений. Однако в регрессионную модель (табл. 6) вошла только добросовестность. 
Таблица 6

Регрессионная модель субъективной оценки изменений в знаниях по результатам онлайн-курса

\begin{tabular}{l|c|c|c}
\hline \multicolumn{1}{c|}{ Переменная } & Коэффициент & $\begin{array}{c}\text { Стандартная ошибка } \\
\text { коэффициента }\end{array}$ & $p$-значение \\
\hline (Intercept) & 4,47 & 0,63 & 0,00 \\
\hline Добросовестность & 0,17 & 0,07 & 0,01 \\
\hline
\end{tabular}

Данная модель объясняет только 5 \% дисперсии. Отсутствие показателей мотивации в данной модели объясняется умеренной корреляцией этих показателей с добросовестностью $(0,48$ и 0,39 для познавательной мотивации и мотивации достижений соответственно), вследствие чего эти показатели были элиминированы в результате пошагового исключения.

Наконец обратимся к корреляциям с субъективными показателями полезности онлайн-курсов (табл. 7).

Таблица 7

Значимые корреляции психологических качеств с субъективной оценкой полезности онлайн-курсов

\begin{tabular}{l|c}
\hline \multicolumn{1}{c|}{ Психологическое качество } & Субъективная оценка полезности \\
\hline Доброжелательность & $0,28^{* *}$ \\
\hline Добросовестность & $0,21^{\star}$ \\
\hline Нейротизм & $-0,18^{\star}$ \\
\hline Познавательная мотивация & $0,21^{\star}$ \\
\hline Мотивация достижения & $0,18^{\star}$ \\
\hline Серия В & $0,20^{*}$ \\
\hline Серия D & $0,19^{*}$ \\
\hline \multirow{2}{*}{ * значимо на уровне $0,05 .{ }^{* *}-$ значимо на уровне $0,01}$.
\end{tabular}

Здесь мы можем наблюдать большое количество крайне слабых, но статистически значимых коэффициентов корреляции. Студенты с более высокими показателями доброжелательности, добросовестности, познавательной мотивации, мотивации достижения, а также результатами теста Равена серий В и D демонстрируют более высокую оценку полезности курсов. Нейротизм же, напротив, 
отрицательно коррелирует с этой оценкой. Регрессионная модель представлена в табл. 8.

Таблица 8

Регрессионная модель субъективной оценки полезности онлайн-курсов

\begin{tabular}{l|c|c|c}
\hline \multicolumn{1}{c|}{ Переменная } & Коэффициент & $\begin{array}{c}\text { Стандартная ошибка } \\
\text { коэффициента }\end{array}$ & $\begin{array}{c}p \text {-значе- } \\
\text { ние }\end{array}$ \\
\hline (Intercept) & $-7,71$ & 3,69 & 0,04 \\
\hline Доброжелательность & 0,35 & 0,13 & 0,01 \\
\hline Добросовестность & 0,14 & 0,10 & 0,15 \\
\hline Серия В & 0,55 & 0,32 & 0,09 \\
\hline Серия D & 0,18 & 0,12 & 0,13 \\
\hline
\end{tabular}

Данная модель объясняет около 12 \% наблюдаемой дисперсии оценок. Отметим, что только коэффициент при шкале «доброжелательность» имеет достаточную статистическую значимость. Коэффициенты при шкале «добросовестность», а также при шкалах теста Равена не достигают данного уровня, однако их вклад в наблюдаемую дисперсию не позволяет исключить их из модели.

\section{Обсуждение результатов}

Отметим, что все полученные нами корреляции являются слабыми, а модели объясняют лишь незначительную долю дисперсии. Для всех показателей результативности обучения никакой роли не играют:

1) экстраверсия и открытость опыту;

2) уровень развития аудиальной и кинестетической модальности;

3) показатели экстернальной и интроецированной мотивации;

4) мотивация самоуважения и саморазвития;

5) самоконтроль.

Единственным общим фактором, связанным со всеми показателями результативности обучения, является добросовестность. Для объективного показателя результативности очного обучения она вообще является единственным предиктором.

В соответствии с описанием черт, заложенных в личностный опросник Большой пятерки (Big five), добросовестность определяет- 
ся как ответственное выполнение своих обязанностей или серьезное отношение к другим. Сопутствующими характеристиками, которые являются маркерами добросовестности, также выступают честность, верность и справедливость. В целом это одна из наиболее важных черт личности, которые не только играют важную роль для достижения субъективного благополучия, но также имеют решающее значение для достижения успеха в различных сферах, в том числе и в обучении. Люди с выраженным уровнем добросовестности более организованы, трудолюбивы и целеустремленны, и это очевидный плюс в ситуации онлайн-обучения.

Дополнительным предиктором для оценок по онлайн-курсам является уровень развития визуальной модальности. Однако его влияние является парадоксально отрицательным. Для этого результата возможно следующее объяснение: баллы по всем модальностям коррелируют между собой на уровне 0,5-0,6. Это, вероятнее всего, говорит о наличии некоторого общего фактора восприимчивости к внешним стимулам. Такая восприимчивость может быть фактором, не позволяющим учащимся сосредоточиться на учебном материале, подаваемом с экрана компьютера. Но это объяснение является, скорее, гипотетическим, особенно с учетом незначительного уровня корреляции с рассматриваемым показателем результативности.

Показатели мотивации достижения и познавательной мотивации играют роль только для субъективных оценок результативности. Однако эти показатели не попадают в регрессионные модели, поскольку они в значительной мере коррелируют с добросовестностью и удаляются при пошаговом исключении.

Интересными являются корреляции с субъективной оценкой полезности курса. Помимо связей с добросовестностью и показателями мотивации, имеются значимые взаимосвязи с нейротизмом, доброжелательностью и показателями интеллекта по двум сериям теста Равена. Это позволяет предполагать, что более спокойные и доброжелательные учащиеся, обладающие более высокими частными показателями интеллекта, склонны выше оценивать субъективную полезность. 
В целом же мы можем утверждать, что психологические качества играют незначительную роль для показателей результативности онлайн- и очного обучения, во всяком случае те, которые были взяты для данного исследования. Оставшаяся дисперсия показателей результативности, на наш взгляд, объясняется различного рода педагогическими и ситуационными факторами: дизайном курса, системой оценки, характеристиками преподавателя и т. д.

\section{Выводы}

В целом полученные данные не столько дают ответы, сколько ставят вопросы. Их интерпретация может быть развернута по разным траекториям. Прежде всего, считаем важным актуализировать вопрос об итоговом балле за курс, освоенный студентом в онлайнформате. По данным нашего исследования, он в среднем выше, чем балл за офлайн-курс. Возможно, это связано с психологическими характеристиками, которые были нами выделены на основе опубликованных исследований по схожей тематике и требуют дальнейшего изучения и дополнения.

Очевидно, что система обучения и воспитания стремительно трансформируется. Меняются форматы обучения, подходы к преподаванию и стили переработки информации, психологический портрет современного студента сильно отличается от образцов 10- или 15-летней давности. Тенденция к исследованию психологических особенностей людей объективными (аппаратурными, психофизиологическими методами), в том числе и в ситуации обучения, ставит вопрос об определении степени актуальности классического психодиагностического инструментария в современных условиях.

Основной вывод данного исследования заключается в том, что успешный студент успешен в любом формате обучения. В связи с этим фокус научного поиска повышения путей эффективности онлайн-обучения должен быть сосредоточен не на психологических особенностях студентов, успешных в онлайн-формате, а на решении задач усовершенствования педагогического дизайна онлайн-курса. В свою очередь, богатый психолого-педагогический опыт обучения в традиционном формате может быть вполне эффективным и в онлайн-формате с учетом содержания образовательного процесса. 
Итак, результаты представленного эмпирического исследования не столько конкретизируют, сколько актуализируют принцип адаптивного обучения в онлайн-формате как основы для конкретных дидактических решений.

«Скромные» эмпирические результаты, слабые связи между психологическими особенностями студентов и уровнем академической успешности, с нашей точки зрения, свидетельствуют о необходимости продолжения подобных поисковых проектов. Умозрительное предположение о том, что дистанционный формат получения знаний в высшей школе проигрывает привычной лекционно-семинарской очной системе, требует дальнейшей эмпирической разработки. Но даже выявленные нами на данной конкретной выборке корреляционные связи говорят о том, что перспективным вектором продолжения исследований является именно эмоционально-волевая сфера обучающихся. И это соотносится с базовыми принципами гуманистической педагогики, такими как субъектное отношение к студенту, индивидуальный подход, воспитание ценностного отношения к обучающему материалу. В условиях онлайна, который, как правило, сопровождается отсутствием живого личностного общения, реализовать это сложно. Однако определенная автоматизированная компенсация этого в будущем определенно возможна.

В настоящий момент ученые, изучающие эти проблемы, в основном находятся на этапе сбора данных. Это относится и к представленному исследованию, которое будет продолжаться в плане расширения выборки и обогащения диагностического инструментария.

1. О внесении изменений в Закон Российской Федерации «Об образовании» в части применения электронного обучения, дистанционных образовательных технологий : ФЗ РФ от 28 февраля 2012 г. № 11-ФЗ [Электронный pecypc]. URL: http://www.consultant.ru/document/cons_doc_ LAW_126574/ (дата обращения: 20.07.2020).

2. Виндекер О. С., Голендухина О. А., Клименских М. В. идр. К вопросу об эффективности дистанционного обучения: исследование представлений [Электронный ресурс] // Педагогическое образование в России. 2017. № 10. C. 41-47. URL: http://elar.uspu.ru/bitstream/uspu/7856/1/ povr-2017-10-06.pdf (дата обращения: 18.05.2019). 
3. Vayre E., Vonthron A. M. Psychological Engagement of Students in Distance and Online Learning: Effects of Self-Efficacy and Psychosocial Processes // Journal of Educational Computing Research. 2016. Vol. 55, № 2. P. 197-218. DOI: $10.1177 / 0735633116656849$ (in English).

4. Williams D., Kluev A. The Entrepreneurial University: Evidence of the Changing Role of Universities in Modern Russia // Industry and Higher Education. 2014. Vol. 28 (4). P. 271-280.

5. Broadbent J. Academic success is about self-efficacy rather than frequency of use of the learning management system // Australasian Journal of Educational Technology. 2016. Vol. 32(4). P. 38-49. DOI: 10.14742/ajet.2634 (in English).

6. Arens A. K., Marsh H. W., Pekrun R. et al. Math self-concept, grades, and achievement test scores: long-term reciprocal effects across five waves and three achievement tracks // Journal of Educational Psychology. 2016. Vol. 109, № 5. P. 621-634. DOI: 10.1037/edu0000163 (in English).

7. Смирнов С. Д., Корнилова Т. В., Корнилов С. А., Малахова С. И. О связи интеллектуальных и личностных характеристик студентов с успешностью их обучения // Вестн. Моск. ун-та. Сер. 14 : Психология. 2007. № 3. C. 82-87. 


\section{ПОДХОДЫ К ТРАКТОВКЕ ПСИХОЛОГО-ПЕДАГОГИЧЕСКИХ ВЗАИМОДЕЙСТВИЙ: РЕТРОСПЕКТИВНЫЙ АНАЛИЗ*}

E. B. Коротаева

Научная область, изучающая психолого-педагогических взаимодействия, достаточно обширна. Ретроспективный анализ позволил выявить четыре этапа ее развития, различающихся подходами к пониманию психолого-педагогических взаимодействий и трактовкой терминов и понятий. Это реконструктивный, интегративный, «модернизационный» этапы и этап «опережающей практики». Имеет смысл уточнить временные рамки ретроспективного анализа: с 60-х гг. XX в. до наших дней.

Дадим краткую характеристику каждого из этапов.

1-й эman (1960-1980-е гг.) можно обозначить как этап реконструкции в психолого-педагогической области науки. В эти годы, с одной стороны, продолжала свое развитие советская педагогика, имеющая основной целью воспитание будущего строителя коммунизма, с другой - вновь начала развиваться отечественная психология (после кризиса предвоенного десятилетия, военного времени, послевоенного строительства), актуализирующая наработки школ, запрещенных в 30-е гг. (школы В. М. Бехтерева, Л. С. Выготского). Это активизировало интерес не только к прежним, но и к новым исследовательским направлениям - когнитивной и возрастной психологии (работы Л.И. Божович, В. В. Давыдова, М. А. Холодной и др.).

В педагогике доминировали коллективистские подходы к пониманию взаимодействий в учебно-воспитательном процессе. Поэтому и основной типологией взаимодействий, к которой обращались чаще всего, была классификация стилей руководства, предложенная еще К. Левиным: авторитарный, демократический и либеральный. В более поздний период названия стилей были номинально транс-

* Исследование выполнено при финансовой поддержке РФФИ в рамках научного проекта № 20-013-00308 «Изучение феномена несоответствия зрительного и тактильного восприятия при использовании дошкольниками информационных устройств с сенсорным экраном (технология тачскрин)». 
формированы (директивный, коллегиальный и попустительский), хотя суть их практически не изменилась (И. К. Киянова, Л. М. Кроль, Е. В. Ксенчук, Е. Л. Михайлова, Н.Н. Обозов и др.).

Отметим при этом, что педагогика и психология в этот период существовали параллельно, развиваясь преимущественно в своей научной области. Хотя исследователи-психологи (Б. Г. Ананьев, Л. И. Божович, Л. С. Славина, Н. Д. Левитов и др.) активно обращались к учебно-воспитательному процессу как продуктивной базе для научных изысканий (где имелись группы детей, подростков, соотнесенные по возрастным, социально ориентированным и другим критериям).

2-й эman (с конца 80-х гг. до начала 2000-х гг.) характеризуется интеграцией педагогики и психологии относительно образовательного процесса. Поэтому он условно обозначен как «интегративный». С точки зрения политического и социокультурного развития страны в этот период происходит смена государственного курса, меняется форма собственности, рушатся границы, разделяющие до того «запад» и «восток». Это не могло не сказаться на общей атмосфере и на подходах в сфере психолого-педагогических исследований. Стали активно развиваться контакты ученых в области психологии; идеи гуманистической психологии были с энтузиазмом восприняты отечественными теоретиками и практиками и были положены в основу исследований жизнедеятельности индивида и общества, а также к педагогической среды.

Сменился и ракурс изучения межличностных взаимодействий образовательной сферы. Коллективистская педагогика (труды А. С. Макаренко, С. А. Сухомлинского и др.) начала сменяться установками гуманистической психологии (педагогикой и психологией ненасилия и т. п.), усилилось внимание к изучению конкретного индивида, ученика, учителя (работы С. Л. Братченко [1], И. А. Зимней, А. Н. Леонтьева, А. К. Марковой [2], Ю.М. Орлова и др.).

В качестве одного из направлений исследования был представлен подход, базирующийся на идее постепенного перенесения ответственности за собственную жизнь и самостоятельное решение индивидуальных проблем на самого растущего человека, что нашло отражение в таких видах взаимодействий, как «защита», «помощь», 
«поддержка» и «сопровождение» (О. С. Газман [3], а также В. П. Бедерханова, Н. Б. Крылова и др.).

Данное положение сказалось и на изменении терминологии: до названного периода применительно к педпроцессу чаще всего использовались существительные, имеющие, обобщающие значения: ученик, учитель, педагог, воспитанник и т. п. Но с конца ХХ в., благодаря интеграции психологии и педагогики, участников педпроцесса начали рассматривать в качестве «субъектов», подчеркивая внимание к их личности, субъектности, инициативности, самостоятельности и т. д. Стал активно пониматься вопрос о допустимости отношения к ученику как к «объекту» педагогических воздействий.

Появилась типология взаимодействий, описывающая варианты сочетаемости субъект-объектных позиций учителя и ученика [4, c. $82-88]$ :

- объект-объектные взаимодействия: и учитель и ученик ощущают себя объектами воздействий, взаимодействие равновесное (O-O), непродуктивное, поскольку стороны не заинтересованы в совместном достижении цели деятельности;

- субъект-объектные: учитель выступает как носитель активного начала, а ученик довольствуется пассивной ролью; взаимодействие неравновесное (S-O), но может оказаться продуктивным в зависимости от степени активности педагога, учителя;

- объект-субъектные: здесь, напротив, учащийся занимает активную, заинтересованную позицию (субъекта) в процессе обучения, тогда как учитель характеризуется пассивностью, безынициативностью; взаимодействие неравновесное $(\mathrm{O}-\mathrm{S})$, чаще всего малопродуктивное, поскольку происходит подмена роли ведущего в деятельности;

- субъект-субъектные: для участников обучения характерны активность, устремленность к новому, продуктивность в образовательном процессе. Взаимодействие равновесное $(\mathrm{S}-\mathrm{S})$, при этом продуктивность его определяется единством осознания цели участниками совместной деятельности (в иных случаях совместная деятельность может привести к конфликтным ситуациям).

Отметим, что именно в этот период в нормативных документах («Закон об образовании» 1992 г.) за учеником закрепилось опреде- 
ление «обучающийся». Это субстантивированное причастие полно внутренних противоречий. С одной стороны, приставка «об-» явно подводит к пониманию учащегося как объекта, которого обучают. С другой стороны, возвратная частица «-ся» свидетельствует о том, что ученик вполне способен обучить себя сам. Частично это положение соответствует позиции студента, ученика старших классов, где самообучение допустимо и даже приветствуется. Но применительно к начальной школе, к пятому-шестому классам, понятие «обучающиеся» оказывается значительно шире тех функций и действий, которые выполняются учениками в этот период обучения.

Эту двойственность трактовки «обучающегося» стоит рассматривать как своеобразный индикатор нелинейной ситуации в осмыслении психолого-педагогических взаимодействий второго этапа.

3-й эman (с 2000-х гг. до 2010 г.) можно обозначить как «модернизационный» относительно всего российского образования. Идея модернизации заключалась в принципиальном обновлении образовательной системы во всех ее звеньях в соответствии с требованиями современности, с установками общественного сознания, с сохранением лучших традиций отечественного образования. Провозглашались принципы доступности и качества, равенства возможностей в получении образования; были утверждены стандарты образования второго поколения, введен единый государственный экзамен в общеобразовательную школу (2003 г.). Россия вошла в состав участников Болонского соглашения и т.д.

Адаптация двухуровневой системы высшего образования закономерно вызвала пересмотр и совершенствование программ профессиональной подготовки будущих педагогов, компетенции которых были тесно связаны с знаниями и умениями в области психолого-педагогических взаимодействий. В отдельных дисциплинах государственного образовательного стандарта по направлению 540600 «Педагогика» были обозначены установки, связанные с анализируемой нами областью: формы взаимодействия человека с миром («Психология человека»); человек как субъект взаимодействия («Практическая социальная психология»); психология взаимодействия в системе: учитель - ученик - класс («Педагогическая 
психология»); формы взаимодействия субъектов в педагогических процессах («Практическая педагогика»).

Возникло противоречие между ожиданиями общества, перспективой развития образования как социального института, с одной стороны, и психологической и педагогической неготовностью педагогов к реализации этих ожиданий - с другой. Это отразилось и на анализе, и на трактовке взаимоотношений и взаимодействий участников образовательного процесса.

Психологические исследования в образовательной деятельности носили в большей степени прикладной характер, с опорой на широкую диагностическую базу. Данное обстоятельство помогло более реально обозначить проблемы, существующие между участниками образовательной деятельности. Достаточно новым аспектом стало признание того факта, что взаимодействия в педагогике могут носить как позитивный, так и негативный характер. Я. Л. Коломинский в «Психологии педагогического взаимодействия» (2007) описывает четыре типа взаимоотношений учителя со своими учениками: «тепло - тепло»; «внутри тепло - снаружи холодно»; «внутри холодно - снаружи тепло»; «холодно - холодно» [5].

Разнонаправленность психолого-педагогических взаимодействий, изучаемых в формате специфической социальной области (коей является система образования), привела к пониманию того, что нужна типология, которая была бы равноприменима и к субъектам (индивидуальным, групповым) и к объектам (одушевленным, неодушевленным), включенным в образовательные ситуации. Что было обозначено в типах взаимодейстивй с учетом процесса и результатов контактирующих сторон: деструктивный (разрушающий), рестриктивный (ограничивающий), реструктивный (поддерживающий) и конструктивный (развивающий) типы взаимодействия в образовательном пространстве.

В этот период встал вопрос о базисе психолого-педагогических взаимодействий, который бы закрепил изменение когнитивной центрации на ценностно-ориентированную, породил бы поиск соответствующих сценариев психолого-педагогической поддержки и сопровождения и т.д. Однако к концу второго этапа стало очевидным рассогласование между наработанной теорией и практикой 
в психолого-педагогической области и запаздывающей нормативной документацией.

В 2012 г. выходит новый «Закон об образовании Российской Федерации». И это последнее десятилетие можно считать началом 4-го этапа в процессе развития и изучения психологопедагогических взаимодействий. Особенность этого этапа обозначена в его номинации - этап «опережающей практики».

Социально-культурные преобразования этого периода привнесли в систему образования новые аспекты, связанные с организацией новых взаимодействий в сфере образования.

Внедрена новая - дистанционная - форма обучения. Новые электронные средства обучения позволили не только удлинить дистанцию между субъектами образовательного процесса, но и видоизменить методы (наглядные, словесные, практические). Умелый учитель, используя возможности цифрового обучения, не предоставляет готовую информацию ученику, но делает его активным, инициативным со-участником процесса познания и освоения нового с учетом возможностей цифровых гаджетов.

Появился новый тип взаимодействия — «электронное», сетевое взаимодействие, вебинары, открытые образовательные платформы, которые делает систему контактов субъектов более открытой, способствует преодолению автономности, установлению разнообразных партнерских - как горизонтальных, так и вертикальных связей. Но это, в свою очередь, вскрыло ряд вопросов, связанных с психологической безопасностью самой образовательной среды (как внешней, так и внутренней), психологическим благополучием субъектов образования (как обучающегося, так и педагога) и др.

При этом в освоение и реализацию новых форм психологопедагогического взаимодействия в большей степени оказались вовлечены студенты педагогических вузов, обучавшиеся по направлению 44.03.02 «Психолого-педагогическое образование». Стандарт обучения по психолого-педагогическому образованию включает достаточно большое количество обращений к видам и формам взаимодействий:

- в расшифровке видов деятельности: создание условий для полноценного обучения, воспитания обучающихся, взаимодействия 
и общения ребенка со сверстниками и взрослыми, участие во взаимодействии со смежными специалистами и т. п.;

- в формируемых компетенциях: способность принимать участие в междисциплинарном и межведомственном взаимодействии специалистов в решении профессиональных задач (ОПК-10); способность организовать совместную деятельность и межличностное взаимодействие субъектов образовательной среды (ОПК-6); способность осуществлять взаимодействие с семьей, педагогическими работниками, в том числе с педагогом-психологом образовательной организации, по вопросам воспитания, обучения и развития дошкольников (ПК-6);

- в дисциплинах базовой части профессионального цикла учебного плана («Психолого-педагогическое взаимодействие участников образовательного процесса») и др.

Другими словами, подготовка педагога-психолога опирается именно на формирование готовности включаться в психологопедагогическое взаимодействие или организовывать его различные варианты. Тогда как в федеральном образовательном стандарте по педагогическому образованию (направление подготовки 44.03.01 «Педагогическое образование) апелляции к взаимодействию не обозначены вовсе.

Также отметим, что в нормативных документах федерального уровня устоявшееся словосочетание «участник образовательной деятельности» было заменено на «участников образовательных отношений». Отношения - это более широкое понятие по сравнению с деятельностью, включающее в себя различные роли участников активные, нейтральные, пассивные.

А вот понятие субъекта образовательного процесса практически ушло из активного словаря. Обращение к «субъекту» в контексте психолого-педагогических взаимодействий, правда, можно встретить в соответствующих учебных пособиях (работы И. В. Дубровиной [6]), Е.В. Неумоевой-Колчеданцевой, А. П. Панфиловой и А. В. Долматова [7]), но, как показывает анализ, в них представлены наработки, относящиеся ко второму и третьему этапам описываемого феномена. 
По мнению А. С. Обухова, наиболее актуальными направлениями в исследовании психологии образования, которая, безусловно, охватывает психолого-педагогические взаимодействия, являются: сопровождение участников образовательного процесса в ситуации полипозиционного и диадного взаимодействия; обеспечение психологического сопровождения индивидуальной образовательной траектории каждого учащегося с учетом его возрастных потенциалов, личностных особенностей и социальной ситуации развития; содействие психическому, физическому и духовному развитию человека и образовательной общности; определение ориентиров и критериев оценки эффективности образовательных условий для развития познавательных процессов личностных потенциалов и способностей обучающихся [8].

Актуальность обозначенных направлений очевидна, однако они ориентированы в большей степени на одного из участников образовательных отношений и в меньшей степени затрагивают собственно характер психолого-педагогических взаимодействий различных субъектов, включенных в образовательные ситуации.

Дальнейшее развитие исследований в означенной области, возможно, будет связано с постановкой следующих задач: систематизировать имеющиеся подходы по проблемам педагогических взаимодействий с учетом актуальных и перспективных реалий развития образовательной системы; определить стратегию и тактику организации педагогических взаимодействий в современном образовательном процессе с учетом меняющейся социокультурной ситуации; учитывать междисциплинарный характер освоения взаимодействий субъектов образовательного процесса в единстве психосоциопедагогической интеграции наук; продолжить разработку и уточнение тематического тезауруса, позволяющего формировать терминологическое пространство педагогики взаимодействий; создавать банки данных, включающие приемы и методы взаимодействий субъектов обучения, соответствующие новационным подходам в современном образовательном пространстве (интерактивное, дистанционное обучение, e-learning, сетевое взаимодействие, отношения партнерства в образовании и т. д.). 
Итак, на данный момент можно выделить четыре этапа в развитии и осмыслении психолого-педагогических взаимодействий и взаимоотношений участников образовательного процесса: 1-й этап может быть определен как этап реконструкции психологопедагогической науки (1960-1980-е гг.); 2-й этап отмечен интеграцией педагогики и психологии в рамках образовательного процесса (с конца 80-х до 2000-х гг.); 3-й этап связан с началом модернизации российского образования (первое десятилетие XXI в.); 4-й этап, этап «опережающей практики», начавшийся с цифровой эпохи XXI в., еще ждет своего анализа и методологического осмысления как в теории, так и в практике.

В итоге можно сделать вывод о том, что психолого-педагогические взаимодействия в образовательном пространстве представляют собой систему взаимообусловленных контактов, включающих социальные, психологические и собственно педагогические связи, где социальная сторона предопределяет направленность этих взаимодействий, психологическая - анализирует и уточняет механизмы и прогнозирует результаты контактов, а педагогическая - обеспечивает сам формат взаимодействий участников системы образования.

1. Братченко С. Л. Введение в гуманитарную экспертизу образования. СПб. : С.-Петер. гос. ун-т пед. мастерства, 2003. 55 с.

2. Маркова А.К., Никонова А.Я. Психологические особенности индивидуального стиля деятельности учителя // Вопр. психологии. 1987. № 5. С. 40-48.

3. Газман О.С. Педагогическая поддержка детей в образовании как инновационная проблема // Новые ценности образования: десять концепций и эссе. М., 1995. Вып. 3. С. 58-64.

4. Коротаева Е. В. Педагогика взаимодействий. Екатеринбург : Урал. гос. пед. университет. 1999. 147 с.

5. Коломинский Я. Л., Плескачева Н. М., Заяи И. И., Митрахович О. А. Психология педагогического взаимодействия. СПб. : Речь, 2007. 240 с.

6. Психолого-педагогическое взаимодействие участников образовательного процесса : в 2 ч. Ч. 1 : Учебник для академического бакалавриата / под ред. И. В. Дубровиной. М. : Юрайт, 2019. 237 с. 
7. Неумоева-Колчеданцева Е. В. Психолого-педагогическое взаимодействие участников образовательного процесса : учеб. пособие для акад. бакалавриата. М. : Юрайт, 2019. 159 с

8. Обухов А. С. Психология образования в контексте развития психологической науки и практики XXI века [Электронный ресурc]. URL: http:// fpp-mpsu.ru/uploads/all/all-1dWGPNiBzuCcYNo4zNsJRLAqzE3W7a.pdf (дата обращения: 16.03.2020). 


\section{АКСИОЛОГИЯ ЦИФРОВОГО ОБРАЗОВАНИЯ: НАЗАД В БУДУЩЕЕ?}

\section{С. Н. Костромина}

Идея цифровизации образования, постепенно входившая в нашу жизнь, сегодня стала частью реальности. Педагогическое сообщество разрабатывает дидактическую концепцию цифрового образования [1]. Электронные ресурсы в области цифрового образования агрегируют различные сетевые сервисы, технологии, данные, программы для поддержки и продвижения цифровизации образовательного пространства. Правительство объявляет о начале эксперимента по внедрению в 2020-2022 гг. целевой модели цифровой образовательной среды в сфере общего образования, среднего профессионального образования и соответствующего дополнительного образования детей и взрослых [2]. Участниками эксперимента станут 1,7 тыс. российских школ, в которых учится не менее 500 тыс. учеников. Предполагается, что модель цифровой образовательной среды к 2024 г. будет внедрена по всей стране. Авторы проекта обещают устойчивое достижение образовательных результатов группой «отстающих» школьников; соразмерную и своевременную подготовку школьников с высокими способностями; устранение перегрузки учителей рутинными задачами; преодоление ограниченности образовательных ресурсов; освоение современных цифровых технологий.

Что же стоит за термином «цифровое образование»?

Запрос в интернете на тему «цифровое образование» выдает более 46 млн результатов поиска, а ресурс «Российский индекс научного цитирования» в электронной библиотеке e-library - более 500. Причем если за десять лет с момента появления первых (с 2005 г.) отечественных публикаций можно найти не более двух десятков работ, то только за 2019 г. и первую половину 2020 г. их опубликовано уже более 300.

* Работа выполнена при поддержке гранта РФФИ № 18-013-00599 «Жизненные модели молодежи: межпоколенное и внутрипоколенное исследование». 
В зарубежной научной литературе наблюдается схожая тенденция. В наукометрической базе Web of Science Core Collection содержится около 30 тыс. научных публикаций, связаных с термином «digital education». Самая ранняя из них датируется 1962 г. [3]. В течение следующих 30 лет вышло не более пятидесяти релевантных рецензируемых научных работ, в то время как только за 2019 г. - более 5 тыс. При этом стоит отметить, что в зарубежной литературе разводятся понятия «цифровое образование» (digital education) и «цифровое обучение» (digital learning). В первом случае «реальность» образования (преподавание, обучение, управление, взаимодействие и т.д.) переформулирована в формат цифровых практик, которые реализуются с помощью нового программного обеспечения и соответсвующих им стандартов, кодов и алгометрических процедур, инфраструктуры баз данных и цифровых технологий [4]. Во втором случае чаще всего речь идет о цифровых технологиях, оптимизирующих учебный процесс за счет контроля времени, места, траектории, темпа учебной деятельности. Цифровое обучение сконцентрировано на практике учения с целью улучшения качества академических достижений. Это не только предоставление обучающимся доступа к цифровым устройствам, которое, кстати, не обязательно улучшает результат обучения, но и осознанная интеграция технологий, позволяющая активно вовлекать в идеи, взаимодействовать в классе, организовывать сотрудничество [5].

Обобщение подходов российских авторов к содержанию понятия «цифровое образование» позволило предложить следующее определение: «Под цифровым образованием следует понимать процесс организации взаимодействия между обучающими и обучающимися при движении от цели к результату в цифровой образовательной среде, основными средствами которой являются цифровые технологии, цифровые инструменты и цифровые следы как результаты учебной и профессиональной деятельности в цифровом формате» $[6$, с. 30]. Иными словами, системообразующими компонентами цифрового образования выступают: цифровая образовательная среда, цифровые алгоритмы организации учебного процесса и проверки знаний, цифровые образовательные технологии, цифровой контент, цифровые ресурсы и цифровые технологии взаимодействия. 
С точки зрения авторов проекта цифровой образовательной среды [7], цифровое образование - это появление принципиально новых цифровых учебно-методических комплексов (ЦУМК), создание системы фильтров-поисковиков, использование цифровых обучающих игр и цифровых симуляторов, размещение открытых онлайн-курсов и использование цифровых решений для упрощения отчетности. Цифровая образовательная среда (ЦОС), согласно постановлению Правительства РФ, определяется как совокупность условий, созданных для реализации образовательных программ с применением электронного обучения, дистанционных образовательных технологий. Она объединяет сразу несколько элементов: материально-техническое оснащение, скоростной интернет, образовательные сервисы с контентом, систему цифровых видеотрансляций и дистанционного обучения, электронные базы данных и т. д. В целом эта идея довольно четко была сформулирована мэром г. Москвы С. С. Собяниным в 2017 г.: « ...следующий этап информатизации образования - чтобы каждый учитель мог иметь у себя электронный план ведения конкретного урока с электронными методическими пособиями, с лучшими вариантами проведения данного урока, с созданием единой информационной базы и очень качественного цифрового контента [8].

Казалось бы, цель четкая и актуальная. Вряд ли кто-то будет возражать против скоростного интернета в школах или оснащения образовательных учреждений современным мультимедийным оборудованием или программным обеспечением, доступа учителей к лучшим педагогическим практикам, сетевой коммуникации профессионалов, родителей и школьников, модернизации системы управления образованием, в том числе через внедрение технологий анализа массивов больших данных. Но идея унификации и автоматизации образовательных процессов не может не настораживать. Особенно в ситуации, когда речь идет о персонализации и избавлении учителей от решения рутинных педагогических задач. Что же заставляет тревожиться педагогов, общественность и родителей? 


\section{Образование как ценность: \\ научные подходы к образовательной практике}

Есть мнение, что кризис - это шанс для технологий доказать свою ценность. Пандемия оказалась таким испытанием для цифрового образования, вернее, для цифровых технологий в образовании. Обучение в ситуации самоизоляции не только стало проверкой эффективности предлагаемой идеи цифровизации образования, но и заставило нас задуматься над ценностной стороной образования. Причем не только на уровне, что для нас ценнее - телекоммуникация или реальное общение в классе, онлайн-курс или традиционный урок? Вопрос гораздо глубже: в чем смысл современного образования? Чем для нас ценно образование? И что мы ценим в образовании больше всего? В 2017 г. А. Г. Асмолов сформулировал его так: «Для чего собственно нам нужно образование в современном мире?» [9, с. 1].

Ситуация пандемии стала проверкой системы образования на идентичность. Идентичность есть проекция отношений, которые формируются и закрепляются в ходе социального взаимодействия. Для образования идентичность - точка опоры, вокруг которой выстаиваются подходы и парадигмы. Идентичность «...вырастает из избирательного отказа от одних и взаимной ассимиляции других идентификаций и их объединения в новую конфигурацию, которая, в свою очередь, определяется процессом, посредством которого общество (часто через субкультуры) идентифицирует индивида с тем, кем... он должен стать» [10, с. 170]. Таким образом, в основе идентичности всегда лежат выбор, избирательность, рефлексивность, конструирование и осознание себя.

В широком смысле образование - это особая форма человеческого бытия. А. Г. Асмолов [11] называет образование механизмом социогенеза в развитии человека. Поэтому образование как система всегда стремилось к отождествлению себя с определенными ценностями и смыслами, с определенным мировоззрением и местом в обществе (общественной ролью). Через аккумуляцию опыта, трансляцию общественных отношений и интериоризацию культуры система образования конструирует свою идентичность. Через обратную связь, востребованность, полезность она постоянно верифицирует себя. 
Любые общественные изменения эхом отражаются на системе образования. Множественность выборов современного транзитивного общества проявляется во множественной идентичности образования при сохранении целостности - возможности выбора способов реализации своего назначения: разнообразии подходов к обучению, воспитанию и развитию личности, вариативности программ и образовательных траекторий. При этом независимо от выбора в центре образования всегда был и есть человек: ребенок или взрослый.

Ретроспективный взгляд на историю развития системы образования (во всяком случае, отечественной системы образования) позволяет отчетливо выделить три основных парадигмы образования или, по-другому, три образовательных подхода (см. таблицу): а) академический (естественно-научная ориентация, приоритет знания); б) технологический (практическая ориентация, приоритет освоения способов и техник работы); антропологический (гуманитарная ориентация, приоритет саморазвития в условиях образовательной общности) [12, с. 19].

Исторически каждый из подходов отражает ценностную идентификацию образования или, в проекции культурно-исторической концепции Л.С. Выготского, культурную идентичность.

\section{Академический подход в образовании}

В основе академического подхода лежит ценность знания (ценность усвоения). Или, говоря современным языком, - ценность информации. Знание - одна из немногих ценностей, присущая представителям разных эпох и типов общества. Со времен Платона знание трактуется как постижение истинной, духовной реальности, не связанной с чувственным опытом. Знание как постижение высшего смысла выступало ценностью духовной элиты, поэтому всегда отождествлялось с принадлежностью к определенной касте, избранностью, с делением на «посвященных» и «непосвященных». Знание длительное время не было доступно всем. И стремление к знанию свидетельствовало о потребности человека преодолеть свою ограниченность. Доступ к знаниям обеспечивал социальный статус и превосходство (во всяком случае, интеллектуальное) как 
Динамика развития научных представлений о личности и содержании ее развития в образовании

\begin{tabular}{|c|c|c|c|}
\hline \multirow{2}{*}{$\begin{array}{c}\text { Содержание } \\
\text { представлений }\end{array}$} & \multicolumn{3}{|c|}{ Научные подходы к образовательной практике } \\
\hline & академический & технологический & $\begin{array}{c}\text { антропологиче- } \\
\text { ский }\end{array}$ \\
\hline $\begin{array}{l}\text { Понятие лич- } \\
\text { ности }\end{array}$ & $\begin{array}{l}\text { Система качеств } \\
\text { и свойств }\end{array}$ & $\begin{array}{l}\text { Функция или } \\
\text { набор функций }\end{array}$ & Субъектность \\
\hline $\begin{array}{l}\text { Механизмы раз- } \\
\text { вития личности }\end{array}$ & Интериоризация & $\begin{array}{l}\text { Сдвиг мотива } \\
\text { на цель и резуль- } \\
\text { тат }\end{array}$ & Рефлексия \\
\hline $\begin{array}{l}\text { Процесс разви- } \\
\text { тия личности }\end{array}$ & $\begin{array}{l}\text { Формирование } \\
\text { качеств } \\
\text { и свойств }\end{array}$ & $\begin{array}{l}\text { Активность } \\
\text { (деятельность, } \\
\text { действия, опера- } \\
\text { ции, поступок, } \\
\text { творение) }\end{array}$ & $\begin{array}{l}\text { Трансцендиро- } \\
\text { вание (прида- } \\
\text { ние и обрете- } \\
\text { ние смысла) }\end{array}$ \\
\hline $\begin{array}{l}\text { Стратегия под- } \\
\text { готовки }\end{array}$ & $\begin{array}{l}\text { Информирова- } \\
\text { ние, формиро- } \\
\text { вание знаний, } \\
\text { умений и навы- } \\
\text { ков и контроль } \\
\text { за их усвоением }\end{array}$ & $\begin{array}{l}\text { Транслирование } \\
\text { и освоение техно- } \\
\text { логий эффектив- } \\
\text { ной деятельности } \\
\text { и поведения }\end{array}$ & $\begin{array}{l}\text { Передача } \\
\text { ценностного } \\
\text { отношения } \\
\text { к миру и себе } \\
\text { как субъекту } \\
\text { деятельности }\end{array}$ \\
\hline
\end{tabular}

за счет владения информацией, неизвестной другим, так и за счет образованности, свойственной определенным социальным группам. Даже сегодня возможность учиться в университете (получить высшее образование) рассматривается как социальный лифт. Знание дает свободу, позволяет делать выбор, раскрывать смысл, понимать мир, преодолевать отчужденность.

Парадигма ценности знаний направлена на формирование общества интеллектуалов. Доступность знания, вылившаяся в обязательное обучение в школах в XX в., способствовала расширению интеллектуального слоя общества. Эрудированный человек привлекал внимание, а интеллектуальные игры вызывали интерес. Фундаментализация образования способствовала формированию экспертов высочайшего уровня. Энциклопедизм советской школы долгое время был предметом восхищения со стороны зарубежных коллег. Однако высокий уровень теоретических знаний и боль- 
шой объем информации, заложенные в академическом подходе, предполагают соответствующий уровень способностей. Это стало вызовом для советской школы: учить всех на одинаково высоком уровне. В связи с чем возникла проблема расслоения учащихся на «успевающих», «неуспевающих» и «средних». Родилась идея о дифференциации знания на «обязательное» и «второстепенное», «нужное» и «ненужное», «доступное» и «избранное».

Мнение, что фундаментальные знания «нужны не всем», бытующее в обществе, фактически продолжает идентифицировать это направление как культуру элитарности, а не культуру интеллекта. Внедряемая в сознание идея «ненужности» знания создает условия для его девальвации, особенно на фоне информационной открытости и мгновенной доступности. Информированность постепенно вытеснила ценность Знания. В свое время Френсис Бэкон говорил: «Знание - сила!», а Натан Ротшильд уточнял: «Кто владеет информацией - владеет миром». Что из этого сегодня больше ценится в обществе: информация или знание? Может быть, ответ кроется в словах А.Н. Леонтьева, описавшего современное образование как «обнищание души при обогащении информацией» [цит. по: 13, с. 49].

\section{Технологический подход и культура полезности}

Технологический подход, «расцвет» которого пришелся на конец 70-х гг. ХХ в., связан с подготовкой к успешной деятельности и мобильностью. Согласно ему, центральное место в учебном процессе занимают инновационные образовательные технологии, обеспечивающие освоение ситуативных моделей (способов) эффективной деятельности. Разработка технологического подхода позволила учесть психологический механизм освоения любого вида деятельности, который раскрывался А.Н. Леонтьевым следующим образом: «Чтобы овладеть какой-либо конкретной деятельностью, нужно осуществить деятельность, адекватную той, которая воплощена в предмете, явлении и системе, которую они образуют» [14 с. 48].

Технологический подход повлек за собой включение в процесс обучения таких приемов и методов, которые учитывают цели, результаты (производство материальных и духовных ценностей) и средства деятельности, способствующие не только отражению, 
но и преобразованию действительности. Преимуществами технологического подхода стали «живость» и «практичность» учебного материала, который обеспечивает не только мотивационную вовлеченность в процесс обучения, но и актуальность формируемых профессиональных компетенций.

Современный компетентностный подход в образовании фактически «вышел» из технологического, стал его логическим продолжением. Согласно ему, образовательный опыт выступает средством сближения содержания обучения и потребностей общества (сферы деятельности), сокращая разрыв между теоретической и практической сторонами образования, формируя способность и готовность человека к решению определенного типа задач. В отличие от академического подхода в технологическом на первое место выступает ценность действия и результата (ценность освоения), компетентности и востребованности в обществе. Его символом является технология, а не человек. При этом роль фундаментальных знаний и гуманистических ценностей редуцируется.

Через технологический подход система образования идентифицирует себя с культурой полезности. Культура полезности представляет собой прагматичную адаптивную культуру, в которой личность сводится к функциям, господствует прагматизм, ценится исполнительность. Как уточняет А. Г. Асмолов, наиболее явно суть культуры полезности передается высказыванием «незаменимых нет». Такая культура всегда стремится к равновесию, к самосохранению, озабочена тем, чтобы выжить, а не жить [15]. В культуре полезности ценность знания девальвирует, неизбежно приводя к «интеллектуальному расточительству» [Там же, с. 9]. Она ориентирована на формирование технократического мышления, т. е. «мировоззрения», существенными чертами которого являются примат средства над целью, цели над смыслом и общечеловеческими интересами, смысла над бытием и реальностями современного мира, техники над человеком и его ценностями [16]. Культура полезности ориентирована на мобилизацию материальных ресурсов, людей, идей под задачу, выдвигая на первый план ценности безопасности, управляемости, предсказуемости [17]. 


\section{Антропологический подход и культура достоинства}

Антропологический подход предполагает проектирование образования через выявление и создание условий становления личности во всем многообразии ее проявлений. Его отличительная черта и новизна состоит в преодолении традиционных представлений об образовании в категориях «познание» и «практическое освоение». Антропологический подход, с одной стороны, ориентирован на сохранение общей цели образования (получение нового знания, формирование необходимых умений и навыков - обретение новых компетенций) и его содержание (освоение технологий эффективной профессиональной деятельности), а с другой - усиливает ориентацию на субъектность (как ключевую характеристику личности в деятельности) и совместность (как ключевую характеристику человеческой общности, социума). Постулатами антропологического подхода выступают базовые социальные ценности - признание уникальности человека, взаимопомощь, кооперация, солидарность. «Ценность, - писал Н. О. Лосский, - есть нечто всепроникающее, определяющее смысл и всего мира в целом, и каждой личности, и каждого события, и каждого поступка» [18, с. 250]. Она высвечивает отношение к сущему. Антропологический подход сфокусирован на уникальности (ценности) каждого человека, на гуманистических ценностях, на человечности. Он наполняет образование жизненным смыслом или, как говорил В. П. Зинченко, - душой [16]. Его развитие создает формат конструирования системы образования как культуры достоинства. Постулатом культуры достоинства является иенность личности, независимо от ее «полезности» для общества. Культура достоинства признает вариативность, многообразие и не боится непредсказуемости, ей свойственен «принцип солидарности» и чужда идеология конкуренции.

\section{Цифровое образование в зеркале культуры}

Рефлексия идей образовательных парадигм в зеркале культуры позволяет увидеть их глубинный общественный смысл. «Сила культуры в ее преемственности, в непрерывности ее внутреннего существования и развития, в ее порождающих и творческих возможностях... Культура — это граница времени», — писал В. П. Зинченко 
[16, с. 41]. Поэтому она является мерой исторического движения вперед, движущей силой развития. Именно культура порождает смысловой контекст того или иного исторического периода. Через действия и мысли, присущие определенному времени, мы можем понять его значение, цели, источник движения. Любые новшества через культуру преломляются в свете духовного содержания общества: ценностей, смыслов, традиций. Так что же несут цели и идеи цифрового образования? Те действия, которые направлены на цифровизацию образовательной среды, с точки зрения культуры, в координатах гуманистических ценностей, составляющих нравственную основу жизни человека?

\section{Ценность личности}

Человек и человечность всегда рассматривались как высшие ценности. Все современные концепции образования ориентированы на персонализацию и индивидуализацию. Цифровое образование - не исключение. Научные и популярные публикации оптимистично описывают преимущества нового цифрового пространства: планшеты в классе, обеспечивающие доступ каждому ученику к использованию интересных инновационных продуктов, информационных ресурсов (в том числе доступность библиотечного фонда) и технологичных инструментов; широкополосный интернет, позволяющий выйти в онлайн-коммуникацию большому количеству учеников одновременно из разных мест; лазерные проекторы, призванные улучшить визуальный ряд, используемый в учебном процессе; компьютерные программы, помогающие обмениваться изображениями и файлами, редактировать документы в реальном времени, общаться посредством чата или видеоконференций; оцифрованные учебники, которые не нужно переиздавать и покупать [19]; индивидуальный набор учебных заданий и информации, которые соответствуют возрасту и уровню подготовки обучающегося. Педагог сможет целенаправленно проектировать среду обучения под каждого обучающегося. Обучающиеся смогут управлять своим образованием. У учителя появится возможность отслеживать прогресс каждого, учитывая его способности. 
Описание цифрового образования в целом пересекается и перекликается с такими понятиями, как адаптивное обучение, дифференцированное обучение, компетентностное образование [20]. Но гуманизм не есть индивидуализм, в связи с чем индивид не может быть ценностью. Ценность представляет каждая отдельная личность во всем многообразии ее проявлений, уникальность каждого человека, его жизнь, его активность, его переживания. То есть потенциал цифрового образования должен быть ориентирован на поддержку разнообразия, а не сужен личными целями и пристрастиями.

Пока эта поддержка выливается исключительно в персонализацию учебного процесса (вернее, в его подстройку под каждого) посредством цифровых средств: индивидуальных гаджетов, высокоскоростного интернета, виртуальной (дистанционной, онлайн) коммуникации, а должна быть ориентирована на развитие личности. Концептуализация цифрового образования в формате адаптивности - «быть востребованным», «быть готовым к изменениям», «соответствовать времени», «стать эффективным» и т.д. - возвращает нас к подготовке «компетентных» профессионалов, способных к исполнению «полезных функций», только уже в цифровом мире. Получается, что образование технологически прогрессирует, но идея не меняется - основное место продолжает занимать оптимизация учебного процесса и освоение эффективных моделей деятельности, позволяющих развивать способность приспосабливаться к изменениям, проявлять гибкость и устойчивость к внешним воздействиям [21].

Переход же от технологической парадигмы образования к антропологической возможен только в случае, если центром образования будет ценность личности и личностные смыслы, а не ее компетентность и нужность. «Если рассматривать человека как индивидуальность, - пишет Б. С. Братусь, - то люди предстают как бесконечно разные миры, становящиеся все более обособленными и неповторимыми по мере их развития» [22, с. 319]. Реальное приобщение к человеческой действительности происходит через восходящее движение в нравственно-ценностной плоскости [14, c. 221]. Образование, ориентированное на становление личности, 
в первую очередь видит своей целью погружение в систему духовных координат общества, создающих поле переживания ценности личности. Оно должно приобщать к общечеловеческим ценностям: добру, любви, красоте, вере; формировать отношение к происходящему, к другому как к ценности, быть местом личностного, смыслового выбора, смысловыражения, смыслодвижения. Смысл - это эскиз будущих действий, говорит А. Г. Асмолов вслед за А. Бине. Смыслы определяют движение личности вперед. Мир, в котором живет личность, - «царство целей»: «...мое определение самого себя дано мне... в категориях цели и смысла, в смысловом будущем» [23 с. 109]. Становление личности происходит благодаря целеустремленности и интенциональности. Какое место эта составляющая образования занимает в цифровом образовании? Нужны ли нам технологии без смыслов? Или нам нужны технологии под смыслы? [17].

\section{Свобода и ответственность}

Свобода - высшая гуманистическая ценность. Подлинное образование всегда рассматривало свободу как цель. Образование по своей сути диалогично, в идеале оно предполагает диалог на «высшем уровне» - диалог личностей (т. е. межличностный диалог), способствующий становлению внутренней культуры человека, способного к самобытному творческому саморазвитию. Цифровое образование манит своей свободой открытого информационного пространства, доступностью лучших образовательных практик и ресурсов. Цифровой контент и виртуальная среда способствуют самовыражению и самореализации, расширяют возможности: временные, пространственные, ресурсные. Поясним свои слова примером. Ladson-Billings [24] иллюстрирует свободу цифровой образовательной среды для учителей и учащихся через создание ремиксов - редактирование и изменение культурных артефактов. По его мнению, их цифровизация позволит педагогам и школьникам творчески комбинировать достижения культуры в зависимости от потребностей учебного процесса, интересов и способностей, тем самым поддерживая культуру и способствуя ее усвоению.

Действительно, цифровые технологии реально позволяют перейти от педагогики необходимого к педагогике возможного. Но для 
того чтобы ориентироваться в пространстве возможного, необходимы внутренняя свобода и автономия. Педагогика необходимого ограничивает и учителей, и учащихся рамками класса, стандарта, программы и т.д. Но «если все необходимо и причинно обусловлено, то автономия личности лишена практического смысла» [25, с. 12]. Современная школа страдает от жестко заданной необходимости. Она задает рамки необходимых знаний, регламентирует поведение и деятельность учеников, выстраивает причинно-следственные связи между способностями и академическими достижениями, результативностью и выполнением требований.

Возможное же превращается в действительное только через свободный выбор и решение человека. Дает ли цифровое образование такую свободу выбора? И, может быть, более важный вопрос: готов ли педагог или ученик к осуществлению свободного выбора и принятию решений? Для этого необходим переход из режима детерминированности в режим самодетерминации. Выбор - это всегда выбор одного из возможных вариантов [26]. В его основе лежит рефлексивное сознание. Значит, расширяя пространство возможного и давая свободу выбора, педагогическое сообщество должно озаботиться проблемой становления рефлексивного сознания как учителей, так и учеников. Смысл свободы в цифровом образовании не в доступности, а в усилении осознанности учебной и педагогической деятельности. В противном случае можно получить одержимость «цифровым бытием», стать объектом манипуляции, оказаться жертвой недостоверной информации.

Пространство возможного переносит нас в мир неопределенного. Оно отражает сложный динамический характер взаимоотношений между необходимым, т.е. детерминированным, и возможным, т. е. самодетерминированным. Но кто определит это соотношение? Пока мы видим, что ключевую роль в этом процессе играют чиновники от образования. Неопределенность сложно контролировать. Поэтому включаются административные регуляторные рычаги: регламенты, алгоритмы, методические рекомендации; лучшие образовательные практики, которые кто-то определил; список онлайнкурсов, которые кто-то разрешил использовать; электронные учебники, содержание которых кто-то утвердил. Это позволяет совладать 
с избыточностью, сужая спектр возможностей. Потребитель же должен верить в то, что это лучшее для его образования.

Важно помнить, что свобода - это не дар, свобода должна быть построена $[16$, с. 9]. Свобода - это, прежде всего, труд и ответственность. Тем более если мы говорим про «свободу для...». Она требует осознания, самосознания, внутренней связи элементов личности. «Свобода для...» - это «свобода моего поступления» [23, с. 105]. Она подразумевает, что человек принимает на себя ответственность за себя, за свое бытие и свои поступки. «Я всегда свободен осуществить ответственный поступок, стать автором своей жизни, “нравственным субъектом”» [Там же, с. 110].

Таким образом, свобода для выбора «лучших педагогических практик» или для доступа к информации, к цифровому контенту, цифровым ресурсам требует нравственно значимой и ответственно активной установки сознания. Иными словами, расширение возможностей образования за счет его цифровизации должно сопровождаться становлением ответственности личности, ее готовностью и способностью к выбору, развитием критичности мышления. Постулируемая в цифровом образовании свобода, в противовес традиционному содержанию и ограниченному рамками классной комнаты пространству, подразумевает, что педагог или учащийся должен уметь быть ответственным за свой выбор. При этом задача образования как системы создать условия для свободного ответственного выбора, не требуя от сообщества учителей, родителей и учащихся слепой веры в то, что выбрали как лучшее за них и для них. Иначе создается ситуация «выбора без выбора». Слепая вера и общечеловеческие ценности не совместимы, поскольку гуманизм подрывает командный режим централизованного управления. Слепая вера в отличие от знания не сомневается в своей монополии на истину [15]. Имея монополию на цифровые технологии, идеологам цифровизации образования важно не превратиться в тех, кто лучше всех знает, что нужно образованию. И это уже их ответственность. 
Солидарность, коопераиия,

поддержка и другие социальные иенности

Ситуация пандемии ярко показала, насколько для нас ценны взаимопомощь, кооперация, солидарность. Мы привыкли, что общение и коммуникация - это вещи, само собой разумеющиеся. Кто может лучше других понять ценность общения? Только человек, находящийся в изоляции. Дистанционное обучение показало, насколько люди чувствуют себя потерянными и разобщенными, взаимодействуя на расстоянии, как важно для них физически находиться вместе в общем реальном пространстве.

Как будут реализованы социальные ценности в цифровом мире образования? Пока решение ограничено возможностями дистанционной кооперации при реализации командных и групповых проектов или онлайн-коммуникацией, тьюторством, наставничеством, поддержкой. Потенциально подразумевается, что социальная ценность образования при его цифровизации сохранится сама собой.

Человек по своей природе коммуникативен, но в первую очередь для него важно межличностное взаимодействие. Общение имеет для личности витальный смысл: вне напряженной «встречи» с другим личности не существует [27]. Бахтин намеренно обращает наше внимание - именно встречи с другим человеком (не с содержанием, не с инструментом, ни с каким-то другим объектом или явлением), поскольку только встреча с другим создает ситуацию со-бытия. Со-бытийность - способ существования личности. Она возникает в ходе диалога личностей, т. е. диалога на высшем уровне. Его ключевой характеристикой является равноправие - взаимное отношение друг к другу людей, вступающих в общение, как к суверенным, полноценным Я, со своими мирами, со своей позицией в со-бытии, имеющими равные права в отношении к истине и в отношении авторства собственных поступков [28, с. 73]. Это взаимная диалогическая позиция, которая отражает самостоятельность, равноправие и уважение друг к другу. Пространство «Я - Ты (другой)» образуют духовный слой со-бытия. Именно такое пространство и такая позиция наиболее ценны в образовании. Они задают нравственно полноценный контекст взаимного со-бытия и отличают диалог в высшем смысле этого слова от других видов общения. 
Социальные ценности как ценности со-бытия развиваются через сопричастность - активность человека в переживании: переживании того, как я мыслю, как я поступаю. Шпет называет такое переживание опытом или «испытанием» [29, с. 272]. Мы это почувствовали во время пандемии, когда «активность в переживании» проявилась в поддержке, взаимопомощи друг другу. Поэтому становление социальных ценностей завязано на единство культуры, сознания, мысли, переживания, деятельности, воли, поступка [30]. Их взаимосвязь создает особую «ценностную активность», обусловливающую формирование ценностной позиции деятельностно-этической направленности человека, отражающей уважение и признание ценности другого во всем многообразии проявлений. Ценностная позиция личности выступает внутренним носителем социальной регуляции [31], нравственным императивом.

Как будет выглядеть класс, где каждый погружен в свой ноутбук, решает свою индивидуальную задачу? А зачем в принципе идти для этого в класс? Можно остаться дома и подключиться к сети (можно даже не включать экран, чтобы педагог не видел, что ты делаешь, пока он объясняет), выполнить присланное именно тебе с учетом твоего уровня подготовки задание, сфотографировать поделку и отправить на проверку, ожидая персонализированной обратной связи от учителя. Эффективно. Функционально. Результативно. Образовательный процесс, несомненно, индивидуализируется, но какие общественные ценности и человеческие качества при этом формируются? И будет ли из одноклассников складываться некоторая общность, даже если они будут готовить совместный проект, но на расстоянии, общаясь онлайн.

В своей работе «К философии поступка» М. Бахтин [23] укорял психологию в ориентации на пассивно переживающего субъекта. Один из рисков цифровизации образования кроется как раз в пассивном переживании, исключении (или в сведении к минимуму) со-бытия, диалога личностей, невозможности быть причастным к бытию другого, предлагая взамен цифровой контент или виртуального собеседника. «Ценности вступают в сознание не иначе как посредством чувств субъекта, интенционально направленных на них. В связи с чувством субъекта, они становятся ценностями, 
переживаемыми им» [18, с. 308]. Важно не свести активные переживания, диалогическое общение, со-бытийность и со-причастность в образовании к пассивным или виртуальным переживаниям интересного цифрового контента. Иначе мы рискуем получить такую же виртуальную ценностную позицию, которая при столкновении с реальной действительностью обернется ценностной пустотой.

\section{Выводы}

В одной из работ, посвященных гуманистическим ценностям образования, мне встретилась такая фраза: «Неуправляемая культура становится технократической клеткой, в которой человек чувствует себя несчастным, одиноким покинутым, потерянным, утратившим самое главное - самого себя [31, с. 32]. Может ли духовное содержание стать клеткой? Может, если в содержании отсутствует духовное начало, источник развития. Эту ситуацию В.П. Зинченко обозначил как «сложноорганизованный социокультурный вакуум». Человек может находиться в культуре и оставаться вне ее [32].

Важно, чтобы идея цифровизации образования не была воплощена подобным образом. Это произойдет, если средства (инструменты) возобладают над целью, возобладает технократическое мышление. По В. П. Зинченко, технократическое мышление - это мировоззрение, существенными чертами которого являются примат средства над целью, цели над смыслом, смысла над бытием и реальностями современного мира, техники над человеком и его ценностями [16].

Взгляд технократа на человека отличается прагматичностью и утилитарностью, человек воспринимается как обучаемый программируемый компонент системы. В нем нет места для самодеятельности личности, свободы в возможном пространстве деятельностей. Ключевую роль играют интересы социума. Все подчинено внешним целям, а не личностным смыслам.

Если приложить это понимание к цифровым инновациям в образовании, то нетрудно заметить, что сейчас они довольно технократичны: внедрение цифровых инструментов и гаджетов, замена бумажного (как предполагается, устаревшего) контента на цифровой. Цифровизация образования идет в ногу с цифровой 
экономикой, цифровыми сетями, цифровыми телекоммуникациями, продвигает цифровую культуру, цифровую безопасность и цифровую грамотность. Идея цифровизации образования пропитана мыслью: «необходимо подготовить подрастающее поколение к жизни в цифровом обществе» и при этом не отстать в области технологий от всего мира. По всем признакам, несмотря на глобальные изменения в обществе и очередную промышленную революцию, образование продолжает двигаться в колее технологического подхода, технократического мышления и, соответственно, культуры полезности.

Культура полезности в образовании рефлекторна, а не рефлексивна. В этом ее ограниченность. Она реагирует на изменения с той или иной степенью мобильности, стараясь доказать свою нужность как на уровне сохранения традиций, так и с позиции соответствия («я соответствую требованиям»). Рамки, задаваемые этой культурой, не требуют от личности принятия собственных решений или совершения личностного выбора. Мы можем научить решать задачи, быть находчивыми и оригинальными в контексте заданного плана действий, сформировать понимание, как нужно и не нужно действовать, чтобы добиться успеха. Только контекст этот будет теперь цифровой. Суть же не изменится, поскольку наиболее ценимой компетенцией останется исполнительность.

В свое время В.П. Зинченко сказал, что большинство инновационных или альтернативных образовательных систем из всех атрибутов души выбирают познание, к тому же не во всей полноте этого понятия, а в его «знаниевой» форме [16, с. 29]. Но такая форма, как, впрочем, и «компетентностная», никогда не была и не может быть «чистой культурой», потому что суть культуры - связь людей. Связь же вещей - это суть цивилизации [22, с. 337]. Для развития цивилизации важен технический прогресс, где запускающим моментом становятся цели деятельности, результаты, достижения, средства, инструменты. Культура же является источником для развития человека. Но чтобы она стала таким источником, важно, чтобы человек не прошел через нее как через пустоту. Это возможно, только если артефакты культуры будут осмыслены и присвоены. 
Если ключевым вопросом образования станет не «как?», а «зачем?» или «для чего?».

Когда культура и смысл совмещаются (а именно это центральная идея антропологического подхода в образовании), происходит смещение акцента с усвоения или присвоения к самотворчеству. Человек предстает как осмысляющий культуру, придающий значениям жизнь и смысл. Он становится смыслоносителем, смыслоискателем [22, с. 321], личностью, осмысляющей то пространство, в котором находится. «Школа должна учить мыслить, в том числе мыслить о смысле» - это высказывание В. П. Зинченко относится не только к школе [16, с. 21]. Любое антропологическое действие, ориентированное на человека и общество, должно быть в очень четкой фокусировке: что оно дает для реализации определенных смыслов и ценностей. Сначала ценности и смыслы, замечает А. Г. Асмолов, и только потом технологии и инструменты для их реализации [17, с. 42].

В силу действия принципа гетерохронности, продолжает Асмолов, технология как средство всегда опережала антропологию. И система образования здесь не исключение. В то же время сегодня мы имеем уникальную возможность следовать не за технологиями, а за гуманистическими ценностями, ориентированными на человека и человечность. Эта возможность определяется тем, что мы уже знаем, каким будет результат, если образовательная парадигма строится на идеологии культуры полезности, а в ее основе лежит технологический (читай: компетентностный) образовательный подход. У нас есть выбор - остаться в идеологическом прошлом, хоть и современном цифровом, или наконец сделать шаг в будущее. В первом случае цифровое образование будет способно подготовить к решению сложных задач, к жизни в изменившейся реальности, но вряд ли обеспечит движение общества вперед. Если же мы изначально будем опираться на антропологическую парадигму образования и сможем заложить в концепцию цифрового образования не только технологии, но и механизм саморазвития личности взаимодействие культуры и смысла, мы сможем наконец перейти от культуры полезности к культуре достоинства, построенной на ценности личности, свободе, ответственности, сотрудничестве, поддержке и уважении. У нас еще есть время подумать об этом 
и прислушаться к словам В.П. Зинченко: «Образование без души опустошает душу».

1. Блинов В. И. Дулинов М. В., Есенина Е. Ю., Сергеев И. С. Проект дидактической концепции цифрового профессионального образования и обучения. М. : Перо, 2019. 72 с.

2. Школа цифрового века: 12 решений для нового образования [Электронный ресурс]. URL: https://www.hse.ru/twelve/part2 (дата обращения: 20.07.2020).

3. Silberman H. F. The Digital-Computer in Education // PHI DELTA KAPPAN. 1962. Vol. 43, iss. 8. P. 345-347.

4. Lawn M. The Rise of Data in Education // The Rise of Data in Education Systems: Collection, Visualization and Use / ed. by M. Lawn. Oxford : Symposium, 2013. P. 7-25.

5. Englund C., Oljfsson A.D., Price L. Teaching with tehnology in higher education: understanding conceptual change and development in practice // Higher Education Research \& Development. 2017. Vol. 36, iss. 1. P. 73-87. DOI: 10.1080/07294360.2016.1171300

6. Вайндорб-Сысоева М.Е., Субочева М. Л. «Цифровое образование» как системообразующая категория: подходы к определению // Вестн. Моск. гос. обл. ун-та. Сер. : Педагогика. 2018, № 3. С. 25-36. DOI: 10.18384/23107219-2018-3-25-36

7. О проведении в 2020-2022 годах эксперимента по внедрению целевой модели цифровой образовательной среды в сфере общего образования, среднего профессионального образования и соответствующего дополнительного профессионального образования, профессионального обучения, дополнительного образования детей и взрослых : постановление Правительства РФ. Москва, июнь 2020 г.

8. Заседание совета по стратегическому развитию и приоритетным проектам - 2017 [Электронный ресурc]. URL: http://www.kremlin.ru/events/ president/news/54983 (дата обращения: 20.07.2020).

9. Асмолов А.Г. На фига образование в современном мире? Щкола уходит в цифру [Электронный ресурс] // Московский комсомолец. 2017. 1 нояб. URL: https://www.mk.ru/social/2017/11/01/aleksandr-asmolov-nafiga-obrazovanie-v-sovremennom-mire.html (дата обращения: 05.08.2020). 
10. Эриксон Э. [Erikson Е.] Идентичность: юность и кризис. М. : Прогресс, 1996.

11. Асмолов А. Г. Психология личности. Принципы общепсихологического анализа. М., 1990.

12. Черникова Т.В. Психолого-педагогические основания профессионального развития специалистов образования и социальной работы : автореф. дис. ... д-р психол. наук. М., 2005.

13. Асмолов А.Г. Образование как ценностное полагание: диалог между педагогикой сотрудничества и культурно-исторической психологией // Народное образование. 2008. 5. С. 48-52.

14. Леонтьев А. Н. Деятельность. Сознание. Личность. М., 1975.

15. Асмолов А. Г. Непройденный путь: от культуры полезности к культуре достоинства // Вопр. психологии. 1990. № 5. С. 6-12.

16. Зинченко В. П. Аффект и интеллект в образовании. М. : Тривола, 1995. $64 \mathrm{c}$.

17. Асмолов А. Г. Сочтемся смыслами // Коммерсантъ Наука. 2020. 24 марта, № 6. С. 42.

18. Лосский Н. О. Ценность и бытие // Бог и мировое зло. М. : Республика, 1994. С. 250-315.

19. Dyer K. The Ultimate List - 65 Digital Tools and Apps to Support Formative Assessment Practices. 2018. 9 Jan. Retrieved 19 Nov., 2018, from https://www.nwea.org/blog/2018/the-ultimate-list-65-digital-tools-and-appsto-support-formative-assessment-practices/

20. Digital Learning. 2018. Retrieved 1 Nov., 2018, from https://library. educause.edu/topics/teaching-and-learning/digital-learning

21. Smit B., Wandel J. Adaptation, Adaptive Capacity and Vulnerability [Electronic resource] // Global Environmental Change. 2006. № 16. P. 282-292. http://dx.doi.org/10.1016/j.gloenvcha.2006.03.008

22. Братусь Б. С. Аномалии личности. Психологический подход. 2-е изд., перераб. и доп. М. : Никея, 2019. 912 с.

23. Бахтин М. М. К философии поступка // Философия и социология науки и техники. М., 1986. С. 82-160.

24. Ladson-Billings G. Culturally Relevant Pedagogy 2.0: a.k. a. the Remix [Electronic resource] // Harvard Educational Review. 2014. Vol. 84(1). P. 74-84. URL: https://doi.org/10.17763/haer.84.1.p2rj131485484751. 
25. Леонтьев Д. А. Новые ориентиры понимания личности в психологии: от необходимого к возможному // Вопр. психологии. 2011. № 1. С. 3-27.

26. Киркегор С. Наслаждение и долг. Киев : AirLand, 1994.

27. Бахтин М. Н. Эстетика словесного творчества. М., 1979. 424 с.

28. Братченко С. Л. Концепция личности: М. Бахтин и психология // М. М. Бахтин и философская культура ХХ века. Проблемы бахтинологии. СПб., 1991. Вып. 1, ч. 1. С. 66-75.

29. Шnет Г. Г. Philosophia Natalis : избр. психол.-пед. тр. М. : POCСПЭН, 2006.

30. Зинченко В. П. Ценности в структуре сознания [Электронный ресурс] // Вопр. философии. 2011. 30 авг. URL: https://gtmarket.ru/laboratory/ expertize/6612 (дата обращения: 05.08.2020).

31. Леонтьев Д. А. Психология смысла: природа, строение и динамика смысловой реальности. М. : Смысл, 1999.

32. Дерюга В.Е. Гуманистические ценности как основа и цель образования личности // Проблемы современного образования. 2013. № 6. С. 31-40.

33. Лефевр В. А. Рефлексия. М. : Когито-Центр, 2003. 


\section{НАВИГАЦИОННЫЕ ХАРАКТЕРИСТИКИ ЦИФРОВЫХ ТЕКСТОВ КАК ФАКТОР УСПЕШНОГО ИНФОРМАЦИОННОГО ПОИСКА ОБУЧАЮЩИХСЯ*}

\section{Т. С. Леднева \\ А. И. Ковалев}

Пандемия COVID-192020 г. создала беспрецедентные условия для проверки эффективности цифровых технологий в разных областях и особенно в сфере образования. Во всем мире взаимодействие людей в максимально допустимой степени перешло в цифровой формат. В подобных условиях длительного и безальтернативного по форме взаимодействия с информацией остро встал вопрос эргономичности цифровых материалов при выполнении различных задач.

За последние десятилетия цифровизация не только повысила эффективность работы с информацией, но и значительно трансформировала практики ежедневного взаимодействия с данными, в частности в виде текстов. Стремительный переход от преимущественно книжного, газетного и журнального чтения к чтению с экранов цифровых устройств сочетается с переменами в структуре чтения как деятельности. Так, в аспекте чтения наблюдаются тенденции к переходу от досуговых практик к чтению служебному и функциональному, направленному на поиск конкретной информации [1]. В отличие от досугового чтения, которое может являться целью читателя, служебное встраивается в деятельности более высокого порядка и исполняет роль операции. Служебное чтение, превалирующее в образовании и профессиональной подготовке, имеет свою специфику. Содержательная составляющая такого вида чтения определяется конкретной поставленной перед читателем задачей, тогда как по форме эта деятельность всегда представляет собой поиск. Служебное чтение подразумевает активное взаимо-

* Исследование выполнено при финансовой поддержке РФФИ в рамках научного проекта № 18-29-22049 «Фундаментальные проблемы создания и исследования обобщенной модели цифрового образования на основе системно-деятельностного подхода». 
действие с текстом как совокупностью единиц информации. В зависимости от задачи размер этих единиц возрастает от знаков, слов, предложений до абзацаев и страниц. Эффективность взаимодействия с данными единицами включает в себя необходимость точно и быстро локализовать их в тексте [2]. При этом важно учитывать, что поиск информации человеком в цифровых текстах во многом определяется как характеристиками формы представления текста на экране цифрового устройства, так и способами взаимодействия читателя с ним. Таким образом, возникает проблема изучения функционального или служебного чтения через призму навигационных характеристик цифровых текстов.

\section{Характеристики цифровых текстов}

Ключевыми характеристиками текста, как способствующими, так и лимитирующими эффективность поиска, являются разборчивость, читабельность и физические атрибуты текста [3]. Разборчивость (иногда в литературе используется термин «удобочитаемость») текста определяет легкость идентификации текстовых знаков читателем [4]. Исследователи рассматривают влияние различных факторов внешнего графического облика текста на пригодность к прочтению, например, оптимальный контраст между фоном страницы и единицами текста, цвет и шрифт текста, его размер и плотность [4], фрагментарность и искаженность единиц текста. Читабельностью называют степень легкости, с которой может быть усвоен смысл текста [3]. Читабельность текста является более широким понятием и включает в себя разборчивость.

Помимо разборчивости и читабельности, которые в большей степени описывают структурные элементы текста, важно рассмотреть его физические атрибуты как целого, а именно динамические и навигационные характеристики. Под навигационными характеристиками понимаются различные ориентиры и памятные зацепки в тексте, с которыми читатель может связать информацию. Печатные и цифровые тексты предоставляют множество таких ориентиров. Например, заголовки, иллюстрации, таблицы, схемы, разделение на абзацы, отступы, нумерация страниц и прочие визуальные подсказки значительно способствуют построению нави- 
гации в тексте, однако они используются не в каждом тексте, так как определяются содержанием. Универсальными же атрибутами любого текста являются поверхность, на которую он нанесен, ее свойства и протяженность текста. Именно границы листа и позиция страницы относительно объема текста до и после нее могут служить подобием оси координат при решении задачи информационного поиска. Данные ориентиры задаются по-разному в печатных и цифровых текстах. В печатной книге страницу можно условно разделить на три части: верхняя треть (начало), средняя (середина) и нижняя (конец). Сгиб корешка делит разворот на правую и левую части. Высота стопки бумажных листов создает дополнительные ориентиры через соотнесение большей и меньшей частей, указывающих, где примерно в тексте находится читатель [5]. Таким образом, если читатель помнит, что нужная информация находилась в конце книги на левом развороте в верхней части страницы, то поисковая задача значительно упрощается.

С цифровыми текстами ситуация иная. Как правило, такой текст имеет вид луча с четко фиксированным и видимым началом документа и субъективно необозримым концом. Объем текста оценивается опосредовано, через обозначения номеров страницы (если они есть) или шкалу прокрутки (обычно располагается сбоку). Эксперименты показывают, что если читатель намеренно не создает ассоциацию между содержанием страницы и ее номером посредством создания пометки, закладки или повторения, то он не использует нумерацию как индикатор положения, а опирается на примерные ориентиры текста (начало, конец, середина) [6]. Предполагается, что функция ползунка на шкале прокрутки - показывать положение в документе и объем текста до и после текущего фрагмента. Эта функция может считаться цифровым аналогом трехмерной стопки листов печатного текста [5]. Однако в ряде исследований показано, что шкала прокрутки является слабой навигационной подсказкой $[7,2]$. Чтобы имитировать возможность обзора текста целиком, как будто все листы документа физически разложены перед читателем, современные текстовые редакторы предлагают расположение в окне просмотра миниатюрных изображений всех станиц документа. Данная опция позволяет не только визуально оценить объем текста, 
но и быстро перемещаться по нему посредством нажатия на изображение нужной страницы. В таблице указаны актуальные для цифрового текста универсальные навигационные ориентиры и их реализация в текстовом редакторе.

Универсальные навигационные подсказки цифрового текста

\begin{tabular}{l|l}
\hline \multicolumn{1}{c|}{ Навигационная подсказка } & Реализация в текстовом редакторе \\
\hline Объем текста & Миниатюры страниц \\
\hline Границы листа & $\begin{array}{l}\text { Фиксированность страницы в окне } \\
\text { просмотра }\end{array}$ \\
\hline
\end{tabular}

Динамическое взаимодействие с цифровым текстом в современных текстовых редакторах осуществляется в целом двумя способами - постраничным перелистыванием или прокруткой (скроллингом) [8]. Многообразие соотношений сторон экранов цифровых устройств и их размеров серьезно лимитирует возможность использовать границы страницы в качестве ориентира. Нередко страница текста не помещается целиком в окне просмотра текстового редактора, что затрудняет читателю процесс определения положения видимого фрагмента относительно начала и конца как страницы, так и текста в целом [5]. Чтобы избежать потери ценного источника навигационных данных, многие текстовые редакторы позволяют гибко настраивать параметры отображаемой страницы так, чтобы она была зафиксирована в окне просмотра. При выборе данной опции остается доступным только один способ динамического взаимодействия с текстом - постраничное перелистывание. Если же страницу не фиксировать, то по тексту можно перемещаться плавным прокручиванием (скроллингом).

Все три описанных типа характеристик текста (разборчивость, читабельность и динамически-навигационные характеристики) влияют на эффективность поискового чтения. Однако различаются возможности пользователя цифрового текста манипулировать данными характеристиками, чтобы увеличить их положительный эффект и нивелировать отрицательный. Изменение читабельности не рассматривается в рамках данной работы, так как специфика поискового чтения подразумевает взаимодействие с готовым текс- 
том. Цифровизация снимает ограничения разборчивости, которые присутствовали в печатных текстах, так как цифровой текст обладает высокими возможностями преобразования, позволяющими читателю гибко настраивать тип, цвет, размер шрифта и взаимное расположение элементов текста.

Остается открытым вопрос оптимизации динамических и навигационных характеристик цифрового текста и его атрибутов для повышения эффективности поискового чтения. Критерием для выбора лучшего сочетания навигационно-динамических характеристик текста может стать когнитивная нагрузка, возникающая при поисковом чтении в заданных условиях. Когнитивная нагрузка это широкий термин, под которым понимается совокупность умственных ресурсов человека, необходимых для решения конкретной задачи [9]. Исследователи данного феномена описывают явления ограниченного внимания и емкости рабочей памяти как конкретные узкие места, которые постоянно оказывают нагрузку в процессе обработки человеком информации [10-12]. Так, Дж. Свеллер, один из основоположников исследований данного феномена, выделяет три типа когнитивной нагрузки [11]: внутренняя нагрузка (intrinsic load) напрямую связана с заданием, которое необходимо выполнить в определенных условиях, внешняя нагрузка (extraneous load) создается характеристиками интерфейса, или среды, в которой разворачивается реализации процесса, и «внутренняя сложность», связанная с выполнением основной задачи. Также выделяют ситуационную нагрузку (germane load), или количество умственных усилий, необходимых для понимания сути процесса и материалов. Возможность разделить три типа сложности достигается путем сравнения показателей эффективности испытуемых в процессе выполнения одинаковых задач в средах с разными характеристиками. Во многих областях, где человек тесно взаимодействует с большим объемом информации и решает ответственные задачи, остро стоит вопрос снижения количества ошибок и повышения эффективности. Таким образом, в вопросах эргономики, дизайна и цифровизации многих сфер жизни исследователи когнитивной нагрузки фокусируются на разработке принципов для создания сред и интерфейсов, которые снижают внешнюю когнитивную нагрузку, чтобы доступ- 
ные интеллектуальные ресурсы могли быть направлены на решение основных задач [11].

Когнитивная нагрузка может быть исследована различными методами. На сегодняшний день обязательным атрибутом все большего числа когнитивных исследований становится применение метода регистрации окуломоторной активности, или айтрекинга, в качестве индикатора протекания нейрокогнитивных процессов, психических явлений и поведения [12]. С помощью данной технологии по характерным паттернам движения глаз испытуемого возможно отслеживать динамику работы высших психических функций в реальном времени [13]. Основные компоненты глазодвигательной активности - это саккады и фиксации. Первые представляют собой быстрые согласованные перемещения глаз, а вторые - статические, во время которых происходит прием зрительной информации [13]. В своих многочисленных работах Рейнер с коллегами выделяют ключевые параметры, которые необходимо учитывать при анализе процесса чтения, такие как длительность фиксаций, амплитуда саккад и возвратные саккады. Особенности траекторий движения глаз позволяют ответить на вопрос, какой способ навигации в тексте создает дополнительный вклад в когнитивную нагрузку при решении задач поиска информации в цифровом тексте. В терминологии теории когнитивной нагрузки подобная добавочная к основной задаче активность является компонентом внешней когнитивной сложности и должна быть минимизирована [9]. А изменение паттернов глазодвигательной активности дает информацию о динамике когнитивной нагрузки при работе в цифровых текстовых средах с разными навигационно-динамическими характеристиками.

Таким образом, цель данного исследования - определить влияние навигационных и динамических характеристик представления текста на цифровых устройствах на процесс поиска информации в тексте. Основной гипотезой является предположение о наличии зависимости между успешностью навигации в тексте и степенью обогащенности цифровой среды навигационными подсказками. В качестве частных гипотез были выдвинуты следующие предположения: в наиболее обогащенных подсказками средах испытуемые будут затрачивать меньше времени на поиск информации; в наиболее 
обогащенных подсказками средах испытуемые будут использовать более простые траектории движения глаз.

Участники. На данном этапе в исследовании участвовало 15 испытуемых (мужчин - 6, женщин - 9), средний возраст 32 года. Все испытуемые имели нормальное или скорректированное до нормального зрение, не имели черепно-мозговых травм и органических поражений головного мозга.

Стимулы. Путем комбинирования способов динамического взаимодействия с текстом и навигационных подсказок было сформировано четыре типа информационных сред. Навигация через прокручивание («Прокрутка») или постраничное перелистывание («Постранично») определила две большие группы сред по способу взаимодействия с текстом. Фиксированность окна просмотра была реализована в группе с постраничным перелистыванием («Постранично»). Внутри каждая группа также была разделена на две подгруппы по признаку наличия или отсутствия возможности совершать обзор текста целиком, реализованной через опцию текстового редактора «Миниатюры текста» («+миниатюры»). Среда с постраничным перелистыванием и миниатюрами текста (типа «Постранично + миниатюры») предполагалась как наиболее обогащенная навигационными подсказками (рис. 1).

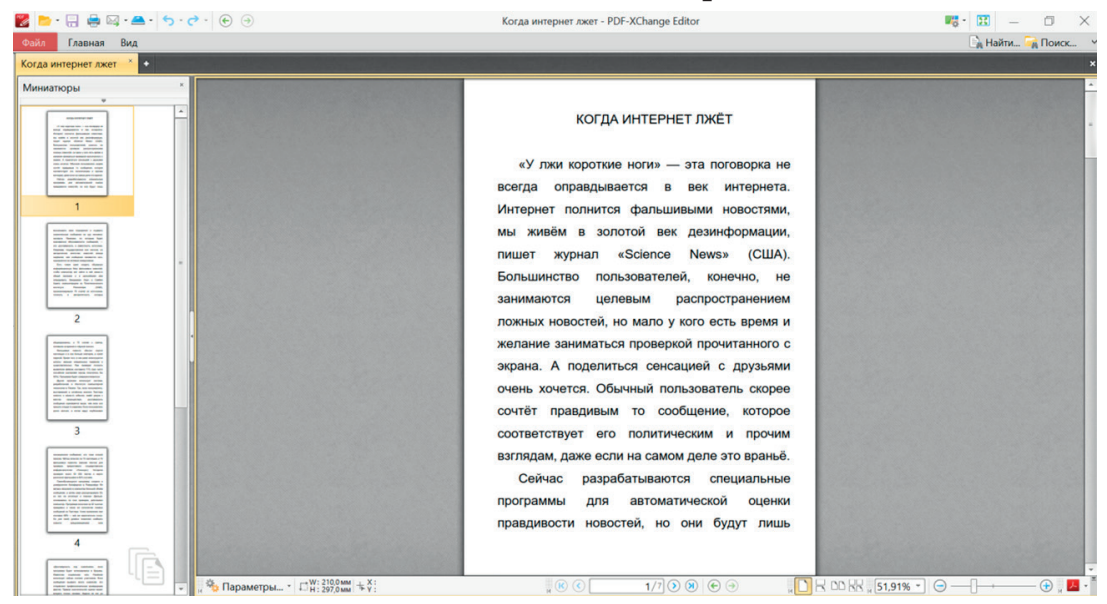

Рис. 1. Пример представления стимула в формате «Постранично + миниатюры» 
Стимульный материал представлял собой четыре текста, нормированных по читабельности и разборчивости, или по содержанию и сложности, и визуальным характеристикам, соответственно. Нормированность по читабельности текстов была реализована за счет двухэтапного отбора. Первичный подбор текстов осуществлялся через расширенную метатекстовую разметку Национального корпуса русского языка [14]. Далее тексты были автоматически оценены по наиболее популярным метрикам сложности [15]. Средние значения базовых характеристик отобранных текстов - 3160 знаков, 400 слов, 25 предложений, 11,7 \% сложных слов, уровень читабельности 13,1. Разборчивость текстов нормировалась через одинаковое форматирование (шрифт, кегль, интервал, поля). Тексты были распределены по одному для каждого типа среды. К каждому стимулу были подобраны по 6 вопросов по содержанию этих текстов, направленных на поиск конкретной, а не смысловой информации в них.

Оборудование. Тексты предъявлялись на экране монитора с диагональю экрана 23 дюйма, разрешением $1920 \times 1080$. Регистрация движений глаз осуществлялась с помощью айтрекера SMI RED 120 с частотой 120 Гц, точность регистрации составила $<0.1$ углового градуса. Построение экспериментальной процедуры осуществлялось в программе ExperimentCenter 3.6. Обработка полученных глазодвигательных результатов проводилась в программе BeGaze 3.6.

Процедура. Всем участникам эксперимента предъявлялись тексты по одному в каждом типе среды. После прочтения текста испытуемым предлагалось найти и выделить в тексте ответы на шесть вопросов по содержанию прочитанного текста.

Эффективность поиска была операционализирована через показатели времени, затраченного на поиск ответов на вопросы к тексту, и сложность пространственно-временных траекторий движений глаз в процессе поиска при каждом способе предъявления текста. Сложность траектории была определена как избыточный путь, пройденный взором при поиске ответа. Данный показатель был рассчитан как отношение реальной траектории поиска к идеальной. Идеальная траектория, в свою очередь, была определена как минимальное расстояние между концом текста и строкой с искомым 
ответом. Операционально данные величины были получены путем присвоения каждой строке текста порядкового номера при обработке данных записи рабочего экрана в ходе эксперимента. Далее происходила процедура вычитания номера строки с ответом из номера последней строки текста. На уровне визуализации поискового поведения испытуемых фиксация идеальной траектории пути взора при анализе глазодвигательной активности выглядела бы как линия, близкая к вертикальной прямой, и свидетельствовала бы о том, что участник, прочитав вопрос, точно и безошибочно по памяти после прочтения текста определил локализацию ответа на вопрос и переместился к нему наикратчайшим путем.

\section{Результаты}

Методом двухфакторного дисперсионного анализа с повторными измерениями были обнаружены значимые различия $(p<0,05)$ влияния факторов способа навигации и наличия миниатюр на сложность траектории движения глаз (рис. 2) и время поиска ответов в тексте (рис. 3).

Пути взора при перемещении по тексту через скроллинг или постраничное перелистывание продемонстрировали различие на высоком уровне статистической значимости $(F=18,1, d f=1, p=0,004)$, так же как и время поиска $(F=6,5, d f=1, p=0,038)$. В условиях наличия или отсутствия миниатюр достоверно различались временные

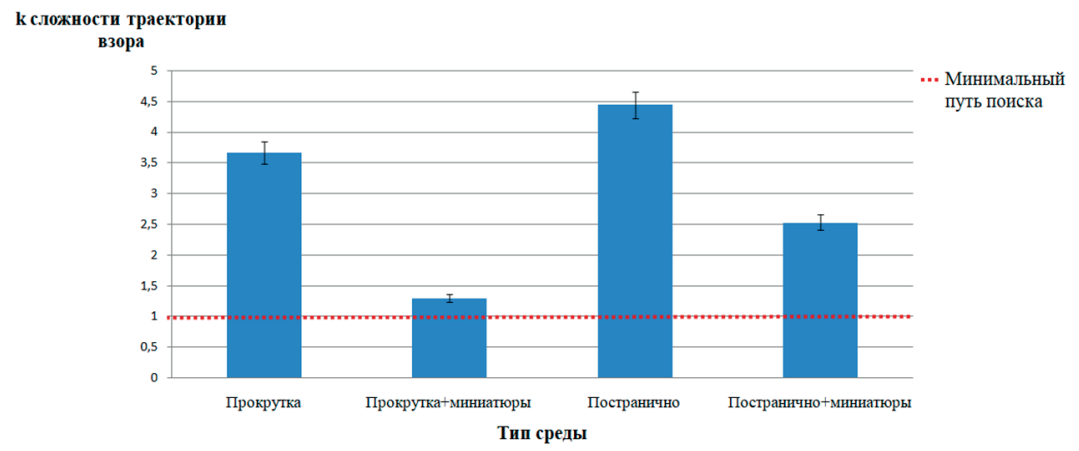

Рис. 2. Отношение реального пути взора испытуемых к идеальному при поиске в четырех текстовых средах 
и глазодвигательные паттерны навигации $(F=6,170, d f=1, p=0,042$ и $F=21,260, d f=1, p=0,002$ соответственно). Взаимодействие факторов на достоверном уровне значимости обнаружено не было.

\section{Обсуждение}

В среде с миниатюрами и возможностью перемещаться по тексту через скроллинг («Прокрутка + миниатюры») наблюдались самые высокие показатели эффективности поиска ответов. Путь взора был близок к минимальному, а у двоих испытуемых была зафиксирована траектория короче идеальной (рис. 2). То есть в данных условиях участники не только использовали возможность ускоренного перемещения по тексту с помощью функции «Миниатюры», но и не допускали ошибки в выборе страницы, на которой ожидали найти ответ. Возможно, данный тип предъявления текста, учитывающий непрерывный способ перемещения по тексту и возможность совершать его обзор целиком через миниатюры, способствует формированию макроструктуры текста, или его когнитивной карты, дающей примерное представление о локализации той или иной информации в теле текста. Сопоставление результатов времени поиска ответов участниками в средах «Прокрутка + миниатюры» и «Прокрутка» показывает, что использование миниатюр дает ощутимое преимущество в скорости выполнения задачи (рис. 3). Для данного способа перемещения по тексту характерны лаконичные

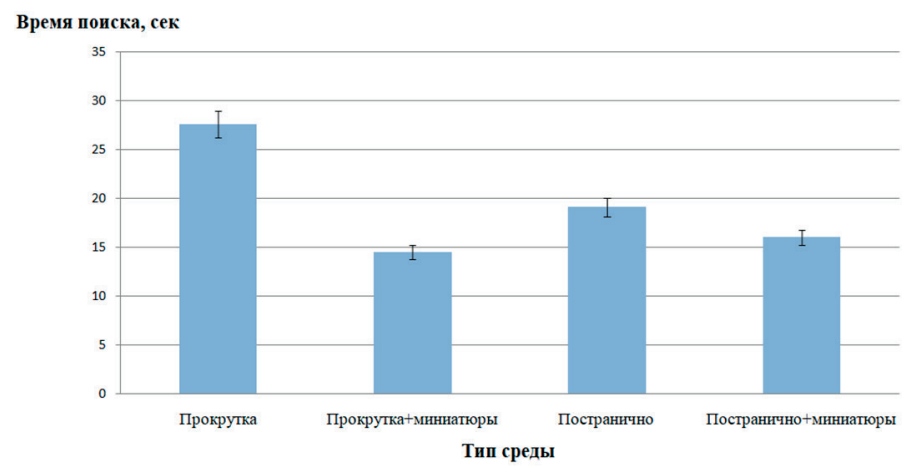

Рис. 3. Среднее время поиска ответов испытуемыми в каждой текстовой среде 
траектории движения глаз. Путь взора испытуемых в процессе поиска ответов в среде «Прокрутка» принимал форму «флага» (рис. 4, a), а именно: в данной информационной среде большинство испытуемых плавно и методично поднимались от вопросов в нижней части документа до предполагаемой области с ответом и затем более подробно сканировали эту часть текста. В условиях, когда испытуемым была доступна опция ускоренного перемещения по тексту с помощью функции миниатюр, путь взора принимал ее более минималистичные и прерывистые очертания (рис. 4, б). В данном случае многие участники пропускали этап плавного прокручивания текста до предполагаемой области с ответом и сразу переключались на нужную страницу.

В средах с постраничным типом навигации по тексту все испытуемые продемонстрировали более длинные и сложные траектории поиска, чем при перемещении прокруткой (рис. 5). В обеих подгруппах независимо от наличия миниатюр наблюдались пилообразные траектории движения глаз по странице, а также частые глобальные возвраты от текста в область вопросов к нему. Самый сложный и длинный путь поиска не только в группе с постраничной навигацией, но и во всех сформированных информационных средах участники демонстрировали в условиях постраничного перелистывания без миниатюр - «Постранично» (рис. 5, a). Паттер-

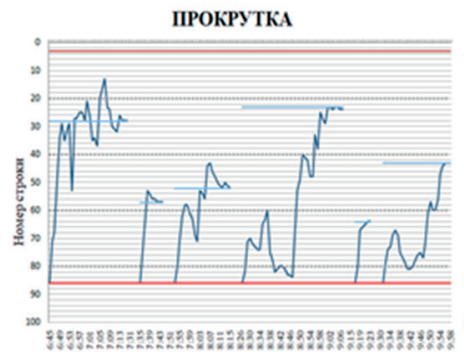

$a$

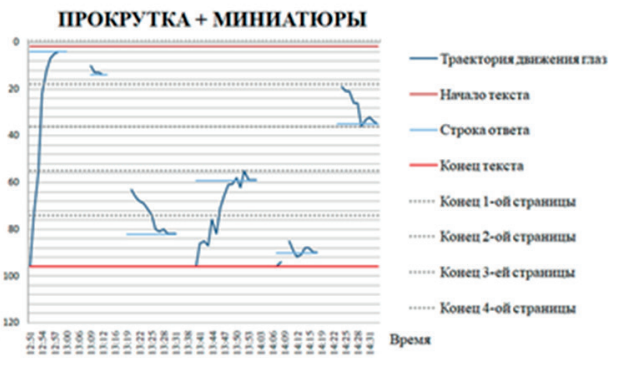

6

Рис. 4. Траектории пути взора испытуемых по строкам текста в процессе поиска ответов на вопросы в среде с типом навигации «Прокрутка»: $a-6 е з$ миниатюр; 6 - с миниатюрами 
ны глазодвигательной активности в данной среде дают основания полагать, что подобный способ навигации не позволил испытуемым создать целостную и связанную в памяти модель текста, а именно: специфика данного способа навигации в тексте давала возможность очень быстро передвигаться сразу на несколько страниц, и после каждого длинного скачка траектория взора принимала пилообразные очертания. Это указывает на то, что каждый раз, переместившись в тексте, участники начинали подробно сканировать страницу строчку за строчкой. Таким образом, им приходилось снова читать текст, чтобы по смыслу определить, где могла находиться нужная информация. Именно в этой среде участники чаще всего прерывали поиск, спускались в конец текста, перечитывали вопрос и снова возвращались к поиску. Данное наблюдение позволяет предположить, что среда с постраничным перелистыванием без возможности использовать миниатюры страниц создавала хаотичную навигацию по тексту и тем самым задействовала значительное количество ресурсов рабочей памяти. Таким образом, можно заключить, что выполнение поисковой задачи в условиях среды «Постранично» индуцировало у участников серьезную когнитивную нагрузку. А с учетом того, что все текстовые материалы и вопросы к ним прошли процедуру нормирования по сложности, есть основания полагать, что эта когнитивная нагрузка была не внутренней, относящейся

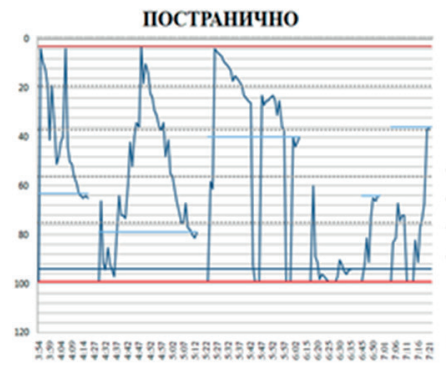

$a$

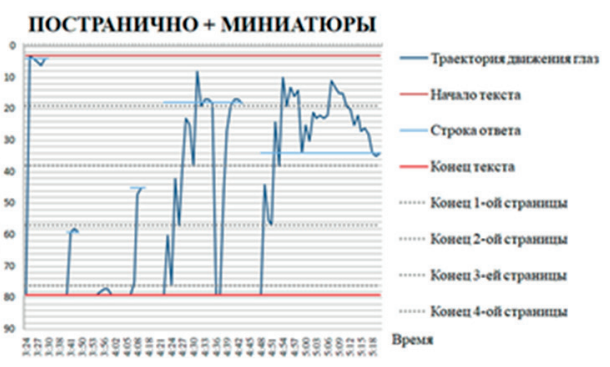

6

Рис. 5. Траектории пути взора испытуемых по строкам текста в процессе поиска ответов на вопросы в среде с типом навигации «Постранично»: $a-6 е з$ миниатюр; $6-$ с миниатюрами 
к задаче, а внешней, создаваемой средой, в которой выполнялась поисковая задача.

Особое внимание стоит обратить на пространственные (рис. 2) и временные (рис. 3) характеристики поиска в среде «Постранично + миниатюры». Данная среда была спроектирована как наиболее обогащенная навигационными подсказками, и, согласно гипотезе, способствующая наиболее эффективному поиску. Однако по всем показателям данная среда уступила среде «Прокрутка + миниатюры», но в то же время показатели эффективности поиска оказались гораздо выше, чем в условиях среды «Постранично». В среде «Постранично + миниатюры» участники затрачивали времени на поиск лишь немногим больше, чем в среде «Прокрутка + миниатюры». В то же время движения глаз участников при поиске в среде «Постранично + миниатюры» (рис. 5, б) демонстрировали менее сложные траектории, чем в среде «Постранично» (рис. $5, a$ ). Возможное объяснение различий в сложности путей взора заключается в том, что миниатюры в среде «Постранично + миниатюры» брали на себя часть нагрузки на рабочую память и, будучи представлены на экране как последовательные элементы, упорядочивали хаотичную навигацию «скачками». Меньшее количество глобальных возвратов в область вопросов в пределах поиска одного ответа подтверждает это предположение. Иными словами, негативное влияние постраничного перелистывания на эффективность поиска нивелировалось при наличии миниатюр страниц. Однако отсутствие плавных переходов между страницами, позволяющих выстроить по навигационным подсказкам связанную карту (как в средах «Прокрутка»), существенно усложняло навигацию и провоцировало больше ложных переходов, что отразилось и на времени поиска (рис. 3).

Сопоставление траекторий движения глаз в процессе поиска ответов в тексте способами при отсутствии возможности использования функции ускоренного перемещения нажатиями на миниатюры страниц может дать ответ на вопрос, какой способ навигации в тексте - прокруткой или перелистыванием - внес наибольший вклад в когнитивную нагрузку при решении задач информационного поиска в цифровом тексте. В сравнении с путями взора, полученными при перемещении только постраничным перелисты- 
ванием (рис. 5, a), траектории движения глаз при навигации только прокруткой документа имеют более простые очертания (рис. $4, a$ ). Последовательная реконструкция процесса поиска позволяет идентифицировать моменты возникновения избыточной когнитивной нагрузки. Так, при плавном прокручивании страницы взор преимущественно перемещается по одной области экрана, наиболее удобной и привычной для читающего (как правило, это верхняя треть экрана), а текст подтягивается прокручиванием к этому уровню. Этот паттерн движения глаз при чтении был подробно описан в работе Дж. Бушера с коллегами в 2010 г. [16]. В этом исследовании подчеркивалось, что возможность плавно и непрерывно подтягивать текст с помощью функции скроллинга в определенную область экрана, комфортную для чтения, и минимизировать движения глазами является предпочтительной стратегией чтения для большинства участников эксперимента. Наблюдаемые при навигации прокруткой возвраты и регрессии в большей степени обусловливаются не технической необходимостью работы с текстовым редактором, а важностью понимания текста читателем. Особенность же постраничного перемещения по тексту чаще всего создает избыточную глазодвигательную активность. Так, дойдя до конца страницы, взор оказывается в правом нижнем углу экрана и после перехода на следующую страницу должен совершить длинную диагональную саккаду в верхний левый угол на начало первой строки. Возможно, при чтении описанное действие занимает лишь малую часть всего процесса и не оказывает значимого влияния на увеличение объема необходимых когнитивных ресурсов. Однако при поиске информации, когда за короткий промежуток времени необходимо просканировать большое количество страниц, что соответствует условиям данного эксперимента, подобные избыточные действия могут внести значительный вклад в неэффективное распределение умственных усилий и лимитировать успешность выполнения основной задачи. В терминологии теории когнитивной нагрузки подобная дополнительная к основной задаче активность является компонентом внешней когнитивной сложности и должна быть минимизирована [10]. 
Наиболее яркой иллюстрацией, подтверждающей наличие существенного влияния условий выполнения поисковой задачи в цифровых текстах на количество избыточной глазодвигательной активности, является сравнение траекторий пути взора испытуемых в средах «Прокрутка + миниатюры» (рис. 4, б) и «Постранично». Значительная длина и сложность траекторий движения глаз в цифровой среде с постраничным перемещением по тексту без возможности использования функций миниатюр в сравнении с минимальными путями взора при поиске ответов в среде «Прокрутка + миниатюры» демонстрирует, что способ навигации, отвечающий условиям среды «Постранично», создает существенный дополнительный вклад в когнитивную нагрузку при решении задач поиска информации в цифровом тексте.

Результаты данного исследования следует сопоставить с более ранними работами по этой же теме. Одни из первых экспериментов по оценке качества чтения цифрового текста с прокруткой или с постраничным перелистыванием проводила П. Коллерс с коллегами в 1981 г. Исследования показали, что текст с прокруткой испытуемые читали медленнее и пропускали большее число ошибок [17]. Похожие результаты были получены позднее Е. Вастлундом с коллегами, которые экспериментально доказали снижение умственной нагрузки при постраничной работе с текстом [6]. Качество чтения в данных экспериментах оценивалось через анализ правильности ответов испытуемых на вопросы на понимание текстов. В 2007 г. У. Вегнер и А. Инхофф использовали технологию айтрекинга при анализе чтения [18]. Исследователи просили читателей взглянуть на слова, которые они только что прочитали, и оказывалось, что глаза испытуемых сразу же находили слова на экране без необходимости перечитывать отрывок. Ученые показали, как пространственное расположение текстовых единиц может быть связано с когнитивной нагрузкой. Так как текст в документе, перемещаемом с помощью прокрутки, сдвигается, читатели теряют преимущество фиксированного положения слов на странице как на карте. Прежние навигационные ориентиры листа, такие как начало, конец, середина страницы, заголовки или иллюстрации, становятся не актуальны, и читателю приходится опираться на контекст, чтобы найти нужную 
информацию. Это требует подключения дополнительных ресурсов памяти, отвлекает от основной задачи поиска и повышает когнитивную нагрузку. Результаты описанных экспериментов позволяют сделать вывод, что представление текста в постраничном виде в процессе чтения предпочтительнее для понимания и идентификации в нем смысловых единиц.

Расхождение в результатах оценки эффективности способа навигации в тексте прокруткой и постраничным перелистыванием в упомянутых исследованиях и в данной работе может иметь несколько объяснений. В первую очередь необходимо учесть, что во многих этих работах в качестве оценки эффективности чтения в определенных условиях испытуемым давали задачи на понимание текста, а не на поиск информации. В исследовании У. Вегнера и А. Инхоффа, где подразумевается поиск слов, в качестве стимульного материала использовали короткие тексты, что затрудняет корректное соотнесение результатов. Когда же измерялась эффективность выполнения заданий сканирующего характера, именно плавное прокручивание страницы показало лучший результат, как например, в работе Е. Вастлунда 2008 г. и в исследовании К. ван Нимвегена с коллегами 1999 г. $[6,19]$. Также важно отметить время проведения исследований - прогресс и конкуренция в сфере цифровых технологий и развитие юзабилити-инженерии каждые десять лет повышают стандарты и качество цифровых устройств, что делает данные, полученные двадцать или тридцать лет назад, неактуальными. Стоит также отметить, как практика отдельного действия может изменять его вклад в совокупную когнитивную сложность всей деятельности. Вопрос о том, как привычка работать в цифровой среде определенным конкретным образом влияет на эффективность выполнения задач, рассматривался российскими исследователями. В эксперименте 2016 г. И. Блинникова с коллегами сравнивали показатели эффективности поисковой активности пользователей при решении типичных задач на сайтах с разными интерфейсами [20]. В данной работе было обнаружено, что нервноэмоциональное напряжение нарастает при поисковых задачах именно в непривычных или неудобно организованных информационных средах. Таким образом, если учесть, что за последние годы благодаря 
популярности социальных сетей и распространенности работы с текстовой информацией с экрана телефона скроллинг стал самым используемым методом чтения длинных текстов на цифровых устройствах [21], то возникает необходимость пересмотра вклада конкретных способов навигации в когнитивную нагрузку при работе с цифровыми текстами.

\section{Выводы}

В рамках данного исследования было изучено влияние навигационных и динамических характеристик представления текста на цифровых устройствах на процесс поиска информации в тексте. Была сформулирована гипотеза о наличии зависимости между успешностью навигации в тексте и степенью обогащенности цифровой среды навигационными подсказками. Для эмпирической проверки гипотезы на основе выделенных навигационных и динамических характеристик цифровых текстов были сформированы текстовые среды, различающиеся по данным характеристикам, и разработан стимульный текстовый материал, нормированный по разборчивости и читабельности. Методом айтрекинга были зафиксированы пространственно-временные траектории движения взора участников эксперимента в процессе поиска информации в текстах, построены траектории пути взора при работе в каждой информационной среде и проведен статистический и содержательный анализ полученных результатов.

Частично подтвердилась гипотеза о том, что в наиболее обогащенных подсказками средах испытуемые будут затрачивать меньше времени на поиск информации. Вопреки ожиданиям авторов, среда с наибольшим количеством навигационных подсказок «Постранично + миниатюры», сочетающая возможности целостного обзора страницы, визуальной оценки текста и ускоренного перемещения по нему с помощью миниатюр текста, уступила по показателям пространственно-временных характеристик поиска среде «Прокрутка + миниатюры». Однако на высоком уровне статистической значимости подтвердилась гипотеза о том, что в наиболее обогащенных подсказками средах («Прокрутка + миниатюры» и «Постранично + миниатюры») испытуемые будут использовать более простые тра- 
ектории движения глаз, чем в условиях отсутствия возможности обозревать текст целиком.

Полученные в данной работе результаты могут быть интерпретированы следующим образом: среды, обогащенные навигационными подсказками, в которых учтены возможности совершать обзор текста целиком и непрерывное динамическое взаимодействие, способствуют целенаправленному перемещению в тексте при поиске информации, снижают внешнюю когнитивную нагрузку и позволяют построить эффективные когнитивные карты.

Таким образом, была разработана и апробирована экспериментальная процедура определения влияния навигационных и динамических характеристик представления текста на цифровых устройствах на процесс поиска информации в тексте. Разработанная процедура благодаря анализу пространственно-временных траекторий движений взора позволила количественно оценить различия в навигационном поведении человека при чтении текстов, представленных в различных форматах.

1. Гросс И.С. Функциональное чтение и работа с текстом как одно из направлений работы с учащимися в условиях ФГОС // Школьная педагогика. 2018. № 3. С. 15-16.

2. Li L. Y., Chen G.D., Yang S. J. Construction of cognitive maps to improve e-book reading and navigation // Computers and Education. 2013. № 1 (60). P. 32-39.

3. Феличи Дж. Типографика: шрифт, верстка, дизайн. СПб. : БХВ-Петербург, 2004. 496 с.

4. Sysuev I. A. et al. Assessment of perception of electronic publications, made on white and colored backgrounds (qualimetric aspect) // Omsk Scientific Bulletin. 2018. № 161. P. 39-44.

5. Золотарев Д. А., Белько Т.В. Сравнительный анализ особенностей восприятия текста на бумажном носителе и в интерактивной среде // Изв. Самар. науч. центра Рос. акад. наук. 2011. Т. 13, № 2. С. 215-220.

6. Wästlund E., Norlander T., Archer T. The effect of page layout on mental workload: A dual-task experiment // Computers in Human Behavior. 2008. № 3 (24). P. 1229-1245. 
7. Hill W. C. et al. Edit wear and read wear // Conference on Human Factors in Computing Systems - Proceedings. 1992. P. 3-9.

8. Piolat A., Roussey J., Thunin O. Effect of screen presentation on text reading and revising // International Journal of Human-Computer Studies. 1997. P. 565-589.

9. Oviatt S., Arthur A., Cohen J. Quiet interfaces that help students think. N. Y., USA : ACM Press, 2008. P. 191-200.

10. Sweller J. Cognitive load during problem solving: Effects on learning // Cognitive Science. 1988. № 2 (12). P. 257-285.

11. Sweller J. Cognitive load theory: Recent theoretical advances // Cognitive Load Theory. 2010. May (9780521860). P. 29-47.

12. Величковский Б. Когнитивная наука. Основы психологии познания : в 2 т. М. : Смысл : Академия, 2006. Т. 1. 448 с.

13. Rayner K. Eye movements and attention in reading, scene perception, and visual search. 2009. P. 1457-1506.

14. Национальный корпус русского языка [Электронный ресурс]. URL: http://www.ruscorpora.ru/new/ (дата обращения: 19.04.2020).

15. Проверка на читабельность текстов | PlainRussian.ru [Электронный pecypc]. URL: http://ru.readability.io/ (дата обращения: 19.04.2020).

16. Buscher G. et al. Eye tracking analysis of preferred reading regions on the screen. N. Y., USA : ACM Press, 2010. P. 3307-3312.

17. Kolers P. A., Duchnicky R. L., Ferguson D. C. Eye movement measurement of readability of CRT displays // Human Factors. 1981. № 5 (23). P. 517-527.

18. Weger $U$. W., Inhoff $A$. W. Long-range regressions to previously read words are guided by spatial and verbal memory // Memory and Cognition. 2007. № 6 (35). P. 1293-1306.

19. Nimwegen C. van, Pouw M., Oostendorp H. van. The influence of structure and reading-manipulation on usability of hypertexts // Interacting with Computers. 1999. № 1 (12). P. 7-21.

20. Блинникова И. В., Капица М. С., Леонова А. Б. Психологические исследования информационного поиска в интернет-среде // Мир психологии. 2016. № 4 (88). С. 246-256.

21. Brady K. et al. Is scrolling disrupting while reading? // Proceedings of International Conference of the Learning Sciences, ICLS. 2018. № 2018, June (1). P. 152-159. 


\section{ПСИХОЛОГИЧЕСКИЕ МЕХАНИЗМЫ РАЗВИТИЯ ПРАВОВОГО САМОСОЗНАНИЯ ЛИЧНОСТИ: ТЕОРЕТИКО-МЕТОДОЛОГИЧЕСКИЕ АСПЕКТЫ}

Р.Р. Муслумов

Проблема самосознания и самоопределения обучающихся представляет собой одну из острейших проблем развития образования в современных условиях. Вступление общества в постиндустриальную эпоху и демократические преобразования способствуют социальной самоорганизации, расширению условий для эффективного самоуправления индивидов. Развитие правового самосознания студентов является важнейшей составляющей в формировании базовой культуры будущего специалиста. Необходимость изучения психологических механизмов развития правового самосознания студентов определяется задачами повышения эффективности правовоспитательной и профилактической деятельности, целями формирования духовного мира человека. Исследование правового самосознания личности имеет важное теоретическое и прикладное значение, однако сегодня оно сопряжено с существенными методологическими трудностями. Учитывая потребность в развитии правового самосознания личности и отсутствие специальных работ в данной области, выявление психологических механизмов правового самосознания является весьма актуальным.

Целью нашего исследования является теоретико-методологический анализ психологических механизмов развития правового самосознания личности.

Самосознание - целостное представление о самом себе, отношение к себе, самооценка своих качеств (внутренних и внешних), осознание своих недостатков и достоинств, определение путей самосовершенствования и самовоспитания. «Ведущее место в самосознании, — пишет А. Г. Спиркин, — занимает осознание требований общества к личности, своего общественного долга и смысла жизни...» [1, с. 147]. «Я-концепция» - это относительно устойчивая система представлений индивида о самом себе, на основе которой он строит взаимодействие с другими людьми и относится к себе. Японский 
ученый Д. Мацумото, определяя роль самосознания в жизни человека, указывает на то, что «наше ощущение “Я” находится в сердцевине нашего бытия, бессознательно и автоматически влияя на каждую нашу мысль, действие и чувство. Каждый человек использует эти внутренние атрибуты, которые направляют его мысли и действия в различных социальных ситуациях» [2, с. 55].

Правовое самосознание - это познание себя в правовом бытии, выбор своей правовой роли, правовой позиции, своих юридически значимых целей и действий, определение собственного места и значения в мире права. Это осознание, оценка, контроль субъектом права своего положения, действий и их последствий в правовой сфере. Правовое самосознание личности представляет собой многоуровневое интегральное образование, включающее в себя эмоционально-чувственную, рациональную, волевую сферы, проявляющееся в отношении человека к себе, к другим людям, в деятельности и правовом поведении.

\section{Определение понятия «психологический механизм», классификация психологических механизмов развития правового самосознания личности}

Для понимания и объяснения сущности психологического явления или процесса, его возникновения и закономерного хода развития требуется проникнуть в его внутреннее устройство, понять взаимосвязь и взаимозависимость частей или элементов целого, иначе говоря, рассмотреть психологические механизмы.

В современной психологии проблема психологических механизмов достаточно актуальна и изучается в таких областях, как психология личности, мышления, деятельности, в социальной психологии, педагогической психологии, юридической психологии. В гуманитарных исследованиях рассмотрение вопроса о существовании и функционировании психологических механизмов является спорным. Нет однозначного определения понятия «психологический механизм», не сформированы единые взгляды на его происхождение и методы диагностики. Наиболее общее определение механизма дается в толковом словаре С.И. Ожегова: «1) Внутреннее устройство (система звеньев) машины, прибора, аппарата, приводящее их в действие. 
2) Система, устройство, определяющие порядок какого-нибудь вида деятельности. 3) Последовательность состояний, процессов, определяющих собою какое-нибудь действие, явление» [3, с. 300].

В понимании психологического механизма, как правило, исходят из двух возможных парадигм: естественно-научной и социальнопсихологической. Первая предполагает понимание психологических механизмов как «механических устройств» (т.е. создание неких моделей на основе представлений механики и физики). Акцент при этом сделан на изучении нервных механизмов в процессе отражения. В отечественной психологии естественно-научный подход представлен, в частности, работами Б. М. Теплова, Е. И. Бойко. В социально-психологической парадигме психологические механизмы рассматриваются в контексте понятия «личность», т. е. с учетом особенностей потребностей, мотивов, ценностей и деятельности конкретного человека.

Психологические механизмы нашли освещение в трудах 3. Фрейда и его последователей. Одним из первых понятие «механизм» в отечественной психологии применил Л. С. Выготский, причем отождествляя термины «психологический» и «психический». Это использовано для описания процесса становления и развития личности и для раскрытия механизмов ее поведения [4, с. 241]. Проводя теоретический анализ литературы, мы обнаружили многообразие психологических механизмов, обеспечивающих развитие того или иного психологического явления. Интерес представляют работы Л. И. Анцыферовой, В. Г. Леонтьева, Р. Д. Санжаевой, Л. Н. Антилоговой, С. Г. Косарецкого, В.И. Слободчикова, А. М. Столяренко и др. Психологические механизмы характеризуются как «психологические превращения, посредством которых совершается действие закономерностей и происходят переходы от причины к следствию» [5, с. 19].

Психологические механизмы развития правового самосознания личности представляют собой динамическую психологическую систему, которая включает различные условия, факторы и средства, структуры и отношения, связи и другие психические явления, обеспечивающие формирование, протекание и регуляцию этого процесса. Воздействие психологических механизмов обеспечивает 
эффективное правовое развитие личности, а при определенных условиях, наоборот, может способствовать деформации личности, возникновению и формированию противоправного поведения.

Развитие правового самосознания личности - это процесс его количественного и качественного изменения под влиянием внешних и внутренних, социальных и природных, управляемых и неуправляемых факторов. Развитие - это направленный процесс: движение по восходящей линии - прогрессивное развитие; движение вспять, назад - регресс. Развитие человека непосредственно побуждается внутренними движущими силами, оно обусловлено чрезвычайно многообразными обстоятельствами, средой, включающей в себя природные, социальные, правовые, культурные, психобиологические факторы.

Процесс развития правового самосознания личности осуществляется на основе многих психологических механизмов, которые можно подразделить на следующие группы:

1) в зависимости от решающих факторов детерминации: правовая социализация, адаптация, интериоризация, индивидуальноличностные и психофизические механизмы;

2) в зависимости от содержательных особенностей: познавательные механизмы, мотивационный механизм, механизм принятия и освоения роли, защитные механизмы, рефлексия, индивидуализация, механизм самооценки, эмпатии, эмоциональные, волевые, психомоторные механизмы;

3) по социально-психологическому основанию: подражание, внушение, убеждение, идентификация, социальное восприятие, групповое давление, манипуляция, заражение, подчинение, социальная ингибиция, фасилитация и др.

Правовая социализация. Общим механизмом правового становления человека, формирования и развития его правовой сущности, в том числе его правового самосознания, выступает процесс правовой социализации. Впервые понятие «социализация» было введено в научный обиход французским социологом Э. Дюркгеймом, а в середине XX в. оно получило широкое распространение в разных отраслях науки. Понятие «правовая социализация» стало употребляться в науке с 60-х гг. XX в. в работах американской 
школы правовой психологии. Правовая социализация составляет необходимую и важную часть общей социализации: «Правовая социализация в своем развернутом виде означает все более полное осознание человеком, гражданином своей социальной роли, места в социальной структуре общества, выработку самосознания... все более широкое включение в социально-правовые отношения, наполненные их личностным содержанием» [6, с. 105]. Правовая социализация - это процесс включения личности в правовые отношения, приобретение определенных правовых знаний, убеждений и навыков, способность реализовать их в своей повседневной деятельности, в отношениях с другими людьми. Правовая социализация осуществляется во взаимодействии социально-биологических и социальных факторов развития человека. Поведение человека зависит как от социальных, так и от биологических факторов. Причем авторитет должен быть за социальными факторами, так как личность формируется и действует в определенной социальной среде и ее поступки зависят не столько от физиологических особенностей и состояния организма, сколько от межличностных отношений различного уровня и общности.

Правовая социализация включает в себя воздействие социальных условий на человека, а также деятельность самого человека. По словам Г.М. Андреевой, «социализация - это двусторонний процесс, включающий в себя, с одной стороны, усвоение индивидом социального опыта путем вхождения в социальную среду, систему социальных связей, с другой стороны, процесс активного воспроизводства системы социальных связей индивидом за счет его активной деятельности, активного включения в социальную среду» [7, с. 338]. Правовая социализация может осуществляться стихийно, в непосредственном социальном окружении, и целенаправленно, на основе разработанной системы воздействия на человека в соответствии с «социальным заказом».

Составной частью процесса правовой социализации выступают правовое воспитание, правовое обучение, просвещение и пропаганда. Полученные знания помогают индивиду формировать ценностные ориентации, социальную установку, выступают стержнем правового сознания. Важное звено в правовом воспитании - непо- 
средственное включение субъекта в правовую деятельность, участие в осуществлении права. Пользование на деле правами и свободами, реальное исполнение обязанностей, дальнейшее развертывание правовых начал в общественной жизни стимулируют формирование демократической правовой культуры. От уровня и качества воспитания в значительной мере зависит уровень правовой культуры, перевод правовых требований в привычку, в социально-активное поведение. В процессе правового воспитания важно учитывать индивидуальные интересы и потребности, реальные и потенциальные возможности, уникальность и неповторимость каждой личности, однако не менее важно учитывать и интересы общества, в котором живет человек. Мы стремимся к свободе личности, но ее свобода не должна нарушать права и свободы других людей, общественные интересы. Органическое единство интересов индивида и общества создает возможность формирования современной цивилизованной правовой личности.

В социализации личности выделяют две фазы - социальную адаптацию и интериоризацию, которые рассматриваются как основополагающие механизмы правовой социализации. Социальная адаптация означает приспособление индивида к социальной среде. Интериоризация (превращение внешнего во внутреннее) - это процесс включения социальных норм и ценностей во внутренний мир человека, обусловленный структурой каждой конкретной личности, ее предшествующим опытом. Правовая социализация относится к процессу освоения правовых знаний, норм, ролей, процедур соблюдения законов, выступает как механизм интеграции индивида в общество. В условиях демократизации правовая социализация предполагает не только усвоение правовых норм, но и умение творчески применять нормы права, отстаивать правовыми средствами свои собственные интересы, а также права других людей, бороться с преступностью.

В процессе правовой социализации осуществляется не только типизация, но и индивидуализация личности, которая приобретает самостоятельность, относительную автономность. Д.И. Фельдштейн отмечал, что процессы индивидуализации-социализации «...есть моменты единого процесса социального развития... необходимо 
предполагают друг друга. Индивидуализация есть неизбежный результат (оборотная сторона) процессов социализации, и, наоборот, дальнейшее развитие индивидуализации возможно лишь через социализацию, лишь на ее основе, только социализация дает “материал”, из которого могут строиться индивидуальные “формы поведения"» [8, с. 75].

Становление правовой личности осуществляется в сферах деятельности, общения и самосознания. Личность осваивает различные виды деятельности, формируются ее интересы, потребности, ценностные ориентации и пр. В сфере общения приобретаются навыки цивилизованного взаимодействия с окружающими. В сфере самосознания происходит становление образа Я, определение своего места в правовом пространстве, формируются самооценка, отношение к себе, контроль своих действий и их последствий в каждой конкретной социальной ситуации. Правовая социализация осуществляется в единстве изменений в этих трех сферах. На процесс социализации влияют многие объективные факторы (мега-, макро-, мезо-, микрофакторы) и субъективные факторы (личностные характеристики, индивидуальные особенности, психологические свойства и состояния личности, уровень социальной зрелости).

Сущность мотивационного механизма. Экскурс в историю изучения проблемы. В правовом развитии личности, в развитии ее правового самосознания решающую роль играет мотивационный механизм. Мотивационный механизм определяет избирательность отношений личности к окружающему миру, происходящим событиям, к будущему и, соответственно, ее активность. “"Проникнуть” в личность, оказать на нее воздействие как на личность, в том числе и с помощью социальных норм и предписаний, можно лишь через мотивационную систему этой личности» - пишет М.И. Бобнева [9, с. 120].

Проблема мотивации рассматривалась уже в работах древних философов (Сократ, Платон, Гераклит, Демокрит, Аристотель, Конфуций). В рассмотрении сущности мотивации наблюдается две крайности: рационализм и иррационализм. Рационалисты видят мотивационный источник человеческого поведения исключительно в разуме. Если человек совершает преступление, это происходит 
от «незнания» (Сократ). С середины XIX в. началось интенсивное изучение инстинктов человека (материнский инстинкт, стадный инстинкт, половой инстинкт, инстинкт выживания и др.). В начале XX в. появились работы В. Вунда, Т. Рибо, В. Джеймса, У. Макдауголла, в которых дается анализ мотивационных действий человека, раскрывается роль мотива в поведении. В зарубежной психологии возникли следующие направления, изучающие сферу мотивации:

1) бихевиоризм и необихевиоризм (Дж. Уотсон, К. Халл, Э. Торндайк, Э. Толмен, Б. Скинер и др.), объясняющие поведение человека в рамках «стимул-реакция»;

2) фрейдизм и неофрейдизм (3. Фрейд, А. Адлер, В. Юнг, К. Хорни);

3) гештальтизм (М. Вертгеймер, К. Коффка, Ф. Перлз, К. Левин);

4) теории гуманистической психологии (Г. Олпорт, А. Маслоу и др.), в которых мотивация тесно увязывается с актуализацией личности;

5) частные специальные концепции, представленные в трудах Дж. Роттера, Г. Келли, Х. Хекхаузена, Дж. Аткинсона, Р. Кеттела и др.

В настоящее время только в зарубежной психологии существуют десятки теорий мотивации. Объединить эти теории сложно, поскольку у них разные исходные позиции, разный смысл вкладывается даже в основные понятия (мотив, мотивация, потребности и т.д.).

Среди отечественных исследований начала XX в., решающих проблемы мотивации человеческого поведения, следует отметить работы Л. И. Петражицкого, А. Ф. Лазурского, Н. Н. Ланге, В. П. Боровского, Н. Ю. Войтонис, Л.С. Выготского. В последующие годы эти проблемы рассматриваются в трудах С. Л. Рубинштейна, Д. Н. Узнадзе, А. Н. Леонтьева, В. С. Мерлина, А. Г. Ковалева, П. М. Якобсона и др. Советскими психологами была разработана теория деятельностного происхождения мотивационной сферы человека, обоснованы принципы единства сознания и деятельности, единства сознания и общения, личностный принцип, требующий исследовать психические процессы и состояния как процессы и состояния личности. Мотивацию и мотивы анализируют В. Г. Асеев, В. К. Вилюнас, В. И. Ковалев, Е.П. Ильин, В. Г. Леонтьев, М.Ш. Магомед-Эминов, П. В. Симонов, С. Г. Москвичев, В. И. Моросанова, Е. А. Аронова и др. 
Проведено немало исследований мотивации в различных сферах жизнедеятельности. Мотивы учения исследовали Л.И. Божович, М. И. Алексеева, В. М. Рутковская, П. М. Якобсон, А. К. Маркова и др. Мотивацию студентов изучали Р. Р. Бибрих, И. А. Васильев, С. В. Бобровицкая, В.Я. Кикоть, В.А. Якунин, А. Т. Колденкова, И. С. Кон, И. С. Копеина, В. И. Косырев, В. А. Сластенин, В. Г. Леонтьев, А. А. Реан, Т. В. Андреева, Н.Н. Киреева, И. Л. Москвичева, М. Г. Рогов, В. А. Сонин, Р. И. Цветкова, В. А. Якунин Т. О. Гордеева, А. Г. Бугрименко, В.Г. Чайка, Г. А. Цукерман и др.

Несмотря на многочисленные исследования мотивации, среди российских ученых отсутствует единый подход, наблюдается разнобой в определении основных понятий. Авторы по-разному определяют даже само понятие «мотив»: как потребность, предмет потребности, как намерение, как устойчивое свойство личности, как побуждение и пр.

Структура мотивационного механизма, влияние мотивации на правовое самосознание. Понятие «мотив» означает «двигатель», т. е. то, что движет человеком в его деятельности. Мотив принадлежит самому субъекту поведения, является его устойчивым личностным свойством или психологической причиной, изнутри побуждающей к совершению конкретных действий. В качестве мотива могут выступать идеалы, интересы, потребности, социальные установки, ценности субъекта, побуждающие его действовать определенным образом. Мотив приводит к постановке цели. Цель определяет, что человек намерен делать, а мотив - для чего и почему. Совокупность ведущих мотивов характеризует направленность личности, которая выступает как системообразующий фактор в правовой психологии личности.

Мотивационный механизм образует взаимодействие различных внутренних и внешних факторов. К внутренним факторам относятся потребности, интересы, ценностные ориентации, убеждения, идеалы, установки и пр. Условия жизни порождают определенные потребности и интересы, последние, в свою очередь, формируют мотивы деятельности. Все внешние побуждения, которые влияют на поведение личности, могут быть названы стимулами в широком смысле слова. Именно взаимодействие мотивов и стимулов характе- 
ризует механизм мотивации. Мотивация не охватывает весь процесс поведения человека, но она является основным психологическим стержнем формирования и осуществления поведения.

Реальной силой, которая заставляет человека совершать определенные поступки, являются убеждения. Сердцевину мотивационной структуры личности образуют ее ценностные ориентации, которые подразделяются на терминальные (ценности-цели) и инструментальные (ценности-средства). Проблема ценностей - одна из центральных в гуманистической и экзистенциальной психологии (А. Маслоу, К. Роджерс, Г. Олпорт, В. Франкл). В отечественной психологии ценностные ориентации рассматриваются в работах Б. Г. Ананьева, Г. М. Андреевой, А. И. Донцова, Л. И. Анцыферовой, В. С. Мухиной, Г. Г. Дилигенского и др. Формирование ценностных ориентаций студентов изучали Л. Д. Демина, Н. З. Кайгородцева, А. П. Супрун, Н.С. Ладыжец и др. Ценностные ориентации являются важнейшим компонентом структуры личности, характеризующей и определяющей ее направленность.

В мотивационном механизме существенное значение имеет установка личности, ее готовность к совершению определенного действия или к реагированию в определенном направлении. Проблема установки широко представлена в исследованиях отечественных психологов. Д.Н. Узнадзе и его последователями была создана теория установки. В.А. Ядов разработал диспозиционную концепцию регуляции социального поведения личности. Согласно его теории, человек обладает сложной системой диспозиций (личностные предрасположенности), которые регулируют его поведение. Диспозиции образуются на стыке потребностей и ситуаций. В. А. Ядов выделяет четыре уровня потребностей, ситуаций и соответствующих им диспозиций:

- первый уровень составляют установки, формируемые на основе потребностей биологического характера в простейших ситуациях - в бытовых условиях;

- второй уровень диспозиций - это социальные установки, формируемые на основе потребностей в общении в обычных повседневных обстоятельствах; 
- третий уровень диспозиций характеризует общую направленность интересов личности в различных сферах жизни - это базовые социальные установки;

- четвертый уровень диспозиций - высший - образует система ценностных ориентаций личности [10].

Для того чтобы правовые знания переросли в убеждения, вошли в систему ценностных ориентаций личности, они должны проникнуть в сферу чувств и переживаний. Л.И. Петражицкий придавал эмоциям огромное значение и считал, что правовые эмоции являются элементами «действительного права». Правовые эмоции и чувства выражаются в переживаниях человека по поводу права, своих прав и обязанностей, правотворческой, правоприменительной, правоохранительной деятельности, существующей преступности и системы борьбы с ней. Правовые эмоции, чувства, настроения, аффекты, переживания оказывают существенное влияние на развитие правового самосознания личности. Готовность и решимость личности в достижении поставленной цели связаны с волей. Основной функцией воли является регуляция деятельности и поведения. Анализируя правовое поведение, Д. А. Керимов называет волю «средством реализации правовой установки, особым психическим процессом, соединением потребности, интереса, установки и цели с действием» [11, с. 16].

Представители гуманистического направления в психологии (Г. Олпорт, А. Маслоу, К. Роджерс и др.) считают ведущими движущими силами развития личности мотивы, побуждающие ее к постоянному поиску творческого напряжения. По К. Роджерсу, расцвет личности происходит под влиянием мотива роста. В центр своей концепции А. Маслоу выдвинул понятие самоактуализации. Согласно теории А. Маслоу, каждый человек обладает мотивационным набором. Потребность в самоактуализации относится к высшему из пяти уровней иерхически организованных систем потребностей (физиологических, потребностей в безопасности, любви и социальных связях, самоуважении и самоактуализации). Удовлетворив потребность в самоактуализации, человек, по мнению А. Маслоу, может стать здоровой, творческой и независимой личностью. 
Ценностные ориентации тесно связаны с мировоззрением личности, которое, в свою очередь, опирается на знания закономерностей природы и общества. Взаимосвязь мировоззрения и правосознания представлена, главным образом, в содержании правовых принципов (демократизм, справедливость, гуманизм и др.). Правовое самосознание обычно не существует в чистом виде, оно взаимосвязано с другими видами и формами осознания действительности. Оно переплетается с моральными воззрениями, люди оценивают правовые явления, свое место в системе правовых отношений с точки зрения моральных категорий добра и зла, справедливости и несправедливости, совести, чести и др. Отношение к праву часто определяется политическими взглядами. Правосознание находится в прямом взаимодействии с другими формами общественного сознания - экономическим, экологическим, религиозным, философским. В формировании правового самосознания существенную роль играют не только конкретные правовые нормы, но и общие мировоззренческие знания, понимание своего места в мире, различие добра и зла и пр.

Необходимой основой актуализации и формирования мотивов являются значение и смысл (С.Л. Рубинштейн). Под значением понимается устойчивая система обобщений, одинаковая для всех людей, а смысл - это индивидуальное значение слова. А. Н. Леонтьев считал, что подлинным регулятором поведения и деятельности является понимание смысла, «личностный смысл». Правовое сознание человека не просто отражает то, что находится вне его, оно активно и избирательно.

Поведение человека полимотивировано, порождается не одним, а несколькими мотивами, между которыми могут возникать противоречия. Кроме того, в правовом пространстве действует личность как целое, входящая в общественную среду посредством личностного компонента, регулирующая свои поступки на основе сознания. Личность в правовом поведении следует своим личностным нормам, «спаянным» с внутренним миром.

Рефлексия. Понятие «рефлексия» (от позднелат. reflexio - обращение назад) обозначает «принцип человеческого мышления, направляющий его на осмысление и осознание собственных форм 
и предпосылок; предметное рассмотрение самого знания, критический анализ его содержания и методов познания; деятельность самопознания, раскрывающая внутреннее строение и специфику духовного мира человека» [12, с. 579]. Рефлексия представляет собой теоретическую деятельность человека, направленную на осознание и понимание своих действий, мыслей, умение стать в позицию наблюдателя, размышлять над тем, что ты делаешь, как познаешь. Рефлексия в широком смысле слова включает в себя процессы самопознания и понимания другого, понимания прошлого и предвосхищения будущего, анализ собственной деятельности. Без этих процессов невозможно нормальное развитие человека.

Впервые проблема рефлексии стала обсуждаться в древнегреческой философии. Сократ считал, что наиболее важной задачей человека является самопознание, и применял его методы на практике. В работах Платона, Аристотеля, Плотина рефлексия рассматривается как направленность сознания на самого себя, как атрибут ума, как добродетель. В средневековой философии (А. Августин, И.С. Эриуген и др.) утверждается, что истина заключена в душе, и обращаясь к своему сознанию, человек приходит к Богу. Мыслители Возрождения и Нового времени (Р. Декарт, Дж. Локк, И. Кант, Г. Лейбниц, Г. Гегель и др.) рассматривали рефлексию в основном в связи с познавательными способностями человека. В философии Гегеля рефлексия представлена как движущая сила развития духа. Проблемы рефлексии в марксизме анализировались в двух направлениях: критика метафизического понимания рефлексии и анализ философского знания как рефлексии о культуре человечества, о его социальной истории. К. Маркс и Ф. Энгельс критиковали рассудочную деятельность, оторванную от практики, доказывали обусловленность рефлексии практикой, всей деятельностью человека. На современном этапе в зарубежной науке наблюдается многообразие подходов к пониманию рефлексии, ее функций и условий развития. Рефлексия рассматривается преимущественно в гносеологическом аспекте (Ж. Пиаже, В. Вундт, В. Джемс и др.), понимается как мышление о мышлении и представляет собой наблюдение со стороны за когнитивными процессами и деятельностью сознания. 
Проблемы рефлексии активно разрабатывались и разрабатываются в отечественной психологии (Г. П. Щедровицкий, С. Л. Рубинштейн, К. С. Абульханова-Славская, В.С. Мухина, А. Н. Леонтьев, В. А. Петровский, Н. Г. Алексеев, В. И. Слободчиков, О. С. Анисимов, И. Н. Семенов, А. З. Зак, В. М. Розин, В. А. Лефевр, В. Е. Лепский, А. В. Карпов, А. Цукерман, А. С. Шаров и др.). В современной философии проблемы формирования и развития рефлексии рассматриваются в работах А.П. Огурцова, В. В. Бажанова, Е. М. Ковшова, И. Г. Курова, В. А. Лекторского, Т. П. Матяш, М. А. Розова, К. И. Степанова, В.С. Швырева, Э. Г. Юдина и др. Российские мыслители анализируют сущность и роль рефлексии в познании, в творческом мышлении, в совместной деятельности людей, в исследованиях саморегуляции, в развитии самосознания. Рефлексия выступает как фундаментальный механизм самосознания и самопонимания, как способность человека познать себя, свой внутренний мир, свое место во взаимоотношениях с другими, формы и способы познавательной и преобразующей деятельности.

Наиболее изученными в науке типами рефлексии являются следующие: интеллектуальная, коммуникативная, кооперативная. В работах В.В. Барцалкиной, П. Зелазо и других проводится анализ личностной рефлексии, под которой понимается рефлексия в области самосознания человека, т. е. исследование человеком собственного самосознания. М.Ю. Двоеглазова в личностной рефлексии выделяет несколько взаимодействующих компонентов: рефлексивнокогнитивный, рефлексивно-аффективный, рефлексивно-оценочнорегулятивный $[13$, с. 5].

Осознанность и осмысленность себя, своих действий в правовых отношениях является основой отношения личности к себе как к субъекту права. Рефлексия в сфере правового самосознания направлена на осмысление права, его границ и нормативов, на уяснение способов и средств обращения с ним, на упорядочивание и совершенствование знаний о праве. Она включает анализ личного и коллективного опыта правового общения, деятельности правовых институтов, определяет отношение (оценки) личности к себе и другим людям, к способам и результатам своей деятельности и деятельности других. 
Рефлексия позволяет полнее и точнее отразить свое положение, действия и их последствия в правовой сфере, социальные потребности, притязания субъекта, расширить правовые знания, обогатить и углубить правовые навыки, способствует самовоспитанию. Посредством правового самосознания личность регулирует не только правовое поведение, но и свои потребности, позиции, социальные связи, определенную правовую активность, формирует отношение к явлениям, мешающим осуществлению права.

Рефлексия является комплексным образованием, выступающим одновременно как психологический механизм, процесс, свойство и состояние субъекта. Важнейшими условиями развития рефлексии как психологического механизма являются познавательные потребности, стремление к самоактуализации и самореализации.

Выделение и анализ психологических механизмов развития правового самосознания не означает признания того, что они изолированы друг от друга. Напротив, они внутренне взаимосвязаны, сочетаются, проникают друг в друга. Каждый из них, обладая спецификой, включен в общий психологический механизм и одновременно может включать в себя другие механизмы. Психологические механизмы многообразны и достаточно сложны. Действуют они чаще всего незаметно, и порой проходит довольно длительный период до их обнаружения. Определяющую роль в развитии правового самосознания играет именно личность. Являясь важнейшим показателем социальности, личность сама конструирует свое самосознание. Формирование правового самосознания осуществляется одновременно с развитием личности. Успех зависит от правовой информированности, мотивации, целеустремленности, трудолюбия, воли, требовательности к себе, уровня рефлексии и пр. В зависимости от конкретной ситуации и особенностей самой личности (возраста, здоровья, способностей и возможностей, социальной роли, профессии, имущественного положения, межличностных отношений, мировоззренческой платформы и пр.) значимость отдельных механизмов изменяется.

В развитии правового самосознания личности психологические механизмы выполняют следующие функции: 
- отражательную - реализуется детерминация правового самосознания личности внешней средой, основными свойствами и качествами индивида;

- побудительную - непосредственной побудительной силой являются потребности, интересы, мотивы, убеждения, ценностные ориентации, идеалы, эмоции, чувства, страсти;

- регулятивную - заключается в выборе пути и средств в достижении поставленной цели;

- контролирующую - помогает дать оценку принятым решениям и поступкам, преодолевать препятствия в достижении цели.

\section{Выводы}

Формирование и развитие индивидуального правового самосознания представляет внутренне противоречивый процесс, зависящий от наследственности, среды, воспитания и собственной деятельности человека. Индивидуальное правовое самосознание имеет личностную неповторимость, так как индивидуальное бытие представляет собой диалектическое единство общего, особенного и единичного.

Правовое самосознание личности формируется целенаправленно и стихийно. Оно включает не только усвоенное индивидом содержание общественного правосознания, но и результат своего личного опыта.

В основе развития правового самосознания личности лежат психологические механизмы. Психологический механизм развития правового самосознания личности определяется как система взаимодействующих факторов и условий, обеспечивающих этот процесс. Существуют многообразные психологические механизмы развития правового самосознания личности. Общим механизмом правового становления человека, формирования и развития его правовой сущности, его правового самосознания выступает процесс правовой социализации.

Взаимодействие мотивов и стимулов характеризует механизм мотивации. Мотивация не охватывает всего поведения человека, но она является основным психологическим стержнем развития правового самосознания и правового поведения, от ее направлен- 
ности зависят особенности поведения, жизнедеятельности, весь стиль и образ жизни человека.

Поиск методов и средств актуализации рефлексивных процессов, содействующих правовому становлению личности, является важнейшим требованием настоящего времени. Уровень развития рефлексивных умений - необходимое условие формирования правового самосознания.

Развитие правового самосознания личности формируется поэтапно, и в каждый период развития действуют определенные психологические закономерности и механизмы. Знание и использование психологических механизмов задает управленческий ориентир для оптимизации и обеспечения эффективного процесса развития правового самосознания личности.

Практика зарубежного и российского опыта правового образования и воспитания показывает, что на развитие правового самосознания студентов влияет не только изучение учебных дисциплин, но и организация студенческой жизни в вузе. Задача вуза состоит в том, чтобы передавать знания и способствовать личностному росту студентов. Оптимизации условий правового развития личности студентов может способствовать специально организованная программа психологического сопровождения студентов, направленная на активизацию их правового самосознания. На развитие правового самосознания студентов влияет весь образ их жизни. Их правовое самосознание связано как с учебой в вузе, так и со всеми явлениями общественной жизни, культуры, с явлениями в сфере быта и досуга.

1. Спиркин А. Г. Сознание и самосознание. М. : Политиздат, 1972. 480 с.

2. Мацумото Д. Психология культуры. СПб. : Прайм-ЕВРОЗНАК, 2003. 720 c.

3. Ожегов С. И. Словарь русского языка. М., 1987. - 797 с.

4. Выготский Л. С. Собрание сочинений : в 6 т. Т. 3 : Проблемы развития психики / под ред. А. М. Матюшкина. М., 1984. 369 с.

5. Прикладная юридическая психология / под ред. А. М. Столяренко. М. : ЮНИТИ-ЛАДА, 2001. 639 с.

6. Кудрявцев В. Н., Казимирчук В. П. Современная социология права. М. : Юристъ, 1995. 297 с. 
7. Андреева Г. М. Социальная психология. М. : Изд-во МГУ, 1980. 374 с.

8. Фельдштейн Д. И. Психология взросления: Структурно-содержательные характеристики процесса развития личности : избр. тр. М. : Моск. психол.-соц. ин-т : Флинта, 1999.670 с.

9. Бобнева М. И. Социальные нормы и регуляция поведения. М. : Наука, 1978. $311 \mathrm{c.}$

10. Саморегуляция и прогнозирование социального поведения личности / под ред. В. Я. Ядова. Л. : Наука, Ленингр. отд-ние, 1979. 264 с.

11. Керимов Д.А. Психология и право // Государство и право. 1992. № 1. C. 10-20.

12. Философский энциклопедический словарь / гл. редакция: Л. Ф. Ильичев, П.Н. Федосеев, С. М. Ковалев, В. Г. Панов. М. : Сов. энцикл., 1983. $840 \mathrm{c}$.

13. Двоеглазова М. Ю. Структура личностной рефлексии студентов : автореф. дис. ... канд. психол. наук. М., 2008. 24 с. 


\section{Раздел 2 \\ ПСИХОЛОГИЧЕСКОЕ БЛАГОПОЛУЧИЕ \\ СУБЪЕКТОВ ОБРАЗОВАНИЯ}

\section{ПОДХОДЫ К ИЗУЧЕНИЮ \\ ПСИХОЛОГИЧЕСКОГО БЛАГОПОЛУЧИЯ*}

Г.И. Борисов

Благополучие является предметом исследования многих наук (психологии, социологии, философии, экономики, экологии и др.). Тем не менее вопросами внутреннего благополучия, счастья человека занимается психология. Актуализации интереса к проблеме благополучия человека способствовала позитивная психология как направление, которое занимается изучением того, что помогает человеку жить лучше и предотвращает серьезные нарушения. Изначально в данной проблематике центральным было понятие счастья, которое, по мнению М. Селигнама, потеряло свой смысл из-за чрезмерного использования, и на смену ему пришло понятие благополучия. Так благополучие стало основным предметом позитивной психологии. М. Селигман считает, что различие между счастьем и благополучием состоит в том, что благополучие является конструктом, что означает невозможность измерить его напрямую, требуется определить признаки и критерии, по которым его можно оценить. Данный переход Т. Кашдан и М. Штегер описали в своей книге в главе «От одержимости счастьем к многомерной матрице благополучия». Авторы также отмечают падение интереса к счастью как характеристике, которая отражает, по их мнению, правиль-

* Исследование выполнено при финансовой поддержке РФФИ в рамках научного проекта № 19-013-00431 «Личностная мобильность как предиктор сохранения профессионального здоровья в пожилом возрасте».

() Борисов Г.И., 2020 
ность проживания жизненного пути. В то время как благополучие предполагает более широкий подход, который охватывает целую группу различных явлений (цель в жизни, осознанность, гибкость, компетентность и т. д.) [1].

Таким образом, в психологии стали рассматривать различные виды благополучия, подходы к его изучению и концепции, его описывающие. В целом благополучие является характеристикой, которая может отражать успешность человека в чем-либо и то, что способствует развитию человека.

Целью данного исследования является теоретическое рассмотрение благополучия в следующих аспектах:

- виды благополучия в психологии;

- подходы к психологическому благополучию;

- теории психологического благополучия;

- отечественные теории психологического благополучия.

Проведение подобного анализа позволит расширить и структурировать представления о благополучии в современной психологии.

\section{Виды благополучия}

В психологическом тезаурусе существуют различные виды благополучия. Это эмоциональное благополучие, физическое благополучие, социальное благополучие, профессиональное благополучие, общественное благополучие, психическое благополучие, духовное благополучие, сексуальное благополучие, психологическое благополучие, субъективное благополучие и др.

Рассмотрим отдельные виды благополучия.

Тики Дэвис выделяет эмоциональное, физическое, социальное, профессиональное и общественное благополучие.

Эмоциональное благополучие - это способность самостоятельно совладать со стрессом, быть жизнестойким, переживать эмоции, которые обеспечивают хорошее настроение. Эмоциональное благополучие зависит от таких навыков, как позитивное мышление, эмоциональная регуляция, осознанность, жизнестойкость и т.д. Когда человек эмоционально благополучен, он лучше справляется со стрессом и сильными эмоциями в проблемных ситуациях, с ра- 
зочарованием. Все это позволяет получать удовольствие от жизни, быть счастливым и более эффективно достигать цели.

Физическое благополучие отражает способность к улучшению функционирования своего тела через здоровое питание и регулярные тренировки. Для формирования физического благополучия человек должен подобрать подходящую здоровую диету и оптимальную программу упражнений. Развитие физического благополучия позволяет чувствовать себя лучше, в том числе и в вопросах эмоционального благополучия, уменьшать количество проблем со здоровьем.

Социальное благополучие можно представить как способность общаться, создавать значимые отношения с другими людьми и сохранять уже существующие для преодоления чувства одиночества. Оно связано с такими качествами личности, как признательность, доброжелательность, коммуникативность, позволяющими облегчить взаимодействие с другими людьми, не чувствовать себя одиноким, озлобленным, отчужденным, а также ощущать значимую связь с другими.

Профессиональное благополучие представляет собой способность реализовывать свои интересы, ценности и цели для достижения смысла и развития в профессиональной среде. Профессиональное благополучие связано с тем, чем человек занимается, с важным для него делом. Это подразумевает развитие профессиональных навыков, которые помогут человеку осуществлять профессиональную деятельность более эффективно, а также реализовывать собственные ценности и поддерживать баланс между работой и личной жизнью. Профессиональное благополучие позволяет получать удовольствие от работы, помогая оставаться сосредоточенными, мотивированными и успешными. Когда человек достиг профессионального благополучия, его работа и, как следствие, повседневная жизнь становятся более насыщенными.

Общественное благополучие можно представить как стремление к улучшению общества, культуры, окружающей среды. Общественное благополучие связано со способностью человека чувствовать связь с окружающим миром, с его стремлением защищать окружающую среду, поддерживать общественные трансформации, стремить- 
ся к развитию позитивной культуры. Это позволяет ему ощущать себя частью чего-то большего и поддерживать других людей [2].

Далее рассмотрим такие виды благополучия, как психическое, духовное и сексуальное.

Психическое благополучие связано со способностью человека противостоять психическим заболеваниям и способствует улучшению его здоровья и функционирования. Психическое благополучие охватывает как гедонистическое, так и эвдемоническое благополучие, речь о которых пойдет далее. Предполагается, что для обеспечения психического благополучия требуется интеграция этих видов благополучия [3]. Так, психическое благополучие включает в себя психологическое функционирование, а также когнитивные и эмоциональные аспекты благополучия [4].

Духовное благополучие рассматривается как показатель качества жизни в духовном измерении и как показатель духовного здоровья, а также как «утверждение жизни в отношениях с Богом, собой, обществом и окружающей средой, которые способствуют достижению целостности» [цит. по: 5, p. 21].

Дж. Фишер считал, что духовное благополучие образовано четырьмя сферами: личностной, общественной, окружающей среды, трансцендентной.

В личностной сфере человек внутренне связан со своей целью, жизненными смыслами, ценностями. Самосознание - это движущая сила или трансцендентный аспект человеческого духа в его поисках идентичности и самооценки.

В общественной сфере духовное благополучие отражается в качестве и глубине связей между человеком и другими людьми, относящихся к морали, культуре и религии и выражающихся в любви, прощении, доверии, надежде и вере в человечество.

Область окружающей среды подразумевает заботу о физическом и биологическом, чувство удивления перед ними; единение с окружающей средой.

Трансцендентная область - это связь с тем, что выходит за границы человека: космос, Бог, высшее дело (благо). Включает в себя веру, поклонение источнику Тайны Вселенной [5]. 
Относительно новым понятием в контексте изучения благополучия является сексуальное благополучие, применительно к которому нет четких представлений. Так, сексуальное благополучие рассматривалось с позиций удовлетворённости сексуальной жизнью, сексуальной тревоги и в качестве элемента общения в отношениях. Также существует подход, который предлагает рассматривать сексуальное благополучие как самовосприятие сексуального здоровья [6]. Сексуальное благополучие как удовлетворённость сексуальной жизнью и близостью связывают с такими факторами, как стыд, зависть, самосознание, доверие, любовь, привязанность, мотивация удовольствия и самооценка [7].

Можно предположить, что данные виды благополучия отражают состояние различных сфер жизни человека. Однако за рамками обзора осталось понятие психологического благополучия. Это связано с тем, что психологическое благополучие предполагает его рассмотрение с позиции по меньшей мере двух подходов и описывается различными концепциями. Наш дальнейший обзор будет посвящен анализу подходов к изучению концепций психологического благополучия.

\section{Подходы к изучению психологического благополучия}

Р. Райан и Е Дейзи предложили рассматривать психологическое благополучие человека с позиции двух подходов: гедонистического и эвдемонического [8].

К гедонистическому подходу относятся теории, в которых психологическое благополучие характеризуется аффективным переживанием, отражающим состояние «удовлетворенности-неудовлетворенности», «удовольствия-неудовольствия», и основывается на балансе позитивного и негативного эффекта, соотношении положительных и отрицательных эмоций. Ключевым понятием для данного подхода является «субъективное благополучие», которое включает эмоциональный и когнитивный аспекты. Гедонистический подход подвергался критике по причине того, что положительные и отрицательные эмоции могут быть независимыми друг от друга. Другим основанием для критики стало положение о том, что чем больше человек потребляет удовольствий, тем большая их интенсив- 
ность ему требуется для удовлетворения в дальнейшем. Это приводит к избеганию обычного течения жизни, потребности в получении новых и более сильных эмоций, впечатлений и отношений [9].

Эвдемонический подход рассматривает психологическое благополучие как личностный рост, развитие собственной индивидуальности. В данном подходе делается акцент на том, что события, не обеспечивающие удовольствие, способствуют достижению психологического благополучия. Это связано с пониманием человеком своих жизненных целей, увеличением осмысленности жизни, способности к сопереживанию. В рамках эвдемонического подхода одним из основных факторов психологического благополучия является смысл жизни. Его отсутствие (с учетом социально-демографических факторов, стилей жизни, симптомов и способов контроля здоровья и удовлетворенности жизнью) положительно коррелирует со смертностью [10].

Эвдемонический подход к благополучию был эмпирически подтвержден норвежскими учеными при помощи факторного анализа. Также экспериментальные интервенции с каждодневными упражнениями частично подтвердили данные результаты [11].

Стоит отметить способы достижения гедонистического и эвдемонического благополучия. S. Zuo и коллеги определили, что у стремящихся к гедонистическому благополучию людей более выражен сенсорный и аффективный опыт, в то время как у людей, стремящихся к эвдемоническому благополучию, более выражен интеллектуальный, поведенческий и духовный опыт [12].

\section{Концепции психологического благополучия}

Теоретические основы психологического благополучия заложены Н. Брэдберном, который вводит понятие психологического благополучия, отделяя его от психологического здоровья и сопоставляя с ощущением счастья и удовлетворённостью жизнью в целом. С точки зрения Н. Брэдберна, содержательно психологическое благополучие отражается через континуум «болезнь-здоровье», и описать данные характеристики можно при помощи терминов, отражающих состояние счастья или несчастья, субъективных переживаний удовлетворенности или неудовлетворенности жизнью. 
Модель психологического благополучия в исследованиях Н. Брэдберна представляет собой баланс, который достигается постоянным взаимодействием позитивного и негативного эффекта. События человеческой жизни, которые несут радость и ощущение счастья, повышают позитивный эффект, и наоборот, события, которые огорчают человека, повышают негативный эффект. Разница между данными эффектами является показателем психологического благополучия и отражает переживание удовлетворённости жизнью. Так, когда уровень позитивных переживаний превышает уровень негативных, человек чувствует себя счастливым и удовлетворённым и, как следствие, имеет высокий уровень психологического благополучия. Если же количество негативных переживаний превышает количество позитивных, человек ощущает себя несчастливым и неудовлетворенным и имеет низкий уровень психологического благополучия. Важным положением теории Н. Брэдберна является то, что позитивный и негативный эффект не взаимосвязаны друг с другом: имея данные о состоянии позитивного эффекта, мы не знаем, является ли негативный эффект больше, меньше или равным позитивному [13].

Другим автором, чьи взгляды внесли весомый вклад в понимание вопроса психологического благополучия, является Э. Динер. Он вводит в тематику психологического благополучия понятие «субъективное благополучие», которое близко по содержанию к подходу Н. Брэдберна. Субъективное благополучие состоит из трех элементов - приятные эмоции, неприятные эмоции, удовлетворенность, которые вместе создают единый показатель. Э. Динер рассматривал субъективное благополучие как совокупность эмоциональной (наличие хорошего или плохого настроения) и когнитивной (оценка удовлетворенности различными аспектами своей жизни) сторон самопринятия. Подход Э. Динера предполагает, что люди оценивают все происходящее с ними при помощи характеристик «хорошо плохо», и данная когнитивная оценка строится на соответствующей эмоциональной основе.

По мнению Э. Динера, субъективное благополучие отражает не только погруженность человека в депрессивные и тревожные состояния, но и демонстрирует, насколько один человек субъективно 
счастливее другого. Продолжая традицию Н. Брэдберна, автор отождествляет субъективное благополучие с состоянием счастья. Так, человек имеет высокий уровень субъективного благополучия, если он по большей части удовлетворен собственной жизнью и в редких случаях испытывает грусть или злость. При низком уровне субъективного благополучия человек неудовлетворен жизнью, редко испытывает чувства любви и счастья, для него типичны отрицательные эмоции [14].

Теории Н. Брэдберна и Э. Динера относят к гедонистическому типу благополучия, они схожи между собой, однако последний не считал их аналогами. Э. Динер рассматривал субъективное благополучие в качестве элемента психологического благополучия, акцентируя внимание на том, что для описания психологического благополучия необходимо исследовать дополнительные характеристики, и ссылался на работы К. Рифф как на удачный пример такого подхода.

Автор, предложивший отличную от предшествующих теорию психологического благополучия, - К. Рифф. Ее теория продолжает традиции, заложенные Н. Брэдберном, но при этом критически пересматривает данный подход к психологическому благополучию как балансу позитивного и негативного эффекта. К. Рифф, считая, что гедонистическая ориентация психологического благополучия страдает ограниченностью, создает собственную теорию, которая строится на основе концепций, касающихся позитивного функционирования человека (теории А. Маслоу, К. Роджерса, Г. Олпорта, К. Г. Юнга, Э. Эриксона, Ш. Бюлер, М. Яходы и др.). Данный подход позволил описать шесть основных компонентов психологического благополучия: самопринятие, позитивные отношения с окружающими, автономия, управление окружающей средой, цель в жизни, личностный рост.

Самопринятие отражает позитивную самооценку себя и своей жизни в целом, осознание и принятие не только своих положительных качеств, но и своих недостатков. Противоположность самопринятия - чувство неудовлетворенности собой, характеризующееся неприятием определенных качеств своей личности, неудовлетворенностью своим прошлым. 
Под позитивными отношениями с окружающими подразумевается как умение сопереживать, так и способность быть отрытым для общения, а также наличие навыков, помогающих устанавливать и поддерживать контакты с другими людьми. Кроме того, данная характеристика включает в себя желание быть гибким во взаимодействии с окружающими, умение прийти к компромиссу. Отсутствие этого качества свидетельствует об одиночестве, неспособности устанавливать и поддерживать доверительные отношения, нежелании искать компромиссы, замкнутости.

Человек, обладающий высокой автономией, способен быть независимым, он не боится противопоставлять свое мнение мнению большинства, может позволить себе нестандартное поведение и мышление, он оценивает себя, исходя из собственных предпочтений. Отсутствие достаточного уровня автономии ведет к конформизму, излишней зависимости от мнения окружающих. Такому человеку тяжело самому принимать решения, его поведение и образ мысли сильно подвержены влиянию социума.

Управление окружающей средой подразумевает наличие качеств, которые обусловливают успешное овладение различными видами деятельности, способность добиваться желаемого, преодолевать трудности на пути реализации собственных целей. При недостатке этой характеристики наблюдается чувство собственного бессилия, некомпетентности, присутствует неспособность что-то изменить или улучшить, чтобы добиться желаемого.

Другой важный компонент психологического благополучия наличие жизненных целей - сопряжен с переживанием осмысленности собственного существования, ощущением ценности того, что было в прошлом, происходит в настоящем и случится в будущем.

Личностный рост предусматривает стремление развиваться, учиться и воспринимать новое, а также наличие ощущения собственного прогресса. Если по каким-то причинам личностный рост невозможен, то следствием этого становится чувство скуки, стагнации, отсутствие веры в свои способности к переменам и овладению новыми умениями и навыками, при этом уменьшается интерес к жизни. 
К. Рифф отмечает, что предложенные компоненты психологического благополучия соотносятся с различными теориями, которые касаются позитивного функционирования личности. Так, самопринятие соотносится не только с понятиями «самоуважение» и «самопринятие», введенными и разработанными А. Маслоу, К. Роджерсом, Г. Олпортом и М. Яходой, но и включает в себя признание человеком своих достоинств и недостатков, соотносимое с концепцией индивидуации К.Г. Юнга, а также позитивную (в основном) оценку человеком собственного прошлого, описанную Э. Эриксоном как часть процесса эго-интеграции [15].

Данная теория стала основой для оригинального метода психотерапии - терапии благополучия (well-being therapy). На данный момент методика «The scales of psychological well-being» («Шкала психологического благополучия») получила признание и интегрировалась в различные направления исследований. На данный момент изучены закономерности психологического благополучия, связанные с возрастом, полом и культурной принадлежностью, а также продолжаются исследования по определению особенностей и детерминант психологического благополучия. Так, в ходе исследований, в которых применялся опросник «Шкала психологического благополучия», было установлено, что психологическое благополучие имеет определенную возрастную динамику. Исследование, которое проводилось в США, показало, что с возрастом происходит увеличение показателей по шкалам «Автономия» и «Управление средой», в то же время показатели по шкалам «Личностный рост» и «Цели в жизни», имеющее большие значения у представителей молодого возраста, испытывают снижение. Характеристики «Позитивное отношение с окружающими» и "Самопринятие» не показали каких-либо изменений, а значит, не обусловлены возрастом.

Другое направление исследований нацелено на изучение закономерностей и различий, связанных с полом. Было установлено, что женщины всех возрастов имеют более высокие показатели позитивных отношений с окружающими и личностного роста.

Исследовалось и влияние культуры на психологическое благополучие. Гипотеза гласила, что люди западного общества будут иметь более высокие показатели самопринятия и автономии, в то же 
время люди, принадлежащие к традиционной культуре восточного типа, будут отличаться высокими показателями позитивных отношений с окружающими. Сопоставление эмпирических данных американской и южнокорейской выборки кросс-культурного исследования в целом подтвердило данную гипотезу. Южнокорейская выборка отличалась более высокими показателями по шкале «Позитивные отношения с окружающими», а показатели шкал «Самопринятие» и «Личностный рост», напротив, были значительно ниже, чем у представителей американской выборки. Интересным представляется тот факт, что структура гендерных различий была идентична в обеих выборках, что говорит об отсутствии культурного влияния на гендерные особенности структуры психологического благополучия.

Исследования связи психологического благополучия и соматического здоровья К. Рифф и Б. Сингреа показало, что включенность человека в близкие доверительные отношения с другими предотвращает опасность высокого кровяного давления, способствует повышению иммунитета, снижает риск сердечно-сосудистых заболеваний, сосудистых расстройств, инсульта [16].

Стоит так же обратить внимание на теорию самодетерминации Р. Райана и Э. Диси. Ключевым понятием данной теории является личностное благополучие с его базовыми психологическими потребностями: потребности в автономии, компактности, связи с другими.

В данной теории под автономией понимается восприятие своего поведения как конгруэнтного внутренним ценностям и желаниям личности. В основе автономии лежит поддержка и отсутствие контроля со стороны других людей.

Потребность в компетентности - это склонность к влиянию на свое окружение и к эффективной деятельности в нем, она поддерживается средой, которая ставит перед человеком задачи оптимального уровня сложности и дает ему положительную обратную связь.

Под потребностью связи с другими понимается стремление к близости с другими людьми, она развивается, если человек получает тепло и заботу от окружающих. Удовлетворение этих потребностей напрямую связано с актуальным социальным подтекстом: если он способствует удовлетворению потребностей, то уровень 
благополучия повышается, если нет, то уровень благополучия снижается [17].

Р. Райан и Э. Диси соотносили свою теорию с предложенной К. Рифф, акцентируя внимание на схожести трактовки благополучия: функционирование человека как личности, а не получение удовольствия. Другое сходство заключается в значимости для благополучия автономии, компетентности и связанности с другими людьми. Отличие в подходах выражается в том, что в теории К. Рифф выделено 6 компонентов, образующих психологическое благополучие, в то время как в теории самодетерминации автономность, компетентность и позитивные отношения предполагаются как его предпосылки [18].

\section{Отечественные теории психологического благополучия}

Проблема психологического благополучия разрабатывалась не только в зарубежной, но и в российской психологической науке. Опираясь на теорию К. Рифф, П. П. Фесенко рассматривает психологическое благополучие как сложное переживание удовлетворенности собственной жизнью, отражающее одновременно как актуальные, так и потенциальные аспекты жизни личности. Учитывая, что существует разрыв между тем, чем человек является, и тем, чем он может быть, П.П. Фесенко выделяет актуальное и идеальное психологическое благополучие.

Актуальное психологическое благополучие - переживание, характеризующее отношение человека к тому, чем он является по его собственному мнению, отражающее степень реализации основных компонентов позитивного функционирования личности, степень удовлетворенности своим становлением.

Идеальное психологическое благополучие характеризует потенциальные аспекты функционирования личности, степень направленности на реализацию компонентов позитивного функционирования.

Очевидно, что актуальное и идеальное психологическое благополучие могут не совпадать друг с другом. Идеальное благополучие представляет собой определенный уровень, по отношению к которому может проявляться изменение каждого компонента актуального психологического благополучия. Также компоненты идеального 
психологического благополучия рассматриваются как зависящие от обстоятельств жизни человека, но тем не менее в большей степени оно связано с ответственностью человека за свою жизнь, с его стремлением к реализации различных позитивных аспектов собственного функционирования как личности. Расхождение между интегральным показателем и степенью выраженности каждого из компонентов актуального и идеального психологического благополучия также может свидетельствовать о том, насколько человек считает желанным или возможным реализовать себя в жизни [19].

Автор концепции эмоционально-личностного благополучия Л.В. Карапетян характеризует данный феномен «...как комплексную динамическую систему - целостное экзистенциальное переживание состояния гармонии между внутренним и внешним миром, возникающее в процессе жизни, деятельности и общения человека. Результатом снижения уровня такой гармонии является переживание состояния эмоционально-личностного неблагополучия» [20]. Автор предлагает девятифакторную модель эмоционально-личностного благополучия, которая делится на три группы факторов.

Первая группа - это позитивные факторы, направленные на внутренний мир человека и формирующие позитивный эмоциональный компонент благополучия, который можно охарактеризовать как отношение человека к своей жизни, установки по отношению к своему прошлому и будущему, чувство защищенности или незащищенности. К данной группе факторов относятся оптимизм, счастье и везение, которые в самооценке человеком своего внутреннего благополучия находят выражение в представлении о себе как о счастливом, везучем человеке.

Вторая группа факторов - это позитивные факторы, направленные на внешний мир и формирующие личностный компонент благополучия, который можно охарактеризовать как отношения с людьми (друзьями, близкими и т.д.), а также деятельность и ее качество. К данной группе факторов относятся надежность, успех и компетентность, которые при оценке своего внутреннего благополучия находят выражение в представлении о себе как надежном, успешном и компетентном человеке. 
Третья группа факторов - это негативные факторы, имеющие связь как с внутренним, так и с внешним миром, снижающие уровень благополучия через неактивное отношение человека к различным аспектам своей жизни и взаимодействию с миром. К данной группе факторов относятся пессимизм и несчастность (ориентация на внутренний мир), зависть (ориентация на внешний мир), которые в самооценке внутреннего благополучия создают представления о человеке как о пессимистичном, несчастливом, завистливом.

В целом автор характеризует эмоционально-личностное благополучие как комплексную динамическую систему, имеющую трехкомпонентную и трехуровневую структуру, опираясь на которую возможно оказывать воздействие на него с целью оптимизации [20].

А. В. Воронова создала уровневую модель психологического благополучия. Автор представляет ее следующим образом: на разных уровнях человеческого бытия, которые формируются в различных деятельностях, создаются внутренние интенции. Они формируются в качественно различные уровни психологического благополучия человека, которые имеют иерархическую связь. Это уровни психосоматического здоровья, социальной адаптивности, психического здоровья и психологического здоровья. Автор предполагает, что каждый следующий уровень формируется в процессе развития и воспитания, позволяет человеку видеть самого себя, мир и себя в мире и по этой причине находить возможности для реализации замыслов, творческой активности, обретать большую «степень свободы» для выбора способов адекватного реагирования.

Первым уровнем бытия А.В. Воронова представляет биологический, в котором человек обозначен как индивид, биологическое существо. Условием его формирования выступает способность к защите биологических систем организма, повышающая возможности его психической адаптации. Объективная характеристика этого уровня - соответствие образов отражаемой действительности, соответствие психических реакций влиянию среды, отсутствие болезненных психических проявлений. Психологическое благополучие на данном уроне представляется как психосоматическое здоровье, выступающее отражением процесса взаимосвязи психического и соматического. 
Следующим уровнем бытия человека выступает социальнопедагогический, на котором происходит социализация как усвоение общественных норм и требований. Условиями формирования данного уровня являются предметная деятельность человека, взаимодействие и общение с разными социальными группами. Объективные характеристики данного уровня - соответствие реакции человека социальному воздействию, осознание себя в качестве члена общества, проявление социального интереса, толерантность к социальным требованиям. Психологическое благополучие на данном уровне представлено социальной адаптированностью, которая характеризуется как состояние гомеостаза с обществом. Субъективными Я-критериями социально-педагогического уровня являются: степень принятия других людей (Я как часть микросреды), адекватность или неадекватность общественного поведения, удовлетворенность своим социальным статусом (Я как носитель социальной роли); навыки поведения в малых группах, необходимые для вступления в группу, навыки поведения в конфликтной ситуации, эмпатия по отношению к другим людям и социальным группам.

Третий уровень бытия человека в данной теории - это социально-культурный, на котором происходит ценностно-смысловое самоопределение человека в осознаваемых культурных нормах. Условием формирования данного уровня является познание, направленное на постижение достижений культуры и приобщение к ним. Объективной характеристикой данного уровня выступает способность совладать с кризисными ситуациями и справляться с личными трудностями, независимость, критичность, способность к планированию на тактическом и стратегическом уровне, стремление к достижению целей, осознанность внутренней жизни, вера в себя. Психологическое благополучие на данном уроне представлено как психическое здоровье, проявляющееся в виде внутренней цельности, постоянства и гармонии человека с внешним миром, зрелости личности. Субъективными Я-критериями данного уровня являются: способность к принятию мира и его правил (Я как часть социума), самопознание как знание своих сильных и слабых сторон, особенностей ценностно-мотивационной сферы, самоопределение, которое проявляется как готовность к выбору, независимость от об- 
щества, нонконформизм, удовлетворенность в жизненных сферах, способность к самовыражению.

Последним уровнем бытия в данной модели является духовнопрактический, который отражает гуманистические ценности, познание истины. Данный уровень формируется в творческой и продуктивной деятельности, познании философских и этических достижений культуры. Объективными характеристиками этого уровня являются открытость переживаниям, стремление к творчеству и познанию бытия, уникальное мировоззрение, дающее неповторимый взгляд на мир, чувство единения с человечеством и вера в него. Психологическое благополучие на данном уровне представлено психологическим здоровьем при наличии противоречий в поисках смысла жизни. Субъективными Я-критериями данного уровня являются: социально значимая деятельность, вершинные переживания, отсутствие страха перед смертью и завершением бытия, экзистенциальная наполненность жизнь [21].

\section{Выводы}

Благополучие является многомерным феноменом, который затрагивает все сферы жизни и области функционирования человека, охватывает как эмоции, так и действия, позволяет человеку ощутить полноту жизни и стремиться к развитию и самореализации. Теоретические исследования данной проблемы становятся базой для эмпирического изучения благополучия различных категорий населения и охватывают разные сферы их жизни - семью, образование, трудовую и общественную деятельность. В конце XX - начале XXI в. увеличилось количество и усилилось влияние стрессогенных факторов, действию которых подвергается буквально каждый человек. Это, несомненно, сказывается на психологическом благополучии людей. Для оказания им психологической и социальной поддержки и помощи дальнейшее изучение проблемы психологического благополучия представляется нам актуальной и важной задачей.

1. Леонтьев Д. А. Позитивная психология : повестка дня нового столетия // Психология : журнал Высшей школы экономики. 2012. Т. 9, № 4. C. $36-58$. 
2. What Is Well-Being? Definition, Types, and Well-Being Skills. Available at: https://www.psychologytoday.com/us/blog/click-here-happiness/201901/ what-is-well-being-definition-types-and-well-being-skills (accessed: 26.08.2020).

3. Hunter S. C., Houghton S., Wood L. Positive mental wellbeing in Australian adolescents: evaluating the Warwick-Edinburgh mental wellbeing scale //Australian Educational and Developmental Psychologist. 2015. Vol. 32, iss. 2. P. 93-104.

4. Tennant R. et al. The Warwick-Edinburgh mental well-being scale (WEMWBS): development and UK validation // Health and Quality of life Outcomes. 2007. Vol. 5, iss. 1. P. 63.

5. Fisher J. The four domains model: Connecting spirituality, health and well-being // Religions. 2011. Vol. 2, iss. 1. P. 17-28.

6. Lorimer K. et al. A Rapid Review of Sexual Wellbeing Definitions and Measures: Should We Now Include Sexual Wellbeing Freedom? // The Journal of Sex Research. 2019. Vol. 56, iss. 7. P. 843-853.

7. Wylie K. Sex education and the influence on sexual wellbeing // ProcediaSocial and Behavioral Sciences. 2010. Vol. 5. P. 440-444.

8. Deci E. L., Ryan R. M. Hedonia, eudaimonia, and well-being: An introduction //Journal of happiness studies. 2008. Vol. 9, iss. 1. P. 1-11.

9. Водяха С. А. Современные концепции психологического благополучия личности // Дискуссия. 2012. № 2. С. 133-138.

10. Becchetti L., Bachelet M., Pisani F. Poor eudaimonic subjective wellbeing as a mortality risk factor // Economia Politica. 2019. Vol. 36, iss. 1. P. 245-272.

11. Thorsteinsen K., Vittersø J. Now you see it, now you don't: Solid and subtle differences between Hedonic and Eudaimonic Wellbeing // The Journal of Positive Psychology. 2020. Vol. 15, iss. 4. P. 519-530.

12. Zuo S. et al. The behavioural paths to wellbeing: An exploratory study to distinguish between hedonic and eudaimonic wellbeing from an activity perspective // Journal of Pacific Rim Psychology. 2017. Vol. 11. DOI: https:// doi.org/10.1017/prp.2017.1

13. Bradburn N. M. The structure of psychological well-being. Aldine, 1969.

14. Emmons R. A., Diener E. Personality correlates of subjective well-being // Personality and Social Psychology Bulletin. 1985. Vol. 11, iss. 1. P. 89-97.

15. RyffC. D., Keyes C. L. M. The structure of psychological well-being revisited //Journal of personality and social psychology. 1995. Vol. 69, iss. 4. P. 719. 
16. Ryff C. D., Singer B. Psychological well-being: Meaning, measurement, and implications for psychotherapy research // Psychotherapy and psychosomatics. 1996. Vol. 65, iss. 1. P. 14-23.

17. Deci E. L., Ryan R. M. Self-determination theory: A macrotheory of human motivation, development, and health // Canadian psychology. 2008. Vol. 49, iss. 3. P. 182.

18. Козлова Н. С., Комарова Е. Н. Особенности субъективного благополучия личности в зависимости от уровня ее образования // Интеграция образования. 2015. Т. 19, № 1 (78). С. 60-64.

19. Фесенко П. П. Осмысленность жизни и психологическое благополучие личности : автореф. ... дис. канд. псих. наук. М., 2005. 28 с.

20. Карапетян Л. В., Глотова Г. А. Эмоционально-личностное благополучие : монография. Екатеринбург : Урал. ин-т Гос. противопожар. службы МЧС России, 2017. 211 с.

21. Воронина А. В. Проблема психического здоровья и благополучия человека: обзор концепций и опыт структурно-уровневого анализа // Сиб. психол. журн. 2005. № 21. С. 142-147. 


\section{ПСИХОЛОГИЧЕСКОЕ БЛАГОПОЛУЧИЕ СТУДЕНТОВ С ПОЗИЦИИ СУБЪЕКТНО-РЕСУРСНОГО ПОДХОДА (НА ПРИМЕРЕ СТУДЕНТОВ-ПСИХОЛОГОВ)}

H. Е. Водопьянова

Актуальность изучения феномена психологического благополучия определяется тем, что оно является одним из индикаторов социально-психологической адаптации, здоровья личности, противостоит личностным кризисам и другим личностным дисфункциям $[1,2]$. Понятие и категория психологического благополучия (ПБ) активно применяется с 60-х гг. прошлого столетия в контексте позитивного функционирования личности. Теоретическую базу для понимания феномена ПБ заложили исследования Н. Брэдберна, по мнению которого для описания данного феномена необходимо оперировать признаками, отражающими состояние счастья или несчастья, субъективного ощущения общей удовлетворенности или неудовлетворенности жизнью.

Несмотря на многочисленные исследования и широкую распространенность термина «психологическое благополучие», учеными отмечается, что до сих пор не существует его общепринятого научного определения. В содержательном плане нет четкого разграничения понятий «психологическое благополучие» и «субъективное благополучие». Мы согласны с Р. М. Шамионовым, предлагающим определять психологическое (субъективное) благополучие как «эмоционально-оценочное отношение человека к своей жизни, своей личности, взаимоотношениям с другими и процессам, имеющим важное для него значение с точки зрения усвоенных нормативноценностных и смысловых представлений о “благополучной” внешней и внутренней среде, выражающееся в удовлетворенности ею, ощущении счастья» [3].

Феномен «психологическое благополучие» рассматривается, как правило, с позиций четырех основных направлений: гедонистического и эвдемонистического, психофизиологической сохранности функций, позитивного функционирования личности [4]. 
В гедонистических теориях благополучие описывается в терминах удовлетворенности - неудовлетворенности, строится на балансе достигаемого постоянным взаимодействием двух видов аффекта - позитивного и негативного (концепции Н. Брэдберна). Понятие «субъективное благополучие», введенное Э. Динером, состоит из трех основных компонентов: удовлетворение, приятные эмоции и неприятные эмоции. Совокупность этих трех компонентов формируют интегральный показатель субъективного благополучия. Согласно учению Э. Динера, субъективное благополучие - это интеллектуальная оценка удовлетворенности различными сферами своей жизни, которая всегда имеет под собой соответственно окрашенную эмоцию. Оно сопоставимо с переживанием счастья, поэтому может демонстрировать, насколько один человек счастливее другого, а также служить индикатором погруженности в депрессию или тревогу.

В эвдемонистических теориях проблема ПБ базируется на представлениях о личностном росте как главном и необходимом аспекте благополучия, синонимичном понятию счастья (А. Вотермен). Счастье понимается как форма переживания полноты бытия, связанного с самоосуществлением. Психологические способы обретения счастья автор понимает как способы саморегуляции человеком своей мотивации к миру и выделяет две формы такой саморегуляции: усиление человеком значимости мира и усиление своих возможностей. На основе этих двух форм саморегуляции образуется четыре относительно независимых принципа саморегуляции человеком своей мотивации к миру: максимизация полезности, минимизация потребностей, минимизация сложности, максимизация способностей.

Отношение человека к возможным способам обретения счастья также формирует эвдемонистические установки: гедонистические, аскетические, деятельные, созерцательные (А. А. Кроник). Данные установки создают психологическую основу стремлений личности к самоосуществлению в области определенных видов объективной деятельности и выбора способов, с помощью которых она пытается это сделать.

С позиций эвдемонистических теорий ПБ рассматривается на основе позитивного психологического функционирования личности 
(теории А. Маслоу, К. Роджерса Г. Олпорта, К.-Г. Юнга, Э. Эриксона, Ш. Бюлер, Б. Ньюгартена, М. Яходы, Д. Биррена). Основоположником данного направления является К. Рифф. Она обобщила и выделила шесть основных компонентов психологического благополучия: самопринятие, позитивные отношения с окружающими, автономия, управление окружающей средой, цель в жизни, личностный рост. Данные компоненты ПБ К. Рифф соотносит с различными структурными элементами теорий, в которых речь идет о позитивном функционировании личности.

Адаптация к окружающей среде подразумевает успешное овладение различными видами деятельности, способность добиваться желаемого, преодолевать трудности на пути реализации собственных целей. Позитивные отношения с окружающими - это желание быть гибким во взаимодействии с окружающими, умение сопереживать и прийти к компромиссу, способность быть открытым для общения, а также наличие навыков, помогающих устанавливать и поддерживать контакты с другими людьми. Отсутствие этого качества ведет к одиночеству, неспособности устанавливать и поддерживать доверительные отношения.

Автономия способствует независимости, нестандартному мышлению и оцениванию себя исходя из собственных предпочтений. Личностный рост - это стремление развиваться, учиться и воспринимать новое, а также наличие ощущения собственного прогресса. Отсутствие личностного роста ведет к переживанию скуки, стагнации, потере веры в способности к переменам, при этом уменьшается интерес к жизни.

Наличие жизненных целей придает чувство осмысленности существования, ощущение ценности того, что было в прошлом, происходит в настоящем и будет в будущем. Отсутствие целей в жизни влечет ощущение бессмысленности, тоски, скуки. Самопринятие отражает позитивную самооценку себя и своей жизни в целом, осознание и принятие не только своих положительных качеств, но и своих недостатков.

К. Рифф отмечает, что выделенные компоненты ПБ соотносятся с различными структурными элементами теорий, в которых так или иначе речь идет о позитивном функционировании личности. 
Например, «самопринятие» (компонент ПБ по К. Рифф) соотносится не только с понятиями «самоуважение» и «самопринятие», введенными и разработанными А. Маслоу, К. Роджерсом, Г. Олпортом и М. Яходой. Оно также включает в себя признание человеком своих достоинств и недостатков, соотносимое с концепцией индивидуации К. Г. Юнга, а также позитивную (в основном) оценку человеком собственного прошлого.

К этой же группе относится теория самодетерминации Р. Райана и Э. Диси, которые рассматривают личностное благополучие в связи с базовыми психологическими потребностями: потребностью в автономии, компетентности и связи с другими. Автономия здесь понимается как восприятие своего поведения как конгруэнтного внутренним ценностям и желаниям личности. В основе автономии лежат поддержка и отсутствие контроля со стороны других людей. Потребность в компетентности - это стремление к овладению своим окружением и к эффективной деятельности в нем; она поддерживается такой средой, которая выдвигает перед человеком задачи оптимального уровня сложности и дает ему положительную обратную связь. Все компоненты ПБ в русле эвдемонистических теорий (самопринятие, позитивные отношения с окружающими, автономия, управление окружающей средой, цель в жизни, личностный рост) представляют собой атрибуты субъектности - проявление активности субъекта жизни, способствующие самоактуализации личности.

К третьему направлению относится понимание феномена психологического благополучиия на основе психофизиологической сохранности функций - психофизиологии здоровья. Э. Л. Диси и Р. М. Райан считают, что связь между физическим здоровьем и психологическим благополучием является очевидной, генетические факторы также могут объяснить индивидуальные различия в ПБ. Авторы определили, что субъективная жизнеспособность является индикатором психологического благополучия. Они пришли к выводу, что субъективная жизнеспособность соотносится не только с такими шкалами психологического благополучия, как «автономия» и «позитивные отношения с окружающими», но и с физическими симптомами. Болезнь часто вызывает функциональные ограни- 
чения, которые уменьшают возможности для удовлетворенности жизни [5].

Представители четвертого направления понимают феномен «психологическое благополучие» как позитивное функционирование личности, основу которого составляет субъективная оценка человеком себя и собственной жизни, целостное позитивное переживание, выраженное в субъективном ощущении счастья, удовлетворенности собой и собственной жизнью, а также связанное с базовыми человеческими ценностями и потребностями. Авторы отмечают, что наиболее удачно данные аспекты интегрированы в шестикомпонентной теории психологического благополучия К. Рифф.

\section{Психологическое благополучие с позиций субъектно-ресурсного подхода}

На основе теоретического анализа имеющихся представлений о психологическом благополучии мы рассматриваем его как ментальную конструкцию, которая формируется вследствие мотивационных, поведенческих, эмоциональных переменных, ситуационных факторов, эмоционально-оценочного отношения к ним. Психологическое благополучие способствует пониманию и оценке происходящих событий относительно жизни и самореализации субъекта, т. е. выполняет функцию различения, контроля, оценки, на основе которых выстраивается реагирование на многообразные вызовы социальной ситуации. С позиций ресурсного подхода ПБ представляет собой ментальный ресурс человека, включающий опыт реагирования на многообразные динамические вызовы социальной ситуации, выполняющий функцию психической регуляции.

По определению В. А. Толочека, ресурсы - это психические свойства, которые устойчиво связываются в ментальном опыте субъекта с позитивным эффектом, наличием ощутимого преимущества и могут быть использованы для повышения эффективности жизнедеятельности [6]. В.А. Бодров рассматривает ресурсы как некий функциональный потенциал, обеспечивающий высокий уровень реализации активности субъекта при выполнении трудовых задач, достижении заданных показателей в течение определенного времени. Ресурс это - функциональная система, каждое из функ- 
циональных звеньев которой представляет собой определенные инструменты-ресурсы регуляции [7].

Личностные ресурсы человека можно определить как систему его способностей к устранению противоречий личности с жизненной средой через совокупность ценностей и смыслов жизни человека, которые определяют его направленность и создают основу для самореализации [8].

В.Н. Марков считает, что на каждом уровне личности существует свой уровень ресурсов и ресурсы одного уровня тесно связаны друг с другом [9]. Например, на уровне индивидуальных психических процессов ресурсами являются черты характера. В связи с этим автор выделяет принципы изучения личностных ресурсов. Принцип полноты заключается в необходимом изучении всех базовых ресурсов одного уровня, при этом ресурсы могут иметь разную степень выраженности. Принцип концентрации подразумевает определение ресурсов на всех уровнях личности, так как нижележащие уровни подчинены вышележащим, к примеру, цели и задачи, которые определяются на уровне направленности личности, реализуются посредством характера. Принцип соответствия друг другу предполагает развитие ресурсов личности на разных уровнях ее структуры. Принцип внешних/внутренних ресурсов заключается в фокусировании внимания исследователя на совокупности внешних ресурсов, которые есть в наличии у человека, и на том, как они влияют на развитие внутренних ресурсов.

Согласно развиваемому нами субъектно-ресурсному походу, ресурсы понимаются как любые внутренние и внешние условия, реальные и идеальные объекты, индивидуальные качества, отношения, установки, ценности, которые субъект создает или вовлекает для решения собственных задач и достижения значимых целей. Благодаря субъектной активности, ресурсы могут актуализироваться, накапливаться, распределяться, расходоваться, реконструироваться и восстанавливаться. Ресурсы - это эмоциональные, мотивационно-волевые, когнитивные, ценностно-смысловые и поведенческие инструменты психической регуляции (конструкты), которые человек актуализирует для адаптации к стрессогенным ситуациям и стрессовым эпизодам жизни [10]. 
Субъектно-ресурсный подход опирается на представление о развитии ресурсов личности как субъекта деятельности в процессе жизненного и профессионального пути. Субъект как интегральная инстанция психического отражения и регуляции управляет собственными функциональными ресурсами и возможностями. Сущностью данного процесса является качественная трансформация механизмов психической регуляции активности, изменение удельного веса внешнего и внутреннего в детерминации личностного развития и бытия.

Одним из ключевых постулатов субъектно-ресурсной концепции противодействия личностному дисфункционированию является «ресурсная база», которая понимается как сложное структурноуровневое образование ресурсов психической регуляции, доступных и вовлекаемых субъектом для решения значимых текущих задач и стратегических целей деятельности [11]. Ресурсная база - это трехмерное пространство ресурсов профессионально-личностного развития, ресурсов сохранения устойчивости позитивного функционирования и ресурсов совладания с трудными (стрессогенными) жизненными ситуациями и обстоятельствами. Наличие, осознание и актуализация ресурсов разных уровней регуляции способствует психологическому благополучию человека.

Ключевыми методологическими основами субъектно-ресурсного подхода к личностному функционированию являются следующие положения:

- субъект и ресурсы - это единая система проявления активности человека в процессе реализации различных видов деятельности, в том числе и предметной (трудовой);

- ресурсы - это субъектные качества, обеспечивающие достижение цели деятельности и психологического благополучия человека (удовлетворенность трудом, самореализация, сохранность профессионального здоровья);

- актуализированные ресурсы меняют качество жизни человека и психологическое благополучие в объектном (материальном) и субъектном мире (субъективной картине мира: мире переживаний, ценностей, жизненной позиции), социальном, духовном, культурном пространствах; 
- основными функциями субъектно-личностных ресурсов являются реализация целей, потенциальных возможностей, притязаний личности, психологического благополучия в соответствии с объективными условиями, требованиями деятельности и среды;

- психологические ресурсы субъекта деятельности - это конструкты биопсихосоциальной регуляции жизнедеятельности человека;

- развитие ресурсов имеет сложную детерминацию - зависит от внешних (внесубъектных) и внутренних (интра- и интерсубъектных) факторов; личностные ресурсы динамичны (имеются периоды их развития, стагнации, инволюции; сложные закономерности потерь и приобретений); в зависимости от субъектной активности ресурсы вовлекаются, сонастраиваются и развиваются в соответствие с требованиями профессиональной деятельности и ситуационных условий, а также в зависимости от жизненной позиции и установок $[12,13]$.

Если говорить о ресурсном подходе в образовании, то основной задачей образования является развитие ресурсов личности, которые позволят ей быть здоровой, адаптивной и устойчивой. К таким ресурсам можно отнести стратегии копинг-поведения, стрессоустойчивость, способность к саморегуляции, жизнестойкость и др. [14].

Ресурсный подход нашел свое развитие и в психологическом сопровождении профессионализации субъекта труда. В рамках этой научной области выдвигают три идеи:

1. Человек рассматривается как обладатель психологических ресурсов, под которыми понимаются актуальные и потенциальные качества и свойства, реализуя которые, человек получает новые возможности и перспективы роста.

2. Исходные свойства человека ограничены биологически (например, объем и распределяемость внимания), темпорально (эти ограничения связаны с тем, что на протяжении всего жизненного пути происходят изменения в протекании психических процессов и в психических свойствах человека, и каждый жизненный период характеризуется максимальными возможностями в развитии определенных психических свойств), социально. 
3. Психологический ресурс рассматривается как функция, которая может возрастать даже при заданных отдельных переменных. Такое увеличение ресурсов связано с приобретением опыта текущей деятельности, а также со вступлением в новую деятельность, которая требует актуализации потенциальных возможностей. Авторы О. Г. Власова и Н.А. Белых считают, что психологические ресурсы являются психологическим капиталом, который будет умножаться при правильном его вложении [15].

\section{Постановка проблемы}

В исследованиях многих авторов обнаружены корреляции ПБ с внутренними и внешними факторами $[16,17]$. Согласно результатам наших прошлых исследований, высокое психологическое благополучие наблюдается при отсутствии профессионального выгорания специалистов социономических профессии, а также при их высокой удовлетворенности самореализацией в личностной и профессиональной сферах. На этом основании мы рассматриваем ПБ как ментальный ресурс противодействия профессиональноличностным деформациям.

Следует отметить, что малоизученными остаются факторы, препятствующие или способствующие психологическому благополучию нового поколения специалистов, вступающих на профессиональный путь. В литературе подчеркивается, что ПБ субъектов обучения является необходимым условием успешной учебной деятельности и дальнейшей профессионализации, важным результатом образовательного процесса $[18,19]$. Проблема психологического благополучия студенческой молодежи, многие аспекты которой недостаточно изучены, представляется актуальной в современных социальных и экономических реалиях РФ.

К актуальным аспектам проблемы ПБ относится вопрос о его устойчивости в зависимости от изменчивости характеристик социальной ситуации или эмоционального состояния человека. Можно предполагать, что ситуации с высокой социальной неопределенностью вызывают сильное эмоциональное напряжение у лиц с низкой резистентностью к неопределенности, определенными жизненными установками и позициями, что сказывается на ухудшении их ПБ. 
Учет данных личностных особенностей будет способствовать индивидуализации педагогической и психологической поддержки нового поколения специалистов. В связи с этим было предпринято исследование психологического благополучия студентов, получающих образование по одной из помогающих профессий - психологии. Исследование проводилось в два этапа.

Целью первого этапа исследования являлась оценка и сравнение ПБ студентов первого (бакалавриат) и седьмого (магистратура) года обучения, выявление личностных предикторов (ресурсов) психологического благополучия как ориентиров для профессиональноличностного развития посредством системы психологического сопровождения учебно-воспитательного процесса.

Общая гипотеза первого этапа исследования: психологическое благополучие повышается по мере взросления на этапе входа в профессию - этапе профессионального обучения и интеграции (профессиональной идентификации) с ней. Формы интерактивного образования и психологического сопровождения обучающихся, ориентированные на развитие их субъектности, способствуют повышению позитивного функционирования личности - психологическому благополучию: чем больше развиты компоненты субъектности, тем выше психологическое благополучие.

Учитывая внезапно изменившуюся социальную ситуацию в связи с пандемией коронавируса 2020 г. и срочным переходом от очного к дистанционному обучению, можно было предположить, что это привнесет множество объективных и субъективных стресс-факторов, что скажется на ПБ наших студентов. К стресс-факторам новой ситуации можно отнести: неожиданность и неопределенность ситуации; неопределенность относительно угрозы здоровью и продолжительности вынужденной самоизоляции; трудности дистанционного обучения по техническим причинах (недостаточная оснащенность современной техникой и программным обеспечением, сбои интернета); методические трудности (различия в форме преподавании очного и онлайн-обучения); коммуникативные особенности дистанционной формы обучения; психологические барьеры (сложность принятия ситуационных изменений) [20]. 
Мы предположили, что существуют также и другие имплицитные ментальные конструкции, которые актуализируются при определенных ситуационных условиях и предопределяют характер переживания «благополучие-неблагополучие». Данное рассуждение определило одну из наших гипотез о связи переживаний ПБ с когнитивными искажениями и субъективными репрезентациями трудной ситуации, в частности ситуации перехода от классической формы обучения студентов к удаленному (онлайн).

Задачи первого этапа исследования:

1. Сравнить параметры психологического благополучия студентов 1-го и 7-го годов обучения.

2. Сравнить параметры личностных ресурсов студентов 1-го и 7-го годов обучения.

3. Изучить взаимосвязь параметров психологического благополучия и личностных ресурсов студентов 1-го и 7-го годов обучения.

4. Определить вклад личностных ресурсов (самоорганизации деятельности, самоотношения, самоэффективности, жизнестойкости и перфекционизма) в психологическое благополучие студентов.

Выборка. В исследовании приняли участие 120 студентов: 60 студентов 1-го года обучения, средний возраст 18,3 лет; 60 студентов 7-го года обучения, средний возраст 24,5 лет.

Методы исследования:

1. Шкала психологического благополучия Рифф, адаптированная Т. Шевельковой, П. Фесенко (2005), показатели «самопринятие», «автономия», «управление средой», «личностный рост», «позитивные отношения с окружающими», «цели в жизни», индекс общего психологического благополучия.

2. Опросник самоорганизации деятельности Е. Мандриковой (2010), показатели «планомерность», «целеустремленность», «настойчивость», «фиксация», «самоорганизация», «ориентация на настоящее», индекс общего уровня самоорганизации.

3. Многомерная шкала перфекционизма Хьюитта и Флетта в адаптации И. Грачевой (2006), показатели «перфекционизм, ориентированный на себя», «перфекционизм, ориентированный на других» и «социально предписанный перфекционизм», индекс общего уровня перфекционизма. 
4. Шкала общей самоэффективности Шварцера, Ерусалема в адаптации В. Ромека (1996), определение ролевых позиций в межличностных отношениях по Берну.

5. Методика исследования самоотношения С. Р. Пантелеева (МИС, 1989), показатели «закрытость», «самоуверенность», «саморуководство», «отраженное самоотношение», «самооценнность», «самопринятие», «самопривязанность», «внутренняя конфликтность» И «самообвинение».

6. Тест жизнестойкости С. Мадди в адаптации Д. А. Леонтьева и Е.И. Рассказовой (2006), показатели вовлеченности, контроля и принятия риска, общий балл жизнестойкости.

Целью второго этапа исследования явилось изучение взаимосвязи между психологическим благополучием, выраженностью когнитивных искажений и типами жизненной позиции. В исследовании приняли участие 60 студентов бакалавриата, перешедших на онлайн-обучение с апреля 2020 г.

Гипотезы второго этапа исследования: психологическое благополучие выше у студентов с более низкими проявлениями когнитивных искажений. Когнитивные искажения связаны с типами жизненной позиции в виде оптимизма, пессимизма. Наименьшими когнитивными искажениями отличаются реалисты, наибольшие когнитивные искажения присутствуют у пессимистов.

Задачи второго этапа исследования:

1. Определить жизненные установки, когнитивные искажения и психологическое благополучие у студентов в ситуации удаленного обучения.

2. Изучить взаимосвязь когнитивных особенностей и психологического благополучия.

Использовались следующие методики:

1. Для оценки жизненной позиции - шкала реализма-активности-оптимизма «РАО-2018» Н.Е. Водопьяновой и В.Б. Чеснокова (2018).

2. Шкала психологического благополучия Рифф, адаптированная Т. Шевельковой, П. Фесенко (2005), показатели «самопринятие», «автономия», «управление средой», «личностный рост», «позитив- 
ные отношения с окружающими», «цели в жизни», индекс общего психологического благополучия.

3. Методика для оценки наличия и выраженности иррациональных установок (А. Эллис).

4. Авторская анкета оценки стрессогенности ситуации перехода на дистанционное обучение. Оценка осуществлялась по 7-балльной шкале, оценивались пять наиболее осознаваемых студентами трудностей дистанционного обучения: отсутствие реального общения с сокурсниками и преподавателями; увеличение объема домашних работ, трудности их выполнения; дефицит эмоциональных впечатлений (эмоциональная депривация); необходимость многочасовой работы у компьютера (гиподинамия, физические боли в спине, шее и других частях тела); похожесть всех дней (потеря чувства времени, недифференцированность времени).

Для оценки достоверности различий групп обучающихся по эмпирическим параметрам данные предварительно проверялись на нормальность распределения с помощью критерия Колмогорова-Смирнова. При нормальном распределении группы обучающихся сравнивались с помощью критерия Стьюдента. В случае ненормального распределения параметров достоверность различий оценивалась по $U$-критерию Манна - Уитни. Для оценки взаимосвязей между показателями использовался коэффициент корреляции Пирсона. Для выявления вклада личностных ресурсов (самоорганизации деятельности, самоотношения, самоэффективности, жизнестойкости и перфекционизма) в психологическое благополучие применялся множественной регрессионный анализ.

\section{Результаты исследования}

На первом этапе обнаружено, что количество студентов со средним и высоким уровнем ПБ больше среди магистрантов, чем среди студентов 1-го года обучения. А именно высокий и средний уровень общего ПБ имеют соответственно 80 \% и $13 \%$ магистрантов (7-й год обучения). Среди студентов 1-го года обучения высокий и средний уровень общего благополучия присутствует только у $4 \%$ и $75 \%$ соответственно. Это подтверждает гипотезу о том, что ПБ повышается по мере взросления на этапе входа в профессию - этапе 
профессионального обучения и интеграции с ней (профессиональной идентификации).

Выявлено, что у магистрантов (7-й год обучения) по сравнению с бакалаврами (1-й год обучения) прослеживается тенденция к повышению переживания психологического благополучию по общему индексу, достоверно выше показатели по шкалам «компетентность», «личностный рост», «цели в жизни» (табл. 1).

Результаты исследования показали, что общий уровень жизнестойкости среди студентов 7-го года обучения достоверно выше, чем у первокурсников. Статистически достоверные различия наблюдаются по показателям вовлеченности, контроля, а также самоэффективности (табл. 2).

Не обнаружены достоверные различия между первокурсниками и магистрантами по параметрам самоотношения и самоорганизаици. При этом имеется тенденция к более высоким показателям позитивного самоотношения (самоуверенность, саморуководство, отраженное самоотношение, самооценнность, самопринятие, самопривязанность) и самоорганизации («планомерность», «целеустремленность», «настойчивость», «фиксация», «самоорганизация», «ориентация на настоящее», индекс общего уровня самоорганизации) у магистрантов по сравнению с первокурсниками. Имеется тенденция к более высокой оценке уровня самоорганизации у студентов 7-го года обучения $(M=112,22 \pm 2,33)$ по сравнению с первокурсниками $(M=104,50 \pm 3,47)$. Можно ожидать положитель-

Таблица 1

Значимые различия между студентами по параметрам психологического благополучия

\begin{tabular}{l|c|c|c|c}
\hline $\begin{array}{c}\text { Компоненты психо- } \\
\text { логического благоп-- } \\
\text { лучия }\end{array}$ & $\begin{array}{c}1 \text {-й год } \\
\text { обучения, } \\
M \pm m\end{array}$ & $\begin{array}{c}7 \text {-й год } \\
\text { обучения, } \\
M \pm m\end{array}$ & $\begin{array}{c}t \text {-крите- } \\
\text { рий }\end{array}$ & $\begin{array}{c}\text { Достовер- } \\
\text { ность разли- } \\
\text { чий }\end{array}$ \\
\hline Компетентность & $53,02 \pm 1,70$ & $59,48 \pm 1,07$ & $-2,823$ & $p=0,005$ \\
\hline Личностный рост & $56,26 \pm 1,67$ & $62,91 \pm 1,04$ & $-3,517$ & $p=0,001$ \\
\hline Цели в жизни & $54,63 \pm 1,76$ & $61,65 \pm 1,24$ & $-3,349$ & $p=0,001$ \\
\hline Индекс общего ПБ & $325,3 \pm 60$ & $358,3 \pm 40,8$ & $-2,886$ & $p=0,006$ \\
\hline
\end{tabular}


ную динамику развития данного ресурса на последующих этапах профессионализации.

Результаты говорят о том, что обучающиеся в магистратуре по сравнению со студентами 1-го курса в большей степени уверены в себе в различных жизненных ситуациях, имеют более выраженные показатели субъектности по сравнению с первокурсниками.

Обнаружено, что в целом студенты-психологи характеризуются низкими показателями «перфекционизма» (показатели общего уровня перфекционизма, перфекционизма, ориентированного на себя и на других). Общий уровень перфекционизма у магистрантов достоверно выше $(M=187,8 \pm 28,0)$, чем у первокурсников $(M=170,9 \pm 36,2)$. Это говорит о том, что магистранты более требовательны к себе и другим, чем первокурсники.

В результате корреляционного анализа были обнаружены статистически значимые положительные взаимосвязи между общим уровнем ПБ, интра- и интерсубъектными ресурсами в обеих группах обучающихся. При этом в группе магистрантов количество взаимосвязей значительно больше, чем в группе первокурсников. Это говорит о более высокой интегрированности ресурсной базы ПБ и позитивном личностном функционировании старшекурсников по сравнению с первокурсниками, что может свидетельствовать об их более высокой психологической устойчивости.

Таблица 2

Значимые различия между студентами по параметрам жизнестойкости и самоэффективности

\begin{tabular}{l|c|c|c}
\hline $\begin{array}{l}\text { Параметры жизнестой- } \\
\text { кости и самоэффектив- } \\
\text { ности }\end{array}$ & $\begin{array}{c}1-\text { й год обуче- } \\
\text { ния, } \\
M \pm m\end{array}$ & $\begin{array}{c}7 \text {-й год обуче- } \\
\text { ния, } \\
M \pm m\end{array}$ & $\begin{array}{c}\text { Достовер- } \\
\text { ность разли- } \\
\text { чий }\end{array}$ \\
\hline Вовлеченность & $31,79 \pm 1,3$ & $35,57 \pm 1,2$ & $p \leq 0,001$ \\
\hline Контроль & $24,17 \pm 8,4$ & $29,34 \pm 8,1$ & $p \leq 0,001$ \\
\hline Принятие риска & $14,91 \pm 4,39$ & $16,98 \pm 5,69$ & $p \geq 0,05$ \\
\hline $\begin{array}{l}\text { Общий показатель } \\
\text { жизнестойкость }\end{array}$ & $78,1 \pm 21,9$ & $86,9 \pm 20$ & $p \leq 0,001$ \\
\hline Самоэффективность & $30,50 \pm 0,53$ & $33,35 \pm 0,64$ & $p \leq 0,05$ \\
\hline
\end{tabular}




\section{Результаты множественного регрессионного анализа}

В качестве зависимой переменной был избран общий показатель психологического благополучия. В качестве независимых переменных выступали все показатели личностных ресурсов (самоорганизация деятельности, самоотношение, самоэффективность, жизнестойкость и перфекционизм).

В группе первокурсников R2 в 1-й модели равен 0,232. Таким образом, в группе первокурсников дисперсия общего уровня психологического благополучия только на 23 \% обусловлена перечисленными переменными. R-коэффициент множественной корреляции 0,48, что говорит об умеренном уровне взаимосвязей личностных предикторов (ресурсов). Наибольшей прогностической ценностью в полученной модели обладают параметр самоорганизации деятельности - целеустремленность ( $\beta$-коэффициент 0,482).

Полученные данные подтверждают важность ресурса самоорганизации для психологического благополучия первокурсников. Целеустремленность студентов является основным фактом в формировании настойчивости, которая, в свою очередь, позволяет преодолевать возникающие трудности, в том числе в адаптации к вузу, к новым условиям учебной деятельности и др. Это говорит о том, что для повышения ПБ необходимо развивать у студентов целеустремленность и другие переменные самоорганизации, используя различные психолого-педагогические технологии личностного развития и поддержки.

В группе магистрантов обнаружено, что R2 в 6-й модели равен 0,784, т. е. регрессионная модель объясняет более 78 \% дисперсии (изменчивости) переменной «психологическое благополучие». Таким образом, в группе магистрантов дисперсия общего уровня психологического благополучия на 78 \% обусловлена перечисленными переменными. R-коэффициент множественной корреляции - 0,885, что говорит о высоком уровне взаимосвязей личностных предикторов (ресурсов). Наибольшей прогностической ценностью в полученной модели обладают следующие параметры: перфекционизм, ориентированный на других ( $\beta$-коэффициент 0,435$)$, принятие риска ( $\beta$-коэффициент 0,360$)$, вовлеченность ( $\beta$-коэффициент 0,355$)$, перфекционизм, ориентированный на себя ( $\beta$-коэффициент 0,354$)$. 
Данные переменные в большей степени определяют изменчивость уровня психологического благополучия. В меньшей степени определяют изменчивость уровня психологического благополучия такие показатели, как саморуководство ( $\beta$-коэффициент 0,248$)$, ориентация на настоящее ( $\beta$-коэффициент 0,251).

На втором этапе исследования с помощью шкалы «РАО-2018» было обнаружено, что большая часть студентов относится к типу реалистов (47\%). «Активные оптимисты» составляют $30 \%$, «пассивные оптимисты» - $15 \%$, «активные пессимисты» - $8 \%$. Не было выявлено студентов с пассивным пессимизмом («выученной беспомощностью»).

Наибольшие показатели когнитивных искажений и оценки стрессогенности в период перехода к дистанционному обучению обнаружены у активных пессимистов. Согласно нормативным данным методики А. Эллиса, активные пессимисты характеризуются высокой выраженностью иррациональных установок, наименьшим индексом психологического благополучия, наиболее высокими оценками стрессогенности ситуации самоизоляции и дистанционного обучения. В отличие от других типов жизненной позиции, у «реалистов» отсутствуют иррациональные установки, они в наименьшей мере катастрофизировали ситуацию (наименьший показатель стрессогенности ситуации), показали наиболее высокий уровень ПБ. «Пассивные» и «активные» оптимисты характеризуются средним уровнем наличия иррациональных установок (табл. 3).

\section{Обсуждение полученных результатов}

В результате проведенного исследования удалось выявить личностные предикторы ПБ обучающихся в бакалавриате и магистратуре. Обнаружено, что у магистрантов по сравнению с первокурсниками показатели ПБ имеют более тесные связи с ресурсами разных уровней психической регуляции, а именно с показателями волевой регуляции (настойчивость, контроль, целеустремленность), ценностно-смысловой регуляции (перфекционизм, ориентированный на других, перфекционизм, ориентированный на себя), с ресурсами самоподдержки (самоэффективность), отраженного самоотношения (самоуверенность, самооценность), с жизнестой- 
Таблица 3

Психологическое благополучие и когнитивные искажения у студентов с разными жизненными позициями

\begin{tabular}{|c|c|c|c|c|c|}
\hline 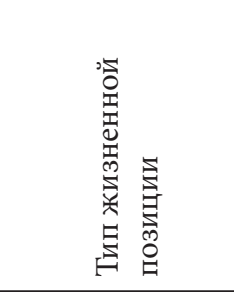 & 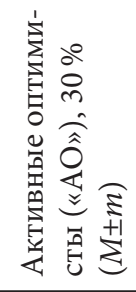 & 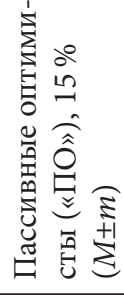 & 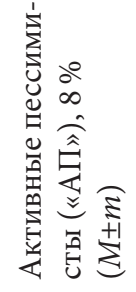 & 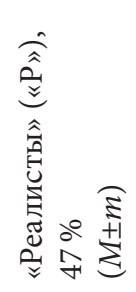 & 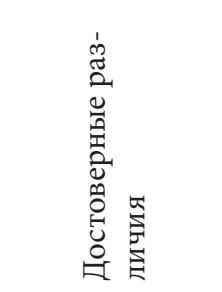 \\
\hline Индекс ПБ & $358,3 \pm 41$ & $345 \pm 41$ & $295,3 \pm 45$ & $375,3 \pm 35$ & $\begin{array}{c}p \leq 0,001 \text { меж- } \\
\text { ду «АП» и «Р» }\end{array}$ \\
\hline $\begin{array}{l}\text { Стрессоген- } \\
\text { ность ситуации }\end{array}$ & 5,3 & 5,1 & 6,2 & 4,9 & $\begin{array}{l}p \leq 0,001 \text { меж- } \\
\text { ду «АП» и «Р» }\end{array}$ \\
\hline $\begin{array}{l}\text { Когнитивные } \\
\text { искажения } \\
\text { (уровень, } \\
\text { иррациональ- } \\
\text { ные установки) }\end{array}$ & 42 & 40 & 25 & 50 & $\begin{array}{c}p \leq 0,001 \text { меж- } \\
\text { ду «АП» и «Р» }\end{array}$ \\
\hline
\end{tabular}

костью. То есть такие личностные ресурсы, как самоорганизация деятельности, жизнестойкость, уважение и перфекционизм, оказывают существенное влияние на уровень благополучия магистрантов.

В обеих группах обучающихся выявлена взаимосвязь между показателями ПБ и показателями самоорганизации. При этом у первокурсников наибольший вклад в ПБ вносит целеустремленность. На седьмом году обучения наибольший вклад в ПБ вносят перфекционизм, ориентированный на других и на себя, принятие риска и вовлеченность. У магистрантов по сравнению с первокурсниками имеется выраженная связь ПБ с психологическими защитами личности: прямая связь с замкнутостью и обратная связь с самообвинением. Чем выше замкнутость - защитное поведение личности, желание соответствовать общепринятым нормам поведения и взаимоотношений с окружающими людьми, избегать самокритики, тем больше выражена закрытость; чем выше самообвинение, тем ниже ПБ. Можно предположить, что в процессе профессионального обучения развивается механизм профессиональной самоидентич- 
ности, требовательности самооценки, что проявляется в обвинении себя за поступки и действия, которые не соответствуют профессиональным ценностям и компетентностям. Связи ПБ с психологическими защитами, очевидно, свидетельствует о сложности формирования механизмов душевного благополучия.

Полученные факты подтверждают предположение о том, что по мере взросления и профессиональной идентификации атрибуты субъектности (интра- и интеросубъектные ресурсы) оказывают все большее влияние на ПБ. Повышению психологического благополучия старшекурсников содействует развитие волевых, ценностносмысловых и когнитивно-оценочных ресурсов, т. е. расширение «ресурсной базы» субъектности способствует эффективной профессионализации специалистов-психологов.

Сравнение групп с разной жизненной позицией говорит в пользу нашей гипотезы о связи переживаний психологического благополучия с когнитивными искажениями, в частности, с преувеличением трудностей ситуации - катастрофизацией. Когнитивные искажения представляют собой систематические ошибки в мышлении или паттерны отклонений в суждениях, которые происходят и обостряются в сложных ситуациях под влиянием эмоций. Природа их имеет сложную онтогенетическую и ситуационную обусловленность. Дефицит общения, обратной связи с преподавателем и учебной группой может способствовать когнитивным искажениям в ситуации дистанционного обучения. В этой связи в учебно-воспитательном процессе следует особое внимание уделять формированию самоконтроля, критериям дифференциации иррационального и рационального в мышлении, поведении, эмоциональных переживаниях.

Кратковременность наблюдений и небольшая выборка нашего исследования не позволяют в настоящее время говорить о наличии или отсутствии динамики изменения когнитивных искажений в период погружения в сложную ситуацию дистанционного обучения и возможных ее предикторах. Имеются лишь косвенные данные о возможных когнитивных трудностях студентов в данный период. В частности, повысилось число студентов, которые испытывали большие затруднения в понимании и выполнении учебных заданий, у них отмечено повышение тревожности (преувеличение трудностей 
и катастрофизация возможных ошибок при выполнении контрольных заданий), значительное количество студентов взяли академический отпуск, не выдержав трудностей нового формата обучения.

Выявленный нами факт более сильной выраженности иррациональных установок среди лиц с низким ПБ и с пессимистической жизненной позицией (тип «активные пессимисты») указывает на то, что в целях психологической помощи педагогические и психологические действия должны быть ориентированы на предупреждение и коррекцию когнитивных искажений. В качестве ориентиров могут быть приняты возможные предикторы психологического благополучия личности, которые способствуют позитивному функционированию в сложных условиях профессиональной деятельности. Среди них такие, как эмоциональный интеллект, автономность, стремление к компетентности и личностному росту, положительное самоотношение - самопринятие, самоэффективность и самоуважение в профессии, оптимизм, активность, реализм.

В связи с этим одной из задач повышения квалификации преподавателей высшей школы должно быть расширение компетентности в области психологии личности, психической регуляции состояний, стрессоустойчивости, технологий профилактики/коррекции ментальных конструктов, препятствующих развитию субъектности и позитивному функционированию (самоконтроль, самоорганизованность, внутренняя мотивация профессионализации, реализм, оптимизм и др.).

С позиций ресурсного подхода психологическое благополучие представляет собой ресурс самоконтроля (эмоционально-оценочный конструкт отношения человека к процессу и результату собственной деятельности). Это важный диспозиционный ресурс личности - эмоционально-когнитивный конструкт, оказывающий влияние на субъективную репрезентацию «субъект-ситуация». Психологическое благополучие выполняет функцию регуляции вовлеченности для самореализации, самоосуществления с позиций эмоциональной и функциональной привлекательности. Оно формируется посредством взаимодействия со средой и оценкой результатов этого взаимодействия, изменяется под влиянием жизненного опыта, этапов жизненного пути и его задач [21]. В течение всей жизни человек 
накапливает когнитивные конструкты оценок относительно событий, других людей и самого себя, выполняя регулирующую функцию [22, 23]. В данном контексте психологическое благополучие - ментальный ресурс регуляции жизнедеятельности субъекта.

В целом можно резюмировать, что система психологического сопровождения эффективного обучения и развития ПБ специалистов помогающих профессий (на примере психологов) должна выстраиваться как полифакторное воздействие на развитие личностных ресурсов, содействующих мотивации профессионально-личностного развития, волевой регуляции (настойчивость, контроль, целеустремленность), механизмам (ресурсам) сохранения устойчивости позитивного функционирования и совладания с трудными (стрессогенными) профессиональными и жизненными ситуациями.

\section{Выводы}

1. Количество лиц с высоким и средним уровнем психологического благополучия больше среди магистрантов (7-й год обучения) по сравнению с первокурсниками. Магистранты отличаются от первокурсников более высокими показателями ПБ (компетентность, личностный рост, цели в жизни), что очевидно обусловлено взрослением и профессионально-личностным развитием.

2. Магистранты достоверно отличаются от первокурсников более высокими показателями жизнестойкости, самоэффективности. Наблюдается тенденция к более высоким показателям позитивного самоотношения (самоуверенность, саморуководство, отраженное самоотношение, самооценнность, самопринятие, самопривязанность) и самоорганизации (планомерность, целеустремленность, настойчивость, фиксация, самоорганизация, ориентация на настоящее, индекс общего уровня самоорганизации) у магистрантов по сравнению с первокурсниками. Общий уровень перфекционизма у магистрантов достоверно выше, чем у первокурсников. Это говорит о том, что магистранты более требовательны к себе и другим, чем первокурсники.

3. Среди магистрантов количество значимых корреляций ПБ с личностными ресурсами больше, чем среди первокурсников. Это свидетельствует о более высокой интегрированности ресурсной 
базы ПБ и позитивном личностном функционировании старшекурсников по сравнению с первокурсниками.

4. Наибольший вклад в ПБ в группе первокурсников вносит параметр самоорганизации деятельности - целеустремленность. В группе магистрантов предикторами ПБ являются перфекционизм, ориентированный на себя и на других, принятие риска, вовлеченность, саморуководство, ориентация на настоящее.

5. Наименьшими когнитивными искажениями отличаются реалисты, наибольшие когнитивные искажения присущи активным пессимистам.

6. Учитывая тенденцию к взаимосвязи реалистической и оптимистической жизненной позиции, психологического благополучия и когнитивных искажений, можно полагать, что в новых социальных реалиях одной из задач образования и воспитания нового поколения специалистов представляется противостояние пессимизму и неуверенности в собственном потенциале.

7. Выявленные личностные предикторы ПБ должны учитываться при планировании целей и средств профессионально-личностного развития студентов посредством системы их психологического сопровождения с учетом возраста и этапа профессионализации. Подтвердилась гипотеза о повышении психологического благополучия в процессе обучения по мере профессионально-личностного развития, повышения профессиональной компетентности и самоидентификации.

1. Идобаева О. А. К вопросу о психолого-педагогической модели формирования психологического благополучия личности // Вестн. МГЛУ. 2013. № 7 (667). С. 93-101.

2. Идобаева О.А. К построению модели исследования психологического благополучия личности: психолого-развитийный и психологопедагогический аспекты // Вестн. Том. гос. ун-та. 2011. № 351. С. 128-134.

3. Шамионов Р. М. Этнокультурные факторы субъективного благополучия личности // Психол. журн. 2014. № 35(4). С. 68-81.

4. Шевеленкова Т. Д., Фесенко П. П. Психологическое благополучие личности (обзор основных концепций и методологическое исследование) // Психологическая диагностика. 2005. № 3. С. 95-130. 
5. Deci L., Ryan R.M. The general causality orientation scale: Self-determination in personality // Journal of Research in Personality. 1985. Vol. 19. P. 109-134.

6. Толочек В. А. Профессиональная успешность: понятия «способности» и «ресурсы» в объяснении феномена // Человек. Сообщество. Управление. 2010. № 2. С. 20-38.

7. Бодров В.А. О психологических механизмах регуляции процесса преодоления стресса // Психология субъекта профессиональной деятельности : сб. науч. тр. / под ред. В. А. Барабанщикова, А. В. Карпова. Москва ; Ярославль : Аверс-Пресс, 2002. Вып. 2. С. 99-117.

8. Калашникова С. А. Личностные ресурсы как интегральная характеристика личности // Молодой ученый. 2011. Т. 2, № 8. С. 84-87.

9. Марков В. Н. Ресурсный подход к психологической диагностике: основные принципы // Вестн. Рос. ун-та дружбы народов. Сер. : Психология и педагогика. 2010. № 4. С. 5-10.

10. Водопьянова Н. Е. Современные концепции ресурсов субъекта профессиональной деятельности // Вестн. С.-Петерб. ун-та. Сер. 16. 2015. Вып. 1. С. 45-54.

11. Водопьянова Н.Е. Ресурсное обеспечение противодействия профессиональному выгоранию субъектов труда : автореф. дис. ... д-ра психол. наук. СПб., 2014. 48 с.

12. Водопьянова Н.Е. Противодействие синдрому выгорания в контексте ресурсной концепции человека // Вестн. С.-Петерб. ун-та. Сер. 16. 2011. Вып. 2. С. 38-50.

13. Водопьянова Н. Е. Субъект-ориентированный подход к профилактике и коррекции синдрома выгорания // Актуальные проблемы психологии труда, инженерной психологии и эргономики / под ред. В. А. Бодрова. М. : Изд-во «Институт психологии РАН», 2012. С. 415-437.

14. Толочек В. А. Профессиональная успешность: от способностей к ресурсам (дополняющие парадигмы) // Психология : журнал Высшей школы экономики. 2009. Т. 6, № 3. С. 27-61.

15. Власова О. Г., Бельх Н. А. Психологическое сопровождение профессионализации потенциального субъекта труда: ресурсный подход // Изв. Юж. федер. ун-та. Технические науки. 2006. Т. 68, № 13. С. 201-204.

16. Куликов Л. В. Здоровье и субъективное благополучие // Психология здоровья / ред. Г. С. Никифоров. СПб. : Питер, 2000. С. 33-45. 
17. Huang J. Emotional Intelligence and Subjective Well-Being: Altruistic Behavior as a Mediator // Social Behavior and Personality: an international journal. 2018. Vol. 46, iss. 5. P. 749-762.

18. Водяха С. А. Предикторы психологического благополучия студентов // Педагогическое образование в России. 2013. № 1. С. 70-74.

19. Козьмина Л. Б. Динамика психологического благополучия студентов-психологов в период обучения в вузе [Электронный ресурс] // Теория и практика общественного развития. 2013. № 11. URL: http://cyberleninka. $\mathrm{ru} /$ article/n/dinamika-psihologicheskogo-blagopoluchiya-studentov-psihologovv-period-obucheniya-v-vuze (дата обращения: 30.05.2015).

20. Азарнов Н. Н., Азарнова А. Н. Проблема взаимопонимания преподавателей и студентов в процессе дистанционного обучения // Дистанционное и виртуальное обучение. 2014. № 8. С. 12-19.

21. Костина С. С., Осин Е. Н. Представления о счастливой и осмысленной жизни: связаны ли они с психологическим благополучием? // Парадигма: философско-культурологический альманах. 2012. № 3. С. 179-188.

22. Turner R. M. Adaptive Reasoning for Real-World Problems: A SchemaBased Approach. Lawrence Erlbaum Associates, Hillsdale, NJ., 1994. 260 p.

23. Чернов А. Ю., Зиновьева Д. М., Водопьянова Н. Е., Фомина О.О. Структура и виды когнитивных схем психологического благополучия // Изв. Сарат. ун-та. Сер. : Акмеология образования. Психология развития ; вып. 1 (33). С. 33-44. 


\section{СУБЪЕКТНОСТЬ КАК ПРЕДИКТОР ПСИХОЛОГИЧЕСКОГО БЛАГОПОЛУЧИЯ ОДАРЕННЫХ ПОДРОСТКОВ}

Е. Н. Волкова

И. В. Волкова

Психологические и педагогические исследования подросткового возраста часто сосредоточены на изучении и анализе разного рода трудностей этого возрастного периода. Основной пафос таких исследований заключается в том, чтобы подчеркнуть проблемность подростка, диссинхронию и дефицитарность его личностного развития. Негативная коннотация доминирует в частом определении этого возраста: подростков, как правило, называют «трудными». Даже в названии возраста заложено специфическое отношение к подростку, определенное обесценивание растущего человека. Подросток - значит еще не выросший, несостоявшийся взрослый, этакий «недо-человек». Слово «отрок» буквально означает «не имеющий права говорить». Важно, что такое отношение к подростку закреплено не только в понятии, но и в нашей повседневной жизни, и в профессиональной педагогической позиции. Очень часто педагогическое воздействие на подростка направлено на устранение этого несовершенства. Между тем этот возраст для самого ребенка предстает скорее как время новых открытий в себе и окружающем мире и основное его ощущение - это ощущение захватывающей новизны жизни, ее многообразия и возможностей найти в этой жизни свое неповторимое Я. Динамизм и пластичность в развитии всех основных жизненных и личностных функций представляют неоспоримое достоинство подросткового возраста.

В последние годы появились исследования, которые рассматривают подростка не как источник проблем, а, скорее, как ценный актив в общем процессе развития $[1,2]$. В этих исследованиях происходит смещение фокуса внимания с проблемности подростка,

Исследование выполнено при финансовой поддержке РФФИ в рамках научного проекта № 19-013-00729 «Субъективные факторы психологического благополучия одаренных подростков».

(с) Волкова Е.Н., Волкова И. В., 2020 
с изучения трудностей взаимодействия с ним на преимущества и достижения этого возраста. В этом контексте перспективными оказываются исследования психологического благополучия и субъектности подростков.

Субъектность как активное деятельное начало составляет основу для преобразований окружающего мира и себя в соотношении с ним, выступая условием поступательного развития. Это обстоятельство позволяет конституировать субъектность в статусе принципа для нового, современного понимания детерминации психического и личностного развития [3].

Современная образовательная ситуация в России характеризуется непрерывным поиском новых моделей и форм содержания образования. Внешние вызовы, начиная от вступления в цифровую эпоху и заканчивая глобальными потрясениями природного и техногенного характера, заставляют систему образования перестраивать свои целевые установки: действительные цели образования все больше становятся субъектно-ориентированными, а воспитание личности все чаще связывают с процессом саморазвития субъекта, способного к поиску и построению собственной жизненной траектории.

Активная преобразовательная жизнь и деятельность в среде с высокими параметрами изменчивости и неопределенности для многих современных людей является часто недостижимой, а неопределенность и изменчивость жизни воспринимается ими как угроза благополучию. Между тем одаренные дети и подростки - это уникальная группа, в которой изменчивость и неопределенность среды не только не вызывает разного рода деструктивных переживаний, но и выступает условием полноценного функционирования и развития. Более того, недостаточная выраженность изменчивости и неопределенности образовательной среды приводит к снижению креативного потенциала детей и подростков, что представлено в ставших уже классическими работах Э. Торренса, Р. Стернберга, Дж. Рензулли, Д. Б. Богоявленской, В.Н. Дружинина [4]. Неопределенная и изменчивая образовательная среда выступает для одаренных детей и подростков развивающей средой. Не случайно создание такой образовательной среды представлено в современных 
концепциях школьного образования США и Европы (например, в концепциях STEM и STEAM). С этой точки зрения изучение субъектности одаренных детей и подростков представляется попыткой ответа на вопрос о развитии субъектности как условия преодоления негативных последствий хаоса изменчивости. Это делает актуальной задачу изучения субъектности и психологического благополучия одаренных детей и подростков не только в контексте изучения интеллектуального ресурса, но и с точки зрения общих закономерностей развития в современном мире.

Вопросы возникновения и развития одаренных детей и подростков активно изучаются отечественными и зарубежными педагогами, психологами, философами, врачами и биологами уже не одно десятилетие [5-8]. Однако вопрос о соотношении психологического благополучия и развития субъектности одаренных детей и подростков до настоящего времени не имеет однозначного ответа [9]. Наше исследование направлено на проверку гипотезы о возможности рассматривать субъектность в качестве предиктора психологического благополучия одаренных подростков. Работа представляет собой часть комплексного исследования субъективных предпосылок психологического благополучия одаренных подростков. Программа и протокол комплексного исследования были рассмотрены и одобрены этическим комитетом Российского государственного педагогического университета им. А. И. Герцена (IRB00011060 Herzen State Pedagogical University of Russia IRB\#1, протокол № 5 от 28.01.2019).

\section{Материалы и методы исследования}

Выборку исследования составили 422 подростка (191 девушка и 231 юноша) в возрасте 15-17 лет, обучающихся в специализированных образовательных учреждениях для одаренных детей и подростков открытого и интернатного типов в Санкт-Петербурге и Нижнем Новгороде. Зачислению на программы обучения в этих учреждениях предшествовал педагогический отбор. Для сопоставления данных были использованы результаты обследования контрольной группы - подростков с нормативным уровнем способностей, обучающихся в общеобразовательных школах Санкт-Петербурга и Смоленска (141 подросток - 79 девушек и 62 юноши). 
Для измерения психологического благополучия использовалась шкала К. Рифф в адаптации Л. В. Жуковской, Е. Г. Трошихиной [10]. Данная методика является одним из основных диагностических инструментов эмпирических исследований психологического благополучия, в том числе и подростков. Она имеет интегральную шкалу психологического благополучия, а также шесть субшкал, направленных на оценку уровня «автономности» (самостоятельности, независимости), «компетентности» (чувство мастерства в овладении средой и разнообразными видами деятельности), стремления к «личностному росту» (продолжению развития и реализации своего потенциала), «жизненных целей» (чувства направленности и осмысленности жизни), «позитивного отношения» с другими людьми, а также уровня «самопринятия» (позитивного отношения к себе).

Особенности развития субъектности подростков изучались с помощью модифицированного опросника «Структура субъектности подростка», разработанного на основе опросника «Структура субъектности» Е. Н. Волковой и И. А. Серегиной $[11,12]$. Опросник включает в себя 62 вопроса, объединенных в 6 шкал, соответствующих атрибутивным характеристикам субъектности: активности, связанной со способностью к целеполаганию, способности к рефлексии, возможности свободы выбора и ответственности за него, осознанию и переживанию собственной уникальности, пониманию и принятию другого человека, саморазвитию.

Математический анализ полученных данных производился с помощью методов описательной статистики, сравнения средних и регрессионного анализа. Расчеты осуществлялись с помощью программного пакета SPSS 22.

\section{Результаты исследования}

Результаты исследования особенностей психологического благополучия подростков представлены в табл. 1.

Анализ данных не выявил значимых различий по показателям как общего психологического благополучия, так и его структурных компонентов в сопоставляемых группах, кроме значения показателя «автономность». Эти различия обнаружены как по всей выборке одаренных подростков, так и в группе подростков-мальчиков. 


\begin{tabular}{|c|c|c|c|c|c|c|c|}
\hline \multirow{3}{*}{\multicolumn{2}{|c|}{ लै }} & \multirow{3}{*}{ 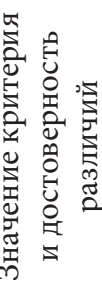 } & ભ & $\stackrel{m}{M} \stackrel{m}{I}$ & 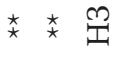 & $\stackrel{m}{M} \stackrel{m}{I}$ & $\stackrel{m}{M} \stackrel{m}{I}$ \\
\hline & & & $a$ & 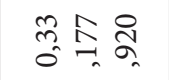 & 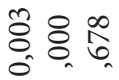 & 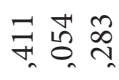 & $\infty \overrightarrow{0}$ \\
\hline & & & 空 & 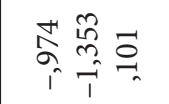 & 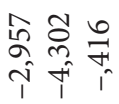 & 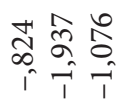 & 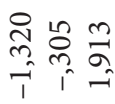 \\
\hline 垴 & & 点 & \begin{tabular}{l}
5 \\
\multirow{2}{*}{$\curvearrowright$} \\
0 \\
0 \\
0 \\
0 \\
0
\end{tabular} & 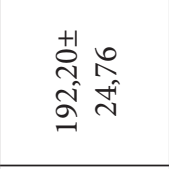 & 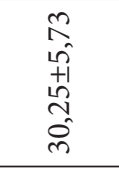 & 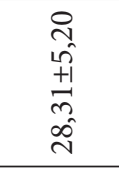 & 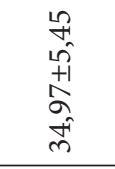 \\
\hline 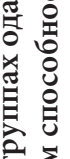 & 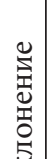 & 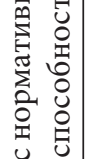 & 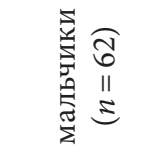 & 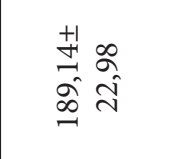 & 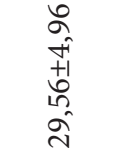 & 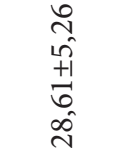 & $\begin{array}{l}\hat{\sigma} \\
\hat{+} \\
+1 \\
\hat{n} \\
\hat{n}\end{array}$ \\
\hline 空 & 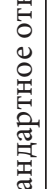 & 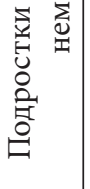 & 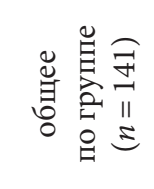 & 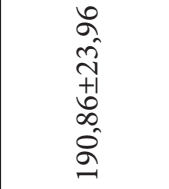 & \begin{tabular}{l}
$m$ \\
$\infty$ \\
+1 \\
+1 \\
\multirow{1}{n}{} \\
$\hat{n}$
\end{tabular} & $\begin{array}{l}0 \\
\text { No } \\
i n \\
+1 \\
\infty \\
\infty \\
\infty\end{array}$ & ח̃ \\
\hline$\sum_{\infty}^{\frac{\pi}{3}}$ & 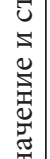 & 袩 & 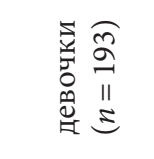 & 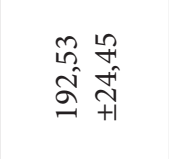 & \begin{tabular}{l}
0 \\
\multirow{1}{*}{} \\
+1 \\
10 \\
10 \\
0 \\
0
\end{tabular} & $\begin{array}{l}\text { ते } \\
\text { ஸn } \\
+1 \\
0 \\
0 \\
\text { ปे }\end{array}$ & $\begin{array}{l}\text { J } \\
\text { ñ } \\
+1 \\
\text { ते } \\
\text { nn }\end{array}$ \\
\hline 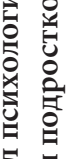 & 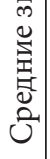 & $\begin{array}{l}0 \\
0 \\
0 \\
0 \\
0 \\
0 \\
0 \\
0\end{array}$ & 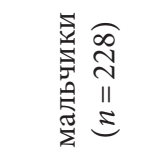 & $\begin{array}{l}+1 \\
\infty \\
\stackrel{n}{n} \\
\stackrel{n}{d}\end{array}$ & $\begin{array}{l}\text { ñ } \\
n \\
+1 \\
\infty \\
0 \\
\text { ñ }\end{array}$ & $\begin{array}{l}\vec{b} \\
n \\
+1 \\
n \\
0 \\
0\end{array}$ & $\begin{array}{l}n \\
\hat{+} \\
+1 \\
\hat{n} \\
\hat{म}\end{array}$ \\
\hline & & 气ّ̂ & 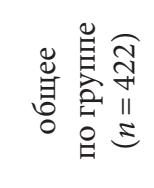 & 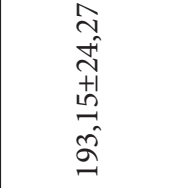 & $\begin{array}{l}\hat{\sigma} \\
n \\
+1 \\
\hat{n} \\
\hat{n}\end{array}$ & 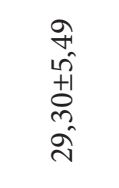 & $\begin{array}{l}0 \\
0 \\
n \\
+1 \\
n \\
n \\
n\end{array}$ \\
\hline & & 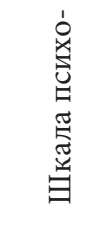 & 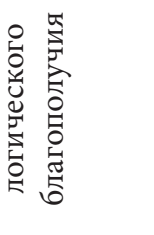 & 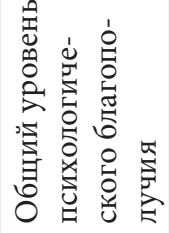 & 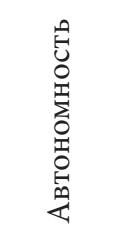 & 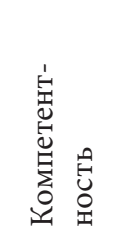 & 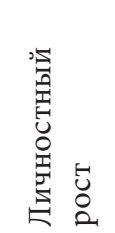 \\
\hline
\end{tabular}




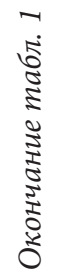

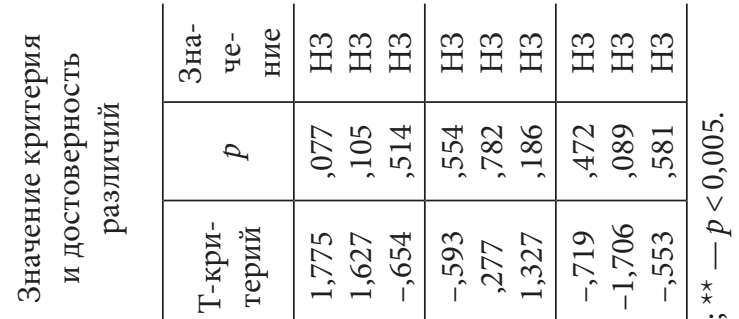

\begin{tabular}{|c|c|c|c|c|c|}
\hline \multirow{6}{*}{ 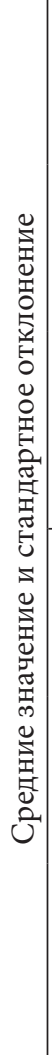 } & \multirow{3}{*}{ 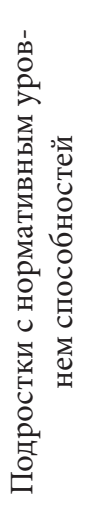 } & 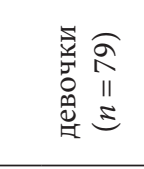 & $\begin{array}{l}n \\
n \\
0 \\
+1 \\
2 \\
m \\
m\end{array}$ & $\begin{array}{l}\text { O̊ } \\
\text { ஸी } \\
+1 \\
\text { ல̂ } \\
\text { ก̂ }\end{array}$ & $\begin{array}{l}= \\
7 \\
0 \\
+1 \\
0 \\
-1 \\
m\end{array}$ \\
\hline & & 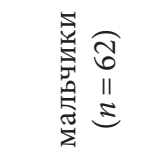 & $\begin{array}{l}\infty \\
0 \\
n \\
+1 \\
\infty \\
m \\
m\end{array}$ & $\begin{array}{l}0 \\
-1 \\
+1 \\
0 \\
0 \\
\text { ஸ̂ }\end{array}$ & $\begin{array}{l}\text { Õ } \\
0 \\
+1 \\
\text { N } \\
\text { ? } \\
0 \\
\text { nn }\end{array}$ \\
\hline & & 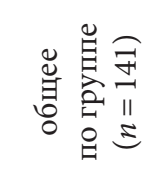 & $\begin{array}{l}n \\
0 \\
6 \\
+1 \\
\text { ते } \\
\text { nీ }\end{array}$ & $\begin{array}{l}m \\
\infty \\
n \\
+1 \\
n \\
n \\
\text { n̂ }\end{array}$ & $\begin{array}{l}\text { ते } \\
\hat{6} \\
+1 \\
\frac{+1}{6} \\
\text { m }\end{array}$ \\
\hline & \multirow{3}{*}{ 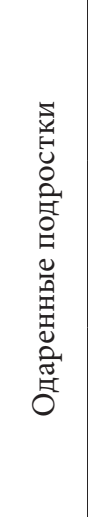 } & 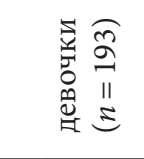 & $\begin{array}{l}\infty \\
\infty \\
n+1 \\
\infty \\
\infty \\
\text { nీ }\end{array}$ & $\begin{array}{l}\text { ñ } \\
\text { ô } \\
+1 \\
\hat{\sigma} \\
\text { nీ}\end{array}$ & 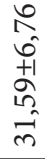 \\
\hline & & 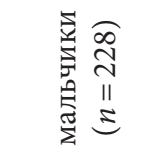 & 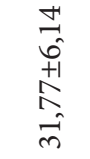 & 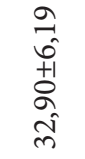 & $\begin{array}{l}\hat{N} \\
\text { in } \\
+1 \\
\text { बे } \\
\text { ले }\end{array}$ \\
\hline & & 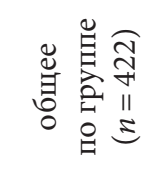 & $\begin{array}{l}5 \\
0 \\
0 \\
+1 \\
0 \\
\text { ñ } \\
\text { nీ}\end{array}$ & $\begin{array}{l}\text { ô } \\
\hat{0} \\
0 \\
+1 \\
0 \\
\text { mీ }\end{array}$ & 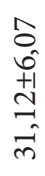 \\
\hline & 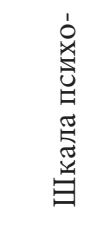 & 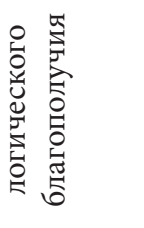 & 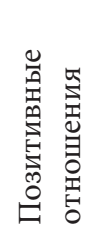 & 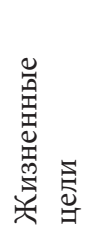 & 泀 \\
\hline
\end{tabular}


У одаренных подростков (в первую очередь у одаренных мальчиков) способность вести себя независимо, формировать внутренние эталоны оценки собственной деятельности развита лучше, чем у их сверстников с нормативным уровнем способностей. Также можно отметить, что на уровне тенденции в группе одаренных подростков средние значения по общему показателю психологического благополучия и по пяти его структурным компонентам (кроме показателя «позитивные отношения») выше, чем в группе сравнения.

Результаты исследования структуры субъектности и выраженности ее компонентов у одаренных подростков и подростков с нормативным уровнем способностей представлены в табл. 2.

Сравнительный анализ выраженности компонентов субъектности показал различия для одаренных подростков и подростков с нормативным уровнем способностей. В отличие от подростков с нормативным уровнем способностей, у одаренных подростков выше способность к рефлексии. Различия значимы для подростковмальчиков: у одаренных мальчиков способность к рефлексии выше, чем у мальчиков из группы сравнения. Для девочек отличия по этому компоненту субъектности оказались статистически не значимыми. У одаренных подростков также лучше развита способность делать выбор и нести за него ответственность. Эти различия также статистически значимы только для мальчиков. Кроме того, одаренные подростки больше осознают и принимают собственную уникальность. Эти различия значимы для девочек.

Для изучения связи психологического благополучия одаренных подростков и субъектности был предпринят регрессионный анализ показателей психологического благополучия и компонентов субъектности. Поскольку значения показателей психологического благополучия и субъектности для одаренных подростков и подростков с нормативным уровнем способностей различались в зависимости от пола ребенка, были построены четыре регрессионных уравнения в зависимости от пола и уровня способностей подростка. Регрессионные модели, построенные для одаренных подростков и подростков с нормативным уровнем способностей, обладают удовлетворительными характеристиками для генерализации полученных результатов: в каждой модели величина статистической 
苂

\begin{tabular}{|c|c|c|c|c|c|}
\hline \multirow{3}{*}{ 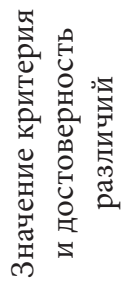 } & 总 & $\stackrel{m}{M} \stackrel{m}{I}$ & 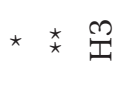 & * $\stackrel{\star}{*} \stackrel{M}{*}$ & * $\underline{m}$ * \\
\hline & 2 & ్ㅠ $\underset{\sim}{\sim}$ & অ্ঠ & 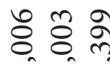 & 귱 \\
\hline & 点 & 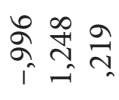 & 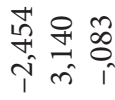 & 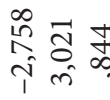 & 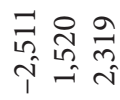 \\
\hline
\end{tabular}

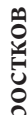

\begin{tabular}{|c|c|c|c|c|c|}
\hline 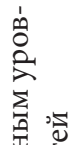 & \begin{tabular}{l}
5 \\
\multirow{2}{5}{} \\
0 \\
0 \\
0 \\
0
\end{tabular} & $\begin{array}{l}\hat{\infty} \\
\hat{+1} \\
\hat{+1} \\
\hat{N}\end{array}$ & $\begin{array}{l}\infty \\
\stackrel{+}{+1} \\
\stackrel{+}{\hat{~}} \\
\text { nी }\end{array}$ & $\begin{array}{l}\stackrel{6}{N} \\
+1 \\
\stackrel{+1}{N} \\
N\end{array}$ & $\begin{array}{c}\hat{n} \\
+1 \\
\hat{n} \\
\hat{n}\end{array}$ \\
\hline
\end{tabular}

\%

.

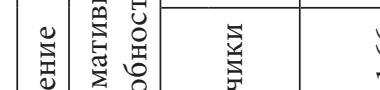

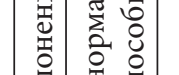

苂

\%

$\sum_{0}$

:

幽

缃 完

㱐

起

ํํㅇ

疍

엉

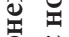

帘

인

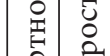

兼

疍

勻

a $n$ 年

5

空

胥

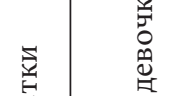

嵌

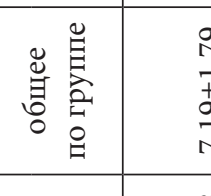

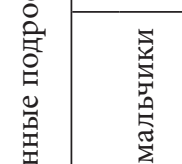

过

U

要

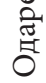

\begin{tabular}{|c|c|c|c|c|}
\hline 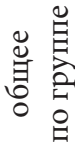 & 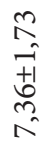 & $\begin{array}{l}\stackrel{n}{N} \\
\stackrel{+}{+1} \\
\stackrel{+}{N} \\
\hat{n}\end{array}$ & $\begin{array}{l}m \\
\stackrel{m}{N} \\
+1 \\
0 \\
\infty \\
\infty\end{array}$ & $\begin{array}{l}\text { to } \\
+1 \\
+1 \\
6 \\
6\end{array}$ \\
\hline
\end{tabular}

ڤै

Ũ

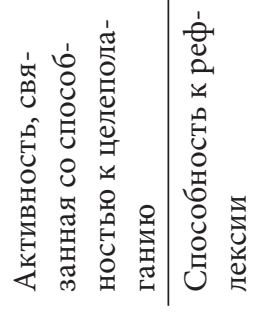

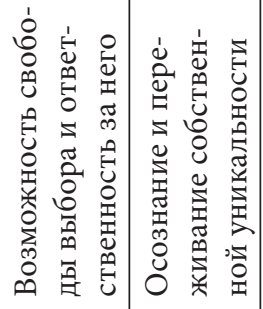




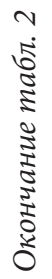

\begin{tabular}{|c|c|c|c|}
\hline 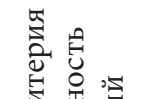 & 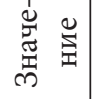 & 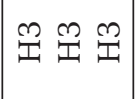 & $\stackrel{9}{M}$ \\
\hline 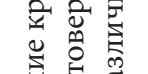 & $a$ & 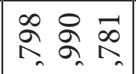 & 苙 \\
\hline 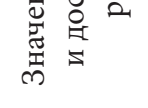 & 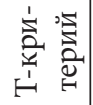 & 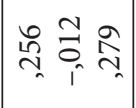 & 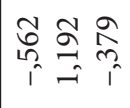 \\
\hline
\end{tabular}

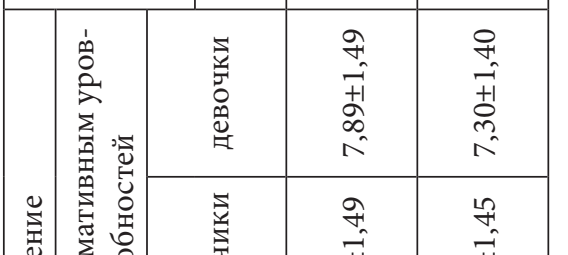

\begin{tabular}{|c|c|c|c|}
\hline 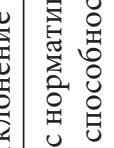 & 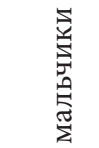 & $\begin{array}{l}\text { Fे } \\
\text { +1 } \\
\infty \\
\text { N } \\
N\end{array}$ & ¿ี \\
\hline 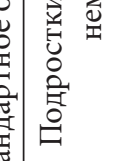 & 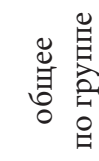 & $\begin{array}{l}\text { Ñ } \\
\text { N-1 } \\
\text { ปn } \\
\text { N }\end{array}$ & $\begin{array}{l}7 \\
+ \\
+ \\
+\end{array}$ \\
\hline 点 & 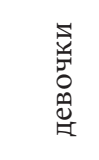 & 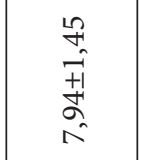 & $\frac{2}{+}$ \\
\hline 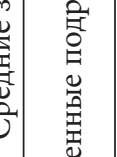 & 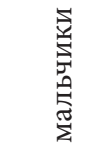 & $\begin{array}{l}\underset{\sigma}{\sigma} \\
\stackrel{-1}{+1} \\
\infty \\
\stackrel{N}{N}\end{array}$ & $\begin{array}{l}q \\
7 \\
+ \\
\infty \\
n\end{array}$ \\
\hline 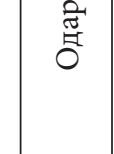 & 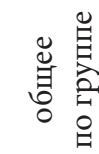 & $\begin{array}{l}\hat{n} \\
\hat{n} \\
+1 \\
\infty \\
12 \\
N\end{array}$ & $\begin{array}{l}7 \\
7 \\
\dot{7} \\
2\end{array}$ \\
\hline 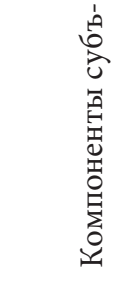 & & 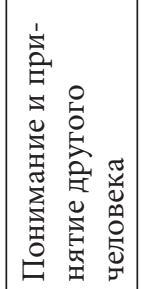 & 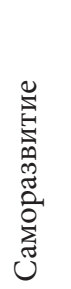 \\
\hline
\end{tabular}


значимости равна нулю; значения коэффициента детерминации расположены в диапазоне от 0,651 до 0,757, что свидетельствует о наличии взаимосвязи между психологическим благополучием подростков и развитием субъектности; значения коэффициентов R-квадратов располагаются в следующем интервале: 0,424 - модель уравнения для одаренных мальчиков-подростков; 0,586 - модель для мальчиков с нормативным уровнем способностей; 0,523 - модель для одаренных девочек; 0,573 - модель для девочек с нормативным уровнем способностей; 0, 493 - модель для одаренных подростков и 0,538 - модель для подростков с нормативным уровнем способностей.

Коэффициенты в моделях регрессионного анализа психологического благополучия и субъектности для одаренных подростков и подростков с нормативным уровнем способностей представлены в табл. 3.

Результаты регрессионного анализа показывают, что различные компоненты субъектности выступают предикторами психологического благополучия подростков сравниваемых групп: для одаренных мальчиков это активность, связанная со способностью к целеполаганию, способность к рефлексии, возможность свободы выбора и ответственности за него; для одаренных девочек к этим компонентам добавляется осознание и переживание собственной уникальности; для подростков-мальчиков с нормативным уровнем способностей это активность, связанная со способностью к целеполаганию, понимание и принятие другого человека; для подростковдевочек с нормативным уровнем способностей это способность к рефлексии, возможность свободы выбора и ответственности за него, понимание и принятие другого человека, саморазвитие.

\section{Обсуждение результатов и выводы}

В научных исследованиях и в практической деятельности идея о том, что одаренные дети и подростки имеют особенности личностного развития, часто считается аксиоматичной. Психологи обращают внимание на то, что становление личности одаренного ребенка проходит неоднозначно, заметно отличаясь от развития сверстников. В современных исследованиях, посвященных про- 


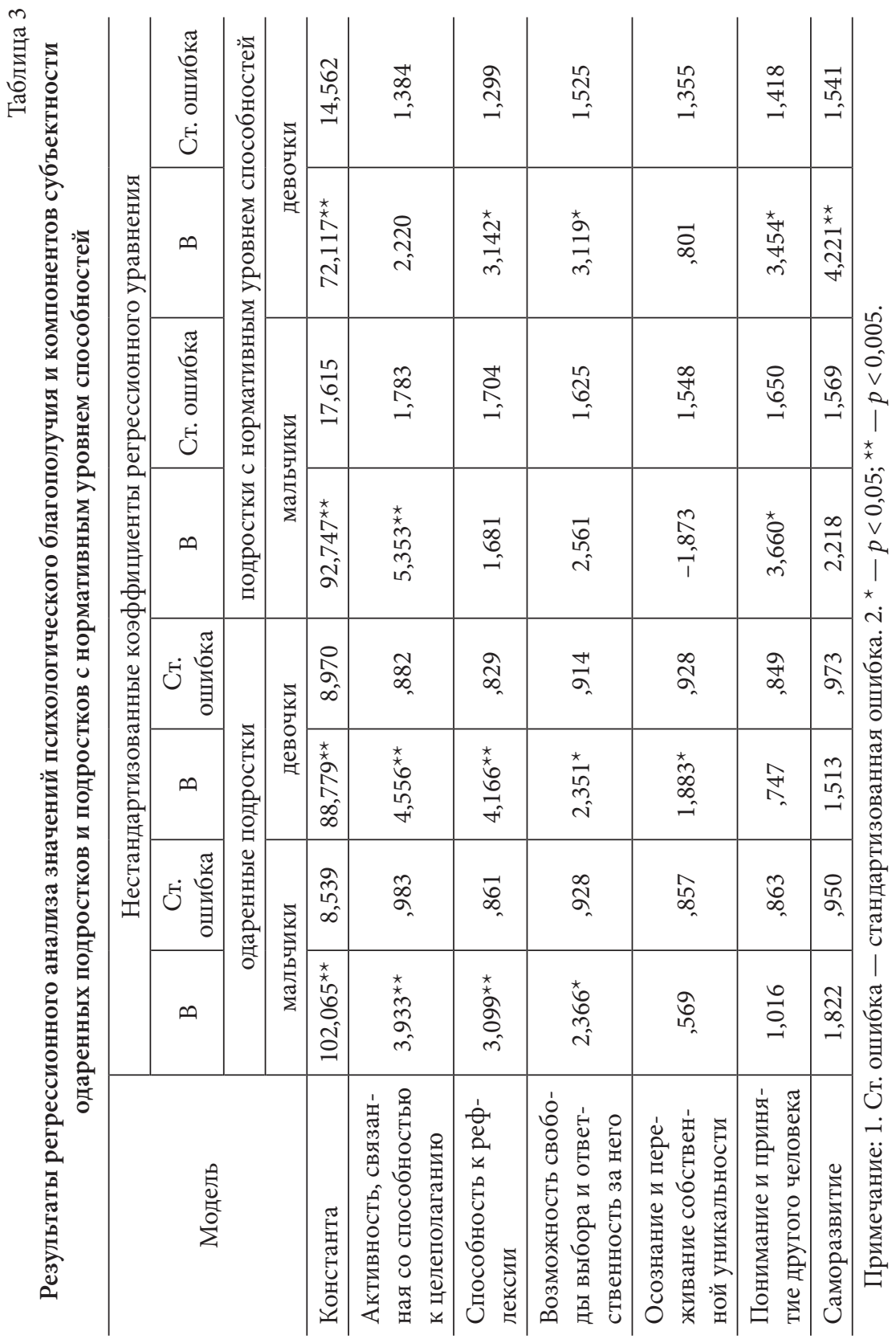


блемам детской и подростковой одаренности, подчеркивается, что одаренный ребенок - это «особый ребенок», и его личностное развитие может довольно существенно отличаться от нормативных возрастных эталонов.

В нашем исследовании, посвященном изучению психологического благополучия и развития субъектности одаренных подростков, выявились тенденции, поддерживающие эти закономерности, и тенденции, опровергающие их.

Показатели психологического благополучия как интеграции субъективного переживания счастья и ощущения самореализации человека, его самоосуществления [13-15] и у одаренных подростков, и у подростков с нормативным уровнем способностей довольно высокие. Значения общего показателя психологического благополучия близки к представленным в литературе [10]. При этом нам не удалось обнаружить значимых различий ни по признаку пола, ни по признаку одаренности в сравниваемых группах. Вероятно, психологическое благополучие и его развитие у одаренных подростков и подростков без признаков одаренности характеризуется схожими тенденциями. Одаренные подростки в целом воспринимают и оценивают свою самореализацию, осмысленность жизни, способности и удовлетворенность собой так же, как их сверстники с нормативным уровнем способностей. Психологическое благополучие одаренных подростков как параметр личностного развития не отличается у этой группы детей от их сверстников.

Вместе с тем, возможно, существует некий опосредующий фактор этой связи, не выявленный в данном исследовании. Например, таким фактором может быть профиль одаренности, в частности, вербальная или математическая направленность интеллекта: так, учащиеся с математической одаренностью могут демонстрировать более высокий уровень самоуважения и более низкий уровень депрессии в сравнении с вербально одаренными учащимися [16]. Существуют исследования, в которых показана неоднородность уровня психологического благополучия одаренных подростков: уровень благополучия сопряжен со сферой учебной деятельности, и он высокий для одаренных подростков, в то время как в тех сферах жизни, которые не связаны с учебой - в сфере общей самооцен- 
ки, счастья, отношения к миру, - он значительно ниже [17]. Эти исследования заставляют продолжить изучение психологического благополучия одаренных подростков в зависимости от профиля одаренности, характера деятельности и других особенностей.

Единственное достоверно установленное отличие одаренных подростков - более высокое, чем у сверстников, развитие автономности. Это характеризует одаренных подростков-мальчиков. Они лучше, чем их сверстники, могут дать себе оценку, опираясь на собственные предпочтения, проявляют нестандартное мышление и поведение, не боятся противопоставить свое мнение окружающим, способны быть независимыми. Не достигая значимости различий, но все же существуя как тенденция, у одаренных подростков несколько хуже выражена способность устанавливать позитивные отношения с людьми, т. е. способность быть открытым для общения, умение сопереживать, устанавливать и поддерживать контакты с другими людьми, а также желание быть гибким и умение искать компромисс. Важно подчеркнуть, что в исследованиях авторов русскоязычной версии применяемого нами опросника показано, что именно эти характеристики - автономность и позитивные отношения - оказываются наиболее устойчивыми и определенными в подростковом возрасте [10]. Поэтому можно предполагать, что уровень психологического благополучия одаренных подростков определяется развитием способности к автономности и позитивным отношениям.

Развитие субъектности у одаренных подростков и подростков с нормативным уровнем способностей различается. Эти различия в значительной степени опосредованы полом подростка. У одаренных подростков значимо выше уровень развития способности к рефлексии, осознание свободы выбора и ответственности за него, осознание собственной уникальности. Причем для одаренных мальчиков эти различия обнаруживаются в способности к рефлексии и в осознании свободы выбора и ответственности за него, а у девочек - в осознании собственной уникальности. Эти компоненты в структуре субъектности занимают особое положение. Ряд авторов относят их к ключевым компонентам и наряду с активностью определяют их как некое целостное структурное образование - ядро 
субъектности [11]. Большая выраженность этих компонентов, при высоких значениях показателей активности, связанной со способностью к целеполаганию, позволяет предположить, что у одаренных подростков динамика развития субъектности все же выше, чем у подростков с обычным уровнем развития. Однако процесс развития целостной субъектности пока еще не достигает значений, позволяющих говорить о качественном своеобразии этого личностного свойства. Характерно, что у мальчиков и у девочек наблюдаются разные доминанты в развитии этого свойства: если развитие субъектности одаренных мальчиков при высоком уровне активности происходит за счет развития способности к рефлексии и признания свободы выбора и ответственности за этот выбор, то у одаренных девочек - за счет развития представлений о собственной уникальности. Способность к рефлексии выступает и как средство самопознания для одаренных подростков-мальчиков, и как способ структурирования и осмысленности своей жизни в целом. Осознание свободы как возможности выбора подростком собственного жизненного пути, целей и средств, способов контроля своей деятельности, а также ответственности за этот выбор свидетельствует, с одной стороны, об уже имеющемся опыте принятия таких решений подростком, а с другой - о пока еще латентной, но уже наметившейся направленности в будущее, т.е. о начале процесса управления сегодняшней жизнью из представлений о завтрашнем дне.

Для одаренных подростков-девочек важным обстоятельством является отражение собственной уникальности, которое понимается как неповторимость во времени и в пространстве, как переживание своего особого предназначения в жизни. Уникальность находит свое выражение в чувстве симпатии к себе, в отношении к себе как к уверенному, самостоятельному, надежному человеку, которому есть за что уважать себя. Как показано в наших предыдущих исследованиях [11], отражение собственной уникальности тесно связано с предположением человека о ценности собственной личности для себя и одновременно ценности своего Я для других.

Различные компонентны субъектности по-разному определяют психологическое благополучие одаренных подростков и под- 
ростков с нормативным уровнем способностей. Психологическое благополучие одаренных мальчиков определяется их активностью, способностью к рефлексии, свободой выбора; для одаренных девочек к этим компонентам добавляется осознание и переживание собственной уникальности. Дифференцирующим параметром для определения психологического благополучия одаренных подростков и подростков с нормативным уровнем способностей выступает характеристика, связанная с наиболее значимой сферой жизни с общением и взаимодействием людей. Сравнение регрессионных моделей показывает, что психологическое благополучие подростков с нормативным уровнем способностей (и мальчиков, и девочек) связано с развитием способности к пониманию и принятию другого человека. Для одаренных подростков этот компонент субъектности не влияет на переживание психологического благополучия. Эти тенденции, с одной стороны, свидетельствуют о высокой значимости общения и взаимодействия для подростков, с другой - о недостаточном уровене развития способностей к такому взаимодействию, а порой и фрустрированности, как отмечают многие авторы $[8,18]$. Наше исследование также выявило это противоречие. Способность понимать и принимать другого человека, как и способность устанавливать позитивные отношения с другими людьми, представляют собой проблемную зону личностного развития одаренных подростков и задают одно из важных направлений психологической работы с ними - работы по развитию коммуникативной компетентности подростка, актуализации его желаний и умений идти на компромисс для поддержания и укрепления связи с другими людьми.

Предикторами психологического благополучия и у одаренных подростков, и у подростков с нормативным уровнем способностей могут выступать не только характеристики развивающейся субъектности, но и другие личностные особенности. Причем у одаренных мальчиков вклад других личностных переменных в психологическое благополучие наибольший. Эти подростки представляют собой самую разнородную группу с точки зрения личностных особенностей. Однако в целом мы можем сделать вывод о схожести тенденций личностного развития одаренных подростков и подростков с нормативным уровнем способностей. Это соотносится с позицией 
исследований, доказывающих, что одаренность представляет собой норму развития любого ребенка [19], особенно в аспекте изучения личностного развитии, в частности, психологического благополучия и его субъектности.

1. Roth J. L., Brooks-Gunn J. What is a Youth Development Program? Identification and Defining Principles // Jacobs F., Wertlieb D., Lerner R. M., ed. Handbook of Applied Developmental Science: Promoting Positive Child, Adolescent and Family Development Through Research, Policies and Programs. Sage Publications; Thousand Oaks, CA, USA, 2003. Vol. 2. P. 197-223.

2. Lerner R. M. The positive youth development perspective: Theoretical and empirical bases of a strength-based approach to adolescent development // Snyder C. R., Lopez S. J., ed. The Oxford Handbook of Positive Psychology. $2^{\text {nd }}$ ed. Oxford, UK : Oxford University Press, 2009. P. 149-163.

3. Сергиенко Е.А. Принципы психологии развития: современный взгляд [Электронный ресурс] // Психологические исследования. 2012. T. 5, № 24. C. 1. URL: http://psystudy.ru (дата обращения: 10.05.2020). 0421200116/0037.

4. Основные современные концепции творчества и одаренности / под ред. Д. Б. Богоявленской. М. : Молодая гвардия, 1997. 402 с.

5. Batey M., Furnham A. Creativity, intelligence, and personality: a critical review of the scattered literature // Genetic, Social, and General Psychology Monographs. 2006. Vol. 132(4). P. 355-429.

6. Subotnik R. F., Olszewski-Kubilius P., Worrell F. C. Rethinking Giftedness and Gifted Education: A Proposed Direction Forward Based on Psychological Science // Psychological Science in the Public Interest. 2011. Vol. 12(1). P. 3-54.

7. Богоявленская Д. Б., Богоявленская М. Е. Психология одаренности: понятие, виды, проблемы. М. : МИОО, 2005. 176 с.

8. Ландау Э. Одаренность требует мужества: Психологическое сопровождение одаренного ребенка / пер. с нем. А. П. Голубева ; науч. ред. текста Н. М. Назарова. М. : Академия, 2002. 144 с

9. Ведикова Е. Ю., Калягина Е. А. Особенности психологического благополучия старшеклассников с признаками одаренности // Проблема процесса саморазвития и самоорганизации в психологии и педагогике. Уфа : Агентство междунар. исслед., 2018. С. 50-57. 
10. Жуковская Л. В., Трощихина Е. Г. Шкала психологического благополучия К. Рифф // Психол. журн.. 2011. Т. 32, вып. 2. С. 82-93.

11. Волкова Е.Н., Гришина А. В. Структура субъектности младших подростков с разным уровнем игровой компьютерной зависимости // Психол. журн. 2015. Т. 36, № 2. С. 20-31.

12. Волкова Е.Н., Суворова О. В., Сорокоумова С. Н. и др. Исследование развития субъектности в онтогенезе в современном социокультурном пространстве. Н. Новгород : Минин. ун-т, 2012. 302 с.

13. Ryan R. M., Deci E. L. On happiness and human potentials: A review of research on hedonic and eudaimonic well-being // Fiske S., ed. Annual review of psychology. 2001. Vol. 52. P. 141-166.

14. Ryff C.D. Happiness is everything, or is it? Explorations on the meaning of psychological well-being // Journal of Personality and Social Psychology. 1989. Vol. 57 (6). P. 1069-1081.

15. RyffC. D., Keyes C. L. M. The structure of psychological well-being revisited // Journal of Personality and Social Psychology. 1995. Vol. 69. P. 719-727.

16. Гавриченкова Т. К. Мотивационные профили и психологическое благополучие математически одаренных старшеклассников : диплом. работа / науч. рук. Т. О. Гордеева. М. : МГУ им. М. В. Ломоносова, 2014 [Электронный ресурс]. URL: https://istina.msu.ru/diplomas/6444440/ (дата обращения: 13.02.2019).

17. Neihart $M$. The impact of giftedness on psychological well-being: What does the empirical literature say? // Roeper Review. 1999. Vol. 22. P. 10-17.

18. Мешкова Н. В. Зарубежные исследования одаренности: социальнопсихологический аспект // Современная зарубежная психология. 2015. T. 4, № 1 С. 26-44.

19. Мелик-Пашаев А. А. Проявление одаренности как норма развития // Психологическая наука и образование. 2014. Т. 19, № 4. С. 15-21. 


\title{
ЗДОРОВЫЙ ОБРАЗ ЖИЗНИ И ЖИЗНЕСТОЙКОСТЬ СОВРЕМЕННЫХ СТУДЕНТОВ
}

\author{
Д. А. Галочкина \\ М. Е. Пермякова
}

В последние годы все чаще в СМИ, в научной и популярной литературе поднимаются вопросы здоровья и здорового образа жизни (далее - ЗОЖ), что способствует росту внимания граждан к этим вопросам и увеличению числа людей, которые стараются повысить качество своей жизни, приобщаясь к ЗОЖ. Однако интерес к ведению ЗОЖ преимущественно возникает вследствие ухудшения показателей здоровья. Это обусловлено спецификой современного общества, а именно высоким темпом жизни, при котором у человека не остается времени на себя и на поддержание собственного здоровья до появления явных негативных последствий, ведущих к снижению качества жизни.

Одной из наиболее уязвимых групп населения являются студенты. Обладая более определенными и последовательными представлениями о природе и причинах здоровья, чем их сверстники-представители предшествовавших поколений [1], знаниями и рекомендациями специалистов о ведении ЗОЖ, студенты далеко не всегда мотивированы применять их на практике, следовать правилам 3ОЖ [2], у них не накоплен опыт реализации своих внутренних ресурсов. При этом студенты - это те, кто в ближайшем будущем войдут в состав экономически активной части населения, а также станут родителями и будут транслировать собственные установки и паттерны поведения подрастающему поколению.

На сегодняшний день здоровье российских студентов вызывает большую тревогу. Еще до поступления в учреждения профессионального образования оно ослаблено под воздействием различных неблагоприятных факторов, а у 60-70 \% молодых людей имеются хронические заболевания [3]. Процесс обучения в вузе влияет на показатели физического и психического здоровья. В связи с этим создание условий для формирования ЗОЖ студентов в процессе 
обучения является важным направлением деятельности вуза по поддержанию их здоровья.

В контексте проблематики выбора студентами здорового образа жизни актуальным становится изучение связи ЗОЖ с жизнестойкостью. Понятие «жизнестойкость» в отечественной психологии было введено Д. А. Леонтьевым [4], содержательно оно адекватно понятию «hardiness», предложенному С. Мадди в связи с разработкой им проблем личностного потенциала, позволяющего справляться со стрессами. Hardiness рассматривается Мадди в качестве одного из ресурсов «стойкого совладания» с трудностями, способствующего успешной адаптации, повышению физического и психического здоровья. Жизнестойкость представляет собой один из ключевых параметров индивидуальной способности к зрелым и сложным формам саморегуляции, одну из опорных переменных личностного потенциала [5], использование и пополнение которого, несомненно, связано с фактором здоровья и ведением здорового образа жизни.

По определению Всемирной организации здравоохранения, здоровье - это состояние полного физического, духовного и социального благополучия, а не только отсутствие болезней и физических дефектов. Сохранению и укреплению здоровья в значительной степени способствует здоровый образ жизни, который представляет собой «оптимальное качество жизни, определяемое мотивированным поведением человека, направленным на сохранение и укрепление здоровья, в условиях воздействия на него природных и социальных факторов окружающей среды» [6].

В современной научной литературе широко представлена проблематика отношения человека к здоровью $[1,3,7,8]$, здорового образа жизни $[6,9,10,11]$, жизнестойкости $[4,5,12]$ и их связи с отдельными психологическими характеристиками личности [2, 13-19], однако взаимосвязь здорового образа жизни и жизнестойкости на сегодняшний день не изучена.

Выявление связей между данными феноменами позволит не только расширить знания о них, но и более продуктивно использовать их потенциал, разрабатывая и применяя на практике комплексные коррекционно-развивающие программы, направленные на повышение жизнестойкости граждан, благодаря их сознательно- 
му выбору и следованию здоровому образу жизни. Именно поэтому проблема взаимосвязи здорового образа жизни и жизнестойкости, на наш взгляд, является актуальной и достойной внимания современных исследователей.

Для студентов-психологов тема здорового образа жизни и жизнестойкости особенно значима, так как ведение здорового образа жизни, повышение жизнестойкости способствуют профилактике профессионального выгорания, увеличению ресурсов будущих специалистов. В исследовании приняли участие студенты первогочетвертого курсов, обучающиеся по направлениям «Клиническая психология» и «Психология», в количестве 100 человек (из них 87 - девушки, 13 - юноши). Возраст участников исследования от 18 до 22 лет.

Цель: исследовать связи между показателями здорового образа жизни и жизнестойкости у студентов

Гипотеза исследования: существует прямая связь между показателями здорового образа жизни и жизнестойкости.

Первой дополнительной гипотезой стало предположение о том, что имеется прямая связь между эрудированностью студентов в вопросах здорового образа жизни и их субъективной оценкой своего образа жизни и соматического здоровья.

Второй дополнительной гипотезой стало предположение о том, что компоненты профиля здорового образа жизни (ответственность за здоровье, физическая активность, питание, духовный рост, межличностные отношения, управление стрессом) связаны с эрудированностью студентов в вопросах здорового образа жизни.

\section{Методики исследования}

В связи с целями и задачами исследования нами были использованы 4 методики:

1) тест «Субъективная оценка образа жизни и соматического здоровья»;

2) опросник «Профиль здорового образа жизни - ПроЗОЖ» (Health Promoting Lifestyle Profile - HPLP-II);

3) авторский опросник эрудированности в вопросах здорового образа жизни (ЗОЖ); 
4) тест жизнестойкости С. Мадди (в адаптации Д.А. Леонтьева, Е.И. Рассказовой).

При обработке полученных данных использовались следующие методы математической статистики: $U$-критерий Манна - Уитни, коэффициент корреляции Спирмена.

Анализ результатов, полученных по тесту «Субъективная оценка образа жизни и соматического здоровья» показал, что средняя оценка образа жизни и соматического здоровья у студентов соответствует хорошему уровню. Среди студентов преобладают респонденты, имеющие высокий уровень ведения здорового образа жизни, однако есть и лица с удовлетворительным уровнем, и отдельные студенты, показавшие низкий уровень ведения здорового образа жизни.

Результаты, полученные по опроснику «Профиль здорового образа жизни», свидетельствуют о том, что у студентов отсутствует баланс между анализируемыми составляющими профиля здорового образа жизни. Разница между самым низким значением, полученным по составляющей профиля здорового образа жизни «физическая активность» $(53,15)$, и самым высоким значением, полученным по составляющей профиля здорового образа жизни «межличностные отношения» $(80,26)$, равна 27,11 . Показатели по уровням варьируется от низкого уровня развития составляющей до высокого. В связи с этим можно утверждать, что помимо низкого уровня сформированности ряда составляющих, негативное влияние на образ жизни студента оказывает дисбаланс составляющих, так как неотъемлемой частью ведения здорового образа жизни является сбалансированность и гармоничное развитие всех его составляющих.

Анализ данных, полученных по каждой составляющей профиля ЗОЖ, показал, что респонденты преимущественно уделяют внимание межличностным отношениям, внутреннему росту и лишь немногие из них контролируют свое питание и физическую активность. На наш взгляд, это отражает специфику мировоззрения студентов-психологов, для которых внимание к внутреннему миру превышает внимание к собственному телу. Для большинства студентов характерна низкая ответственность за свое здоровье. Между тем для психолога крайне важно заботиться о собственном здоровье 
для поддержания профессиональной пригодности и профилактики профессионального выгорания. Показатель управления стрессом по выборке в целом находится на среднем уровне, однако есть и респонденты с низкими показателями по данной составляющей профиля здорового образа жизни, следовательно, у этих студентов уже имеются признаки истощения и недостаточно ресурсов для борьбы со стрессом. Для достижения профессионального успеха стремления к внутреннему росту, развития межличностных отношений, если не уделяется внимания остальным составляющим профиля здорового образа жизни, физиологическим составляющим здоровья, может оказаться недостаточно. В целом для выборки характерны средние значения по интегральному показателю общего профиля 3ОЖ.

Согласно результатам, полученным по опроснику эрудированности в вопросах здорового образа жизни (ЗОЖ), уровень эрудированности респондентов в вопросах здорового образа жизни выше среднего. Однако студенты, имея достоверные знания о здоровом образе жизни, применяют их на практике не в полной мере. А. И. Донцов и Т.П. Емельянова выделяют в структуре социальных представлений три измерения: информацию, представления и установки [20]. Обладая информацией о ЗОЖ, имея достаточно четкие представления о нем, в целом высоко оценивая свой уровень ведения здорового образа жизни, студенты, по-видимому, не готовы регулярно поддерживать его, что свидетельствует о недостаточной сформированности установок, детерминирующих их поведенческое отношение к различным элементам 3ОЖ.

При анализе результатов, полученных по методике «Тест жизнестойкости С. Мадди» (в адаптации Д. А. Леонтьева, Е. И. Рассказовой), было выявлено, что как интегрированный показатель жизнестойкости, так и показатели по отдельным ее компонентам находятся у респондентов в зоне нормы. Однако уровень вовлеченности приближен к нижней границы нормы, что свидетельствует о том, что у студентов отсутствует погруженность в происходящее, они больше уделяют внимание анализу и рефлексии при решении возникающих ситуаций и стараются по возможности дистанцироваться от происходящего. Уровень принятия риска приближен 
к верхней границе нормы, что указывает на готовность действовать и принимать решения без гарантированного успеха.

Были собраны данные о том, хотят ли испытуемые повысить уровень своих знаний относительно здорового образа жизни. Из 100 человек лишь 12 ответили положительно. Эти студенты были объединены нами в условную группу «проявляющих интерес к ЗОЖ». Для того чтобы сравнить показатели проявляющих и не проявляющих интерес к ЗОЖ студентов, мы сократили выборку респондентов, не проявляющих интерес к ЗОЖ, чтобы сделать выборки соразмерными; сокращение проводилось случайным образом и общее количество испытуемых составило 24 человека. В результате сравнительного анализа по критерию Манна - Уитни было определено, что у проявляющих интерес к ЗОЖ студентов достоверно более высокие показатели по параметрам «ответственность за здоровье» $\left(U_{\text {эмп }}=33,5 ; p=0,03\right)$, «питание» $\left(U_{\text {эмп }}=24,5 ; p=0,01\right)$ и интегральному показателю «общий профиль ЗОЖ» $\left(U_{\text {эмп }}=35\right.$; $p=0,05)$ (табл. 1).

Так как юношей, участвовавших в исследовании, значительно меньше, чем девушек, сравнительный анализ в данном случае также проводился с применением рандомного исключения данных с целью уравнивания выборок юношей и девушек по численности $(n=24)$. Сравнительный анализ показал, что юноши более склонны к принятию риска, чем девушки $\left(U_{\text {эмп }}=43 ; p=0,04\right)$. По остальным параметрам достоверных различий обнаружено не было. Юноши и девушки не отличаются друг от друга по желанию получить обратную связь относительно их жизнестойкости и установок на здоровый образ жизни, а также по стремлению повысить свою осведомленность в области ЗОЖ.

В ходе проведения корреляционного анализа были выявлены прямые взаимосвязи субъективной оценки образа жизни и соматического здоровья, составляющих профиля здорового образа жизни и общего профиля здорового образа жизни, а также эрудированности в вопросах здорового образа жизни с жизнестойкостью и ее компонентами (табл. 1). Анализируя полученные результаты, можно отметить следующее: 
1. Субъективная оценка образа жизни и соматического здоровья, т. е. оценка человеком собственного образа жизни, связана с жизнестойкостью и всеми ее компонентами, кроме принятия риска. Следовательно, чем выше человек оценивает свой образ жизни и здоровье, тем выше его жизнестойкость.

2. Общий профиль здорового образа жизни тесно связан с жизнестойкостью. Имеет существенное значение то, что общий профиль здорового образа жизни связан со всеми без исключения составляющими жизнестойкости (вовлеченность, контроль, принятие риска), т. е. чем выше показатели общего профиля здорового образа жизни, тем выше жизнестойкость личности.

Таблица 1

Взаимосвязь между показателями жизнестойкости и параметрами здорового образ жизни ( $n=100$, коэффициент корреляции Спирмена)

\begin{tabular}{|c|c|c|c|c|}
\hline Шкала & $\begin{array}{c}\text { Интеграль- } \\
\text { ный показа- } \\
\text { тель жизне- } \\
\text { стойкости }\end{array}$ & $\begin{array}{c}\text { Вовлечен- } \\
\text { ность }\end{array}$ & $\begin{array}{l}\text { Конт- } \\
\text { роль }\end{array}$ & $\begin{array}{c}\text { Принятие } \\
\text { риска }\end{array}$ \\
\hline $\begin{array}{l}\text { Субъективная оценка } \\
\text { образа жизни и сома- } \\
\text { тического здоровья }\end{array}$ & $0,30^{* *}$ & $0,31^{\star *}$ & $0,26^{* *}$ & 0,16 \\
\hline $\begin{array}{l}\text { Ответственность } \\
\text { за здоровье }\end{array}$ & 0,15 & $0,21^{\star}$ & 0,12 & 0,00 \\
\hline $\begin{array}{l}\text { Физическая актив- } \\
\text { ность }\end{array}$ & $0,27^{\star *}$ & $0,22^{*}$ & $0,28^{\star *}$ & 0,19 \\
\hline Питание & $0,37^{\star * *}$ & $0,39^{\star * *}$ & $0,32^{\star \star}$ & 0,17 \\
\hline Внутренний рост & $0,55^{\star * *}$ & $0,59^{* * *}$ & $0,47^{\star * *}$ & $0,32^{\star *}$ \\
\hline $\begin{array}{l}\text { Межличностные отно- } \\
\text { шения }\end{array}$ & $0,36^{\star * *}$ & $0,49^{\star * *}$ & 0,17 & $0,23^{\star}$ \\
\hline Управление стрессом & $0,25^{*}$ & $0,26^{\star *}$ & $0,21^{*}$ & 0,13 \\
\hline Общий профиль ЗОЖ & $0,45^{\star * *}$ & $0,50^{* * *}$ & $0,35^{\star *}$ & $0,25^{\star *}$ \\
\hline $\begin{array}{l}\text { Эрудированность } \\
\text { в вопросах здорового } \\
\text { образа жизни }\end{array}$ & $0,31^{\star *}$ & $0,32^{\star *}$ & 0,17 & $0,33^{\star \star *}$ \\
\hline
\end{tabular}

Примечание. Здесь и в табл. $2:^{\star} p \leq 0,05 ;{ }^{* *} p \leq 0,01 ;{ }^{\star * *} p \leq 0,001$. 
3. Анализ связей жизнестойкости с составляющими ЗОЖ показал, что в наибольшей степени жизнестойкость связана с внутренним ростом, в наименьшей - с ответственностью за здоровье.

4. Эрудированность студентов в вопросах здорового образа жизни взаимосвязана с жизнестойкостью в целом, а также с ее компонентами «вовлеченность» и «принятие риска». Следовательно, чем более эрудированы студенты в вопросах ЗОЖ, тем выше их жизнестойкость.

Таким образом, основная гипотеза исследования о том, что существует прямая связь между показателями здорового образа жизни и жизнестойкости, по результатам нашего исследования была подтверждена.

С целью проверки дополнительных гипотез исследования была определена взаимосвязь эрудированности в вопросах здорового образа жизни с прочими исследуемыми показателями (табл. 2).

Корреляционный анализ показал, что эрудированность в вопросах здорового образа жизни связана с субъективной оценкой образа жизни и соматического здоровья в общей выборке и у юношей, но не имеет связи у девушек. Следовательно, первая дополнительная гипотеза о том, что имеется прямая связь между эрудированностью студентов в вопросах здорового образа жизни и субъективной оценкой своего образа жизни и соматического здоровья была подтверждена частично - на выборке в целом и на подвыборке юношей.

Установлено также наличие взаимосвязи эрудированности в вопросах здорового образа жизни с некоторыми составляющими профиля здорового образа жизни, а именно питанием и межличностными отношениями. Отметим, что данная взаимосвязь проявляется только на общей выборке и подвыборке девушек. С остальными составляющими профиля здорового образа жизни не было выявлено ни одной взаимосвязи. Однако эрудированность в вопросах здорового образа жизни связана с показателем «общий профиль ЗОЖ», и данная взаимосвязь проявляется как на общей выборке, так и на подвыборках юношей и девушек. Эрудированность в вопросах здорового образа жизни связана с жизнестойкостью как на общей выборке, так и на подвыборке девушек, но не имеет связи на подвыборке юношей. Что касается компонентов жизнестойкости 
и их связи с эрудированностью в вопросах здорового образа жизни, то можно констатировать, что данная связь отсутствует у компонента жизнестойкости «контроль», у компонента «вовлеченность» проявляется в общей выборке и подвыборке девушек, это же относится к показателю «принятие риска». Таким образом, вторая дополнительная гипотеза, согласно которой компоненты профиля здорового образа жизни (ответственность за здоровье, физическая активность, питание, духовный рост, межличностные отношения, управление стрессом) связаны с эрудированностью студентов в вопросах здорового образа жизни, была подтверждена частично.

Таблица 2

Взаимосвязь эрудированности в вопросах здорового образа жизни с остальными исследуемыми параметрами ( $n=100$, коэффициент корреляции Спирмена)

\begin{tabular}{|c|c|c|c|}
\hline \multirow[b]{2}{*}{ Шкала } & \multicolumn{3}{|c|}{ Эрудированность в вопросах ЗОЖ } \\
\hline & $\begin{array}{c}\text { общая выбор- } \\
\text { ка }(n=100)\end{array}$ & $\begin{array}{l}\text { юноши } \\
(n=13)\end{array}$ & $\begin{array}{c}\text { девушки } \\
(n=87)\end{array}$ \\
\hline $\begin{array}{l}\text { Субъективная оценка } \\
\text { образа жизни и сомати- } \\
\text { ческого здоровья }\end{array}$ & $0,25^{\star}$ & $0,61^{\star}$ & 0,20 \\
\hline $\begin{array}{l}\text { Ответственность за здо- } \\
\text { ровье }\end{array}$ & 0,11 & $-0,44$ & 0,19 \\
\hline Физическая активность & 0,19 & $-0,13$ & 0,20 \\
\hline Питание & $0,20^{*}$ & 0,34 & $0,21^{\star}$ \\
\hline Внутренний рост & 0,18 & 0,31 & 0,16 \\
\hline $\begin{array}{l}\text { Межличностные отно- } \\
\text { шения }\end{array}$ & $0,27^{\star *}$ & 0,44 & $0,27^{\star}$ \\
\hline Управление стрессом & 0,07 & 0,18 & 0,06 \\
\hline Общий профиль ЗОЖ & $0,70^{* * *}$ & $0,87^{\star * *}$ & $0,68^{* * *}$ \\
\hline Жизнестойкость & $0,31^{* *}$ & 0,19 & $0,33^{\star *}$ \\
\hline Вовлеченность & $0,32^{\star *}$ & 0,11 & $0,36^{* * *}$ \\
\hline Контроль & 0,17 & $-0,14$ & 0,20 \\
\hline Принятие риска & $0,33^{\star *}$ & 0,40 & $0,30^{\star *}$ \\
\hline
\end{tabular}


Известно, что по мере взросления у людей могут меняться взгляды, ценности, в том числе в отношении своего здоровья и здорового образа жизни. Поскольку в исследовании принимали участие студенты 1-5-х курсов в возрасте 18-22 лет, мы решили проверить, связаны ли показатели респондентов с их возрастом.

Установлено, что с возрастом показатели жизнестойкости студентов повышаются, а ответственность за здоровье, напротив, становится ниже: «вовлеченность» $\left(r_{s}=0,27\right.$ при $\left.p \leq 0,01\right)$, «принятие риска» $\left(r_{s}=0,45\right.$ при $\left.p \leq 0,001\right)$, интегральный показатель «жизнестойкость» $\left(r_{s}=0,31\right.$ при $\left.p \leq 0,01\right)$ и «ответственности за здоровье» $\left(r_{s}=-0,22\right.$ при $\left.p \leq 0,05\right)$. Этот результат оказался для нас неожиданным и требует проверки на других выборках. Следовательно, проблемы взаимосвязи здорового образа жизни и жизнестойкости требуют дальнейшего изучения.

Практическим психологам, специалистам в вопросах здорового образа жизни можно рекомендовать использовать полученные нами данные в их работе, направленной на улучшение качества жизни студентов. В соответствии с требованиями ФГОС ВО по направлению «Психология» у студентов в результате освоения программы бакалавриата, специалитета и магистратуры должны быть сформированы универсальные компетенции, среди которых и категория компетенций под общим названием «Самоорганизация и саморазвитие (в том числе здоровьесбережение)». С целью приобщения студентов к здоровому образу жизни и, соответственно, повышения их жизнестойкости организациям, предоставляющим образовательные и иные услуги студентам, можно рекомендовать следующее:

1. Оптимизация графика обучения студентов, с учетом правил здорового образа жизни.

2. Включение в учебную программу студентов лекций и практических заданий о здоровом образе жизни.

3. Создание для студентов электронных ресурсов с информацией о здоровом образе жизни и базы данных о специалистах в сфере здорового образа жизни для оперативного поиска необходимых конкретному студенту консультантов и т.д. 
Следует отметить, что данный список не окончательный. Помимо общих принципов и правил ЗОЖ, существуют индивидуальные для каждого человека. Ежедневно появляется новая информация, связанная с вопросами ЗОЖ, и именно возможность доступа к достоверной информации о здоровье, оперативного нахождения необходимых для данного человека специалистов дает наибольшее количество ресурсов для перспективного, своевременного, результативного и гармоничного развития собственного образа жизни, собственного здоровья.

1. Дыхан Л. Б., Марченко Б. И., Страшевская Л. О. Динамика отношения к здоровью у студентов вуза // Валеология. 2015. № 1. С. 29-36.

2. Журавская Н. В. Проблемы формирования мотивации к здоровому образу жизни у студентов нефизкультурного вуза // Учен. зап. Ун-та им. П. Ф. Лесгафта. 2009. № 12. С. 49-52.

3. Здоровье студентов: социологический анализ / отв. ред. И. В. Журавлева. М. : Изд-во Ин-та социологии РАН, 2012.

4. Леонтьев Д. А., Рассказова Е. И. Тест жизнестойкости. М. : Смысл, 2006. 63 c.

5. Maddi S. R., Khoshaba D. M. Hardiness and Mental Health // Journal of Personality Assessment. 1994. Vol. 63, Oct. P. 265-274.

6. Про здоровый образ жизни [Электронный ресурc]. URL: https:// www.ymrc.ru/medicina/pro-zdorovyj-obraz-zhizni-332.html (дата обращения: 17.07.2020).

7. Березовская Р. А. Исследования отношения к здоровью: современное состояние проблемы в отечественной психологии // Вестн. С.-Петерб. гос. ун-та. Сер. 12 : Психология. Социология. Педагогика. 2011. Вып. 1. C. 221-226.

8. Доронина Н.Н., Кузнец,ов Л.Б. Особенности внутренней картины здоровья современных студентов вуза // Научный результат. Педагогика и психология образования. Т. 5, № 2. С. 52-63.

9. Дудченко 3. Ф. Психологическое обеспечение здорового образа жизни личности // Здоровая личность / под ред. Г.Н. Никифорова. СПб. : Речь, 2013. С. $356-367$.

10. Москвичева М. Г., Бредихина Н. В. Проблема здоровья и здоровый образ жизни современного человека (социологический анализ) // Вестн. 
Юж.-Урал. гос. ун-та. Сер. : Социально-гуманитарные науки. 2006. № 2 (57). С. 196-201.

11. Петраш М. Д., Муртазина И.Р. Понятие «здоровый образ жизни» в психологических исследованиях // Вестн. С.-Петерб. ун-та. Психология и педагогика. 2018. Т. 8, вып. 2. С. 152-165.

12. Александрова Л.А. К концепции жизнестойкости в психологии // Сибирская психология сегодня : сб. науч. тр. / под ред. М. М. Горбатовой, А. В. Серого, М. С. Яницкого. Кемерово : Кузбассвузиздат, 2004. Вып. 2. C. 82-90.

13. Васильева Н. Ю. Представление о здоровом образе жизни в подростковом и юношеском возрасте // Вестн. ЯГУ. 2009. Т. 6, № 4. С. 103-108.

14. Залевский Г. В., Кузьмина Ю. В. Здоровье в системе структуры ценностей студенческой молодежи // Сиб. психол. журн. 2010. № 38. С. 20-23.

15. Гуцунаева С. В. Копинг-стратегии подростков с различным уровнем жизнестойкости // Междунар. журн. прикладных и фундаментальных исслед. 2015. № 3-1. С. 92-95. URL: https://applied-research.ru/ru/article/ view?id=6485 (дата обращения: 29.06.2020).

16. Наливайко Т. В. Исследование жизнестойкости и ее связей со свойствами личности : автореф. дис. ... канд. психол. наук. Ярославль, 2006. 27 с.

17. Особенности формирования жизнестойкости и совладания с трудными жизненными и стрессовыми ситуациями несовершеннолетних в образовании : метод. пособие / под ред. Ю.Н. Денисова. Барнаул, 2014. $184 \mathrm{c}$.

18. Пермякова М.Е., Барсуков А.А., Ершова И.А. Исследование связи жизнестойкости, счастья и копинг-стратегий у студентов // Изв. Урал. федер. ун-та. Сер. 1 : Проблемы образования, науки и культуры. 2017. № 3 (165). С. 132-140.

19. Ершова И.А., Пермякова М.Е., Садкина Т. М. Связь жизнестойкости с самооценкой и копинг-стратегиями у юношей и девушек подросткового возраста // Педагогическое образование в России. 2019. № 4. С. 133-140.

20. Донцов А. И., Емельянова Т. П. Концепция социальных представлений о феноменах обыденного сознания // Идеологические и психологические аспекты исследования массового сознания : сб. обзоров. М., 1989. С. 11-44. 


\section{ВУЗОВСКИЙ ЭТИКЕТ И ЭТИКЕТНОЕ ПОВЕДЕНИЕ В ВУЗЕ: СОВРЕМЕННАЯ СИТУАЦИЯ И ПЕРСПЕКТИВЫ ИЗУЧЕНИЯ*}

\section{О. И. Даниленко}

Современный вуз является сложной организационной системой, в которой решается задача подготовки высококвалифицированных специалистов. Одним из условий эффективности процесса вузовского обучения является создание и поддержание благоприятного психологического климата для всех участников образовательной организации - представителей администрации, преподавателей и студентов. Взаимодействие между людьми, принадлежащими к этим группам, обеспечивается нормативными документами вуза - должностными инструкциями, уставами и иными официально закрепленными предписаниями. Не менее важную роль в согласовании поведения как внутри групп с разными статусами и должностными полномочиями, так и между ними традиционно выполняли неписаные правила вузовского этикета. В силу ряда причин, обусловленных быстрыми общественными, экономическими и культурными изменениями, определенность и императивность этих правил уменьшается. Недостаток общепринятых правил вузовского этикета создает трудности для всех участников учебного процесса, препятствует взаимопониманию и согласованности их действий, создавая напряжение в контактах, провоцируя отрицательные переживания и неудовлетворенность как в учебной, так и во внеучебной деятельности.

Особенно важны правила вузовского этикета для установления оптимальных рабочих отношений между студентами и преподавателями. Объективные обстоятельства могут стать и становятся основанием для возникновения конфликтогенных ситуаций, и прежде всего это асимметрия в статусах, предполагающая различие прав и обязанностей участников этих групп $[1,2]$. Представления о том,

Работа выполнена при финансовой поддержке РФФИ (проект № 19-013-00369 «Интрапсихические предикторы этикетного поведения субъектов учебного процесса в вузе»). 
какие права и обязанности, а также формы поведения соответствуют статусам преподавателя и студента, зачастую не совпадают, причем не только у лиц, входящих в эти группы, но и представителей обеих групп. В качестве примера можно привести дискуссию студентов о том, следует ли вставать, приветствуя преподавателя, вошедшего в аудиторию. Те, кто высказываются за вставание, пишут, что таким образом студенты выражают уважение к преподавателю; протестующие рассматривают это действие как проявление подчинения и «преклонения перед вышестоящим». При этом и те и другие ссылаются на мнение самих преподавателей, высказывающихся как за, так и против того, чтобы студенты приветствовали их вставанием [3].

Значимость этикета в регуляции вузовского межличностного общения состоит не только в его позитивной роли для осуществления учебного процесса, но также в том, что опыт этикетного взаимодействия оказывает безусловное влияние на формирование личности учащегося. Выражая посредством различного рода этикетных форм поведения свое уважение к преподавателю, молодой человек фиксирует свой статус студента, которого добивался, поступая в высшее учебное заведение. Правила вузовского этикета обеспечивают подтверждение этого статуса со стороны преподавателя, что создает условия для укрепления позитивной идентичности учащегося, его самоуважения.

Еще один аргумент в пользу вузовского этикета состоит в том, что в вузах осуществляется подготовка будущих профессионалов, не только имеющих знания по своей специальности, но обладающих коммуникативной компетентностью. Одним из условий успешного прохождения интервью при отборе на работу является умение вести себя в соответствии с правилами этикета [4]. Работа в коллективе, особенно в роли руководителя, предполагает умение выстраивать отношения с сотрудниками как равными по статусу, так и занимающими более или менее высокое место в системе иерархически выстроенных отношений. Правила этикета обеспечивают реализацию таких отношений в ситуациях делового общения. Освоение этикетных моделей поведения в период обучения в вузе способствует трудоустройству и эффективности работы будущего специалиста как профессионала. 
Не менее важно, что, применяя освоенные в вузе модели этикетного поведения в других социальных интеракциях, выпускники вуза реализуют в своих контактах с расширенным кругом партнеров по общению важнейший нравственный принцип уважения к личности. Последние десятилетия внимание ученых привлекает проблема нравственного состояния российского общества. Многочисленные факты свидетельствуют о разнообразных нарушениях традиционных нравственных требований в сферах экономической, общественной и частной жизни [5]. Хотя неправомерно отождествлять нормы морали и правила этикета [6], соблюдение традиционных моделей этикетного поведения способствует реализации в повседневной жизни важнейшего нравственного принципа - уважения к личности и поэтому получает позитивную моральную оценку. Этикет можно рассматривать как один из наиболее значимых культурных инструментов нравственного совершенствования человека в разных сферах общественной жизни.

Существует обширная литература, в которой представлены правила этикета, обеспечивающие успешную коммуникацию в разнообразных видах профессиональной деятельности. Что касается этикетного поведения в сфере образования, оно вызывает интерес прежде всего педагогов, занимающихся проблемами воспитания детей в дошкольных образовательных учреждениях и школе. В работах, посвященных вузовскому этикету, основное внимание уделяется описанию тех или иных форм рекомендованного поведения, оформления внешнего облика и т. п. [7-9], однако в них не всегда учитываются значительные изменения в организации учебного процесса, способные оказать влияние на модели поведения студентов и преподавателей.

В статье британского культуролога Т. Иглтона показано, что бюрократизация и коммерциализация в университетах Великобритании негативно сказываются на исследованиях в области гуманитарных наук и содержании образовательного процесса. Рост расценок за обучение стимулирует потребительское отношение к нему; при этом преподаватели, озабоченные экономическим благополучием вузов, вынуждены снижать требовательность к учащимся [10]. Российские преподаватели вузов также фиксируют изменения 
в организации работы высшей школы, имеющие негативные последствия для их педагогической и научной деятельности, мотивации и удовлетворенности работой [11-13]. «Низкая востребованность государством сущностной составляющей педагогического и научного труда, его низкая оплата привели к падению престижа этих видов профессиональной деятельности. Для многих такие профессии перестали быть источником позитивных ценностей и поведенческих образцов. Их обладатели более не являются теми, на кого смотрят, на кого равняются, кому стараются подражать» - пишет доктор физико-математических наук, профессор В.С. Сенашенко $[14$, c. 36]. Негативные последствия этой ситуации проявляются не только в уменьшении воспитательного влияния преподавателя вуза, но и в нередко наблюдаемом скептическом отношении студентов к требованиям преподавателя как организатора учебного процесса.

На взаимодействие преподавателей и студентов существенное влияние оказывает превращение вузов в сферу образовательных услуг, что предполагает необходимость отвечать на запросы и требования студентов при составлении учебных программ и проведении занятий. Такое положение зачастую подвергается критике со стороны преподавателей, сомневающихся в наличии у студентов достаточной компетентности для решения вопросов о содержании и формах образовательного процесса. Однако находятся и аргументы в пользу признания компетентности студентов в качестве экспертов в формировании образовательных программ [15].

Какие модели поведения преподавателей и студентов, по мнению специалистов, соответствуют новым реалиям? Нам удалось обнаружить лишь некоторые осторожные предположения, что в основе такого взаимодействия должен лежать принцип равенства участников образовательного процесса. «С точки зрения формирования отвечающей требованиям времени психологической атмосферы на уровне “преподаватель - студент”, нам вполне импонирует и кажется оптимальной концепция... в которой преподаватель, сохраняя за собой все функции наставника... психологически становится в образовательной среде “равным среди равных”, что избавит отечественное образовательное пространство от риска антагонизма 
и тем более, открытой конфронтации его главных “действующих лиц” - преподавателей и студентов». При этом у авторов остаются сомнения: «Насколько приемлем подобный тип взаимоотношений в такой специфической профессии, как медицина?» [16, с. 39-40]. Заметим, что конфронтация «среди равных» бывает ничуть не меньше, чем между людьми с разным статусным весом. О сложности для студента позиции потребителя образовательных услуг пишут О. К. Крокинская и С. Ю. Торпицын. Ролевая неопределенность такого статуса предполагает «непрерывные метаморфозы “потребитель -производитель”, а в каждой из них - свой рисунок поведения» $[15$, с. 72]. Такая неопределенность способна существенно затруднить взаимодействие участников учебного процесса. Очевидно, на практике будут вырабатываться взаимоприемлемые модели поведения. Однако исследований, посвященных анализу сложившейся ситуации и изменениям, которые происходят в отношении студентов и преподавателей к нормативной регуляции поведения в вузе, а также тому, как меняются этикетные модели поведения участников образовательного процесса, недостаточно.

Цель настоящей статьи - обозначить перспективные направления исследования трансформации этикета в высшей школе.

Представляется важным прежде всего разграничить объекты изучения - вузовский этикет и этикетное поведение в вузе. Для этого обратимся сначала к содержанию понятия «этикет». Анализ научной литературы позволил нам выявить две принципиально различные трактовки этого понятия. Первую мы обозначили как этическую; в соответствии с ней этикет трактуется как «...совокупность правил поведения, касающихся внешнего проявления отношения к людям... Этикет в конечном счете выражает содержание тех или иных принципов нравственности, уважения к человеку...» [17, с. 377-378]. Вторую трактовку этикета можно назвать социокультурной. С этой точки зрения сущность этикета состоит в фиксации форм выражения отношений между людьми, принадлежащими к группам с разными статусами. Определяется статус субъекта в коммуниативной ситуации его социальной принадлежностью, возрастом, полом, спецификой ситуации (например, статусы гостя и хозяина) и другими характеристиками, которые более или 
менее осознано учитываются всеми участниками взаимодействия. По словам А. К. Байбурина, «в конечном счете все актуальные этикетные противопоставления могут быть представлены (свернуты) в виде оппозиции выше-ниже или старше-младше, понимаемой в социальном смысле, ибо для этикета важен сам факт неравенства» [18, с. 24]. Социокультурная трактовка этикета, на наш взгляд, продуктивна для исследования этикета как регулятивного механизма взаимодействия участников общения с разными статусами, каковым и является общение студентов и преподавателей вуза.

Принимая социокультурную трактовку этикета, нам представляется важным уточнить ее содержание. Правила этикета диктуют поведение людей не только в ситуациях, когда они взаимодействуют с теми, кто обладает иным статусом, и где важно зафиксировать эти различия, но также там, где соблюдение определенных правил является маркером принадлежности к определенной группе - социальной, профессиональной, культурной и др. Покажем это на примере застольного этикета. Правила этикета предполагают, что рассадка людей за столом учитывает положение каждой персоны среди сотрапезников. Так, дипломатический протокол предписывает рассадку гостей в соответствии с официальным старшинством: «Особое внимание следует уделять распределению почетных мест, поскольку на такие места претендуют многие, обычно очень чувствительно относящиеся к рассадке... Почетное место располагается напротив входной двери... На завтраках, где присутствуют только мужчины, самым почетным местом является место справа от хозяина... Когда на завтраке или обеде присутствует жена хозяина, то почетным местом является место справа от хозяйки» [19, с. 152-153]. В общегражданских правилах этикета также предписывается учитывать положение гостей, предлагая им место за столом. При этом правила обращения со столовыми приборами не различаются в зависимости от положения гостя и регулируются общепринятыми в стране или специфической культурной группе правилами этикета.

Это позволяет выделить в общем корпусе правил этикета те, посредством которых в символической форме выражаются статусные различия взаимодействующих лиц (стратифицирующие правила) и правила, посредством которых выражается принадлежность участ- 
ников взаимодействия (по крайней мере здесь и сейчас) к той или иной группе (интегрирующие правила).

В вузе интегрирующие правила этикета обеспечивают взаимодействие людей внутри своих статусных образований; они отличаются в сообществе преподавателей от тех, что приняты в студенческих группах. Есть и такие, которые являются общими, причем они, очевидно, имеют истоки в общекультурной традиции данного города, региона, страны, а также традициях образовательного учреждения. Стратифицирующие правила работают при взаимодействии студентов и преподавателей. Именно они находятся в центре нашего внимания в этой статье.

Поиск подходов к пониманию того, как работают правила этикета, побудил нас различать этикет как систему специфических правил и этикетное поведение как реализацию этих правил субъектами в ситуациях межличностного взаимодействия. Этикет и этикетное поведение являются предметом интереса разных специалистов. Правила этикета оказываются в сфере изучения представителей гуманитарного знания - философов, культурологов, историков. Психологические факторы реализации правил этикета - предмет интереса психологов [20]. Соответственно, правила вузовского этикета и этикетное поведение участников образовательного процесса в вузе - разные объекты, требующие разных подходов и методов исследования. Оба этих подхода необходимы для понимания процессов, определяющих формы взаимодействия студентов и преподавателей в современном вузе и разработки рекомендаций, направленных на оптимизацию коммуникативных практик участников учебного процесса.

Происходящие изменения в общественной и культурной жизни порождает трудные вопросы. Соответствуют ли традиционные правила этикета современной социокультурной ситуации? Как экономические, социальные, культурные изменения жизни людей сказываются на изменениях коммуникативных практик, регулируемых правилами этикета? Как эти перемены проявляются в организации взаимодействия студентов, преподавателей и администрации вуза? Какие психологические факторы обеспечивают принятие или отвержение правил этикета? Ответы на эти и другие вопросы требуют 
глубокой теоретической проработки, основанной как на изучении обширной литературы из разных областей гуманитарного знания, так и на данных эмпирических исследований, полученных на основе разработанных в психологической науке подходов с использованием надежных и валидных инструментов эмпирического исследования.

Представим некоторые соображения о перспективных направлениях исследований вузовского этикета и этикетного поведения в вузе.

Первое направление состоит в выявлении объективных факторов, способных оказать влияние на отношение к традиционным этикетным моделям поведения. Известно, что этикетная регламентация поведения в наибольшей степени характерна для обществ с жестко закрепленной иерархической структурой [21]. Пример мы находим в Древней Индии, где существовала иерахически выстроенная система сословий - варн. Высшее место в ней занимало сословие брахманов, хранителей религиозного знания. Именно брахманы выступали в качестве учителей для тех молодых людей, кто по праву рождения получал возможность изучать священные тексты. Авторитет наставника был непререкаем, и уважение к нему следовало проявлять в определенных формах поведения. В книге законов Ману - своде правил поведения в общественной и частной жизни, созданном в основном во II в. до н. э. - II в. н.э., сформулировано, как должен вести себя ученик в присутствии своего учителя (гуру). «Побуждаемый гуру или не побуждаемый, пусть [ученик] всегда проявляет прилежание при изучении [Веды] и оказании услуг учителю...». «Обуздав тело, речь, органы чувств и разум, следует стоять, почтительно сложив руки, глядя в лицо гуру». «В присутствии гуру надо всегда есть меньше, [чем тот], носить худшую одежду и украшения...». «Нельзя ни отвечать, ни разговаривать [с ним] ни лежа, ни сидя, ни принимая пищу, ни стоя отвернувшись». «Надо стоять, когда [гуру] сидит, приближаться, когда тот стоит, идти навстречу приближающемуся, бежать вслед бегущему...». «Даже в отсутствие его не следует произносить его имя без [почетных эпитетов] ...» и т. п. [22, с. 72-73].

Еще в недавнем прошлом отношения студента и преподавателя вуза признавались заведомо неравноправными; более высокий статус преподавателя находил символическое выражение в правилах 
вузовского этикета: студенты были обязаны стоя приветствовать преподавателя, избегать в его присутствии использования сленга и грубых выражений и т. д. В этом проявлялось уважение к традициям системы высшего образования. Происходящие в последние десятилетия изменения сказываются на формах взаимодействия студентов и преподавателей вузов. Учащиеся имеют все больше возможностей влиять на учебный процесс, что делает отношения преподавателей и студентов менее асимметричными.

Благодаря вовлечению студентов в совместные научные проекты, ученики становятся коллегами своих преподавателей. Включение вуза, как и всей образовательной среды, в сферу услуг превращает студента в потребителя услуги, оказываемой преподавателем. Это создает предпосылки для инверсии традиционных статусных отношений в глазах учащихся, что позволяет, например, студенту оказывать давление на преподавателя, требуя от него исправления оценки, полученной на экзамене. Общая тенденция упрощения форм общения в школе и в повседневной жизни проникает также и в вуз. Все это приводит к тому, что реально практикуемые в вузе способы поведения в коммуникативных ситуациях зачастую существенно отличаются от ранее принятых традиционных моделей вузовского этикета.

Особенностью образовательного процесса в современном мире является значительное число студентов, у которых формирование моделей поведения, регулирующих взаимодействие субъектов в этикетных ситуациях, происходило в разных культурных средах. В таких случаях неизбежно различие в оценке студентами приемлемости тех или иных поведенческих практик в учебном классе. Это было показано, в частности, в исследовании, проведенном в одном из американских университетов, где английский язык изучали приехавшие из разных стран студенты, имевшие опыт получения высшего образования на родине. В опросе приняли участие студенты из Аргентины, Китая, Италии, Японии, Кореи, Тайваня, Украины и Вьетнама. Респонденты оценивали по шкале Лейкерта допустимость/недопустимость ряда поведенческих практик во время занятий в вузе. Обнаружилось, что полного совпадения в оценках всех практик не наблюдалось. Однако были отдельные формы поведения, 
которые оценивались как недопустимые во всех перечисленных странах: обращение по имени к преподавателю и прием пищи и напитков во время занятия. При этом опоздание на занятие на три минуты оценивалось скорее как приемлемое в Аргентине, Корее и Италии и неприемлемое в Тайване и Японии [23]. Во многих российских вузах учатся студенты из-за рубежа, в том числе из стран, где модели поведения учителя и ученика, преподавателя и студента существенно отличаются от тех, которые являются традиционными для российских образовательных учреждений. Привычные для одной стороны способы поведения могут оказаться неприемлемыми для другого участника педагогического процесса. Отсутствие общих для всех участников учебного процесса правил вузовского этикета создает затруднения как для студентов, так и для работающих с ними преподавателей.

Второе перспективное направление исследований вузовского этикета и этикетного поведения в вузе связано с развитием информационных технологий. Повседневностью стала практика онлайнобщения преподавателей и студентов для решения образовательных и научных задач. В ситуации распространения COVID-19 такой способ взаимодействия стал вынужденным, однако очевидно, что в дальнейшем контакты преподавателей и студентов посредством электронных средств связи будут лишь расширяться. При этом для деловой онлайн-коммуникации недостаточно разработаны формальные требования. Например, нет общепринятых представлений о том, что может быть предметом запроса студента в письме к преподавателю, о сроках ответа на письма преподавателей и студентов друг другу, о формах обращения в письмах и т. п. Не зная правил деловой онлайн-переписки, ее участники, чаще студенты, невольно нарушают статусные отношения. Это создает неблагоприятное впечатление у адресата и может негативно сказаться на процессе и результате взаимодействия. Значительное напряжение у преподавателей создает использование студентами во время учебного процесса гаджетов, не оправданное содержанием занятия. Отсутствие четких правил, регулирующих соответствующие практики, является потенциальным триггером конфликта. Важно определить, какие общие правила делового этикета, регулирующие формы онлайн- 
общения и использования гаджетов в рабочей ситуации, могут быть адаптированы и рекомендованы для вуза, обеспечивая продуктивное и уважительное взаимодействие студентов и преподавателей.

Третьим перспективным направлением является изучение этикета и этикетного поведения как компонентов организационной культуры вуза, которая также за последние годы претерпела значительные изменения [24]. Базовые компоненты организационной культуры - доминирующие ценности и связанные с ними нормы поведения сотрудников администрации, преподавателей и студентов - заметно трансформировались. Они включают в себя значительную долю рыночных предпринимательских составляющих и конкурентных отношений [25]. Особенности восприятия организационной культуры вузов могут быть рассмотрены с точки зрения поколенческих различий ее основных участников, их отношения к вузовским нововведениям. При этом не надо забывать, что процесс вузовской социализации студентов и, соответственно, усвоения ими социальных норм, в том числе правил этикета, носит «спрессованный», краткий характер, и особенно это касается обучения в магистратуре [26].

Четвертое направление связано с поиском психологических факторов отношения личности к правилам этикета. Что побуждают субъекта принимать или отвергать саму практику этикетной регуляции поведения? Какой смысл видят в правилах этикета преподаватели и студенты? Как это влияет на их отношение к правилам? Какие механизмы - страх перед наказанием, боязнь осуждения или осознание важности правил побуждают соблюдать этикет? Как это связано с личностной зрелостью субъекта? Какие личностные характеристики могут служить предикторами этикетного поведения? Созданные нами методики позволили провести ряд эмпирических исследований, направленных на измерение разных аспектов отношения субъекта к этикетным моделям поведения, а также обнаружить связь показателей отношения к этикетным моделям поведения с рядом психологических характеристик личности.

В 2015 г. нами проведено эмпирическое исследование проявления уровней морального сознания в мотивации этикетного поведения студентов. Посредством специально разработанной проектив- 
ной методики определялись показатели субъективной значимости аргументов, соответствующих разным уровням морального сознания, в пользу соблюдения правил служебного (вузовского) и общегражданского этикета. Теоретической основой для определения уровней морального сознания стала концепция Л. Колберга [27]. Выявлено, что для студентов наиболее значимыми в пользу соблюдения правил этикета являются аргументы, соответствующие уровню автономной морали; несколько менее значимыми - уровню конвенциональной морали; следующие по значимости - соответствующие внеморальному уровню; наименее значимыми для студентов являются аргументы, соответствующие доморальному уровню регуляции поведения [28]. Впоследствии близкие результаты с использованием этой же методики были получены на выборках китайских и российских студентов [29].

На основе социокультурного подхода к пониманию этикета и концепции отношений В.Н. Мясищева нами был создан опросник «Отношение к репрезентативным правилам этикета». Под репрезентативными подразумеваются правила, в которых эксплицированы сложившиеся в культуре предписания того, какие знаки, маркирующие статусные различия, следует использовать людям в коммуникативных ситуациях, требующих выражения этих различий. Например: «В соответствии с правилом делового этикета, человек, обладающий меньшими полномочиями, должен первым приветствовать того, кто обладает большими полномочиями (студент - преподавателя, подчиненный - начальника и пр.)». На основе оценки когнитивного, эмоционального и поведенческого компонента каждого правила определяется общий показатель отношения к репрезентативным правилам этикета. Проведено исследование, обосновывающее надежность и валидность этой методики [30]. Аспирантка из Китая Ли Цзыхань, успешно защитившая в 2017 г. кандидатскую диссертацию на тему «Психологические факторы отношения к этикетным моделям поведения у китайских и российских студентов», провела необходимые процедуры по адаптации этого опросника для китайской выборки: была обеспечена эквивалентность перевода; проверка подтвердила надежность и валидность китайского варианта опросника [29]. Посредством этого опросника 
были получены данные о взаимосвязи отношения к этикету и ценностных ориентаций личности (использована концепция и метод измерения ценностей личности Ш. Шварца) на выборках российских и китайских студентов. В частности, выявлено, что в обеих группах позитивное отношение к правилам этикета связано с предпочтением типов ценностей, выражающих консервативные ориентации личности и заботу об интересах других людей и общества $[29,31]$.

В рамках психологического направления исследований мы также занимались выявлением смыслов, которые студенты усматривают в правилах этикета. В частности, искали ответ на вопрос, чем сами студенты обосновывают свое положительное отношение к этикету. Контент-анализ аргументов, полученных с помощью методики незаконченных предложений, показал, что чаще всего студенты упоминают аргументы, смысл которых состоит в возможности, соблюдая правила этикета, выразить уважение к человеку, с которым происходит общение. Также, по мнению студентов, правила этикета помогают оптимизации процесса общения, сохранению культуры и благополучия общественной жизни; самоидентификации и самопрезентации и пр. [32].

Заметим, однако, что хотя больше половины опрошенных нами студентов проявляют безусловно положительное отношение к правилам этикета и лишь весьма малая доля безусловно их отвергает, значительное число отвечавших усматривают как позитивные, так и негативные стороны в этикетной регламентации поведения. В чем основания такого амбивалентного отношения к этикету? Можно предположить, что оно обусловлено характеристиками респондентов, связанными как с возрастом, так и с индивидуальнопсихологическими особенностями. К настоящему времени нами были получены данные о связи отношения к традиционным этикетным моделям поведения с некоторыми личностными чертами, однако они весьма невыразительны. Возможно, это объясняется тем, что использованная модель Big Five оказалась недостаточно чувствительной для выявления таких связей. Одно из направлений дальнейших исследований мы видим в продолжении поисков личностных коррелят этикетного поведения с опорой на другие модели, описывающие структуру личностных черт. 
Также нами были выявлены различия как в оценке желательности этикетной регуляции поведения, так и в признании того, в чем состоит позитивный смысл соблюдения правил этикета у студентов, обучающихся по разным специальностям [32]. Эти различия, возможно, объясняются спецификой не только содержания обучения и, соответственно, личностными особенностями, интересами и способностями людей, поступающих на ту или иную специальность, но также особенностями организационной культуры вузов, где готовят этих специалистов. Это побуждает нас к постановке задачи исследования факторов отношения к правилам этикета и этикетному поведению в контексте организационной культуры вузов.

Результаты намеченных исследований, как мы полагаем, могут способствовать созданию обоснованных рекомендаций по совершенствованию психологического климата в образовательных учреждениях, разработке мер по предупреждению конфликтов между преподавателями и студентами, а также быть полезными при разработке программ по развитию коммуникативной компетентности студентов как учащихся вуза и будущих профессионалов.

1. Кузнецов А. Ю., Небалуева А. И. Специфика отношения к конфликтам студентов и преподавателей [Электронный ресурс] // Совершенствование гуманитарных технологий в образовательном пространстве вуза: факторы, проблемы, перспективы. Екатеринбург : Изд-во УМЦ УПИ, 2019. С. 120-127. URL: http://elar.urfu.ru/bitstream/10995/76995/1/978-5-8295-0648-3_2019_20. pdf (дата обращения: 07.09.2020).

2. Лукин-Григорьев В. В. Специфика психологических конфликтов в вузе (в диаде «преподаватель-студент») [Электронный ресурс] // Вестн. Алт. гос. пед. ун-та. 2019. № 41. С. 53-57. URL: https://journals-altspu.ru/ vestnik/article/view/1314/1240 (дата обращения: 07.09.2020).

3. Должны ли студенты вставать, когда преподаватель входит в аудиторию? [Электронный ресурс]. URL: http://pink-rabbit.ru/questions/132166/ dolzhny-li-studenty-vstavat-kogda-prepodavatel-vhodit-v-auditoriyu (дата обращения: 17.09.2020).

4. Tews M. J., Frager K., Citarella A.I., Orndorff R. M. What is Etiquette Today? Interviewing Etiquette for Today's College Student [Electronic resource] // 
Journal of Advances in Education Research. 2018. Vol. 3, № 3. P. 166-175. URL: https://dx.doi.org/10.22606/jaer.2018.33005 (accessed: 18.07.2020).

5. Юревич А. В. Нравственное состояние современного российского общества: эмпирические оценки // Вопр. психологии. 2016. №6. С. 49-62.

6. Лихачева Л. С. Этикет как культурная универсалия // Фундаментальные проблемы культурологии : сб. ст. по материалам конгр. / отв. ред. Д. Л. Спивак. М. : Новый хронограф : Эйдос, 2009. Т. 6 : Культурное наследие: От прошлого к будущему. С. 146-156.

7. Дорофеев А.А. Этикет в повседневной культуре студентов [Электронный ресурс] // Педагогика высшей школы. 2016. № 3 (6). С. 18-21. URL: https://moluch.ru/th/3/archive/43/1349/ (дата обращения: 01.09.2020).

8. Сиюхова А.М., Кубова А.А. Дресс-код как элемент профессиональной культуры преподавателя вуза [Электронный ресурс] // Человек и культура. 2017. № 2. С. 73-81. DOI: 10.25136/2409-8744.2017.2.17964. URL: https://nbpublish.com/library_read_article.php?id=17964 (дата обращения: 18.07.2020).

9. Лабунская В.А., Бзезян А.А. Внешний облик в образовательной среде: оценка, самооценка, функциональная значимость // Современное образование. 2018. № 4. C. 8-18. DOI: 10.25136/2409-8736.2018.4.27965.

10. Иглтон Т. Медленная смерть университета / пер. с англ. Е. Бучкина // Alma mater : Вестн. высш. шк. 2016. № 2. С. 109-112.

11. Красинская Л. Ф. Модернизация, оптимизация, бюрократизация... что ожидает высшую школу завтра? // Высшее образование в России. 2016. № 3. С. 73-82.

12. Трубникова Е. И. Паттерны поведения в образовательной среде // Высшее образование в России. 2016. № 1. С. 95-103.

13. Зубарев В. Ф., Бондарев Г.А. «Зеркальный имидж» современного преподавателя высшей школы // Азимут научных исследований: педагогика и психология. 2019. № 3. С. 101-104.

14. Сенашенко В.С. О престиже профессии «преподаватель высшей школы», ученых степеней и ученых званий // Высшее образование в России. 2017. № 2. С. 36-44.

15. Крокинская О.К., Трапицын С. Ю. Студент как «потребитель образования»: содержание категории // Высшее образование в России. 2015. № 6. C. 65-75. 
16. Бондарев Г.А., Зубарев В. Ф., Бобровская Е. А. Преподаватель и студент: конфронтация или новый уровень общения // Азимут научных исследований: педагогика и психология. 2019. № 1. С. 36-40.

17. Словарь по этике. 3-е изд. М., 1975.

18. Байбурин А. К. Об этнографическом изучении этикета // Этикет у народов Передней Азии. М., 1988. С. 12-37.

19. Вуд Д., Серре Ж. Дипломатический церемониал и протокол : принципы, процедура и практика. М. : Прогресс, 1976. 395 с.

20. Даниленко О. И. Этикет и этикетное поведение: от культурологического анализа к психологическому исследованию // Научное обозрение: гуманитарные исследования. 2014. № 8. С. 50-56.

21. Титаренко А. И. Структуры нравственного сознания (Опыт этикофилософского исследования). М. : Мысль, 1974. 278 с.

22. Законы Ману. М. : ЭКСМО-Пресс, 2002. 496 с.

23. Beckman-Brito K. Classroom Etiquett: a Cross-Cultural Study of Classroom Behaviours [Electronic resource] // Journal of Second Language Acquisition and Teaching. 2003. Vol. 10. URL: https://journals.uair.arizona.edu/index.php/ AZSLAT/article/view/21305/20882 (accessed: 18.07.2020).

24. Почебут Л. Г., Чикер В. А. Организационная социальная психология. М. : Проспект, 2020. 552 с.

25. Кларк Б. Р. Создание предпринимательских университетов: организационные направления трансформации. М. : Изд. дом Высш. шк. экономики, 2011. 240 с.

26. Чикер В. А., Волкова Н. В., Почебут Л. Г. Психологические аспекты консолидации социального капитала вуза // Университетское управление: практика и анализ. 2019. № 23(1-2). С. 33-46. DOI: 10.15826/umpa.2019.012.002 .

27. Kohlberg L. Essays on moral development. New York; Toronto : Harper \& Row, 1984.

28. Даниленко О. И. Моральная регуляция этикетного поведения студентов // Вестн. Ленингр. гос. ун-та им. А. С. Пушкина. 2015. Т. 5 : Психология. № 1. С. 48-59.

29. Ли Ц. Психологические факторы отношения к этикетным моделям поведения у китайских и российских студентов : автореф. дис. ... канд. психол. наук. СПб., 2017. 
30. Даниленко О.И. Опросник «Отношение к репрезентативным правилам этикета» // Научное обозрение: гуманитарные исследования. 2016. № 7. С. 74-80.

31. Даниленко О. И., Ли Ц. Отношение к правилам этикета в связи с ценностными ориентациями у китайских и российских студентов // Электронный научный журнал. 2017. № 1. С. 37-46.

32. Даниленко О. И. Студенты о правилах этикета: пространство смыслов // Герценовские чтения : Психологические исследования в образовании : материалы II Междунар. науч.-практ. конф. 2019. С. 151-159. 


\section{КОНСТРУКТИВНОЕ ОТНОШЕНИЕ К СЕБЕ КАК ПРОФЕССИОНАЛУ И БЛАГОПОЛУЧИЕ ЛИЧНОСТИ}

С. В. Духновский

Отношение к себе как профессионалу является одним из важных факторов благополучия субъектов трудовой деятельности, влияя на ее качество, эффективность, в том числе на удовлетворенность карьерой. Особую значимость это приобретает в сфере образования. Полагаем, что отношение к себе субъектов образовательного процесса позволяет конструктивно переживать кризисы, возникающие в том числе и в профессиональной деятельности, сохраняя свое психологическое и соматическое здоровье, снижать риск возникновения профессиональных деструкций и деформаций. Соответственно, вопросы благополучия субъектов образовательного процесса в профессиональной сфере получают особую актуальность.

В научном плане вопросы благополучия личности (психологического, эмоционально-личностного) поднимались в исследованиях В. А. Ананьева [1], Л. В. Куликова [2], Р. М. Шамионова [3], С. В. Духновского [4], О. Ю. Зотовой [5], Л.В. Карапетян, Г. А. Глотовой [6] и др. Проблема самоотношения, в том числе и профессионального, раскрывалась в исследованиях К.В. Карпинского, А. М. Колышко [7], С. Р. Пантилеева [8], Ю. В. Синягина [9], В. В. Столина [10] и др.

Несмотря на интерес к заявленной проблеме со стороны ученых, применительно к сфере образования она является недостаточно изученной. В частности, научный интерес представляет поиск ответов на вопросы: какие параметры отношения к себе как профессионалу взаимосвязаны с благополучием как отражением кризисного профиля субъектов образовательного процесса; является ли удовлетворенность карьерой и профессиональная мотивация индикаторами конструктивного отношения к себе и благополучия субъектов образовательного процесса.

Как отмечает Р. М. Шамионов, в вопросе о субъективном благополучии личности существует по крайней мере две позиции: «от личности» - проблема самосознания, рефлексивного Я и «К личности» - проблема внешнего по отношению к ней содержания как 
условия субъективного благополучия и его вариативности (что обычно связывается с профилактикой функциональных нарушений и настроениями масс) [3, с. 7]. В этом контексте, на основании проведенных исследований, О. Ю. Зотовой показано, что «психологическое благополучие имеет социокультурную обусловленность, которая проявляется через систему отношений личности, формируемых в соответствии с традициями общества» [5, с. 7].

По мнению Р. М. Шамионова, субъективное благополучие - это «понятие, выражающее собственное отношение человека к своей личности, жизни и процессам, имеющим важное для нее значение с точки зрения усвоенных нормативных представлений о “благополучной” внешней и внутренней среде и характеризующееся переживанием удовлетворенности» [3, с. 8].

Одним из проявлений благополучия является эмоциональноличностное благополучие, под которым Л. В. Карапетян, Г. А. Глотова понимают «...целостное экзистенциальное переживание состояния гармонии между внутренним и внешним миром, возникающее в процессе жизни, деятельности и общения человека. Результатом снижения уровня такой гармонии является переживание состояния эмоционально-личностного неблагополучия» [6, с. 26].

В своем исследовании, рассматривая благополучие субъектов образовательного процесса, мы будем придерживаться позиции Л. В. Куликова, согласно которой субъективное благополучие «...обобщенное и относительно устойчивое переживание, имеющее особую значимость для личности. Именно оно в большей степени определяет характеристики доминирующего психического состояния: благоприятного состояния - способствующего согласованному протеканию психических процессов, успешному поведению, поддерживающему психическое и физическое здоровье, или, напротив, неблагоприятного» [2, с. 123].

Мы считаем, что отражением благополучия/неблагополучия субъектов образовательного процесса будет являться их «кризисный профиль». Суть в том, что наличие кризисов в жизни человека, на наш взгляд, явление необходимое, неизбежное. Неизбежность кризисов обусловлена индивидуально-психологическими особенностями субъекта. Необходимость кризиса(ов) мы объясняем тем, 
что в процессе его переживания происходит познание субъектом самого себя, своего места в окружающем мире, качественное изменение отношений, а также переосмысление жизни в целом. Придерживаясь позиции В. А. Ананьева [1], считаем, что свою «конструктивную необходимость» кризис приобретает, когда в процессе его переживания субъект воспринимает его как некое испытание, некую «ступень», позволяющую ему по-новому взглянуть на свою жизнь, кардинально пересмотреть, а порой и изменить ее, увидев новые горизонты и перспективы существования.

В данном контексте о благополучии личности будет свидетельствовать выраженность психологической устойчивости и ситуационных реакций личности - реакций, проходящих на непатологическом уровне и связанных с возникновением психологического кризиса [11]. Они образуют индекс ситуационного реагирования, определяющего величину кризисной нагрузки субъекта [12].

В нашем исследовании предлагаем использовать понятие отношение к себе как профессионалу. В качестве аргументов выступили положения кризисной теории развития личности, выдвинутые В. А. Ананьевым [1], представление о профессионале как субъекте трудовой деятельности, имеющееся в исследованиях В. А. Толочека [13], классификация типов и видов деятельности профессионала, разработанная Ю.П. Поварёнковым [14], и представление о структуре отношений личности, имеющееся в работах Л. В. Куликова [15].

Так, Л.В. Куликов указывал на то, что источники отношений (в том числе и отношения к себе) могут быть как внешними, так и внутренними, и даже навязанными средой. Процессами отношения к себе выступают познание себя, самооценка и саморегуляция, а компонентами - познавательный (представления о себе), эмоциональный (принятие себя) и поведенческий (установки на себя, активность, направленная на себя) [15].

Согласно В. А. Толочеку, профессионал - «субъект профессиональной деятельности, длительно специализирующийся в определенной трудовой сфере, успешно справляющийся с возложенными на него должностными функциями, имеющий соответствующую квалификацию, интегрированный в профессиональном сообществе (в контактных группах, в организации, в профессии)» [13, с. 61]. 
При определении типов деятельности профессионала мы использовали классификацию задач, решаемых профессионалом, предложенную Ю. П. Поварёнковым [14]. По этому основанию ученый выделяет профессиональные и метапрофессиональные типы деятельности. Деятельности, относящиеся к профессиональному типу, «...ориентированы на решение профессиональных задач, связанных с созданием материальных и духовных ценностей (потребительских стоимостей). Их название определяется содержанием конкретных профессий и специальностей» [14, с. 23]. Виды деятельности, относящиеся $к$ метапрофессиональному типу, «...ориентированы на "воспроизводство" самого профессионала. Они делятся на два подтипа: на деятельности профессионально-содержательного и статусного развития профессионала» [Там же]. Применительно по отношению к себе это может выражаться в установках, направленных на профессиональное саморазвитие и должностное (статусное) развитие профессионала.

Итак, с нашей точки зрения отношение к себе как профессионалу предполагает познание себя, самооценку, саморегуляцию и осознание себя, проявляющиеся в представлении и принятии себя как профессионала, а также в установках на профессиональное саморазвитие и должностное развитие субъекта профессиональной (в том числе и будущей) деятельности. Под конструктивностью отношения $\kappa$ себе будем понимать стремление к развитию своих индивидуальнопсихологических и профессионально-психологических качеств, построение карьеры, позволяющей добиваться личностно и профессионально значимых целей, удовлетворяющих субъекта трудовой деятельности. Конструктивность отношения к себе как профессионалу правомерно рассматривать в континууме «личность - профессиональное развитие (саморазвитие) - карьера».

Мы предполагали, что субъекты с конструктивным отношением к себе как профессионалу обладают более благоприятным кризисным профилем, удовлетворены своей карьерой и обладают трудовой мотивацией, позволяющей достигать личностно и профессионально значимых целей. 


\section{Методика исследования}

Общая выборка исследования составила 97 субъектов образовательного процесса - преподавателей Российской академии народного хозяйства и государственной службы при Президенте РФ (Курганский филиал), Югорского государственного университета (г. Ханты-Мансийск) и Курганского государственного университе-

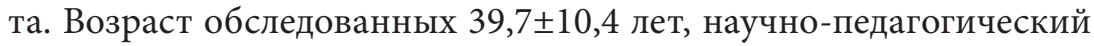

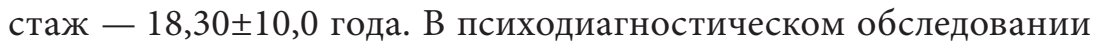
использовались следующие методики:

- «Определение отношения к себе профессионала» (ОСП). Предмет методики - оценка уровня притязаний, представления и принятия себя как профессионала, а также установок на профессиональное саморазвитие и должностное развитие работника (кандидата);

- «Переживание кризиса личностью» (ППК), предназначена для выявления степени (глубины) переживания кризиса, кризисного профиля личности и его характеристик [12];

- «Шкала удовлетворенности карьерой», разработанная К. В. Карпинским, Т. В. Гижук [16];

- методика определения мотивационных типов («Мотайп», разработанная В.И. Герчиковым). Предмет методики - выявление и оценка доминирующего типа трудовой мотивации: инструментального, профессионального, патриотического, хозяйского и люмпенизированного (избегательного) [17].

Для обработки результатов исследования применялись методы математической статистики: анализ первичных статистик, оценка достоверности различий в выраженности исследуемых характеристик, выявление взаимосвязей между характеристиками методом корреляционного анализа.

Далее обратимся к описанию наиболее значимых эмпирических данных. На первом этапе исследования на основании данных, полученных по методике «Переживание кризиса личностью» (ППК), в зависимости от преобладающего кризисного профиля обследованные были разделены на 2 группы.

В первую группу вошли преподаватели $(n=63)$ с кризисным профилем «Психологическое здоровье с благоприятным прогнозом» 
(с низким и пониженным индексом ситуационного реагирования от 43 до 45 Т-баллов и повышенным показателем психологической устойчивости личности - 58 Т-баллов). Данную группу мы обозначили как «благополучные» субъекты образовательного процесса.

Вторая группа представлена преподавателями $(n=34)$ с профилем «Истощение с неопределенным прогнозом» (с пониженным индексом ситуационного реагирования - 43 Т-балла и пониженным показателем психологической устойчивости личности - 44 Т-балла). Соответствующую категорию обследованных мы обозначили как «неблагополучные». Результаты представлены в табл. 1.

Результаты, представленные в табл. 1, показывают следующее. «Благополучные» субъекты характеризуются высоким уровнем психологической устойчивости, выраженной энергичностью в сочетании с низкой эмоциональностью. Они способны интенсивно выполнять стоящие задачи в течение длительного времени, оставаясь устойчивыми к эмоциогенным воздействиям. Благоприятное психическое состояние предполагает: активность, оптимистическое отношение к жизненной ситуации, готовность к преодолению препятствий, веру в свои возможности; ощущение сил для преодоления препятствий и достижения своих целей, жизнерадостность; повышенное, бодрое настроение, положительный эмоциональный фон; выраженное желание действовать; удовлетворенность жизнью, самореализацией.

«Неблагополучные» субъекты обладают низким уровнем психологической устойчивости. Для них характерны: отсутствие веры в себя, неуверенность в своих силах, возможно, депривация основ-

Таблица 1

Средние стандартные значения по методике «Переживание психологического кризиса личностью» (ППК) у субъектов образовательного процесса

\begin{tabular}{l|c|c}
\hline \multirow{2}{*}{ Шкала методики ППК } & \multicolumn{2}{|c}{ Т-баллы } \\
\cline { 2 - 3 } & $\begin{array}{c}\text { благополуч- } \\
\text { ные субъекты }\end{array}$ & $\begin{array}{c}\text { неблагополуч- } \\
\text { ные субъекты }\end{array}$ \\
\hline Индекс ситуационного реагирования & 44 & 43 \\
\hline Психологическая устойчивость & 57 & 44 \\
\hline
\end{tabular}


ных жизненных потребностей (самореализации, самоуважения, самоутверждения); неспособность соразмерять уровень напряжения с ресурсами своей психики и организма; слабая способность противостоять жизненным трудностям, неблагоприятному давлению обстоятельств. В психическом состоянии выражено пассивное отношение к жизненной ситуации, в оценке многих жизненных ситуаций преобладает пессимистическая позиция, неверие в возможность успешного преодоления препятствий; пониженное настроение, разочарованность ходом событий, сужение интересов; переживание субъективного неблагополучия: неудовлетворенность жизнью, собой, своим социальным статусом и межличностными отношениями; низкая оценка личностной успешности. Переживание субъективного неблагополучия личности.

Далее по методике «Определение отношения к себе как профессионалу» нами были выявлены уровень притязаний, степень принятия и представление о себе как профессионале, установки на профессиональное саморазвитие и должностное развитие «благополучных» и «неблагополучных» субъектов образовательного процесса с разным «кризисным профилем» личности. Результаты представлены в табл. 2.

Результаты, представленные в табл. 2, показывают следующее. «Благополучные» субъекты образовательного процесса обладают

Таблица 2

Средние значения показателей по шкалам методики

«Отношение к себе как профессионалу» (ОСП) у обследованных субъектов образовательного процесса

\begin{tabular}{l|l|l}
\hline \multirow{2}{*}{\multicolumn{1}{c|}{ Шкала ОСП }} & \multicolumn{2}{c}{ Средние значения } \\
\cline { 2 - 3 } & $\begin{array}{c}\text { благопо- } \\
\text { лучные } \\
\text { субъекты }\end{array}$ & $\begin{array}{r}\text { неблаго- } \\
\text { получные } \\
\text { субъекты }\end{array}$ \\
\hline Уровень притязаний & $53,1 \pm 7,8$ & $32,2 \pm 4,7$ \\
\hline Представление о себе как профессионале & $49,3 \pm 7,4$ & $29,0 \pm 3,9$ \\
\hline Принятие себя как профессионала & $44,5 \pm 6,5$ & $30,5 \pm 4,0$ \\
\hline Установки на профессиональное саморазвитие & $47,8 \pm 7,0$ & $30,7 \pm 4,2$ \\
\hline Установки на должностное развитие & $39,7 \pm 6,1$ & $27,9 \pm 4,6$ \\
\hline
\end{tabular}


повышенным уровнем притязаний, установками на профессиональное саморазвитие и представлением о себе как профессионале. Тогда как показатели по шкалам «принятие себя как профессионала» и «установки на должностное развитие» выражены умеренно. Возможно, мотивационным фактором в данном случае выступает некоторая степень неудовлетворенности собой как профессионалом, выражающаяся в стремлении к достижению профессиональных целей, используя личностно-профессиональные качества, способности и умения, что, в свою очередь, способствует переживанию позитивных чувств относительно себя, своего профессионального и карьерного выбора, позитивному отношению к себе как профессионалу. Такое отношение к себе нами обозначено конструктивным.

В группе «неблагополучных» субъектов показатели по шкалам методики ОСП имеют пониженный уровнь. Соответственно, субъекты обладают пониженным уровнем притязаний, принятия себя и представлений о себе как профессионале, у них слабая ориентация на профессиональное саморазвитие и должностное развитие. Отношение к себе педагогов данной группы мы обозначили как деструктивное, которое может быть обусловлено наличием кризиса у субъектов образовательного процесса, о чем, в свою очередь, свидетельствует их кризисный профиль.

Взаимосвязь показателей кризисного профиля с показателями отношения к себе также установлена нами в ходе корреляционного анализа с использованием критерия Пирсона. Данные представлены в табл. 3.

Как видим из табл. 3, значимые корреляции шкал методики ОСП наблюдаются со всеми шкалами методики ППК. Отметим, что имеется обратно пропорциональная взаимозависимость с показателем «индекс ситуационного реагирования». Это свидетельствует о том, что чем выраженнее показатели по шкалам «уровень притязаний», «представление о себе как профессионале», «принятие себя как профессионала», "установка на профессиональное саморазвитие» и «должностное развитие», тем ниже показатели по шкалам ситуационных реакций и тем меньше величина кризисной нагрузки, и наоборот. Тогда как с показателем «психологическая устойчивость» все корреляции прямые. Соответственно, конструктивное 
отношение к себе как профессионалу предполагает выраженность психологической устойчивости, представляющей собой «...качество личности, отдельными аспектами которого являются стойкость, уравновешенность, сопротивляемость. Оно позволяет личности противостоять жизненным трудностям, неблагоприятному давлению обстоятельств, сохранять здоровье и работоспособность в различных испытаниях» [2, с. 92]. Отметим, что наиболее высокие связи установлены по шкалам «уровень притязаний», «представление о себе как профессионале» и «установка на профессиональное саморазвитие». Считаем, что данные показатели могут выступать ресурсными характеристиками в плане профилактики деструктивного переживания кризисов, способствуя благополучию субъектов образовательного процесса.

Конструктивность отношения к себе как профессионалу и благополучие личности находят выражение в удовлетворенности карьерой и профессиональной мотивации субъектов образовательного процесса. Укажем, что чем выше уровень удовлетворенности карьерой, тем выше оценка своих достижений в профессии и связанных с ней прямых и косвенных выгод в других (внепрофессиональных) сферах жизни. Как отмечают К.В. Карпинский, Т. В. Гижук, «в карьерной удовлетворенности “суммируется” вся совокупность жизненных приобретений, удобств и привилегий, достигнутых путем усердной профессиональной деятельности» [16, с. 106]. Полагаем, что у субъектов с умеренным и пониженным уровнем удовлетво-

Таблица 3

Матрица интеркорреляций шкал методики

«Отношение к себе как профессионалу» (ОСП) и шкал методики «Переживание кризиса личностью» (ППК)

\begin{tabular}{l|c|c|c|c|c}
\hline \multirow{1}{*}{ Шкала методики ППК } & \multicolumn{5}{|c}{ Шкала методики ОСП } \\
\cline { 2 - 6 } & УП & Ког & Эмо & Ср & Др \\
\hline $\begin{array}{l}\text { Индекс ситуационного реагиро- } \\
\text { вания }\end{array}$ & $-0,42^{*}$ & $-0,60^{*}$ & $-0,46^{*}$ & $-0,55^{*}$ & $-0,25^{*}$ \\
\hline Психологическая устойчивость & $0,44^{*}$ & $0,26^{*}$ & 0,18 & 0,23 & 0,14 \\
\hline
\end{tabular}

Примечания: 1. УП - уровень притязаний; Ког - представление о себе; Эмо - принятие себя; Ср - установка на саморазвитие; Др - установка на должностное развитие. 2 . $^{\star}$ - коэффициенты корреляции на уровне $p \leq 0,05$. 
ренности карьерой имеют место «сожаления об упущенных, неиспользованных карьерных возможностях» [16, с. 106]. Так, по методике «Шкала удовлетворенности карьерой» нами установлено следующее. В группе «благополучных» субъектов образовательного процесса с конструктивным отношением к себе как профессионалу зафиксирован повышенный уровень удовлетворенности карьерой. Тогда как в группе «неблагополучных» субъектов образовательного процесса с деструктивным отношением к себе как профессионалу отмечен пониженный уровень удовлетворенности своей карьерой.

Далее обратимся к анализу трудовой мотивации субъектов образовательного процесса. Результаты, полученные по методике определения мотивационных типов (Мотайп), представлены в табл. 4.

Данные, представленные в табл. 4, говорят о следующем. В группе «благополучных» субъектов образовательного процесса с конструктивным отношением к себе как профессионалу и повышенным уровнем удовлетворенности карьерой доминирующим мотивационным типом является «профессиональный». По мнению В.И. Герчикова, субъекты с данным типом мотивации ценят в работе ее содержание, возможность проявить себя и доказать (не только окружающим, но и себе), что они могут справиться с трудным заданием, которое не каждому посильно; предпочитают самостоятельность и отличаются развитым профессиональным достоинством. Доминирующие мотивы: содержание труда, самосовершенствование, творчество и разнообразие, признание (собственной уникальности и квалификации) [17].

В группе «неблагополучных» субъектов образовательного процесса с деструктивным отношением к себе как профессионалу, пониженным уровнем удовлетворенности своей карьерой выражен «избегательный» (люмпенизированный) тип мотивации. Субъекты с данным мотивационным типом избегают ответственности, активности и инициативы, обладают слабой мотивацией к эффективной работе. Основное стремление таких работников, как отмечает В.И. Герчиков, - минимизировать свои трудовые усилия на уровне, допустимом со стороны непосредственного руководителя. Основными мотивами могут являться сохранение сил и здоровья, избегание 
ответственности, следование традициям, часто власть и статус (ради «выгодного» положения в организации) [17].

Таким образом, результаты исследований показали, что благополучие субъектов образовательного процесса возможно рассматривать в рамках «кризисный профиль - отношение к себе как профессионалу - удовлетворенность карьерой - трудовая мотивация». В частности, нашло свое эмпирическое подтверждение предположение, что конструктивное отношение к себе как профессионалу является условием (источником) благополучия личности. Индикаторами этого выступают благоприятный кризисный профиль, удовлетворенность карьерой и профессиональная мотивация. Ресурсными характеристиками отношения к себе выступают уровень притязаний, представление о себе как профессионале и установка на профессиональное саморазвитие. Соответственно, для «благополучных» субъектов образовательного процесса с конструктивным отношением к себе как профессионалу и повышенным уровнем удовлетворенности карьерой актуальным будет являться повышение уровня принятия себя как профессионала позитивные чувства относительно себя, своего профессионального и карьерного выбора, своих личностно-профессиональных качеств и способностей. В группе «неблагополучных» субъектов образовательного процесса с неконструктивным отношением к себе как

Таблица 4

Средние значения по методике определения мотивационных типов («Мотайп») у обследованных субъектов образовательного процесса

\begin{tabular}{l|c|c}
\hline \multirow{2}{*}{ Шкала методики «Мотайп» } & \multicolumn{2}{|c}{ Средние значения } \\
\cline { 2 - 3 } & $\begin{array}{c}\text { благопо- } \\
\text { лучные } \\
\text { субъекты }\end{array}$ & $\begin{array}{c}\text { неблаго- } \\
\text { получные } \\
\text { субъекты }\end{array}$ \\
\hline Инструментальная мотивация & $4,9 \pm 1,4$ & $3,5 \pm 0,9$ \\
\hline Профессиональная мотивация & $7,7 \pm 2,3$ & $3,9 \pm 1,2$ \\
\hline Патриотическая мотивация & $4,6 \pm 1,1$ & $3,4 \pm 1,1$ \\
\hline Хозяйская мотивация & $4,5 \pm 1,0$ & $3,0 \pm 0,7$ \\
\hline Люмпенизированная (избегательная) мотивация & $3,0 \pm 0,9$ & $6,7 \pm 1,5$ \\
\hline
\end{tabular}


профессионалу и пониженным уровнем удовлетворенности своей карьерой необходимо формировать психологическую устойчивость с акцентом на повышенный уровень притязаний, представление о себе как профессионале, установку на профессиональное саморазвитие.

1. Ананьев В.А. Введение в потрясающую психотерапию // Журнал практического психолога. 1999. № 7-8. С. 15-31.

2. Куликов Л. В. Психогигиена личности. Вопросы психологической устойчивости и психопрофилактики : учеб. пособие. СПб. : Питер, 2004. $464 \mathrm{c}$.

3. Шамионов Р. М. Психология субъективного благополучия личности. Саратов : Изд-во Сарат. ун-та, 2004. 180 с.

4. Духновский С.В. Психология отношений личности : монография. Курган : Изд-во Курган. гос. ун-та, 2014. 380 с.

5. Зотова О.Ю. Психологическое благополучие личности : монография. Екатеринбург : Гуманитар. ун-т, 2017. 312 с.

6. Карапетян Л. В., Глотова Г.А. Теоретико-методологические основы эмоционально-личностного благополучия: монография. Екатеринбург : Урал. ин-т ГПС МЧС России, 2019.

7. Карпинский К. В., Кольшко А. М. Профессиональное самоотношение личности и методика его психологической диагностики : монография. Гродно : ГрГУ, 2010. 140 с.

8. Пантилеев С. Р. Самоотношение как эмоционально-оценочная система. М. : МГУ, 1991. 110 с.

9. Синягин Ю. В. Личностно-профессиональные факторы успешности карьеры современных государственных служащих // Мир психологии. 2010. № 4 C. 226-240.

10. Столин В. В. Самосознание личности. М. : МГУ, 1983. 284 с.

11. Амбрумова А. Г. Анализ состояний психологического кризиса и их динамика // Психол. журн. 1985. № 6. С. 107-115.

12. Духновский С.В. Психология личности и деятельности педагога : учеб. пособие. М. : РИОР : ИНФРА-М, 2016. 299 с.

13. Толочек В.А. Профессиональная карьера как социально-психологический феномен. М. : Ин-т психологии РАН, 2017. 262 с. 
14. Поварёнков Ю. П. Уточненная характеристика типов и видов деятельности профессионала // Ин-т психологии Рос. акад. наук. Организационная психология и психология труда. 2018. Т. 3, № 2. С. 4-26.

15. Куликов Л. В. Психология настроения. СПб. : Изд-во С.-Петерб. ун-та, 1997. 234 с.

16. Карпинский К. В., Гижук Т. В. Шкала удовлетворенности карьерой: разработка и психометрическая апробация // Теоретическая и экспериментальная психология. 2016. Т. 9, № 4. С. 101-116.

17. Герчиков В.И., Опарина Н. Н. Мотивация персонала : метод. пособие : Прил. к журн. «Справочник по управлению персоналом». М., 2006. 


\title{
ЛИЧНОСТНЫЕ ФАКТОРЫ АДАПТАЦИИ СТУДЕНТОВ К НОВОЙ СОЦИОКУЛЬТУРНОЙ СРЕДЕ
}

\author{
E. А. Столярчук \\ М. А. Круглова
}

Процессы глобализации и повышения мобильности населения затрагивают систему высшего образования в России, что выражается в том числе в возможности обучения и стажировок студентов за рубежом по различным образовательным программам. Процесс включения в незнакомую культурную среду часто бывает сложным и болезненным, требует адаптации студентов к новым условиям, к изменению своего положения, социальной роли. Наиболее выраженной потребность в адаптации становится у индивида, кардинально изменившего условия проживания, переместившись в иную культурную среду. Сфера образования, безусловно, несет ответственность за понимание студентами ментальных характеристик представителей других национальных культур, за формирование культуры межнационального общения, знание принципов межкультурной коммуникации и приобретение этнопсихологической компетентности и гендерной идентичности. В то же время, оказавшись в совершенно незнакомых условиях проживания и общения, индивид сталкивается с тем, что имеющиеся у него социальные и культурные навыки оказываются невостребованными, а иногда даже противоречащими тем, которые сложились в соответствующей социокультурной среде. В этом случае возникает ситуация, описываемая в научной литературе как культурный шок. Она характеризуется различными психологическими, поведенческими и соматическими симптомами, стимулируя потребность в адаптации, в том числе на психофизиологическом уровне $[1,2]$.

Культурный шок, как правило, в первую очередь провоцируется рассогласованием привычек, норм и правил поведения, характерных для новой среды и принятых в родной стране студента. Таким образом, у индивида происходит ломка устоявшихся стереотипов, которая вызывает дезориентацию и панику. Однако Дж. Берри указывал на то, что культурный шок не всегда связан лишь с нега- 
тивными переживаниями, и предлагал изменить данный термин на понятие «стресс аккультурации», подчеркивая, что в результате межкультурного контакта возможен также положительный опыт, приводящий к переоценке проблем и их преодолению [3].

H. C. Triandis выделяет пять этапов процесса адаптации визитеров [4]. Первый этап — «медовый месяц», сопровождается приподнятым настроением, энтузиазмом, надеждами. Среди студенческой молодежи в последнее время существует стремление попасть в чужую страну по обмену, многие молодые люди желают учиться или работать за границей. Когда студенты приезжают в чужую страну по обмену, их ждут на новом месте: встречают специально подготовленные, ответственные за их прием люди, которые стараются, чтобы иностранные студенты чувствовали себя «как дома», их даже на начальном этапе обеспечивают некоторыми привилегиями.

Однако второй этап адаптации связан с тем, что непривычная окружающая среда начинает оказывать свое негативное воздействие. Непривычные или неподходящие продукты питания, жилищные условия, транспортное сообщение, сложная криминальная обстановка и т. п., различные психологические факторы, к примеру, чувство взаимного непонимания с местными жителями и непринятие ими, вызывают у индивида разочарование, приводят его в замешательство, которое сопровождается фрустрацией и депрессией. Чтобы снизить уровень психического напряжения, визитер пытается нивелировать реальность и старается общаться исключительно с земляками, обсуждая негативные аспекты поведения местных жителей.

Третий этап является переломным: в этот период симптомы культурного шока, как правило, достигают критической точки. Это может проявляться в чувстве беспомощности, желании «забиться в угол» и даже в серьезных болезнях. Если визитер не имел поддержки со стороны окружающих и не смог успешно адаптироваться, то он вынужден покинуть среду и вернуться домой ранее положенного срока. Если же визитер получил социальную поддержку и преодолел культурные различия, то он начинает активно изучать язык, знакомиться с местной культурой, ощущая любопытство и проявляя любознательность. 
Четвертый этап характеризуется тем, что депрессия медленно заменяется оптимизмом, ощущением уверенности в себе, удовлетворением собой и происходящим вокруг. Таким образом, человек постепенно начинает чувствовать себя все более приспособленным и интегрированным в жизнь общества.

Пятый этап говорит о наличии полной или долгосрочной (по терминологии J.W. Berry) адаптации, которая вызывает относительно стабильные изменения индивида в ответ на требования среды. В идеале по завершении процесса адаптации уровень адаптированности визитера должен быть сопоставим с уровнем его адаптированности на родине.

Взяв за основу общетеоретическую интегративную модель кросскультурной коммуникации Y.Y. Kim [5], можно выделить следующие основные компоненты кросскультурной адаптации студентов, участвующих в международных обменах: индивидуально-психологические адаптивные особенности; особенности культуры родной страны; особенности культуры страны пребывания; культурные различия; жизненные стратегии; особенности взаимодействия с социальной средой; институциональная и организационная среда (см. рисунок).

В данной концепции особо подчеркивается важность межкультурных различий в социокультурной адаптации, при этом утверждается, что чем менее выражены межкультурные различия, тем проще индивиду влиться в чужую культуру [5]. В то же время автор практически не обращает внимание на содержание культурных норм и ценностей, тогда как известно, что различные ценности могут стимулировать разную интенсивность и направление адаптационных усилий. Особое значение имеет гибкость или ригидность принимающей страны, соответственно, можно предположить, что содержание культуры представляет собой некий самостоятельный фактор, оказывающий влияние на вектор адаптации и особенности ее протекания. Следует отметить значимость различных личностных факторов: индивидуальные способности преодолевать стресс и сохранять психологическую устойчивость; любознательность и открытость новому опыту; профессиональная и учебная мотивация и др. В то же время на адаптационные возможности индивида оказывают влияние жизненные стратегии - фактор, 


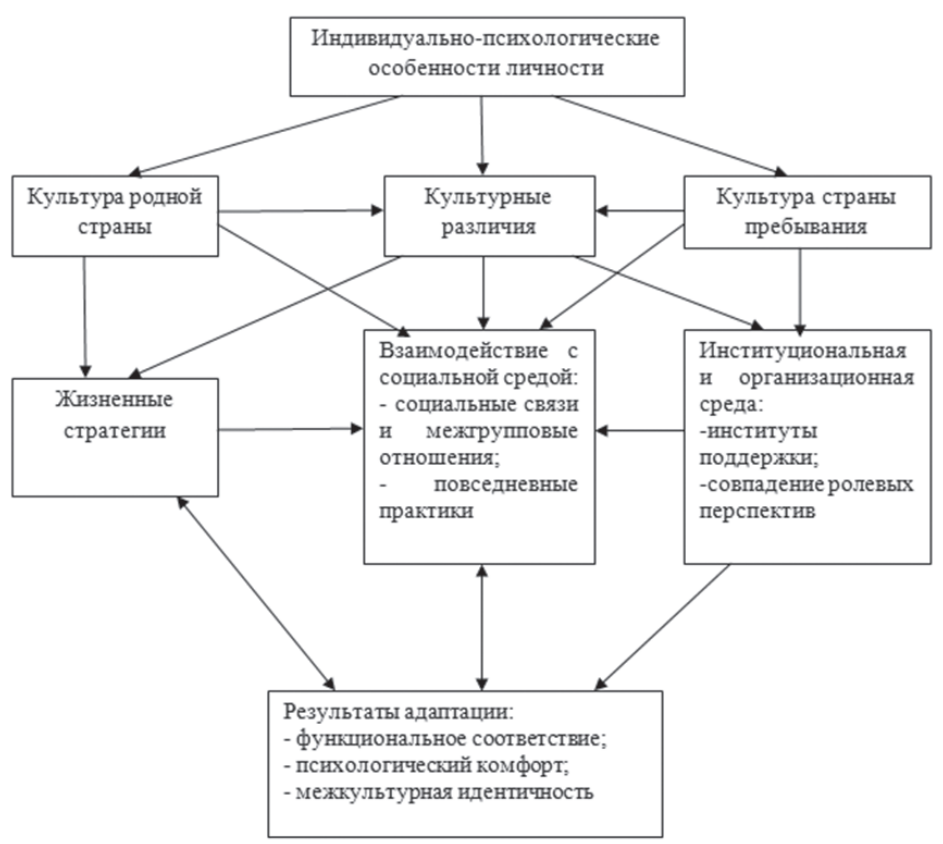

Основные компоненты процесса социокультурной адаптации студентов-участников международных обменов

который не всегда учитывается исследователями. Однако именно долгосрочные жизненные стратегии задают общие рамки восприятия учебы в зарубежном высшем учебном учреждении, что влияет на последующую жизненную траекторию, определяющую профессиональную и географическую мобильность. Обычно выделяются три базовые стратегии:

- стратегия возврата (студент планирует после обучения в иностранном высшем учебном заведении вернуться в свою родную страну);

- стратегия прямой миграции (студент строит планы продолжить профессиональную карьеру за границей и переехать в страну обучения);

- стратегия трамплина (студент использует учебу в зарубежном высшем учебном заведении для профессиональной социализации, которая позволит ему в дальнейшем мигрировать в третью страну). 
Соответственно, «можно предположить, что различные стратегии по-разному ориентируют адаптационные усилия индивида и могут приводить к разной глубине адаптации, с точки зрения культуры страны пребывания» [6, с. 137].

Следующий фактор в данной концепции - институциональную и организационную среду - принято рассматривать в двух аспектах. Первый аспект описывает различия в институциональной и организационной среде между странами. При этом указывается, что данные различия могут способствовать возникновению рассогласования в восприятии базовых норм и ролей института образования. В качестве примера приводится кардинально различное восприятие роли преподавателя в западной и восточной образовательной модели. При этом в западной модели преподаватель рассматривается в качестве некоего фасилитатора, способствующего автономии и интеллектуальной самостоятельности студента. Напротив, в восточной культуре роль преподавателя оценивается совершенно по-другому: преподаватель выступает в качестве непререкаемого и морального, и интеллектуального авторитета $[7,8]$. Второй аспект описывает степень развитости институтов социальной поддержки, которая также определяет возможности адаптации студента [7]. При этом подчеркивается, что существующие в стране институты социальной поддержки обычно напрямую реализуются на уровне высшего учебного заведения либо значительно опосредуются конкретной образовательной организацией.

В общетеоретической интегративной модели кросскультурной коммуникации Y.Y. Kim фактор взаимодействия с социальной средой определяет основное содержание адаптационного процесса. В данной концепции этот фактор трактуется как коммуникативный процесс. Причем указанное взаимодействие включает в себя и социальные, и несоциальные компоненты, однако социокультурная адаптация проявляется исключительно в социальной коммуникации. При этом указывается, что социальные связи включают в себя социальные коммуникации, протекающие в трех основных типах сетей, выявленных в эмпирических исследованиях: 1) связи с представителями своей страны; 2) связи с представителями страны пребывания; 3) связи с другими иностранными студентами в том 
учебном заведении, в котором обучается студент [9]. Рассматривая коммуникации с процессуальной и динамической точек зрения, можно предположить, что конфигурация социальных связей будет изменяться по мере адаптации студента к новой среде. Систему социальных связей образуют не только межличностные, но и межгрупповые отношения, которые рассматриваются в контексте различий в социальной структуре, а также выраженности ключевых проблем социального познания и поведения, что может проявляться в предвзятости, предрассудках, дискриминации и т. п.

Опираясь на общую теорию социокультурной адаптации, принято рассматривать три типа (уровня) результатов адаптационного процесса, которые иерархически упорядочены и соответствуют разной глубине и успешности адаптации: первый тип - аккомодация, т. е. функциональное соответствие, которое позволяет индивиду уверенно, корректно и эффективно решать практические задачи в соответствии с нормами и ожиданиями местной культуры; второй тип - ассимиляция, которая предполагает более глубокую аккомодацию, сопровождающуюся чувством психологического благополучия; третий тип - аккультурация. Это наиболее полная степень адаптации, при которой формируется межкультурная идентичность. Она позволяет индивиду гармонично включиться в местную культуру и считать себя ее частью. При этом совершенно не обязательно, что у индивида будет сформировано полное и прямое принятие всех ценностей, традиций и норм местной культуры. Он может остаться приверженцем норм, ценностей и традиций своей родной страны, но эффективно корректировать свое поведение с учетом требований страны пребывания.

Безусловно, адаптация может оказаться неудачной и на одном, и на двух, и на всех трех уровнях, соответственно, результаты дезадаптации будут оказывать негативное воздействие на жизненные стратегии и конфигурацию социальных связей. В то же время жизненная стратегия может предполагать сознательную защиту своей культурной идентичности, что будет выражаться в сознательном активном отказе от адаптации.

Исследования подтверждают тот факт, что процесс адаптации к условиям проживания в чужой стране связан в первую очередь 
с внутренней позицией личности и стратегиями поведения [10]. Адаптация индивида к новым условиям внешней среды требует определенных затрат сил по взаимному приспособлению индивида и среды, а с другой стороны, с адаптивностью личности связаны понимание особенностей чужой культуры и толерантное отношение к ней, с проявлением положительных эмоций в отношениях с окружающими, удовлетворительным самочувствием и ощущением душевного комфорта. Субъективные критерии адаптированности личности отражают изменения на всех уровнях личностной сферы - когнитивном (информированность о новой среде), эмоциональном (удовлетворенность различными сторонами жизни), ценностном (изменения в системе отношений), поведенческом (достижения в области деятельности и общении, социальной активности и т. д.) [11]. Анализ факторов адаптированности к новым социальным условиям мы рассматриваем с позиции системнокомплексного подхода. П. С. Кузнецов выделяет семь комплексных факторов, влияющих на успешность адаптации: экономический (материальный), самосохранения, регулятивный, воспроизводственный, коммуникативный, когнитивный и самореализации. Каждый комплексный фактор включает в себя ряд частных факторов. Выделенные им комплексные факторы соответствуют основным потребностям человека. Первые четыре фактора характеризуют насыщаемые потребности, т. е. те, которые по мере удовлетворения утрачивают свою актуальность - это низшие потребности. Три других фактора характеризуют высшие потребности, т. е. ненасыщаемые. Их удовлетворение вызывает ощущение радости, сопутствующее всему промежутку времени, в течение которого данная потребность удовлетворялась [12].

Таким образом, наиболее успешный вариант социально-психологической адаптации личности определяется удовлетворением ее потребностей в самоуважении и самоактуализации, что выражается в удовлетворенности профессиональной деятельностью; наличии смысла жизни и оптимистической оценки жизненной ситуации, высокой активности, эмоциональной стабильности и интернального локуса контроля. Вследствие чего наиболее успешной адаптацией личности в новых социокультурных условиях жизни будет 
адаптация, которая предполагает сохранение представителями разных культур позитивной социо- и этнокультурной идентичности и обретение ими новой социальной идентичности, адекватной изменившейся реальности.

Молодежь, как специфическая социально-возрастная группа, которая находится в процессе активного профессионального и социального становления в другой социокультурной среде, в силу своих возрастных и психических особенностей эффективнее приспосабливается к системе рыночных отношений, быстрее включается в нее, чувствует себя увереннее, приобретая новый экономический и социальный опыт. В то же время российская молодежь в силу своей внутренней неоднородности обладает разными социальнопсихологическими ресурсами. В работах Л. Г. Почебут по кросскультурной и этнической психологии высказывается предположение о том, что решение о миграции чаще принимают люди с интернальным локусом контроля, которые являются более самостоятельными и относительно автономными от своей культурной среды. В ситуации попадания в новую социокультурную среду локус контроля приобретает особую значимость для адаптации личности к новой культуре. Люди с внутренней атрибуцией контроля характеризуются направленностью на поиск выхода из кризисных ситуаций. Такие люди имеют высокий уровень саморегуляции, позволяющий блокировать воздействие травмирующих событий на психику; воспринимают события (как положительные, так и отрицательные) в их целостности; обладают повышенной чувствительностью к особенностям ситуации; способны предвидеть отдаленные последствия происходящего; склонны воспринимать экстремальные ситуации как требующие преодоления; нацелены на активное преобразование негативных компонентов внешней среды. Для людей с внешней атрибуцией контроля, имеющих пассивную жизненную ориентацию, в кризисных ситуациях характерно нарастание переживания стресса, так как свойственное им ощущение невозможности контролировать события блокирует действия по достижению успеха или избеганию неудачи. Многочисленные кросскультурные исследования локуса контроля свидетельствуют о благоприятности 
именно внутреннего локуса контроля для успешной межкультурной адаптации [13].

Успешная межкультурная коммуникация предполагает постоянную готовность человека к восприятию, пониманию и принятию чужих этнических стереотипов поведения, нравов, обычаев, интересов, культурных ценностей, т.е. толерантное отношение к новому, непонятному и неопределенному. Толерантность как компонент социального поведения, способствующий более успешной адаптации человека к неопределенности, является основополагающим принципом социальных отношений. С точки зрения социальной психологии, толерантность можно рассматривать как социальную установку; как отношение личности (включающее отношение к себе, к людям, к своему делу); как причину или следствие защитных механизмов личности; как свойство личности, ее ценностную ориентацию и мировоззрение.

К чертам толерантной личности исследователи относят: расположенность к другим, снисходительность, терпение, чувство юмора, чуткость, доверие, альтруизм, терпимость к различиям, умение владеть собой, доброжелательность, умение не осуждать других, гуманизм, способность слушать, любознательность, способность к сопереживанию. К основным факторам толерантного сознания относят семейное воспитание и условия школьного обучения [14].

Человек с рождения усваивает правила и нормы, определяемые культурной средой, которые в дальнейшем регулируют его поведение. Ценности, установки, социальные нормы обладают адаптивной функцией. Они позволяют личности успешно существовать в рамках своей культуры и порождают чувство сопричастности с ней. Студент, выезжающий учиться за границу, прежде всего сталкивается с проблемой адаптации к новому социокультурному окружению, к иным ценностным ориентациям, традициям, ритуалам, нормам поведения, природным условиям, климату. Поэтому столь важно изучение влияния таких личностных факторов, как принятие себя, принятие других, эмоциональный комфорт, на адаптацию студента в новой социокультурной среде.

Для большинства студентов смена привычной обстановки и переезд в другую страну на время участия в программах студенческой 
мобильности является новой стрессовой ситуацией. Поскольку не всем молодым людям удается быстро адаптироваться к изменившимся условиям, знание своих индивидуально-личностных резервов и умение их подключать помогает им справиться со стрессом в тех случаях, когда они оказываются наиболее уязвимы. Такие качества, как страстность, находчивость, оптимизм, смелость и предприимчивость, уверенность в себе и в своих силах, позволяют лучше адаптироваться к новым социокультурным условиям.

Успешность адаптации предполагает достижение социальной и психологической интеграции с другой культурой без потери богатств собственной. Поэтому актуально научное исследование, посвященное изучению личностных особенностей, влияющих на адаптацию молодых людей, участвующих в программах международного обмена.

Целью исследования являлось изучение влияния личностных факторов студентов, обучающихся за рубежом, на адаптацию к новой социокультурной среде.

Гипотезы исследования. У студентов с такими личностными особенностями, как интернальный локус контроля, готовность к переменам, толерантность к неопределенности, повышается адаптация к новым социокультурным условиям страны прохождения стажировки.

Задачи исследования:

1. Оценить и сравнить особенности адаптации к новым социокультурным условиям и социально-психологической адаптации студентов, участвующих в программах академической мобильности.

2. Оценить и сравнить такие личностные особенности студентов, как готовность к переменам, толерантность к неопределенности и локус контроля.

3. Выявить взаимосвязи между показателями адаптации и личностными особенностями студентов и их влияние на адаптивность.

Выборка исследования. В исследование приняли участие 65 студентов СПбГУ, из них 35 девушек и 30 юношей в возрасте от 18 до 26 лет, участвующих в программах академической мобильности в таких странах, как Германия, Финляндия, Швейцария, Швеция, Голландия, Англия, Эстония, Латвия и США. Продолжительность 
программ студенческого обмена - один или два семестра (нахождение в стране пребывания 2-3 месяца).

\section{Методики и методы исследования}

В процессе проведения исследования изучались следующие показатели: адаптация к новым социокультурным условиям (методика Л. В. Янковского); социально-психологическая адаптация (методика К. Роджерса и Р. Даймонда в адаптации А. К. Осницкого); личностные факторы: готовность к переменам (методика Родник, Хезер, Голд, Хал в адаптации Н. А. Бажанова, Г.Л. Бардиер), толерантность к неопределенности (методика С. Баднер в адаптации Г. У. Солдатова) и локус контроля (методика Дж. Роттера). Для подтверждения степени обоснованности и достоверности результатов исследования были использованы методы математико-статистической обработки данных: сравнительный анализ с использованием критерия Манна - Уитни для выявления достоверности различий между показателями в зависимости от пола респондентов; корреляционный анализ с использованием коэффициента ранговой корреляции Спирмена для выявления взаимосвязей между показателями адаптации и личностными факторами; регрессионный анализ с целью выявления влияния личностных факторов на общий показатель адаптивности студентов.

\section{Результаты исследования и их обсуждение}

Высокий уровень социально-психологической адаптации $(M=149.82 ; \sigma=17.01)$ свидетельствует о том, что студенты из России, попадая в новую социокультурную среду, быстро и активно приспосабливаются к ее условиям, что подтверждается низким показателем по шкале дезадаптивности $(M=62.03 ; \sigma=22.37)$. Высокий разброс по этой шкале характеризуется тем, что у $67 \%$ студентов чрезвычайно низкий показатель дезадаптивности и только у $33 \%$ он в пределах нормы. Ни у одного студента не выявлено показателя с высоким уровнем дезадаптации, что является основанием для успешной социально-психологической адаптации студентов. Высокий показатель приятия себя $(M=46.95 ; \sigma=5.96)$ говорит о приятии обучающимися, понимании ими своих личностных особенностей, 
о их зрелости, самостоятельности и умения оптимально соотнести собственные интересы с интересами группы. Высокий показатель приятия других людей из новой социокультурной среды $(M=27.53$; $\sigma=3.97)$ способствует интеграции их в новое для себя социокультурное общество страны обучения, получении поддержки со стороны других людей, как жителей страны, так и других студентов. Высокий показатель внутреннего контроля $(M=56.32 ; \sigma=6.68)$ характеризует студентов как склонных приписывать результаты своей деятельности внутренним факторам: своим усилиям, собственным положительным и отрицательным качествам, наличию или отсутствию необходимых знаний, умений и навыков. Они считают себя ответственными за состояние своих дел, способными добиваться большего успеха и при этом склонны испытывать чувство вины за события, которые с ними происходят. Низкий показатель эмоционального дискомфорта $(M=10.64 ; \sigma=5.781)$ может свидетельствовать о том, что студенты чувствуют себя спокойно, уверенно в ситуации адаптации к новой среде и редко чем-то обеспокоены или расстроены. Средние показатели ведомости $(M=14.05 ; \sigma=5.01)$ и доминирования $(M=11.43 ; \sigma=6.01)$ находятся на границе с высокими уровнями, что характеризуют обучающихся как самостоятельных, целеустремленных, способных выражать свое собственное мнение и убеждать окружающих в своей правоте, управлять сложившейся ситуацией в собственных интересах. Средний уровень выраженности показателя эскапизма (уход от проблем) $(M=11.28$; $\sigma=3.81)$ свидетельствует о их зрелом подходе к решению сложных жизненный ситуаций, поиску верных решений, активной жизненной позиции. Высокое значение по шкале адаптивность $(M=8.01$; $\sigma=1.49)$ свидетельствует о личной удовлетворенности, положительном отношении обучающихся к окружающим и принятии их, чувствах социальной и физической защищенности, принадлежности к данному обществу и сопричастности с ним. Это можно расценивать как стремление студентов к самореализации, высокому уровню активности и уверенности в отношениях с другими. Высокий уровень интерактивности $(M=6.43 ; \sigma=0.92)$ говорит о принятии студентами новой социокультурной среды; активном вхождении в эту среду; настроенности на расширение социальных связей; чувстве 
уверенности в своих возможностях; критичности к собственному поведению. У них повышается готовность к самопреобразованию; направленность на сотрудничество с другими; контроль над собственным поведением с учетом социальных норм, ролей и социальных установок данного общества; направленность на определенную цель и подчинение себя этой цели. Низкие показатели уровней депрессивности $(M=2.92 ; \sigma=1.59)$ и отчужденности $(M=3.43 ; \sigma=1.63)$ характеризуют обучающихся как уверенных в своих силах, с высокой самооценкой, ориентированных на перспективу и принятием себя и других. Средний уровень показателя ностальгии указывает, что они могут испытывать чувство временного эмоционального смятения при воспоминании о близких людях, привычном круге общения и быте.

Рассмотрим личностные особенности студентов, участвующих в программах академической мобильности. При анализе готовности к переменам было обнаружено, что показатели страстности $(M=21.03 ; \sigma=4.12)$, находчивости $(M=21.05 ; \sigma=4.01)$ и оптимизма $(M=19.92 ; \sigma=2.82)$ находятся на высоком уровне, свидетельствуя о том, что студенты ведут себя энергично, неутомимо, рассматривают сложные ситуации, обращаясь к новым источникам для их решения, верят в себя и свои силы, сохраняют веру в успех, ориентируются только на лучшее развитие событий, сохраняют бодрость духа и не унывают. Высокий показатель уверенности $(M=20.98 ; \sigma=4.29)$ свидетельствует о том, что обучающиеся верят в себя и свои силы. Низкий показатель толерантности к двусмысленности $(M=13.99 ; \sigma=2.89)$ можно объяснить тем, что такие их качества, как страстность, возможности развития и проявления своих способностей и навыков, чрезмерная уверенность в себе, могут побудить студентов действовать вопреки здравому смыслу. Молодые люди, участвующие в программах академической мобильности, характеризуются как интолерантые к неопределенности $(M=69.03$; $\sigma=6.07)$. Высокие значения показателей новизны $(M=21.51 ; \sigma=3.51)$ и неразрешимости проблемы $(M=16.41 \sigma=4.44)$ могут вызывать у студентов сомнения и неспособность быстро принимать решения в напряженных ситуациях, а также проявляться в боязни неудачи. Они склонны воспринимать необычные и сложные ситуации ско- 
рее как угрожающие их успеху, чем дающие новые возможности. Ощущение неуверенности в себе может возникать из-за недостатка информации или ее двусмысленности. При этом обучающиеся стараются сохранить себя в новых условиях и разумно измениться под их влиянием. Поэтому возникающие новые, ранее не встречаемые на родине проблемы могут показаться неразрешимыми.

По локусу контроля показатель интернальности $(M=11.86$; $\sigma=2.34)$ преобладает над показателем экстернальности $(M=11.06$; $\sigma=2.24)$. Студенты оценивают все происходящие с ними значимые события как результат собственной деятельности. Они считают, что могут влиять на события своей жизни, управлять ими и нести ответственность за них и за свою жизнь в целом.

Обнаружены взаимосвязи между показателями адаптации к новым социальным условиям, социально-психологической адаптации и личностными особенностями студентов, участвующих в программах академической мобильности. Показатель адаптации к новым социальным условиям положительно взаимосвязан с личностной готовностью к переменам: страстностью $(r=0.462 ; p<0.01)$, находчивостью $(r=0.475 ; p<0.01)$ и уверенностью $(r=0.502 ; p<0.01)$. Показатель ведомости отрицательно взаимосвязан с показателями страстности $(r=-0.43 ; p<0.05)$, находчивости $(r=-0.48 ; p<0,05)$ и уверенности $(r=-0.32 ; p<0.05)$. Чем больше выражены такие личностные качества, как страстность, находчивость и уверенность, тем более высокий показатель адаптации к новой социокультурной среде. Показатель социально-психологической адаптации положительно взаимосвязан со страстностью $(r=0.42 ; p<0.01)$, находчивостью $(r=0.61 ; p<0.01)$, принятию других $(r=0.51 ; p<0.01)$, уверенностью $(r=0.48 ; p<0.01)$ и интернальностью $(r=0.41 ; p<0.01)$. Из чего мы можем утверждать, что умение находить выходы из сложных ситуаций способствует наилучшей адаптации студентов, участвующих в программах академической мобильности, при взаимодействии с окружающим социумом, а также их активной интеграцией в него. Личностный показатель страстности имеет положительную связь со стремлением к доминированию $(r=0.59 ; p<0.01)$, самовосприятию $(r=0.53 ; p<0.01)$ и эмоциональному комфорту $(r=0.41 ; p<0.01)$. Показатель находчивости имеет положительную связь с показателя- 
ми самовосприятия $(r=0.41 ; p<0.01)$ и эмоционального комфорта $(r=0.57 ; p<0.01)$. Показатель уверенности положительно взаимосвязан с эмоциональным комфортом $(r=0.41 ; p<0.01)$ и самовосприятием $(r=0.35 ; p<0.01)$. Из полученных данных мы можем сделать вывод, что такие личностные факторы, как страстность, находчивость и уверенность, могут рассматриваться как личностный ресурс в преодолении трудных жизненных ситуаций. Энергичность, повышенный жизненный тонус, возможность обращаться к новым источникам для решения возникающих проблем основаны на вере в себя, свои силы и достоинства и способствуют наилучшей адаптации студентов к новой социокультурной среде. Представленные личностные особенности помогают обучающимся оградить себя от стресса в ситуациях, в которых они наиболее уязвимы.

Показатель толерантности к неопределенности имеет положительные взаимосвязи с показателями интернальности $(r=0.35$; $p<0.01)$, принятия других $(r=0.51 ; p<0.01)$, эмоционального комфорта $(r=0,52 ; p<0,01)$ и адаптацией к новым социальным условиям $(r=0.70 ; p<0.01)$. Студенты интолерантны к новым жизненным ситуациям. Чем менее студенты толерантны, тем больше у них выражен внешний локус контроля и непринятия других. Они в незнакомой обстановке чувствуют себя неуверенно, боясь ставить себе новые цели и задачи из-за возможности неуспеха, недостатка информации или ее двусмысленности.

Показатель новизны проблемы имеет положительные корреляционные связи с показателями интернальности $(r=0.47 ; p<0.01)$ и принятия других людей $(r=0.50 ; p<0.01)$. Попадая в новые, ранее не встречавшиеся условия, студенты чаще руководствуются своими убеждениями и мнениями, чем прибегают к помощи окружающих, рассматривая точки зрения других людей.

Показатель сложности проблемы имеет положительные взаимосвязи с показателями эмоционального комфорта $(r=0.48 ; p<0.01)$, социально-психологической адаптацией $(r=0.48 ; p<0.01)$ и адаптацией к новым социальным условиям $(r=0.463 ; p<0.01)$. В трудной ситуации студенты не испытывают дискомфорта, а наоборот, эмоционально мобилизуются для наиболее успешной адаптации к новой социокультурной среде. 
Обнаружены положительные корреляционные взаимосвязи интернальности с социально-психологической адаптацией $(r=0.48$; $p<0.01)$, адаптацией к новым социальным условиям $(r=0.40$; $p<0.01)$ и отрицательные с экстернальностью. Внутренний локус контроля связан с процессом адаптации и непосредственно влияет на ее результат.

Показатель толерантности к двусмысленности положительно взаимосвязан с таким показателем адаптации, как интерактивность $(r=0.38 ; p<0.01)$. Спокойное отношение к отсутствию четких ответов, самообладание и положительные ожидания в трудных ситуациях повышают процесс адаптации студентов к новой социокультурной среде, и они лучше справляются с переменами.

Для выявления личностных факторов адаптации студентов к новой социокультурной среде был проведен регрессионный анализ, по результатам которого были выделены 3 предиктора успешной адаптации, которые представлены в табл. 1.

$\mathrm{R}$-квадрат в модели 3 равен 0.52 и является самым высоким. Это значит, что изменчивость адаптации к новой социокультурной среде на 51 \% обусловлена тремя показателями, которые входят в модель (толерантность к неопределенности, адаптивность и находчивость), коэффициент множественной корреляции $R 0.74$ говорит о высоких взаимосвязях. Данные регрессионного анализа влияния личност-

Таблица 1

Предикторы успешной адаптации

\begin{tabular}{c|c|c|c|c|c}
\hline $\begin{array}{c}\text { Мо- } \\
\text { дель }\end{array}$ & $\mathrm{R}$ & $\begin{array}{c}\text { R-ква- } \\
\text { драт }\end{array}$ & $\begin{array}{c}\text { Скорректи- } \\
\text { рованный } \\
\text { R-квадрат }\end{array}$ & $\begin{array}{c}\text { Стандар- } \\
\text { тизованная } \\
\text { ошибка }\end{array}$ & Дурбин-Уотсон \\
\hline 1 & $0.66 \mathrm{a}$ & 0.44 & 0.42 & 6.64 & - \\
\hline 2 & $0.69 \mathrm{~b}$ & 0.47 & 0.45 & 6.45 & - \\
\hline 3 & $0.74 \mathrm{c}$ & 0.52 & 0.48 & 6.28 & 1.67 \\
\hline
\end{tabular}

Примечание: а - толерантность к неопределенности - личностная черта, помогающая чувствовать себя комфортно в незнакомой ситуации; $\mathrm{b}$ - адаптивность - умение менять свои планы и решения, перестраиваться в новых ситуациях; с - находчивость - умение находить выходы из сложных ситуаций, обращаться к новым источникам для решения новых проблем. 
ных особенностей на адаптацию к новой социокультурной среде представлены в табл. 2.

Из табл. 2 можно увидеть, что стандартные коэффициенты регрессии $\beta$ являются статистически достоверными, что позволяет интерпретировать относительную степень влияния каждого из трех предикторов: для переменной «толерантность к неопределенности» $\beta=0.53$, для переменной «адаптивность» $\beta=0.26$, для переменной «находчивость» $\beta=0.29$. Наибольшее влияние на адаптацию к новой социокультурной среде имеет последняя переменная - находчивость.

Следовательно, чем выше выраженность таких личностных факторов, как находчивость, адаптированность и толерантность к неопределенности, тем выше показатели адаптации к новой социокультурной среде студентов, участвующих в программах академической мобильности, что подтверждает гипотезу исследования.

\section{Выводы}

При оценке особенностей социально-психологической адаптации к новым социальным условиям было установлено, что студенты, участвующие в программах академической мобильности, характеризуются высоким уровнем адаптации. У них выявлен

Таблица 2

Влияние личностных особенностей на адаптацию

\begin{tabular}{l|c|c|c|c|c}
\hline \multirow{2}{*}{ Модель } & \multicolumn{2}{|c|}{$\begin{array}{c}\text { Нестандартизован- } \\
\text { ные коэффициенты }\end{array}$} & $\begin{array}{c}\text { Стандартизо- } \\
\text { ванные коэф- } \\
\text { фициенты }\end{array}$ & \multirow{2}{*}{$t$} & Значение \\
\cline { 2 - 5 } & В & $\begin{array}{c}\text { стандарти- } \\
\text { зованная } \\
\text { ошибка }\end{array}$ & $\beta$ & & \\
\hline 1 (константа) & -6.42 & 12.62 & & -0.51 & 0.618 \\
\hline $\begin{array}{l}\text { Толерантность } \\
\text { к неопределен- } \\
\text { ности }\end{array}$ & 0.81 & 0.22 & 0.53 & 3.72 & 0.001 \\
\hline Адаптивность & 0.53 & 0.21 & 0.26 & 2.41 & 0.020 \\
\hline Находчивость & 0.67 & 0.34 & 0.29 & 1.95 & 0.060 \\
\hline
\end{tabular}


высокий уровень приятия себя и других людей, внутреннего контроля и интерактивности; низкий уровень дезадаптивности и эмоционального дискомфорта. При оценке готовности студентов к переменам установлено, что они обладают такими личностными особенностями, как страстность, уверенность в себе и оптимизм. Обнаружена интолерантность по отношению к новизне и неразрешимости проблемы при интернальном локусе контроля. Выявлены положительные взаимосвязи между показателеми страстности, находчивости, уверенности в себе и адаптивности; отрицательная взаимосвязь между показателями экстернальности и адаптивности. Данная проблема является особенно актуальной в условиях современной глобализации образования и расширения возможностей для российских студентов получать образование за рубежом. С учетом результатов исследования можно разработать индивидуальные рекомендации для студентов, участвующих в программах академической мобильности, и дать рекомендации по развитию качеств личности, способствующих наилучшей адаптации к новой социокультурной среде.

1. Oberg K. Cultural shock: Adjustment to new cultural environments // Practical Anthropology. 1960. Vol. 7, № 4. P. 177-182.

2. Смолина Т. Л. Симптомы культурного шока: обзор и классификация // Психологическая наука и образование. 2012. № 3. С. 1-7.

3. Berry J. W. Immigration, acculturation, and adaptation // Applied Psychology: An International Review. 1997. Vol. 46, № 1. P. 5-34.

4. Triandis H. C. McGraw-Hill series in social psychology. Culture and social behavior. Mcgraw-Hill Book Company, 1994.

5. Kim Y. Y. Becoming Intercultural: An Integrative Theory of Communication and CrossCultural Adaptation. Thousand Oaks : Sage Publications, 2001.

6. Рябкова Е. Л. Социокультурная адаптация международных студентов: разработка теоретической модели // Власть и управление на востоке России. 2018. № 1 (82). С. 134-139.

7. Zhou Y., Jindal-Snape D., Topping K., Todman J. Theoretical models of culture shock and adaptation in international students in higher education // Studies in Higher Education. 2008. Vol. 33. P. 63-75. 
8. Cortazzi M., Jin L. Communication for learning across cultures // Overseas Students in Higher Education / Ed. by D. McNamura, R. Harris. L. : Routledge, 1997. P. 76-90.

9. Bochner S., McLeod B., Lin A. Friendship patterns of overseas stu-dents: A functional model // International Journal of Psychology. 1977. Vol. 12. P. 277297.

10. Троиук И. В., Витковская М. И. Адаптация иностранных студентов в условиях жизни и учебы в России // Вестн. РУДН. Сер. : Социология. 2004. № 6-7. С. 267-283.

11. Столярчук Е.А. Адаптация персонала в организации // Психологическое обеспечение профессиональной деятельности: теория и практика : учебник / под ред. проф. Г. С. Никифорова. СПб. : Речь, 2010.

12. Кузнецов П.С. Концепция социальной адаптации. Саратов : Сарат. ун-т, 2000. $260 \mathrm{c.}$

13. Почебут Л. Г. Кросскультурная и этническая психология : учеб. пособие. СПб. : Питер, 2012. 336 с.

14. Абакумова И. В., Ермаков П.Н. О становлении толерантной личности в поликультурном образовании // Вестн. психологии. 2003. № 3. С. $76-82$. 


\section{ПСИХОЛОГИЧЕСКОЕ БЛАГОПОЛУЧИЕ СТУДЕНТОВ БЕЛАРУСИ}

\section{Г. А. Фофанова}

Студенчество как социальная группа — важнейший потенциал общества. Это подтверждает история, и это наиболее актуально в современности. С одной стороны, от студентов зависит экономическое благополучие страны, так как именно из них формируется интеллектуальная элита, развивающая и предлагающая концепции и идеи развития, создающая новые технологии и, как следствие, выводящая материальное и духовное производство на новый уровень. С другой стороны, от самого общества в целом и его институционализированной части в частности зависит, насколько данный потенциал раскроется и будет реализовывать необходимые для общества и государства задачи. Студент приходит в университет со своим багажом социализации, но именно университет определяет его будущее как профессионала и активного социального субъекта. Поэтому так важно осуществлять регулярный всесторонний мониторинг студенчества (на биологическом, психологическом и социальном уровнях) и предпринимать адекватные меры для оптимального развития каждого субъекта данной социальной группы. Одним из значимых параметров этого мониторинга, на наш взгляд, является психологическое благополучие как субъективная картина собственной жизни, оценка функционирования с точки зрения реализации своих потенциальных возможностей в прошлом, настоящем и будущем.

Исследование психологического благополучия, предполагающее фиксацию внимания на возможностях и потенциале личности, ее эффективном функционировании, связано с появлением позитивной психологии, основная идея которой заключается в констатации необходимости изучения закономерностей благополучной, полноценной жизни человека как самостоятельного объекта психологических исследований без привязки к отклонениям или болезням психики. В научный обиход термин «психологическое благополучие» ввел Н. Брэдберн, который определил его как субъективное ощущение счастья и удовлетворенность жизнью [1]. К. Рифф рас- 
сматривает психологическое благополучие как базовый конструкт, отражающий субъективную оценку человеком своего функционирования с точки зрения его максимальных потенциальных возможностей. Но психологическое благополучие является и интегральным показателем степени направленности человека на реализацию основных компонентов позитивного функционирования, а также степени реализованности этой направленности [2]. К. Рифф была первой, кто осуществил попытку выделить личностные детерминанты благополучного функционирования субъекта. Другими словами, психологическое благополучие - это и наличие у личности определенных «инструментов» (черт), благодаря которым она функционирует более успешно, чем при их отсутствии. К. Рифф выделяет основные составляющие психологического благополучия, определяя и критерии психологического благополучия личности. В структурную модель К. Рифф входят: самопринятие (способность принять свои негативные стороны и слабости одновременно с позитивными сторонами и достоинствами, уверенность, позитивная оценка собственного прошлого); личностный рост (применение и развитие имеющихся навыков, возможностей для развития своего потенциала, открытость накоплению опыта, способность выявлять в окружающем мире вызовы, требующие собственной активности); автономия (независимость и контроль над своей жизнью, здравый нонконформизм, независимость оценки себя, событий и окружения); компетентность в управлении средой (реализация обычных повседневных дел, участие в различных сферах жизни, эффективное применение возможностей окружающего мира); позитивные отношения с окружающими (способность развивать себя, быть эмпатичным и проявлять заботу, доверять людям и формировать близкие отношения с ними); жизненные цели (не только их наличие, но и осознанная регуляция и направленность жизни в сторону их реализации) [3].

По мнению ряда российских авторов, психологическое благополучие личности - это фактор и результат ее саморегуляции, психических состояний, восприятия жизни [4]. А. В. Воронина считает, что психологическое благополучие - обретенное системное качество личности, отражающее ее внутреннюю целостность, это ее согласие 
с самой собой, при этом «психическое здоровье» и «психологическое здоровье» личности являются уровнями психологического благополучия $[5,6]$. Психологическое благополучие рассматривается также и в контексте проблемы качества жизни, которое, как отмечает И.А. Джидарьян [7], психологически обусловлено настолько, что многие авторы предпочитают определять его как внутреннюю удовлетворенность или чувство субъективного благополучия, поэтому трудно понять, направлена работа на исследование качества жизни или посвящена психологии счастья и благополучия.

Другая тенденция в изучении психологического благополучия заключается в его понятийном обособлении от других терминов, которые находятся в близком смысловом поле, но не являются ему тождественными. Наиболее близким к термину «психологическое благополучие» и практически синонимичным ему понятием является «субъективное благополучие». Но разделение этих понятий и по сей день является дискуссионным. Одни исследователи рассматривают субъективное благополучие как составляющую психологического, другие - психологическое благополучие понимают как часть субъективного. В отдельных работах данные понятия трактуются как синонимичные. Но чаще эти понятия рассматриваются как взаимодополняющие показатели позитивного функционирования человека [8].

Значим вклад в разработку содержания данного понятия как самостоятельного российских исследователей П. П. Фесенко и Т. Д. Шевеленковой, которые выделяют актуальное психологическое благополучие (степень реализованности основных компонентов позитивного функционирования) и идеальное психологическое благополучие (степень направленности на реализацию компонентов позитивного функционирования). Кроме того, авторы вводят понятие уровня психологического благополучия. Низкому уровню актуального психологического благополучия соответствует преобладающий негативный аффект (ощущение неудовлетворенности собственной жизнью, несчастливость). При высоком и нормативном уровне психологического благополучия преобладает позитивный аффект (удовлетворенность собственной жизнью, счастье) [Там же].

Необходимо также отметить, что психологическое благополучие личности имеет свои особенности на каждом этапе возрастного 
развития. Так, например, О.А. Идобаева отмечает, что специфика психологического благополучия, присущая каждому возрасту, определяется достаточно или недостаточно развитыми психологическими новообразованиями, соответствующими возрасту, и характерной для данного возраста ведущей деятельностью; а также специфичной для каждого возраста социальной ситуацией развития, индивидуально-психологическими особенностями, эмоциональным состоянием и механизмами психологической защиты [9]. Ведущим индикатором психологического благополучия подростка, по ее мнению, является эмоциональное благополучие, детерминированное особенностями детско-родительских отношений, и уровень коммуникативной компетентности подростков. Психологическое благополучие в старшем юношеском возрасте зависит от уровня сформированности главных новообразований возраста: ориентировки в особенностях собственной индивидуальности, умения строить жизненные планы, определения профессиональных перспектив (и уровня сформированности профессиональной идентичности), а также от возможности реализации социальных активностей. В зрелом возрасте предиктором психологического благополучия становится самоактуализация и удовлетворение других ведущих потребностей данного возраста, быстрота реакции на ситуативные изменения, активность в реализации своих целей, ценностей, убеждений [Там же].

Таким образом, можно говорить о тенденции понимания содержания психологического благополучия как гармоничности личности, ее целостности, которые зависят от наличия ясных целей, ресурсов для достижения целей, успешности в реализации своих планов, удовлетворенности межличностными отношениями, наличия положительных эмоций. Психологическое благополучие рассматривается либо как интегративное личностное относительно устойчивое образование, либо как один из иерархических уровней общего благополучия человека.

Особый интерес исследователей вызывает процесс личностных изменений студентов в период обучения в учреждениях высшего образования, а также возможность оптимизации уровня психологического благополучия за счет актуализации социально- 
психологических феноменов, имеющих место в процессе профессионального становления. Многое в учебной деятельности и в переживании студентами своего благополучия зависит и от того, как они воспринимают и интерпретируют учебные ситуации [10]. Не стоит забывать и о высокой потребности студентов в социальной активности, значимости для них общественных и политических событий, экономической составляющей социальной и бытовой жизни. Значительная часть студентов начинают самостоятельную жизнь с самообслуживания, планирования расходов, поиска профессиональной занятости (или ее реализации), которые необходимо совмещать с жизнью в университете. Студенты, которые продолжают жить в родительской семье, так или иначе также оказываются вовлечены в решение схожих задач, кроме того, осуществляют сравнение содержания и качества своей жизни с жизнью студентов из первой группы. Таким образом, данный этап социализации характеризуется целым спектром вызовов, оказывающих существенное влияние на психологическое благополучие студентов.

В нашем эмпирическом исследовании мы будем понимать под психологическим благополучием актуальное переживание, отражающее восприятие и оценку человеком своего функционирования с точки зрения использования потенциальных возможностей в перспективе и ретроспективе. Целью исследования явилась не попытка концептуализировать феномен заново, а, основываясь на существующих концепциях и используя имеющийся инструментарий, определить психологическое благополучие студентов, обучающихся в различных городах Беларуси, с последующей разработкой определенных практических рекомендаций. В эмпирическом исследовании, проведенном совместно с Е. В. Гаврильчик, приняло участие 150 студентов (65 юношей и 85девушек) 1-5-х курсов университетов различных специальностей из Минска, Гродно и Новополоцка. Применялись следующие методики исследования: 1) шкала психологического благополучия К. Рифф в адаптации П.П. Фесенко, Т.Д. Шевеленковой; 2) анкета, содержащая вопросы, касающиеся курса обучения, города проживания, пола и т. п.

В исследовании психологического благополучия студентов Беларуси были получены следующие результаты. 
У 24,6 \% студентов был выявлен высокий уровень психологического благополучия, связанный с преобладанием позитивного аффекта (ощущением удовлетворенности собственной жизнью, счастья). Такие студенты отличаются позитивным отношением к себе и миру, у них преобладают разные по интенсивности и содержанию позитивные переживания. Полученные результаты свидетельствуют об умеренном эмоциональном комфорте этой части опрошенных студентов: они не испытывают серьезных эмоциональных проблем, достаточно уверены в себе, активны, успешно взаимодействуют с окружающими, адекватно управляют своим поведением. У 12,6 \% студентов был выявлен низкий уровень психологического благополучия, свидетельствующий об их склонности к депрессии и тревогам, пессимизму, замкнутости, зависимости и о плохой переносимости ими стрессовых ситуаций. У студентов с низким уровнем психологического благополучия возможно наличие комплекса неполноценности, неудовлетворенности собой и своим положением, лишенности доверия к окружающим и надежды на будущее. Это может быть объяснено тем, что сложность современной социальнополитической и социально-экономической ситуации особенно сильно влияет на студентов. Следует отметить, что наиболее выраженные переживания в данной социальной группе связаны с процессом адаптации к учебно-профессиональной деятельности, что может отражаться на переживаниеи ими психологического благополучия. У 48,6 \% студентов был выявлен средний уровень психологического благополучия, что свидетельствует об отсутствии у них серьезных психологических проблем, однако нельзя говорить и о полном эмоциональном комфорте. Такие студенты активны, адаптивно взаимодействуют с окружающими, адекватно управляют своим поведением, эффективно действуют в условиях стресса, получаемые результаты способствуют улучшению их психологического благополучия, которое, в свою очередь, способствует большей успешности в повседневной активности. Полученные нами результаты в целом подтверждаются результатами исследования Л.Е. Тарасовой [11]. Среди факторов, потенциально влияющих на психологическое благополучие студентов, можно назвать некоторые психологические проблемы, связанные с учебно-профессиональной деятельностью, 
например, отсутствие или недостаток материальных средств у студентов, обучающихся на платной основе, ожидаемые трудности трудоустройства в процессе или после окончания учебного заведения, смена места жительства и др.

В результате проведенного исследования также были обнаружены статистически значимые различия $(p<0,01)$ по шкале «автономия» у студентов 1-х и 4-5-х курсов. Студенты старших курсов отличаются большей независимостью и самостоятельностью, они способны противостоять социальным нормам, неприемлемым для них, быть менее зависимыми от общественного мнения; они более самостоятельно регулируют собственное поведение; оценивают себя в соответствии с личными критериями и стандартами. Студенты же 1-го курса в большей степени зависят от мнения и оценки окружающих; в принятии важных решений полагаются на мнение других; находятся в процессе адаптации к новой социальной и экономической среде. Безусловно, данные результаты ожидаемы и естественны в силу возникающей у первокурсников необходимости отыскивать ресурсы для адаптации к новой среде, повышения тревожности из-за смены социальной ситуации, поиска и появления у них новых авторитетов. Однако данные результаты как раз и показывают, что психологическое сопровождение студентов первого курса со стороны специальных служб и институтов университета недостаточно. Вероятно, методы работы, применяемые университетскими психологическими службами, кураторами из числа профессорско-преподавательского состава и студентов старших курсов, осуществляющими сопровождение каждой студенческой группы 1-го курса, а также совокупность проводимых мероприятий не в полной мере адекватны актуальным потребностям студентов. На наш взгляд, работа со студентами не должна воспроизводить паттерны, присущие школам. На настоящий момент кураторы воспроизводят деятельность классных руководителей, а работа психологической службы схожа с работой школьного психолога, когда у сотрудников фактически есть возможность проводить только экспресс-диагностику, а не полноценное сопровождение. В университете, на наш взгляд, деятельность данных институтов должна быть направлена на интенсификацию развития самостоятельности, 
выработку компетенций, связанных с гибкостью мышления, критичностью, работой в команде, способствовать формированию навыков управления и самоуправления.

Это предположение подтверждается следующими результатами. Выявлены статистически значимые различия $(p<0,01)$ по шкале «управление окружением» у студентов 1-х и 4-5-х курсов. Студенты 4-5-х курсов в большей степени обладают властью и компетенцией в управлении окружением, контролируют внешнюю деятельность, эффективно используют предоставляющиеся возможности. Они способны улавливать или создавать условия и обстоятельства, подходящие для удовлетворения личных потребностей и достижения целей. Студенты же 1-го курса, как правило, испытывают сложности в организации повседневной деятельности, чувствуют себя неспособными изменить или улучшить складывающиеся обстоятельства, менее рассудительны в отношении предоставляющихся им возможностей, а также лишены чувства контроля над происходящим вокруг. На наш взгляд, это также связано с процессом адаптации к новой социальной и учебной среде: студенты 1-го курса сталкиваются с непривычными для них методами и формами обучения, новыми эмоциональными переживаниями, новыми социальными отношениями и требованиями, у них меняется режим труда/учебы/отдыха, усложняются межличностные отношения, возникают проблемы в связи с оторванностью (или наоборот - избыточной привязанностью) от родительской семьи.

Также были обнаружены статистически значимые различия $(p<0,01)$ по шкале «позитивные отношения с окружением» у юношей и девушек. Девушки в большей степени склоны иметь удовлетворительные, доверительные отношения с окружающими, они больше заботятся о благополучии других, способны сопереживать, у них чаще возникают привязанности и близкие отношения. Юноши же имеют ограниченное количество доверительных контактов с окружающими, склонны в меньшей степени проявлять заботу о их благополучии. Такие особенности подтверждаются и результатами исследования Е. Ю. Григоренко [12] и, на наш взгляд, связаны с развитием гендерной идентичности и углублением в гендерные роли в новых социальных условиях. Традиционная женская роль пред- 
полагает тесную эмоциональную связь с окружением (как в детскородительских отношениях, так и социальных, и романтических), поэтому переход на следующую ступень социализации не вызывает необходимости смены данной ориентации, более того, предполагается ее углубление в связи с актуализирующейся потребностью создания семьи (вне зависимости от степени ее формализации). Перед юношами же стоит новая задача: стать более независимыми от родительской семьи, что предполагает в определенной степени разрыв эмоциональной связи (по крайней мере, на первых порах становления автономности), потенциальные конфликты с окружением в борьбе за свою самостоятельность. Кроме того, юноши находятся под достаточно сильным давлением от ожиданий окружающих (родителей, возлюбленных и друзей) их большей финансовой состоятельности. Таким образом, юноши в силу социальнопсихологических причин менее психологически благополучны в этот период, чем девушки.

Статистически значимых различий в общем уровне психологического благополучия и по частным шкалам у студентов из различных городов выявлено не было, что может быть связано, с одной стороны, с влиянием на психологическое благополучие более глубинных факторов, а не места жительства, например, личностных особенностей, способности к адаптации, межличностной компетентности, а с другой - с вовлеченностью в учебный процесс и необходимостью отвечать на вызовы, связанные с получением высшего образования. Отчасти эти результаты идут вразрез с распространенным мнением, что жители крупных и малых городов различаются по показателям психологического благополучия.

Полученные результаты позволяют сделать определенные практические выводы. В целом можно говорить о достаточно хороших показателях психологического благополучия студентов Беларуси. Однако психологическое благополучие студентов первого курса вызывает определенную тревогу, поскольку именно у этой группы студентов выявлен невысокий уровень психологического благополучия по шкалам «автономия» и «управление окружением». Безусловно, такие результаты могут быть обусловлены самой социальной ситуацией студентов, стоящей перед ними необходимостью адап- 
тации к новым учебным, бытовым, экономическим и социальным условиям. Ситуация во многом может быть связана и с определенным разочарованием студентов в выбранной специальности. Это происходит по нескольким причинам. Во-первых, многие студенты выбирают специальность, не основываясь на своих склонностях, а ориентируясь на сумму баллов за централизованное тестирование и при получении диплома о среднем образовании, а также на проходные баллы на те или иные специальности. Поскольку перечень вступительных дисциплин на многие специальности схож, студент (или его родители) принимает решение в пользу специальности, прохождение по конкурсу на которую наиболее вероятно. К сожалению, не всегда такой выбор делается в пользу склонностей и искреннего интереса к профессии. Во-вторых, даже в случае поступления на изначально выбранную специальность у многих студентов достаточно стереотипные, а порой существенно искаженные представления о ней. Так, например, студенты-психологи первого курса искренне не понимают, как психология связана со статистикой или философией, а студенты-программисты - зачем им физика или общая теория систем. Отчасти это может быть связано с недостаточной профориентационной работой в школе и на уровне средств массовой информации. О «модных» профессиях говорят много, но не показывают нюансы и изнанку. Много говорится о «профессиях будущего» и необходимых для них компетенциях, но это опять-таки перечень «модных профессий». О «немодных», но нужных профессиях (сельскохозяйственных, например) в медийном пространстве информации практически нет либо она представлена скупо и тенденциозно: благородные профессии педагога и врача в ореоле нищеты и бесправия в лучшем случае. Другими словами, транслируются стереотипы и оценки либо не транслируется ничего, содержательная сторона профессий остается за кадром.

Однако следует отметить, что имеются и определенные положительные тенденции к изменениям в сфере профориентации: многие работодатели осознают, что им нужны «просвещенные» и мотивированные молодые кадры, они организовывают встречи со школьниками и студентами как в онлайн-, так и офлайн-пространстве, проводят различные кейс-чемпионаты и другие мероприятия с за- 
даниями, максимально приближенными к повседневной профессиональной практике и на приемлемом уровне доступности для обучающихся. Учреждения высшего образования стали также активнее и разнообразнее сотрудничать со школами (например, проект Белорусского государственного университета «Студент на неделю» дает возможность школьникам во время каникул посещать занятия по выбранной специальности в университете). Однако, к сожалению, данные мероприятия еще не имеют массового характера, и потому эффект от них нельзя назвать значительным. Третья причина разочарования студентов - сами учебные планы, по которым они учатся на младших курсах. На настоящий момент студенты Беларуси обучаются по учебным планам 2013/14 уч. г., которые были разработаны при переходе высшего образования с пятилетнего на четырехлетнее обучение. За прошедшие годы накопилось немало нареканий и на структуру, и на содержание данных учебных планов. Основной жалобой со стороны студентов младших курсов является то, что первые годы обучения они осваивают в основном общие дисциплины, а доля дисциплин, непосредственно связанных с профессией, минимальна (она существенно увеличивается на старших курсах). Студенты также считают, что непрофильные дисциплины им вовсе не нужны. С данным мнением мы не можем полностью согласиться. Во-первых, общие дисциплины (например, философия, экономика, психология, социология) составляют фундаментальную основу высшего образования, с одной стороны, и формируют общекультурный уровень специалиста с высшим образование - с другой. Специалист с высшим образованием должен понимать, что происходит с экономикой, разбираться в социальных процессах и иметь высокую психологическую культуру. Это позволит ему также расширить свои возможности для профессиональной деятельности, уметь лучше находить общий язык со специалистами смежных или иных областей деятельности. Во-вторых, уже сегодня очевидно, что перечень «чистых» профессий стремительно сужается, все чаще для успешной реализации профессиональных задач необходимы знания из других областей. Так, например, программисту, работающему над программным обеспечением химической лаборатории, необходимы знания по химии; инженеру бывают весьма 
полезны знания анатомии, журналисту совершенно необходимы знания психологии и социологии вне зависимости от профилизации деятельности. Сегодня уже очевидно, что залог дальнейшего развития техники и технологий в междисциплинарности, в межпредметных связях, во взаимном обогащении наук. Об этом говорят на научных конференциях и пишут в научных журналах. Но в школьной программе и в распространенных среди школьников информационных ресурсах это практически не представлено. Безусловно, студенты со временем отчасти понимают и осознают, зачем им общие дисциплины, но студенты младших курсов сложно переживают их обилие, так как не понимают, наличие знаний из каких предметных областей предполагает их будущая профессия, что усугубляется факторами, описанными выше. Все это свидетельствует о недостаточности у студентов ресурсов для успешной реализации актуальных для них на данном этапе задач. Разработанный учреждениями высшего образования для данной группы студентов комплекс мероприятий сопровождения мы считаем недостаточным и не в полной мере адекватным с точки зрения содержательного наполнения. Безусловно, значимыми мерами по изменению сложившейся ситуации являются изменение учебных планов с более взвешенными долями общих и специальных дисциплин на каждом курсе обучения, с обязательным наличием дисциплины «Введение в профессию» на первом курсе. Немаловажным является усиление и содержательное разнообразие профориентационной работы всеми заинтересованными сторонами. И, на наш взгляд, следует усилить собственно психологическое сопровождение обучающихся. Усиление данного сопровождения необходимо начинать даже не с учреждений высшего образования, а еще со «школьной скамьи», создавая целостную систему и формируя психологическую культуру обучающихся. Но данная система должна основываться на актуальной информации о текущем физическом, психологическом и социальном состоянии студентов. В последние же десять лет в Беларуси не было проведено ни одного республиканского мониторингового исследования психического и физического статуса обучающихся, которое включало бы оценку их интеллектуальных, эмоциональных, мотивационных, поведенческих и физических возможностей. 
Отсутствие такой информации существенно затрудняет принятие оперативных и релевантных решений как по текущим вопросам, так и по реформированию и внедрению инновационных технологий в процесс обучения и воспитания современных детей и подростков в целом. Кроме того, нынешний объем задач, который стоит перед педагогом-психологом, работающим в школе, может быть успешно реализован только в условиях небольшой численности учеников. По действующим нормативам численности работников учреждений образования увеличение ставки педагогов-психологов предполагается только при численности учеников свыше пятисот (полторы ставки), две ставки - при 851 ученике и больше и, наконец, при наличии 1400 и более обучающихся дополнительно вводится по 0,5 штатной единицы на каждые последующие 250 обучающихся. Еще более сложная ситуация обстоит в учреждениях высшего образования. Так, например, численность штатных сотрудников психологической службы Белорусского государственного университета составляет семнадцать человек, в то время как численность студентов - около 15 тыс. Понятно, что о полноценном психологическом сопровождении в таких условиях речь идти не может.

На наш взгляд, полноценное сопровождение учащихся в школе возможно при соотношении не менее одной ставки специалиста на двести учащихся. Кроме того, мы считаем необходимым переименовать должность «педагога-психолога» на «школьного психолога». В нынешнем названии психологическая составляющая играет второстепенную роль, в то время как реальная практика и содержание должностных обязанностей психолога, работающего в учреждениях общего среднего образования, состоит из психологических видов деятельности (психологическая диагностика, психологическая профилактика, психологическая помощь и т.д.) и соответствует компетенциям специалиста с квалификацией «психолог». Как следствие, требуется и корректировка квалификационных требований к должности «педагог-психолог» (при переименовании, о котором писалось выше), согласно которым на данной должности может работать специалист только с высшим психологическим образованием.

Что касается численности сотрудников психологических служб университета, то, на наш взгляд, соотношение должно быть не ме- 
нее одной ставки психолога на триста студентов дневной формы обучения. Уменьшение «психологической доли» связано с меньшей формальной регламентацией деятельности психологических служб в университете со стороны государства (на настоящий момент количество психодиагностических срезов в школе достаточно велико, что снижает возможности реализации остальных видов работ консультирования, групповых тренингов и т. д.). Территориально кабинеты психологической помощи необходимы в каждом учебном корпусе (в случае широкой пространственной дифференциации университета), особенно в условиях больших городов. Так, например, психологическая служба Белорусского государственного университета располагается в трех точках Минска. На первый взгляд это решение кажется удачным, так как точки (центры) размещены недалеко от основных корпусов общежитий (или в зданиях самих общежитий). Однако это может быть удобным для студентов, в них проживающих, но не для студентов-жителей этих городов или снимающих жилье в других районах. В условиях значительной учебной занятости (а у некоторых еще и трудовой) высвободить или найти время, чтобы добраться до психолога (даже в случае осознанной потребности), для студентов становится дополнительным препятствием, которое усугубляется режимом работы самой психологической службы. Внесение соответствующих изменений в организацию работы позволит психологической службе университета с содержательной точки зрения в полной мере реализовывать все те направления, которые заявлены в Положении о ней. А это: психологическая диагностика первокурсников на предмет социально-психологической адаптации, психологического благополучия, личностных особенностей, диагностика коллектива и т.д. (по специальным запросам - диагностика и студентов остальных курсов); индивидуальное консультирование (в кризисных ситуациях, по вопросам профессионального самоопределения и т. д.); проведение групповых тренингов на развитие различных психологических компетенций, необходимых для реализации учебной и трудовой деятельности, улучшения межличностных отношений и т.д. Кроме того, сотрудники психологической службы могли бы существенно усилить подготовку и реализацию общественных мероприятий, 
проводимых различными объединениями университета, участвуя в разработке их содержания, актуализируя психологические методы и приемы, учитывающие психологические особенности самого студента, и развивая необходимые для личностного и профессионального развития знания, умения и навыки.

Таким образом, очертим основные направления работы, которые потенциально могут повысить психологическое благополучие студентов Беларуси. Во-первых, усиление и содержательное расширение направлений профориентационной работы со школьниками и студентами. Это позволит развивать профессионально значимые склонности и умения еще со школьной скамьи и формировать более целостный и адекватный образ будущей профессии, причем не только той, которую учащийся выберет в качестве ориентира своего профессионального будущего, но и остальных, что позволит формировать более адекватную картину профессионального мира и, как следствие, адекватные ожидания от специалистов других областей, более эффективную коммуникацию с ними. Вовторых, изменение учебных планов учреждений высшего образования и корректировка содержания образования в средней школе (с усилением междисциплинарного компонента). Последнее будет наиболее полно отражать современную научную и технологическую картину мира у школьников, а более сбалансированная система общих и специальных дисциплин в университете позволит, с одной стороны, формировать специалиста с фундаментальными знаниями, навыками и умениями, а с другой стороны - у студентов уже с первого курса будут формироваться специальные компетенции, необходимые для реализации себя в профессии. В-третьих, усиление психологического сопровождения учащихся школ и университетов за счет формальных и содержательных трансформаций. Реализация предложений по психологическому сопровождению учащихся школ, на наш взгляд, позволит школьным психологам выполнять возложенные на них обязанности в полном объеме и с должным содержанием, не ограничиваясь проведением обязательной психологической диагностики и написанием планов и отчетов, как зачастую происходит в настоящий момент по объективным обстоятельствам. Такая психологическая практика в школе позволит 
не только определять среди учащихся группы риска и обеспечивать работу с ними по особой программе, но и, например, развивать необходимые для успешной адаптации и самореализации навыки у учащихся различных возрастов, реализуя и профилактическую, и развивающую составляющие деятельности психолога. Это, в свою очередь, поможет сформировать психологическую грамотность и культуру учащегося, выработать адекватную установку на обращение за психологической помощью в затруднительных ситуациях (которая, к сожалению, на настоящий момент представлена еще очень слабо). Когда учащийся с таким опытом переходит на следующую ступень социализации, он будет обладать большими ресурсами (как минимум на уровне знаний) для совладания с затруднительными ситуациями, будет адекватно относиться к психологической помощи (в отличие от нынешних распространенных стереотипов в отношении субъектов, за ней обращающихся). Таким образом, предлагаемый комплекс мероприятий может сыграть существенную роль в повышении уровня психологического благополучия не только учащихся учреждений высшего образования, но в перспективе - работающих взрослых людей. Описанные нами предложения, безусловно, основаны на результатах не только локального эмпирического исследования, направленного на определение психологического благополучия студентов, но и длительной практики взаимодействия с ними, анализе исследований коллег. Мы не претендуем на полноту освещения проблемы и приглашаем заинтересованную общественность к обсуждению.

1. Bradburn N.M. The structure of psychological well-being. Chicago : Aldine, 1969. $332 \mathrm{p}$.

2. Ryff C. D. Psychological Well-Being // Encyclopedia of Gerontology. 1996. Vol. 2. P. 365-369.

3. Ryff C. D., Keyes C. L.M. The structure of psychological well-being revisited // Journal of Personality and Social Psychology. 1995. Vol. 69. P. 719-727.

4. Батурин Н. А., Башкатов Н. А., Габарова Н. В. Теоретическая модель личностного благополучия // Вестн. ЮУрГУ. Сер. : Психология. 2013. Т. 6, № 4. C. 4-14. 
5. Воронина А. В. Оценка психологического благополучия школьников в системе профилактической и коррекционной работы психологической службы : автореф. дис. ... канд. психол. наук. Томск, 2002. 25 с.

6. Воронина А. В. Проблема психологического здоровья и благополучия человека: обзор концепций и опыт структурно-уровневого анализа // Сиб. психол. журн. 2005. № 3. С. 142-145.

7. Джидарьян И.А. Психология счастья и оптимизма. М. : Изд-во «Институт психологии РАН», 2013. 268 с.

8. Шевеленкова Т. Д., Фесенко П. П. Психологическое благополучие личности (обзор концепций и методика исследования) // Психологическая диагностика. 2005. № 3. С. 95-129.

9. Идобаева О.А. Психолого-педагогическая модель формирования психологического благополучия личности : автореф. дис. ... д-ра психол. наук. М., 2013.

10. Лесовская М. И., Лесовская Л. В. Удовлетворенность процессом обучения в вузе как прогноз удовлетворенности будущей работой // Междунар. журн. прикладных и фундаментальных исслед. 2012. № 3. С. 53-56.

11. Тарасова Л. Н. Психологическое благополучие студентов на этапе адаптации к образовательной среде вуза // Изв. Сарат. ун-та. Новая серия. Сер. : Акмеология образования. Психология развития. 2014. Т. 3, № 4 (12). C. 358-362.

12. Григоренко Е. Ю. Психологическое благополучие студентов и определяющие его факторы // Проблемы развития территории. 2009. Вып. 2(48), окт. - дек. С. 98-105. 


\section{АКТИВНАЯ ЖИЗНЕННАЯ ПОЗИЦИЯ КАК ФАКТОР ПСИХОЛОГИЧЕСКОГО БЛАГОПОЛУЧИЯ СТУДЕНТОВ}

Е.А. Хохолева

С. Д. Липатова

Проблема формирования активной жизненной позиции всегда была актуальной в нашей стране. Однако если в XX в. она должна была проявляться в общественно-политической жизни, то в современном мире «...в центре личностно-ориентированного подхода стоит личность и ее интересы, активная жизненная позиция становится необходимой для успешной самореализации личности. Она является отражением психологического благополучия современной личности. Психологическое благополучие выступает как интегральное понятие, обобщенный показатель степени направленности человека на реализацию целей и личностный рост, управление средой и формирование доброжелательных отношений с окружающими, самопринятие и автономию» [1, с. 103].

Становится актуальным вопрос формирования активной жизненной позиции в новых социально-экономических условиях. В силу произошедших в стране изменений за последние 30 лет многие прежде найденные механизмы потеряли возможность осуществления [2].

Таким образом, встала необходимость рассмотреть современные виды и формы проявления жизненной позиции студентов, а также определить методы ее формирования в условиях вуза.

Цели данного исследования: 1) определить виды и формы проявления жизненных позиций студентов вуза как фактор психологического благополучия; 2) экспериментально доказать возможность развития активной жизненной позиции в условиях образовательной среды с использованием активных методов обучения.

Жизненная позиция, по мнению Г. М. Коджаспировой, - это «...внутренняя установка, обусловленная мировоззренческими, моральными и психологическими качествами личности и отражающая ее субъективное отношение к обществу. Жизненная позиция проявляется в реальном поведении человека, может быть активной 
(постоянное стремление изменить окружающую действительность) и пассивной (следование установившимся традициям и нормам)» [3].

Активная жизненная позиция может проявляться как активнопозитивная либо как активно-негативная. Это зависит от моральных качеств и психологических особенностей личности: мировоззрения, самопознания, самоопределения, стремления к коллективности и дружескому общению и многих других характеристик.

Авторы работы придерживаются следующих концептуальных положений:

- Жизненную позицию личности можно разделить на четыре вида: пассивно-негативная, пассивно-равнодушная, активнопозитивная, активно-негативная.

- Активная жизненная позиция проявляется и формируется не только во внеучебной и в образовательной деятельности.

- Активная жизненная позиция может проявляться как в позитивном, так и в негативном плане. При активно-позитивной позиции человек интересуется всем происходящим в стране и в мире, принимает живое участие в любых начинаниях, хочет внести определенный вклад в окружающую его действительность. Он может справиться со всеми трудностями, быстро найти решения всевозможных вопросов. Такой человек инициативен, ответственен, принимает активное участие в жизни коллектива, старается быть в центре событий, ориентироваться в ситуации.

- Активно-негативная жизненная позиция выражается в пренебрежении общественными нормами, поиске собственного Я вне социума в различных группировках. Это может быть и стремление построить собственную действительность. К примеру, человек не принимает нормы социума, имеет свое представление о том, каким должен быть мир, активно привлекает других людей для усовершенствования бытия. Такой человек может отстаивать свои позиции через ссоры и драки. Его поведение и установки направлены на антисоциальные действия, противостояние сложившемуся социальному укладу.

- Антиподом активности является пассивность. Пассивная жизненная позиция подразделяется на пассивно-негативную и пассивно-равнодушную. 
- Пассивно-негативная жизненная позиция характерна для людей, которых не устраивает существующая действительность, однако они не представляют себе, как ее можно изменить. У них появляется негативизм, нонконформизм. В некоторых случаях такие люди оценивают себя как жертву или неудачника, а окружающий мир воспринимают как враждебный, глупый, деградирующий. В своих жизненных неудачах они обвиняют внешние обстоятельства. Собственных идей по улучшению жизненной ситуации у них нет, а если есть, то они не собираются их реализовывать.

- Пассивно-равнодушная жизненная позиция проявляется в стремлении не менять свою жизнь, круг общения и интересы, полагаться на волю случая. Такие люди снимают с себя большую часть ответственности, предоставляя многие важные решения государству, значимым людям или вышестоящему руководству. Они практически лишены лидерских качеств, безынициативны. В условиях меняющейся внешней среды они теряются и ведут себя пассивно, проявляя равнодушие и отстраненность.

- Активно-позитивная жизненная позиция является основой формирования психологического благополучия человека.

- Активно-негативная, пассивно-негативная и пассивно-равнодушная жизненные позиции являются факторами, препятствующими психологическому благополучию.

- Формы проявления активной жизненной позиции молодых людей: образовательная, культурно-досуговая, помощь социально незащищенным группам граждан, участие в социально значимых проектах, защита окружающей среды, волонтерство, политическая активность, общественно значимые мероприятия (акции, митинги, шествия, демонстрации).

Мировоззрение личности переходит в активную фазу формирования в студенческие годы, в это время ярко проявляется потребность устанавливать причинно-следственные связи, анализировать и обобщать явления и факты общественной жизни.

Активная жизненная позиция начинает формироваться в юношеском возрасте и в студенческие годы может проявиться как в позитивной, так и в негативной форме. «С одной стороны, общество накопило огромный духовно-нравственный опыт, получило широ- 
кое признание идеи гуманизма, добра и справедливости. С другой стороны, отсутствие нравственного компаса и моделей поведения привело к явлениям дегуманизации и безнравственности в современном обществе, амбивалентности нравственных взглядов, бессмысленности внутреннего мира человека» [4, с. 215]. Эти факторы формируют психологическое недовольство собой и миром.

Анализируя сознание и систему ценностей современной молодежи, Ф.А. Игебаева описывает следующие факторы:

«- возросший уровень образованности и недостаточную согласованность социального и личностного смысла образования;

- признание молодежью социальной значимости участия в общественной жизни и стремление самоутвердиться в непроизводственной сфере, главным образом в сфере досуга;

- приоритет потребительских ориентаций над творческими, созидательными;

- вытеснение ценностей национальной культуры западными образцами поведения и символами;

- слабая индивидуализированность и избирательность культуры, связанная с диктатом групповых стереотипов» [5, с. 47-48].

Для формирования активно-позитивной жизненной позиции необходимо, с одной стороны, учитывать возрастные особенности студенчества, с другой стороны, создавать условия для снижения потребительских наклонностей и эгоцентризма у студентов.

Современные молодые люди относятся критично к окружающему миру, свою свободу некоторые из них понимают как неотъемлемое право игнорировать общественные интересы в угоду собственным желаниям. Многие предпочитают находиться в виртуальном мире - там они герои, лидеры. В реальности быть такими намного сложнее, отсюда появляется замкнутость, неприятие существующей действительности. Сегодня как никогда необходимо развивать у молодежи умение и желание общаться, уверенность в себе, инициативность, ответственность за себя и других людей.

В большинстве публикаций $[2,6-9,11]$ авторы предлагают формировать активную жизненную позицию студентов через внеучебные мероприятия. Мы предлагаем расширить сферу влияния 
и ввести в образовательную среду вуза активные методы обучения для решения этой задачи.

\section{Организация и методы исследования}

Этап 1:1) психодиагностика преобладающих видов жизненной позиции у студентов, направленная на выявление степени выраженности пассивно-негативной, пассивно-равнодушной, активнопозитивной и активно-негативной жизненной позиции (опросник «Виды жизненной позиции», автор С. Д. Липатова); 2) анкетирование, направленное на выявление отношения студентов к активной жизненной позиции и выявление доминирующих видов деятельности (анкета «Активная жизненная позиция», автор Е. А. Хохолева).

Этап 2: проведение формирующего эксперимента. Цель - формирование активно-позитивной жизненной позиции студентов посредством использования активных методов обучения: групповая дискуссия, кейс-стади, командная и проектная работа, мозговой штурм.

Этап 3: анализ изменения жизненной позиции после коррекции.

Цель - сопоставление результатов уровня активно-позитивной жизненной позиции до и после коррекции с применением Т-критерия Вилкоксона.

В исследовании принимали участие студенты и магистранты УрФУ в возрасте от 19 до 23 лет в количестве 64 человека.

\section{Результаты исследования}

Психодиагностика преобладающих видов жизненной позиции у студентов показала, что у них преобладает ситуационное проявление различных видов этой позиции (пассивно-негативная жизненная позиция - 65 \%, пассивно-равнодушная - 69 \%, активно-позитивная - 65 \%). У 30 \% опрошенных преобладает активнопозитивная жизненная позиция; активная-негативная жизненная позиция не проявляется у 67 \% респондентов (табл. 1).

Таким образом, поведение студентов зависит от ситуации с преобладанием активно-позитивной жизненной позиции.

В каких видах деятельности студенты проявляют свою активность? 
Студентам были предложены для анализа следующие формы появления активной жизненной позиции: образовательная деятельность, культурно-досуговая деятельность, благотворительность (помощь социально незащищенным группам граждан), волонтерство (участие в социально значимых проектах). Вопросы анкеты допускали множественный выбор.

В ходе анкетирования было выявлено, что 82 \% студентов под активной жизненной позицией понимают участие в различных акциях и мероприятиях (благотворительные акции, помощь другим людям, уборка территории и т.п.), 66 \% - молодежные выезды, форумы, слеты, 45 \% - студенческое самоуправление (рис. 1). В этих формах деятельности студенты принимали наиболее активное участие: 68 \% участвовали в благотворительных акциях, 63 \% - в молодежных форумах, 37 \% - в студенческом и школьном самоуправлении (рис. 2).

В досуговой деятельности студентов доминирует виртуальная активность. 97,4 \% студентов предпочитают свободное времени

Таблица 1

Виды жизненной позиции у студентов вуза до и после эксперимента (по результатам опросника С.Д. Липатовой «Виды жизненной позиции»)

\begin{tabular}{l|l|c|c}
\hline $\begin{array}{l}\text { Вид жизнен- } \\
\text { ной позиции }\end{array}$ & $\begin{array}{c}\text { Степень выраженности } \\
\text { жизненной позиции }\end{array}$ & $\begin{array}{c}\text { До экспери- } \\
\text { мента, \% }\end{array}$ & $\begin{array}{c}\text { После экспе- } \\
\text { римента, \% }\end{array}$ \\
\hline \multirow{3}{*}{$\begin{array}{l}\text { Пассивно- } \\
\text { негативная }\end{array}$} & Не выявлена & 34.694 & 46.938 \\
\cline { 2 - 4 } & Проявляется ситуативно & 65.306 & 53.061 \\
\cline { 2 - 4 } & Выявлена & 0 & 0 \\
\hline \multirow{3}{*}{$\begin{array}{l}\text { Пассивно- } \\
\text { равнодушная }\end{array}$} & Не проявляется & 30.612 & 44.897 \\
\cline { 2 - 4 } & Проявляется ситуативно & 69.388 & 55.102 \\
\cline { 2 - 4 } $\begin{array}{l}\text { Активно- } \\
\text { позитивная }\end{array}$ & Выявлена & 0 & 0 \\
\cline { 2 - 4 } & Не проявляется & 4.081 & 0 \\
\cline { 2 - 4 } & Проявляется ситуативно & 65.306 & 48.979 \\
\hline \multirow{2}{*}{$\begin{array}{l}\text { Активно- } \\
\text { негативная }\end{array}$} & Не проявлена & 30.612 & 51.020 \\
\cline { 2 - 4 } & Проявляется ситуативно & 30.612 & 73.469 \\
\cline { 2 - 4 } & Выявлена & 2.041 & 26.530 \\
\hline
\end{tabular}


проводить в интернете. Реальное взаимодействие осуществляется через общение с друзьями (76\%) и семьей (50 \%) (рис. 3).

Результаты анкеты показали, что доминирующей формой проявления активной жизненной позиции у студентов является учеба (76,3 \%), на втором месте по значимости стоит активное участие в жизни группы (50 \%), на третьем месте - занятия спортом $(47,4 \%)$ (рис. 4).

Проанализировав данные анкеты, можно предположить, что активно-позитивная жизненная позиция выражается в положительном отношении к делу, которым студент занимается, увлеченности многими делами. Это и участие в социально значимых проектах (82\%), и волонтерство (32\%), и занятие спортом (48\%). При этом студенты получают удовольствие от результатов своей деятельности.

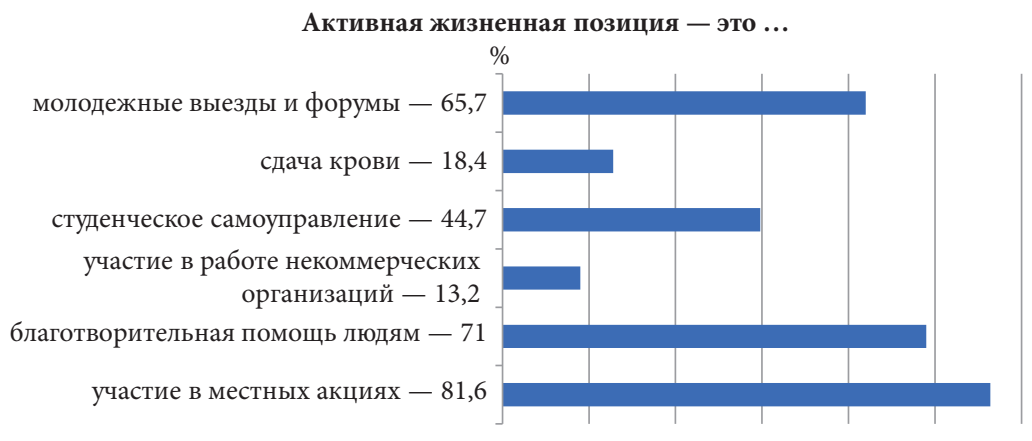

Рис. 1. Активная жизненная позиция в восприятии студентов (по результатам анкеты Е.А. Хохолевой «Активная жизненная позиция»)

В каких мероприятиях вы принимали участие?

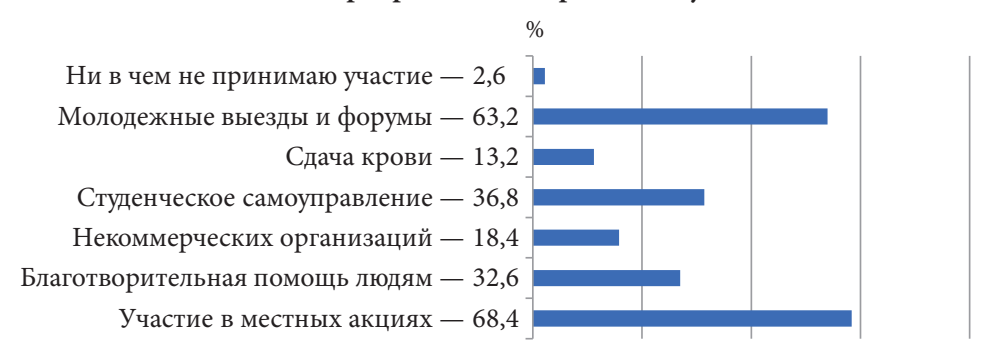

Рис. 2. Участие студентов в социально значимых мероприятиях (по результатам анкеты Е. А. Хохолевой «Активная жизненная позиция») 
Образовательная деятельность у студентов лидирует по сравнению в другими формами проявления жизненной активности (76\%). В связи с этим мы предположили, что образовательная среда может способствовать развитию активной жизненной позиции.

Нами были разработаны и апробированы активные методы формирования жизненной позиции студентов. В ходе учебных занятий были использованы активные методы обучения: дискуссия, мозговой штурм, кейс-стади, командная и проектная работа. Цель - развить активно-позитивную жизненную позицию.

Важной характеристикой дискуссии является аргументированность. Обсуждая спорную проблему, студенты оппонируют мнению собеседника, аргументируя свою позицию. Так, дискуссия на тему

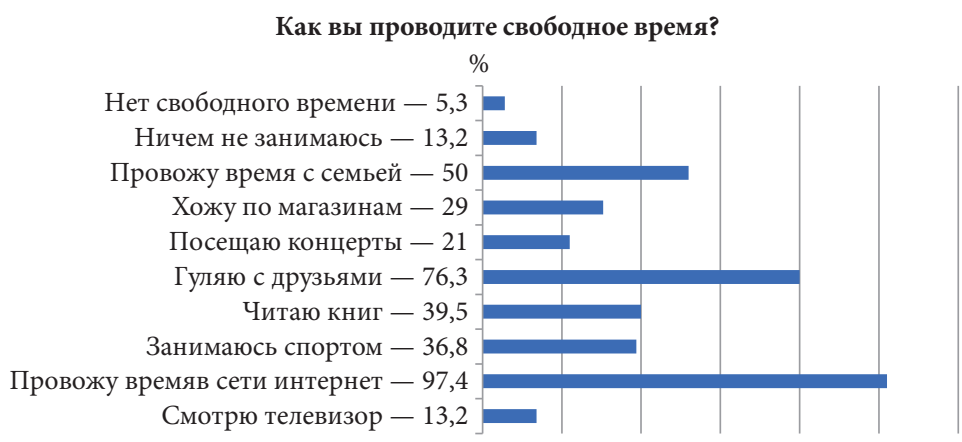

Рис. 3. Досуговая деятельность студентов (по результатам анкеты Е.А. Хохолевой «Активная жизненная позиция»)

В каких формах общественной деятельности вы принимаете участие?

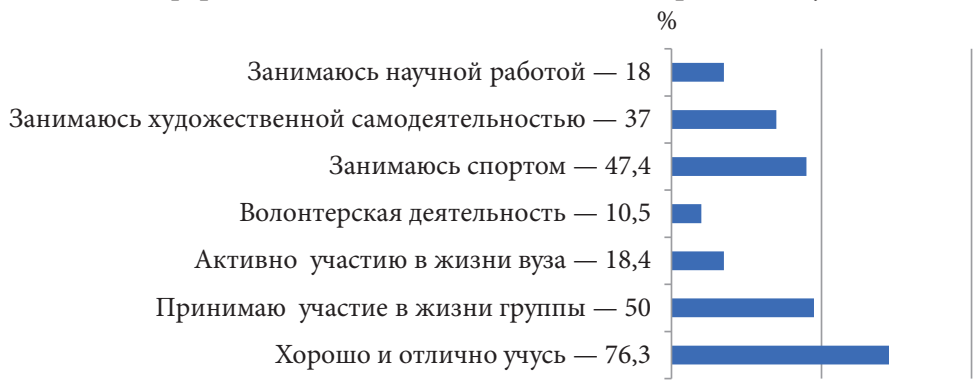

Рис. 4. Формы проявления активной жизненной позиции студентов (по результатам анкеты Е.А. Хохолевой «Активная жизненная позиция») 
«Какие проекты можно назвать социально значимыми» преследовала цель - акцентирование внимания студентов на вопросах помощи социально незащищенным группам граждан; развитие навыков аргументации.

Проектная работа формирует умение критически оценивать личностные достоинства и недостатки, умение конструктивно реагировать на критику в свой адрес, способность эффективно организовывать групповую работу, умение осуществлять распределение функций, полномочий и ответственности [11]. Технологический процесс проектной деятельности включает следующие этапы: 1) подготовка к выполнению творческого задания (постановка задачи, темы, проблемы; формирование микрогрупп; распределение командных ролей); 2) групповая работа (планирование; распределение заданий; выполнение проекта; презентация проекта); 3) оценка результатов работы (анализ познавательной задачи, рефлексия; общий вывод о групповой работе и достижении поставленной цели) [Там же].

Цель проектной работы - создать условия для того, чтобы студенты с пассивно-негативной жизненной позицией научились сопереживать и вникать в социальные проблемы, которые их лично не касаются. «Метод проектов позволяет каждому студенту приобрести опыт социального взаимодействия в творческом коллективе единомышленников, использовать полученные знания в конкретной деятельности» [12, с. 26].

С целью формирования ответственности за свои действия и поступки, коллективного поиска решения новой проблемы, нетрадиционных путей решения возникших задач использовался метод мозгового штурма. «Мозговой штурм (мозговая атака, брейнсторминг) - широко применяемый способ продуцирования новых идей для решения научных и практических проблем. Его цель организация коллективной мыслительной деятельности по поиску нетрадиционных путей решения проблем» [13]. Например, студенты использовали метод мозгового штурма при обсуждении проблем иждивенчества в современном мире.

Метод анализа конкретных ситуаций развивает способность к анализу жизненных и производственных задач. Сталкиваясь 
с конкретной ситуацией, студент должен определить: есть ли в ней проблема, в чем она состоит, определить свое отношение к ситуации. Студентам была предложена тема «Я уважаю себя - я уважаю других». Цель - формирование толерантного отношения к представителям разных социальных групп (инвалидам, пожилым людям).

Цель применения метода кейс-стади - создать условия, при которых студенты научатся отстаивать свою позицию. Работа на занятиях была посвящена обсуждению следующих проблем: «Инициатива наказуема?», «Я не жертва обстоятельств!».

Совместная групповая работа позволяет научиться отстаивать свою точку зрения, при этом уметь слушать и учитывать точку зрения других членов команды.

После осуществления мероприятий был проведен повторный опрос студентов. Результаты представлены в табл. 1.

В результате формирующего эксперимента студенты смогли смоделировать поведение, повышающее уровень активно-позитивной жизненной позиции. Повторный опрос показал различия в представлениях о жизненной позиции до и после коррекции (табл. 2).

Полученная величина T = 40 попадает в зону значимости. Следовательно, можно утверждать, что зафиксированные в эксперименте изменения являются неслучайными, т.е. полученные результаты являются значимыми. Активные методы обучения способствуют формированию активно-позитивной жизненной позиции студентов вуза.

\section{Выводы}

Сегодня исследователи озабочены ситуацией, когда молодые люди имеют желание приносить пользу людям, быть полезными обществу, но, погруженные в виртуальную реальность (98 \% тратят свободное время в сети Интернет), зачастую не знают, как это сделать в реальном мире. Поставить «лайк» - еще не значит сделать доброе дело. Быстро меняющаяся бизнес-среда требует не созерцательности, а активных действий, дающих возможность для профессиональной и личностной самореализации.

Очевидна необходимость расстановки мировоззренческих акцентов в современной системе образования вуза. Информационная 
Таблица 2

Сопоставление результатов уровня активно-позитивной жизненной позиции до и после коррекции с применением Т-критерия Вилкоксона

\begin{tabular}{|c|c|c|c|c|c|}
\hline № & «До» & «После» & $\begin{array}{c}\text { Сдвиг } \\
\left(\mathrm{T}_{\text {после }}-\mathrm{T}_{\text {до }}\right)\end{array}$ & $\begin{array}{c}\text { Абсолютное } \\
\text { значение } \\
\text { сдвига }\end{array}$ & $\begin{array}{c}\text { Ранговый } \\
\text { номер сдвига }\end{array}$ \\
\hline 1 & 61 & 58 & -3 & 3 & 7,5 \\
\hline 2 & 59 & 60 & 1 & 1 & 2 \\
\hline 3 & 57 & 63 & 6 & 4 & 10,5 \\
\hline 4 & 70 & 68 & -2 & 2 & 4,5 \\
\hline 5 & 58 & 71 & -13 & 13 & 18,5 \\
\hline 6 & 59 & 64 & 5 & 5 & 12,5 \\
\hline 7 & 49 & 62 & 13 & 13 & 18,5 \\
\hline 8 & 36 & 67 & 31 & 31 & 24 \\
\hline 9 & 49 & 68 & 19 & 19 & 22 \\
\hline 10 & 49 & 67 & 18 & 18 & 21 \\
\hline 11 & 55 & 62 & 7 & 7 & 14,5 \\
\hline 12 & 51 & 60 & 9 & 9 & 16 \\
\hline 13 & 39 & 38 & -1 & 1 & 2 \\
\hline 14 & 37 & 42 & 5 & 5 & 12,5 \\
\hline 15 & 42 & 45 & 3 & 3 & 7,5 \\
\hline 16 & 43 & 50 & 7 & 7 & 14,5 \\
\hline 17 & 44 & 48 & 4 & 4 & 10,5 \\
\hline 18 & 57 & 54 & -3 & 3 & 7,5 \\
\hline 19 & 37 & 39 & 2 & 2 & 4,5 \\
\hline 20 & 35 & 55 & 30 & 30 & 23 \\
\hline 21 & 39 & 51 & 12 & 12 & 17 \\
\hline 22 & 47 & 48 & 1 & 1 & 2 \\
\hline 23 & 35 & 38 & 3 & 3 & 7,5 \\
\hline 24 & 25 & 42 & 17 & 17 & 20 \\
\hline \multicolumn{5}{|c|}{ Сумма рангов нетипичных сдвигов } & 40 \\
\hline
\end{tabular}

Примечание. За нетипичный сдвиг было принято «увеличение значения». 
составляющая уходит на второй план, а мировоззренческая, формирующая активно-позитивную жизненную позицию, становится крайне актуальной. Система высшего образования не должна выполнять только функцию передачи знаний, информации, ей необходимо активнее влиять на формирование принципов, мировоззрения, убеждений, моральных норм студентов. Через это влияние развивается способность человека проявлять активную жизненную позицию и адаптироваться к изменяющейся социальноэкономической среде, что в итоге обеспечивает психологическое благополучие личности.

Инструментами такого влияния могут стать активные методы обучения: дискуссии, мозговые штурмы, кейс-стади, командная, проектная работа, а также игровые технологии. Они позволяют реализовывать личностно-ориентированный подход в образовании и создают условия для самореализации.

1. Шевеленкова Т. Д., Фесенко П. П. Психологическое благополучие личности (обзор основных концепций и методик исследования) // Психологическая диагностика, 2005. № 3. С. 95-129.

2. Петунова С.А., Илларионова Е. С. Формирование активной жизненной позиции как фактор психологической адаптации личности в новых социально-экономических условиях // Социологическая мысль Чувашской Республики : сб. ст. науч.-теорет. конф. (Чебоксары, 24 нояб. 2000 г.). Чебоксары, 2000. С. 236-245.

3. Коджаспирова Г.М. Педагогический словарь [Электронный ресурс]. URL: http://slovo.yaxy.ru/87.html (дата обращения: 25.01.2020).

4. Tarasova E. N., Gorodetskaya I. M. Student's moral development in the engineering university environment // Proceedings of 2015 international conference on interactive collaborative. learning, icl. 2015. P. 215-219.

5. Игебаева Ф.А. Ценностные ориентации молодежи в современном российском социуме // Социально-экономические аспекты развития современного государства : материалы III Междунар. науч.-практ. конф. (Саратов, 6 марта 2014). Саратов, 2014. С. 47-48.

6. Васильева Л.Е., Кириллова О.В. Активная жизненная позиция, ее формирование у студенческой молодежи [Электронный ресурс] // Вестн. ЧГУ, 2013. № 1. URL: https://cyberleninka.ru/article/n/aktivnaya-zhiznennaya- 
pozitsiya-ee-formirovanie-u-studencheskoy-molodezhi (дата обращения: 04.02.2020).

7. Карташова В.Н. Социализация личности как часть проблемы формирования активной жизненной позиции в системе среднего профессионального образования // Социосфера : сб. конф. НИЦ. 2013. № 11. С. 32-34.

8. Музыченко Л. С. Формирование активной жизненной позиции личности в образовательной среде // Современные проблемы права и управления : сб. докл. 6-й Междунар. науч. конф. / Ин-т законоведения и управления ВПА (Тула, 27-28 окт. 2016 г.). Тула, 2016. С. 198-202.

9. Окулова Е.Е. Формирование активной жизненной позиции подростков в процессе социально значимой деятельности [Электронный ресурс] // Научное сообщество студентов XXI столетия. Гуманитарные науки : сб. ст. по материалов XLIX Междунар. студ. науч.-практ. конф. № 1 (49). URL: https://sibac.info/archive/guman/1(49).pdf (дата обращения: 01.02.2019).

10. Пеи, О. И., Даниленко О.Г. Формирование активной жизненной позиции студента - одна из задач высшего профессионального образования // Современная наука. 2015. № 2. С. 82-86.

11. Липатова С. Д. Технология творческого проекта в образовательной деятельности Уральского федерального университета // Дискуссия. 2012. № 11 (29). С. 132-137.

12. Сухорукова Г.П. Применение метода проектов как способа формирования активной жизненной позиции студентов // Вестн. алтайской науки. 2009. № 4. С. 25-27.

13. Бачаева E. А. Активные формы и методы обучения [Электронный pecypc]. URL: https://infourok.ru (дата обращения: 25.01.2020). 


\section{ПРОБЛЕМА ПРОФЕССИОНАЛЬНОЙ ИДЕНТИЧНОСТИ СТУДЕНТОВ-ПСИХОЛОГОВ В СОВРЕМЕННОМ ВУЗЕ}

M. В. Чумаков

И. В. Васильева

Представления о профессии, связанные с профессиональной мотивацией и ценностями, их формирование у студентов (особенно у тех, чья будущая профессия относится к системе «человек - человек») является значимой социальной проблемой, которая имеет объективные, в том числе экономические последствия. В то же время целостность этих представлений имеет значение для субъективного благополучия личности студентов психологических специальностей.

Ю.П. Поваренков выделяет компоненты профессиональной идентичности: «...принятие ценностей профессионального сообщества, принятие себя как профессионала и принятие профессиональной деятельности как средства самореализации. Профессиональная идентичность рассматривается как состояние личности, как один из критериев ее профессионализации, как регулятор процесса профессионального становления» [1, с. 9]. В настоящее время можно наблюдать изменения в динамике формирования профессиональной идентичности студентов-психологов. С одной стороны, это вызвано переходом на двухуровневое обучение по программам бакалавриата и магистратуры. Возможность изменить профессиональную направленность в магистратуре, в том числе изменить радикально, меняет установки в отношении выбора профессии на этапе поступления в университет на программы бакалавриата. Ранее особую тревогу родителей и абитуриентов вызывала потенциальная «неправильность» и неизменность выбора профессии. В условиях двухуровневого обучения, когда становятся возможными различные траектории профессиональной подготовки, снижается беспокойство в отношении неизменности совершаемого выбора направления обучения. Вызывает интерес и требует исследования тот факт, что многие выпускники программ бакалавриата по психологии не продолжают обучение в магистратуре по психологии, выбирая, по сути, другую профессию. Некоторые выпускники ба- 
калаврских программ по психологии «берут паузу» и поступают в магистратуру спустя год или несколько лет. Наконец, некоторые выпускники ограничивают свое образование программой бакалавриата, считая, что этого достаточно и можно получить дальнейшее развитие путем самообразования или через реализацию различных проектов. Профессиональная идентичность части студентов, напротив, отличается цельностью. Они последовательно заканчивают бакалавриат, магистратуру по психологии и продолжают в будущем обучение в аспирантуре или по программам повышения квалификации. Ситуация с профессиональной идентичностью и выбором траектории обучения студентов-психологов осложняется тем, что по ряду направлений подготовки сохраняются программы специалитета. Изменения в системе подготовки психологов, влияющие на становление профессиональной идентичности, касаются и взаимодействия психологии и педагогики.

В настоящее время существует возможность получить образование по направлениям подготовки «Психология» (37.03.01) и «Психолого-педагогическое образование» (44.03.02). В случае подготовки по психологии, даже при направленности «Психология образования», идентичность остается в пространстве психологии. Выпускник ощущает себя психологом, ориентированным на проблемы образования и работающим в системе образования. В случае получения психолого-педагогического образования многое зависит от того, какая кафедра является выпускающей по программе бакалавриата, и от идеологии этой кафедры. В случае если выпускающей кафедрой является кафедра психологии, идентичность выпускников остается психологической. Они ощущают себя психологами, глубоко интегрированными в систему образования, сделавшими это выбор еще на этапе бакалавриата. Если выпускающей кафедрой является кафедра педагогики, идентичность, с нашей точки зрения, меняется существенно. В данном случае нередко акцентируется, что на первом месте в названии квалификации «педагог-психолог» стоит «педагог», кафедра психологии привлекается к подготовке в качестве вспомогательной и не может оказать решающего влияния на формирование идентичности выпускников, на содержание программы подготовки в целом. В некоторых классических университетах и некоторых 
педагогических университетах сохраняются обе образовательные траектории, что требует дополнительной работы преподавательского коллектива университета по формированию профессиональной идентичности. Мы не подходим к данному вопросу с оценочных позиций и не пытаемся делать выводы о том, какая идентичность «лучше». Тем не менее следует констатировать, что в некоторых конкретных случаях при подготовке психологов для системы образования происходит очевидная существенная замена профессиональной идентичности - с идентичности «психолог» на идентичность «педагог». Эту ситуацию необходимо рассмотреть с точки зрения возможностей и рисков появления «спутанности идентичности», по Э. Эриксону [2], и обретения статуса «достигнутой идентичности», по Дж. Марсиа, в том числе и как факторов, способствующих или препятствующих субъективному благополучию личности. Ландшафт образовательного пространства в области психологии изменился значительно. Существенным признаком этих изменений является плюрализм в подготовке психологов, возможность выбора различных образовательных программ и траекторий подготовки. Эти изменения требуют новых исследований по проблеме профессиональной идентичности психологов. В то же время вместе с изменениями в обществе меняются личностные особенности студентов, их взгляды на жизнь, требования к профессии и путям ее освоения. Л. Б. Шнейдер пишет, что «в период вузовской подготовки становление профессиональной идентичности испытывает два воздействия: организующее и активизирующее, что соответствует двум направлениям образования: познавательному и личностному» $[3$, c. 55]. Все это требует исследований и осмысления как с позиций эффективности профессиональной подготовки и последующей работы по специальности, так и с позиций субъективного благополучия личности, профилактики ее профессиональной деформации.

Как отмечает Р. М. Шамионов, в современном обществе необходима профилактика психологического неблагополучия в профессиональной сфере [4]. Это требует раскрытия механизмов формирования субъективного благополучия, изучения динамики его развития на различных этапах профессиональной социализации, что может способствовать социальной адаптации личности [5]. Данная про- 
блематика имеет значение для понимания психологических аспектов социальной активности молодежи [6]. Если рассматривать профессиональную идентичность как один из факторов субъективного благополучия [7], то исследования в этой области демонстрируют крайне мозаичную картину.

С одной стороны, показано, что чем активнее студенты-психологи вовлекаются в профессиональную деятельность, тем более разнообразные эмоции они испытывают (в том числе и отрицательные), чем пассивнее студенты-психологи относятся к профессиональным видам деятельности, тем они эмоционально стабильнее [8]. С другой стороны, показано снижение профессиональной идентичности к выпускным курсам [9]. Наблюдается неблагоприятная картина для процесса профессионального становления будущего психолога: ожидания, с которыми студенты приходят в университет, не оправдываются, эмоциональная вовлеченность студентов в академическую и профессиональную активность снижается. Судя по тому, что в магистратуру по направлению «Психология» поступают преимущественно студенты-непсихологи (чаще педагоги, медики, экономисты, юристы, менеджеры, инженеры), бакалавры-психологи либо полагают, что в достаточной мере обучены для самостоятельной профессиональной деятельности, либо стремятся выстроить междисциплинарный профессиональный трек.

Полагаем, что ожидания студентов-психологов, в частности, связаны с такими активно рекламируемыми в социальных сетях видами деятельности, как тренинги продаж, «женского предназначения», «трансформации финансового мышления». Необходимость погружаться в изучение теоретических исследований, осуществлять анализ текстов, внешне «оторванных» от столь привлекательной практики, контрастирует с ожиданиями будущих психологов. Наблюдается существенный разрыв между демонстрируемым образом психолога в социальных сетях и реальной психологической работой. У студентов же отсутствуют полноценные критерии оценки эффективности работы психологов, которые презентуют себя в доступных для студентов социальных сетях. Формируется представление о профессиональном пути психолога как о легком, не требующем подготовки, не обремененном трудностями. 
Необходимость точного понимания динамики процессов профессиональной идентичности в том числе обусловлена тем, что это является фактором субъективного благополучия студентов в процессе обучения и проявляется в посещаемости учебных занятий, активности участия в научно-исследовательской работе, неформальной вовлеченности во все виды практики по получению профессиональных умений и навыков, снижении количества повторных аттестаций, повышении качественной успеваемости.

В нашем исследовании ставится частная задача - оценить динамику параметров профессиональной идентичности студентовпсихологов в зависимости от курса обучения. Это позволит прогнозировать возможности развития будущих психологов как профессионалов и оценить риски ухода из профессии. Кроме того, исследование дает возможность получить информацию, необходимую для осознанной коррекции учебного процесса. Мы исходим из того, что профессиональная подготовка заключается не только в получении знаний и навыков, необходимых для успешного выполнения деятельности, но и в целенаправленном формировании мотивации, создании позитивного эмоционального фона в процессе учебной деятельности. Это позволит в будущем увеличить результативность профессионала и повысить показатели субъективного благополучия личности.

\section{Методы и материалы}

Исследование проводилось в сентябре - ноябре 2019 г. В нем участвовало 117 психологов-бакалавров, обучающихся на 1-4-м курсах Курганского государственного и Тюменского государственного университетов (60 и 57 человек соответственно), а также студенты первого и второго курсов магистратуры. Метод сбора данных: опросник профессиональной идентичности студентов У.С. Родыгиной [10]. Методика содержит следующие параметры: особенности эмоционального реагирования, связанные с удовлетворением потребностей в профессии, и позиция активного/пассивного отношения студента к приобретаемой профессии. Шкала «особенности эмоционального отношения к удовлетворенности/ неудовлетворенности потребностей в данной профессии» описывает 
представления студента о себе и собственных потребностях и то, как профессия психолога может удовлетворить эти потребности. Шкала «позиция активного/пассивного отношения студента к приобретаемой профессии» выражает степень субъектности, осознанной вовлеченности в процесс получения профессиональных знаний: освоение теоретических знаний, освоение практических умений, применение этих знаний и умений в рамках производственных практик, подготовка курсовых и дипломных проектов. Сочетания шкал дают возможность использовать типологию студентов с разной степенью профессиональной идентичности [10]. Э. Ф. Зеер в качестве одного из значимых факторов, обусловливающих профессиональное становление личности, выделяет собственную активность субъекта образования [11]. Причем акцентируется внимание на изменении характера активности: «...нормативно заданная активность определяет учебно-профессиональную и профессионально-образовательную ведущую деятельность, адаптивная - нормативно одобряемую профессиональную деятельность (или воспроизводящую), надситуативная - продуктивную (высококвалифицированную), сверхнормативная — творческую самодеятельность» [11, с. 85]. Профессиональная идентичность психолога развивается в той же логике.

Метод обработки данных: дисперсионный однофакторный анализ ANOVA (для независимых выборок). В качестве независимой переменной выступал курс, на котором обучался студент. Это позволило установить наличие динамики в показателях профессиональной идентичности студентов в зависимости от продолжительности обучения в университете.

\section{Результаты}

Расчет результатов методом дисперсионного однофакторного анализа показал (ANOVA), что профессиональная идентичность снижается в зависимости от курса, на котором учится студент $(F(32,385,13)=1,8065, p=0,005538)$, а именно:

- на первом курсе бакалавриата наблюдаются наиболее выраженные позитивные эмоции относительно удовлетворения потребностей в профессии, но уже начиная со второго курса интенсивность 
положительных эмоций резко снижается и остается на таком уровне до окончания обучения;

- интенсивность отрицательных эмоций относительно удовлетворения потребностей в профессии наименее выражена в начале обучения и начинает резко расти уже со второго курса, достигая пика на третьем курсе;

- позиция активного отношения студентов бакалавриата к профессии неуклонно снижается с первого по четвертый курс;

- позиция пассивного отношения к профессии повышается, начиная с первого курса и достигая пика к третьему курсу, на четвертом курсе пассивное отношение несколько снижается;

- в целом и эмоциональное реагирование, и активность позиции по отношению к приобретаемой профессии у студентов бакалавриата неуклонно снижается по мере продолжения обучения;

- у магистров наблюдается более позитивное эмоциональное отношение и более активная позиция по отношению к приобретаемой профессии, чем у выпускников бакалавриата, однако необходимо учесть, что в магистратуру приходят для обучения преимущественно бакалавры других направлений обучения, не психологического.

\section{Обсуждение}

В данном исследовании на операциональном уровне концепт профессиональной идентичности был представлен показателями преобладания положительных эмоций, связанных с профессией психолога, а также позицией активного отношения студента к приобретаемой профессии. Положительные эмоции связаны с представлением о том, что профессия удовлетворяет потребностям. Снижение этого показателя по мере увеличения курса обучения означает, что изменяются либо потребности личности, либо представления о профессии, либо оба эти фактора вместе. Потребности могут изменяться в связи с тем, что студенты из периода юношеского возраста переходят в период ранней взрослости, становятся более автономными и начинают предъявлять иные требования к профессии, в том числе ее возможностям обеспечивать материальное благополучие. Планирование создания семьи также может быть в этом 
смысле немаловажным фактором. Профессия психолога, например психолога в системе образования, является социально значимой, что привлекает людей в юношеском возрасте, в котором проявляется тенденция к некоторому романтизму. Привлекает и возможность быстрее почувствовать себя более взрослым в среде детей и подростков, занять позицию эксперта. Вместе с тем относительно невысокая оплата труда может стать значимым фактором оценки по мере изменения возраста. Тенденция изменения представлений о профессии психолога также имеет место. Студенты по мере обучения лучше понимают трудоемкость профессионального совершенствования, утрачивают иллюзии, навеянные средствами массовой информации и собственным воображением. Кроме того, на легкость восприятия психологии настраивают и некоторые психологические источники. Как отмечает Б. С. Братусь [12], это может привести к ложному выводу о том, что психологию можно осваивать «без труда и усилий». Профессиональное развитие требует трудоемкой перестройки когнитивной сферы, в том числе на структурном уровне, формирования профессиональной речи, развития коммуникативных навыков и т. д. Эта внутренняя перестройка сопряжена с психологическими трудностями и снижением субъективного благополучия. Создается впечатление, что некоторые студенты не преодолевают эти сложности и не достигают уровня профессионального развития, который позволяет получать удовольствие от работы и учебы без снижения требований, упрощения, свойственных популярной психологии. Активное отношение предполагает осознанные усилия по освоению профессии, планы на будущее, связанные с ней. Профессия воспринимается как перспективная, позволяющая чувствовать себя уверенно в материальном плане, реализовывать себя как компетентного и статусного специалиста, выполняющего важную социально значимую работу, испытывать к самому себе уважение. Противоположный полюс концепта профессиональной идентичности означает негативные эмоции, представления о том, что профессия психолога не соответствует потребностям личности, пассивное отношение к освоению профессии, разочарование в ней и нежелание заниматься ею в будущем. Профессия воспринимается как не позволяющая удовлетворить материальные, статусные потребности будущего 
психолога, не позволяющая испытывать к самому себе уважения на должном уровне. Проблемы с профессиональной идентичностью, понимаемой таким образом, будут отражаться на субъективном благополучии личности студентов. Профилактика психологического неблагополучия в профессиональной сфере во многом относится к периоду обучения в университете. Эмоции в процессе обучения являются прямым индикатором психологического благополучия, а активность по освоению профессии - хотя и косвенным, но все же достаточно важным. Кроме того, пассивность в освоении профессии является фактором психологического неблагополучия в этой сфере в будущем. Действительно, пассивное отношение приводит к недостаточному освоению различных видов профессиональной деятельности и слабой их интеграции. В дальнейшей профессиональной жизни при этом вероятны снижение результативности и увеличение трудностей, ошибок в выполнении деятельности. Студенты не связывают знания, получаемые в ходе теоретического и практического обучения, с реальной профессиональной деятельностью: 1) содержание теорий не переносится на реальные жизненные ситуации и связанные с ними психологические запросы; 2) техники психологического консультирования и тренингов воспринимаются как лабораторные процедуры, не применимые в реальной деятельности; 3) методы психологической диагностики обесцениваются.

Психологи-выпускники с низким уровнем профессиональной идентичности уходят в смежные виды занятости (фитнес-тренеры, специалисты по фейсбилдингу, ароматерапии) или меняют профессиональную траекторию в целом.

Используя типологию профессиональной идентичности студентов У. С. Родыгиной [10], можно говорить о том, что на первых курсах бакалавриата преобладают студенты с эмоционально-положительным отношением и выраженной субъектностью в отношении учебной деятельности, связанной с освоением профессии психолога. На последних же курсах обучения в бакалавриате преобладают студенты со сниженным эмоциональным фоном и сниженной субъектностью в отношении обучения. 
Студенты-магистры демонстрируют более благополучную картину профессиональной идентичности. Мы полагаем, что это обусловлено следующими факторами: 1) совершением осознанного выбора программы магистратуры, не связанного с «давлением» выбора из доступного перечня экзаменов ЕГЭ; 2) возможностью удовлетворять собственные образовательные потребности, а не ожидания родителей/других значимых людей; 3) возможностью более быстрой реализации профессиональных компетенций, получаемых в процессе обучения, что дает большее удовлетворение обучающимся в магистратуре от профессиональной деятельности, позволяет чувствовать себя более субъектными. Возможно, это связано с более развитой рефлексией, на роль которой указывает А.А. Бехтер [13]: рефлексия выступает механизмом формирования социальнопрофессиональной идентичности психолога. Вместе с тем, как указывалось выше, существенен процент выпускников бакалавриата по психологии, которые не поступают в магистратуру по психологии или берут паузу в образовании. Кроме того, в магистратуру по психологии поступают выпускники других специальностей, совершенно не связанных с психологией. Резкая смена образовательной траектории, с нашей точки зрения, нуждается в дополнительных исследованиях как с точки зрения психологии личности и мотивации, так и с точки зрения эффективности. Программы многих магистратур по психологии ориентированы на квалифицированных слушателей, владеющих знаниями общей психологии. В итоге для поступления в магистратуру университеты организуют дополнительную подготовку слушателей в течение года, что делает систему образования в целом еще более мозаичной.

В качестве основных затруднений в профессиональной деятельности выпускники-психологи называют дефицитарность материального положения, связанную со сложностями трудоустройства, отсутствием достаточного количества клиентов в условиях частного психологического консультирования, недостатком профессиональных навыков для работы в крупных корпорациях, отсутствием готовности работать с супервизором, повышать квалификацию (при этом возникают сложности с адекватным оцениванием качества предлагаемых курсов повышения квалификации). Одним из относи- 
тельно новых приложений деятельности психологов стали социальные сети и адаптация всех видов профессиональной деятельности для этой сферы: психологическое онлайн-консультирование, диагностика, курсы повышения квалификации, написание текстов психопросветительского характера. Однако, несмотря на доступность и даже «низкопороговость» такого рода занятости, это не позволяет выпускникам-психологам профессионально реализоваться с той скоростью, как бы им хотелось. Профессиональная реализация чаще понимается выпускниками как выход на уровень материального достатка, который позволяет быть автономным от родительской семьи, вести собственное домохозяйство, реализовывать те виды активностей, которые приняты в соответствующей социальной страте. Это, в свою очередь, снижает субъективное благополучие в профессиональной сфере.

Полученные в нашем исследовании данные свидетельствуют о тревожной тенденции в подготовке психологов, прежде всего, в рамках программы бакалавриата. Последовательно, от курса к курсу, снижается мотивация обучения и приобретения профессии, нарастают негативные эмоции, снижается активность в освоении профессиональных навыков. Особенно быстро данные тенденции нарастают в период обучения на первом и втором курсах бакалавриата. Это может свидетельствовать о том, что разочарование связано, прежде всего, с неправильными представлениями о профессии психолога, сформированными в школьные годы. Полученные нами результаты согласуются с результатами психосемантического исследования профессиональной идентичности студентов-психологов, выполненного М. М. Абдуллаевой [14]: студенты первых курсов оценивают себя более профессионально идентичными (соответствующими образу «идеального психолога»), чем студенты старших курсов. Причем к старшим курсам нарастает количество негативных характеристик, которые студенты ассоциируют с собой как с профессионалами. Такое оценивание своей профессиональной идентичности кажется им более реалистичным, нежели соответствие «идеальному» образу психолога. Учитывая временную разницу между исследованиями (2014 и 2019 гг.), можно предположить, что снижение декларируемой профессиональной идентичности 
у студентов-психологов в ходе получения профессионального образования является устойчивой тенденцией.

С одной стороны, это кажется странным, так как в настоящее время профессия психолога стала довольно распространенной, в отличие от недавнего прошлого. Психологи работают в школах, и учащиеся имеют возможность к ним обращаться. С другой стороны, в средствах массовой информации, например, на телевидении, в социальных сетях, профессия психолога нередко освещается или односторонне, или искаженно. В школе психолог один, и учащиеся взаимодействуют с ним фрагментарно. Возможно, в отношении психологии действуют механизмы романтизации профессий, свойственные юношескому возрасту. В таком случае сходные тенденции должны проявиться и при изучении аналогичными методами студентов-бакалавров других гуманитарных специальностей. Впрочем, вполне возможно, что для романтизации некоторых профессий по самой их природе есть больше предпосылок и психология относится к их числу. Не исключено, что негативные тенденции могут отчасти объясняться переходом на обучение по системе бакалавриата и магистратуры. Возможность изменения профессионального пути без необходимости получать второе высшее образование как бы снимает часть напряжения, позволяя относиться к получению образования на ступени бакалавриата как к «обязательной программе социализации», не подразумевая при этом необходимости дальнейшего профессионального развития.

В случае обучения по программам специалитета выбор профессии становится более ответственным и значимым, так как нет возможности существенно изменить дальнейшую траекторию профессионального обучения. Косвенно о данной тенденции свидетельствует тот факт, что в магистратуре по психологии обучается много студентов, не имеющих базовой психологической подготовки в бакалавриате. В данном случае речь идет о тенденции. Можно проверить это предположение, сравнив с показателями психологов, обучающихся по программам специалитета, например, по клинической психологии или психологии служебной деятельности. Не исключено, что в снижении показателей идентичности, заложенных в используемую методику, играют роль естественные процессы, 
связанные с овладением профессией. При поступлении в университет невозможно иметь представления о профессии, полностью соответствующие реальности. В любом случае студент сталкивается с некоторыми трудностями и коррекцией первоначальных ожиданий. Профессионализм требует упорства, воли и далеко не всегда связан с положительными эмоциями. Расширение рамок исследования, включение в него студентов различных направлений позволит прояснить этот вопрос.

Интересно в будущем выделить студентов, чья эмоциональная и мотивационная динамика иная и характеризуется нарастанием положительных эмоций, повышением активности и дальнейшим продолжением учебы в магистратуре по психологии. В целом возможность изменять профиль подготовки после бакалавриата имеет свои плюсы, такая система является более гибкой и вариативной. Психологическая компетентность становится так называемым «soft skills» - характеристикой, важной в широком спектре видов профессиональной деятельности. В этом смысле психологическое образование на ступени бакалавриата становится способом расширения социально-психологических компетенций. Возможно, в этом случае сдвигается фокус мотивации в обучении - от профессиональной, ориентированной на помощь клиенту, к личной, ориентированной на эффективную самопрезентацию, установление успешной коммуникации. Тем не менее при подготовке профессионалов необходимо учитывать эти новые реалии, негативные тенденции, которые могут возникать, и менять подходы в обучении. Новые форматы обучения, например, онлайн-курсы по психологии, нужно исследовать с точки зрения последствий для мотивации, динамики преобладающих эмоций. Выборка, сформированная на базе двух университетов, не достаточна для того, чтобы делать глобальные выводы, но тенденция снижения операциональных показателей профессиональной идентичности по мере увеличения курса обучения проявилась достаточно явно. Эпидемия COVID-19, стремительно преобразовавшая социальные практики, значительно изменила и подходы к организации высшего образования. Привычным стало проведение университетских занятий в онлайн-формате на платформах Zoom, Teams и пр. В условиях карантина и социального дистанцирования студенты ощутили дефицит 
непосредственного взаимодействия с преподавателями и однокурсниками, с университетской средой в целом. Повлияло ли это как-то на параметры профессиональной идентичности - эмоциональное отношение к профессии (в зависимости от удовлетворенности/неудовлетворенности потребностей в ней) и активное/пассивное отношение к осваиваемой профессии? Это предстоит оценить в будущих исследованиях. Кроме того, желательно понять, насколько общими являются выявленные тенденции для подготовки психологов, а также в чем заключается специфика, связанная с различными условиями обучения. Для этого нужно расширить выборку университетов и регионов, провести повторные замеры в университетах, представленных в данной выборке, чтобы увидеть ситуацию в динамике; сравнить студентов, обучающихся платно и на бюджетной основе, обучающихся очно, заочно и очно-заочно, обучающихся по программам бакалавриата и специалитета и т.д. Таким образом, мы считаем сделанные выводы предварительными и рассматриваем их как стимул для дальнейшей работы в этом направлении.

\section{Выводы}

По мере увеличения курса обучения по программе бакалавриата в процессе освоения профессии психолога у студентов нарастают отрицательные эмоции и пассивное отношение, свидетельствующие о негативных тенденциях, связанных с профессиональной идентичностью.

На первом курсе магистратуры по психологии отмечается рост показателей позитивного эмоционального отношения и более активная позиция по отношению к приобретаемой профессии в сравнении с бакалавриатом, что свидетельствует о нормализации ситуации с профессиональной идентичностью в этот период. Однако, учитывая то, что на первый курс магистратуры по психологии поступают студенты других специальностей, динамика развития ситуации может быть такой же, как и на бакалавриате. Необходимы дальнейшие исследования проблемы с увеличением выборки. Дополнительную информацию может дать сравнение динамики исследуемых показателей при освоении студентами программ бакалавриата и специалитета по психологии. 
1. Поварёнков Ю. П. Психологическая характеристика профессиональной идентичности субъекта труда // Вестн. Костром. гос. ун-та. Сер. : Педагогика. Психология. Социокинетика. 2014. Т. 20, № 3. С. 9-16.

2. Эриксон Э. Идентичность: юность и кризис. М. : Прогресс, 1996. $344 \mathrm{c}$.

3. Шнейдер Л. Б. Профессиональная идентичность как психологопедагогическая проблема вузовской подготовки психологов-практиков // Актуальные проблемы психологического знания. 2009. № 4. С. 49-58.

4. Шамионов Р. М. Субъективное благополучие личности: психологическая картина и факторы. Саратов : Изд-во Сарат. ун-та, 2008. 240 с.

5. Шамионов Р. М., Григорьева М. В. Психология субъективного благополучия и социальной адаптации личности. Саратов : Изд-во Сарат. ун-та, 2014. 196 с.

6. Шамионов Р. М., Григорьева М.В. Психология социальной активности молодежи: проблемы и риски. Саратов : Изд-во Сарат. ун-та, 2012. 384 с.

7. Ермолаева Е. П. Профессиональная идентичность и маргинализм: концепция и реальность // Психол. журн. 2001. № 4. С. 51-59.

8. Манукян В.Р., Трубицина А. А. Профессиональная идентичность и субъективное благополучие студентов старших курсов // Петерб. психол. журн. 2019. № 26. С. 1-18.

9. Соловьева Н.В. Особенности формирования профессиональной идентичности // Профессиональная ориентация. 2017. № 1. С. 186-190.

10. Родыгина У.С. Психологические особенности профессиональной идентичности студентов // Психологическая наука и образование. 2007. № 4. С. 39-51.

11. Зеер Э. Ф. Профессионально-образовательное пространство личности: синергетический подход // Образование и наука. 2003. № 5. С. 79-90.

12. Братусь Б. С. Психология без труда и усилий // Вопр. психологии. 1999. № 1. C. 117-119.

13. Бехтер А.А. Рефлексия как механизм формирования социальнопрофессиональной идентичности психолога // Вестн. НГУ. Сер. : Психология. 2012. Т. 6, вып. 2. С. 57-59

14. Абдуллаева М.М. Формирование профессиональной идентичности у студентов-психологов // Вестн. Моск. гос. лингв. ун-та. Образование и педагогические науки. 2014. № 693. С. 20-32. 


\title{
ИССЛЕДОВАНИЕ ТОЛЕРАНТНОСТИ К НЕОПРЕДЕЛЕННОСТИ У ЮНОШЕЙ И ДЕВУШЕК СТАРШЕГО ПОДРОСТКОВОГО В0ЗРАСТА В СВЯЗИ С ИХ ЛИЧНОСТНЫМИ ОСОБЕННОСТЯМИ*
}

\author{
Е. П. Шаньгина \\ O.C. Виндекер
}

Мир современного человека все чаще характеризуется как пространство неопределенности и риска [1-3]. По словам Т. В. Корниловой, «неопределенность при этом выступает тем “полем” взаимодействия, на котором разворачивается активность человека, отвечающего вызовам конкретной ситуации, так и в более широком контексте собственной судьбы» [4, с. 159].

Для социальной ситуации развития детей старшего подросткового возраста характерен поиск самостоятельных ответов на вопросы личностного и профессионального самоопределения, выбор ценностных ориентиров в общении со сверстниками, определение степени своего влияния на собственную жизнь. Все это подразумевает максимальную опору на личностные качества подростков, наличие у них способности выдерживать неопределенность в процессе принятия жизненно значимых решений.

В психологических исследованиях понятие неопределенности раскрывается через категории недостатка информации, противоречивости, новой ситуации, множественности суждений, изменчивости, неструктурированности, непредсказуемости, неразрешимости $[3,6]$. В широком смысле толерантность к неопределенности рассматривается «в связи с готовностью личности принимать неизвестное, изменчивое, неоднозначно интерпретируемое, новое и необычное, действовать и принимать решения в условиях субъективной неопределенности» [7, с. 63].

Во многих работах, посвященных истории конструкта и актуальному состоянию его изучения, отправной точкой считаются исследо-

Исследование выполнено при финансовой поддержке РФФИ в рамках научного проекта № 19-29-07016 «Трансфер человеческого капитала образовательных общностей: от неуспешности к успешности». 
вания авторитарной личности Т. Адорно и его коллег Р. Сэндфорда, Э. Френкель-Брунсвик, Д. Левинсона. В рамках выявления различий восприятия и их влияния на особенности авторитарной личности авторы пришли к выводу о нежелательности однозначности восприятия, которую обозначали как «интолерантность к неопределенности» и трактовали ее как синоним понятия "ригидность», неспособность человека совладать со сложностью окружающего мира $[2,3,5]$. Авторство понятия толерантности и интолерантности к неопределенности принадлежит Э. Френкель-Брунсвик. Она определяла толерантность к неопределенности как «эмоциональную и перцептивную переменную, играющую существенную роль при оценке вероятностных исходов принятия решения и опосредующую эмоциональный фон принятия решения» [цит. по: 5, с. 303].

Е. Г. Луковицкая обращает внимание на то, что в зарубежных исследованиях акцент в изучении неопределенности делался на ее качественном содержании, а в отечественной психологии «неопределенность рассматривалась в контексте психологии мышления, вероятностного прогнозирования и определялась во взаимосвязи с вероятностью - количественном ее выражении» [6, с. 17].

В настоящее время отмечается многообразие представлений о сущности и содержании конструкта толерантности к неопределенности. Он рассматривается как индивидуальная склонность, способность, свойство личности, социально-психологическая установка, характеристика личностной саморегуляции, перцептивная установка при решении познавательных задач, когнитивный стиль, эмоциональная реакция, одно из проявлений толерантности $[2,3$, $5,6]$. Наиболее популярной при разработке опросников стала трактовка толерантности к неопределенности как личностной черты [2]. В целом можно говорить о том, что человек сочетает в себе оба полюса данной тенденции: толерантность и интолератность, но одна из них обычно доминирует $[2,3,5]$.

Е. Г. Луковицкая указывает, что М. Рокич одним из первых высказал идею о возможном отличии людей в отношении ориентации определенность-неопределенность. Он предположил наличие континуума, в котором с одной стороны находятся личности с «потребностью когнитивной структуры знать и понимать», 
а с другой - личности с «потребностью отражать угрожающие аспекты реальности». Таким образом, «личности с широким кругозором обладают когнитивной системой мнений (belifes), которая ориентируется на новое (информацию или мнения), а личности противоположного типа в основном ориентируются на известные и предсказуемые события» [6, с. 18].

Различия личностных качеств толерантной и интолерантной к неопределенности личности описаны в исследованиях российских и зарубежных ученых $[2,3,5,6,8]$. Интолерантному человеку свойственно избегание неопределенных стимулов и ситуаций, восприятие неопределенности как угрозы, отторжение всего необычного, высокий уровень тревоги и беспокойства в неопределенных ситуациях, «черно-белое» мышление, конформизм, принятие поспешных решений как способа минимизации непредсказуемости и противоречивости поступающей информации.

Субъект с высокой толерантностью к неопределенности проявляет способность к эмпатии, внутренний локус контроля, чувство юмора; воспринимает неопределенные ситуации/стимулы как желательные, бросающие вызов, интересные; не проявляет отрицания или тревоги по поводу их сложности или неконгруэнтности; способен не выносить поспешных суждений в ситуации противоречивости информации; опирается на собственные критерии оценки ситуаций.

Различия по толерантности к неопределенности между индивидами увеличиваются по мере взросления. Чем старше человек, тем в большей степени данное качество зависит от индивидуальных особенностей личности, ее ведущей деятельности и степени структурированности этой деятельности [6, с. 9].

Толерантность к неопределенности влияет на широкий спектр индивидуальных личностных особенностей, таких как возможность решения творческих задач, склонность к риску, мировоззренческие установки, социальное взаимодействие, когнитивный стиль, на что неоднократно указывают исследователи $[2,5,6,9]$. С толерантностью к неопределенности связаны устойчивость к стрессу, конструктивное поведение в конфликте, гибкость в отношении норм и правил. 
Установлено наличие взаимосвязи толерантности к неопределенности и таких параметров, как креативность, способность к инновациям и открытость новому опыту. Человек, обладающий толерантностью к ситуациям неопределенности, сохраняет мотивацию к творческой деятельности, что способствует принятию эффективных творческих решений. Е. Носенко и М. Шаповал предлагают рассматривать толерантность к неопределенности как «системообразующий личностный фактор творческой одаренности» [цит. по: 5, с. 316].

Неопределенность стала одним из важнейших понятий в исследованиях, выдвигающих на первый план проблемы самодетерминации и саморегуляции [2]. Т. В. Корнилова предложила концепцию толерантности к неопределенности как латентной переменной, которая проявляется в том числе на уровне других личностных свойств, в первую очередь связанных с личностной регуляцией решений и действий в условиях неопределенности [5, с. 306]. В работах Д. А. Леонтьева толерантность к неопределенности относится к категории конструктов, влияющих на личностный потенциал и продуктивность личностного развития человека $[5,10]$.

Старший подростковый возраст - время активного решения задачи самореализации и личностного самоопределения. Подросток стремится к признанию ценности своей личности и автономии [11]. В процессе конструктивной, значимой деятельности он проявляет свои возможности, пытается занять определенную социальную позицию. Происходит активное формирование потребностно-мотивационной сферы личности. В жизни подростка возникают постоянные интересы, которые подталкивают к постановке отдаленных целей. Активизируется стремление к самореализации, самовыражению, самоутверждению, самовоспитанию на основе собственных оценок и притязаний. Решение этих задач сопряжено с нахождением в новых, неизвестных подростку ситуациях: поиск нового круга общения, узнавание своих возможностей, ранние профессиональные пробы, утверждение себя в новых видах деятельности.

Авторы неоднократно указывают на то, что толерантность к неопределенности является одним из факторов успешной реализации личностного потенциала и психологического благополучия человека. Однако эмпирические исследования в основном проводятся на сту- 
денческих выборках, а имеющиеся данные относительно старших школьников довольно противоречивы. Мы предположили, что старший подростковый возраст является критическим для формирования толерантности к неопределенности, но уже в этом возрасте выражены особенности ее проявления у юношей и девушек.

Для выявления особенностей толерантности к неопределенности у девушек и юношей старшего подросткового возраста в связи с их личностными особенностями были выбраны качества, являющиеся важными факторами эффективной самореализации личности: мотивация достижения, самоэффективность (коммуникативная и предметная компетентность) и автономия. Мотивация достижения и самоэффективность были выбраны нами в качестве основных исследуемых личностных качеств, так как, во-первых, они влияют на различные деятельности, значимые для старших подростков (учеба, интересы, взаимодействие с ровесниками и взрослыми); во-вторых, данные качества являются надежными предикторами образовательной успешности, поэтому могут быть заложены в мониторинг эффективности образовательных, развивающих программ.

Дополнительной изучаемой личностной диспозицией стала автономия, положительно влияющая на готовность старших подростков реализовывать свои намерения с опорой на собственное мнение и ценности.

Анализ исследований, проведенных на выборках взрослых людей, показал наличие связи между принятием неопределенности и риска, с верой в свою компетентность, манифестируемую переменными самоэффективности и эмоционального интеллекта, готовностью к риску [2, с. 194]. Также есть подтверждения связи между толерантностью к неопределенности и автономией (выборочная совокупность взрослых от 28 до 42 лет) [12]. В исследовании толерантности к неопределенности студентов авторами было выявлено отсутствие автономности, подчинение авторитетам, свойственное интолерантным к неопределенности студентам [13].

На примере студенческой выборки Е. В. Сараева и С. Г. Николаев выявили взаимосвязь толерантности к неопределенности и мотивации достижения. Авторы установили, что люди, мотивированные на достижение успеха, более толерантны к неопределенности, а мо- 
тивацию достижения можно назвать одной из черт толерантных к неопределенности людей. С учетом того, что мотивация достижения является предиктором эффективности человека в значимой деятельности, исследователи предположили, что мотивация достижения повышает его эффективность в условиях неопределенности через повышение толерантности к ней. По мнению авторов, связующим звеном между этими феноменами в психике человека является интернальный локус контроля: «Уверенность в контролируемости собственной жизни объединяет мотивацию достижения и толерантность к неопределенности» [14, с. 133].

Е. Ю. Зотова описывает результаты исследования взаимосвязи толерантности к неопределенности и креативности школьников в работах К. Стойчевой. Автор указывает на наличие положительных корреляций между мотивацией к творчеству и потребностью в достижении, а также между мотивацией к творчеству и толерантностью к неопределенности. К. Стойчева приходит к выводу, что толерантность к неопределенности и мотивация связаны с креативностью, но не коррелируют межу собой.

Также в статье приводится исследование французских психологов, посвященное семейной преемственности толерантности к неопределенности и креативности (F. Zenansi, M. Besancon, T. Lubard, 2008, цит. по: [15]). Было установлено наличие позитивной связи между креативностью родителей и креативностью детейподростков. Гипотеза о положительной корреляции толерантности к неопределенности подростков и их родителей не подтвердилась. Авторы это объясняют неустойчивостью, нестабильностью личности подростка, что влияет на сформированность толерантности к неопределенности. Этим же объясняется более сильная выраженность связи между толерантностью к неопределенности и креативностью у родителей по сравнению с детьми [15].

В диссертационном исследовании Е. Г. Луковицкой получены интересные данные о личностных качествах, помогающих переносить неопределенность. С использованием личностного опросника Кеттелла выборке студентов и взрослых людей (от 17 лет и старше) были выявлены три фактора, имеющие наибольшее значение для 
толерантности к неопределенности: фактор Q1 (радикализм/гибкость), фактор М (мечтательность), фактор Е (доминантность).

Гибкость (радикализм) подразумевает наличие широких интеллектуальных интересов, стремление самостоятельно анализировать ситуации без апелляции к мнению авторитетов, хорошую информированность, спокойное восприятие новых идей. Мечтательность проявляется в самобытности мышления, своеобразии поведения, высоком напряжении внутреннего мира, интересе к абстрактным вопросам и мировоззренческим проблемам [6, 16]. Доминантность в данном случае рассматривается как настойчивость, которая сопряжена со стремлением к самостоятельности и независимости, с игнорированием условностей и авторитетов, потребностью в самоутверждении $[6,16]$.

Таким образом, в эмпирических исследованиях, выполненных на выборках взрослых и студентов, содержатся данные, подтверждающие положительную связь между толерантностью к неопределенности и исследуемыми нами личностными особенностями. Для подтверждения или опровержения данных тенденций у старших подростков было проведено корреляционное исследование.

\section{Методики исследования}

В качестве выборочной совокупности выступили обучающиеся старшего подросткового возраста, участвующие в летних проектных сменах по программам дополнительного образования. Всего в исследовании приняли участие 72 человека, среди них 45 девушек и 27 юношей. Средний возраст испытуемых - 15,3 \pm 1,11 лет. Математическая обработка данных проводилась с использованием программ Excell и SPSS 17.0.

Для проведения эмпирического исследования были использованы следующие методики:

1. Шкала общей толерантности к неопределенности (Д. МакЛейн, 1993; Е. Г. Луковицкая, 1998) в адаптации Е. Н. Осина (2010) [8, 17]. Д. Мак-Лейн определяет толерантность к неопределенности как «спектр реакций (от отвержения до влечения) на стимулы, которые воспринимаются индивидом как незнакомые, сложные, изменчивые или дающие возможность нескольких принципиально различных 
интерпретаций» [17, с. 67]. Данная шкала измеряет поведенческие и эмоциональные характеристики отношения к неопределенности [7]. Опросник включает в себя 19 утверждений, оцениваемых по 7-балльной шкале. Толерантность к неопределенности рассматривается по 5 субшкалам: отношение к новизне, отношение к сложным задачам, отношение к неопределенным ситуациям, предпочитание неопределенности, толерантность/избегание неопределенности. Данные субшкалы соответствуют трем типам стимулов и двум типам отношения.

2. Опросник «Мотивация успеха и боязнь неудачи» (А. А. Реан, 2006) [18], состоящий из 20 утверждений, с которыми отвечающему предлагается согласиться или не согласиться (дихотомическая шкала ответов). Опросник диагностирует преобладающий полюс мотивации: мотивация на успех или мотивация избегания неудачи.

3. Шкала «Автономия» из опросника «Шкала психологического благополучия» К. Рифф (адаптация Т. Д. Шевеленковой, П. П. Фесенко, 2005) [19], включающая в себя 14 утверждений, с которыми испытуемый может выразить свое согласие или несогласие, поставив отметку на шкале, содержащей 6 возможных градаций. Она оценивает способность соблюдать гармоничный баланс между собственными и общественными интересами.

4. Тест определения уровня самоэффективности (Дж. Маддукс, М. Шеер, модификация Л. Бояринцевой под руководством Р. Кричевского, 2011) [20]. Данная методика направлена на изучение самооценки и самосознания личности в части оценки человеком своего потенциала в сфере коммуникативной компетентности и предметной деятельности, которым он реально может воспользоваться. Опросник включает 2 шкалы: предметная компетентность и коммуникативная компетентность (всего 23 утверждения, с каждым из которых испытуемый оценивает степень своего согласия по 11-балльной шкале) [20].

\section{Результаты и их обсуждение}

Для оценки уровневых различий по исследуемым параметрам между юношами и девушками использовался критерий Манна Уитни $(U)$ (табл. 1). При сравнении средних показателей юношей 
и девушек с нормативными значениями для мужчин и женщин (подвыборка школьников была исключена из выборки стандартизации) [17] обнаруживается, что в целом сохраняется описанная в литературе тенденция: у юношей выражено более спокойное отношение к ситуациям неопределенности. Отметим, что при этом у юношей более выражен и общий показатель толерантности к неопределенности (по данным Е. Н. Осина [17], эти различия недостоверны).

Из представленных в табл. 1 данных видно, что у юношей толерантность к неопределенности достоверно выше. Дифференцированный анализ показателей отдельных субшкал методики «Шкала общей толерантности к неопределенности» свидетельствует о том, что эта особенность проявляется у юношей за счет таких параметров, как «отношение к новизне», «отношение к неопределенным

Таблица 1

Результаты сравнительного анализа толерантности к неопределенности и других личностных характеристик у юношей и девушек

\begin{tabular}{|c|c|c|c|c|}
\hline Шкала & Юноши & Девушки & $U_{\text {эксп }}$ & p-уровень \\
\hline Отношение к новизне & 13,89 & 11,64 & 376,50 & 0,01 \\
\hline $\begin{array}{l}\text { Отношение к сложным } \\
\text { задачам }\end{array}$ & 31,41 & 31,49 & 588,50 & 0,83 \\
\hline $\begin{array}{l}\text { Отношение к неопределен- } \\
\text { ным ситуациям }\end{array}$ & 41,11 & 36,07 & 394,50 & 0,01 \\
\hline $\begin{array}{l}\text { Предпочтение неопределен- } \\
\text { ности }\end{array}$ & 46,33 & 41,53 & 453,00 & 0,07 \\
\hline $\begin{array}{l}\text { Толерантность/ } \\
\text { избегание неопределенности }\end{array}$ & 41,41 & 38,91 & 479,50 & 0,14 \\
\hline $\begin{array}{l}\text { Общий показатель толе- } \\
\text { рантности к неопределен- } \\
\text { ности }\end{array}$ & 87,74 & 80,44 & 429,50 & 0,04 \\
\hline $\begin{array}{l}\text { Мотивация достижения } \\
\text { успеха }\end{array}$ & 15,22 & 13,04 & 327,00 & 0,00 \\
\hline Автономность & 54,78 & 51,62 & 468,00 & 0,11 \\
\hline Предметная компетентность & 35,33 & 27,69 & 485,50 & 0,16 \\
\hline $\begin{array}{l}\text { Коммуникативная компе- } \\
\text { тентность }\end{array}$ & 4,74 & 4,22 & 594,00 & 0,88 \\
\hline
\end{tabular}


ситуациям» и частично «предпочтение неопределенности». Отметим, что различия между юношами и девушками максимально сглажены по параметру «отношение к сложным задачам». В литературе встречаются разные данные о степени выраженности толерантности к неопределенности у юношей и девушек. В основном авторы приходят к выводу о том, что уровневые различия общей толерантности к неопределенности сглажены, и значение имеет выраженность отдельных параметров $[21,22]$. Что касается остальных исследуемых параметров, то выявлено различие в уровне мотивации достижения успеха: у юношей стремление к успеху выражено больше, чем у девушек. В целом это соотносится с имеющимися в литературе данными, хотя чаще всего авторы также указывают на различия между юношами и девушками, которые скорее связаны с отдельными диспозициями мотивации достижения. Например, юноши более смелые, независимые, чаще предпочитают трудные задачи и проявляют упорство, а также более уверены в успехе, чем девушки [21]. В целом как в отношении толерантности к неопределенности, так и мотивации достижения авторы делают акцент не столько на количественных (уровневых), сколько на качественных (содержательных) различиях между юношами и девушками $[21,22]$.

Для того чтобы выяснить, каким образом толерантность к неопределенности юношей и девушек связана с их личностными особенностями, использовался коэффициент корреляции Спирмена (табл. 2).

Из представленных данных видно, что, несмотря на небольшой возрастной диапазон, и у юношей, и у девушек параметры толерантности к неопределенности связаны с возрастом. То есть чем старше подросток, тем более спокойно он относится к ситуациям неопределенности и, более того, отдает предпочтение таким ситуациям, чувствует себя вовлеченным и заинтересованным, готовым решать сложные задачи. Также в обеих подвыборках совершенно независимой отказалась шкала «отношение к новизне»: независимо от уровня открытости новому опыту, юноши и девушки в возрасте 14-17 лет могут иметь разный уровень мотивации достижения, автономии и самоэффективности. Отметим, что при этом наблюдаются уровневые отличия между юношами и девушками по данному параметру: юноши более открыты новому опыту. 


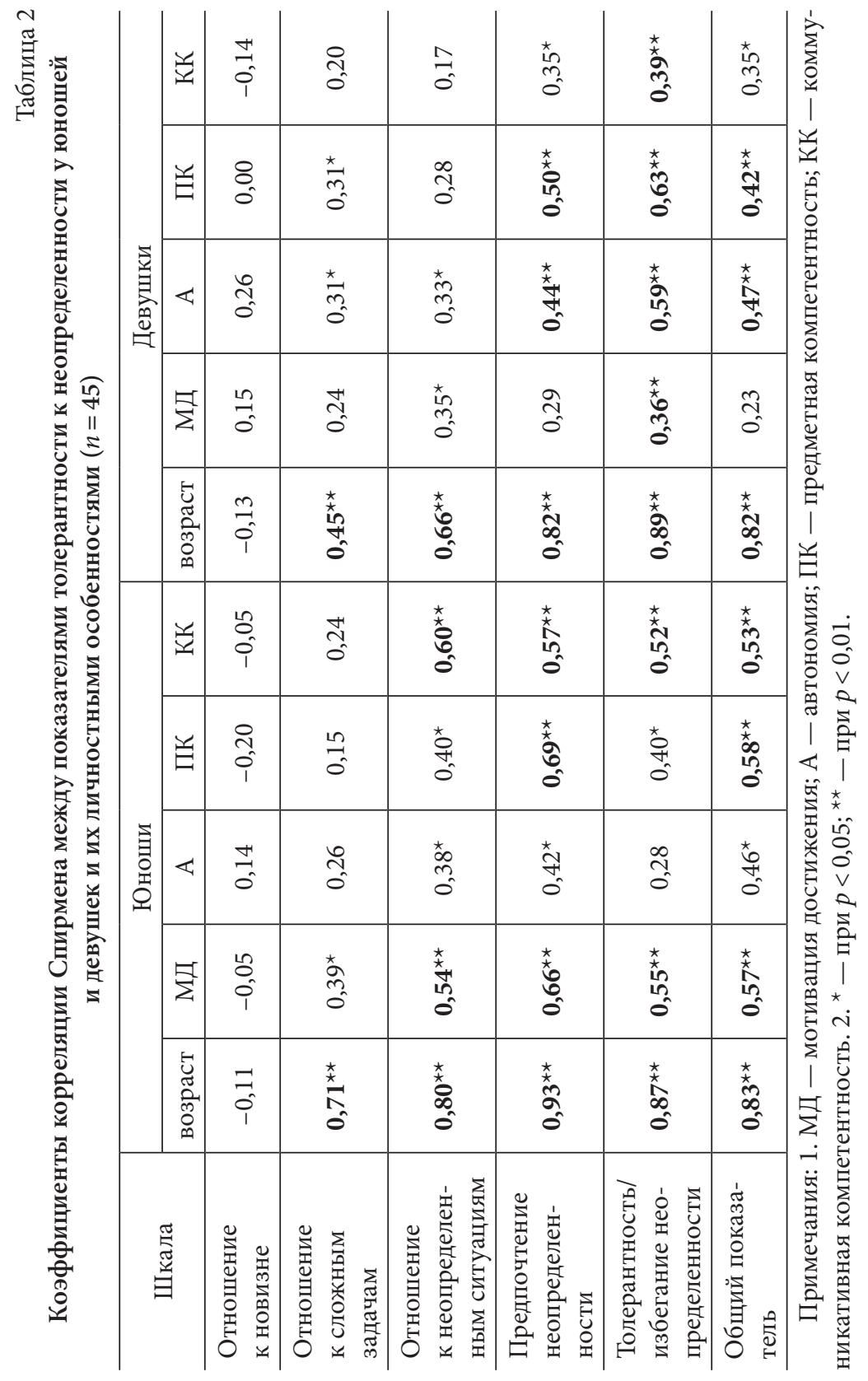


Независимо от пола, положительное отношение к неопределенным ситуациям связано с высокой мотивацией достижения и автономией испытуемых. Предпочтение таких ситуаций связано с предметной и межличностной самоэффективностью и высоким уровнем независимости и самостоятельности подростков.

По остальным параметрам толерантности к неопределенности юноши и девушки так или иначе отличаются друг от друга спецификой корреляционных связей. Так, у юношей отношение к сложным задачам связано с мотивацией достижения, а у девушек - c автономией и предметной компетентностью. В литературе отношение к сложным задачам упоминается как устойчивый коррелят мотивации достижения [21], независимо от пола испытуемых в возрасте старше 18 лет. Согласно Х. Шулеру, предпочтение трудных задач входит в структуру диспозиционной мотивации достижения [цит. по: 21, с. 41]. Полученные нами данные свидетельствуют о том, что самостоятельные и независимые в своих суждениях и поступках девушки, имеющие высокий уровень самоэффективности в важной для них предметной деятельности, чаще предпочитают браться за решение трудных задач. У юношей такой взаимосвязи не выявлено, но при этом их самоэффективность (в предметном и межличностном плане) связана с положительным отношением к ситуациям неопределенности. У девушек их самоэффективность никак не сопряжена с отношением к неопределенности: они могут принимать или не принимать ее, имея при этом совершенно разный уровень предметной и межличностной самоэффективности.

Интегральный показатель толерантности к неопределенности, независимо от пола подростков, связан с общей самоэффективностью и автономией, а у юношей - еще и с выраженной мотивацией к успеху.

\section{Выводы}

Таким образом, у юношей и девушек общая толерантность к неопределенности связана с возрастом - чем старше подросток, тем более выражена его готовность реагировать на сложные, неопределенные стимулы. Данная тенденция подтверждается в исследовании Е. Г. Луковицкой: возраст оказывает существенное влияние на восприятие и отношение к ситуациям неопределенности. 
Это обусловлено большей инструментальной подготовленностью индивида. Автор заключает, что толерантность к неопределенности меняется нелинейно: до 29 лет идет ее возрастание, в среднем возрасте (29-38 лет) наблюдается снижение и в старшем возрасте (от 39 лет и старше) происходит ее повышение согласно методике Д. Мак-Лейна [6, с. 115-116].

Учитывая имеющиеся в литературе нормативные данные [17], которые несколько выше, чем полученные нами (для сравнения приводим показатели среднего значения: $\mathrm{M}_{\text {норм (M) }}=101,22 \pm 20,68$; $M_{\text {норм(Ж) }}=98,97 \pm 18,53$ и $\left.M_{\text {эмп(Ю) }}=87,74 \pm 14,72 ; M_{\text {эмп(Д) }}=80,44 \pm 15,12\right)$, можно предположить, что в старшем подростковом возрасте толерантность к неопределенности еще только формируется. Но при этом у юношей и девушек уже наблюдаются предпочтения по отношению к неопределенности. Так, у юношей толерантность к неопределенности достоверно выше, преимущественно за счет отношения к новизне и ситуациям неопределенности. В отличие от девушек, у юношей принятие неопределенности и предпочтение трудных задач сопряжено с высокой мотивацией достижения. У девушек выбор трудных задач связан с автономностью и самоэффективностью в значимой для них деятельности, но при этом уровень их самоэффективности никак не связан с положительным отношением к ситуациям неопределенности.

Таким образом, подтвердились тенденции, выявленные в эмпирических исследованиях на выборках взрослых и студентов: наличие положительной связи между толерантностью к неопределенности и мотивацией достижения, самоэффективностью и автономией. Положительный характер связи между личностными качествами, входящими в развивающуюся потребностно-мотивационную сферу, и толерантностью к неопределенности косвенно подтверждает предположение о сензитивности подросткового возраста для развития толерантности к неопределенности.

Результаты исследования могут быть учтены при разработке дополнительных образовательных программ для школьников, занимающихся проектной деятельностью, с учетом возраста и пола обучающихся. 
1. Зинченко В. П. Толерантность к неопределенности: новость или психологическая традиция? // Вопр. психологии. 2007. № 6. С. 3-20.

2. Корнилова Т. В. Принятие решений и риск: психология неопределенности. 2014 [Электронный ресурc]. URL: https://docplayer.ru (дата обращения: 10.02.2020).

3. Леонов И. Н. Толерантность к неопределенности как психологический феномен: история становления конструкта // Вестн. Удмурт. ун-та. 2014. № 4. С. 43-52.

4. Леонтьев Д. А., Овчинникова Е. Ю., Рассказова Е. И., Фам А. Х. Психология выбора. М. : Смысл, 2015. 464 с.

5. Личностный потенциал: структура и диагностика / под ред. Д. А. Леонтьева. М. : Смысл, 2011. 680 с.

6. Луковищкая Е.Г. Социально-психологическое значение толерантности к неопределенности : дис. ... канд. психол. наук / С.-Петерб. гос. ун-т. СПб., 1998. 173 с.

7. Корнилова Т. В., Новикова М. А. «Психологическая разумность» в структуре интеллектуально-личностного потенциала (адаптация опросника) [Электронный ресурс] // Психол. журн. 2013. Т. 34, № 6. С. 63. URL: http://www.cognitivepsy.ru (дата обращения: 10.02.2020).

8. McLain D. L. The MSTAT-I: a new measure of an individual's tolerance for ambiguity [Electronic resource] // Educational and Psychological Measurement. 1993. Vol. 53, № 1. P. 183-189. URL: http://www.researchgate.net (accessed: 11.02.2020).

9. Корнилова Т. В. Принцип неопределенности в психологии выбора и риска [Электронный ресурс] // Психол. исслед. 2015. Т. 8, № 40. С. 3. URL: http://psystudy.ru_дата обращения: 10.02.2020).

10. Леонтвев Д. А. Вызов неопределенности как центральная проблема психологии личности [Электронный ресурс] // Психол. исслед. 2015. Т. 8 , № 40. C. 2. URL: http://psystudy.ru_(дата обращения: 10.02.2020).

11. Шаповаленко И. В. Возрастная психология (Психология развития и возрастная психология). М. : Гардарики, 2005. 349 с.

12. Вотинцева Т. С., Петренко В. Р. Взаимосвязь уровня толерантности к неопределенности и психологического благополучия // Педагогика и психология образования. 2016. № 4. С. 145-149. 
13. Гусейнов Ш. А. Толерантность к неопределенности как регулятор субъектной активности личности [Электронный ресурс] // Общество: социология, психология, педагогика. 2018. № 12. URL: https://cyberleninka.ru/ article/n/tolerantnost-k-neopredelennosti-kak-regulyator-subektnoy-aktivnostilichnosti (дата обращения: 20.05.2020).

14. Сараева Е. В., Николаев С. Г. Связь толерантности к неопределенности и мотивации достижения // Вестн. Удмурт. ун-та. Вып. 4. 2014. № 4. С. $129-134$.

15. Зотова Е. Ю. Современные исследования толерантности к неопределенности в зарубежной психологии // Вестн. НГУ. 2009. Т. 3, вып. 1. С. $147-155$.

16. Рукавишников А.А., Соколова М.В. Факторный личностный опросник Кеттелла : методическое руководство. СПб. : ИМАТОН, 2006. 96 с.

17. Осин Е.Н. Факторная структура русскоязычной версии шкалы общей толерантности к неопределенности Д. Маклейна // Психологическая диагностика. 2010. № 2. С. 65-86.

18. Реан А.А. Психология и психодиагностика личности: теория, методы исследования : практикум. СПб. : Прайм-Еврознак, 2006. 255 с.

19. Шевеленкова Т. Д., Фесенко П. П. Психологическое благополучие личности (обзор основных концепций и методика исследования) // Психологическая диагностика. 2005. № 3. С. 95-129.

20. Краснояриева О.М., Кабрин В.И., Мураввева О. И. и др. Психологические практики диагностики и развития самоэффективности студенческой молодежи : учеб. пособие. Томск : Изд. дом ТГУ, 2014. 274 с.

21. Виндекер О. С., Сморкалова Т. Л., Заложных А. И. Исследование структуры мотивации достижения в связи с отношением к неопределенности и стрессу (на примере студенческой выборки) // Благополучие и безопасность в условиях социальных трансформаций : материалы Х Междунар. симпоз. (9-10 июля 2019 г.). Екатеринбург : Гуманитар. ун-т, 2019. С. $40-43$.

22. Марченко Е.Е., Орловцева Е.В. Взаимосвязь толерантности к неопределенности и локуса контроля в юношеском возрасте // Актуальные проблемы психологии личности и социального взаимодействия. Гродно : ГрГУ, 2018. С. 162-171. 


\section{Раздел 3 \\ ПСИХОЛОГИЯ ПРОФЕССИОНАЛЬНОГО \\ РАЗВИТИЯ ПЕДАГОГА}

\section{МЕТОДИКА ПРОФЕССИОНАЛЬНО-ОРИЕНТИРОВАННОГО АВТОБИОГРАФИРОВАНИЯ КАК СРЕДСТВО СОПРОВОЖДЕНИЯ ПРОФЕССИОНАЛЬНОГО САМООПРЕДЕЛЕНИЯ СТУДЕНТОВ - БУДУЩИХ ПЕДАГОГОВ}

Е.Г.Белякова

В современном обществе, специфику которого А. Г. Асмолов характеризует через триаду «неопределенность - сложность разнообразие», профессиональное самоопределение становится процессом непрерывной включенности человека в свое профессиональное развитие на протяжении всей жизни. В этих условиях возникает потребность в активизации обучающихся как субъектов профессионального пути.

В современной научной литературе одним из основных критериев оценки профессионального самоопределения считается достижение профессиональной идентичности. Весьма продуктивными для выявления индивидуальных различий в представлениях студентов о своем профессиональном пути как существенного критерия для их дифференциации в условиях сопровождения являются методы, основанные на нарративном подходе. Профессиональная идентичность может трактоваться как субъективная самотождественность в избранной профессиональной сфере, принятие профессиональных ценностей, переживание аутентичности опыта исполнения

Исследование выполнено при финансовой поддержке РФФИ в рамках научного проекта № 18-013-00106 «Смысловые механизмы профессионального самоопределения студентов - будущих педагогов». 
профессиональных ролей, самооценка и образ «Я-профессионал», которые объективируются в профессиональном нарративе. Автобиографический нарратив с профессионально-ориентированным содержанием может рассматриваться как средство не только диагностики, но и собственно создания индивидуального проекта профессионального саморазвития. Акцентируя феноменологический аспект профессиональной идентичности, становится возможным использовать ряд современных подходов (теория смысла, нарративная психология, конструкционизм) для создания средств диагностики и активизации профессионального самоопределения.

Цель исследования состоит в анализе профессионально-ориентированного автобиографирования как особой социокультурной практики и выявлении его развивающих возможностей в процессе вузовской подготовки педагога. Мы приводим описание авторских методик сопровождения профессионального самоопределения студентов-педагогов, построенных на методологии нарративного подхода и современных исследований автобиографической памяти.

\section{Обзор}

Корни нарративного подхода в образовании связаны с так называемым «нарративным поворотом» («narrative turn») на рубеже XX-XXI вв., суть которого состоит в экспорте идей текстового опосредования социокультурного бытия личности в различные области социогуманитарного знания. Нарративный подход берет свое начало в филологической нарратологии, где сложилась особая область изучения структурно-содержательных и процессуальнодинамических характеристик повествовательных произведений не только художественных жанров, но и документальных текстов, в которых автор воссоздает реальные события своей жизни. В философских исследованиях формирование познавательной парадигмы постструктурализма, герменевтики и конструкционизма (радикального, социального) позволило рассматривать нарратив как способ объективации опыта субъекта в форме авторского повествования, актуализировало идеи множественности интерпретаций и роли контекстов в создании нарративных текстов. 
В психологии нарративный подход стал весьма популярным направлением, позволившим сконцентрировать исследования на смысловых компонентах индивидуально-личностного опыта. В настоящее время сложилось несколько вариантов определения понятия нарратива, под которым может пониматься особый модус мышления, позволяющий осуществлять интерпретацию и реконструирование жизненных событий в их взаимосвязи (J.S. Bruner), объяснительный принцип психологии, раскрывающий способы организации человеческого опыта и понимания его смысла (T. Sarbin), и в более расширенном варианте - как организующий фактор человеческой психики и личности (Р. J. Eakin), жизненная история, интегрирующая прошлое, настоящее и будущее личности и являющаяся основой переживания идентичности (J. S. Bruner, D. P. McAdams), схема opганизации опыта (W. Labov, J. Waletzky) [1]. Е. Е. Сапогова рассматривает автобиографирование как рефлексивно-герменевтический процесс, упорядочивающий, фиксирующий и «высвечивающий» для личности результаты анализа проживаемой жизни, как способ трансляции вовне приемлемой версии себя, что является актом самоопределения на основе собственных смыслов. На базе разрабатываемого экзистенциально-нарративного подхода предложена полупроективная методика «Незаконченная автобиография», сконструированная на основе техники незаконченных предложений, позволяющая выявлять рефлексивные доминанты разных возрастов (представления о себе, жизни, реальности, система жизненных ценностей и смыслов, сложившийся образ Я) [2]. В работах В.В. Нурковой с позиций культурно-деятельностной психологии автобиографический нарратив определяется как «процесс и результат реализации мотивированного целенаправленного мнемического действия, исполняемого по семиотическим правилам в речевой форме, позволяющего актуализировать механизм осознания своего жизненного пути и направленного на стабилизацию или изменение существующей иерархии мотивов для оптимизации характеристик будущей деятельности» [3, с. 73]. Создание нарратива подчиняется когнитивной логике самого субъекта, отражает результаты осмысления человеком значимых событий своей жизни. При этом нарратив, выступающий базовой формой объективации автобиографической 
памяти личности, одновременно испытывает влияние культурных жизненных сценариев, приписывающих оценку значимости событий и ситуаций в соответствии с принятыми в обществе представлениями. Соответственно, «индивидуальная концепция судьбы» может являться результатом самостоятельного самоанализа жизненного пути или воспроизводить интериоризованные социокультурные значения, либо являться результатом их взаимодействия. Автобиографический нарратив, выполняющий функции конструирования и стабилизации личности, выступает как организующий и направляющий внутриличностный фактор по отношению к деятельности [3, с. 73]. Смыслодеятельностный аспект нарратива также подчеркивается в исследовании Ю. Е. Зайцевой, по мнению которой «интеграция целостного жизненного опыта через призму поиска ответов на вопросы “Кто Я как человек, проживающий именно эту жизнь?”, “Кто Я в своей жизни в целом?” позволяет в качестве образа идентичности сконструировать образ героя жизненного пути как субъекта жизненных решений» [4, с. 122]. Соответственно, можно предположить, что результаты нарративной активности субъекта могут оказывать влияние на его реальную деятельность, в том числе выступать внутренними предикторами профессионального развития.

Создание нарратива на основе осмысления опыта является актом самоопределения личности, способом самопрезентации своего проекта жизни. Нарративная идентичность может рассматриваться как «способность воплощения индивидуального проекта самосозидания вопреки ситуативной детерминации» [5, с. 22]. Отметим также специфику современного истолкования феномена нарративной идентичности. Как отмечает Е.П. Белинская, в настоящее время произошел сдвиг в концептуализации проблем идентичности, обусловленный динамикой социального пространства, в связи с чем «исследования идентичности последних десятилетий во многом становились попыткой понимания того, как человек противостоит нарастающей неопределенности, множественности и изменчивости социального мира» [6, с. 7]. Тем самым признается множественность идентичности и ее контекстуальная обусловленность, поскольку в изменяющихся условиях либо на новых этапах 
жизненного цикла человеку приходится отвечать на новые вызовы и решать возникающие задачи, одновременно конструируя через нарративные практики обновленные персональные проекты своей жизни. Взгляд на идентичность как на непрерывно изменяющуюся, динамическую характеристику позволяет расценивать нарратив как особый психологический механизм, обеспечивающий гибкое переструктурирование субъективной картины мира и себя в этом мире. Автобиографический нарратив связывает в единое смысловое целое различные временные модусы существования личности, интегрируя ретроспективную, актуальную и проспективную идентичности, и выступает как гипотеза о себе в мире, открытая для создания новых версий.

Методология и методы нарративной психологии получили широкое применение в психотерапии и психологическом консультировании, в исследованиях персональной временной перспективы, а в последние годы начинают активно интегрироваться в образовательную теорию и практику. Так, обращаясь к отечественным исследованиям, можно отметить возникновение соответствующей терминологии («нарративная педагогика», «нарративные методы обучения») и поиск возможностей практической реализации нарративного подхода применительно к проблемам обучения, воспитания и развития личности (А. О. Бухаров, Е. В. Казанцева, А. А. Утюганов, М. С. Ясницкий, А. В. Серый, М. В. Луканина, Т. В. Борзова, К. А. Литвинов, И. А. Рудакова). Как отмечает Е. В. Казанцева, нарративная педагогика ориентирована на раскрытие личностных смыслов учащихся, что позволяет сформировать их персональный образовательный путь. В условиях вузовского обучения в технологии нарративной педагогики должен быть включен анализ персональных нарративов профессионалов, дающий возможность углубить представления учащихся о себе как будущих профессионалах, учитывать контекст создания и презентации нарративов в условиях группового взаимодействия [7]. В последние десятилетия возродился интерес к «феноменологической педагогике», по своим методологическим основаниям связанной с идеями феноменологического анализа и герменевтики понимания внутреннего мира личности ребенка 
и достаточно близкой по своим концептуальным идеям к нарративному подходу (Е. А. Александрова, Н. Б. Крылова, С. В. Кривцова).

В зарубежных и отечественных исследованиях нарративные практики используются в качестве как средства диагностического исследования, так и метода развития личности, в том числе применительно к проблемам профессионального развития педагога (D. J. Clandinin, F. M. Connelly, J. Huber, I. Goodson, S. R. Gill, L. A. Taylor, А.Ф. Закирова, Т.В. Борзова и др.). D. Beijaard, P.C. Meijer, N. Verloop, G.E. Brooke подчеркивают значимость феноменологического анализа внутреннего мира студентов и молодых педагогов для сопровождения их профессионального роста, важность создания условий для их субъективного перехода от осознания себя как «умеющего преподавать», т. е. овладевшего инструментальными характеристиками педагогической деятельности, к восприятию себя как целостной интегрированной личности - профессионала, способного «быть учителем» $[8,9]$. Достижение переживания внутренней целостности и аутентичности в профессии педагога может быть реализовано через нарративную активность.

Одним из способов реализации нарративных практик в образовании, по мнению N. Layons, V. Kubler LaBoskey, может являться включение в профессиональное портфолио обучающихся персональных нарративов с рефлексией процесса преподавания и накопленного опыта в ходе обучения преподаванию [10]. L. Schaefer, D. J. Clandinin приводят данные своего нарративного исследования, согласно которым у начинающих учителей с разным стажем работы биографические профессиональные нарративы выполняют мотивирующую роль, стимулируют желание заниматься педагогической деятельностью. В случае, если не удается поддерживать нарративы своими действиями, учителя могут оставить преподавание [11]. По данным М.В. Клементьевой, рефлексивный биографический тренинг способствует профессионально-личностному развитию. В качестве конкретной технологии с использованием нарративных практик для студентов-психологов предложен рефлексивный биографический тренинг, включающий знакомство со структурой биографического текста, развитие умений интерпретации жизненного нарратива, обучение способам изменения жизненного нарратива 
и рефлексии биографического тезауруса, построение рефлексивного взаимодействия в группе в рамках учебно-профессиональной деятельности [12]. А. А. Утюганов, М. С. Яницкий, А. В. Серый использовали нарративные методы для формирования профессиональноориентированной системы ценностно-смысловых ориентаций студентов. Технология включает поэтапное развитие профессиональных смыслов через сторителлинг, метод нарративного интервью, групповое обсуждение нарратива, метод «коллективных писем», нарративную игру, создание большой истории, методику «Автобиография будущего» [13].

Анализ современного состояния проблемы показывает, что, несмотря на значительный интерес к возможностям нарративного подхода в образовании, пока недостаточно изученным является вопрос о том, в каких формах нарративный подход может использоваться для такой задачи, как сопровождение профессионального самоопределения студентов - будущих педагогов. При этом, на наш взгляд, следует понимать место нарративных практик в целостном образовательном процессе, их уникальную роль для формирования идентичности и одновременно ряд ограничений, которые предполагают интеграцию нарративных методов с рядом других образовательных технологий, которые обеспечивают деятельную реализацию личности в соответствии с представлением о своем профессиональном пути.

\section{Результаты исследования}

Цель исследования состояла в разработке методики, построенной на методологии нарративного подхода, которая была бы встроена в сопровождение профессионального самоопределения студентов. Методика профессионально-ориентированного автобиографирования апробирована нами в нескольких вариантах в ходе опытно-экспериментальной работы, в которой принимали участие студенты младших курсов педагогического бакалавриата. Каждый из предложенных вариантов методики предполагает создание авторских нарративных текстов, отражающих субъективные представления о профессиональном пути. Нарративные методики выполняют особую роль в целостном процессе сопровождения, позволяя акти- 
визировать работу понимания, осмысленное отношение к новому опыту и самоизменениям. Основное требование к нарративному тексту состоит в наличии выраженной авторской позиции. Это должно быть свободное и развернутое описание ситуаций, событий, переживаний, связанных с профессионально-личностным развитием, в которых автор сосредотачивается на своем личном опыте, значимом для профессионального становления и оказавшем существенное влияние на мотивацию к занятиям педагогической деятельностью.

В опытно-экспериментальной работе была использована предложенная нами ранее модель сопровождения [14], цель которого состоит в создании условий для профессиональной самоидентификации студентов. Сопровождение реализуется через ряд взаимосвязанных этапов, в ходе которых организуется циклическая деятельность проектирования профессионального развития, его деятельностной реализации и рефлексии с последующей постановкой новых целей саморазвития. Разрабатывая данную модель, мы понимали, что столь сложная и длительная работа не может быть реализована в рамках изолированной от целостного учебно-воспитательного процесса деятельности студентов. Сопровождение осуществляется в формах учебной, внеучебной работы, в период прохождения студентами практик, является сквозным процессом и не имеет жестко ограниченных временных рамок. Выделение этапов в определенной степени условно, поскольку процесс профессионального самоопределения является полидетерминированным, имеет различные «точки отсчета», что обусловлено уже имеющимся субъектным опытом студентов и особенностями социальной ситуации их развития как будущих педагогов. Темпы и достижения в самоопределении также весьма индивидуальны, а нелинейность данного процесса допускает возвратно-поступательные траектории движения, в том числе кардинальную смену векторов развития.

Важным условием реализации сопровождения является полисубъектность, которая означает, прежде всего, понимание всеми субъектами образовательного процесса (преподаватели, тьюторы, специалисты по внеучебной работе, руководители практик) необходимости развития профессиональной идентичности студентов 
и их совместное участие в данном процессе. Профессиональное автобиографирование как способ коммуникации представляет собой авторское повествование, адресованное профессиональному сообществу. Нарратив как дискурсивный феномен отражает специфику процессов коммуникации в сообществах через принятые ими терминологию и «систему правил». Соответственно, развитие способности к созданию профессионально-ориентированных нарративов становится возможным через диалог с представителями данного сообщества. У студентов-педагогов развитие способности к самопониманию и интерпретации опыта профессионально-личностного развития осуществляется через содержательное взаимодействие с педагогами-практиками, наставниками и преподавателями, способными организовать профессиональный диалог, обладающими достаточным уровнем развития рефлексии и коммуникативных техник и, что очень существенно, строящими данное взаимодействие как развивающее, в формате поддерживающих отношений.

Кратко охарактеризуем содержание основных этапов сопровождения и роль нарративных методик, вводимых на каждом из них.

1. Смыслоориентационный этап. Его содержанием является первоначальная ориентация студентов в аксиологических основах педагогической деятельности, формирование представлений о содержании и структуре педагогической деятельности. Значение смыслоориентации состоит в конструировании субъективного эталонного образа педагога-профессионала, который выступает ориентиром для проектирования собственного профессионального развития, т. е. предметом идентификации. Смыслоориентация осуществляется через интерпретацию текстов с педагогическим содержанием, создание авторских встречных текстов и рефлексивных эссе, в которых студенты описывают свое видение педагогической профессии. На данном этапе предметом восприятия, понимания и интерпретации выступают уже «готовые» автобиографические нарративы, представленные в педагогической культуре. Ими могут являться тексты разной модальности (художественные, научнопублицистические и научно-популярные произведения, видеоматериалы, результаты наблюдений и обсуждения «живого» педагогического процесса, а также непосредственного общения с педагогами), 
отражающие педагогический опыт. Формой, в которой на данном этапе студенты могут актуализировать свой персональный автобиографический нарратив, является «встречный текст», в котором выражаются собственная точка зрения, мысли, чувства, переживания, возникшие при анализе и интерпретации культурного текста.

2. Смыслоцелеполагание. В форме нарративного текста конструируется проспективная идентичность, выполняющая роль персонального проекта становления в профессии. Формулируются «перспективные линии» развития, определяются ближайшие и отдаленные цели, осмысляются ценностно-смысловые основания собственного выбора педагогической профессии. Проект может носить неконкретный характер, выражаться метафорами, основное же в нем - это очерчивание перспективы. Согласно предложенной нами модели, смыслоцелеполагание осуществляется в начале каждого нового цикла «проектирование профессионального развития - его деятельностная реализация - рефлексия». В нашем исследовании рамки данного цикла были условно ограничены периодом первого года обучения на педагогическом бакалавриате, в течение которого студенты осваивали теоретические дисциплины, приняли участие в тренинге профессионально-личностного роста, прошли летнюю производственную практику в пришкольных и загородных детских лагерях.

3. Организационно-деятельностный этап. Осуществляется перевод проекта в более конкретную форму - своего рода «дорожную карту», «траекторию» профессионального развития в контексте реальной деятельности (учебно-профессиональной, профессиональной), планируются конкретные действия, необходимые для достижения поставленных целей и задач.

4. Деятельностный этап. Происходит реализация проекта в деятельности, одновременно накапливается опыт переживаний самоидентичности в профессии педагога, которые становятся предметом текущей рефлексии. При организации деятельностного этапа мы ввели в качестве необходимого условия реализацию ежедневного микроцикла «планирование задач на предстоящий день - их выполнение - краткая рефлексия сделанного за день и степени его успешности». На данном этапе нарративные тексты (актуальная 
идентичность) более лаконичны, поскольку вследствие загруженности студентов возникают существенные ограничения во времени, отводимом на самоанализ. Кроме того, особенностью нарративов становится акцент не только на личностной рефлексии, но и на предметной. Используется «язык действий», поскольку студенты сосредоточены, прежде всего, на освоении операциональнотехнологических компонентов педагогической деятельности, а их эмоциональные состояния отражают степень успешности в практической деятельности, реакцию на возникающие затруднения или, напротив, на достижение поставленных целей. В качестве более развернутой формы автобиографирования студентам предлагалось составлять еженедельную рефлексию с оценкой достижений в профессионально-личностном развитии (ретроспективная идентичность).

5. Рефлексивный этап. Содержание этапа состоит в смысловом обобщении всего субъектного опыта, полученного в ходе реализации проекта профессионального саморазвития, интеграции осмысленного опыта в целостную личностную структуру. На рефлексивном этапе готовится итоговое обобщающее рефлексивное эссе, значимые события профессиональной автобиографии выстраиваются в целостную связную последовательность, отражающую определенный период профессионального пути, делаются выводы о том, насколько достигнуты поставленные на начальных этапах цели, какие изменения в себе как будущем профессионале студенты могли бы отметить, как воспринимают себя в контексте нового опыта и результатов, достигнутых ими за прошедший с момента смыслоцелеполагания и планирования профессионального развития период (ретроспективная идентичность).

6. Новое смыслоцелеполагание. Этап является завершающим по отношению к предыдущему циклу и начальным для нового, на котором повторяются все этапы самоопределения. Через автобиографический нарратив происходит конструирование новой проспективной идентичности с опорой на обновленное восприятие себя как будущего профессионала.

Как показывают специальные исследования и наши собственные результаты апробации методики, для студентов, не владеющих 
средствами профессионально-личностной рефлексии и практиками создания авторских текстов, требуется предварительная подготовка, своего рода обучение деятельности по созданию нарративов. Необходимость развития текстовой деятельности, включающей восприятие, осмысление, интерпретацию и порождение текстов, обоснована в исследованиях Т. М. Дридзе, А.Ф. Закировой, Т. В. Обласовой и др. Наши выводы согласуются с результатами исследований Е.Е. Сапоговой, которая характеризует особое новообразование взрослости - способность к упорядочению экзистенциального и жизненного опыта - как семиотическую компетентность, позволяющую осуществлять акты личностной герменевтики через осмысление и интерпретацию уникальных событий индивидуальной жизни [2].

С учетом того, что нарративная активность требует специального развития, были разработаны списки вопросов, направляющих создание автобиографического нарратива. Все вопросы носят открытый характер. В отличие от традиционных опросников, не желательны ограничения ответов по форме изложения, объему и стилю.

В качестве иллюстрации приведем описание вариантов методики профессионально-ориентированного автобиографирования.

Написание нарратива на основе работы с педагогическими текстами. На основе анализа и интерпретации текстов с педагогическим содержанием, в качестве которых могут использоваться художественные произведения, научно-популярные статьи, кейсы, видеофрагменты уроков, фильмы, студентам предлагается составить собственный «встречный текст», в котором нашло бы отражение их понимание педагогической реальности, своего нового опыта и возможных изменений в восприятии себя как будущего профессионала. Процедура предполагает групповое обсуждение, в ходе которого студенты имеют возможность выразить свои мысли и чувства, расширить границы собственного понимания педагогического содержания текстов. Инструкция: «Ориентируясь на предложенные вопросы, в свободной форме подготовьте свой собственный текст. Какой опыт вы получили в процессе работы с текстом (вопрос только для участников)? Какой опыт вы получили сегодня, когда участвовали в совместном обсуждении текстов? Изменилось ли каким-то образом ваше представление о профессии педагога? Если 
да, то в чем именно? Произошли ли изменения в вашем восприятии себя как будущего педагога? В чем именно они заключаются?»

Эссе «Мое профессиональное будущее». Методика стимулирует смыслоцелеполагание, а ориентировочные вопросы направляют процесс осмысления перспективных целей и задач. Инструкция: «Ориентируясь на предложенные вопросы, в свободной форме подготовьте авторское эссе. Почему я выбрал(а) профессию педагога? Каким должен быть современный педагог? Какой я педагог? Каким педагогом я хочу быть? Что нужно и что я готов(а) сделать для достижения поставленной цели? Каков мой педагогический опыт (опыт переживания себя как педагога) за период обучения в вузе? Как полученный опыт повлиял на мое становление как педагога? Вижу ли я себя педагогом в будущем?»

Методика «Мотивационное письмо». Методика разработана для этапа смыслоцелеполагания, который условно соотносился нами в опытно-экспериментальной работе с периодом выхода студентов на практику. Мотивационное письмо позволяет выстроить перспективные цели, создать образ «профессионального будущего», как его себе представляют студенты, наметить траекторию движения, попытаться выявить личные ресурсы и необходимые средства его достижения, определить индикаторы, по которым можно было бы сделать вывод о позитивных изменениях. Методика позволяет студентам осознать имеющийся у них «бэкграунд» и наметить перспективные точки роста. Инструкция: «Перечисленные ниже вопросы помогут вам при составлении мотивационного письма. Представьте, что вас принимают на работу в образовательную организацию. Вам надо принять участие в собеседовании с будущими работодателями. Подготовьтесь к нему и напишите свое мотивационное письмо, в котором нужно представить себя. Опишите свой педагогический опыт. Как он повлиял на ваше решение стать педагогом? Насколько вы в настоящее время являетесь педагогом-профессионалом? Какие цели развития вы перед собой ставите? Опишите ваши планы на период прохождения практики либо, если готовы, на более продолжительный период. Какие компетенции вы собираетесь развивать? Что вы будете для этого делать? Какой результат вы бы считали положительным?» 
Методика «Персональный план профессионального развития». Данную методику нельзя отнести к категории автобиографического нарратива, но в условиях консультирования она может быть развернута в нарративный текст. Использование планирования мы посчитали необходимым, поскольку на организационно-деятельностном этапе требуется «заземление» проекта профессионального саморазвития применительно к условиям его деятельностной реализации (в нашем исследовании - при прохождении практики). В плане конкретизируется состав целей, условий и средств их достижения, выстраивается индивидуальный маршрут действий, определяются индикаторы для оценки их результативности, указываются имеющиеся ресурсы и те, которые могут понадобиться дополнительно. Инструкция: «Составьте план своего профессионального развития. Это может быть план на период практики или более продолжительное время, на ваше усмотрение. Основные пункты плана: 1. Мои цели профессионального развития как будущего педагога. 2. Мои ближайшие задачи профессионального развития. 3. Каких знаний, умений, навыков мне не хватает, чтобы достигать желаемого результата при решении профессиональных задач. 3. Какую компетенцию буду развивать (можно указать несколько). 4. Сколько времени мне для этого понадобится. 5. Каким образом я буду развивать эту компетенцию. 6. Какие условия для этого нужны. 7. Какая помощь мне понадобится. 8. Как я узнаю о том, что поставленная мной задача достигнута (по каким признакам, индикаторам)». Студенты отвечают на все пункты плана и продолжают работать с ним в течение практики (могут уточнять, дополнять). Наиболее заметная коррекция плана, введение новых данных происходит на рефлексивном этапе.

Текущая рефлексия. Непосредственно в ходе практики (деятельностный этап) студенты составляют ежедневные краткие рефлексивные самоотчеты о текущих результатах своей деятельности. Инструкция: «Опишите свои сегодняшние результаты. Что получилось? Что не получилось? Почему? Как предполагаете преодолевать затруднения?» Деятельностный этап предполагает непрерывный содержательный диалог студента с преподавателем, включенным 
в процесс сопровождения, обратную связь, консультативную и психологическую поддержку.

«Итоговое рефлексивное эссе». Методика используется на заключительном этапе практики. Студентам предлагается осмыслить полученный опыт и наметить новые цели профессионального саморазвития. Инструкция: «В течение практики вы собирали материал, который теперь нужно осмыслить. Постарайтесь создать свою историю, свое повествование о том, как происходило накопление вашего педагогического опыта и что менялось в вашем восприятии себя как педагога-практика. Содержание может включать как опыт положительный, так и затруднения, с которыми пришлось столкнуться. Желательно выделять наиболее запомнившиеся, яркие события и ситуации. Они должны быть эмоционально окрашенными и значимыми для вашего профессионального становления. Важно! Ваши воспоминания надо не только кратко описать, но и прокомментировать, осмыслить. Что происходило, что вы делали, что переживали, что в итоге «приросло» к вашему педагогическому опыту. Произошли ли какие-то заметные изменения в том, как вы теперь себя воспринимаете в качестве будущего педагога? Или ничего существенного не поменялось? Постарайтесь показать свой собственный уникальный опыт на пути в профессию педагога. История должна получиться более-менее целостной. В начале нашей работы вы поставили перед собой цели профессионального развития, выделили индикаторы их достижения. Сейчас надо вернуться к своему изначальному плану и посмотреть, что в результате получилось. Произошли ли изменения? По каким признакам это заметно. Что бы вы сейчас включили в свой персональный план профессионального развития. Какие-то новые цели? Задачи? Что понадобится для их достижения?»

Опыт апробации профессионально-ориентированного автобиографирования как средства сопровождения профессионального самоопределения студентов - будущих педагогов позволил определить его функции:

1) смыслообразующая, поскольку в процессе создания автобиографического нарратива задействованы смысловые механизмы 
профессионального самоопределения в пространстве педагогической культуры и ее ценностей;

2) диагностическая, суть которой в том, что анализ нарратива дает возможность выявить актуальное состояние «профессионального самочувствия» студента, восприятие им его персональных достижений и проблем вхождения в профессию, отражает признаки кризисных переживаний. Это придает сопровождению профессионального самоопределения индивидуализированный характер, позволяет строить на основе нарративных текстов направленное профориентационное консультирование и поддержку;

3) развивающая / формирующая, состоящая в том, что через повествование о себе в связке «прошлое - настоящее - будущее в профессии» студент создает целостную картину своего профессионального пути, связывая в единую смысловую последовательность значимые эпизоды, ситуации, события. Тем самым разрозненные ранее факты профессиональной биографии могут выстроиться в целостную концепцию профессиональной судьбы, что важно для самоидентификации личности в избранной профессиональной сфере;

4) мотивирующая, обеспечивающая в условиях сопровождения осмысленность и высокий уровень субъектности студентов в управлении собственным профессиональным развитием;

5) рефлексивная. Нарратив является формой личностной рефлексии в условиях постоянно обновляющихся контекстов профессионального становления. Профессиональное автобиографирование строится как процесс понимания и интерпретации приобретаемого опыта в профессиональной деятельности и коммуникации;

6) проектировочная, связанная с продуктивной природой индивидуального нарратива, его «порождающими» свойствами по отношению к активности личности. Нарратив воспроизводит модель деятельности субъекта, он же является организующим фактором для разворачивания различных форм его активности;

7) интеграционная. Овладение практиками создания субъективного образа траектории профессионального роста и осмысленного восприятия формирующегося педагогического опыта обеспечивает накопление переживаний самоидентичности в избранной профес- 
сии, их непрерывную аккумуляцию и последующую интеграцию в персональный образ «Я-профессионал».

Перечисленные выше функции автобиографического профессионально-ориентированного нарратива тесно взаимосвязаны и взаимообусловлены. В комплексе они обеспечивают создание «нарративной идентичности», причем в нескольких временных модусах, - ретроспективной, актуальной и проспективной. Отметим также, что непрерывность процесса профессиональной самоидентификации, его зависимость от образовательного и профессионального «ландшафтов» также находят отражение в профессиональноориентированных нарративах.

В исследовательских целях нарративы могут быть проанализированы с использованием контент-анализа, что позволяет выявить динамику проявления смысловых механизмов профессионального самоопределения. Содержание нарративов представляет собой важную диагностическую информацию для преподавателей, осуществляющих сопровождение. Так, например, в ходе практики у студентов с большой вероятностью могут возникнуть негативные эмоциональные состояния при затруднениях в самостоятельных профессиональных пробах. Тем самым расширяются задачи преподавателя, осуществляющего сопровождение, который становится уже не только консультантом, способным дать рекомендации, непосредственно касающиеся способов решения той или иной педагогической ситуации, но также выполняет роль консультанта по личностному росту, отслеживает возникновение кризисных состояний, своевременно может оказать психологическую поддержку, предложить студентам позитивную интерпретацию полученного опыта, актуализировать личностные ресурсы для преодоления внутренних барьеров.

Использование методик профессионально-ориентированного автобиографирования может осуществляться не только в традиционной (очной) форме, но дистанционно. В нашем исследовании сопровождение студентов на ряде этапов организовывалось через социальную сеть «ВКонтакте» и платформу Trello. Было установлено, что использование методик профессионально-ориентированного автобиографирования с применением современных информаци- 
онно-коммуникационных технологий достаточно продуктивно, поскольку их современные модификации (Web 2.0, Web 3.0) обеспечивают интерактивность, диалогичность и оперативность педагогического взаимодействия, позволяют обновлять и обогащать авторский контент.

Тем не менее полагаем, что наиболее продуктивными для работы с нарративами являются индивидуальное и групповое консультирование в форме непосредственного межличностного контакта студентов и преподавателей, включенных в процесс сопровождения профессионального самоопределения.

\section{Выводы}

Результаты исследования указывают на продуктивность нарративного подхода для сопровождения профессионального самоопределения студентов - будущих педагогов как смыслового процесса, в котором ключевое значение имеет развитие профессиональной идентичности через создание профессионально-ориентированных автобиографических нарративов. Предложен ряд конкретных вариантов использования профессионально-ориентированного автобиографирования. Методики соотнесены с разными по содержанию этапами сопровождения профессионального самоопределения, на каждом из которых выполняют роль средства, активизирующего осмысленное отношение студентов к своему профессиональному развитию. Многофункциональность профессионально-ориентированного автобиографирования позволяет активизировать мотивацию студентов к профессиональному саморазвитию, рефлексию и самопроектировочную деятельность. Одновременно методика позволяет получать содержательную обратную связь о динамике процесса профессионального самоопределения студентов, становлении их самоидентичности в профессии педагога, являясь тем самым средством диагностики изменений.

1. Кутковая К. С. Нарратив в исследовании идентичности // Национальный психологический журнал. 2014. № 4 (16). С. 23-33.

2. Сапогова Е. Е. Автобиографирование: «Бытие-под-собственнымвзглядом» // Развитие личности. 2016. № 1. С. 92-114. 
3. Нуркова В. Рассказывать о себе, рассказывать себя, рассказывать собой: автобиографический нарратив с позиций культурно-деятельностного подхода // Развитие личности. 2010. № 1. С. 73-96.

4. Зайцева Ю.Е. Время смысла: нарративный модус временной перспективы // Вестн. С.-Петерб. ун-та. Психология. 2018. Т. 8, № 1. С. 16-33.

5. Нуркова В. В. Самоопределяющие нарративы в развитии личности // Психологическая наука и образование. 2014. Т. 19, № 4. С. 22-30.

6. Белинская Е.П. Современные исследования идентичности: от структурной определенности к процессуальности и незавершенности // Вестн. С.-Петерб. ун-та. Психология. 2018. Т. 8, № 1. С. 6-15.

7. Казанцева E. В. К характеристике практического уровня реализации феноменологической педагогики // Новое в психолого-педагогических исследованиях. 2013. № 1. С. 96-103.

8. Beijaard D., Meijer P. C., Verloop N. Reconsidering research on teachers' professional identity // Teaching and teacher education. 2004. Vol. 20, № 2. P. 107-128.

9. Brooke G. E. My Personal Journey toward Professionalism // Young Children. 1994. Vol. 49, № 6. P. 69-71.

10. Lyons N., LaBoskey V. K. (ed.). Narrative inquiry in practice: Advancing the knowledge of teaching. Teachers College Press, 2002. Vol. 22.

11. Schaefer L., Clandinin D. J. Sustaining teachers' stories to live by: Implications for teacher education //Teachers and Teaching. 2019. Vol. 25, № 1. P. 54-68.

12. Клементьева М. В. Биографическая рефлексия как ресурс профессионально-личностного развития студентов-психологов // Образовательные технологии. 2015. № 4. С. 103-110.

13. Утюганов А. А., Яниикий М. С., Серый А. В. Нарративные технологии формирования ценностно-смысловых ориентаций личности: психологическое содержание и применение в образовательной практике // Science for education today. 2019. Т. 9, № 1. С. 76-92.

14. Белякова Е. Г. Сопровождение профессионального самоопределения студентов - будущих педагогов: ценностно-смысловой подход // Инновационные проекты и программы в образовании. 2018. № 4. С. 64-72. 


\section{РАЗВИТИЕ РЕФЛЕКСИВНОЙ КОМПЕТЕНТНОСТИ ПЕДАГОГА ОБЩЕОБРАЗОВАТЕЛЬНОГО УЧРЕЖДЕНИЯ}

Т.И. Гречухина

А. В. Усачева

Особенностью современной российской системы образования является организация образовательного процесса на основе компетентностного подхода и профессиональной рефлексии педагогов, реализующих данный подход.

Системе образования потребовались профессионалы, обладающие развитой рефлексивной способностью проектирования индивидуальной образовательной траектории, осознания затруднений в коллективных и индивидуальных формах мышления и деятельности субъектов образовательного процесса. Как отмечает О.С. Анисимов, «...профессионал не может избежать рефлексии. И чем более высокий уровень профессионализма, тем в большей степени рефлексивная составляющая предполагает успешность эффекта, но только тогда, когда эта рефлексия организована, когда все упорядочено и достаточно собрано. Рефлексивность еще следует обеспечить средствами языковой культуры и соответствующей культурой мышления... Сама живая практика рефлексии привела к радикальной проблематизации построения всего профессионально-деятельностного процесса. Лучшее, что можно сделать для нашей страны... иметь в виду, что рефлексивные механизмы и механизмы рефлексивной самоорганизации - это есть интегральные механизмы развития и саморазвития человека...» [1].

В связи с этим возникает необходимость формирования рефлексивной среды школы, которая является условием профессионального и личностного развития учителя [2]. Образовательная среда - это часть социокультурного пространства, объединяющая педагогические условия и средства, способствующие достижению целей образования. По мнению В. Я. Ясвина, для организации творческого процесса взаимодействия и развития личности образовательная среда должна представлять собой «...педагогически организованную систему условий, влияний и возможностей для 
удовлетворения иерархического комплекса потребностей личности и трансформации этих потребностей в жизненные ценности...» [3]. Кроме того, чтобы образовательная среда способствовала актуализации творческих резервов, она должна быть насыщенной и структурированной [4]. В свою очередь А. А. Бизяева определяет среду, способствующую творчеству, создающую условия выбора, изменяющую представление о личности и профессионализме, как рефлексивно-инновационную [5].

В Европе проблемам рефлексии и развития рефлексивных способностей учителя были посвящены следующие исследования: деятельность, направленная на результат [6]; размышления о конкретной ситуации и воплощение предположений о ситуации [7]; критическая рефлексия [8]; модель рефлексивного цикла [9]; ALACTмодель рефлексивного цикла [10]; развитие рефлексивных способностей учителя [11]; компонент профессионализма преподавателей и одно из качеств успешных студентов [12]; превращение учителя новичка в эксперта [13]; трансформация рефлексии в знание [14].

В российской педагогике, психологии понятие «рефлексивная компетентность» имеет различные трактовки: часть умственного действия (В.В. Давыдов), механизм группового взаимодействия и способ осуществления деятельности (Н. Г. Алексеев, О.С. Анисимов, К.Е. Данилин), составляющая эвристики (Ю.Н. Кулюткин), осозание средств и оснований, регулирующих деятельность (И.Н. Семенов, С. Ю. Степанов, А.З. Зак), рефлексивная компетентность как качество личности учителя, позволяющее осуществлять рефлексивные процессы и реализовывать рефлексивные способности; качество, способствующее реализации рефлексивно-креативных способностей; качество личности педагога, характеризующее степень усвоения совокупности рефлексивных компетенций.

Приоритетными аспектами нашего исследования являлись компоненты рефлексивной компетентности педагога в зависимости от наличия условий и средств рефлексивной среды в общеобразовательном учреждении.

Нами были соотнесены условия рефлексивной среды с механизмами и способами педагогической рефлексии. Кроме того, рассматривалось влияние средств рефлексивной среды на развитие 
рефлексивной компетентности учителя. В табл. 1 представлены условия, механизмы и способы действий рефлексивной среды общеобразовательного учреждения.

Рефлексивная компетентность учителя определяется как интеграция интеллектуального, личностного, кооперативного, коммуникативного видов рефлексии, обеспечивающих профессиональное развитие и саморазвитие учителя [15].

Интеллектуальный компонент рефлексивной компетентности учителя представлен осмыслением индивидуального опыта деятельности в процессе реализации педагогической задачи.

Личностный компонент рефлексивной компетентности учителя включает критическое осмысление своей профессиональной деятельности, вхождение в культуру сообразно своим индивидуальным особенностям.

Таблица 1

Условия, механизмы и способы действий рефлексивной среды общеобразовательного учреждения

\begin{tabular}{l|l|l}
\hline \multicolumn{1}{c|}{$\begin{array}{l}\text { Условия рефлексивной } \\
\text { среды }\end{array}$} & \multicolumn{1}{|c}{ Механизм } & \multicolumn{1}{|c}{ Способ действия } \\
\hline $\begin{array}{l}\text { Наличие групп сов- } \\
\text { местной деятельности }\end{array}$ & $\begin{array}{l}\text { Организация взаимо- } \\
\text { действия в группах сов- } \\
\text { местной деятельности }\end{array}$ & $\begin{array}{l}\text { Развитие мотивации, } \\
\text { поиск возможностей } \\
\text { профессионального } \\
\text { развития }\end{array}$ \\
\hline $\begin{array}{l}\text { Систематическая } \\
\text { работа (обсуждение } \\
\text { проблем) в группах } \\
\text { совместной деятель- } \\
\text { ности }\end{array}$ & $\begin{array}{l}\text { Продуктивное общение } \\
\text { участников групп сов- } \\
\text { местной деятельности }\end{array}$ & $\begin{array}{l}\text { Формирование по- } \\
\text { требности развития } \\
\text { профессионально-пе- } \\
\text { дагогических отноше- } \\
\text { ний }\end{array}$ \\
\hline $\begin{array}{l}\text { Вертикальное и гори- } \\
\text { зонтальное професси- } \\
\text { ональное взаимодей- } \\
\text { ствие }\end{array}$ & $\begin{array}{l}\text { Определение направ- } \\
\text { ленности групп сов- } \\
\text { местной деятельности }\end{array}$ & $\begin{array}{l}\text { Развитие сотрудниче- } \\
\text { ства и сотворчества } \\
\text { в профессиональ- } \\
\text { но-педагогических } \\
\text { отношениях }\end{array}$ \\
\hline $\begin{array}{l}\text { Актуальные професси- } \\
\text { ональные связи }\end{array}$ & $\begin{array}{l}\text { Побуждение к измене- } \\
\text { нию во взаимодействии } \\
\text { и деятельности }\end{array}$ & $\begin{array}{l}\text { Развитие позиций } \\
\text { профессионального } \\
\text { становления }\end{array}$ \\
\hline
\end{tabular}


Кооперативный компонент рефлексивной компетентности учителя рассматривается как осмысление содержания коллективного взаимодействия.

Коммуникативный компонент рефлексивной компетентности учителя содержит осмысление способов позиционирования собственной точки зрения и критического отношения к ней. В.А. Чупина и О.А. Федоренко отмечают, что формирование коммуникативной рефлексии в рефлексивной образовательной среде происходит на четырех уровнях: осознание психологического контекста изучаемого материала (первый уровень), формирование позиции внутреннего собеседника (второй уровень), анализ собственных переживаний (третий уровень), создание ценностей-смыслов (четвертый уровень) $[15$, c. 57].

Интеллектуальный компонент рефлексивной компетентности учителя представлен осмыслением индивидуального опыта деятельности в процессе реализации педагогической задачи. Личностный компонент рефлексивной компетентности учителя включает критическое осмысление своей профессиональной деятельности, вхождение в культуру сообразно своим индивидуальным особенностям. Кооперативный компонент рефлексивной компетентности учителя рассматривается как осмысление содержания коллективного взаимодействия. Коммуникативный компонент рефлексивной компетентности учителя содержит осмысление способов позиционирования собственной точки зрения и критического отношения к ней. В.А. Чупина и О.А. Федоренко отмечают, что формирование коммуникативной рефлексии в рефлексивной образовательной среде происходит на четырех уровнях: осознание психологического контекста изучаемого материала (первый уровень), формирование позиции внутреннего собеседника (второй уровень), анализ собственных переживаний (третий уровень), создание ценностей-смыслов (четвертый уровень) [Там же].

С целью развития компонентов рефлексивной компетенции учителей нами были использованы рефлексивные методики, содержащие процедурные элементы рефлексии: анализ и самоанализ педагогической деятельности в рамках учебного занятия; совместное «сценирование» (новая норма) педагогической деятельности; 
критика процесса и результатов. Отметим, что у применяемых нами рефлексивных методик не существует процедурных рамок, кроме механизма рефлексии. Однако важным является наличие акмеологических условий: единые проблемные поля - образовательный процесс и учебное занятие; соотнесение проблемных полей с профессиональным опытом педагогов; учет актуальных профессиональных затруднений конкретного педагога; способность педагога к новому, продуктивному мышлению, организация коллективной мыследеятельности, рефлексивной среды; активное участие педагогов в исследовании оснований собственной профессиональной деятельности [15, с. 45].

Следует отметить, что современный образовательный процесс требует от педагога не только наличия способности обоснованно отбирать и воспроизводить современные образовательные технологии, но и проектировать собственную деятельность, что невозможно без развитой рефлексивной компетенции.

В работе с учителями хорошо зарекомендовали себя такие рефлексивные методики, как рефлексивный практикум, групповая рефлексия, рефлексивная инверсия, рефлексивный полилог, рефлексивная дискуссия.

Рефлексивный практикум (в нашем случае - системный анализ урока) - самостоятельная форма, помогающая преодолевать профессиональные затруднения, осуществлять выбор оптимальных, обоснованных с психолого-педагогических позиций норм деятельности, проектировать собственную профессиональную траекторию деятельности.

Содержательным ориентиром в развитии рефлексивной компетентности педагогов являются требования профессионального стандарта педагогов образовательного учреждения, которые раскрывают подход к проектированию деятельности педагога. Анализ содержания указанного подхода позволил выделить системообразующий элемент - способность к компетентному выполнению трудовых функций, выраженную, прежде всего, в рефлексивной самоорганизации педагога [16].

Отметим, что профессиональным стандартом определены направления, в рамках которых наиболее часто осуществляются твор- 
ческие поиски педагогов: организация психолого-педагогической диагностики; организация дифференциации и индивидуализации образовательного процесса; применение (поиск или разработка) системы форм, методов, средств, приемов обучения с использованием информационно-коммуникационных технологий, технологий развития универсальных учебных действий, создание особой среды активной познавательной деятельности; совершенствование технологии управления и прогнозирования профессионального развития педагога.

Однако применяемые в настоящее время схемы анализа и самоанализа учебного занятия ориентируют педагога в большей степени на внешнюю оценку и самооценку на основе формальной рефлексии. Подобная практика не нацеливает педагога на содержательный анализ сложившейся ситуации в образовательном процессе в целом и на отдельных учебных занятиях, а также на анализ и обоснование используемых программ, современных образовательных технологий и т. Д.

Оценка эффективности формирования рефлексивной компетентности педагогов может осуществляться посредством автоматизированной программы «Профессионал» [17], которая предназначена для подготовки заместителей директора по учебно-воспитательной работе, курирующих направления образовательного процесса, учителей-предметников образовательного учреждения, для системной работы по развитию и оценке рефлексивно-проектных умений педагогов и управленцев, а также организации мониторинга и оценки качества педагогической деятельности. Качество профессионального мышления является важнейшим показателем компетентности, поэтому рефлексивная компетентность в рамках программы «Профессионал» рассматривается как способность педагога анализировать образовательный процесс, решать поставленные профессиональные задачи в системе актуальных профессиональных связей.

Теоретические основы решения проблемы представлены в исследованиях Н. Г. Алексеева, В. Г. Богина, В. А. Лефевра, И. Н. Семенова и др. (сущность и аспекты рефлексии), Б. С. Гершунского, Ю. В. Громыко, В. В. Давыдова, В. В. Рубцова, В. И. Слободчикова (концепция построения практики развивающего и развивающего- 
ся образования); Ю. В. Конаржевского, Т. И. Шамовой (системный анализ урока); Ю. В. Громыко, Г. П. Щедровицкого и др. (мыследеятельностный подход, деятельностное содержание образования).

Основными задачами деятельности в рамках программы «Профессионал» являются:

- содействие осмыслению педагогами роли рефлексии, системного анализа педагогической деятельности в достижении качества результата образования;

- формирование у педагогов базовых знаний о современных технологиях анализа педагогической деятельности, оценки педагогической деятельности, мониторинга профессиональной компетентности;

- формирование рефлексивно-проектных умений;

- развитие полипозиционной деятельности при анализе и оценке педагогического профессионализма;

- организация системы «внутрифирменного» повышения квалификации педагогов.

Г. Альтрихтер, анализируя проблему профессиональных объединений, отмечает, что исследование педагогом собственной деятельности «не является делом героя-одиночки». «Этические законы» исследования своей деятельности обязательно вовлекают в работу всех, кто имеет отношение к данной проблеме. Наличие инновационных процессов в образовании предполагает и требует сотрудничества всех участников образовательного процесса. Профессиональная дискуссия является основой продуктивного развития инновационных идей. В этом случае педагог получает возможность профессионального развития на протяжении длительного времени, с участием представителей профессионального объединения или сообщества [18].

Процесс обучения педагогов новым способам мышления и деятельности опирается на систему принципов. Система включает в себя принцип активного рефлексивного анализа процесса обучения (осознание себя как активного субъекта процесса), принцип динамичности функциональных ролей (уровни ответственности за решения, степень включенности в реализуемый процесс), принцип свободного моделирования деятельности (самоуправление и са- 
моразвитие субъектов процесса), принцип равновесной статусной позиции участников анализа процесса.

Нами было проведено исследование среди 40 педагогов муниципального автономного общеобразовательного учреждения г. Екатеринбурга: представители администрации образовательного учреждения-управленцы - 6 чел., педагоги со стажем («стажисты») - 32 чел., молодые специалисты - 2 чел.; их возраст составлял от 25 до 63 лет.

Работе по внедрению программы «Профессионал» предшествовало исследование, в ходе которого педагогам предлагалось выполнить четыре задания. Задания предполагали: 1) определение уровня доверия в рамках актуальных профессиональных связей (доверие - уверенность в том, что информация о своих проблемах или ошибках, озвученная коллегам, не будет использована во вред); 2) выделение профессиональных задач, решение которых требует знакомства с опытом работы других педагогов образовательной организации; 3) определение своего отношения к посещению другими педагогами занятий (специально не подготовленных); 4) определение случаев эффективного группового обсуждения проведенных учебных занятий. Результаты персонифицированного анализа представлены в табл. 2.

При обработке полученных результатов применялись контентанализ, методы сравнения, обобщения и математической статистики. Анализ полученных данных позволил выяснить, что указанные проблемы находятся в фокусе внимания всех педагогов образовательной организации. При выполнении педагогами заданий выявились некоторые особенности. Представители управления образовательным учреждением были едины в своих представлениях об уровне доверия, потребности знакомства с опытом педагогического коллектива, необходимости посещения учебных занятий другими педагогами и эффективности групповой рефлексии (100\%).

В свою очередь, «стажисты», имеющие достаточно высокий уровень доверия $(71,9 \%)$ и понимающие значение знакомства с опытом других педагогов $(84,4 \%)$, сомневаются в эффективности групповой рефлексии учебных занятий (40,6\%), что свидетельствует, с одной стороны, о непонимании сущности и значения групповой реф- 
苂

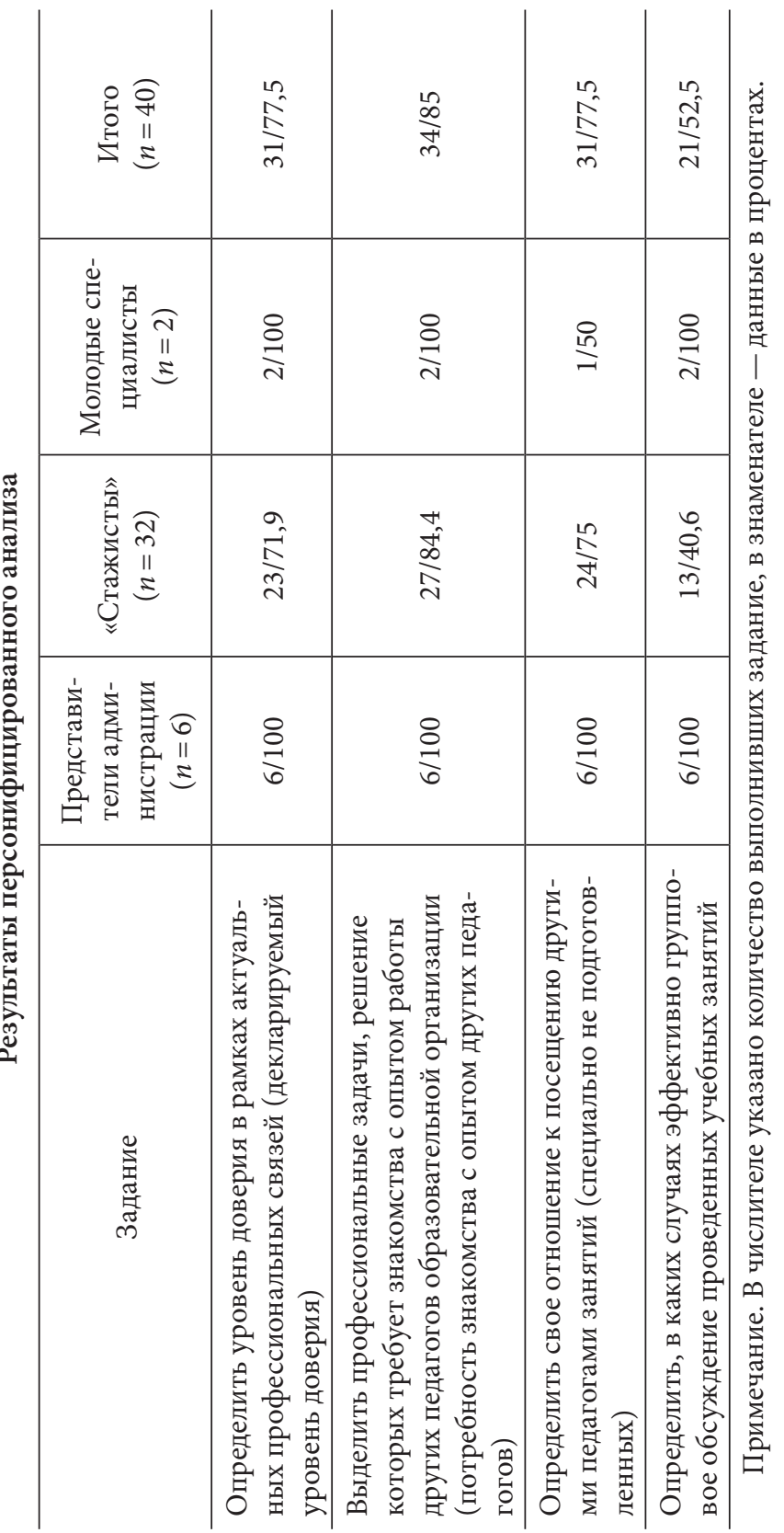


лексии, с другой - об отсутствии четкого алгоритма проведения подобной процедуры.

Молодые специалисты ориентированы на взаимодействие с конкретным наставником из числа «стажистов». Анализ актуальных профессиональных связей подтвердил этот вывод. У молодых специалистов рефлексивная компетентность не имеет необходимого уровня осознания, несмотря на наличие педагогического образования.

В связи с этим возникает необходимость решения проблемы развития рефлексивной компетентности педагога. Следует предположить, что внедрение инновационных подходов к организации процесса профессионального развития в рамках учреждения образования может ориентировать педагогов и представителей управления на поиск средств преодоления стихийности процесса развития рефлексивной компетентности, проектирования целенаправленной методической работы.

С целью развития педагогического профессионализма в программе «Профессионал» предусмотрены механизмы традиционного педагогического взаимодействия с сохранением субъект-объектных отношений и функциональных позиций и выделения позиций дидакта, методиста, антрополога. Такой подход позволяет работать с мышлением, рефлексией, целеполаганием педагога в условиях реального образовательного процесса.

Программа «Профессионал» позволяет осуществлять сбор данных о состоянии управляемого образовательного процесса, перерабатывать, систематизировать и выдавать командную информацию с целью принятия управленческого решения.

Содержательная часть автоматизированного программного комплекса «Профессионал» позволяет обеспечить «сшиваемость» и объективизацию информации об образовательном процессе, деятельности педагога на уроке, получаемой от учителя, ведущего урок, коллег, присутствующих на учебном занятии. В этом случае решается задача смены позиций и ролей: диагност (при посещении и анализе уроков) или самодиагност (рефлексия собственной деятельности).

Деятельность педагогического коллектива в рамках программного комплекса осуществляется по нескольким блокам. Одним 
из них является блок «Анализ», который способствует развитию компонентов рефлексивной компетентности и формированию профессиограммы педагога за счет систематизации результатов психолого-педагогического анализа большого числа учебных занятий с разных профессиональных позиций.

Анализ и самоанализ учебного занятия представлен обязательным алгоритмом:

- Различить учебный материал и содержание образования на уроке.

- Предъявить и обосновать обучающие и развивающие цели урока.

- Обсудить с коллегами, посещающими урок, тип и структуру урока (исходя из цели урока).

- Обосновать структуру урока в зависимости от типа и целей.

- Обосновать дидактические задачи этапов урока.

- Выделить единицу (единицы) содержания образования (передаваемый способ) по следующей схеме:

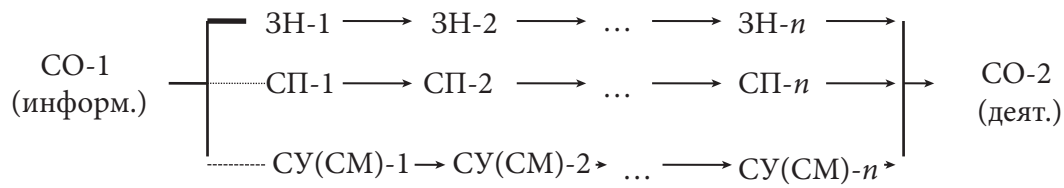

Педагог должен ответить на два диагностических вопроса:

1. Что реально должны научиться делать учащиеся на уроке?

2. Как это педагог делает сам? (Учитель должен не просто назвать способ, но и представить его операции во всей полноте.)

Условные обозначения:

СО-1 - содержание образования (информационное) - трансляция информации репродуктивными методами).

СО-2 - содержание образования (деятельностное) - знания и способы приобретаются в деятельности.

ЗН - предметные знания в их логике

СП - специфические предметные способы деятельности в логической последовательности.

СУ - способы учебной деятельности.

$\mathrm{CM}$ - способы мыслительной деятельности. 
- Выделить единицу (единицы) содержания образования (СО).

- Проанализировать внутреннюю и внешнюю логику урока (межэтапные связи урока).

- Проанализировать формы организации учебной деятельности (основание - психолого-педагогическая диагностика).

- Проанализировать методы обучения (основание - степень самостоятельности учащихся в процессе обучения).

Итоговый расчет данных по всем блокам программы «Профессионал» автоматически корректируется с учетом коэффициента объективности. Общий вид результатов представлен в табл. 3.

Нами зафиксирована положительная динамика развития компонентов рефлексивной компетенции педагогов:

- интеллектуального компонента рефлексивной компетентности: самоанализ учебного занятия (с 79 до $86 \%$ ), реакция на анализ коллегами педагогической деятельности в рамках учебного занятия (с 77,5 до 87,5\%);

- личностного компонента рефлексивной компетентности: критическое осмысление целеполагания, выбора форм, методов обучения, выделение единиц содержания образования и содержания

Таблица 3

Результаты анализа педагогической деятельности

\begin{tabular}{l|l|c|c|c|c|c|c|c|c}
\hline \multirow{2}{*}{ Код } & \multirow{2}{*}{ Фамилия } & \multirow{2}{*}{ NAC } & \multirow{2}{*}{ NAO } & \multirow{2}{*}{ NCС } & \multicolumn{5}{|c}{ Среднее значение } \\
\cline { 6 - 11 } & & & & ПКС & ПКО & R & O & U \\
\hline 1 & А... & 11 & 7 & 6 & 9,2 & 7,6 & 10,0 & 8,2 & 8,1 \\
\hline 2 & Б... & 10 & 7 & 5 & 10,0 & 3,9 & 8,4 & 8,2 & 7,6 \\
\hline 3 & В... & 12 & 6 & 4 & 6,1 & 5,1 & 10,0 & 9,5 & 8,0 \\
\hline 4 & Г... & 10 & 8 & 6 & 6,0 & 6,3 & 9,4 & 8,7 & 8,0 \\
\hline 5 & Д... & 11 & 6 & 4 & 5,2 & 6,0 & 5,3 & 5,1 & 6,2 \\
\hline 6 & Ж... & 12 & 8 & 6 & 7,8 & 7,8 & 8,4 & 8,1 & 8,1 \\
\hline 7 & $3 \ldots$ & 18 & 15 & 16 & 9,3 & 6,8 & 9,2 & 8,2 & 8,2 \\
\hline
\end{tabular}

Примечание. $\mathrm{NAC}$ - количество посещенных субъектом уроков; $\mathrm{NAO}-$ количество посещенных у данного объекта уроков; NCC - количество проанализированных субъектом посещенных уроков; ПКС - профессиональные качества субъекта; ПКО - профессиональные качества объекта; $\mathrm{R}$ - результат обучения; $\mathrm{O}$ - коэффициент объективности; $\mathrm{U}$ - реальный уровень знаний. 
материала, следование внешней и внутренней логике изложения, осуществление межэтапных и межпредметных связей (с 68 до 84 \%);

- кооперативного компонента рефлексивной компетентности: анализ учебного занятия (с 72 до 81 \%). Этот компонент характеризуется потенциальными профессиональными связями, реализованными в условиях системного анализа учебного занятия;

- коммуникативного компонента рефлексивной компетентности: овладение профессиональными позициями диагноста, методиста, антрополога (с 27 до 30 \%). Исследование позволяет сделать вывод о том, что осмысление способов позиционирования собственной точки зрения и критического отношения к ней для многих педагогов является актуальной задачей профессионального развития.

Представленная технология развития рефлексивной компетентности способствует изменению отношения между участниками образовательного процесса, создает возможность обобщения большого числа параметров на основе систематизации данных о деятельности педагога в разные временные промежутки (учебный год, полугодие, четверть и т.д.), в разных профессиональных объединениях (методическое объединение, кафедра, «стажисты», молодые специалисты и т.д.).

Полученные результаты позволили сделать следующие выводы.

1. Выявлена специфика, связанная с организацией процесса развития рефлексивной компетентности в условиях образовательного учреждения.

2. Определено, что представители управления образовательного учреждения достоверно чаще, чем другие педагоги, соотносят свои представления о рефлексивной компетентности, идентифицируют себя как активных пользователей современных технологий.

3. Проведенное исследование ориентирует на дальнейшее выявление особенностей развития рефлексивной компетентности педагогов в условиях общеобразовательного учреждения, поиск адекватного психолого-педагогического инструментария для достоверного измерения уровней рефлексивной компетентности.

4. Исследование может быть продолжено в направлении изучения состояния и особенностей проявления рефлексивной компе- 
тентности педагога в зависимости от вида общеобразовательного учреждения.

5. В общеобразовательном учреждении для развития рефлексивной компетенции педагогов необходима организация специальной деятельности на основе рефлексивных методик с учетом объективных и субъективных факторов (коллективные формы взаимодействия, активная профессиональная коммуникация, возможность исследования оснований собственной профессиональной деятельности, профессионального роста).

1. Анисимов О.С. Методология: функция, сущность, становление (динамика и свзь времен). М. : ЛМА, 1996. 380 с.

2. Wallace $M$. Training Foreign Language Teachers. Cambridge University Press, 1991. $180 \mathrm{p}$.

3. Ясвин В.А. Тренинг педагогического взаимодействия в творческой образовательной среде / под ред. В. И. Панова. М. : Молодая гвардия, 1997. $176 \mathrm{c}$.

4. Осипова Т.А. Социально-личностное самоопределение учащихся в условиях художественно-этетической среды : дис. ... канд. пед. наук. Тюмень, 2006. 188 с.

5. Бизяева А. А. Рефлексивные процессы в сознании и деятельности учителя : автореф. дис. ... канд. психолог. наук. СПб., 1993. 20 с.

6. Mezirow J. Learning as Transformation: Critical Perspectives on a Theory in Progress. San Francisco : Jossey Bass, 2000. 371 p.

7. Peters J.M. Instructors-as-researcher - andtheorists: faculty development in a community college // Training and Professional Development in Adult and Continuing Education / R. Benn, R. Field-house (eds.). Exeter : CRCE, 1994. P. 94-101.

8. Brookfield S. D. Becoming a Critically Reflective Teacher. San Francisco: Jossey-Bass, 1995. 298 p.

9. Smyth J. A critical pedagogy of classroom practice // Journal of Curriculum Studies. 1989. Vol. 21, № 6. P. 483-502.

10. Korthagen F. A. J., Vasalos A. From reflection to presence and mindfulness: 30 years of develop-ments concerning the concept of reflection in teacher education [Electronic resource]. URL: http:// www.kernreflectie.nl/Media/pdf/ EARLI\%20paper.pdf (accessed: 15.01.2020). 
11. Wallace M. Action Research: How to Do It // Paper presented at the $2^{\text {nd }}$ International Conference of the Malaysian English Language Teaching Association, 24-27 May, 1993.

12. Jones C. J., Bell S., Saddler C. Helping high school students improve their academic skills: A necessary role for teachers // High School Journal. 1991. № 74. P. 198-202.

13. Eraut M. Developing Professional Knowledge and Competence. L. : Palmer, 1985.

14. McCombs B. L. Motivation and lifelong learning // Educational Psychologist. 1991. № 26. Р. 117-127.

15. Чупина В.А., Федоренко О.А. Теория и практика профессиональной педагогической рефлексии : монография. Екатеринбург : Изд-во Рос. гос. проф.-пед. ун-та, 2019. 200 с.

16. Козлов П. Г., Кабанова И. В., Стоюшко Н. Ю. Рефлексивная компетентность современного педагога как фактор, влияющий на качество образовательного процесса [Электронный ресурс] // Современная педагогика. 2016. № 1. URL: http://pedagogika.snauka.ru/2016/01/5351 (дата обращения: 24.02.2020).

17. Гречухина Т. И. Управление развитием профессионально-педагогических компетенций педагогов в общеобразовательном учреждении // Профессиональное мастерство современного педагога : монография / отв. ред. А. Ю. Нагорнова. Ульяновск : Зебра, 2016. С. 78-88.

18. Альтрихтер Г. Профессия познается в действии // Директор школы. 1997. № 5. С. 14-17. 


\section{ПРОЕКТИРОВАНИЕ КАРЬЕРНОЙ СТРАТЕГИИ СОВРЕМЕННЫХ ПЕДАГОГОВ В УСЛОВИЯХ ЦИФРОВИЗАЦИИ*}

Е. М. Громова

Д. И. Беркутова

T. А. Горшкова

В развитии человеческой цивилизации можно выделить ряд переломных моментов, связанных с качественно новым уровнем технологического развития.

По мнению А. И. Ракитова, в истории человечества произошло пять «информационных революций» (ИР):

1. Первая ИР связана с возникновением языка (т. е. с технологией устной речи, с передачей, запоминанием, возможностью трансляции информации в пространстве и времени).

2. Вторая ИР обусловлена созданием письменности.

3. Третья ИР произошла в результате изобретения книгопечатания.

4. Четвертая ИР связана с потреблением электричества и появлением новых информационных технологий, которые сделали доступным создание больших массивов информации и передачу их в значительных объемах.

5. Пятая ИР состоялась с изобретением современных микропроцессорных компьютеров и возникновением целой информационной индустрии, позволяющей перерабатывать и передавать информацию в колоссальных масштабах [1].

Следовательно, в настоящее время мы являемся непосредственными участниками этой «пятой информационной революции», которую все чаще называют «цифровизация». Цифровизация - это не просто важнейшая особенность современной жизни, которая меняет все ее сферы, преобразуя привычные нам формы в принципиально новые. В основе цифровизации лежит развитие глобальной

* Исследование выполнено при финансовой поддержке РФФИ в рамках научного проекта № 19-013-00184 «Становление профессиональной идентичности как фактор проектирования карьерной стратегии современного профессионала». 
сети Интернет и изобретение технологий, обеспечивающих мобильность общения и взаимодействия. При этом в широком смысле слова цифровизацию рассматривают как изменение базовой модели коммуникации между отдельными людьми и социумом. Наиболее точная трактовка сущности данного явления определяет смысл цифровизации не просто как перевод информации в цифровую форму (Е. Л. Вартанова, М.И. Максеенко, С. С. Смирнов), а как комплексное решение вопросов инфраструктурного, управленческого, поведенческого, культурного характера [2].

При этом исследователи в области цифровых технологий особо подчеркивают, что именно с появлением и распространением центров обработки данных, предоставляющих возможность удаленной работы с прикладным программным обеспечением, большому количеству пользователей обеспечен переход от «обычной» информатизации к цифровизации. Иными словами, цифровая трансформация общества стала происходить тогда, когда у общества появилась реальная возможность использования коллективного программного обеспечения для коллективного создания коллективных информационных ресурсов и коллективного доступа к ним для решения массовых социальных и экономических задач.

Сегодня правовой основой происходящей трансформации в нашем государстве является Указ Президента «О национальных целях и стратегических задачах развития Российской Федерации на период до 2024 года». В этом документе обозначены ключевые приоритеты «обеспечения ускоренного внедрения цифровых технологий в экономике и социальной сфере» (п. 1ж) [3]. В рамках нашего исследования наибольший интерес представляет нацпроект «Образование», в целях которого указано, что необходимо «создание современной и безопасной цифровой образовательной среды, обеспечивающей высокое качество и доступность образования всех видов и уровней; формирование системы непрерывного обновления работающими гражданами своих профессиональных знаний и приобретения ими новых профессиональных навыков, включая овладение компетенциями в области цифровой экономики всеми желающими» [Там же].

Кроме того, в нацпроекте «Цифровая экономика» обозначено, что с целью повышения производительности труда и поддержки за- 
нятости необходимо «...формирование системы подготовки кадров, направленной на обучение основам повышения производительности труда, в том числе посредством использования цифровых технологий и платформенных решений» [3]. Действительно, цифровизация привела в последние годы к повышению спроса на цифровые навыки, который, как ожидается, будет только усиливаться из-за растущего числа рабочих мест, требующих от сотрудников умения использовать информационные технологии и обладать цифровыми навыками.

Высшее образование - это социальный институт, призванный обеспечить экономику высококвалифицированными кадрами, поэтому неудивительно, что в условиях нарастающих темпов цифровой трансформации общества университеты всего мира стараются использовать наиболее эффективные технологии и приемы обучения. В современных условиях цифровизции, в том числе в образовании, многие прогнозируют быстрый рост аддитивных технологий, расширение использования технологий виртуальной и дополненной реальности, развитие систем аналитики и прогнозирования успеваемости на основе обработки «больших данных» и искусственного интеллекта. Сегодня для большинства образовательных учреждений эти цифровые технологии пока еще остаются недоступными. В основном педагоги сейчас активно реализуют более простые решения: электронные образовательные ресурсы, мобильные приложения, электронные учебники, обучающие игры и многое другое.

Обратим внимание на суть происходящих изменений, связанных с процессами информатизации и цифровизации в сфере профессионального образования педагогов.

Общепризнанно, что уровень высшего профессионального образования, который достигнут в современной России, невозможно повысить, применяя экстенсивный подход, т. е. лишь путем увеличения и без того значительного объема учебной нагрузки. Высокий темп увеличения знаний ограничивается возможностями их усвоения в ходе профессионального образования. Можно констатировать, что направленность системы высшего профессионального образования на освоение студентами определенной суммы знаний себя полностью исчерпала. Знаниевые или квалификационные модели выпускни- 
ка уходят в прошлое. Именно данное обстоятельство определило, в числе прочего, вступление в силу Федеральных государственных образовательных стандартов нового поколения, в частности, стандарта высшего образования ФГОС ВО 3++ [4]. Сегодня необходим новый - «интенсивный» подход. Характерная черта новых стандартов третьего поколения - их практикоориентированность. В качестве методологической основы новых стандартов использован компетентностный подход, который является предпочтительной заменой абстрактным и теоретическим знаниям и предъявляет в качестве требований к результатам освоения образовательной программы такие компетенции, которые созвучны специальным способностям, необходимым будущим специалистам в их профессиональной сфере. Данные требования определены как универсальные, общепрофессиональные и профессиональные компетенции.

Внедрение компетентностного подхода коренным образом меняет роль студента в образовательном процессе. Главной доминантой здесь становится самостоятельная работа с информацией. Это обусловлено тем, что в современных условиях самые значимые качества профессионала основываются не столько на показателях имеющегося знания, сколько на способности самостоятельно его пополнять, уметь самому выявлять профессионально значимые задачи и решать их.

Федеральные государственные образовательные стандарты высшего образования предусматривают, что, например, выпускники по направлению подготовки «Педагогическое образование» для уровня высшего образования «бакалавриат» должны обладать такой универсальной компетенцией, как «способен осуществлять поиск, критический анализ информации и применять системный подход для решения поставленных задач» [4, с. 9]. Причем, на наш взгляд, отнюдь не случайно данная компетенция указана в стандарте самой первой; это подчеркивает ее безусловный приоритет. Кроме того, среди общепрофессиональных компетенций следует выделить такую, как «способен участвовать в разработке и реализовывать основные и дополнительные образовательные программы, разрабатывать отдельные их компоненты (в том числе с использованием ИКТ)» $[4$, с. 10]. 
Таким образом, современный выпускник вуза должен владеть так называемыми «цифровыми навыками» - определенным набором навыков применения цифровой техники, мобильных приложений и информационных сетей в целях поиска и обработки необходимой информации, создания и продвижения цифрового контента, эффективной коммуникации и делового сотрудничества, а также для решения проблем саморазвития, образования, профессиональной деятельности и социальной активности в целом. В качестве примера приведем канадскую классификацию обозначенных цифровых навыков [5]:

1. Фундаментальные, принципиальные минимальные навыки, необходимые, прежде чем работать со сложными цифровыми технологиями, - базовая компьютерная грамотность на уровне пользователя прикладных программ и сетей, компьютерная печать и счет при оформлении документов.

2. Трансверсальные навыки, которые состоят из определенных гибких навыков, в отсутствие которых цифровые технические знания не могут реализовать в полной мере свой потенциал, - командообразование, непрерывное опережающее обучение, решение коммуникативных проблем и регулирование межличностных отношений.

3. Цифровые технические навыки, играющие важную роль в эффективном функционировании современных рабочих мест, работающих по принципу цифровых технологий, и связанные с применением компьютера и программного обеспечения, а также реализации мер кибербезопасности и других.

4. Навыки цифровой обработки информации на основе способностей, необходимых для получения профессий и квалификаций в сфере ИКТ, отвечающие за информационный поиск, анализ и синтез данных, их объективную оценку, применение и обмен информацией.

Основополагающие цифровые навыки, т. е. базовые функциональные умения, необходимые для элементарного использования цифровых устройств и онлайн-приложений, сегодня считаются важнейшей предпосылкой для приобретения нового набора навыков цифровой грамотности, наряду с традиционными навыками чтения, письма и счета. Более продвинутые цифровые навыки 
включают способности высокого уровня, позволяющие пользователям применять технологии для расширения своих возможностей и внедрения преобразований. Значительный прогресс в развитии цифровых технологий, таких как искусственный интеллект (ИИ), машинное обучение, интернет вещей (IoT) и аналитика больших данных, требует новых квалификаций, что, в свою очередь, оказывает воздействие на сферы повышения потенциала и развития навыков в контексте цифровой экономики XXI в. Цифровые навыки теперь не просто желательны, они крайне необходимы и должны быть дополнены сквозными навыками межличностного общения, такими как способность эффективного взаимодействия в двух режимах: онлайн и офлайн [6].

В то же время рассматривать цифровизацию профессионального образования и самообразования лишь с позиции формирования цифровых компетенций и появления на рынке труда новых требований к цифровым навыкам педагогов, на наш взгляд, слишком узко. Не вызывает сомнения тот факт, что процесс цифровизации влияет на все сферы нашей жизни гораздо фундаментальнее. Например, если говорить о профессиональном образовании, то цифровизация оказывает существенное влияние на процессы профессиональной идентификации, способы профессиональной деятельности и пр. Поэтому при оказании помощи в профессиональном становлении и проектировании карьеры очень важно не упустить такую значимую сторону, как включение педагога в профессиональное сообщество. Именно цифровизация во многом облегчает доступ в него. Сегодня профессиональные сообщества (в том числе и неформальные) активно развиваются и действуют в сети Интернет, и большинство из них обладает недюжинным положительным потенциалом, который важно использовать. И здесь необходимо говорить не только об образовательном потенциале данных профессиональных сообществ, но и о присущих им «социальных эффектах», например, о формировании позитивной профессиональной идентичности [7].

Чтобы нивелировать возможные расхождения в трактовке понятия «профессиональная идентичность», которое является краеугольным в вопросе проектирования карьерной стратегии, рассмотрим некоторые важные его аспекты. 
Одной из наиболее разработанных и известных концепций профессиональной идентичности является концепция Л.Б. Шнейдер, которая справедливо отмечала, что проблема идентичности обусловлена реализацией жизненной и профессиональной идеологии человека, профессиональной подготовкой специалиста, становлением его профессионализма [8].

Проведем краткий анализ существующих подходов к определению сущности понятия «профессиональная идентичность» в отечественной психологии.

Так, Э.Ф. Зеер определяет профессиональную идентичность через категорию профессионального «образа Я» [9].

В своих исследованиях Е. А. Климов рассматривает профессиональную идентичность в контексте содержания проблематики профессионального самосознания [10].

По мнению Е. П. Ермолаевой, которая рассматривает данную категорию с позиции взаимосвязей в рамках контента «человек профессия - общество», профессиональная идентичность является ключевым понятием психологии труда и представляет собой психосоциальную структуру, в которой сосредоточены и органично связаны между собой основные отношения профессионала в этой системе [11]. Исследователь полагает, что поскольку о профессиональной идентичности можно говорить, когда человек овладел профессией на достаточно высоком уровне, то она определяет устойчивое согласование составных элементов профессионального процесса. Обозначенная научная позиция представляет Е. П. Ермолаевой возможность рассматривать профессиональную идентичность как системную характеристику субъектно-социально-деятельностного соответствия, изучая ее не просто с позиции принятия профессиональных ценностей, но и с позиции гармоничной идентификации с деятельностью (инструментальная идентичность), социумом (внешняя идентичность) и самим собой (внутренняя идентичность) [11].

В научных трудах Ю. П. Поваренкова наблюдается понимание профессиональной идентичности, близкое к точке зрения, высказанной по данному вопросу западными социальными психологами (Э. Эриксоном, Дж. Марсиа, Дж. Мид, Х. Тэшфелом, Дж. Тернером 
и др.). Ученый исследует профессиональную идентичность как субъективный критерий профессионального развития и ценностную категорию. Согласно его мнению, такая трактовка означает, что человеком на социальном и психологическом уровнях принимаются профессиональные ценностные позиции, присущие данному профессиональному пространству [12].

Целесообразно на данном этапе изучения подходов к сущности феномена «профессиональная идентичность» более детально остановиться на некоторых фундаментальных положениях исследований Л. Б. Шнейдер. Так, профессиональную идентичность она определяет как «психологическую категорию, относящуюся к осознанию своей принадлежности к определенной профессии и определенному профессиональному сообществу» [13, с. 113]. Согласно ее мнению, профессиональная идентичность «...не только осознание своего равенства с профессиональной общностью, но и ее оценка, психологическая значимость членства в ней, разделяемые профессиональные чувства, своеобразная ментальность, ощущение своей профессиональной компетентности, самостоятельности и самоэффективности, то есть переживание своей профессиональной целостности и определенности» [Там же, с. 315].

Таким образом, выполненный нами анализ позиций различных ученых в отношении трактовки понятия «профессиональная идентичность» позволяет выделить общие ключевые моменты. Вслед за Л.Б. Шнейдер мы придерживаемся мнения, что профессиональная идентичность должна рассматриваться как ведущая характеристика профессионального развития человека, которая свидетельствует о степени принятия избранной профессиональной деятельности в качестве средства самореализации и развития [8].

С точки зрения Л.Б. Шнейдер, в процессе становления профессиональной идентичности личность проходит те же ступени, что и при социализации: доверие, автономию, инициативность, достижение, идентичность, интимность, творчество, интеграцию [8]. Она четко обозначает определенные стадии становления профессиональной идентичности: 1) невыраженная идентичность осознание ближних и дальних профессиональных целей при отсутствии профессионального опыта, профессионального общения; 
2) выраженная, но пассивная идентичность - усвоение знаний, осознание возможностей, приобретение профессионального опыта; 3) активная идентичность - практическая реализация намеченных профессиональных целей, формирование индивидуального стиля профессиональной деятельности, расширение круга профессиональных контактов; 4) устойчивая идентичность - свободное выполнение профессиональной деятельности, повышение уровня притязаний, профессиональное саморазвитие, осознание значимости своей деятельности и контактов, возникновение желания передачи опыта [8].

Учитывая вышеописанные стадии формирования профессиональной идентичности, Л. Б. Шнейдер и другие исследователи обозначенной проблемы едины во мнении, что начальным этапом можно смело считать период получения личностью профессионального образования, иными словами, это начало профессиональной подготовки (при этом становление идентичности продолжается в течение всей профессиональной жизни человека). Подчеркнем, что суть самого процесса формирования профессиональной идентичности определяется переходом от внешних источников мотивации профессиональной деятельности к внутренним [14].

Следует отметить изложенную в исследованиях Е. П. Ермолаевой точку зрения о том, что в тех случаях, когда развитие профессионала в системе «человек - профессия - общество» происходит «над» своей профессией, «над» обществом и личными интересами, есть возможность диагностики сформированности профессиональной идентичности [11].

В нашем случае наиболее важным будет выявление и детальное изучение факторов и условий, влияющих на профессиональную идентичность. Так, Л.Б. Шнейдер к основным, определяющим источникам формирования профессиональной идентичности относит следующие условия:

- объективно существующий образовательно-профессиональный компонент;

- субъективную систему притязаний, ожиданий и предпочтений, идеальные образы профессии; 
- признание значимыми другими личности в качестве профессионала;

- профессиональную самопрезентацию;

- профессиональные нормы (ценности) и атрибуты (лексику, мифы, стереотипы);

- эмоционально-положительный фон, на котором стартовало профессиональное самоопределение;

- положительное отношение к себе как субъекту профессиональной деятельности;

- эмоционально-позитивное принятие своей принадлежности к профессиональному сообществу;

- успешное освоение способов профессиональной деятельности, правил и норм профессиональной этики;

- меру принимаемой на себя человеком ответственности;

- уровень личностного развития;

- мотивационную готовность к самореализации в выбранной профессиональной сфере [13].

Именно в обозначенном аспекте Л.Б. Шнейдер говорит о формировании профессиональной идентичности студентов: «...непременными условиями достижения профессиональной идентичности являются практика социальных взаимодействий с другими и с самим собой, личностное включение студента в освоение профессиональной деятельности, профессиональный опыт самостоятельной деятельности студента в процессе обучения, использование диалогического подхода во взаимодействиях преподавателя и студента, обеспечивающие сопряжение эмоционально-ценностного и профессионально-личностного опыта их носителей» [15, с. 12].

Интересно, что современные исследования зарубежных психологов подчеркивают, что среди значимых факторов формирования профессиональной идентичности можно выделить такой, как оправданность ожиданий от программы обучения в университете [16]. Также среди значимых факторов называют соответствие способностей личности профессиональным требованиям (Fors) [17].

В контексте нашего исследования внимания заслуживает и концепция Т.В. Мищенко, которая разделяет учебно-академическую, учебно-профессиональную и профессиональную идентичности [18]. 
Изучение проблемы становления профессиональной идентичности позволяет нам высказать предположение о ее тесной взаимосвязи с проектированием карьерной стратегии личности.

У большинства людей существует традиционное представление о карьере - как перспективе продвижения «вверх по лестнице», «по вертикали», зачастую даже путают понятия «карьера» и «административный рост». Такой вид профессиональной карьеры основан на принципе иерархии: повышение в должности, сопровождающееся подъемом на следующую ступень, как правило, в совокупности с более высокой оплатой труда, расширением полномочий и увеличением степени власти [19].

В педагогической психологии трактовка профессиональной карьеры традиционно существовала в русле анализа личностных и профессиональных качеств учителя. В своих научных трудах Л. А. Магальник следующим образом определяет понятие профессиональной карьеры: «...это продвижение по ступеням профессионального роста работника образовательного учреждения, характеризующееся динамикой профессиональной компетентности, квалификационных возможностей, личностных качеств и потенциальных устремлений, сопровождающихся движением по должностным позициям» [20, с. 29]. Т. Н. Крисковец считает, что профессиональная карьера выстраивается как «цепь индивидуальных педагогических достижений, получивших внешнее признание и имеющих определенное значение для становления личности конкретного учителя на каждом этапе профессиональной деятельности, способствующих росту его профессиональной уверенности и конкурентоспособности» [Там же].

Важная идея, подчеркивающая специфику карьеры педагога, высказана Б. 3. Вульфовым, который акцентирует внимание на том, что карьера учителя не всегда представляет собой траекторию движения в организационной иерархии учебного заведения или же очередность смены видов профессиональной деятельности - вертикальный вид карьеры. Чаще всего карьера учителя - это «карьера внутри профессии, путь становления профессионала - внутриорганизационная профессиональная горизонтальная карьера» [Там же, с. 30]. Следовательно, с позиций педагогической теории и практики понятие «карьера» определяется в первую очередь как некоторое со- 
знательное отношение учителя к собственному профессиональному развитию, которое может выражаться не в традиционном «движением вверх» по карьерной лестнице, а в каких-либо иных профессиональных достижениях (победе в конкурсах профессионального мастерства, образовательных достижениях учеников и пр.).

Отдельный интерес при изучении карьерной стратегии современных педагогов представляют теоретические подходы с позиций менеджмента. Подавляющее большинство исследований, выполненных в данном контексте рассмотрения обсуждаемой проблемы (Т. Ю. Базаров, В. А. Дятлов, П. В. Журавлев, А. Я. Кибанов, Ю. Г. Одегов, В.В. Травин и др.), посвящено изучению вопросов работоспособности и мотивации к достижению успеха. Особое внимание привлекают научные идеи основоположника отечественной школы управления персоналом А. Я. Кибанова, который определяет понятие «карьера» как индивидуально осознанные представления о трудовом будущем, ожидаемые пути самовыражения и удовлетворенности трудом, поступательное продвижение по служебной лестнице, изменение навыков, способностей, квалификационных возможностей и размеров вознаграждения, связанных с деятельностью работника [21]. Следовательно, в теории управления персоналом профессиональная карьера изучается как некая осознаваемая личностью позиция в ходе профессиональной деятельности, основанная на жизненном опыте и мотивации.

Однако, как было сказано выше, нетривиальность карьеры в сфере образования заключается прежде всего в том, что это не простое перемещение в организационной иерархии образовательного учреждения (вертикальная карьера), а путь становления профессиональной идентичности, т. е. карьера внутри профессии (горизонтальная карьера). В ходе нашего исследования мы изучаем проблему проектирования карьерной стратегии будущих педагогов прежде всего с точки зрения их «горизонтального движения». Так, горизонтальный профессиональный рост сопровождается осознанием неисчерпаемости занимаемой должности. Проектирование карьерной стратегии в сфере образования по горизонтальной траектории подразумевает накопление собственного опыта, обобщение опыта коллег, взаимообмен опытом в профессионально-педагогическом 
сообществе, повышение квалификационной категории, формирование профессионального портфолио и др. [14].

Карьерная стратегия в значительной степени обусловлена целями, мотивами, желаниями и установками самого человека. Не менее значимым фактором карьерной стратегии, безусловно, является осознание необходимости освоения новых знаний, овладения новыми профессиональными умениями и компетенциями. Следует назвать такие значимые обстоятельства, влияющие на профессиональную карьеру педагога, как личностные потребности; карьерные устремления и мотивы; повышение квалификации; профессиональная переподготовка; повышение уровня образования, научных достижений, в том числе связанное с обучением в магистратуре, и др. Следовательно, профессиональная карьера в сфере образования, как и в любой другой отрасли, напрямую зависит от активной позиции самого учителя.

В связи с этим представляет интерес следующая классификация траекторий карьерного роста в сфере образования:

1. Вертикальная карьера:

- рост педагога в занимаемой должности в конкретном образовательном учреждении: учитель, заместитель директора по учебной (воспитательной, социальной, научной) работе, директор образовательного учреждения;

- руководитель муниципального, регионального органа управления образованием; работник Министерства просвещения; министр просвещения;

- оказание образовательных услуг в виде предпринимательской деятельности;

2. Горизонтальная карьера:

- учитель, учитель первой квалификационной категории, учитель высшей квалификационной категории;

- бакалавр, магистр, кандидат наук, доктор наук;

3. Карьера в области методики и практики преподавания учебного предмета:

- внутри образовательного учреждения: учитель, учитель-методист, учитель-наставник, учитель-исследователь, руководитель методического объединения школы, председатель методического 
совета школы, специалист-преподаватель предметной комиссии государственной итоговой аттестации (ГИА) и пр.;

- вне образовательного учреждения: «Учитель года», деятельность по руководству методическими структурами на муниципальном и региональном уровнях; эксперт, приглашенный для проведения семинара или мастер-класса в институт развития образования, эксперт конфликтной комиссии ГИА и пр.;

4. Карьера в области общественной деятельности:

- руководитель в органах государственно-общественного управления;

- руководитель коллегиальных органов управления на уровне образовательного учреждения, муниципалитета, региона;

- руководитель в структурах представительных органов [19].

К сожалению, очень немногие ученые в своих исследованиях делают акцент на том, что карьерная стратегия - это сложное переплетение вертикального и горизонтального среза карьеры, что в профессиональной карьере также важно «...накопление опыта, связей, их расширение (горизонтальное движение)», которое в дальнейшем «...переходит в количественный рост, изменение, достижение нового социально-профессионального статуса» [22, с. 187].

Резюмируя сказанное выше, следует подчеркнуть, что становление педагога как профессионала происходит на протяжении всей жизни, и этот путь не выражается только лишь в простом подъеме по ступеням карьерной лестницы. Основные изменения в карьере профессионала, занятого педагогическим трудом, - это те, которые часто не являются явными: понимание своего места и роли в жизни своих учеников, осознание своей ответственности за результаты образовательного процесса, качественные изменения в межличностном общении с коллегами и учениками, овладение новыми компетенциями, накопление педагогического опыта, профессиональный рост, самосовершенствование и пр. При этом можно говорить о том, что у каждого педагога складывается свой уникальный профессиональный путь и карьерная траектория. Созвучно нашему мнению и высказывание А.Н. Ксенофонтовой: «Сущность карьеры учителя заключается в профессиональном росте, определяющем профессиональную уверенность и повышающем ответственность 
учителя за результат своей деятельности, что делает его конкурентоспособным и оказывает влияние на качество организации и результативности образовательного процесса. Специфика развития профессиональной карьеры учителя заключается в ее уникальности, своеобразии, способности привнести обновленное качество, своевременно корректировать ее реализацию, что побуждает к постоянному самосовершенствованию в личностном и профессиональном отношениях» $[20$, с. 30$]$.

Следовательно, рассматривая карьеру педагога, необходимо изучать особенности его мотивационной сферы, уровень сформированности его профессиональной идентичности, так как именно это является основой его профессионального роста, профессионального развития [23]. Здесь заложены главные движущие силы, побуждающие педагога к постоянному самосовершенствованию в личностном и профессиональном планах, а также повышающие индивидуальную ответственность педагога за конечный итог своей профессиональной деятельности, что, в свою очередь, делает его востребованным на рынке труда и оказывает решающее влияние на качество образования.

В контексте нашего исследования большой интерес представляет мнение ученых, занимающихся проблемами рынка труда (например, Л.В. Санковой), о том, что цифровизация - это «новая система координат», которую, к сожалению, нельзя воспринимать только как положительное явление [24].

В настоящее время научное сообщество пока не готово однозначно ответить на вопрос о степени влияния на рынок труда процессов, обусловленных цифровизацией.

В условиях цифровизации и увеличения доли высокотехнологичных производств наиболее востребованной окажется профессиональная деятельность, в которой первостепенным является личностный потенциал, интеллектуальные возможности человека, активная деятельность, связанная с генерацией идей, инновационная деятельность. В связи с ориентацией экономики на инновационный путь развития, внедрением в производство наукоемких технологий, современного оборудования рынок труда будет испытывать потребность в высококвалифицированных кадрах. Таким образом, 
для применения всех предоставленных новой информационной революцией возможностей следует приложить определенные усилия, направленные на модернизацию инфраструктуры рынка труда, повышение уровня профессиональной подготовки специалиста, его квалификации и переподготовки в случае необходимости, внедрение эффективных систем управления, организации и мотивации труда. Глобальная трансформация рынка труда под воздействием цифровизации, связанная с изменением формальных и неформальные институтов, - объективная реальность нашего времени [25].

По утверждению социологов, для общества характерно возникновение нового социального слоя - когнитариата (от англ. cognition - знание, познание; по аналогии с пролетариатом). Появляется принципиально новый тип работника, владеющего интеллектуальным капиталом, в приоритетах которого творческая практическая деятельность [25].

Многие из исследователей сегодня высказывают большие опасения и по поводу сокращения рабочих мест (из-за конкуренции между людьми и компьютерами, внедрения роботов и пр.). Так, согласно самым оптимистичным аналитическим прогнозам, уже буквально через 40 лет не менее половины сотрудников сферы производства будут заменены роботами, а на некоторых предприятиях их число будет составлять около 70 \%. В зоне риска, по мнению аналитиков, находятся и сферы образования и медицины.

Так, консалтинговая группа McKinsey представляет прогнозы, свидетельствующие о том, что к 2036 г. возможна автоматизация до 50 \% работ, выраженных в человеко-часах, а к 2066 г. эта доля может достичь $99 \%$ [26].

Следовательно, процесс цифровизации диктует экономике тактику избавления от работников, которых можно заменить техникой, наряду с так и не решенной проблемой нарастающей востребованности квалифицированных кадров.

Цифровая среда в разы повышает скорость распространения инноваций, сжимаются не только время, но и пространство. Рабочие места больше не стационарны, они уже представляют собой киберместа. Вместо физического перемещения люди перемещают свои идеи и мысли через киберпространство, а также используют 
это пространство для хранения знаний. В этом кроются причины масштабного роста безработицы.

Цифровизация в отдельных кластерах экономики ускоряет процессы старения информации, что, в свою очередь, означает быстрое устаревание профессиональных знаний. Возрастают требования к образованию, которое должно быть востребованным, наукоемким, гибким и быстро адаптироваться под изменяющийся рынок труда [25].

Таким образом, можно резюмировать, что цифровизация ведет не только к трансформации параметров рынка труда, но и к изменению форм взаимодействия между работником и работодателем. Например, в странах с развитой экономикой - таких как Япония и США, по данным Всемирной организации труда, доля работников «вне офиса» или «фриланса» достигает около $40 \%$.

Возникают и другие неблагоприятные тенденции:

- ограничения и трудности в прогнозировании и долгосрочном планировании профессионального роста и карьеры для работников;

- отсутствие стабильности профессиональной деятельности и гарантий занятости ввиду невозможности строить долгосрочные перспективы;

- частые изменения параметров спроса на рынке труда;

- повышенные требования со стороны работодателя и необходимость в быстрой переквалификации работников.

При этом сейчас, в условиях мировой пандемии новой коронавирусной инфекции и перевода значительного числа граждан в режим удаленной работы, подавляющее большинство работающего населения смогло особенно остро ощутить на себе такие негативные тенденции, как увеличение темпа выполнения трудовых задач и нарушение привычного трудового графика (через мобильные устройства рабочие задания достигают работника в любое время). При этом важно осознавать наличие и других негативных последствий удаленной работы. В качестве наглядного примера можно привести данные социологов, которые отмечают снижение уровня консолидации работников, которые систематически не посещают свое рабочее место, трудясь офлайн (т.е. работают удаленно, являются «фрилансерами» и пр.). Социологи утвержда- 
ют, что такие сотрудники утрачивают чувство профессиональной солидарности и менее способны отстаивать общие интересы, что усугубляет упадок профсоюзного движения. Для преодоления этих и других негативных последствий цифровизации необходимо разумно, ответственно и осмысленно подходить к внедрению новых компьютерных технологий.

В завершение хотелось бы вновь обратиться к наследию А.И. Ракитова, высказавшего идею, на наш взгляд, опередившую свое время: «Можно сколько угодно говорить о правах и свободах человека, возможностях для самореализации личности и пр., но до тех пор, пока эта личность не научится грамотно применять свои культурные достижения для разумного обустройства своей жизни, говорить о ее свободе можно будет лишь метафорически, как о некоторой утопии. Интенсивная и продуманная информатизация культуры, проводимая в общегосударственном масштабе на основе государственной и региональной политики - важнейшее средство превращения этой утопии в реальность» $[1$, с. 34$]$.

1. Ракитов А. И. Новый подход к взаимосвязи истории, информации и культуры: пример России // Вопр. философии. 1994. № 4. С. 14-34.

2. Никулина Т. В., Стариченко Е. Б. Информатизация и цифровизация образования: понятия, технологии, управление // Педагогическое образование в России. 2018. № 8. С. 107-113.

3. Национальные проекты: ключевые цели и ожидаемые результаты [Электронный ресурс]. URL: http://government.ru/projects/selection/743/35675/ (дата обращения: 13.03.2019).

4. Приказ об утверждении ФГОС ВО - бакалавриат по направлению подготовки 44.03.01 «Педагогическое образование» [Электронный ресурc]. URL: http://fgosvo.ru/uploadfiles/FGOS\%20VO\%203++/ Bak/440301_B_3_16032018.pdf (дата обращения: 13.03.2019).

5. Asliturk E., Cameron A., Faisal S. Skills In The Digital Economy: Where Canada Stands And The Way Forward [Electronic resource] // The Information and Communications Technology Council. Ottawa, Canada, 2016. P. 19-20.URL: https:/www.ictc-ctic.ca/wp-content/uploads/2016/05/Skills-in-theDigital-Economy-Where-Canada-Stands-and-the-Way-Forward-.pdf (accessed: 13.03.2019). 
6. Головенчик Г. Г. Цифровые компетенции и навыки будущего [Электронный ресурс] // Цифровая трансформация образования : сб. материалов 2-й Междунар. науч.-практ. конф., Минск, 27 марта 2019 г. / отв. ред. А. Б. Бельский. Минск : ГИАЦ Минобразования, 2019. С. 326-328.

7. Нерадовская О.Р. Использование образовательного потенциала неформального профессионального сообщества для развития профессионализма педагогов : автореф. дис. ... канд. пед. наук. Томск, 2018. 24 с.

8. Шнейдер Л.Б. Профессиональная идентичность: структура, генезис и условия становления : автореф. дис. ... д-ра психол. наук. М., 2001. 42 с.

9. Зеер Э. Ф. Теоретико-прикладные основания психологии профессионального развития : монография. Екатеринбург : Рос. гос. проф.-пед. ун-т, 2015. $194 \mathrm{c}$.

10. Климов Е.А. Психология профессионального самоопределения : учеб. пособие для студентов. высш. пед. учеб. заведений. М. : Академия, 2004. 304 c.

11. Ермолаева Е. П. Психология социальной реализации профессионала : монография. М. : Ин-т психологии РАН, 2008. 353 с.

12. Поваренков Ю. П. Психологическое содержание профессиональной идентичности // Сиб. психол. журн. 2006. № 24. С. 53-58.

13. Шнейдер Л. Б. Профессиональная идентичность: теория, эксперимент, тренинг : учеб. пособие. М. : Изд-во Моск. психол.-соц. ин-та, 2004. 599 c.

14. Громова Е. М., Беркутова Д. И., Горшкова Т. А. Проектирование карьерной стратегии современного педагога // Актуальные проблемы технологического образования: традиции, опыт и перспективы : сб. науч. тр. / редкол.: С. Я. Астрейко (отв. ред.) [и др.]. Мозырь : МГПУ им. И.П. Шамякина, 2019. С. 219-222.

15. Шнейдер Л.Б. Профессиональная идентичность: структура, генезис и условия становления : дис. ... д-ра психол. наук. М., 2001. 327 с.

16. Tomer G., Mishra S. K. Professional identity construction among software engineering students // Information Technology \& People. 2016. Vol. 29, iss. 1. P. 146-172.

17. Кузьмин М. Ю., Миронова Е. И., Осипенок О. А. Становление профессиональной идентичности у студентов-бакалавров гуманитарных направлений // Изв. Иркут. гос. ун-та. Сер. : Психология. 2018. Т. 23. С. 68-76. 
18. Мищенко Т. В. Становление профессиональной идентичности у студентов педагогического вуза : автореф. дис. ... канд. психол. наук. Ярославль, 2005. 23 с.

19. Пузикова О.Н., Тимакова А. Ю. Карьерный рост учителя как компонент современной системы образования // Учитель и время. 2018. № 13. C. 239-248.

20. Ксенофонтова А.Н., Леденева А. В. Освещение проблемы развития профессиональной карьеры учителя // Вестн. Оренбург. гос. ун-та. 2018. № 3(215). С. 28-33.

21. Управление персоналом : энцикл. / под ред. проф. А. Я. Кибанова. М. : ИНФРА-М, 2009. 268 c.

22. Дидковская Я.В. Профессиональная карьера: теоретико-методологические подходы к исследованию феномена // Не расстанусь с молодежью, буду... : сб. науч. ст. к 80-летию проф. Ю. Р. Вишневского / под общ. ред. Ю. Р. Вишневского ; отв. за вып. Д. Ю. Нархов. Екатеринбург : Изд-во Урал. ун-та, 2018. С. 185-194.

23. Беркутова Д. И., Громова Е. М., Горшкова Т. А. Становление профессиональной идентичности будущих педагогов в воспитательном пространстве вуза // Профессиональное образование и занятость молодежи: XXI век. Проблемы и направления воспитательной работы в образовательных организациях : материалы Междунар. науч.-практ. конф. (Кемерово, 23 апр. 2020 г.) : в 2 ч. / отв. ред. А. Г. Апухтина. Кемерово : ГБУ ДПО «КРИРПО», 2020. Ч. 2. С. 13-15.

24. Санкова Л. В. Рынок труда в координатах цифровизации: новые тренды и вызовы // Человеческий и производственный потенциал российской экономики перед глобальными и локальными вызовами (Саратов, 30 нояб. 2018 г.) : сб. тр. конф. Саратов : СГТУ им. Ю. А. Гагарина, 2019. С. 293-299.

25. Дигилина О.Б., Тесленко И. Б. Трансформация рынка труда в условиях цифровизации // Вестн. РГГУ. Сер. : Экономика. Управление. Право. 2019. № 4. С. 166-180.

26. Исследование экспертной группы Digital/McKinsey. Цифровая Россия: новая реальность [Электронный ресурс]. С. 53. URL: http://www.tadviser.rU/images/c/c2/Digital-Russia-report.pdf (дата обращения: 13.03.2019). 


\section{ПРОФЕССИОНАЛИЗМ ПЕДАГОГА. ТЕОРИЯ ПОКОЛЕНИЙ: КОМУ У КОГО УЧИТЬСЯ?}

М. Н. Дудина

В смене поколений и поколенческих парадигм, казалось бы, все довольно обычно, включая конфликт «отцов и детей», «потерянные поколения». Новые поколения создают историю, если бы дети не появлялись на свет, история давно бы закончилась. История создает новые поколения, которые обучаются и воспитываются. Отсюда вопросы к тем, кто обучает и воспитывает. Вопросов все больше, важнейший из них: соответствует ли профессионализм педагогов вызовам времени? Современные дети, подростки, особенно старшеклассники, студенты оказались более продвинутыми в вопросах цифровизации, использования инновационных технологий. Они тяготеют к диалогу и не приемлют дидактизм, не терпят авторитарности, замечаний, тем более рукоприкладства. Востребован педагог-гуманист, признающий и поддерживающий каждого обучаемого в его правах, свободе и достоинстве. Этого требуют дети и подростки, мало осведомленные о своих правах, они снимают на мобильные устройства все, заслуживающее их внимания, и выкладывают на всеобщее обозрение в Сеть. Многие педагоги и родители требуют запретить пользоваться в учебном заведении телефонами. То, что веками было тайной, а именно недостойное отношение к обучаемым разных возрастов, стало явным, отсюда традиционное «запретить».

В последнее время значительный интерес стал проявляться к поколению Z - центениалам, следующим за миллениалами. Уже пишут о поколении «альфа» (A), подчеркивая новое начало, которое задают родившиеся после 2010 г. [1]. Примерно 90 \% современных детей к 2 годам умеют пользоваться планшетами, и многие имеют личный гаджет в 3-4 года. Ученые замечают динамику в интеллектуальном развитии, прогнозируют проблемы развития в эпоху искусственного интеллекта, отмечают «необычность» этих детей. Например, они более персонализированы и индивидуализированы, у многих есть свой личный аккаунт в соцсетях, где они форми- 
руют индивидуальную ленту на основе собственных предпочтений. Не разделяют реальный и виртуальный миры, привыкли, что картинка на экране похожа на ту, которая их окружает в жизни. Они одинаково воспринимают информацию на экране и в книге, не обеспокоены вопросами, как выглядят для посторонних. Немало современных детей и подростков с ранних лет становятся блогерами и рано «зарабатывают», рассказывая о том, что происходит каждый день с ними и с другими людьми. Для них важно выложить видео, поделиться радостными или тяжелыми переживаниями не только с близкими, но с незнакомыми, где бы они ни находились.

Для родителей, педагогов и психологов, социологов и культурологов интерес представляет контент - стримы, розыгрыши, челленджи, особенно занимающие первые места рейтингов. При этом появляются новые форматы, трансформируются известные. Как объяснить такие факты: 7-летний мальчик Райан сделал простой обзор детских игрушек и заработал за год 26 млн долл.; Настя Радзинская показала самую обычную жизнь - играет, учится, ходит в парки развлечений, рассказывает вместе с папой сказки и стихи (18 млн долл.); мультик про акул Baby Shark набрал миллиарды (?!) просмотров на YouTube. Всему подобному можно легко обучиться, например, с популярным приложением TikTok, без специального оборудования и знаний. Эти дети неплохо взаимодействуют с родителями, которые осознают собственную ответственность за судьбу своего ребенка, стараются проводить с ним как можно больше времени (принцип осознанного родительства).

Согласно прогнозам, в ближайшее время исчезнет масса профессий, и мало кто знает, какие новые будут востребованы. Тогда возникает вопрос: чему учиться для будущей профессии, чтобы быть готовым к приобретению новых видов трудовой деятельности? Необходим рост потребностей, мотивов и умений самообразования и самовоспитания на основе развития эмоционального интеллекта (El), недоступного машинам, в контексте искусственного, с которым предстоит конкурировать. В целом это вопросы об адаптивности к потоку информации и способности находить возможность взаимодействия с другими людьми, развивая собственную идентичность. Даже на бытовом уровне заметно, что современные дети значимо 
отличаются от своих родителей, воспитателей и учителей. Прежде всего, это «дети Сети», для которых размыты границы виртуального и реального миров, где все время можно играть, общаться в чатах анонимно, значит, ни за что не отвечать. В целом же реальна опасность интернет-зависимости, непреодолимой потребности к чрезмерному использованию интернета.

Станут ли растущие поколения носителями этико-гуманистической миссии в научно-технологическом и социокультурном прогрессе? Будут ли они менее агрессивными, чем предшественники, более толерантными? Спасут ли глобальный мир эрудированные, образованные «через всю жизнь» поколения? Образованные не жестокие? Построят ли отношения гибко и социально ответственно к проблемам терроризма, экологии, исчерпания ресурсов Земли? Главное - будут гуманнее по отношение к человеку, к детям? Какова роль педагогов и их профессиональный вклад в прогрессивное движение из настоящего в будущее?

\section{Методология и дидактика развивающего обучения}

В основе «теории поколений» Нейла Хоува (Neil Howe) и Уильяма Штрауса (William Strauss), созданной в начале 90-х гг. прошлого века, лежит своеобразный взгляд на тех, кто творит историю [2]. Определяя поколение как совокупность людей, рожденных в один двадцатилетний период, авторы выделили три общих критерия их узнаваемости и причастности к данному поколению: возрастное положение в истории, переживание одних и тех же исторических событий; общие, единые верования и модели поведения. Согласно авторам, поколение переживает периоды кризиса и подъема. Первоначально указывались четыре архетипа: «идеалисты», «реагирующие», «гражданские», «приспосабливающиеся», позже их стали называть: «пророки», «кочевники», «герои», «художники» [3]. У. Штраус и Н. Хоув на основе анализа всемирной истории с 1584 по 1991 г. сделали прогноз до 2069 г. В ХХ в. они вычленили пять поколений, а в XXI в. - одно.

Эта теория мало известна отечественным педагогам, больше - психологам и особенно социологам, политологам (Б. В. Дубин В. Т. Лисовский, Ю. Р. Вишневский, В. Т. Шапко, Ю. А. Левада, 
В. В. Гаврилюк, Н.А. Трикоз, Е. Шамис, А. Антипов и др.). Анализируя этот процесс, исследователи отмечают его особенности ценностный конфликт молодого и взрослого поколений, базисные взгляды на экономику и производство, материальную и духовную жизнь общества [4].

Для психологии и педагогики важно иметь в виду феномены значимого изменения процессов развития высших психических функций в современной культуре и образовании. У растущих поколений большие проблемы, связанные с развитием свойств внимания, прежде всего длительности концентрации, поэтому возникают трудности понимания контента - он вызывает интерес или сразу отторгается. Особенно заметны проблемы развития речи: мышление клиповое, речь примитивная, изобилует сленгом, жаргоном, нецензурными выражениями. Необходимо развитие критического мышления, овладение критериями отбора информации и умением ею пользоваться репродуктивно и творчески.

Остановимся на ключевом для теории и практики обучения, для дидактики и частных методик понятии «социальная ситуация развития», введенном Л. С. Выготским. Психолог, исследуя динамику возрастного развития личности, считал «начальным и существенным» понимание отношений между личностью и окружающей социальной средой «на каждой возрастной ступени как подвижных». Предостерегал от ошибки, когда «среда рассматривается как нечто внешнее, как обстановка развития», видел в ней источник развития: складывается «своеобразное, специфическое для данного возраста, исключительное, единственное и неповторимое отношение» [5, т. 4, с. 258]. Сугубо индивидуальная для каждого человека любого возраста социальная ситуация развития определяет «целиком и полностью те формы и тот путь, следуя по которому ребенок приобретает новые и новые свойства личности, черпая их из социальной действительности как основного источника развития, тот путь, по которому социальное становится индивидуальным» [Там же, с. 258-259].

Наш опыт показывает, что современные педагоги общего и высшего образования менее всего осведомлены в методологии развивающего обучения на всех ступенях образования, теории и практики 
реализации личностно-ориентированной модели и, как следствие, в инновационных образовательных технологиях, побуждающих к диалогу. Инновации (позднелат. innovatio, англ. innovation - нововведение) - явления культуры и образования, которых не было на предшествующих стадиях развития. Но они возникли и, возможно, не сразу получили признание, «социализировались». Они зафиксированы в знаковой форме, в деятельности посредством изменения способов, содержания, механизмов, результатов. Прислушаемся к мнению психолога А. Г. Асмолова: «При описании современности через призму разных методологических оптик мы все чаще отмечаем такие ее свойства, как полифоничность, релятивистская природа, ускорение изменений, мобильность, текучесть, разнообразие, сложность, гетерогенность, нелинейность, многомерность и неопределенность» [6].

Необходимо преодолеть традицию «предметника», часто не желающего овладевать метазнаниями и инновационными средствами обучения. Среди современных перспективных концепций назовем реверсивное обучение (часто называют «смешанным», «обратным»; в финской школе - «перевернутый класс», от англ. flipped classroom). Преподаватель вводит в проблему, ориентирует в разных ее аспектах, возможно, предлагает первоисточники для самостоятельного изучения, обращает внимание на бескрайнее пространство интернета, напоминает о критическом осмыслении информации, высказывает пожелание креативно ею пользоваться. Поиск и применение школьниками и студентами самостоятельно найденной информации и приобретенных знаний требуют умений представить их в учебной аудитории, позиционировать себя в качестве источника информации, нести за это ответственность. Однако в отечественной образовательной практике этот дидактический феномен пока теоретически недостаточно осмыслен и редко реализуется. В то же время здесь имеется большой простор для творчества преподавателей и студентов. Образовательная практика начинается с выбора моделей реверсивного обучения. Так, М. Л. Кондакова выделила шесть моделей реверсивного обучения в зарубежном среднем образовании, активно использующем электронные ресурсы [7]. 
В нашем опыте реверсивное обучение успешно используется в проектной деятельности студентов и при разработке кейсов [8]. Предоставляя студентам свободу выбора проблем и способов их решения в конкретных учебных курсах («Теория и практика высшего образования», «Дидактика высшей школы», «Педагогика и психология высшей школы» - уровень магистратуры, «Педагогика высшей школы» - уровень аспирантуры), мы говорим об увеличении личной ответственности каждого в образовательном процессе. Это реально в инновационной дидактической модели, в которой, в отличие от традиционной, по-разному решаются задачи целеполагания, планирования, прогнозирования, а также отбора содержания и методов обучения, оценивания. В настоящее время преподаватель не является единственным или почти единственным источником информации для студентов, причем не только они учатся у преподавателя, но и он сам учится у тех, кого обучает. Это возможно и необходимо в цифровой цивилизации, в современной жизни, культуре и образовании, радикально меняющих образ жизни, коммуникацию, учебную деятельность. Так, трансформируется идентичность личности студентов и преподавателей в условиях доступности интернета и цифровых технологий как инструментов социализации, адаптации и идентификации, детерминирующих процесс развития личности. Масштабное распространение IT-телефонии, социальных сетей и видеосервисов в интернете, исторических и фэнтезийных реконструкций, масштабная геймификация несут значимые педагогические риски.

Реализуя пока еще малоизученную и редко используемую концепцию реверсивного обучения в высшей школе в контексте личностно-ориентированной модели образовательной парадигмы, мы рассматриваем теоретико-методологические вопросы, знакомимся с инновационными технологиями, на теоретико-методологической основе реализуем практику реверсивного обучения, например, в конструировании и решении кейсов. Знакомимся с этапами конструирования кейса: определение цели создания и тематического содержания; поиск источников информации (по ключевым словам), анализ литературы, публикаций, статистики, сбор информации и подготовка первого варианта представления материалов в кейсе 
(макет, презентация - видео, печатная); обсуждение в аудитории и получение экспертной оценки перед апробацией (внести необходимые изменения); подготовка методических рекомендаций по использованию кейса (предложить задания для студентов, возможные вопросы для дискуссии и презентации).

Проблемы и темы, взятые для создания учебных кейсов, могут быть разнообразными - от междисциплинарных до предметных. Например: «История как социальная память человечества: концептуальные взгляды, позиции, убеждения»; «Религиозная толерантность: миф или реальность?»; «Система наказаний в педагогике: преодоление негуманной традиции»; “"Между прошлым и Буниным”: экранизация рассказа “Солнечный удар” (1925) и “Окаянные дни” (дневник писателя, 1918-1919)»; ““Люблю Россию я, но странною любовью”. М. Ю. Лермонтов: “самый антипатриотичный поэт - назвал Родину немытой”?!» [8, с. 106].

Поскольку кейс (случай, ситуация) представляет совокупность взаимосвязанных фактов, событий, явлений, характеризующих жизненные проблемы, постольку требует конкретных ответственных решений. Виды ситуаций могут быть разнообразными: ситуация-проблема (поиск причин возникновения, формулирование проблемы, ее решение); ситуация-оценка (оценивание принятых решений); ситуация-иллюстрация (конкретика решенных жизненных, научных и образовательных проблем); ситуация-упражнение (решение проблем по аналогии). При этом решение кейсов возможно в небольших группах или индивидуально, их можно использовать на зачете, экзамене. Опыт показал, что дидактически продуктивен обмен разработанными студентами кейсами, их решение на учебном занятии и оценивание по заранее обговоренным критериям. Так создается дидактический банк кейсов, разработанных студентами, которые в данном случае выступают как преподаватели (например, разработки магистрантов исторического факультета 1-го года обучения, в духе отечественной традиции использовавших первоисточник - книгу Л. А. Данилкина «Ленин - пантократор солнечных пылинок»). Акцентируя внимание не столько на репродуктивной, сколько на творческой деятельности, следует поддерживать стремление студентов иметь креативную установку личности. Этот опыт 
позволяет оптимистически полагать, что отечественное образование разных уровней обучения может достойно отвечать на вызовы нового века, решительно отказываясь от архаичности некоторых традиций и осваивая богатый опыт инноваций, в частности, при наличии безграничных источников информации можно отказаться от традиционной акроаматической модели обучения - «из уст преподавателя в уши студентов» (Ф. Ницше). Приведем примеры разработок магистрантов-историков - кейсы по книге Л. Данилкина (премия «Большая книга» 2017 г.).

Вряд ли стоит говорить о том, что современный преподаватель, прежде всего, призван мотивировать студентов на самостоятельную творческую работу, на самообразование. Этому содействует поиск проблемы, у которой нет однозначного решения, не может быть одного мнения и одинакового восприятия, поэтому мы выбрали Л. А. Данилкина: «Рассказывать о Ленине - все равно что рассказывать истории “Тысячи и одной ночи”. Кроме магии и тайн, во всех этих историях есть логика: железные “если..., то.... ...Снесите все статуи и запретите упоминать его имя - история и география сами снова генерируют “ленина”» [9, с 783]. Широчайшее проблемное поле исследования, что еще желать для создания кейсов?

Решение кейса предполагает последовательное изучение предложенного текста (задания: познакомьтесь с фрагментом, проанализируйте, сопоставьте, сравните, интерпретируйте, обобичте, сбормулируйте ваши вопросы...). Приведем примеры некоторых авторских студенческих кейсов: Анна Ц. Владимир Ульянов - эксцентричный эрудит или начитанный тиран?; Евгений Я. «Раскачивание Невской заставы»: ответ на социальный запрос или жажда власти?; Мария С. Петербургские годы: начало революционной работы или ее продолжение?; Андрей Ж. «Развитие капитализма в России» - бестселлер?; В. С. Общерусская политическая газета или печатный орган революционной интеллигенции?

В целом результаты использования кейс-технологии связаны с приобретением многих необходимых умений: аналитических (находить общее и особенное, выделять существенное, классифицировать, добывать недостающую информацию, мыслить ясно и логично); практических (использование теории, принципов, мето- 
дов); креативных (генерация идей, поиск альтернативных решений, авторский подход); коммуникативных (слушать других, убеждать оппонентов, находить единомышленников, делать взвешенные выводы); соииальных (оценка поведения других, поиск компромисса, консенсуса, умение контролировать себя); реблексивных (саморефлексия на основе анализа согласия и несогласия с другими, умение владеть собой, убеждать, позиционировать себя, владение вербальными и невербальными средствами).

И все же появляется много вопросов о теоретической разработке и практическом использовании альтернативной традиционному обучению инновационной дидактики. На них каждый преподаватель ищет ответы в соответствии с требованиями к компетентности профессионала XXI в. Проблемное поле современной дидактики ориентирует на сравнение и анализ достоинств и недостатков традиционной и инновационной моделей, выявление их дидактического потенциала и педагогических рисков в ценностном, потребностномотивационном, деятельностном, коммуникативном и рефлексивном аспектах. Если конкретно, то традиционно оценивал обучаемых разных уровней только преподаватель. Стоит ли говорить о том, что было немало тех, кто не понимал, почему так оценен, бывали явно недовольные, порой вступающие в конфликт, особенно когда преподаватель не комментировал выступление на семинаре, ответ на зачете и экзамене. Остановимся на способе, который может существенно изменить традиционную ситуацию в образовании. Конкретно речь идет об использовании такого вида учебной деятельности, как оценивание работ однокурсников (англ. peer to peer review - оценка равного равным). Он имеет социально-педагогическую и дидактическую ценность не только в реальной среде, но и в виртуальной, где многое теряется в отсутствии реального общения, особенно в диалоге. Одной из значимых становится проблема отчуждения. Как его минимизировать? Преодолеть? Ведь всегда было важно - не только у кого учиться, но и с кем учиться. Используя прием оценивания студентами работ однокурсников, прежде всего, необходимо договориться о критериях оценивания. Сами студенты должны выявить необходимые критерии, в их числе актуальность выбранной студентом проблемы и темы, содержатель- 
ное наполнение, технологическая ценность авторской презентации, стимулирование интерактивности в аудитории, источниковая база. Поскольку в онлайн-обучении договариваться не приходится, то выкладывать задания на платформу можно в готовом виде. Творческие задания должны обязательно оцениваться группой, не менее 6 человек, а также необходима самооценка по трем критериям теоретическая и практическая ценность выполненного задания и креативность автора. Оценивается работа по балльно-рейтинговой системе, соответственно, назначаются баллы. Так студенты знакомятся с работами однокурсников и учатся их адекватно оценивать. Результаты использования данного дидактического приема требуют дальнейшего анализа.

\section{Обсуждение}

Актуальность названной проблемы вызывает профессиональный и личностный интерес у педагогов. На развитие личности всех возрастов влияет возрастание роли средств информации как источников развития потребностей и мотивов, интеллекта и чувств, деятельности и общения, мышления и речи, восприятия и воображения, репродуктивности и креативности. Высшее образование как цель, процесс и результат обучения многогранно, его качество в значительной степени определяет успешность обучения и предстоящую профессиональную деятельность выпускников многоступенчатой высшей школы (бакалавриат, магистратура, аспирантура, докторантура). Какие значимые изменения необходимы и возможны в системе «преподаватель - студент», чтобы обучающиеся на всех уровнях стали основополагающими субъектами образования? Какими компетенциями они должны овладеть? Цифровизация меняет жизнь, социальную ситуацию развития личности, процессы адаптации и идентификации. Речь идет о «цифровом детстве». Так, Г. В. Солдатова, исследуя его с позиции культурно-исторического подхода, отмечает значительную динамику в развитии высших психических функций у современных подростков. Информационно-коммуникационные технологии расширяют пространство их жизнедеятельности и влияют на всю структуру личности, интернет ими не воспринимается как совокупность технологий, это - социо- 
культурная среда, являющаяся источником развития личности и ее деградации за счет порождения новых форм деятельности, культурных практик, феноменов, значений и смыслов (самое страшное - «группы смерти», пропаганда суицида) [10]. Стремительно нарастают контентные, коммуникационные, потребительские и технические риски. Интернет-пространство изобилует материалами, содержащими противозаконную, неэтичную информацию (насилие, агрессия, эротика и порнография, нецензурная лексика, пропаганда суицида, наркотических средств). Пользователи Сети попадают в ситуацию негативного межличностного общения (киберпреследование, киберунижение и др.). Существует большой риск приобретения товаров низкого качества, подделок, контрафактной и фальсифицированной продукции, а также хищение денежных средств через онлайн-банкинг, а также реальная возможность повреждения используемых технических средств, раскрытие персональной информации.

Сказанное открывает новые психолого-педагогические и социальные проблемы детей и взрослых. Одна из них проецирует особенность современного образования, которая требует отказа от архаичности «подачи знаний», «передачи опыта старшего поколения», оберегающего и поддерживающего традиции. Изжили себя многие формы, виды и методы вековой образовательной модели. Об этом в свое время говорил Ф. Ницше, связывая ее с проблемой «академической свободы» университета. Он еще во второй половине XIX в. саркастически писал о несостоятельности акроаматической модели: «из уст преподавателя в уши студентов», которые могут при желании «заткнуть уши»: «Часто профессор, говоря, читает. В общем, ему бы хотелось иметь как можно больше таких слушателей... Один говорящий рот и очень много слушающих ушей и вполовину меньше пишущих рук - таков внешний академический аппарат, такова пущенная в ход образовательная машина университета... И эту самостоятельность с гордостью восхваляют как “академическую свободу"» $[11$, с. 175$]$.

Вряд ли стоит говорить о том, что эта привычная модель (так учились сами преподаватели) продолжает реализовываться и в настоящее время. Преподаватель был основным источником необ- 
ходимой информации и «передавал» знания студентам в готовом виде, они их «получали». Использовались два метода - объяснительно-иллюстративный и репродуктивный (дал знания, «передал» и спросил, сам оценил, возможно, не задумываясь о критериях оценивания, тем более о самооценке школьника, студента). Эта модель оправдывала себя в контексте социокультурного хронотопа и соответствующего ему образования в условиях недостаточности источников информации, книг, учебников, пособий, ограниченного доступа к ним во времени и пространстве. Доминирование этой модели, в которой преподаватель-донор «передавал знания», а студенты-реципиенты их «получали» в готовом виде существенно ограничивало возможности самостоятельной работы студентов, тем более творческой. В настоящее время изобилие источников информации, возможность неограниченного в пространстве-времени постоянного доступа к ним делает реальным превращение студентов из пассивных потребителей необходимых знаний «из уст преподавателя» в деятельных субъектов познания и достижения желаемого уровня образования. Заметим, что немало старшеклассников и студентов превосходит учителей и преподавателей, особенно в информационно-коммуникационных технологиях. Это приводит к конфликтным ситуациям и в школе, и в вузе. Исследователь П. А. Амбарова утверждает, что большинство преподавателей и научных сотрудников вузов оказались не готовы к «культурному разрыву» между цифровым поколением студентов, более компетентным, чем преподаватели - «аналоговые», менее продвинутые. Отсюда «личные и профессиональные потери» преподавателей. “Аналоговым” нет места в новой образовательной реальности, сконструированной стейкхолдерами “от бизнеса”, новым университетским менеджментом (“ректорами-бизнесменами”), новыми целевыми аудиториями» $[12$, с. 28].

Наступило время, когда вопрос «кому у кого учиться?» решается в пользу обучаемых, более продвинутых, успешно осваивающих «пространство потоков» (М. Кастельс). Приведем конкретные данные, полученные при опросе 65 аспирантов УрФУ технического, экономического и гуманитарного направлений подготовки (февраль 2020 г.). Ответы респондентов свидетельствуют о том, что все же 
не следует говорить о «смерти профессора» (Ж.-П. Лиотар). Преподаватель в вузе остается мотиватором, навигатором и организатором продуктивной деятельности студентов, в том числе самостоятельной работы в научном поиске. У некоторых преподавателей необходимо учиться умению взаимодействовать с аудиторией, ораторскому мастерству, проблемному изложению материала, знанию первоисточников, их авторов, умению писать тексты. Что касается преподавателей, то многим надо учиться у студентов умению владеть современными инновационными технологиями (студенческие презентации бывают намного лучше, чем у преподавателей), открытости к новому, принятию современной жизненной ситуации такой, какая она есть в соответствии с динамикой культурных трендов, прислушиваться к студентам, «быть на одной волне», быть открытыми к новому, смелее меняться в интересах личностного и профессионального развития.

\section{Выводы}

Всегда были учителя и преподаватели университетов, которые верили в творческий потенциал школьников и студентов. В их числе великий русский писатель и педагог Л.Н. Толстой, создавший школу в Ясной Поляне. О деревенских ребятишках он, известный писатель, написал статью «Кому у кого учиться писать: крестьянским ребятам у нас или нам у крестьянских ребят?». Это настоящий мастер-класс на все времена, и даже сейчас для многих она покажется парадоксальной, что и говорить о его времени. Он опередил образование, отставшее от жизни и от личности учеников, не предоставляющее им свободу и не востребующее их жизненный опыт». Задавал вопрос: «Каким образом люди честные, образованные, искренне любящие свое дело и желающие добра... могли... так глубоко заблудиться?» $[13$, с. 310$]$. Задумаемся над его словами и чувствами: «Я долго не мог дать себе отчета в том впечатлении, которое я испытал, хотя и чувствовал, что это впечатление было из тех, которые в зрелых летах воспитывают, возводят на новую ступень жизни и заставляют отрекаться от старого и вполне предаваться новому» [14, с. 17]. Это императив современной дидактики - «отрекаться от старого и вполне предаваться новому». 
Вернемся к явно новому - применению способа оценивания однокурсниками и самооценки студента в онлайн-обучении (весенний семестр 2020 г.). В работе участвовали 66 студентов: магистранты-лингвисты, 1-й курс - 20 чел., из них 5 - китайские студенты; лингвисты-бакалавры, 2-й курс - 15 чел.; социокультурная деятельность, 3-й курс - 16 чел. и заочное отделение, 4-й курс - 15 чел. Выявлено, что, несмотря на наличие данного задания как обязательного - оценивание однокурсников и самооценка по предложенным преподавателем трем критериям (теоретическая и практическая аргументация, креативность автора), только $6 \%$ выполнили его в полном объеме, остальные после напоминания преподавателя, и только 35-40 \% к назначенному сроку (вопросы учебной дисциплины). Здесь есть проблема педагогических рисков, связанная с исполнительностью студентов, умением и желанием соответствовать интенсивному процессу, в значительной степени задаваемому темпом самостоятельной работы.

Каждое новое поколение детей, подростков, юношей и девушек требует иного подхода от преподавателей: обоснованного отказа от традиций и осознанной направленности на освоение инноваций, в которых используются проблемный, частично-поисковый и исследовательский методы в противовес объяснительно-иллюстративному и репродуктивному. Психолого-педагогическая фасилитация предполагает постоянное повышение психолого-педагогической компетентности учителей и преподавателей вузов. Овладение необходимыми компетенциями требует пересмотра целеполагания, содержания и технологий обучения, включая оценивание, самооценку на основе согласованных критериев получения прогнозируемых результатов, проявляющихся в ассертивном поведении обучающихся $[15,16]$. Раскрытие личностного и профессионального творческого потенциала обучаемых и обучающихся свидетельствует о способности и готовности организовать интерактивное взаимодействие с использованием инновационных технологий. Предвидение неизбежных трудностей на пути к достижению желаемых результатов, выявление их конкретно у каждого обучаемого снимет негативные эмоции, предотвратит неадекватное поведение субъектов образования. Для этого необходимо проводить рефлексию психических 
состояний и последующую коррекцию модели поведения педагогафасилитатора, предупреждающего возможные конфликты между учащимися, студентами и с преподавателем. Цели обучения достигаются на основе высокой мотивации и положительных эмоций от самого учебного процесса и его результатов, овладение умением договариваться - слушать других и стремиться быть услышанным в этике сотворчества, фасилитации снижает количество конфликтов. Эти проблемы должны осознаваться педагогами-профессионалами, исследоваться, с учетом смены поколенческих парадигм, в системе образования в ближайшие десятилетия.

1. На смену поколению $\mathrm{Z}$ идет новое - альфа. Почему к нему стоит присмотреться прямо сейчас [Электронный ресурc]. URL: https://www.adme. ru/svoboda-kultura/na-smenu-pokoleniyu-z-idet-novoe-alfa-pochemu-k-nemustoit-prismotretsya-pryamo-sejchas-2256465/ (дата обращения: 20.02.2020).

2. Howe N., Strauss W. Generations: The History of America's Future, 1584 to 2069. N. Y. : William Morrow \& Company, 1991.

3. Howe N., Strauss W. The Fourth Turning: What the Cycles of History Tell Us About America's Next Rendezvous with Destiny. N. Y. : Broadway Books, 1997.

4. Гаврилюк В. В., Трикоз. Н. А. Динамика ценностных ориентаций в период социальной трансформации (подколенный подход) [Электронный pecypc]. URL: https://studfile.net/preview/460521/ (дата обращения: 03.02.2020).

5. Выготский Л. С. Собрание сочинений : в 6 т. М. : Педагогика, 1982.

6. Асмолов А. Г. Психология современности: вызовы неопределенности, сложности и разнообразия // Психологические исследования. 2015. № 8 (40) [Электронный ресурс]. URL: http://psystudy.ru/index.php/ num/2015v8n40/1109-asmolov40 (дата обращения: 02.07.2019).

7. Кондакова М. Л., Латыпова Е.В. Смешанное обучение: ведущие образовательные технологии современности [Электронный ресурc]. URL: http://vestnikedu-.ru/2013/05/smeshannoe obuchenie vedushhie obrazovatelnyie tehnologii sovremennosti/ (дата обращения: 11.03.2019).

8. Дудина М.Н. Теория и практика высшего образования: реверсивное обучение : учеб.-метод. пособие. Екатеринбург : Изд-во Урал. ун-та, 2020144 c.

9. Данилкин Л. А. Ленин: Пантократор солнечных пылинок. 2-е изд. М. : Молодая гвардия, 2017. 783 с. 
10. Солдатова Г. Цифровое детство: новые риски и безопасность [Электронный ресурc]. URL: https://psiholog-rmo.ru/wp/wp-content/uploads/2017/02/20170215-cifrovoe_detstvo.pdf (дата обращения: 02.07.2019).

11. Ницие Ф. О будущности наших образовательных учреждений // Ницше Ф. Философия в трагическую эпоху. M. : REFL-book, 1994. С. 101188.

12. Амбарова П.А. Сага о форсайтах, или Прогнозные сценарии развития научно-педагогического сообщества в российских вузах // Высшее образование в российских регионах: вызовы XXI века : 93-й сб. материалов Всерос. науч.-практ. конф. (17 сент. 2018 г., Екатеринбург). Екатеринбург : Кабинетный ученый, 2018. 378 с.

13. Толстой Л. Н. Педагогические сочинения. М. : Педагогика, 1989. $542 \mathrm{c}$.

14. Толстой Л. Н. Кому у кого учиться писать, крестьянским ребятам у нас или нам у крестьянских ребят? // Собр. соч. : в 22 т. М. : Худож. лит., 1983. T. 15.

15. Дудина М.Н. Ассертивное поведение в этико-педагогическом дискурсе // Изв. Урал. федер. ун-та. Сер. 1 : Проблемы образования, науки и культуры. 2014. № 4 (132). С. 163-170.

16. Дудина М.Н. Проблема уверенности в себе в контексте смысложизненных ориентаций студентов: результаты эмпирического исследования // Вестн. Челяб. гос. пед. ун-та. 2017. № 8. С. 117-121. 


\section{СТРУКТУРНО-УРОВНЕВАЯ ПЕРИОДИЗАЦИЯ ПРОФЕССИОНАЛЬНОГО СТАНОВЛЕНИЯ ЛИЧНОСТИ*}

Ю. П. Поварёнков

Как следует из названия статьи, речь в ней пойдет о периодизации профессионального или карьерного становления личности. Надо признать, что мы не однократно обращались в своих работах к данной проблеме [1-4]. И на то есть свои причины.

Во-первых, проблема профессиональной периодизации остается чрезвычайно актуальной как в практическом, так и теоретическом плане. На это указывает обилие публикаций на данную тему как в отечественной, так и зарубежной психологии [5-8].

Во-вторых, разработанные в настоящее время концепции периодизации профессионализации подвергаются жесткой критике из-за недостаточной экологической валидности. То есть они не в полной мере отражают реальные закономерности профессионализации личности и затрудняют решение практических задач.

B-третьих, накапливаются эмпирические данные и разрабатываются новые теоретические подходы, которые позволяют обозначить новые направления решения данной проблемы.

Учитывая сказанное, постараемся обозначить специфику структурно-уровневого подхода к разработке периодизации профессионального становления человека. Именно данный подход мы рассматриваем как наиболее перспективный в плане описания и объяснения реальных закономерностей профессионализации.

Напомним, что такое периодизация. В энциклопедическом словаре периодизация определяется как междисциплинарный методический прием, который используется для деления процесса развития на определенные этапы [9]. Выделяют содержательные и формальные основания периодизации. Содержательным основанием для такого деления выступают специфические для каждого

Исследование выполнено при финансовой поддержке РФФИ в рамках научного проекта № 19-013-00782 «Структурно-уровневый подход к периодизации профессионального становления личности». 
этапа новообразования, а формальным основанием являются показатели времени.

Надо признать, в настоящее время в отечественной и зарубежной психологии разработано большое количество различных концепций периодизации профессионального и карьерного развития личности. Однако все они могут быть объединены в две большие группы. В соответствии с терминологией Д. Н. Завалишиной первую группу составляют онтогенетические периодизации профессионализации, а вторую - профессионалогенетические.

В чем заключается их специфика?

Специфика онтогенетических периодизаций заключается в том, что в качестве формального или временного основания для деления процесса развития на стадии, периоды и фазы используется хронологический возраст человека. В профессионалогенетических периодизациях формальным основанием для деления выступает профессиональный возраст человека. Профессиональный возраст в ряде случаев измеряется в единицах профессионального стажа.

Почему преобладают эти две группы или два типа периодизаций? Связано это с историей возникновения психологии профессионального и карьерного развития личности. Как известно, она формировалась на стыке психологии труда и психологии развития, которые оказали существенное влияние на содержание ее понятийного аппарата, на подходы к исследованию профессионализации.

Поэтому очевидно, что онтогенетические периодизации разрабатывались психологами, которые ориентировались на методологию психологии развития. А мы хорошо помним, что именно в психологии развития хронологическому возрасту человека отводится важная методическая функция.

Соответственно, профессионалогенетические периодизации разрабатывались психологами, которые опирались на методологию и методические принципы психологии труда и организационной психологии, в которых основной акцент делается не на возраст человека, а на его профессиональный стаж.

Таким образом, данные периодизации разрабатывались фактически с разных методологических позиций. А коль скоро это так, 
то в большинстве случаев они прямо или косвенно противопоставляются друг другу.

Причем вопрос стоит примерно так: какая из выделенных групп концепций наиболее точно отражает реальные закономерности профессионализации? На какую группу концепций следует опираться специалистам при решении теоретических и прикладных задач?

Поиск ответа на данный вопрос нельзя назвать простым, поскольку выделенные группы концепций обладают как серьезными достоинствами, так и не менее серьезными недостатками. В наших работах мы достаточно подробно обсуждали сильные и слабые стороны каждой группы концепций. Отметим в качестве примера некоторые недостатки выделенных концепций, за которые они активно критикуются.

Развернутая критика онтогенетических периодизаций ведется по следующим направлениям:

1. Онтогенетические периодизации опираются на те или иные представления о жизненном пути человека в целом и в той или иной форме пытаются копировать его. В силу этого основные тенденции жизненного пути в определенной степени маскируют ведущие закономерности становления профессионала, что существенно сказывается на адекватности наших представлений о данном процессе.

2. Все периодизации этой группы в качестве временного параметра используют лишь хронологический возраст человека, который никак не соотносится с его «профессиональным возрастом», т.е. с профессиональным стажем и профессиональным опытом. Тем самым решение отдельных профессиональных задач жестко увязываются с конкретным возрастом человека. Исходя из этого, поиск работы возможен только в юношеском возрасте, окончание профессиональной карьеры связано только со старостью, а достижение максимальных результатов в профессиональной деятельности возможно только в среднем возрасте и т.д. Но такая тесная связь между хронологическим возрастом человека и спецификой решаемых задач профессионального развития прослеживается далеко не всегда.

3. Из сказанного следует, что онтогенетические периодизации реализуют моноциклический подход к пониманию профессионального развития, который образно можно обозначить форму- 
лой «одна жизнь - одна профессия». Такие представления также слабо соотносятся с реальностью, так как человек в течение жизни может неоднократно менять и профессию, и специальность, и специализацию в рамках одной профессии и т. д. Поэтому стабильная профессиональная карьера, полностью совпадающая с жизненным циклом человека, является лишь частным случаем полициклического профессионального развития.

Критика профессионалогенетических периодизаций ведется по следующим направлениям:

1. Несмотря на существование некоторых обобщающих подходов, большинство периодизаций данного типа приспособлены для описания закономерностей профессионального развития человека в рамках конкретного вида профессий (учителей, менеджеров, врачей, инженеров-конструкторов и т.д.) Абсолютизация такого подхода затрудняет выделение и изучение универсальных закономерностей профессионализаций, общих для всех профессий или для их конкретных типов (человек - человек, человек - техника и т.д.).

2. В этих периодизациях практически не учитываются реальные связи жизненного и профессионального пути. Абстрагируясь от этих связей, мы должны будем признать, что профессиональная адаптация юноши будет происходить так же, как профессиональная адаптация человека, находящегося на стадии взрослости. По этим же причинам не будет отличаться профессиональная адаптация человека, который осваивает первую в жизни профессию, или уже вторую, или третью и т. д. профессию. Но эти выводы не соответствуют реальности, так как жизненный и профессиональный опыт субъекта труда влияет на содержание и динамику профессионализации.

3. В рамках профессионалогенетических периодизаций не охватывается весь цикл профессионального становления и реализации личности. Эти периодизации обычно начинаются с описания профессиональной адаптации, т. е. охватывают только этап самостоятельной профессиональной деятельности. Таким образом, за рамками анализа остается поиск и выбор профессии (процесс первичной и вторичной оптации вообще не включается в эти периодизации), профессиональное обучение, формирование профессиональной готовности и т.д. Все указанные моменты существенно сужают концеп- 
туальные возможности профессионалогенетических периодизаций в плане описания и изучения профессионализации как целостного и непрерывного процесса, начинающегося с первичной оптации.

Возникает вопрос, а нужно ли вообе противопоставлять данные периодизации? Может быть, здесь существует другой принцип их взаимодействия?

Чтобы ответить на данный вопрос, обратимся к более глубокому анализу выделенных концепций. А он свидетельствует, что они скорее дополняют друг друга, чем противоречат. Говоря иначе, они не конкурируют между собой, а в совокупности отражают, описывают разные уровни, разные аспекты, разные стороны иелостного процесса профессионального становления и реализации личности.

Какие же уровни профессионализации описывают онтологические и профессионалогенетические периодизации?

Нами было выделено 2 базовых уровня анализа профессионального становления личности, которые тесно взаимодействуют между собой, но при этом обладают своей спецификой.

Первый уровень анализа был назван трудовым путем, а второй - профессиональным путем.

Характеристика трудового пути личности. На данном уровне психологического анализа процесс становления и реализации профессионала рассматривается как часть жизненного пути человека и исследуется его влияние на трудовой путь человека.

Трудовой путь начинается с осознания необходимости трудиться, с принятия труда как ведущей формы развития и реализации человека. Такое принятие трудовой деятельности фиксируется человеком в известных установках типа «чтобы нормально жить человек должен трудиться» или «все работают, и я должен работать» и т.д.

Заканчивается трудовой путь человека тогда, когда он сознательно отказывается от труда как одного из способов жизнеосуществления. Основные причины его нормативного завершения связаны со снижением или полной утратой трудоспособности человека как субъекта труда, с формированием негативного отношения к трудовой деятельности и т. д.

Для описания трудового пути используются такие понятия, как трудоспособность, трудолюбие, отношение к труду, работо- 
способность, трудовой опыт, готовность к труду, общетрудовые знания, умения и навыки и т. д. Тем самым подчеркивается надпрофессиональная или метапрофессиональная сущность трудового пути. В качестве единиц измерения длительности трудового пути используется хронологический возраст человека. Он, как известно, тесно связан (на уровне значимости 0,9 и выше) с общетрудовым стажем, который рассматривается в качестве одного из видов профессионального возраста.

Характеристика профессионального пути. На данном уровне анализа изучаются закономерности становления и реализации профессионала в рамках конкретной профессии, специальности, организации, рабочего места или должности.

Профессиональный путь начинается с выбора профессии на определенном этапе трудового пути. Он может быть частью трудового пути, если человек несколько раз менял свою профессию, а может совпадать с трудовым путем, если человек не менял профессию и место работы в течение всей трудовой жизни. Заканчивается профессиональный путь либо на определенном этапе трудового пути, либо одновременно с ним. Основными причинами нормативного завершения профессионального пути является, прежде всего, изменение отношения человека к профессиональной деятельности и к себе как профессионалу, в нарастании профессиональной монотонии и появлении профессиональных деструкций.

В ходе психологического анализа профессионального пути используются такие понятия, как профессиональный опыт, профессиональные способности, профессиональная мотивация, профессионально важные качества, профессиональная одаренность, профессиональная пригодность и т. д. Тем самым подчеркивается специализированность профессионального становления, его зависимость от содержания и условий конкретной профессиональной деятельности.

Ведущим временным параметром измерения длительности профессионального пути является профессиональный возраст человека или профессиональный стаж, который, в отличии от общетрудового стажа, не всегда коррелирует с хронологическим возрастом. 
Проведенный анализ свидетельствуют, что в рамках трудового пути профессионал решает задачи, связанные с развитием субъекта труда, а в рамках профессионального пути - более специализированные задачи, связанные с формированием субъекта конкретной профессиональной деятельности.

Назовем базовые основания, по которым мы дифференцируем трудовой и профессиональный путь.

1. Длительность осуществления профессионализации.

2. Время старта и финиша профессионального становления.

3. Причины начала и завершения профессионализации.

4. Временные единицы измерения, в качестве которых может выступать хронологический или профессиональный возраст.

5. Специфика этапов, их состав и количество.

6. Содержание используемого понятийного аппарата.

7. Место и роль каждого уровня в структуре профессионального становления.

8. Взаимосвязь с конкретными профессиями.

Проведенный анализ убеждает нас в том, что для каждого уровня профессионализации должна использоваться своя периодизация. Онтогенетические периодизации используются для анализа трудового пути, а для изучения профессионального пути применяются профессионалогенетические периодизации.

Приведем в качестве примера варианты периодизаций трудового и профессионального пути.

Периодизация трудового пути Д. Сьюпера [10], формальным основанием для создания которой является хронологический возраст человека:

1. Стадия пробуждения интереса к профессионализации (от рождения до 14 лет).

2. Стадия исследования (15-24 года), когда индивид пытается опробовать себя в различных ролях при ориентации на свои реальные профессиональные возможности.

3. Стадия консолидации (25-44 года) характеризуется стремлением обеспечить в найденном профессиональном поле устойчивую личную позицию. 
4. Стадия сохранения (45-64 года), в рамках которой профессиональное развитие индивида идет в одном определенном направлении, без выходов за рамки найденного поля.

5. Стадия спада (с 65 лет), когда происходит развитие новых ролей: частичное участие в профессиональной жизни, наблюдение за профессиональной деятельностью других людей.

Обобщенная периодизация профессионального пути:

1. Стадия профессиональной оптации; решаемые задачи: поиск и выбор профессии, формы профессионального образования.

2. Стадия профессиональной подготовки; решаемые задачи: формирование готовности к самостоятельной профессиональной деятельности.

3. Стадия самореализации и самоутверждения в рамках самостоятельной профессиональной деятельности; решаемые задачи: достижение оптимального для работника пика профессиональной продуктивности.

4. Стадия профессиональной стагнации; решаемые задачи: поддержка высокой продуктивности на фоне нарастающей неудовлетворенности, снижения интереса к профессии, проявления профессиональных деструкций.

5. Стадия выбора направления дальнейшей профессионализации; решаемые задачи: смена направления в рамках профессии, принятие маргинальной формы существования в профессии, отказ от профессии, места работы, занимаемой должности и т. д.

В представленной периодизации профессионального пути не указан профессиональный возраст человека. Это сделано не случайно. Дело в том, что мы пока не располагаем достаточной информацией о временных параметрах профессионального пути человека, поскольку профессиональный путь в отличие о трудового поливариативен и полицикличен. Поэтому можно говорить о различных видах и различных циклах профессионального пути, которые обозначены в литературе, но практически не исследованы.

Соответственно, выделяется и большое разнообразие различных периодизаций профессионального пути, которые описывают профессиональное развитие человека в рамках организации и вне 
ее рамок, в рамках одной организации или нескольких, в рамках одной профессии или нескольких профессий и т.д.

Таким образом, представленная нами периодизация является инвариантом для различных видов периодизаций профессионального пути, которые нуждаются в разработке в том числе и с учетом профессионального возраста человека.

Обозначим некоторые гипотетические виды периодизаций профессионального пути:

1. Периодизация профессионального пути в рамках одной профессии и в одной организации.

2. Периодизация профессионального пути в рамках одной профессии и в разных организациях.

3. Периодизация профессионального пути в рамках разных профессий и в одной организации.

4. Периодизация профессионального пути в рамках разных профессий и в разных организациях.

5. Периодизация профессионального пути в рамках одной должности.

6. Периодизация профессионального пути вне рамок организации (фрилансеры).

Итак, сравнивая выделенные периодизации, мы видим, что они отличаются друг от друга, поскольку отражают разные уровни профессионализации личности. Вместе с тем эти периодизации определенным образом пересекаются между собой, взаимодополняют друг друга и каждая из них вносит свой вклад в целостное понимание процесса профессионализации личности.

Поэтому в ходе теоретических и практических исследований необходимо использовать обе периодизации одновременно. Точнее говоря, периодизация должна быть одна, но включать два уровня ее описания: онтогенетический и профессионалогенетический. Только при таком подходе мы сможем и адекватно представить базовые закономерности профессионализации личности, и прогнозировать уровень профессионального развития конкретного человека. 


\section{Выводы}

Проведенный анализ позволяет нам обозначить следующие положения, важные для разработки адекватной периодизации профессионального становления:

1. В психологии сформировались два ведущих подхода к разработке периодизаций профессионального становления личности: онтогенетический и профессионалогенетический. В рамках первого подхода формальным основанием для выделения стадий профессионализации является хронологический возраст профессионала, а для второго - его профессиональный (карьерный) возраст. Каждая из периодизаций в отдельности не отражает полностью всего многообразия закономерностей развития и реализации профессионала.

2. Принимая во внимание сказанное, периодизация профессионального становления личности не может быть линейной и плоской. Она должна быть структурно-уровневой и циклической, т. е. отражать уровневый характер профессионализации как процесса, учитывать специфику каждого ее уровня и систему существующих взаимосвязей между ними. В противном случае содержание периодизации может вступать в противоречие с реальными закономерностями профессионализации, что создает не только теоретические сложности, но и трудности практического плана, в том числе при прогнозировании и диагностике актуального уровня развития профессионала.

3. В структурно-уровневой периодизации должны быть объединены и синтезированы как минимум 2 типа субпериодизаций в соответствие с двумя базовыми уровнями анализа профессионализации: трудовым путем и профессиональным путем. Причем эти субпериодизации могут отличаться и по формальным, и по содержательным показателям, включая основания для выделения стадий, периодов и фаз. В целом они призваны отразить целостный и единый процесс профессионального и карьерного развития личности, но разные его аспекты.

4. Между двумя типами субпериодизаций должны быть установлены взаимосвязи, которые соответствуют реальным взаимоотношениям между двумя уровнями профессионального становления и реализации личности. Они должны выстраиваться как по иерар- 
хическим, так и по гетерархическим основаниям, а также учитывать все многообразие других типов взаимоотношений, которые могут существовать между разными уровнями профессионализации. В общем случае субпериодизация профессионального пути является частью субпериодизации трудового пути. Но они могут в определенной степени и совпадать, когда профессионализация осуществляется по принципу «одна жизнь - одна профессия».

1. Поваренков Ю. П. Периодизация профессионального становления личности // Вестн. КИГИТ. 2013. № 11 (41). С. 46-56.

2. Поваренков Ю. П. Периодизация профессионального становления личности: полициклический подход (часть 1) // Вестн. ЯрГУ им. П. Г. Демидова. Сер. : Гуманитар. науки. 2015. № 4 (34). С. 89-93

3. Поваренков Ю. П. Периодизация профессионального становления личности: анализ отечественных и зарубежных подходов // Актуальные проблемы психологии личности : сб. науч. ст. / науч. ред. К. В. Карпинский, В. А. Мазилов. Гродно : ГрГУ, 2016. С. 145-161.

4. Поваренков Ю. П. Структурно-уровневый подход к периодизации профессионального становления личности // Современное состояние и перспективы развития психологии труда и организационной психологии / отв. ред. А. Н. Занковский, Г. Л. Дикая, А. Л. Журавлев. М. : Ин-т психологии РАН, 2018. С. 26-41.

5. Завалишина Д. Н. Практическое мышление: специфика и проблемы развития. М. : Ин-т психологии РАН, 2005. 376 с.

6. Климов Е. А. Психология профессионального самоопределения. Ростов н/Д : Феникс, 1996. 509 с.

7. Зеер Э. Ф. Психология профессий. М. : Акад. проект : фонд «Мир», 2005. $336 \mathrm{c}$.

8. Маркова А. К. Психология профессионализма. М. : Знание, 1999. $184 \mathrm{c}$.

9. Советский энциклопедический словарь / гл. ред. А. М. Прохоров. М. : Сов. энциклопедия, 1986. 1600 с.

10. Super D. E. The psychology of career. N. Y. : Harper \& Brothers, 1957. $400 \mathrm{p}$. 


\title{
ОСОБЕННОСТИ САМОРАЗВИТИЯ ПЕДАГОГОВ И ПСИХОЛОГОВ С ПРОФЕССИОНАЛЬНЫМИ ДЕФОРМАЦИЯМИ
}

\author{
О.Б. Полякова
}

При обсуждении условий, способствующих успешной социализации, всегда поднимается вопрос саморазвития как осознанной самостоятельной работы над собой как личностью с использованием акмеологического потенциала, т. е. физических, физиологических, психических и психологических ресурсов организма для достижения конкретных жизненных целей, формирования установок на деятельность, убеждений и мировоззренческих позиций [1].

Акцент делается на таких составляющих личности, как:

- поведенческая (восстановление и приумножение ресурсов, действия в отношении себя, других и окружающего мира, доброжелательность, самопознание, саморазвитие, самореализация, творческая деятельность, уважение);

- познавательная (восприятие окружающих на равных и понимание постоянной изменчивости мира, ответственность, оценивание собственной активности, представления о себе, других и окружающем мире, реализация своих возможностей);

- эмоциональная (доверие своим ощущениям, интерес к окружающему миру и окружающим людям, концентрация на положительных сторонах мира при его восприятии, принятие себя и других, способность принимать решения, эмоциональный отклик на происходящие события).

При рассмотрении профессионального пути чаще всего акцент делается на таком компоненте личностного и профессионального роста, как профессиональное саморазвитие, под которым понимается кропотливая работа над собой как специалистом, а в дальнейшем профессионалом, при наличии не только профессиональных знаний, умений и навыков, личностных и профессиональных качеств, но и акмеологических инвариантов, дающих возможность совершенствовать себя как профессионала и свою профессиональную деятельность [2]. К ним относятся: автономность, адекватность восприятия окружающего мира, демократичность, естественность 
и простота, интерес окружающих, концентрация на проблемах, креативность, насыщенность и полнота переживаний, независимость, новизна восприятия, потребность в творческом одиночестве, приятие себя и других, прочные межличностные отношения, разведение средств и целей, чувство юмора.

Для решения задач профессионального саморазвития специалист должен быть готов к эффективному профессиональному саморазвитию, понимать необходимость культивирования профессионально важных качеств, обладать способностью к самодетерминации с целью совершенствования профессиональных знаний, умений и навыков, к самодисциплине, самомотивации карьерного роста и повышения квалификации и др. [3].

Всего этого возможно достичь с помощью работы над собой по следующим направлениям:

1) самоконтроль профессиональной компетентности (как систематической процедуры с помощью самонаблюдения и психодиагностического инструментария) через оценку таких показателей, как использование новаций и технологий, расширение функциональных обязанностей, через оценку собственных профессионально важных качеств, прослеживание динамики положительных качеств и черт, анализ внешних и внутренних факторов, препятствующих профессиональному самосовершенствованию;

2) инвентаризация профессиональных условий и перемен в себе как спеииалисте через анализ, систематизацию и учет изменений производственных задач, содержания работы, требований к работнику, через анализ, систематизацию и учет изменений в собственной личности и составляющих профессиональной компетентности, сравнительную оценку внешних и внутренних профессиональных изменений с целью поддержания высокого уровня профессионального самосовершенствования;

3) повышение готовности и способности учиться у других через добывание новой профессиональной информации, осуществление саморазвития, принимая опыт других, получение необходимых производственных знаний и опыта, управление собственной мотивационно-потребностной сферой, участие в специально организо- 
ванных формах воспитания, обучения и развития, формирование установок на поиск и освоение новаций и технологий;

4) четкое формулирование жизненных и профессиональных иеелей через готовность при необходимости осуществить коррекцию жизненных и профессиональных мотивов, дифференцирование целей относительно сфер жизнедеятельности и социальных ролей, осознание реальных мотивационных компонентов;

5) фиксация успехов и неудач через анализ причин и факторов разных производственных результатов, избегание ситуаций применения случайных, повторных и ошибочных трудовых приемов, критическое осмысление собственного опыта, формулирование не только теоретических, но и практических выводов;

6) моделирование профессионального портрета через описание своих положительных и отрицательных черт, анализ демонстрации качеств и черт в различных жизненных и производственных ситуациях, датирование успешных и неудачных периодов в профессиональной деятельности, готовность к психологической коррекции собственных индивидуально-психологических особенностей, самоконтроль своих форм поведения и действий;

7) развитие управленческой мотивации через стремление к целям и перспективам, принятие ответственности, понимание важности кризисов в развитии людей и организаций, расширение мотивации и представленности ее в различных сферах жизнедеятельности; рефлексии через осуществление сложной интеллектуальной деятельности, оценку своего поведения, принятие решений, самопознание и саморегуляцию собственного Я-образа и профессиональной деятельности.

Эффективному профессиональному саморазвитию могут способствовать определенные условия профессиональной деятельности, а именно: благоприятный социально-психологический климат в трудовом коллективе, возможность расширения своих функциональных обязанностей, грамотно организованный производственный процесс, систематическое включение в решение производственных проблем, стремление всех коллег к личностному и профессиональному росту и др. [4]. 
От специалистов требуется планирование и организация непрерывного самосовершенствования посредством пошаговой работы:

- создание идеального образа Я (поиск собственного представления о себе как специалисте; составление психологического портрета, включающего желаемые и необходимые для эффективной профессиональной деятельности качества; формирование нового образа специалиста; определение перспективных профессиональных целей саморазвития; начертание вектора личностного роста);

- определение реального Я (составление перечня показателей реального самопроявления и восприятия окружающими с последующим сравнительным анализом реального и идеального для вычленения достоинств и недостатков; формирование адекватной профессиональной самооценки; нивелирование защитных механизмов с целью предупреждения возникновения диссонанса и искаженного образа Я);

- разработка траектории самосовериенствования (нахождение ситуаций применения сильных характеристик и нивелирование слабых сторон; исключение ложных (квази) задач профессионального развития; предупреждение развития стресс-состояний профессионального характера; повышение производственных показателей и удовлетворенности профессиональной деятельностью; нахождение времени и сил для самосовершенствования);

- апробация приемов и способов деятельности (применение новых приемов деятельности, совершенствование профессиональных качеств, умений и навыков; формирование индивидуального стиля деятельности; максимальное использование производственных условий для проигрывания новых сценариев выполнения деятельности; создание атмосферы психологической защищенности; готовность в работе над ошибками);

- сочиальное саморазвитие (тренировка способов поддержания эффективных производственных контактов; выполнение совместной профессиональной деятельности; раскрытие потенциала лидера; практика применения приемов профессиональной поддержки с целью саморазвития; выполнение творческой деятельности; анализ социальной оценки собственных поступков; рассмотрение 
социальных отношения как экспертов и помощников профессионального обучения и развития).

Однако профессиональная деятельность может и отрииательно влиять на личность специалиста [5], его производственную результативность [6], поведение и общение [7, 8], другие сферы жизнедеятельности [9], физическое, физиологическое, психическое и психологическое здоровье [10].

В этом случае можно говорить о наличии профессиональных дебормаций и их составляющих: эмоциональном, психоэмоциональном и физическом истощении, деперсонализации, личностном отдалении, редукции личных достижений и профессиональной мотивации, что часто вызвано монотонной и однообразной деятельностью, нахождением в долговременном стрессе профессионального и личного характера, отсутствием благодарности, материального и морального поощрения и признания, отсутствием времени на общение и отдых, слабой поддержкой близких и чрезмерными производственными нагрузками и, в свою очередь, тормозит и препятствует саморазвитию вообще и профессиональному саморазвитию в частности.

В ходе исследования, проведенного на выборке, состоявшей из 636 педагогов и психологов (318 педагогов и 318 психологов), необходимо было:

1) ответить на следующие вопросы: «Влияют ли стрессогенные производственные условия на возникновение профессиональных деформаций педагогов и психологов?», «Выступают ли профессиональные деформации внутренним фактором, влияющим на саморазвитие педагогов и психологов?», «Каковы особенности саморазвития педагогов и психологов с профессиональными деформациями?»;

2) выявить особенности саморазвития педагогов и психологов с профессиональными деформациями с целью последующей психологической профилактики и психологической коррекции их профессиональных деформаций и траекторий саморазвития.

Для определения уровней составляющих профессиональных деформаций у педагогов и психологов был выбран блок методик:

- опросник на выявление выгорания (ОНВВ) (Maslach Burnout Inventory), разработанный C. Maslach \& S. Jackson, адаптированный 
Н.Е. Водопьяновой, модифицированный О. Б. Поляковой, с целью определения уровней выраженности деперсонализации (Д),

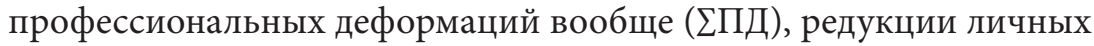
достижений (РЛД), эмоционального истощения (ЭИ);

- модификация опросника на выявление выгорания (ОНВВ мод) (Maslach Burnout Inventory), разработанного C. Maslach \& S. Jackson, адаптированного преподавателями Санкт-Петербургского государственного университета, модифицированного О.Б. Поляковой, с целью определения уровней выраженности деперсонализации (Д),

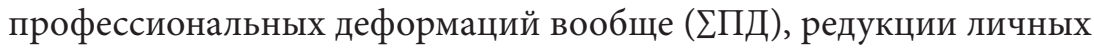
достижений (РЛД), эмоционального истощения (ЭИ);

- опросник определения психического выгорания (ООПВ), разработанный В.А. Farber, адаптированный А. А. Рукавишниковым, модифицированный О.Б. Поляковой, с целью определения уровней выраженности личностного отдаления (ЛО), профессиональных деформаций вообще (ДПД), психоэмоционального истощения (ПЭИ), редукции профессиональной мотивации (РПМ) (табл. 1).

Для диагностики компонентов саморазвития педагогов и психологов был определен блок методик:

- опросник готовности к саморазвитию (ОГСР), разработанный Т. А. Ратановой, Л. И. Золотаревой, Н. Ф. Шляхтой, модифицированный О. Б. Поляковой, с целью определения уровней выраженности готовности к саморазвитию (ГСР);

- опросник диагностики реализации потребностей в саморазвитии (ОДРПСР), разработанный Н. П. Фетискиным, В. В. Козловым и Г. М. Мануйловым, модифицированный О. Б. Поляковой, с целью определения уровней выраженности реализации потребностей в саморазвитии (РПСР);

- опросник диагностики уровня саморазвития в профессиональной деятельности (ОДУСРПД), разработанный Л. Н. Бережновой, модифицированный О. Б. Поляковой, с целью определения уровней выраженности оценки проекта профессиональной поддержки как возможности профессиональной реализации (ОПППКВПР), самооценки личностных качеств, способствующих саморазвитию (СОЛКССР), стремления к саморазвитию (ССР); 
Таблица 1

Шкалы уровней составляющих профессиональных деформаций педагогов и психологов

\begin{tabular}{|c|c|c|c|c|c|c|}
\hline \multirow[b]{2}{*}{ Методика } & \multirow{2}{*}{$\begin{array}{l}\text { Состав- } \\
\text { ляющие }\end{array}$} & \multicolumn{5}{|c|}{$\begin{array}{c}\text { Уровни выраженности составляющих профессио- } \\
\text { нальных деформаций }\end{array}$} \\
\hline & & $\begin{array}{l}\text { низ- } \\
\text { кий } \\
(\mathrm{H})\end{array}$ & $\begin{array}{c}\text { ниже } \\
\text { среднего } \\
\text { (НС) }\end{array}$ & $\begin{array}{c}\text { средний } \\
\text { (С) }\end{array}$ & $\begin{array}{c}\text { выше } \\
\text { среднего } \\
\text { (ВС) }\end{array}$ & $\begin{array}{c}\text { высокий } \\
\text { (В) }\end{array}$ \\
\hline \multirow{4}{*}{$\begin{array}{l}\text { ОНВВ, } \\
\text { ОНВВ мод }\end{array}$} & ЭИ & $0-11$ & $12-22$ & $23-31$ & $32-42$ & $43-54$ \\
\hline & Д & $0-6$ & $7-12$ & $13-17$ & $18-23$ & $24-30$ \\
\hline & РЛД & $0-10$ & $11-19$ & $20-28$ & $29-37$ & $38-48$ \\
\hline & इПД & $0-27$ & $28-53$ & $54-78$ & 79-104 & $105-132$ \\
\hline \multirow[t]{4}{*}{ ООПВ } & ПЭИ & $0-9$ & $10-20$ & $21-39$ & $40-49$ & $50-75$ \\
\hline & лО & $0-9$ & $10-16$ & $17-31$ & $32-40$ & $41-72$ \\
\hline & РПМ & $0-7$ & $8-12$ & $13-24$ & $25-31$ & $32-69$ \\
\hline & इПД & $0-31$ & $32-51$ & $52-92$ & $93-112$ & $113-216$ \\
\hline
\end{tabular}

- опросник определения уровня саморазвития (ООУСР), разработанный И.В. Никишиной, модифицированный О.Б. Поляковой, с целью определения уровней выраженности саморазвития (СР);

- опросник оценки способностей к саморазвитию и самообразованию (ООССРСО), разработанный В. И. Андреевым, модифицированный О.Б. Поляковой, с целью определения уровней выраженности способности к саморазвитию и самообразованию (ССРСО);

- опросник парииальной готовности к профессиональному саморазвитию (ОПГПСР), разработанный Н.П. Фетискиным, В. В. Козловым и Г. М. Мануйловым, модифицированный О. Б. Поляковой, с целью определения уровней выраженности гностического компонента (ГК), готовности к профессиональному саморазвитию ( $Г$ ГПСР), когнитивного компонента (КогК), коммуникативного компонента (КомК), мотивационного компонента (МК), нравственноволевого компонента (НВК), организационного компонента (OK), способности к самоуправлению в профессиональной деятельности (ССУПД) (табл. 2).

Анализ результатов исследования профессиональных деформаций педагогов и психологов позволил выявить уровни их состав- 
ляющих (средние значения по шкалам применявшихся методик по выборке в целом представлены в табл. 3):

1) высокий уровень эмоционального истощения (среднее значение по выборке 42.78, у педагогов - 43.98, у психологов - 41.58). Для специалистов характерны: апатия; безразличие; восприятие проблем как нерешаемых; выраженная раздражительность, скрытая (мимическая) или открытая (вербальная) циничность и эмоциональная реакция даже на слабые негативные факторы; желание исключить эмоциональные проявления; навязчивое прокручивание негативных мыслей; нескрываемое беспокойство; отдельные симптомы депрессии, паники и тревоги; ощущение безысходности, беспросветности,

Таблица 2

Шкалы уровней компонентов саморазвития педагогов и психологов

\begin{tabular}{|c|c|c|c|c|c|c|}
\hline \multirow[b]{2}{*}{ Методика } & \multirow[b]{2}{*}{$\begin{array}{l}\text { Составляю- } \\
\text { щие }\end{array}$} & \multicolumn{5}{|c|}{$\begin{array}{c}\text { Уровни выраженности компонентов самораз- } \\
\text { вития }\end{array}$} \\
\hline & & $\begin{array}{l}\text { низ- } \\
\text { кий } \\
\text { (Н) }\end{array}$ & \begin{tabular}{|c|} 
ниже \\
средне- \\
го \\
(НС) \\
\end{tabular} & $\begin{array}{c}\text { сред- } \\
\text { ний } \\
(\mathrm{C})\end{array}$ & $\begin{array}{c}\text { выше } \\
\text { средне- } \\
\text { го } \\
\text { (BC) }\end{array}$ & $\begin{array}{c}\text { высо- } \\
\text { кий } \\
\text { (В) }\end{array}$ \\
\hline ОГСР & ГСР & $0-2$ & $3-5$ & $6-8$ & $9-11$ & $12-14$ \\
\hline ОДРПСР & РПСР & $15-26$ & $27-38$ & $39-51$ & $52-63$ & $64-75$ \\
\hline \multirow[t]{3}{*}{ ОДУСРПД } & $\mathrm{CCP}$ & $18-24$ & $25-32$ & $33-39$ & $40-47$ & $48-54$ \\
\hline & СОЛКССР & $6-8$ & $9-10$ & $11-13$ & $14-15$ & $16-18$ \\
\hline & ОПППКВПР & $5-6$ & $7-8$ & $9-11$ & $12-13$ & $14-15$ \\
\hline ООУСР & $\mathrm{CP}$ & $15-26$ & $27-38$ & $39-51$ & $52-63$ & $64-75$ \\
\hline ООССРСО & ССРCO & $18-24$ & $25-32$ & $33-39$ & $40-47$ & $48-54$ \\
\hline \multirow[t]{8}{*}{ ОПГПСР } & MK & $9-23$ & $24-37$ & $38-52$ & $53-66$ & $67-81$ \\
\hline & КогК & $6-15$ & $16-25$ & $26-34$ & $35-44$ & $45-54$ \\
\hline & НВК & $9-23$ & $24-37$ & $38-52$ & $53-66$ & $67-81$ \\
\hline & ГК & $17-43$ & $44-71$ & $72-98$ & $99-126$ & $127-153$ \\
\hline & OK & $7-17$ & $18-29$ & $30-40$ & $41-52$ & $53-63$ \\
\hline & ССУПД & $5-12$ & $13-20$ & $21-29$ & $30-37$ & $38-45$ \\
\hline & КомК & $5-12$ & $13-20$ & $21-29$ & $30-37$ & $38-45$ \\
\hline & इГПСР & $58-150$ & $151-243$ & $244-336$ & $337-429$ & $430-522$ \\
\hline
\end{tabular}


ловушки, ненужности, одиночества, тупика; равнодушие; слабое значение, окраска и сила эмоциональных переживаний; уныние; эмоциональная отстраненность, скупость, усталость; эмоциональное бесчувствие. Данные проявления истощения эмоционального плана детерминированы индивидуально-психологическими характеристиками самих специалистов: амбициозностью, гиперответственностью, желанием достижения первенства, заниженной самооценкой, наличием усталости, неспособностью делегирования обязанностей, неудовлетворенностью, обязательностью, ощущением нехватки времени, сил и энергии, опустошенностью личностного и эмоционального характера, переживанием переутомления, пониженным эмоциональным фоном, равнодушием к отдельным производственным функциям и к коллегам, клиентам, пациентам, разочарованием, склонностью к депрессивным проявлениям, стремлением к успеху, тревожностью, унынием;

2) выше среднего уровень деперсонализации (среднее значение по выборке 22.1, у педагогов - 22.21, у психологов - 21.99); личностного отдаления (среднее значение по выборке 32.19, у педагогов - 32.56, у психологов - 31.82). Респондентам свойственны: безразличие или негативизм в отношениях с коллегами, клиентами, пациентами; дистанцирование (устранение) от решения производственных вопросов; желание свернуть свои производственные обязанности; недовольство собой как специалистом, своими результатами; нежелание выполнять профессиональные обязанности; обезличивание межличностных контактов; озлобленность; отказ от личного общения; повышенная зависимость от коллег, клиентов, пациентов; повышенная конфликтность; погруженность в профессиональную деятельность с головой; понижение интеллектуальных способностей; пониженный коэффициент полезного действия; потеря интереса взаимодействия и общения с коллегами, клиентами, пациентами; потеря смысловых ориентиров профессионального характера; пренебрежение своими собственными потребностями и ценностью человеческого фактора в производственных условиях; рассеянность; стремление сократить время на выполнение работы; холодность; циничность; черствость; 
3) выше среднего уровень профессиональных деформаций (среднее значение по выборке 93.46 и 96.55 , у педагогов - 94.31 и 98.28 , у психологов - 92.62 и 94.82); психоэмоционального истощения (среднее значение по выборке 39.65, у педагогов - 40.38, у психологов - 38.92). Как у педагогов, так и у психологов выявлены: безразличное, черствое отношение к окружающим; заниженная оценка профессиональных результатов; негативное отношение к большинству производственных функций; обесценивание собственных производственных достижений; ощущение психологического и психического дискомфорта при общении; перекладывание профессиональной ответственности на коллег, клиентов, пациентов; пониженная самооценка; психосоматическая симптоматика; снижение профессионального мотивационного компонента; снятие с себя производственной ответственности; учащение приема алкоголя, никотина, кофеина;

4) выме среднего уровень редукции личных достижений (среднее значение по выборке 28.58, у педагогов - 28.12, у психологов 29.05); редукиии профессиональной мотивации (среднее значение по выборке 24.71, у педагогов - 25.34, у психологов - 24.08). Респондентам присущи бессилие; восприятие привычной работы как скучной; вытеснение негативных условий работы; доминирование мотивации на избегание неудач; желание отдохнуть, расслабиться; заниженная профессиональная самооценка; игнорирование производственных трудностей; негативность самовосприятия; некомпетентность по многим показателям; неуверенность; неудовлетворенность производственными результатами; обесценивание производственных успехов; отказ от большинства коллективных форм работы и решения производственных задач; отсутствие инициативы и творческого начала; падение профессионального интереса; повышенная социальная конфликтность; подавленность; пониженная работоспособность; пониженный энтузиазм; потеря надежды на личностный и профессиональный рост; профессиональный вакуум; стремление сэкономить свои силы и устраниться от обязанностей; угасание профессиональных навыков; утрата смысла производственных заданий и эмпатических проявлений; 
ухудшение эффективности профессиональной деятельности; хроническая усталость.

Анализ результатов исследования компонентов саморазвития педагогов и психологов позволил выявить уровни их сформированности (средние значения по шкалам применявшихся методик по выборке в целом представлены в табл. 3):

1) низкий уровень мотивационного компонента (среднее значение по выборке 23.18, у педагогов - 22.98, у психологов - 23.37); способности к саморазвитию и самообразованию (среднее значение по выборке 24.3, у педагогов - 24.16, у психологов - 24.43). Полученные результаты позволяют утверждать, что специалисты: не анализируют собственные опыт, чувства и эмоции; не верят в свои возможности; не дискутируют на производственные темы; не желают знать и изучать себя; не ищут обратной связи с окружающими с целью самоузнавания и самооценивания; не находят время для чтения профессиональной литературы; не осознают влияние на них окружающих; не оставляют время для саморазвития; не получают удовольствие от освоения производственных новшеств; не рефлексируют собственную деятельность; не стимулируются возникающими препятствиями; не стремятся к внедрению профессиональных инноваций, открытому взаимодействию и общению, продвижению по службе и самосовершенствованию; не управляют собственным профессиональным развитием; не фиксируются на положительных производственных результатах; пугаются при возрастании профессиональной ответственности;

2) ниже среднего уровень гностического компонента (среднее значение по выборке 70.48, у педагогов - 70.39, у психологов - 70.56); готовности к профессиональному саморазвитию (среднее значение по выборке 235.67, у педагогов - 234.90, у психологов - 236.43); готовности к саморазвитию (среднее значение по выборке 4.36, у педагогов - 4.28, у психологов - 4.43); когнитивного компонента (среднее значение по выборке 25.18, у педагогов - 25.04, у психологов - 25.32); оценки проекта профессиональной поддержки как возможности пробессиональной реализации (среднее значение по выборке 6.5, у педагогов - 6.43, у психологов - 6.56); саморазвития (среднее значение по выборке 38.27, у педагогов - 38.19, 
у психологов - 38.35); способности к самоуправлению в профессиональной деятельности (среднее значение по выборке 20.37, у педагогов - 20.29, у психологов - 20.44); стремления к саморазвитию (среднее значение по выборке 29.87, у педагогов - 29.55, у психологов - 30.18). Специалисты не воспринимают профессиональную поддержку как необходимую составляющую профессионального развития; не выделяют время для саморазвития; не наблюдают у себя выраженного профессионального интереса; не надеются на свои силы и опыт в достижении вершин личностного и профессионального роста; не находят время для отдыха, занятий любимым делом, общения с близкими, друзьями и чтения; не обладают достаточным опытом самовоспитания; не одобряют возможность профессионального становления и перспективы самореализации при профессиональной поддержке; не отмечают у себя среди профессионально важных качеств генерирование идей, дисциплинированность, любознательность, настойчивость, обязательность, организованность, решительность, самокритичность, сообразительность, требовательность, трудолюбие, упорство, целеустремленность; не понимают важности необходимости отстаивания своей профессиональной позиции, ответственности и эрудированности при выполнении производственных заданий; не проявляют силу воли и упорство для профессионального роста; не проявляют творческий подход; не рефлексируют специфику профессионального самосовершенствования; не ставят перед собой задач анализа трудностей саморазвития; не читают специальную литературу;

3) средний уровень коммуникативного компонента (среднее значение по выборке 28.01, у педагогов - 28.00, у психологов - 28.02); нравственно-волевого компонента (среднее значение по выборке 38.13 , у педагогов - 38.21, у психологов - 38.04); организационного компонента (среднее значение по выборке 30.34, у педагогов - 29.99, у психологов - 30.68); реализаиии потребностей в саморазвитии (среднее значение по выборке 38.92, у педагогов - 38.79, у психологов - 39.05); самооценки тичностных качеств, способствующих саморазвитию (среднее значение по выборке 12.46, у педагогов 12.24 , у психологов - (12.67). Полученные результаты указывают на то, что специалисты не всегда высоко оценивают у себя уровень 
методических, общепрофессиональных и специальных профессиональных знаний, умений и навыков; демонстрируют доведение дел до конца, критичность, ответственность, положительное отношение к профессиональным обязанностям, самокритичность, самостоятельность, силу воли, смелость, трудоспособность, целеустремленность; используют ситуации и условия для самопознания; испытывают потребность в самообразовании; могут самостоятельно без помощи коллег выполнять производственные задания, демонстрировать прилежание и трудолюбие, осуществлять самоанализ, самоконтроль, самоорганизацию и мобилизацию, рефлексировать. Педагоги и психологи только ситуативно: отмечают у себя креативность, наблюдательность, независимость суждений, оперативность мышления, психологическую гибкость, способность к глубокому анализу профессиональных проблем, обобщению и синтезу, переносу навыка, умение видеть противоречия, решать производственные задачи, слушать и слышать; осознают значимость непрерывного профессионального образования; поддерживают свой профессиональный интерес; применяют способность взаимопомощи и сотрудничества, избегания конфликтных ситуаций, использования опыта самообразования коллег, организации саморазвития других, отстаивания собственной точки зрения; способны перестраивать деятельность, пользоваться оргтехникой, работать с источниками информации, четко планировать время и работу; стремятся получить достойную оценку собственной самообразовательной деятельности; считают любознательность профессионально важным качеством для эффективного самосовершенствования; уверены в собственных профессиональных силах.

Математическая обработка данных с помощью критерия корреляции К. Пирсона и таблицы Чеддока для определения тесноты (силы) корреляционной связи (менее 0.3 - слабая; от 0.3 до $0.5-$ умеренная; от 0.5 до 0.7 - заметная; от 0.7 до 0.9 - высокая; более 0.9 - весьма высокая) дала возможность выявить взаимосвязи, представленные в табл. 3.

Полученные результаты могут быть интерпретированы следующим образом: 
1. Высокая связь между высоким уровнем эмоционального истощения и низким уровнем мотивационного компонента и способности к саморазвитию и самообразованию.

Следовательно, чем выше уровень эмоционального истощения, тем больше педагогам и психологам не достает компонентов самоменеджмента:

- профессионального самопознания (познания себя как специалиста, своей профессиональной ниши и собственной профессиональной роли; осознания межличностных производственных отношений; проработки векторов карьерного роста; навыков профессионального самопознания: воображения для изыскания производственных условий с целью реализации творческой активности, интуиции в проблемных производственных ситуациях, концентрации на профессиональном функционале, планомерного наблюдения за объектами и субъектами профессиональной деятельности, созерцания как получения информации о специфике профессиональной деятельности);

- профессиональной самоорганизации (организации собственной профессиональной деятельности; овладения методологическими и методическими приемами профессионального самосовершенствования; навыков самоанализа, самовоспитания, самодисциплины, самоконтроля, самокритичности, самообладания, самообучения, саморегуляции, самостоятельности);

- профессионального самовоспитания (формирования профессионально важных качеств; культивирования мотивации к успеху; навыков вычленения профессиональных ценностей, постановки производственных целей, применения инноваций, решения производственных задач, самообучения и саморазвития, саморуководства, самоуправления, стремления к личностному и профессиональному росту, эффективного взаимодействия в рабочих группах, эффективного влияния на себя и окружающих; умений и навыков готовности идти на риск в трудных производственных ситуациях, довольствования даже скромным прогрессом, использования любой производственной возможности для профессионального роста, определения признаков производственных успехов, получения удо- 
苂

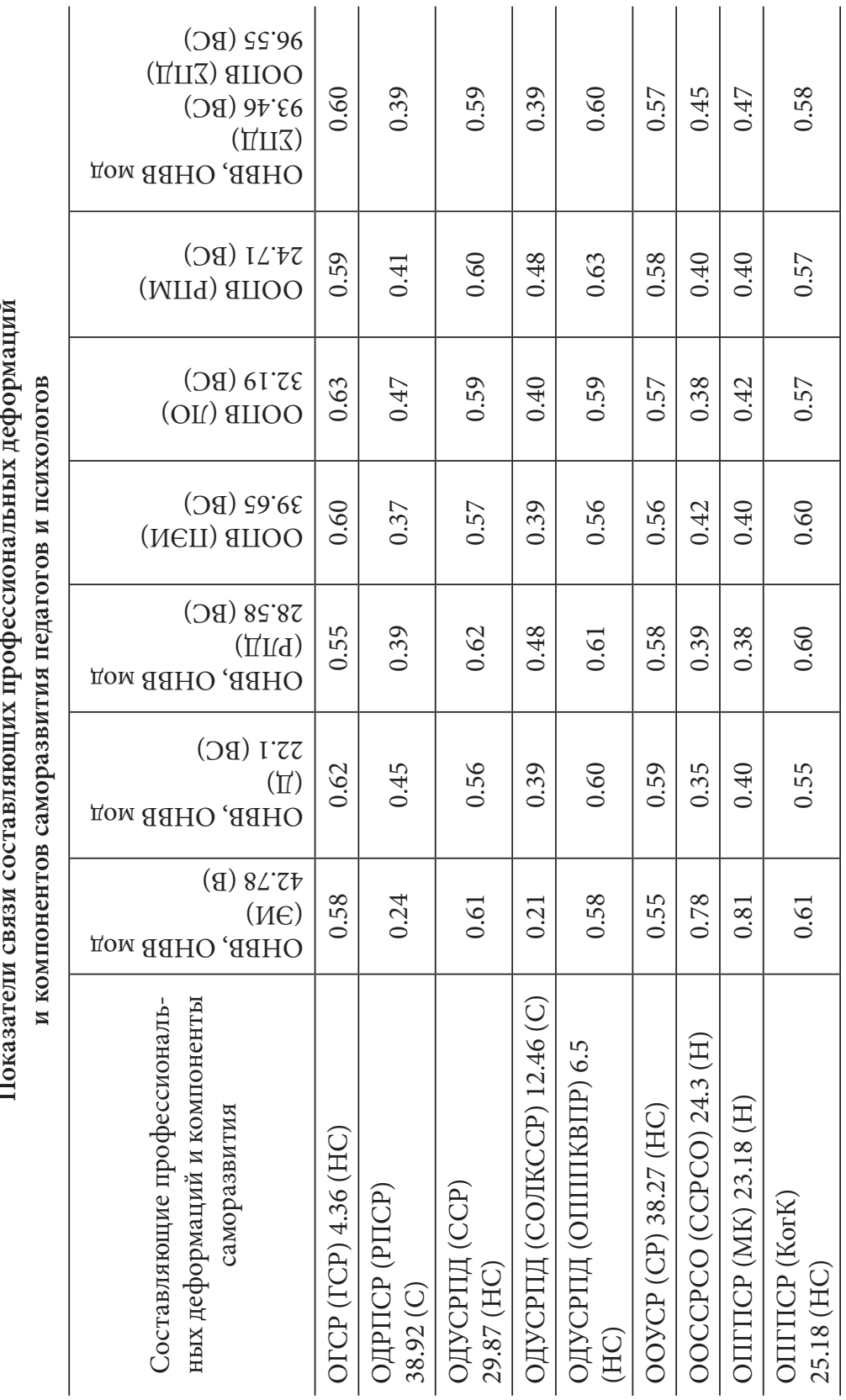




\begin{tabular}{|c|c|c|c|c|c|c|c|}
\hline 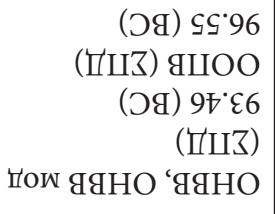 & $\begin{array}{l}\text { : } \\
: \\
:\end{array}$ & $\hat{\text { âे }}$ & 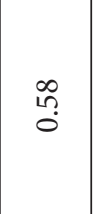 & $\begin{array}{l}\infty \\
\tilde{n} \\
0\end{array}$ & : & గ్రి & $\stackrel{\infty}{\stackrel{0}{0}}$ \\
\hline $\begin{array}{r}\text { (Jq) } L^{\prime} \dagger z \\
\text { (NШd) gUOO }\end{array}$ & ถุ. & ڤై & $\overrightarrow{\breve{0}}$ & f̣̊ & $\begin{array}{l}\infty \\
\substack{0 \\
0}\end{array}$ & $\stackrel{\text { In }}{0}$ & in \\
\hline $\begin{array}{l}\text { (Jq) } 6 \mathrm{I}^{\circ} \mathrm{z \varepsilon} \\
(\mathrm{OI}) \mathrm{g} \amalg O O\end{array}$ & $\begin{array}{l}\tilde{0} \\
0 \\
0\end{array}$ & fí & in & $\ddot{\tilde{\sigma}}$ & $\vec{b}$ & $\stackrel{\infty}{0}$ & $\stackrel{\infty}{\sharp !}$ \\
\hline 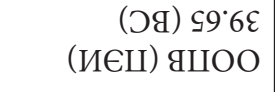 & : & 용 & $\hat{n}$ & $\overrightarrow{\tilde{\sigma}}$ & $\begin{array}{l}8 \\
0 \\
0\end{array}$ & $\stackrel{n}{0}$ & fै \\
\hline 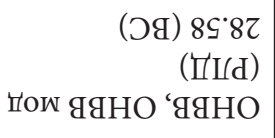 & 望 & m. & în & 苟 & $\begin{array}{l}\infty \\
\text { h? } \\
0\end{array}$ & ले & $\stackrel{\infty}{\sharp !}$ \\
\hline 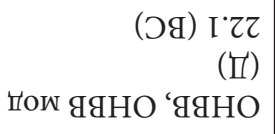 & $\begin{array}{l}\tilde{b} \\
0 \\
0\end{array}$ & Iี: & 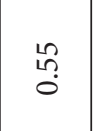 & ֻ̊? & S. & ֻٕ: & f̊ \\
\hline 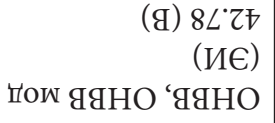 & $\begin{array}{l}\infty \\
\substack{0 \\
0}\end{array}$ & $\stackrel{9}{0}$ & $\begin{array}{l}\stackrel{\infty}{10} \\
0\end{array}$ & 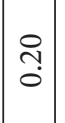 & గิ? & $\stackrel{\overbrace{}}{0}$ & $\stackrel{1}{\circ}$ \\
\hline 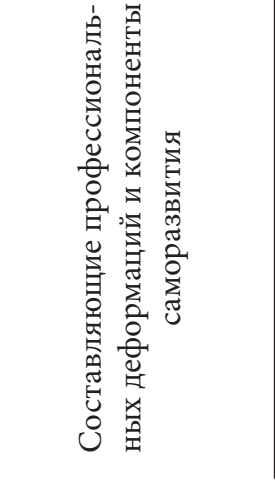 & 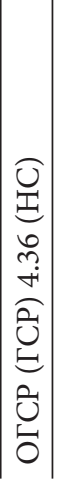 & 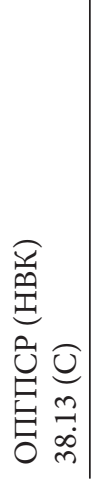 & 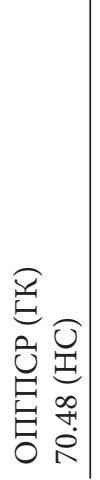 & 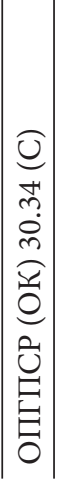 & 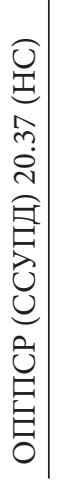 & 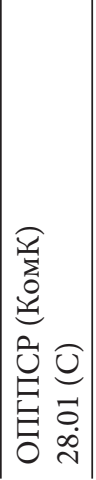 & 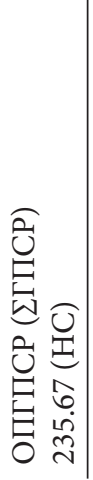 \\
\hline
\end{tabular}


вольствия от собственного развития, умения учиться на ошибках, учиться у коллег);

- профессиональной саморегуляции (самоконтроля) (поддержания внутренней профессиональной гармонии; адекватной профессиональной самооценки и готовности к коррекции собственной профессиональной деятельности; анализа проблем беспокойства; навыков преодоления беспокойства; выработки душевного спокойствия; умений предупреждения наступления усталости);

- профессиональных иелей (построения жизненного и карьерного планов; разработки представлений о профессиональных стремлениях; дифференциации профессиональных целей во времени; систематической инвентаризации профессиональных целей; анализа сочетания личных и профессиональных целей; постановки целей укрепления профессионального здоровья; постановки целей профилактики и нивелирования профессиональных деформаций; анализа целей удовлетворения культурных запросов);

- планирования профессионального времени (навыков структурирования времени, составления производственных заданий рабочего дня, недели, месяца и года, резервирования времени на анализ и работу над ошибками, принятия производственных решений с учетом профессиональных приоритетов, самоконтроля; умений документирования и перепроверки планируемого производственного времени на задания, регулярного и системного планирования времени на личностный рост; своевременного восполнения потерь рабочего времени, выделения времени на непредвиденные дела, соотнесения времени личных профессиональных планов и коллективного планирования);

- поиска профессиональной информации (удовлетворения информационных потребностей; навыков деятельности в информационном поле, применения изучающего, обобщающего и ориентирующего слушания и чтения, рационального слушания и чтения, сбора информации по темам, сортировки профессионального материала);

- технологий поддержания профессионального здоровья (сохранения и укрепления психического, психологического, физического и физиологического здоровья; анализа внешних и внутренних факторов возникновения профессиональных деформаций). 
2. Заметная связь между высоким уровнем эмоционального истощения и уровнем гностического компонента ниже среднего, готовности к профессиональному саморазвитию, готовности к саморазвитию, когнитивного компонента, оценки проекта профессиональной поддержки как возможности профессиональной реализации, саморазвития, способности к самоуправлению в профессиональной деятельности и стремления к саморазвитию.

Следовательно, высокий уровень эмоционального истощения взаимосвязан у педагогов и психологов с целым рядом ограничений в саморазвитии: не до конца определенные личные и профессиональные ценности (неясное понимание ценностей, выделение ценностей, не соответствующих ценностям саморазвития); неспособность содействовать развитию коллег в трудовом коллективе и саморазвитию; неумение обучать коллег и заниматься самообразованием (нежелание помогать коллегам в их развитии, неспособность расширять собственные профессиональные возможности); нечеткость личных и профессиональных целей (неясное понимание целей, выделение целей, не соответствующих целям саморазвития); относительно низкая самоорганизация (пониженная заинтересованность в получении высоких производственных результатов совместно с коллегами).

Специалистам свойственны относительно низкое самоуправление (неумение эффективно использовать рабочее время и справляться со стрессогенными условиями производства); пониженная готовность к влиянию на коллег (неэффективное обеспечение участия и помощи со стороны коллег, неумение влиять на решения коллег) и к проявлению творческого подхода (низкая генерация новых производственных идей, неспособность использования новых идей в практике профессиональной деятельности); симптомы стагнации саморазвития (пониженная настроенность и притупленная восприимчивость новых производственных условий и возможностей); скупость управленческих навыков (недопонимание мотивации сотрудников, неполное представление о роли руководителя); слабость навыка решения профессиональных проблем (непроработанные стратегии принятия рабочих решений, слабое умение решать совместные производственные проблемы). 
3. Заметная связь между уровнем деперсонализации (личностного отдаления), психоэмоционального истощения, профессиональных деформаций вообще, редукиии личных достижений и профессиональной мотивации выше среднего и уровнем гностического компонента, готовности к профессиональному саморазвитию, готовности к саморазвитию, когнитивного компонента, оченки проекта профессиональной поддержки как возможности профессиональной реализации, саморазвития, способности к самоуправлению в профессиональной деятельности и стремления к саморазвитию ниже среднего.

Следовательно, педагоги и психологи с такими профессиональными деформациями не всегда ориентированы на выполнение функциональных обязанностей, соответствующих их профессиональной самооценке; поддержание своего профессионального здоровья (чередование режимов труда и отдыха, профилактика профессиональных деформаций); подкрепление собственной профессиональной мотивации и получение удовлетворения от работы; приобретение профессиональной независимости, автономности; производственные задачи, усиливающие профессиональные возможности и развивающие самих субъектов труда; производственные условия, дающие возможность продолжения активного самообучения и профессионального становления; проявление творческого характера; учет монетарной направленности карьеры (получение достойной оплаты труда и удовлетворения от материальной составляющей мотивации) и производственных условий, дающих возможность сочетать личные и профессиональные интересы.

Специалистам свойственны вялость планирование профессиональных задач на определенные временные промежутки; доминирование ретроспективной рефлексии; заниженная профессиональная самокритичность; медлительность при ориентации в сложных профессиональных ситуациях; не всегда принятие своевременных решений; ненахождение компромиссов между желаниями и профессиональной реальностью; неполное знание возможностей современной техники; невнимательность к коллегам; недостаток профессиональной самодисциплины и решительности в поддержании производственных нововведений; неспособность подчинять личные интересы профессиональным и коллективным; низкая мотивация 
на самопознание и познание коллег; низкий уровень эстетики работы; отставание от передовых методов работы; отсутствие времени на любимые дела и занятия, а также на расширение профессиональных знаний и формирование новых производственных навыков.

Эффективной профессиональной деятельности и саморазвитию мешают пассивность в производственных ситуациях соревнования и аттестации; пониженная личная ответственность за результаты работы, общая эрудиция, способность прислушиваться к мнению коллег; потеря рабочего времени на выполнении монотонных видов деятельности; ситуативная коллективная работа, ориентация на неперспективные направления работы; ситуативное пренебрежение помощью коллег с целью профессионального развития; слабая направленность на личностный и карьерный рост и профессиональная инициатива; трудности обеспечения самоконтроля, требуемого уровня исполнения производственных задач и распознавания и поддержания новаторов, рационализаторов и энтузиастов.

4. Умеренная связь между уровнем деперсонализаиии (личностного отдаления), психоэмочионального истощения, профессиональных деформаций вообще, редукиии тичньх достижений и профессиональной мотивации выше среднего и средним уровнем коммуникативного компонента, нравственно-волевого компонента, организационного компонента, реализации потребностей в саморазвитии и самооценке личностных качеств, способствующих саморазвитию.

Выявленная связь указывает на то, что для педагогов и психологов с данными профессиональными деформациями характерны следующие ограничения в саморазвитии: завуалированный уровень амбиций; несистематическая оценка достигаемых результатов труда; ограниченный круг профессионального общения; отсутствие психологической гибкости профессионального поведения; слабость профессиональной интуиции; средние профессиональные компетенции; умеренный масштаб решаемых профессиональных задач.

Таким образом, у педагогов и психологов выявлены следующие особенности профессиональных деформаций и саморазвития: высокий уровень эмоционального истощения; уровень деперсонализации, личностного отдаления, профессиональных деформаций вообще, психоэмоционального истощения, редукции личных до- 
стижений, редукции профессиональной мотивации выше среднего; средний уровень коммуникативного компонента, нравственноволевого компонента, организационного компонента, реализации потребностей в саморазвитии, самооценки личностных качеств, способствующих саморазвитию; уровень гностического компонента, готовности к профессиональному саморазвитию, готовности к саморазвитию, когнитивного компонента, оценки проекта профессиональной поддержки как возможности профессиональной реализации, саморазвития, способности к самоуправлению в профессиональной деятельности, стремления к саморазвитию ниже среднего; низкий уровень мотивационного компонента, способности к саморазвитию и самообразованию.

Высокое эмоциональное истощение педагогов и психологов приводит к снижению мотивационного компонента саморазвития и способности к саморазвитию и самообразованию.

1. Зеер Э. Ф. Самоопределение человека в современных конфликтующих реальностях // Образование и наука. 2010. № 7 (75). С. 71-81.

2. Зеер Э. Ф. Личностно-развивающие технологии начального профессионального образования. М.: Академия, 2010. 176 с.

3. Зеер Э. Ф., Сыманюк Э.Э., Морозова С. А. Профессиональная мобильность - интегральное качество субъекта инновационной деятельности // Педагогическое образование в России. 2011. № 5. С. 90-97.

4. Mironova O. I., Polyakova O. B., Ushkov F. I. Psychological health of leaders with professional burnout in compelled contacts // RPTSS 2018. The European Proceedings of Social \& Behavioral Sciences EpSBS : International Conference on Research Paradigms Transformation in Social Sciences. P. 801-807. DOI: https://dx.doi.org/10.15405/epsbs.2018.12.99

5. Polyakova O. B., Petrova E. A., Mironova O. I. Features of subjective well-being of leaders with professional deformations (burnout) // RPTSS 2018. The European Proceedings of Social \& Behavioral Sciences EpSBS : International Conference on Research Paradigms Transformation in Social Sciences. P. 958-965. DOI: https://dx.doi.org/10.15405/epsbs.2018.12.117

6. Jafar Zade D. A., Senkevich L. V., Polyakova O. B. et al. Features of professional deformations (burnout) of medical workers depending on working 
conditions // Prensa Medica Argentina. 2019. Vol. 105, № 1. P. 1000 334. DOI: 10.41720032-745X.1000334

7. Bonkalo T. I., Polyakova O. B., Bonkalo S. V. et al. Development of ethnic social identity among the members of ethnic community organizations as the factor of preventing the spread of nationalist sentiments in a multicultural society // Biosciences Biotechnology Research Asia. 2015. Vol. 12, № 3. P. 2361-2372. DOI: http://dx.doi.org/10.13005/bbra/1912

8. Полякова О.Б. Самоконтроль в общении как фактор преодоления состояний деперсонализации психологов и педагогов // Вестн. Том. гос. ун-та. 2011. № 348. С. 133-137.

9. Elshansky S. P., Anufriev A. F., Polyakova O. B., Semenov D. V. Positive personal qualities and depression // Prensa Medica Argentina. 2019. Vol. 105, № 8. P. 461-468. DOI: 10.41720032-745X.1000322

10. Polyakova O. B., Petrova E. A., Mironova O. I., Semenov D. V. Specificity of psychosomatization of psychologist-leaders with professional deformations (burnout) // Prensa Medica Argentina. 2019. Vol. 105, № 1. P. 1-7. DOI: 10.41720032-745X.1000326 


\section{СОЦИАЛЬНО-ПСИХОЛОГИЧЕСКИЕ АСПЕКТЫ РАЗВИТИЯ КРИЗИСА УТРАТЫ ПРОФЕССИОНАЛЬНОЙ ДЕЯТЕЛЬНОСТИ У ПЕДАГОГОВ В ПЕРИОД ПОЗДНЕЙ ЗРЕЛОСТИ*}

Э. Э. Сыманюк

А. А. Печеркина

Т.Д. Буковей

В настоящее время вопросы, связанные с продлением периода активной трудовой деятельности человека, приобретают особое значение. Традиционно период поздней зрелости рассматривается как стадия завершения социально-профессиональной деятельности, объединяющая предпенсионный и начало пенсионного возрастов. В качестве основных характеристик этого периода выступают изменения социальной ситуации развития, затруднения в продуктивности деятельности, возможная ее утрата, возникновение новых переживаний (тревожность, раздражительность, бесперспективность, отсутствие профессиональных достижений и др.), ослабление физического здоровья. Вместе с тем в последнее время происходит смена акцентов. Все больше исследователей рассматривают период поздней зрелости как период активной жизни человека, в котором возможна успешная и продуктивная социальная и профессиональная деятельность.

В современном мире существует большое количество рефлексии личностных состояний, которые объединены общим понятием - кризис. Одним из нормативных кризисов профессионального развития является кризис утраты профессиональной деятельности.

Феноменология понятия «кризис утраты профессиональной деятельности» становится актуальной в условиях перестройки привычного уклада общества. В настоящее время наблюдается тотальная цифровизация, которая обусловила интеграцию современных циф-

Статья написана при поддержке гранта РФФИ № 20-013-00790 «Преодоление кризиса утраты профессиональной деятельности у педагогов в период поздней зрелости». 
ровых образовательных технологий в учебный процесс. Особенно активное проникновение онлайн-образования в жизнь участников педагогического процесса наблюдается с приходом пандемии коронавирусной инфекции (COVID-19).

Все это не могло не коснуться профессиональной деятельности педагога. Так, внедрение онлайн-образования в учебный процесс привело к изменению профессиональной роли педагога. От транслятора знаний педагог переходит к роли тьютора, сопровождающего учебный процесс. Соответственно, это может в скором времени привести к уменьшению потребности общества в педагогах. Данные изменения особенно болезненно воспринимаются педагогами в возрасте поздней зрелости.

Значительная часть педагогов в возрасте поздней зрелости испытывает трудности адаптации к прогрессивно меняющимся социально-экономическим и профессиональным условиям. Неготовность к переосмыслению собственной роли в современном образовательном процессе и неспособность преодолевать возникающие профессиональные трудности подчас становятся причинами возникновения у педагогов серьезных социально-психологических проблем: от усиления внутренней неудовлетворенности до нарастания социальной конфронтации и агрессии. Эмоциональная нестабильность педагогов не только снижает качество образовательного процесса, но и влияет на характер взаимодействия с обучающимися [1].

Снижение потребности в деятельности педагогов и их неготовность осваивать цифровую среду вынуждает многих завершать трудовую деятельность и уходить на пенсию. Это выступает в качестве толчка к развитию кризиса утраты профессии, при котором педагоги хотят продолжать заниматься профессиональной деятельностью, однако внешние факторы и внутреннее нежелание к самоизменению этому препятствуют.

- На основании вышесказанного можно говорить о необходимости исследования феноменологии переживания педагогами кризиса утраты профессиональной деятельности и выделения, прежде всего, социально-психологических аспектов его развития. 


\section{Феноменология кризиса утраты профессиональной деятельности}

Предпенсионный период для многих работников приобретает кризисный характер, что связано с необходимостью освоения новой социальной роли и норм поведения, создания планов на будущее.

Кризис утраты профессии активно изучается в отечественной психологической науке. Так, Б. Г. Ананьев кризис утраты профессиональной деятельности рассматривает как блокирование всех потенциалов трудоспособности и одаренности человека. По мнению автора, прекращение многолетнего труда не может не вызвать глубоких перестроек в структуре человека как субъекта деятельности, а потому и как личности [2]. Данные изменения касаются собственной идентичности, которая может носить либо ресурсный, либо самоуничижительный характер.

Э.Ф. Зеер, Э.Э. Сыманюк характеризуют кризис утраты профессиональной деятельности как последний нормативный кризис профессионального развития, который обусловлен завершением профессиональной жизни, когда по достижении определенного возрастного периода человек уходит на пенсию.

В.А. Куштанина рассматривает кризис как миф в том смысле, что на практике депрессия, ухудшение физического состояния или смерть наступают после выхода на пенсию не чаще, чем до наступления этого события [3].

А. В. Рыбинская указывает на то, что основными характеристиками кризиса утраты профессии являются ригидность и косность взглядов, негативное отношение к себе и к действительности, субъективное чувство одиночества и ненужности обществу, на благо которого человек трудился всю жизнь. Усугубляют течение кризиса трудности с принятием собственной жизни и осознанием ее конечности: осталось не так уж и много, а того, что хотел, так и не успел сделать. Это основная причина кризиса [4].

Следует отметить, что острота протекания кризиса утраты профессиональной деятельности, по мнению авторов, зависит от характера трудовой деятельности (работники умственного труда переживают его труднее, нежели работники физического труда), семейного положения и здоровья [5]. 
Также можно выделить ряд факторов, которые оказывают существенное влияние на развитие кризиса утраты профессиональной деятельности. Данные факторы связаны со спецификой деятельности. Среди них ключевыми для педагогов в возрасте поздней зрелости, с учетом современных особенностей развития системы образования, являются следующие:

- технологические - усложнение (трансформация) прежних способов, технологии выполнения профессиональной деятельности, повышение требований к уровню квалификации;

- социально-психологические - затруднения в межличностных связях, возможные межпоколенческие конфликты, формирование профессиональных деформаций;

- возрастные психофизиологические изменения, отрицательно влияющие на усвоение цифровых технологий;

- негативное влияние прошлого опыта и сформированных стереотипов реализации навыков прошлой квалификации;

- противодействие, предубеждение, отрицание инновационных преобразований и ускорения изменений.

Среди данных факторов на развитие кризиса утраты профессии педагогом наиболее заметное влияние оказывают те, которые относятся к группе социально-психологических.

В силу специфики педагогической деятельности педагог активно включен в систему межличностного взаимодействия с учениками, родителями, коллегами, администрацией образовательного учреждения. Соответственно, возникающие в этой сфере трудности могут выступить серьезной причиной для возникновения кризиса утраты профессиональной деятельности. Рассмотрим их подробнее.

\section{Социально-психологические факторы кризиса утраты профессиональной деятельности педагогом}

Начнем рассмотрение с межпоколенческих конбликтов, которые являются предметом пристального внимания не только психологов, но и представителей других наук на протяжении уже многих лет.

В научной литературе существуют различные подходы к определению межпоколенного конфликта, тем не менее все они сводятся 
примерно к следующему: межпоколенный конфликт - это столкновение противоположных позиций, мнений, оценок, идей, принадлежащих людям различных поколений, которое они пытаются решить с помощью убеждений или действий на фоне проявления эмоций.

Феномен «межпоколенческий конфликт» рассматривался различными учеными - представителями социальных, философских и других наук, такими как И.В. Бестужева-Лада, И. С. Кон, Т. Лисовский, М. Мид, Н. Г. Чернышевский, Е. Шамис и др.

Американский социолог Л. Фойер указывал на то, что конфликт поколений является универсальной темой человеческой истории. Он основывается на самых изначальных чертах человеческой природы и является, может быть, даже более важной движущей силой, чем классовая борьба [6].

Согласно мнению Э.Ф. Зеера, анализ личности специалиста той или иной профессии, его отношения к миру невозможен без изучения системы его ценностных ориентаций, которые являются одним из центральных личностных образований. Ценностные ориентации выражают сознательное отношение человека к социальной действительности и определяют мотивацию его поведения, существенно влияя на все стороны профессиональной деятельности. В зависимости от структуры ценностных ориентаций личности, сочетания и степени предпочтения одних ценностей другим, можно определить, на какие цели направлена профессиональная деятельность человека [7].

Межпоколенческие конфликты субъектов образовательной деятельности вызывают затруднения в педагогическом взаимодействии. Результаты, полученные в исследовании Ю. А. Сыченко, посвященном межпоколенным рассогласованиям ценностных ориентаций, демонстрируют, что взаимодействие не вызывает у испытуемых затруднений при условии, что партнер обладает схожими ценностными ориентациями, в то время как при рассогласовании ценностных ориентаций взаимодействие оценивается как затрудненное. Для педагога с социоцентрическими ценностными ориентациями индивидуалистически ориентированный партнер не совсем понятен (затруднения на когнитивном уровне), порождает негативно окрашенные эмоции (затруднения на эмоциональном уровне), не вы- 
зывает желания устанавливать и развивать контакт (затруднения на поведенческом уровне). Этот комплекс затруднений закономерно порождает негативное отношение к партнеру по взаимодействию [8].

Устранение затруднений в педагогическом взаимодействии, возникающих при межпоколенном рассогласовании ценностных ориентаций (межпоколенческом конфликте), создает психологически благоприятные условия для решения другой психолого-педагогической проблемы - передачи представителям новых поколений базовых ценностей, обеспечивающих стабильное функционирование социума.

Деятельность педагога характеризуется взаимодействием большого количества людей, относящихся к разным возрастным категориям и обладающих различными представлениями, взглядами, жизненным опытом, что неизбежно порождает конфликтные ситуации.

Характер педагогических конфликтов определяется статусом участников конфликта (вертикальный тип межличностного взаимодействия), наличием юридической, моральной и профессиональной ответственности администрации образовательного учреждения и педагогического коллектива за жизнь, здоровье учащихся и результаты учебно-воспитательной деятельности; существенными различиями в возрасте, жизненном опыте, гражданских правах (школьники - несовершеннолетние граждане), образованности учащихся и педагогов и другими специфическими чертами.

С. Ю. Темина приводит следующие объективные и субъективные причины возникновения педагогических конфликтов.

1. Объективные причины педагогических конфликтов:

- недостаточная степень удовлетворения базисных потребностей ребенка;

- противопоставление функционально-ролевых позиций учителя и ученика (задача первого - учить, задача второго - учиться; учитель априорно считается превосходящим ученика умом, знаниями, опытом и наделяется властью над ним);

- существенное ограничение степеней свободы (требования жесткой дисциплины, подчинения, отсутствие возможности выбора учителя, предмета, класса, обязательное посещение уроков и т. д.); 
- различия в представлениях, ценностях, жизненном опыте, принадлежность к разным поколениям (проблема «отцов и детей»), необходимость оценивания учащихся учителем;

- игнорирование личных проблем учащихся в формализованных образовательных системах;

- различие между учебным материалом и явлениями, объектами реальной жизни;

- социальная нестабильность и др.

2. К субъективным причинам относятся:

- психологическая несовместимость учителя и ученика;

- наличие у учителя или ученика определенных черт характера, определяющих так называемую «конфликтную личность» (агрессивность, раздражительность, нетактичность, ехидность, самоуверенность, грубость, жесткость, придирчивость, скептицизм и т. д.);

- отсутствие коммуникативной культуры у учителя или ученика;

- необходимость изучения данного предмета всеми учащимися и отсутствие интереса к нему у конкретного ученика;

- несоответствие интеллектуальных, физических возможностей данного ученика и предъявляемых к нему требований;

- недостаточная компетентность учителя (отсутствие опыта, глубоких знаний по предмету, готовности к разрешению конфликтов, низкий уровень развития определенных профессиональных способностей);

- чрезмерная загруженность учителя или ученика;

- отсутствие самостоятельности, творческого начала в учебном процессе;

- несоответствие самооценки ученика и оценки, данной ему учителем, и др. [9].

А. Меняев в статье «Конфликты в обучении и воспитании» выделяет три объективные причины конфликтности взрослых:

1) взаимодействие консерватизма взрослых и новых культурных ценностей детей;

2) недостаточный культурный уровень взрослых (грубость, бестактность и т.п.), его несоответствие уровню культуры народа; 
3) изменения в психике педагогов или родителей, возникающие в процессе накопления опыта систематического управления поведением ребенка (эти изменения можно образно назвать «развращением властью»): привычка постоянно запрещать, приказывать, поправлять, понуждать, упрекать, выговаривать, «воспитывать» в строгости, покорности и дисциплине [10].

Таким образом, в рамках образовательной организации могут появляться педагогические конфликты, выступающие своеобразным продолжением конфликта поколений и основанные на принципиальных различиях в системах ценностей и мировоззрения, сформированного в процессе социализации. Динамика конфликта детерминирует возрастание негативных переживаний, усугубляя процесс преодоления кризиса утраты профессиональной деятельности.

Следующим фактором кризиса утраты профессиональной деятельности педагога являются профессиональные деформации.

Профессия «педагог» так же, как и любая профессия, инициирует образование (развитие) профессионально обусловленных деструкций личности, которые проявляются в акцентуациях характера, социально-профессиональных деформациях, профессиональной отчужденности и стагнации. Преодоление деструктивных тенденций профессионализации происходит в процессе развития, саморазвития и самоактуализации специалиста.

А. К. Маркова на основе обобщения исследований нарушения профессионального развития личности выделила следующие тенденции профессиональных деструкций:

- отставание, замедление профессионального развития по сравнению с возрастными и социальными нормами;

- дезинтеграция профессионального развития, распад профессионального сознания и, как следствие, нереалистические цели, ложные смыслы труда, профессиональные конфликты;

- низкая профессиональная мобильность, неумение приспособиться к новым условиям труда и дезадаптация;

- рассогласованность отдельных звеньев профессионального развития, когда в одной сфере наблюдается опережение, а в другой - отставание (например, мотивация к профессиональному 
росту есть, но мешает отсутствие целостного профессионального сознания);

- ослабление ранее имевшихся профессиональных данных, профессиональных способностей, профессионального мышления;

- искаженное профессиональное развитие, появление ранее отсутствовавших негативных качеств, отклонений от социальных и индивидуальных норм профессионального развития, меняющих профиль личности;

- появление деформаций личности (например, эмоционального истощения и выгорания, а также ущербной профессиональной позиции);

- прекращение профессионального развития из-за профессиональных заболеваний или потери трудоспособности [11].

Соответственно, профессиональные деструкции нарушают целостность личности, снижают способность к адаптивности, устойчивости, отрицательно сказываются на продуктивности деятельности.

Деятельность педагогов проходит в условиях повышенных требований со стороны всех участников образовательной деятельности. Зачастую особенности профессиональной деятельности приводят к различным деструктивным проявлениям, в том числе и к деформациям.

Приведем перечень профессиональных деформаций, наиболее часто развивающихся у представителей профессии «педагог»:

- авторитарность. Авторитарные педагоги тяготеют к различным наказаниям, нетерпимы к критике. Авторитарность обнаруживается в снижении рефлексии - самоанализа и самоконтроля, проявлении высокомерия и черт деспотизма;

- агрессивность - проявляется в отсутствии стремления учитывать чувства, права и интересы учеников, в приверженности к «карательным» воздействиям, в требовании безоговорочного подчинения. Агрессивность проявляется также в иронии, насмешках и навешивании ярлыков: «тупица», «бездельник», «хам», «кретин» и т. п. Агрессивность как профессиональная деформация обнаруживается у педагогов с увеличением стажа работы, когда усиливаются стереотипы мышления, падает самокритичность и способность конструктивно решать конфликтные ситуации; 
- выученная беспомощность - привычка жить, не оказывая сопротивления, не принимая на себя ответственность;

- догматизм - возникает вследствие частого повтора одних и тех же ситуаций, типовых профессиональных задач. У педагогов формируется склонность к упрощению проблем, применению уже известных приемов;

- консерватизм - предубеждение против нововведений, приверженности устоявшимся технологиям, настороженном отношении к творческим работникам;

- сверхконтроль - подавление спонтанности, сдерживание самореализации, контроль над агрессивностью, ориентация на правила, инструкции, избегание серьезной ответственности. Стиль мышления инертный и несколько догматичный;

- ролевой экспансионизм - фиксация на собственных личностных и профессиональных проблемах и трудностях, преобладание обвинительных и назидательных суждений, преувеличение значения своей роли. Ролевое поведение за пределами учреждения, организации;

- эмоциональное выгорание и др. [12].

Следствием приведенных выше деформаций становятся психическая напряженность, конфликты, кризисы, снижение продуктивности профессиональной деятельности, неудовлетворенность жизнью и социальным окружением.

Анализ результатов исследований деятельности педагогов показал, что выраженность деформации зависит от стажа работы, пола, содержания профессиональной деятельности и индивидуальнопсихологических особенностей личности.

Еще одной причиной развития кризиса утраты профессии являются соицальные установки. В отношении позднего периода жизни человека в общественном сознании на сегодняшний день прочно укоренился негативный стереотип, согласно которому для людей данного возраста характерны низкая двигательная активность, ригидность мышления, устаревшие знания, отрицательное отношение к неизбежному прогрессу, саботирование образовательных реформ [13-15]. 
Негативные установки относительно предпенсионного и пенсионного возраста в равной степени формируются и транслируются как представителями поздней зрелости, так и внешним миром. При этом парадоксальность ситуации заключается в том, что в обществе доминируют негативные установки по отношению к возрасту поздней зрелости, но при этом данный возраст является неизбежным этапом онтогенеза для каждого человека.

Важно отметить, что не только люди при достижении возраста поздней зрелости испытывают на себе влияние негативных общественных установок, но и представители более молодых возрастных групп культивируют страх перед данным этапом жизни. Так, Т.В. Смирнова отмечает, что нивелирование значения позднего периода жизни и нацеливание поколений на избежание старости влекут за собой неумение пожилых людей стариться, а молодых адекватно воспринимать старость [16].

А. А. Зинина по результатам эмпирического исследования пришла к следующим выводам. Социальные представления о престарелых людях различаются в социально-демографических группах. Студенты склонны считать престарелых людей неспособными обойтись без посторонней помощи и нуждающимися в поддержке, больными и немощными. Работающие взрослые чаще отмечают, что престарелые люди получают крайне плохое социальное обслуживание, что их избегают в обществе и относятся к ним пренебрежительно. Они также акцентируют внимание на том, что престарелые люди мудрые и имеют богатый жизненный опыт. Также автором были выделены значимые различия между исследуемыми группами: студенты подчеркивают значимость социальных контактов в старческом возрасте, работающие взрослые большое значение придают наличию целей в жизни, неработающие пенсионеры - деятельному образу жизни [17].

Геронтостереотипы - это устойчивое представление о старении и представителях старшей возрастной группы.

Перечислим некоторые из них:

- пожилые люди не приносят пользы, а, напротив, являются обузой для общества; 
- в пожилом возрасте усиливается угасание когнитивных функций, слабеет интеллект, как следствие, возникают трудности в освоении новых компетенций и адаптации к инфокоммуникационным технологиям;

- пожилые люди неопрятны, меньше следят за собой;

- в пожилом возрасте нет смысла учиться новому, осваивать новые виды деятельности;

- в новой реальности, в условиях пандемии, представителя поздней зрелости держат на работе, потому что «нельзя увольнять», он неугоден работодателю, но «избавиться» от него не предоставляется возможным и др.

Таким образом, можно утверждать, что при достижении периода поздней зрелости происходит завершение профессиональной деятельности, что приводит к усилению психологических переживаний, обусловленных изменением вектора развития.

Игнорируя социальные установки, навязанные обществом, современные психологи выделяют положительные характеристики поздней зрелости:

- высокий социально-профессиональный опыт;

- обеспечение надежности выполняемой деятельности;

- сохранение жизнеспособности и активизация жизнестойкости;

- высокий уровень практического интеллекта.

В отечественной и зарубежной психологии зрелость характеризуется как наиболее продуктивный период жизнедеятельности человека.

\section{Выводы}

Итак, кризис утраты профессии - это нормативный кризис профессионального развития, который обусловлен завершением профессиональной жизни.

В качестве основных факторов, способствующих развитию кризиса утраты профессиональной деятельности педагогов в возрасте поздней зрелости, выделяют технологические, социально-психологические, возрастные психофизиологические изменения, негативное влияние прошлого опыта и сформированных стереотипов 
реализации навыков прошлой квалификации, противодействие, предубеждение, отрицание инновационных преобразований и ускорения изменений.

В качестве социально-психологических факторов кризиса утраты профессии учителем нами выделяются межпоколенческие конфликты, профессиональные деформации и социальные установки в обществе относительно людей в возрасте поздней зрелости.

Исследование данных факторов позволит определить психологические механизмы оказания социально-психологической поддержки педагогам в период переживания кризиса утраты профессии, а также будет способствовать повышению качества жизни в период поздней зрелости.

1. Садовникова Н. О., Заннони Ф. Психологические особенности переживания педагогами профессионального кризиса личности // Образование и наука. 2018. Т. 20, № 3. С. 83-99.

2. Ананьев Б. Г. Избранные психологические труды : в 2 т. М. : Педагогика, 1980. Т. 1.232 с.

3. Куштанина В.А. Кризис после выхода на пенсию: миф и реальность (Россия - Франция) // Вестн. Рос. ун-та дружбы народов. Сер. : Социология. 2009. № 1. С. 82-89.

4. Рьбинская А. В. Психологические характеристики кризиса пожилого возраста // Вестн. Тамб. ун-та. Сер. : Гуманитар. науки. 2013. № 7 (123). C. $128-132$.

5. Зеер Э. Ф., Сыманюк Э. Э. Психология профессиональных деструкций : учеб. пособие для вузов. М. : Акад. проект, 2020.

6. Feuer L. S. The Conflict of Generations. N. Y. : Basic Books, 1996. 543 p.

7. Зеер Э. Ф., Павлова А. М. Психология профессионального образования : практикум : учеб. пособие для студентов высш. учеб. заведений. М. : Академия, 2008.

8. Съченко Ю.А. Оптимизация педагогического взаимодействия в условиях рассогласования ценностных ориентаций субъектов образовательного процесса // Педагогическое образование в России. 2011. № 1. С. 260-269.

9. Темина С. Ю. Конфликты школы или школа конфликтов. Введение в конфликтологию образования. Воронеж, 2002. С. 144-146. 
10. Меняев А. Конфликты в обучении и воспитании // Прикладная психология и психоанализ. 2000. № 3. С. 24.

11. Маркова А. К. Психология профессионализма. М., 1996. С. 151-156.

12. Зеер Э. Ф. Психология профессионального развития. М. : Академия, 2006.

13. Елютина, М.Э. Старость в современном российском обществе: интерсубъективный и интеробъективный контексты. Саратов : Сарат. гос. техн. ун-т, 2010.

14. Микляева А.В. Возрастная дискриминация как социально-психологический феномен. СПб. : Речь, 2009.

15. Calasanti T. Afeminist confronts ageism // Journal ofAging Studies. 2008. Vol. 22. P. 152-157.

16. Смирнова Т. В. Стереотипный образ и социальная дистанция // Социол. исслед. 2008. № 8. С. 49-55.

17. Зинина А. А. Престарелые люди и психологическое благополучие в старческом возрасте в социальных представлениях разных групп общества [Электронный ресурс] // Науч. тр. Моск. гуманитар. ун-та. 2017. № 1. URL: http:// journals.mosgu.ru/trudy/article/view/399 (дата обращения: 30.09.2020.). DOI: $10.17805 /$ trudy.2017.1.8 


\section{Раздел 4 \\ ПРОБЛЕМЫ ПСИХОЛОГИЧЕСКОЙ БЕЗОПАСНОСТИ \\ ОБРАЗОВАТЕЛЬНОЙ СРЕДЫ}

\section{ПСИХОЛОГИЧЕСКИЕ ОСОБЕННОСТИ ВЛИЯНИЯ КИБЕРБУЛЛИНГА НА МОЛОДЕЖЬ}

Е. В. Аверкиева

Во всем мире подростки и молодежь составляют наиболее многочисленную прослойку интернет-пользователей. К примеру, в развитых странах более 90 \% молодежи имеют доступ в интернет, более 80 \% владеют собственными смартфонами [1]. В России $85 \%$ детей не могут обойтись без смартфонов и более трети детей в возрасте 15-18 лет проводят в интернете всё свободное время [2]. Современные технологии предоставляют молодежи множество возможностей для развлечения и общения с ровесниками, друзьями по интересам и членами семьи. По данным Web-Index, аудитория в возрасте 12-24 лет проводит в социальных сетях около 41 \% экранного времени [3]. Социальные сети, чаты и мессенджеры являются важными инструментами обеспечения общественной жизни детей и подростков. Исследование, проведенное в Свердловской области, подтвердило высокую активность молодежи в интернете - из $98 \%$ опрошенных 68 \% чувствуют себя некомфортно, пребывая вне сети. [4]. По данным различных исследований, именно коммуникативная функция интернета вышла на первый план для большинства пользователей. Тем не менее, как и в любом коммуникативном пространстве, в реальности человек может столкнуться в сети с проявлениями деструктивного поведения в общении.

Сложно согласиться с распространенным мнением о том, что интернет заменяет молодежи реальное общение. Скорее, наоборот, сетевые контакты расширяют его, разнообразят, делают более мо- 
бильным, тесным. Если учесть, что ребенок начинает пользоваться интернетом в раннем детстве, эти коммуникации становятся для него совершенно естественными, как разговоры с родителями, сверстниками. Постепенно пользователи перестают воспринимать интернет как обособленную среду, он становится глобальным средством общения. Подросток набирает социальный капитал, который потом будет использовать в своей профессиональной деятельности, в деловом и межличностном общении. Это формы коммуникации, которые будут важны через несколько лет, они востребуют новую этику, новые нормы и правила виртуального общения, где складываются свои язык, логика, психология, культура [5].

Преимущества интернет-среды не вполне компенсируют ее важный недостаток -цифровой мир представляет собой удобную площадку для антисоциального поведения: отправки угрожающих или оскорбительных сообщений, распространения сплетен, преследования, иначе, онлайн-агрессии или кибербуллинга. Под кибербуллингом понимается использование электронных средств связи, интернета или мобильных телефонов с целью неоднократного намеренного причинения вреда или эмоциональных страданий [6]. Интерес зарубежного научного сообщества к феномену кибербуллинга возник в начале 2000-х гг. и был вызван, прежде всего, трагичными последствиями для его жертв, вплоть до суицида. В большей степени проблема кибербуллинга разработана зарубежными учеными, в частности канадскими и американскими, в то время как в России данное явление стало предметом интереса исследователей значительно позже. Среди зарубежных исследователей известны имена Р. Ковальски, С. Лимбер и П. Агатсон, которые выделили и описали различные формы кибербуллинга. К. Блайа исследует влияние кибербуллинга на атмосферу в школах, О. Юбарра изучает взаимосвязь кибербуллинга и депрессивных состояний, С. Хиндуя, Дж. В. Патчин рассматривают проблему взаимосвязи кибербуллинга и суицида. В 2005 г. в США был открыт Центр исследования кибербуллинга, который возглавляют специалисты по уголовному праву С. Хиндуя и Дж. Пэтчин. Центр проводит собственные исследования и выпускает посвященные проблеме кибербуллинга и его противодействию специализированные брошюры, ориентирован- 
ные на разные категории участников образовательного процесса: учеников, родителей, учителей, школьных лидеров.

Среди российских психологов, занимающихся изучением кибербуллинга, Г.В. Солдатова изучает распространенность кибербуллинга, его ролевую структуру и роль детско-родительских отношений, А. С. Зинцова рассматривает влияние кибербуллинга на личность подростка, Л. А. Найденова исследует способы защиты от кибербуллинга, У. Парфентьев рассматривает аспекты интернет-безопасности в целом, А. А. Бочавер и К. Д. Хломов изучают типы личности детей, подвергшихся кибербуллингу. В России с 2007 г. проблемами восприятия и использования ИКТ детьми и подростками занимается Фонд развития интернета, причем в исследовательское поле фонда входит не только кибербуллинг, но также цифровая медиаграмотность, использование детьми социальных медиа, безопасность персональных данных и др. Совместно с факультетом психологии МГУ имени М.В. Ломоносова и Федеральным институтом развития образования фонд участвует в международном исследовательском проекте EU Kids Online III.

Кибербуллинг включает в себя множество проявлений преднамеренного агрессивного поведения в сети онлайн. Н. Виллард (2006), автор одного из первых изданий, посвященного кибербуллингу, «Кибербуллинг и киберугрозы», выделяет следующие формы онлайн-поведения [7]:

- Флейминг (англ. flaming - воспламенение) - обозначает перепалку или обмен репликами между двумя и более людьми с использованием ругательств, угроз или оскорблений. Чаще всего флейминг происходит на публичных интернет-площадках, таких как форумы, чаты, реже - в частной переписке. Посетители форума, свидетели могут присоединяться к одной из сторон и развивать переписку, не до конца понимания изначальный смысл спора и зачастую рассматривая ситуацию как игровую.

- Киберхарассмент (англ. harassment - притеснение) - повторяющиеся оскорбительные сообщения, направленные на жертву [8]. Харассмент наиболее распространён в персональной коммуникации, посредством электронной почты, но может встречаться и на других онлайн-платформах. От флейминга его отличают два критичных мо- 
мента - это увеличенная продолжительность во времени и тенденция к одностороннему воздействию со стороны одного или нескольких обидчиков на жертву, которая не может ответить по причине страха или невозможности опознать агрессоров. Одной из форм харассмента является грифинг (англ. griefing) - преследование одних игроков другими в многопользовательских онлайн-играх с целью испортить им удовольствие. Гриферы могут вести себя агрессивно, использовать нецензурные выражения, блокировать отдельные поля игры или мошенничать. Другой, не менее распространенной формой является троллинг - размещение комментариев, информации на форумах, веб-страницах и социальных сетях, провоцирующих сильную эмоциональную реакцию читателей. В переводе с английского trolling - ловля на блесну, рыболовный термин. Интернеттролли - провокаторы, «поддевающие» человека на блесну своими манипуляциями и получающие удовольствие от его яркой реакции. Как и в любой манипуляции, агрессор получает ощущение власти над жертвой, ее эмоциональным и моральным состоянием. Более интенсивную и носящую характер прямой агрессии форму харассмента называют киберсталкинг (англ. stalk - преследовать). В данном случае агрессор направляет угрожающие, противоправные либо оскорбительные сообщения в адрес жертвы либо членов ее семьи.

- Клевета (англ. denigration) - распространение заведомо ложных сведений, порочащих честь и достоинство другого лица или подрывающих его репутацию. Такая информация может быть опубликована на интернет-сайте, в социальных сетях либо разослана в мессенджерах в частном порядке. В эту форму также включается цифровое редактирование фотографий другого лица в унизительной или сексуализированной манере.

- Самозванство - перевоплощение в определенное лицо (англ. impersonation), выдача себя за другого пользователя сети путем использования его пароля доступа к аккаунту в социальных сетях, в блоге, почте либо создание аккаунта с данными «жертвы» и осуществление от его имени негативного общения с другими пользователями. Такая коммуникация может включать в себя рассылку оскорбительных, жестоких или неуместных сообщений в частном или групповом порядке, которые вредят репутации жертвы. 
- Выманивание конфиденциальной информации, аутинг (англ. outing) - получение персональной информации и публикация ее в интернете или передача тем, кому она не предназначалась. Эта форма кибербуллинга часто используется, когда речь идет о случаях раскрытия сексуальной ориентации индивида. Аутинг аналогичен раскрытию секретов в реальной жизни и также сопровождается ощущением стыда и страха со стороны пострадавшего, отличается лишь количеством свидетелей, число которых в онлайн не поддается подсчету.

- Исключение/остракизм (exclusion/ostracism) - намеренное и жестокое удаление кого-либо из интернет-сообщества либо из списка друзей. Многими исследованиями подтверждено человеческое желание ощущать себя частью какой-либо общности, особенно выраженное у подростков и молодежи, которые собираются в группы, объединенные идеями, интересами, действиями. В сети онлайн эта форма кибербуллинга может происходить при удалении из списка друзей либо из общего чата в мессенджере или группы в социальной сети. Это аналог косвенной травли в реальной жизни, выражающейся в изоляции и отвержении одного из членов группы, намеренное объявление бойкота. Исследование показало, что не только фактическое, но и субъективно воспринимаемое исключение из интернетсообщества может снизить самооценку индивида [9].

В сравнении с традиционным буллингом кибербуллинг обладает существенными отличиями. В первую очередь то, что личность обидчика может остаться неопознанной, является отличительным признаком кибербуллинга [10]. Дозволенная в сети онлайн анонимность влияет на поведение пользователей. Возможность действовать без угрозы наказания и социального порицания приводит к феномену растормаживания, когда индивиды позволяют себе гораздо больше, чем в реальной жизни, где им пришлось бы нести ответственность за свои слова и поступки. Участники, вовлеченные в ситуации кибербуллинга в качестве агрессоров, склонны недооценивать негативное воздействие своих поступков, так как лишены возможности наблюдать за реакцией жертвы [1].

Помимо возможности остаться неопознанным, интернет-среда может предоставлять доступ к опубликованной частной информа- 
ции для широкой аудитории с целью просмотра, комментирования и дальнейшего распространения. Единожды опубликованная информация в интернете, распространенная на публику, может быть расценена жертвой как повторяющаяся ситуация кибербуллинга. В отличие от традиционного буллинга, который происходит в четко ограниченных местах, например, на школьном дворе, кибербуллинг распространен повсеместно. Использование электронных устройств, интернета и мобильной связи делает невозможным его избегание, в противном случае подросток будет вынужден отказаться от использования этих средств коммуникации.

Согласно опросу АО «Лаборатория Касперского», проведенному в 2019 г., по активности в интернете общение занимает первое место для девочек $(73 \%)$ и второе место $(71 \%)$ - для мальчиков. При этом, по данным исследования, у 43 \% детей в младшей школе уже есть своя страница в социальных сетях, а к старшей школе этот показатель достигает 95 \%. Активно осваивая интернет-коммуникации и просматривая видеоконтент, подростки нередко сталкиваются с кибербуллингом, ведь почти 40 \% из них подтвердили, что оставлять записи и комментарии на их странице может кто угодно и около 4-39 \% размещают в сети личную информацию. То же исследование приводит сведения о том, что $33 \%$ детей сталкивались с буллингом либо слышали о нем, из них 7 \% были в роли жертвы, $2 \%$ - в роли обидчика [2].

По данным исследования Microsoft 2012 г., в России $49 \%$ детей в возрасте 8-17 лет сообщали о том, что подвергались в сети буллингу или другим формам обращения, имеющим негативные последствия (для сравнения, средний показатель по 25 другим обследованным странам составил $37 \%$ ), в том числе $27 \%$ столкнулись с грубым и недружелюбным обращением, 20 \% подвергались насмешкам или их дразнили, 24 \% подвергались обзыванию. $67 \%$ детей сообщили о том, что они знают о буллинге онлайн, 34 \% испытывают беспокойство в связи с этой темой [11].

По данным опроса, проведенного в 2018 г. Фондом Развития Интернет, значительная часть подростков и молодых людей (86\%) в той или иной роли, в первую очередь как наблюдатели, сталкиваются хотя бы с одной из форм кибербуллинга. Лишь одному из семи 
посчастливилось не встретиться в сети с агрессией. Каждый второй подросток сталкивался с тремя и более видами кибербуллинга, среди молодежи - каждый третий. Роль кибер-обидчика социально нежелательна, тем не менее некоторые российские подростки и молодые люди признались, что выступали в такой роли (от 1 до 7 \% в разных ситуациях). Количество подростков, признавшихся, что были в роли жертвы, несколько больше (от 1 до 15 \% в разных ситуациях). Тем не менее подростки и молодежь сталкиваются с разными видами киберагрессии в других ролях, преимущественно в ролях свидетелей или наблюдателей [12].

По данным исследования, проведенного в г. Екатеринбург в 2016 г. на выборке из 115 обучающихся в возрасте от 13 до 15 лет, 47 \% мальчикам и 58 \% девочкам никогда не присылали сообщения в социальных сетях, содержащие угрозу, $27 \%$ мальчиков и $26 \%$ девочек получают такие сообщения редко, 20 \% мальчиков и $14 \%$ девочек получают их иногда и 6 \% мальчиков и $2 \%$ девочек получают их часто [13].

В 2019 г. О. Бочавер и К. Хломов провели исследование в 5 общеобразовательных организациях г. Москвы с участием школьников 5-9-х классов в возрасте от 11 до 16 лет. Всего в исследовании приняли участие 294 человека, и только 28,4 \% респондентов сообщили, что не сталкивались с кибербуллингом. Авторы отмечают, что представленное распределение может указывать на существование двух групп подростков, одна из которых почти не сталкивается с кибербуллингом, а для второй группы кибербуллинг - это заметное явление, что говорит либо о другом характере их интернет-активности, либо о большей рефлексивности [14].

Согласно международным исследованиям, количество столкновений с кибербуллингом в подростковом возрасте варьируется в широком диапазоне - от 7 \% [15] до 72 \% [16]. Такое расхождение в данных о распространенности кибербуллинга вызвано рядом факторов, таких как возраст, демографический состав выборки, трактовка понятия «кибербуллинг» и ретроспективы его временного периода (разовое событие либо многократное, в течение определенного периода). 
Таким образом, можно сделать вывод о том, что опыт переживания онлайн-агрессии среди молодежи довольно распространен, и в то же время особенности этого опыта еще недостаточно изучены. Многие исследования подтверждают негативное воздействие ситуаций кибербуллинга на пострадавшего. Так, А. С. Зинцова выделяет последствия психологического, педагогического, физиологического (медицинского) и социального характера [17]. По данным исследований, на физиологическом уровне медицинские последствия кибербуллинга сказываются на работе организма в целом: депрессии, стрессы, как следствие, снижение иммунитета, частые жалобы на головные боли, боли в области сердца, тошноту, быстрая утомляемость, плохой сон, иногда бессонница, ухудшения памяти и внимания, дефекты речи или нервные тики (моргание, глотание), плохой аппетит $[18,19]$. В особо тяжелых случаях стресс, пережитый из-за кибербуллинга, может привести к задержке или даже остановке психического развития. Такой человек никогда не сможет избавиться от психологической травмы. После пережитого у ребенка могут возникнуть сердечные или инфекционные заболевания, язва желудка, невроз. Также после сильного стресса возможно приобретение хронических заболеваний: астма, сахарный диабет (при физических и психических травмах часто повышается уровень глюкозы в крови) [17].

Вариантами социальных последствий могут быть: скрытность, нежелание идти на контакт с родителями и друзьями; потеря коммуникативных навыков; дезадаптация; девиантное поведение; рост употребления алкоголя, наркотиков или курение; делинквентное поведение (кражи в магазинах, нанесение ущерба имуществу и людям). Однако исследователи отмечают, что не до конца очевидно, что является первичным: агрессия в интернете провоцирует отклоняющееся поведение либо такое поведение само по себе является предиктором кибербуллинга [20].

Кибербуллинг влияет на учебную деятельность подростков и влечет за собой снижение успеваемости; нежелание посещать учебное учреждение, прогулы; нестабильные оценки; низкую учебная активность. Социальная и педагогическая подавленность под- 
ростка чревата более серьезными проблемами - психологической подавленностью [21].

Психологическая травма влияет на всю жизнедеятельность ребенка и нередко наносит непоправимый урон его психике. Последствия кибербуллинга психологического характера достаточно серьезные, к ним следует отнести: снижение самооценки подростка; потерю уверенности в себе; нарушение психического развития; психические расстройства; психоэмоциональную нестабильность; постоянное чувство тревоги, страха, развитие паранойи; суицидальные мысли $[22,23]$. Исследователи также указывают, что на усиление связи между кибербуллингом и суицидальными мыслями может влиять публичность и долговременность воздействия, анонимность обидчиков, когда пострадавший не контролирует ситуацию и теряет надежду на помощь.

Наблюдаются также различия в воздействии кибербуллинга на юношей и девушек. По данным Jackson et al., девушки чаще подвергаются таким формам кибербуллинга, как харассмент на почве половой принадлежности, исключение и распространение личной информации и испытывают более негативное воздействие от сообщений. Девушки указывают, что ситуация кибербуллинга сильнее влияет на их репутацию, концентрацию внимания, возможность заводить новых друзей, вызывает суицидальные мысли [24]. Предыдущие исследования показали, что публикация фото-, видеоконтента является более травматичной для подростков, и оскорбления, осуществленные через компьютер в интернете (например, публикации, картинки или e-mail), воспринимаются ими тяжелее, чем с использованием телефона (текстовых сообщений и звонков) [25]. Таким образом, реакция на кибербуллинг зависит также от его формы, а эмоциональный ответ на кибербуллинг в интернете отличается от эмоционального ответа на кибербулинг в телефоне.

Существует большое количество исследований о влиянии кибербуллинга на тех, кто был в роли пострадавшего, но о последствиях для его инициаторов известно существенно меньше. Будучи в роли обидчика, некоторые молодые люди испытывали агрессию, радость мести и удовлетворенность, в то же время другие ощущали вину и сожаление [26]. Кибербуллинг также связывают с гиперак- 
тивностью, проблемами с поведением и низкой просоциальной активностью индивида в отношении ровесников [27]. В исследовании 1438 студентов в Китае выявлены различия в академической успеваемости между теми, кто был вовлечен в кибербуллинг, и теми, кто не был [28]. У киберобидчиков больше вероятность вовлечения в употребление запрещенных веществ и возникновения делинквентного поведения, они с большей вероятностью являются жертвами традиционного буллинга, демонстрируют агрессивное и ненормативное поведение, неуспеваемость, они чаще курят и употребляют алкоголь. Также исследователи выяснили, что молодые люди, вовлеченные в кибербуллинг в роли обидчика, чаще испытывают социальные затруднения, больше подвержены стрессам и депрессиям по сравнению с теми, кто в нем не участвует [29].

Таким образом, очевидно, что кибербуллинг оказывает негативное влияние на все стороны жизни его участников, начиная с ухудшения социальных навыков, заканчивая реальными угрозами физическому здоровью. Обзор исследований показывает, что феномен кибербуллинга и его последствий носит международный характер и связан с серьезными нарушениями психологического благополучия личности, оказывающими существенное влияние на формирование юношеской депрессии, тревожности, сниженной самооценки, эмоционального дистресса, а также употребление ПАВ и суицидальное поведение как среди пострадавших, так и среди его инициаторов. Молодежь в силу своих возрастных особенностей психики наиболее уязвима. Чувство собственного достоинства в подростковый период обострено, и поэтому любые унижающие действия вызывают серьезные переживания. В случае же кибербуллинга данные переживания многократно увеличиваются, поскольку угрозы и унижения в сети имеют публичный и непрерывный характер. Феномен кибербуллинга вызывает опасения по нескольким причинам [30]. Во-первых, коммуникация становится одним из ведущих видов деятельности подростка в процессе традиционной и цифровой социализации. Кроме того, процесс коммуникации и ее последствия выступают важными факторами психологического благополучия. Во-вторых, подростки и молодежь выделяют коммуникативные онлайн-риски как наиболее значимые, опасные 
и травматичные. В-третьих, в связи со значимостью коммуникативной сферы столкновение с деструктивными ситуациями при коммуникации в сети становится сложной жизненной ситуацией для подростков, требующей наличия репертуара возможных специфических действий - способов совладания со стороны самого ребенка и адекватных, компетентных действий со стороны окружающих.

Вышесказанное подчеркивает необходимость дальнейшего исследования процессов, содействующих устойчивости подростка в ситуациях кибербулинга. Известно, что не все участники-пострадавшие испытывают негативные эмоции, поэтому при изучении последствий кибербуллинга необходимо принимать во внимание индивидуальные особенности детей. Согласно транзактной теории стресса и копинга [31], вероятность развития психологического стресса зависит от особенностей личности, обусловливающих степень устойчивости к стрессу. Считается, что успешность адаптации к жизненным стрессам во многом определяется эффективностью развития личностно-средовых копинг-ресурсов [32]. Так, например, S. Folkman выделяет следующие виды копинг-ресурсов [33]: физические (здоровье, выносливость и т. п.); психологические (убеждения, самооценка, локус контроля, мораль); социальные (индивидуальная социальная сеть, социальные поддерживающие системы и т. д.); материальные ресурсы (деньги, оборудование и т. д.). Необходимы дальнейшие корреляционные и лонгитюдные исследования с целью выяснения, как указанные факторы и их сочетания помогут предотвратить неблагоприятные последствия для психологического благополучия подростка. Полученные данные могут быть использованы специалистами при создании и внедрении эффективных программ по предотвращению кибербуллинга и причиняемого им вреда.

1. Holfeld B., \& Grabe M. An examination of the history, prevalence, characteristics, and reporting of cyberbullying in the United States // Q. Li., D. Cross., \& P. K. Smith (Eds.). Cyberbullying in the global playground: Research from international perspectives. West Sussex : John Wiley \& Sons, 2012. P. 117-142.

2. Взрослые и дети в цифровом мире: когда онлайн встречается с офлайном : исслед. АО «Лаборатория Касперского» [Электронный ресурс]. 
URL: https://kids.kaspersky.ru/wp content/uploads/sites/2/2019/04/190402_Children_Russia_Report_Practics-1.pdf (дата обращения: 17.02.2020).

3. Аудитория интернета в России : проект Web Index [Электронный pecypc]. URL: https://webindex.mediascope.net/general-audience (дата обращения: 17.02.2020).

4. Забокрицкая Л. Д. Информационная культура современной молодежи: угрозы и вызовы виртуального социального пространства [Электронный ресурс] // Вестн. ПНИПУ. Социально-экономические науки. 2017. № 4. URL: https://cyberleninka.ru/article/n/informatsionnaya-kultura-sovremennoy-molodezhi-ugrozy-i-vyzovy-virtualnogo-sotsialnogo-prostranstva (дата обращения: 28.02.2020).

5. Жилавская И. В. Медиаобразование молодежи : монография. М. : РИЦ МГГУ им. М. А. Шолохова, 2013. 243 с.

6. Patchin J. W., \& Hinduja S. Bullies move beyond the schoolyard: A preliminary look at cyberbullying // Youth Violence and Juvenile Justice. 2006. № 4. P. 148-169.

7. Willard N.E. Cyberbullying and cyberthreats: Responding to the challenge of online social cruelty, threats, and distress. 2006. Research Press. doi:10.1037/e400292008-008. 320 p.

8. Kowalski R. M., Limber S. P., \& Agatston P. W. Cyber bullying: Bullying in the digital age. Malden, MA : Blackwell publishing, 2008. $294 \mathrm{p}$.

9. Williams K. R., \& Guerra N. G. Prevalence and predictors of Internet bullying // Journal of Adolescent Health. 2007. Vol. 41(6). P. 14-21.

10. Spears B. A., Taddeo C. M., Daly A. L. et al. Cyberbullying, help-seeking and mental health in young Australians: Implications for public health // International Journal of Public Health. 2015. Vol. 60(2). P. 219-226.

11. Health Behaviour in School-aged Children (HBSC) survey 2013/2014. Bullying among adolescents in the Russian Federation [Electronic resource]. URL: http://www.euro.who.int/_data/assets/pdf_file/0018/325512/HSBC-Fact-Sheet-Bullying-among-adolescents-in-the-Russian-Federation.pdf?ua=1 (accesed: 28.02.2020).

12. Отчет о деятельности Фонда Развития Интернет за 2018 год [Электронный ресурс]. URL:_http://www.fid.su/reports/fid-report-2018.pdf (дата обращения: 28.02.2020). 
13. Щипанова Д. Е. Результаты исследования кибербуллинга в образовательных организациях // Новые информационные технологии в образовании. 2016. С. 443-448.

14. Хломов К. Д., Давыдов Д. Г., Бочавер А. А. Кибербуллинг в опыте российских подростков [Электронный ресурс] // Психология и право. 2019. T. 9, № 2. C. 276-295. DOI:10.17759/psylaw.2019090219 (дата обращения: 28.02.2020).

15. Ybarra M. L., Diener-West M., \& Leaf P. J. Examining the overlap in Internet harassment and school bullying: Implications for school intervention // Journal of Adolescent Health. 2007. Vol. 41(6). P. 42-50.

16. Juvonen J, Gross E. F. Extending the school grounds? - bullying experiences in cyberspace // J. Sch. Health. 2008. № 78. P. 496-505. DOI: 10.1111/j.1746-1561.2008.00335.x

17. Зинцова А. С. Социальная профилактика кибербуллинга [Электронный ресурс] // Вестн. Нижегор. ун-та им. Н. И. Лобачевского. Сер. : Социальные науки. 2014. № 3 (35). URL: https://cyberleninka.ru/article/n/ sotsialnaya-profilaktika-kiberbullinga (дата обращения: 17.12.2019).

18. Agatston P., Kowaski R., \& Limber S. Students' perspectives on cyber bullying // Journal of Adolescent Health. 2007. № 41. P. 59-60.

19. Tokunaga R. S. Following you home from school: A critical review and synthesis of research on cyberbullying victimization // Computers in Human Behavior. 2010. Vol. 26(3). P. 277-287. DOI: 10.1016/j.chb. 2009.11.014

20. Cassidy W., Faucher C., \& Jackson M. Cyberbullying among youth: A comprehensive review of current international research and its implications and application to policy and practice // School Psychology International. 2013. Vol. 34(6). P. 575-612. DOI: 10.1177/0143034313479697

21. Sourander A., Klomek A. B., Ikonen M. et al. Psychosocial risk factors associated with cyberbullying among adolescents: a population-based study // Arch Gen Psychiatry. 2010. Vol. 67 (7). P. 720-728.

22. Machmutow K., Perren S., Sticca F., \& Alsaker F. D. Peer victimisation and depressive symptoms: can specific coping strategies buffer the negative impact of cybervictimisation? // Emotional and Behavioural Difficulties. 2012. Vol. 17(3-4). P. 403-420. DOI: 10.1080/13632752.2012.704310

23. Баранов А. А., Рожина С. В. Копинг-стратегии подростка в ситуации кибербуллинга [Электронный ресурс] // Вестн. Удмурт. ун-та. Сер. : Философия. Психология. Педагогика. 2016. № 2. URL: https://cyberleninka. 
ru/article/n/koping-strategii-podrostka-v-situatsii-kiberbullinga (дата обращения: 28.02.2020).

24. Jackson M., Cassidy W., \& Brown K. Out of the mouth of babes: Students' voice their opinions on cyber-bullying // Long Island Education Review. 2009. Vol. 8(2). P. 24-30.

25. Ortega R., Elipe P., Mora-Mercha'n J. A. et al. The emotional impact of bullying and cyberbullying on victims: A European cross-national study // Aggressive Behavior. 2012. № 38. P. 342-356. DOI: 10.1002/ab.21440.

26. Steffgen G., König A., Pfetsch J., Melzer A. Are cyberbullies less empathic? Adolescents' cyberbullying behavior and empathic responsiveness // Cyberpsychol Behav Soc Netw. 2011. Vol. 14(11). P. 643-648. DOI: 10.1089/ cyber.2010.0445

27. Mare'es N. von, \& Petermann F. Cyberbullying: An increasing challenge for schools // School Psychology International. 2012. № 33. P. 467-476. DOI: $10.1177 / 0143034312445241$.

28. Zhou Z., Tang H., Tian Y. et al. Cyberbullying and its risk factors among Chinese high school students // School Psychology International. 2013. № 34. P. 630-647. DOI: 10.1177/0143034313479692.

29. Patchin J. W., \& Hinduja S. Cyberbullying: An update and synthesis of the research // J.W. Patchin, \& S. Hinduja (Eds.). Cyberbullying prevention and response: Expert perspectives. New York, NY : Routledge, 2012. P. 13-35.

30. Солдатова Г. У., Чигарькова С. В., Дренёва А. А., Илюхина С. Н. Мы в ответе за цифровой мир: Профилактика деструктивного поведения подростков и молодежи в интернете : учеб.-метод. пособие. М. : КогитоЦентр, 2019. 176 с.

31. Lazarus R. S., Folkman S. Stress, Appraisal and Coping. N. Y., 1984. $218 \mathrm{p}$.

32. Сирота Н. А. Копинг-поведение в подростковом возрасте : дис.... д-ра мед. наук. СПб., 1994. 283 с.

33. Folkman S. Personal control and stress and coping processes: a theoretical analysis // J. Pers. Soc. Psychol. 1984. Vol. 46, № 4. P. 839-852. 


\section{МАЛЫЙ ГОРОД КАК ПРОСТРАНСТВО ОБРАЗОВАНИЯ: ПСИХОЛОГИЧЕСКИЕ АСПЕКТЫ ${ }^{*}$}

T. Ю. Быстрова

Потенциал малых городов, в том числе российских ${ }^{*}$, чрезвычайно редко рассматривается под психологическим углом зрения. По умолчанию подразумевается, что успешные проекты крупных городов могут масштабироваться на любой территории, но это далеко не так. Жители малых городов больше зависят от климата и погоды, календарного цикла сельскохозяйственных работ. Они более консервативны, обладают более высоким уровнем социального недоверия и вместе с тем сформированы в достаточно устойчивые местные сообщества, имеют ряд специфических стереотипов, таких как нежелание «высовываться», «быть, как все», стремление опираться на решение коллектива или другого человека [1]. В их повседневной культуре переплетаются элементы сельского и собственно городского укладов. Текущие цивилизационные изменения усложняют картину. В условиях активной урбанизации психологи фиксируют симптоматику латентной «культурной травмы», в том числе у жителей малых городов, все чаще копирующих образ жизни мегаполиса, но не имеющих возможности сделать это в желаемом объеме [2]. Парадоксальным образом эти стремления сопровождаются пассивностью и даже скрытым сопротивлением различным инновациям.

Крайности в отношении к месту связаны с тем, насколько человек демонстрирует свою реальную привязанность к нему. Специалисты отмечают, что жители могут гордиться местной историей,

* Исследование выполнено при финансовой поддержке РФФИ и Правительства Свердловской области в рамках научного проекта № 20-49-660009 «Индустриальное наследие Большого Екатеринбурга: методология изучения, принципы презентации, актуализация ценности».

** По данным 2010 г., в России существовал 781 город с населением до 50 тыс человек, где проживало около 10 \% всего населения страны. При этом в градостроительных документах параметры численности малых городов варьируются от 10 тыс. до 50 тыс. человек. 
но не всегда выражают свои чувства до тех пор, пока они не окажутся под угрозой [3]. Противоположная позиция наблюдается в туристических локациях, где имиджевая составляющая места отчуждается от носителей, превращаясь в продукт массовой торговли: история и ценности девальвируются.

Тем не менее именно эти люди являются носителями наиболее устойчивой версии российской и региональной ментальности, этнокультурных и других ценностей. Несмотря на относительно невысокий уровень информированности в области истории и культуры $^{* * *}$, они транслируют свои знания и отношение детям, близким, приезжающим. Свой социокультурный багаж они осознанно или непреднамеренно опредмечивают в среде городов, становящейся благодаря этому насыщенной кодами и смыслами, расшифровка которых становится важнейшим условием культурной динамики. Передача опыта, знаний, социальной памяти может происходить посредством не только письменных текстов, но и городской среды.

Трактовка города как образовательного пространства произведена рядом российских исследователей $[4,5]$, однако не в отношении малых городов, которые представляют собой отдельный социокультурный и урбанистический феномен [6], в ряде случаев дают образцы исторических городов либо так называемых культурных ландшафтов - территорий, где в концентрированном виде сохраняются традиции, ценности, ремесла этноса или региона [7]. Пока развитие этих городов еще довольно часто мыслится сугубо институционально [8], а экономические и инфраструктурные характеристики рассматриваются как залог их успешности, без учета такого важнейшего для современной урбанистики показателя, как качество жизни горожан [9]. Возможно, в силу этого, помимо общепризнанного их статуса в качестве «хранителей» культуры, в последние десятилетия они стали зонами ускоренного оттока жителей в крупные города и перехода от индустриального к постиндустриальному укладу. Закрытие или сокращение промышленного производства

*** Наш с М. В. Певной социологический опрос в 2018 г. в городах Березовском и Верхней Салде Свердловской области показал, что положительно на вопрос о том, знают ли они историю своего города, ответили 41 и $27 \%$ респондентов соответственно. Это почти в два раза ниже, чем в среднем по России. 
негативно сказалось не только на демографии, но и внешнем виде, благоустройстве этих городов, а также состоянии объектов наследия. Переставая быть промышленными центрами, многие малые города не становятся «полноценными местными центрами из-за отсутствия потенциала для развития малого бизнеса» [10, с. 128]. Эти процессы сопровождаются забвением истории, недооценкой значимости и красоты городов, деградацией территорий. Поскольку они имеют далеко идущие социально-экономические и культурные последствия, то чем раньше начать им противодействовать, тем больше шансов сохранить существующую систему расселения страны, снизить темпы урбанизации в крупных и крупнейших городах, сохранить культуру российской провинции.

О том, что для стабилизации и развития территории городов необходимы не столько финансы, сколько действия в области культуры и образования, первым заговорил в 1990-е гг. авторитетный британский урбанист Чарльз Лэндри, чья работа стала бестселлером во многих регионах мира [11]. Обобщая личный опыт проектов и подчеркивая неоднозначность современных городских процессов, он призывал отойти от унифицированных технологий городского развития и «подключить воображение», изменить характер взаимодействия администраций и городских сообществ, активизировать все коммуникативные процессы, привлекать к развитию городов представителей искусства и духовного производства, разрабатывать стратегию развития с учетом культурной и иной уникальности каждого места. За последние тридцать лет к этим установкам прибавилось понимание: а) горожан как неотъемлемой части города и его процессов; б) междисциплинарности и многослойности культурно-исторических городских проектов; в) историко-культурного наследия как драйвера городского развития [12]. Это видение расширялось усилиями самых разных специалистов, от архитекторов до музейных работников $[13,14]$. Постепенно выяснилось, что можно учить людей «читать» город, превращая его, в свою очередь, в разнообразные образовательные площадки. Познавательные туристические маршруты, «красная линия», граффити, фотовыставки под открытым небом, общественные пространства на бывших заводских территориях и другие практики широко рас- 
пространены в российских городах, они поддерживаются грантами и субсидиями. В сторону открытости, хотя и не без сопротивления, меняется и мышление специалистов, существовавших прежде довольно герметично, прежде всего градостроителей, архитекторов, работников музеев. В результате «город участия» («город 2.0.», «город 3.0.», «креативный город», «открытый город», «гибкий город») приходит на смену «городу частей»; ведущую роль играют культурные практики горожан, а крупные проекты все чаще предлагают осуществлять в несколько приемов (концепция поэтапного урбанизма - Incremental Urbanism). Ныне процесс существования города все чаще представляет собой специфический «городской проект» или систему проектов.

В 2010-е гг. в общественном сознании происходит отказ от модернизационной доктрины, с ее стремление заместить «старое» «новым». Проектировщики переходят от статичного мышления о городе или отдельном историческом объекте к динамическому, поскольку одной из их задач является «возвращение» объекта в городские процессы, (вос)создание связей между ним и остальными пространствами, событиями, людьми. Это возможно только при раскрытии горожанами (туристами, инвесторами) функционального и культурного потенциала объекта или территории, включая личные истории, особенности строительных технологий и др.

Одновременно с этим констатация одиночества и отчужденности горожан друг от друга и от территории приводит к разработке темы совместных городских практик, сообществ, вовлечения в проекты в самых разных формах. Так параллельно решаются задача преодоления автономности городского существования и задача досуга жителей. Соучаствуя тому или иному процессу, к примеру, восстановлению объектов историко-архитектурного наследия, люди узнают историю и берут ее под свою защиту, ибо, вложившись, они уже не чувствуют отчуждения от территории.

К сожалению, в России значимыми для себя люди чаще всего считают объекты дореволюционной истории, главным образом, культовые здания. Ценность и рациональность заводских цехов или общественных мест ими практически не признаются в силу того, что аксиологическая вертикаль классической парадигмы (где 
немногие признанные шедеврами объекты задают планку оценки всех остальных зданий и территорий) по-прежнему довлеет в массовом сознании россиян. В малых городах Свердловской области, к примеру, лишь около трети жителей признают ценность объектов, созданных в советский период и в современное время. Плохо поддаются оценке уникальные производственные процессы, технологии, не рефлексируется ценность самого труда. При этом в последние годы наблюдается рост интереса к местной истории, люди ищут сведения в интернете, хотят распространять информацию о своих городах в социальных сетях. Им импонирует участие в городских процессах. В меньшей степени эта тенденция распространяется на жителей отдаленных городов, тогда как приближенные к столице региона уже ощутили «новые веяния», поучаствовали в фестивалях, днях города, акциях в более крупных городах.

Соответственно, работы по благоустройству парков или набережных рек, получающие все большее распространение в малых городах России в 2020 г., должны учитывать эти механизмы и технологии для того, чтобы новые объекты не воспринимались как чужеродные и инаковые, а входили в кругозор горожан. Манна с неба, даже самая прекрасная, не порождает привязанности к ней, если человек не поучаствовал (переживал, осознавал, коммуницировал) в процессе ее возникновения или распространения.

Изменение в природе продуктов городского дизайна с 1990-х гг. связано не только с изменениями в идеологиях городского дизайна, но также и с изменениями в характере эксплуатации капитала. В 2000-е гг. на Западе выявилось противоречие между заинтересованностью международного капитала в инвестициях в городские проекты и непринятием населением городов интернационального, обезличивающего характера проектов, не учитывавших особенности места, его культуру [9]. Снижение заинтересованности проектировщиков в местных финансовых ресурсах имеет пределом отношение горожан к своей территории. Это отношение диктует отказ от типовых проектов. Признанный специалист городского развития Дж. Ланг отказывается называть «городским проектом» процесс, не предполагающий вовлечение горожан в трансформа- 
цию. Он прав, включая подобные действия в разряд «городского планирования» $[15$, р. 49$]$.

В свою очередь, работа в данном направлении в конкретном городе требует наличия инициативной группы, возможно, не располагающей собственными средствами, но привлекающей их и контролирующей их использование, а также проводящей конкурсы для вовлечения и активизации профессионалов. В современных российских условиях это могут быть гранты и субсидии, в том числе с привлечением спонсоров и софинансирования. Достижение долгосрочных результатов осуществляется через множественность краткосрочных проектов с небольшим бюджетом. Для их реализации часто требуются волонтеры, «вводящие» людей в проект и одновременно сокращающие бюджет проекта. Волонтеры обучают первую группу горожан, стремящихся в проект, создавая сетевой эффект взаимодействия. Примером может служить известный проект преобразования района фавел в Сан-Паулу, когда два инициатора проекта подготовили 10 волонтеров к графическим и художественным работам, а те, в свою очередь, задействовали других жителей фавел.

Ориентируясь на структуру кейс-стади малого города, предлагаемую М. В. Певной [10], обозначим основных участников процесса существования малого города как образовательного пространства, показывая психологические характеристики и качества каждого из них. Поскольку данная работа выполняется впервые, мы сосредоточимся на фиксации наиболее часто звучащих качеств. Часть гипотез требует дополнительной проверки данными социологических опросов или интервью.

Так или иначе, эффективность городских проектов зависит от коммуникаций между всеми участниками процесса, и психологические аспекты «чтения» города и раскрытия его потенциала в ходе создания новых объектов или пространств больше всего связаны с двумя моментами: а) умение участников говорить между собой; б) их способность взаимодействовать с городом.

Стейкхолдерами городских процессов являются следующие акторы: чиновники местной администрации, работники культурных и образовательных учреждений, активисты и инициаторы город- 
ских проектов, представители экспертного сообщества (краеведы, архитекторы, историки и др.), волонтеры, обычные горожане разных возрастов. В крупных городах у них больше «подсказок», навыков и возможностей. Перечислим, что препятствует их образовательным действиям в малых российских городах, опираясь в основном на эмпирические наблюдения, собранные в ходе исследования.

1. Чиновники местной администрации. Менталитет, общий для жителей малых городов, может привести к недооценке потенциала их города. Во многом бюрократический характер работы сопряжен с опасностью равнодушия к объектам и артефактам. Амбиции по поводу грантов или конкурсов способны сформировать потребительскую позицию, когда культурный текст города деформируется во имя краткосрочных выгод или показателей. Коммуникации с горожанами могут быть даже более активными, чем в крупных городах.

2. Работники учреждений культуры и образования. Знающие, компетентные люди, любящие свой город и редко стремящиеся «убежать» из него. Носители «духа места». Знакомы со множеством персоналий, историй, фактов. Как правило, не владеют современными методиками проектной работы. Не всегда ориентируются в новых тенденциях жизни городов. Могут с осторожностью относиться к новым практикам. Их знания зачастую либо не находят практического выхода, либо реализуются традиционными шаблонными способами (выставка в классической субъект-объектной парадигме преподнесения материала, мероприятие - а не событие - к какой-либо дате и т. п.). Эти люди могут выступать в роли местных экспертов.

3. Активисты и инициаторы городских проектов. Просвещенные и эмоционально вовлеченные люди, имеющие навыки командной работы, информированные о путях привлечения средств для раскрытия культурного потенциала места. Возраст может быть самым разным. Психологическая задача состоит в сохранении мотивации, настойчивости в достижении цели, стрессоустойчивости при взаимодействии с формальностями. То же касается и другой группы - волонтеров.

О специфике ментальности жителей малых городов сказано выше. Их коммуникации, с одной стороны, долгосрочны и устойчи- 
вы, с другой стороны - тяготеют к стабильности и герметичности. Они уже готовы размещать информацию о городе в интернете, но еще не знают либо не привыкли к публичным действиям.

Это необходимо учитывать всем, кто занимается развитием городов. Нужна корректировка методик, найденных в проектах, реализованных в крупных городах или мегаполисах. В условиях, когда отношение человека к месту его жизни становится важным социоэкономическим обстоятельством, необходимо искать специальные технологии приобщения человека к истории и культуре его города и последующего включения в городские активности.

1. Ковригина Г.Д. Специфика ментальности жителей малых городов Сибири // Урбанистика. 2017. № 4. С. 70-77.

2. Штомпка П. Социальное изменение как травма // Социол. исслед. 2001. № 1. С. 6-16.

3. Petrova P., Hristov D. Collaborative management and planning of urban heritage tourism: public sector perspective // International Journal of Tourism Research. 2014. Vol. 18, № 1. P. 1-9.

4. Мурзина И.Я. Региональное образовательное пространство: к вопросу об одной педагогической категории // Образование и наука. 2008. № 5. С. 51-59.

5. Порозов Р. Ю. Культурно-образовательное пространство города. Екатеринбург : УрГПУ, 2016. 174 с.

6. Глазычев В. Л. Представление о городе и технологии управления средовым развитием. Типология городов [Электронный ресурc]. URL: http://www.glazychev.ru/courses/1998-10-30_predstavlenie_o_gorode.htm (дата обращения: 02.10.2020).

7. Шишкина А. А. Культурный ландшафт: основные концепции // Вестн. Нижегор. ун-та. Сер. : Социальные науки. 2011. № 1 (21). С. 151-157.

8. Тургель И. Д. Монофункциональные города России: от выживания к устойчивому развитию. Екатеринбург : Рос. акад. гос. службы при Президенте РФ, Урал. акад. гос. службы, 2010. 519 с.

9. Зубаревич Н. В. Страна городов: теория и практика российской урбанизации // Стимулы, парадоксы, провалы. Город глазами экономистов : сборник / под науч. ред. В. Аузана. М. : Стрелка Пресс, 2015. С. 112-135. 
10. Певная М. В., Ларионова В.А. Культурно-историческое наследие малых городов: аспекты социологического исследования // Вестн. Сургут. гос. пед. ун-та. 2017. № 5 (50). С. 126-134.

11. Лэндри Ч. Креативный город. М. : Классика-XXI, 2006. 399 с.

12. Быстрова Т. Ю. Теоретико-методологическое обоснование понятия «культуральная регенерация территории» [Электронный ресурс] // Изв. Урал федер. ун-та. Сер. 1 : Образование, наука, культура. 2018. № 1. URL: http://elar.urfu.ru/bitstream/10995/60669/1/iurp-2018-174-13.pdf (дата обращения: 31. 01.2020).

13. Окольникова С. А. Интеграция культурного наследия в современный социокультурный контекст: региональная модель : автореф. дис. ... канд. культурологии. М. : б. и., 2011. 30 с.

14. Rehberg M., Hoffmann A. Methoden räumlicher Planung und partizipative Technologievorausschau - Chancen einer interdisziplinären Anknüpfung? [Electronic resource] // Raumentwicklung 3.0 - Gemeinsam die Zukunft der räumlichen Planung gestalten. URL: http://shop.arl-net.de/media/direct/pdf/ ab/ab_008/ab_008_19.pdf

15. Lang J. Urban Design: A typology of Procedures and Products. Illustrated with over 50 Case Studies. Routledge, 2005. 421 p. 


\section{ПРОБЛЕМА ПОДРОСТКОВОГО БУЛЛИНГА: АКТУАЛЬНЫЕ НАПРАВЛЕНИЯ СОВРЕМЕННЫХ ИССЛЕДОВАНИЙ И ОРГАНИЗАЦИЯ ПОМОЩИ}

Е. Н. Волкова

A. А. Реан

И. В. Волкова

В последнее время и в России, и во всем мире наблюдается рост количества публикаций, в которых феномен буллинга находится в центре внимания авторов: если в конце 70-х гг. XX в. вслед за работами норвежского ученого Д. Олвеуса [1] в России вышло несколько работ, посвященных школьным издевательствам и школьной травле, то сегодня только русскоязычная база научных исследований, размещенная в электронной библиотеке elibrary.ru, насчитывает свыше 2 тыс. публикаций на эту тему. Однако растущее внимание исследователей к подростковому буллингу отнюдь не коррелирует с ростом понимания закономерностей его возникновения и распространения. Следует заметить, что большинство публикаций посвящено скорее констатации актуальности проблемы буллинга, чем выявлению тех его особенностей, которые позволили бы разработать и внедрить эффективные программы помощи и профилактики. Между тем востребованность таких программ трудно переоценить: и специалисты системы образования - педагоги и психологи, и сотрудники правоохранительных органов, и родители, и, конечно, сами подростки нуждаются в таких программах.

Сегодня в мире существует много программ профилактики буллинга и помощи детям, пострадавшим от него. Широко известны и успешно работают программы с доказанной эффективностью: Olweus Bullying Prevention Program [2], проект KiVa (Kiusaamista Vastaan, «Против буллинга») [3]. Кроме того, был представлен обширный систематический обзор и метаанализ эффективности программ профилактики школьного буллинга [4]. Эта работа обновила результаты предыдущих исследований, проведенных Maria M. Ttofi, David P. Farrington и опубликованных в 2011 г. [5], и интегрировала значительную часть публикаций о программах вмешательства 
и профилактики и их эффективности, размещенных в онлайновых базах данных Web of Science, PsychARTICLES, PsychINFO, EMBASE, DARE, ERIC, Google scholar и Scopus.

Однако прямо использовать эти программы не всегда возможно. Дело в том, что подростковый буллинг детерминирован особенностями культуры и среды, в которой он разворачивается. Поэтому эффективность программ помощи и профилактики будет во многом зависеть от культурного и социального контекста жизни подростков.

Что это означает для решения вопроса о разработке и применении эффективных программ предотвращения буллинга и помощи его жертвам? Выявленные в научных исследованиях закономерности подросткового буллинга будут выступать определенной рамкой для проектирования программ помощи и профилактики. В исследованиях о влиянии факторов среды на подростковый буллинг, о влиянии особенностей культуры [6], групповых эффектов [7], школьного климата [8] показано, что общественные установки, доминирующие ценности, культура семейных отношений, школьная атмосфера оказывают непосредственное влияние на число обидчиков и жертв буллинга [9]. Культурный контекст жизни подростка и средовые влияния общества в целом, сообщества школы, семьи, группы сверстников будут существенным образом влиять на поведение подростков. Поэтому разработка эффективных программ помощи и профилактики в России должна опираться на исследования, учитывающие эту специфику, начиная от культурной адаптации международных измерительных инструментов и заканчивая анализом культурных традиций жизни и деятельности российских подростков XXI в.

В мире сегодня исследования проблемы буллинга ведутся в нескольких основных направлениях. Мы попытаемся дать краткое описание полученных результатов этих исследований, чтобы они могли служить отправной точкой для проектирования будущих программ вмешательства и предотвращения буллинга.

Первое направление исследований связано с дефиницией основного понятия, с выявлением дифференцирующих характеристик буллинга в целом и подросткового буллинга в частности, его отличия от других форм деструктивного поведения. Важной и в на- 
учном, и в практическом отношении является задача определения содержания основного понятия «подростковый буллинг», выявления его специфических особенностей, отличия подросткового буллинга от такового в других возрастных группах. Также необходимо различать агрессивное поведение и подростковый буллинг, с одной стороны, школьные драки и буллинг - с другой.

Сюда же относятся исследования, направленные на выявление диагностических критериев подросткового буллинга и разработку на этой основе программы и инструмента мониторинга подросткового буллинга в образовательных учреждениях.

Подавляюее большинство исследователей подросткового буллинга отмечают, что самая важная особенность подросткового буллинга - его групповой характер. Вне группы и без нее нападения на жертву теряют значительную долю смысла, если не исключают его совсем. Даже в тех редких случаях, когда события разворачиваются в диаде «обидчик - жертва», группа сверстников обязательно присутствует, если не физически, то виртуально. Свидетели являются чрезвычайно важными действующими лицами как в сдерживании деморализующих и разрушительных воздействий издевательств, так и в усилении и даже провоцировании их.

В других исследованиях акцент делается на отличие буллинга от спонтанного проявления агрессии, школьной драки тем, что нападение носит умышленный характер и этот умысел связан с намерением подчинить, унизить жертву [10-12]. Это обстоятельство подчеркивается практически во всех исследованиях, начиная с классической работы Д. Олвеуса [1].

В определении Е. Роланда [13] обращается внимание на еще одну важную особенность буллинга - неравенство сил обидчика и жертвы и невозможность для жертвы вследствие этого покинуть ситуацию насилия. Это может быть физическое неравенство, социальное превосходство и даже давление ситуации на жертву в целом. Так, например, ребенок-жертва не может не ходить в школу, которая для него является опасным местом. Пропуски занятий, прогулы, опоздания, являющиеся средством оттягивания неприятных и даже трагических ситуаций в школе, часто воспринимаются как 
дисциплинарное нарушение и тем самым еще больше усугубляют ситуацию.

Таким образом, критериальной основой для идентификации буллинга и его отличия от других форм деструктивного поведения следует считать неоднократность и/или периодичность насильственных ситуаций; умысел, намеренность нанесения вреда; собственно причинение физического или психологического вреда жертве, ее эмоциональному состоянию, здоровью, благополучию; неравенство сил у обидчика и жертвы, злоупотребление силой или влиянием, когда обидчик использует свое фактическое или кажущееся превосходство для того, чтобы причинить вред жертве; невозможность для жертвы покинуть (или избежать в будущем) ситуацию буллинга. Эти критерии позволяют, на наш взгляд, отличать подростковый буллинг от других форм деструктивного поведения и могут быть использованы в качестве основы для разработки программ мониторинга ситуации буллинга в школе.

Второе направление исследований - оценка распространенности буллинга. Опубликованные данные по разным странам свидетельствуют, что от 6 до 35 \% учащихся являются участниками буллинга. Исследование распространенности буллинга среди одиннадцати-пятнадцатилетних детей, проведенное в 27 странах [13], показывает, что в зависимости от страны приблизительно от 5 до 30 \% мальчиков и от 2 до 20 \% девочек регулярно выступают обидчиками в буллинге. Жертвами при этом становятся от 5 до 28 \% мальчиков и от 3 до 27 \% девочек. Согласно данным российских исследованиий, 29 \% старшеклассников подвергались буллингу чаще 2 раз в месяц и 30 \% старшеклассников неоднократно выступали обидчиками [14]. Исследования, выполненные на подростковых выборках, показывают, что от 40 до 50 \% российских подростков сталкивались с различными формами буллинга [15]. В других исследованиях эта цифра достигает 68,6 \%, при этом 31,2 \% подростков являются свидетелями буллинга, 22,2 \% - жертвами, 6,3 \% - обидчиками и $8,9 \%$ - обидчиками-жертвами [16].

По данным PISA-2018, в странах Организации экономического сотрудничества и развития (куда входит и Российская Федерация) в среднем 37 \% школьников сообщают о том, что подвергались 
буллингу [17]. Россия отличается печально высокими показателями распространенности школьной травли; чаще, по данным этого исследования, школьная травля встречается в Иордании, Доминиканской Республике, Марокко, Индонезии, Брунее и на Филиппинах. Наиболее частыми формами буллинга в российской школе являются вербальная и социальная агрессия $[18,15]$.

Как оценить распространенность буллинга в школе? Какие цифры представляются более реалистичными и почему?

Несколько особенностей подросткового буллинга весьма затрудняют ответ на эти вопросы. Во-первых, чаще всего оценка распространенности буллинга основана на оценке количества жертв, так как предполагается по умолчанию, что эта группа детей испытывает самую тяжелую травму в результате нападения. Между тем это не совсем так. В исследованиях, направленных на изучение последствий буллинга, отмечается, что действительно у жертв подросткового буллинга выражена симптоматика тревожных и депрессивных расстройств [19], повышается риск суицидального поведения [20], увеличивается количество случаев самоповреждающего поведения $[19,21,9]$. При этом существуют исследования, показывающие, что выраженная депрессивная симптоматика и суицидальные мысли наблюдаются как у жертв буллинга, так и у подростков-обидчиков. Причем сравнение данных, полученных в исследованиях с кросссекционным и лонгитюдным дизайнами показало, что у мальчиков суициидальные намерения опосредованы психологическими нарушениями и ролью в буллинге: для мальчиков-обидчиков наличие психологических нарушений ассоциировано с суицидальными намерениями в более старшем возрасте. Для девочек-жертв даже в случае отсутствия психологических нарушений суицидальные мысли и суицидальные нарушения весьма вероятны в старших возрастах [22]. И подростки-обидчики, и подростки жертвы, и подростки-свидетели буллинга характеризуются широким спектром эмоциональных и поведенческих проблем и нарушений и в этом смысле скорее похожи друг на друга и отличаются от тех подростков, кто не был вовлечен в ситуацию буллинга ни в какой роли [23].

Другой отличительной особенностью подросткового буллинга является его неустойчивый, ситуативный характер. Исследования 
многих авторов показали, что ролевая структура в буллинге может изменяться: в разных ситуациях (в разных коллективах, в течение учебного года, в новом классе) подросток может быть то жертвой, то преследователем, то свидетелем буллинга [24, 25]. Особая форма буллинга - кибербуллинг - представляет собой способ реагирования подростка на ситуацию буллинга либо для закрепления роли обидчика, если ребенок уже был буллером в школе, либо для освоения роли обидчика в киберпространстве, если ребенок был жертвой школьного буллинга или имел неопределенную, двойственную позицию обидчика-жертвы [16].

Высокая травматичность ситуации буллинга для всех его участников и неустойчивость ролевой позиции в подростковом буллинге делает оценку распространенности буллинга на основе анализа количества жертв (как, впрочем, и других участников) нереалистичной или, по крайней мере, ситуативной. Сравнение распространенности буллинга теряет свою доказательность. Возможным решением этого вопроса может быть использование реверсивного показателя - учет количества детей, не участвующих в буллинге ни в какой роли. Мы полагаем, что для мониторинга и сравнительных исследований распространенности реверсивный показатель более информативен.

Вместе с тем в кросс-секционных исследованиях, в исследованиях лонгитюдного дизайна при оценке эффективности конкретной программы вмешательства анализ количества жертв, обидчиков, обидчиков-жертв, свидетелей сохраняет свою актуальность в зависимости от целевой направленности программы.

Третьим важным направлением исследований является изучение ролевой структуры подросткового буллинга и индивидуальных и личностных характеристик его участников. В структуре подросткового буллинга выделяют жертв, обидчиков, свидетелей буллинга и подростков, которых относят к категории «жертвы-обидчики», это те подростки, которые могут выступать в разных ролях в разных ситуациях буллинга. Как мы уже отмечали, ролевая структура в подростковом буллинге неустойчива, причем в младшем подростковом возрасте эта неустойчивость выше. Обращает на себя внимание то обстоятельство, что разные авторы сообщают разные данные о количестве жертв, жертв-обидчиков и свидетелей буллинга. При 
этом вариабельность значений может иметь диапазон от 3 до $60 \%$. Разное количество свидетелей буллинга можно объяснить совокупным влиянием личностных и средовых факторов в конкретной школе на ситуацию буллинга [18]. Однако количество подростковобидчиков, выступавших только в этой роли, довольно устойчиво и чаще всего составляет около 8-10 \% детей в разных исследованиях.

В российских исследования отмечается, что подросткам-обидчикам свойственны некоторые общие особенности. Они характеризуются средними значениями уровня психологического благополучия, способны ставить и достигать жизненные цели, формировать позитивные отношения с другими, способны противостоять влиянию других и влиять на окружающих [18]. У них высокий уровень удовлетворенности общением, они авторитарны, обладают высокой самооценкой и уровнем притязаний $[26,27]$. Подростки-обидчики отличаются высоким уровнем готовности к проявлению физической агрессии [28].

Российские исследователи подростков-жертв буллинга отмечают, что эти подростки имеют низкий социометрический статус в классе и низкий уровень удовлетворенности общением. Низкая самооценка у них сочетается с высоким уровнем притязаний и высоким уровнем тревожности $[26,27]$. У жертв и жертв-обидчиков показатели по всем шкалам благополучия ниже, чем у других участников, особенно в отличие от обидчиков. Возможно, опыт переживания буллинга негативно сказывается на всех сферах благополучия жертвы, причем особенно страдают коммуникативные способности и способности прогнозировать как личные отношения, так и собственное будущее.

Ключевыми субъектами в подростковом буллинге выступают его свидетели: именно эта группа наиболее многочисленна, разнородна по своим личностным характеристикам и наиболее влиятельна [29]. Свидетели могут занимать активную и пассивную позицию в буллинге. Помощники обидчиков - это, как правило, те ребята, которые не пользуются уважением в классе, они имеют невысокий социометрический статус в классном коллективе, у них средний уровень самооценки и притязаний, но при этом очень велика потребность во власти и влиянии с доминированием авторитарной 
позиции во взаимодействии. Свидетели - защитники жертв - это, как правило, ребята с высоким и очень высоким социометрическим статусом в группе, которые умеют и любят общаться с другими, с высокой, но адекватной самооценкой. Подростки с пассивной наблюдательной позицией отличаются высоким уровнем осознанности межличностных отношений и толерантностью $[30,26]$.

Больше всего трудностей в школе испытывают жертвы и жертвы-обидчики: они сталкиваются с эмоциональными проблемами, с проблемами взаимоотношений со сверстниками, проблемами поведения. При этом жертвы достаточно хорошо знают принятые нормы поведения и подчиняются им. Жертвы-обидчики, наоборот, отличаются гиперактивностью и, возможно, взрывной немотивированной агрессией. Они достаточно тревожны и снимают эмоциональное напряжение путем агрессивных всплесков. Для обидчиков основными проблемами являются поведение в школе, соблюдение школьной дисциплины и гиперактивность. Они стремятся и умеют доминировать над сверстниками. Свидетели часто демонстрируют просоциальное поведение, они хорошо умеют адаптироваться и избегать конфликта [18].

Фактор пола оказывается существенным при изучении подросткового буллинга. Фактически во всех исследованиях подчеркивается более активная вовлеченность мальчиков в буллинг как в роли жертвы, так и в роли обидчика. Девочки чаще становятся свидетелями буллинга $[31,18,15]$. Выступая обидчиками, мальчики чаще, чем девочки, используют непосредственные формы буллинга, например, угрозы, побои, порчу вещей, тогда как девочки чаще исключают из группы, распространяют слухи и манипулируют мнением других о жертве [18]. Важно подчеркнуть, что пол ребенка может определять предрасположенность подростка к вовлечению в ситуацию травли и может выступать индикатором роли, которую, вероятно, подросток покажет в буллинговой ситуации.

Четвертое направление исследований связано с изучением влияния семьи и школы на подростковый буллинг. Семья, как фактор противостояния школьному буллингу, изучается в контексте анализа системы отношений между ее членами, последовательности наказаний и в целом системы воспитания или ее отсутствия, отношения 
к насилию, принятых в семье способов разрешения конфликтов. Факторами буллинга выступают формальный родительский контроль и критика детей, запрет на проявление эмоций и слабости [32]. В качестве фактора-протектора подчеркивается важность материнской поддержки и включенности [33].

Отсутствие родительского внимания, теплых доверительных отношений, заботы, дистанцированность от детей и их проблем - все то, что характерирует дисфункциональность детско-родительских отношений, повышает риск для ребенка стать обидчиком в буллинге. Агрессивное поведение родителей в семье по отношению друг к другу и к другим людям также стимулирует агрессивное поведение ребенка [34]. Так, дети, которые наблюдали, как отец проявляет жестокость к матери или как мать проявляет жестокость к отцу, с большей вероятностью будут обидчиками в буллинге, чем те, у кого не было подобного опыта [35]. Привыкая рассматривать насилие и применение силы как единственный и/или наиболее подходящий способ выяснить отношения или добиться поставленной цели, подросток осваивает эту стратегию для самоутверждения в группе сверстников [36]. Кроме паттернов агрессивного поведения в семье имеет значение непоследовательность в воспитании детей, когда родители то игнорируют негативное поведение ребенка, то вдруг наказывают за агрессивное или любое неправильное поведение, а то вдруг и поощряют его [37]. Влияние социально-экономического статуса семьи на вероятность стать обидчиком неоднородны: в одних случаях доказывается, что этого влияния нет [32], в других показано, что бедность и социальное неравенство вносят существенный вклад в психологическое неблагополучие старшеклассника и в актуализацию распространения буллинга [15].

Как и семья, школа и школьная среда могут выступать провоцирующими и протективными факторами подросткового буллинга. Чаще всего буллинг происходит на школьной площадке во время перемены и после уроков, в коридоре, в классе в присутствии учителя и в его отсутствие, в туалете, в столовой. Учителя склонны объяснять причину буллинга личностными особенностями подростков и особенностями воспитания детей, а не связывать это с атмосферой школы, школьными нормами, собственным поведением $[38,18]$. 
Порой учителя используют буллинг как инструмент поддержания дисциплины. Считая самой распространенной и опасной физическую форму буллинга, уделяя меньше внимания таким формам, как клевета, распространение слухов, принуждение, порча имущества, они видят источники буллинга во внешности, конфликтности или социальном статусе жертвы. Часто учителя предпочитают не вмешиваться во внутренние дела класса [18]. Любопытно, что при этом сами подростки-жертвы объясняют случившее с ними не столько особенностями их собственной внешности или историей отношений с обидчиком, сколько поведением учителя. Подростки-жертвы считают, что учителя демонстрируют по отношению к ним особую позицию или указывают на экономическое положение или другие особенности семьи жертвы. Обидчики при этом склонны объяснять свое поведение как поведением жертвы, так и особенностями взаимоотношений жертвы и учителя: они обвиняют жертв в доносах учителям, игнорировании или передаче сплетен, частых ссорах с другими, высокомерии.

Масштабное исследование отношения подростков к школе, проведенное в 40 странах мира [39], показало, что роль жертвы буллинга и нарушенные отношения с одноклассниками прочно ассоциированы. Нарушение отношений с учителем, в частности, формализация этих отношений отличает подростков-обидчиков.

В нашем исследовании мы рассматривали влияние стиля педагогического общения на ситуацию буллинга в школе и показали, что преобладание в педагогическом коллективе учителей с доброжелательным отношением и одновременно с высоким уровнем контроля и вовлеченности в школьную жизнь способствует снижению числа жертв, обидчиков-жертв и свидетелей буллинга среди учеников, в то время как другие стили педагогического общения не способствуют предотвращению буллинга [40].

В заключение подчеркнем еще раз высокую опосредованность буллинга факторами культуры. Из этого следует признание необходимости разработки программ помощи и профилактики адресно для российских условий. Для этого не хватает современных исследовательских данных, полученных на российских выборках. Сегодня мало изучены влияние особенностей семьи в совокупности 
ее ценностных характеристик, социально-демографических и социально-экономических параметров, социально-психологических особенностей и особенностей детско-родительских, супружеских, детско-детских и межпоколенных отношений на структуру и характер подросткового буллинга. Не раскрыто в полной мере влияние школьной среды - социально-психологического климата школы, характера межличностных отношений в педагогическом и детском коллективах, стиля педагогической деятельности и общения. Программы развития профессиональных компетенций педагогов для прекращения буллинга, разработанные вне понимания этих закономерностей, окажутся неэффективными. Недостаточно изучено сочетанное влияние личностных и средовых факторов подросткового буллинга, особенно в зависимости от того, какую позицию занимает подросток в ситуации буллинга: жертвы, обидчика или свидетеля. Мало известны социально-психологические и личностные особенности свидетелей буллинга, в частности, мотивация подростков-свидетелей и возможности ее трансформации в социально-конструктивном направлении.

Решение этих групп вопросов, организация специальных исследований оказывается принципиальным моментом при разработке программ профилактики буллинга и программ организации помощи участникам буллинга в образовательной среде.

1. Olweus D. Aggression in the schools: Bullies and whipping boys. L., UK: Hemisphere, 1978.

2. Limber S. P. Implementation of the Olweus Bullying Prevention Program in American Schools: Lessons Learned from the Field // Espelage D. L., Swearer S. M. (Eds.). Bullying in American Schools: A Social-Ecological Perspective on Prevention and Intervention. Mahwah, NJ : Lawrence Erlbaum Associates, 2004. P. 351-363.

3. Salmivalli C., Garandeau C., Veenstra R. KiVa antibullying program: Implications for school adjustment // Ladd G., Ryan A. (Eds.) Peer Relationships and Adjustment at School. Charlotte, NC: Information Age Publishing, 2012. P. 279-307.

4. Gaffney H., Ttofi M. M., Farrington D.P. Evaluating the effectiveness of school-bullying prevention programs: An updated metaanalytical review // Aggression and Violent Behavior. 2018. doi:10.1016/j.avb.2018.07.001 
5. Ttofi M. M., Farrington D. P. Effectiveness of school-based programs to reduce bullying: A systematic and meta-analytic review // Journal of Experimental Criminology. 2011. № 7. P. 27-56.

6. Собкин В.С., Смыслова М. М. Буллинг в стенах школы: влияние социокультурного контекста (по материалам кросскультурного исследования) // Социальная психология и общество. 2014. Т. 5, № 2. С. 71-86.

7. Бочавер А. А., Хломов К. Д. Буллинг как объект исследований и культурный феномен // Психология : журн. Высш. шк. экономики, 2013. Т. 10, № 3 .

8. Новикова М. А., Реан А. А. Влияние школьного климата на возникновение травли: отечественный и зарубежный опыт исследования // Вопр. образования. 2019. № 2. doi: 10.17323/1814-9545-2019-2-78-97

9. Cook C. R., Williams K. R., Guerra N. G. et al. Predictors of bullying and victimization in childhood and adolescence: A meta-analytic investigation // School Psychology Quarterly. 2010. № 25(2). P. 65-83. doi:10.1037/a0020149

10. Heinrichs R. R. A whole-school approach to bullying: Special considerations for children with exceptionalities // Intervention in School and Clinic. 2003. № 38(4). P. 195-204.

11. Obermann M.-L. Moral disengagement among bystanders to school bullying // Journal of School Violence. 2011. № 10(3). P. 239-257.

12. Roland E. Bullying: the Skandinavian research tradition // Lane D. A., Tattum D. P. Bullying in schools. Stroke-on-Tent : Trentham, 1989. P. 21-32.

13. Molcho M., Craig W., Due P. et al. HBSC Bullying Writing Group. Cross-national time trends in bullying behavior 1994-2006: findings from Europe and North America // International Journal of Public Health. 2009. № 54. P. 1-10.

14. Петросяни В.Р. Психологическая характеристика старшекласников, участников буллинга в образовательной среде, и их жизнестойкость : дис. ... канд. психол. наук. СПб., 2011.

15. Реан А.А., Новикова М. А. Буллинг в среде старшеклассников: распространенность и влияние социо-экономических факторов // Мир психологии : науч.-метод. журн. 2019. Т. 97, № 1. С. 165-177.

16. Волкова Е.Н., Волкова И. В. Кибербуллинг как способ социального реагирования подростков на ситуацию буллинга // Вестн. Минин. ун-та. 2017. № 3 (20). C. 17.

17. PISA 2018 Results. Combined Executive Summaries: What School Life Means for Students' Lives. 2019. Vol. 3. 
18. Волкова Е. Н., Волкова И. В., Скитневская Л. В. Подростковый буллинг: результаты теоретических и эмпирических исследований / Нижегор. гос. пед. ун-т имени Козьмы Минина. Н. Новгород, 2017.

19. Fekkes M., Pijpers F. I. M., \& Verloove-Vanhorick S. P. Bullying behavior and associations with psychosomatic complaints and depression in victims // The Journal of Pediatrics. 2004. № 144(1). P. 17-22. doi:10.1016/j. jpeds.2003.09.025

20. Espelage D. L., Holt M. K. Suicidal ideation and school bullying experiences after controlling for depression and delinquency // Journal of Adolescent Health. 2013. № 53. P. 27-31.

21. Польская Н. А. Взаимосвязь показателей школьного буллинга и самоповреждающего поведения в подростковом возрасте // Психологическая наука и образование. 2013. Т. 18, № 1. С. 39-49.

22. Klomek A. B., Sourander A., \& Gould M. The association of suicide and bullying in childhood to young adulthood: a review of cross-sectional and longitudinal research findings // The Canadian Journal of Psychiatry. 2010. № 55(5). P. 282-288. doi:10.1177/070674371005500503

23. Rivers I., Poteat P. V., Noret N., Ashurst N. Medway NHS and social care partnership trust. observing bullying at school: the mental health implications of witness status // School Psychology Quarterly. 2009. Vol. 24, № 4.

24. Schäfer M., Korn S., Brodbeck F. C. et al. Bullying roles in changing contexts: The stability of victim and bully roles from primary to secondary school // International Journal of Behavioral Development. 2005. № 29(4). P. 323-335. doi: 10.1177/01650250544000107

25. Maunder R. E., Crafter S. School bullying from a sociocultural perspective // Aggression and Violent Behavior. 2018. № 38. P. 13-20. doi:10.1016/j. avb.2017.10.010

26. Глазман О. Л. Психологические особенности участников буллинга // Изв. Рос. гос. пед. ун-та им. А. И. Герцена. 2009. № 105. С. 159-165.

27. Бутенко В.Н., Сидоренко О. А. Буллинг в школьной образовательной среде: опыт исследования психологических особенностей «обидчиков» и «жертв» // Вестн. Краснояр. гос. пед. ун-та им. В. П. Астафьева. 2015. № 3 (33). С. $138-143$.

28. Реан А.А., Коновалов И. А. Проявление агрессивности подростков в зависимости от пола и социально-экономического статуса семьи // Нац. психол. журн. 2019. № 1 (33). С. 23-33. 
29. Rodkin P. C., Espelage D. L., Hanish L. D. A relational framework for understanding bullying: developmental antecedents and outcomes // American Psychologist. 2015. Vol. 70. № 4.

30. Гусейнова Е. А., Ениколопов С. Н. Влияние позиции подростка в буллинге на его агрессивное поведение и самооценку [Электронный ресурс] // Психол.-пед. исслед. 2014. № 2. С. 246-256. doi:10.17759/psyedu.2014060221.

31. Silva M. A., Pereira B., Mendonça D. et al. The involvement of girls and boys with bullying: an analysis of gender differences // International Journal of Environmental Research and Public Health. 2013. № 10(12). P. 6820-6831. https://doi.org/10.3390/ijerph10126820

32. Olweus D. Familial and temperamental determinants of aggressive behavior in adolescent boys: A causal analysis // Developmental Psychology. 1980. № 6 (16). P. 644-660.

33. Воликова С. В., Калинкина Е. А. Детско-родительские отношения как фактор школьного буллинга // Консультативная психология и психотерапия. 2015. № 4 (88). С. 138-161.

34. Olweus D. Bully/Victim Problems in School. Facts and Intervention // European Journal of Psychology of Education. 1997. № 12. P. 495-510.

35. Baldry A.C. Bullying in schools and exposure to domestic violence // Child Abuse \& Neglect. 2003. № 27. P. 713-732.

36. Dishion T. J., Tipsord J. M. Peer contagion in child and adolescent social and emotional development // Annual review of psychology. 2011. № 62. P. 189-214. doi:10.1146/annurev.psych.093008.100412

37. Бэрон Р., Ричардсон Д. Агрессия / пер. с англ. С. Меленевской, Д. Викторовой, С. Шпак. СПб. : Питер, 2014.

38. Лейн Д. А., Миллер Д. А., Лейн Э. Школьная травля (буллинг) // Детская и подростковая психотерапия. СПб. : Питер, 2001.

39. Harel-Fisch Y., Walsh S.D., Fogel-Grinvald H. et al. Negative school perceptions and involvement in school bullying: A universal relationship across 40 countries // Journal of Adolescence. 2011. № 34. P. 639-652.

40. Волкова И. В. Подростковый буллинг и стиль общения педагога // Научное мнение. 2017. № 5. С. 56-63. 


\section{ПРОСОЦИАЛЬНОЕ ПОВЕДЕНИЕ И ПСИХОЛОГИЧЕСКОЕ БЛАГОПОЛУЧИЕ УЧАЩЕЙСЯ МОЛОДЕЖИ*}

П. А. Кисляков

Е. А. Шмелева

Современная социальная и образовательная политика направлена на обеспечение комфортной и безопасной образовательной среды. Психологическая безопасность обучающихся является одним из критериев эффективности образовательного процесса. Под обеспечением психологической безопасности личности следует понимать комплекс мер, направленных на сокращение внутренних и внешних факторов риска, консолидацию психологических ресурсов личности, способствующих появлению и поддержанию состояния психологической безопасности, что приводит к повышению адаптационных возможностей, результативности деятельности, положительному отношению к окружающей среде, снижению уровня агрессивного поведения и насильственных действий в межличностном взаимодействии, переживанию чувства защищенности и психосоциального благополучия $[1,2]$.

Здоровое чувство безопасности (благополучия) является одним из базовых ощущений нормального человека. Дети лучше учатся, когда они психологически благополучны. Психологическое благополучие учащихся связывают с удовлетворенностью жизнью и способностью совладания со стрессом. С точки зрения позитивной психологии субъективное благополучие является важным конструктом в просоциальном развитии детей школьного возраста. Психологическая безопасность выступает основанием психологического благополучия личности [3]. Просоциальное поведение ведет к хорошему социальному самочувствию человека посредством рефлексии.

Психосоциальное благополучие определяется как совокупность индивидных и социальных предпосылок, обеспечивающих лично-

* Исследование выполнено при финансовой поддержке РФФИ в рамках научного проекта № 18-313-20001 «Психологические механизмы и факторы развития безопасного просоциального поведения личности».

(C) Кисляков П.А., Шмелева Е.А., 2020

491 
сти необходимую меру устойчивости, целостности и последовательности в разрешении противоречий, преодолении препятствий в сложных жизненных обстоятельствах. Категория благополучия согласуется с такими показателями, как позитивный стиль жизни, эмоциональный комфорт, адаптация в социальной среде, саморегуляция поведения, взаимоотношение с окружающими, противостояние факторам социального риска [4].

В соответствии с личностно-деятельностным подходом, определяющим условием обеспечения психологической безопасности и развития гармоничной, нравственно-совершенной, социальноактивной, профессионально-компетентной и саморазвивающейся личности является многоплановая деятельность или совокупность разных видов деятельности. Одним из таких направлений деятельности может быть просоциальная активность, т. е. бескорыстное поведение, которое приносит пользу людям и обществу.

Диапазон определений просоциального поведения достаточно широк, в частности, он включает:

- волевое поведение, направленное на благо других, которое имеет очевидную важность для качественного взаимодействия между людьми и группами;

- поведение, обладающее позитивными социальными последствиями и привносящее вклад в физическое и психологическое благополучие других людей;

- действия, приносящие пользу другим людям, а также способы реагирования на людей, которые проявляют симпатию, сотрудничество, помощь, содействие, альтруизм;

- позитивно оцениваемые межличностные действия, соответствующие культурным и социальным стандартам. Объектом просоциального поведения выступают не абстрактные организации или люди вообще, а конкретные люди, столкнувшиеся с различного рода проблемами (например, голодающие, неимущие, жертвы природных катаклизмов и т.п.);

- выполнение принятых в данном обществе моральных норм (одна из наиболее простых форм нравственного требования) [5].

Просоциальное поведение является системно-личностным социально-биологическим конструктом. На биологическом уровне 
просоциальное поведение детерминируется генетическими характеристиками и направлено на сохранение рода. Эмоциональной основой просоциального поведения выступает эмпатия. На социальном же уровне просоциальное поведение поддерживается такими нормами, как норма социальной ответственности (побуждает человека к оказанию помощи тем, кто в этом нуждается), норма социальной взаимности (люди должны помогать тем, кто помогает им), норма социальной справедливости (правила в отношении честного и справедливого распределения ресурсов) [6].

Просоциальное поведение формируется в дошкольном и младшем школьном возрасте и продолжает развиваться в среднем детстве, подростковом и юношеском возрасте. Поэтому перед различными образовательными системами (школа, школа-интернат, лицей, колледж, вуз и пр.) стоит задача развития социально-безопасного и просоциального поведения, включая формирование помогающего поведения, антиэкстремистской личностной позиции, социальной ответственности, позиции ненасилия, гуманистической позиции, альтруизма, толерантного сознания, экологической культуры и культуры добровольчества и пр. [7].

Этот общественный запрос выражается в конкретных мерах государства по развитию просоциальных практик, в т. ч. волонтерства: регламентируется законодательная база, разработана Концепция развития добровольчества, создаются общественные движения и НКО в сфере волонтерства, проводятся конкурсы на соискание финансовой поддержки для реализации добровольческих инициатив, организуются волонтерские форумы и слеты.

Стратегия развития воспитания в Российской Федерации на период до 2025 г. в числе направлений обновления воспитательного процесса выделяет «развитие в детской среде ответственности, принципов коллективизма и социальной солидарности; развитие у детей нравственных чувств (чести, долга, справедливости, милосердия и дружелюбия)» [8].

Необходимость реализации просоциальных воспитательных ориентиров в школе, как институте социализации, обусловливает потребность в профессионально и нравственно зрелом педагоге как агенте социализации личности, способном помочь сочетать 
осмысление социальных нормативов жизнедеятельности с формированием в себе диспозиционной установки на их соблюдение. Просоциальность субъектов образования декларировалась в проекте Концепции профессионального стандарта педагога, представленной на общественное обсуждение в 2013 г. Так, для эффективного осуществления образовательной, воспитательной и развивающей деятельности педагогу необходимо усвоить ряд фундаментальных понятий, в том числе следующие: «гражданская и социальная идентичность; система ценностей личности; образцы и нормы просоциального поведения, в том числе в виртуальной и поликультурной среде» [9] и др. В утвержденном профессиональном стандарте педагога в числе необходимых трудовых действий педагога присутствует «формирование и реализация программ развития универсальных учебных действий, образцов и ценностей социального поведения...» [10]. Данные показатели социализации определяют уровень сформированности просоциально ориентированного типа личности.

Волонтерская деятельность выступает сегодня одной их форм просоциального поведения. В Концепции развития добровольчества (волонтерства) определены различные направления волонтерской деятельности, включая сферы здравоохранения, образования, социальной поддержки населения, культуры, физической культуры и спорта, охраны окружающей среды, предупреждения и ликвидации последствий чрезвычайных ситуаций, оказания правовой помощи населению и другие сферы. При этом основной упор делается на молодежь. По данным Фонда «Общественное мнение», в 2017 г. значительную часть волонтеров представляла молодежь до 30 лет (56\%) и студенты (21\%) [11].

В отечественной социальной педагогике и социальной психологии накоплен опыт реализации программ гражданского воспитания и развития просоциальности посредством вовлечения детей и молодежи в общественную работу и волонтерство. С 2014 г. в России для осуществления системной работы с желающими оказывать безвозмездную помощь людям действует Ассоциация волонтерских центров, осуществляющая свою деятельность в субъектах России и включающая более 100 организаций (образовательные организации высшего и среднего профессионального образования, 
некоммерческие организации, а также ресурсные центры по поддержке добровольчества). Целью ассоциации является системное вовлечение волонтеров в масштабные национальные проекты, распространение практик по работе с волонтерами: организационная, методическая поддержка, содействие росту числа волонтерских инициатив и организаций, мониторинг развития волонтерства в России, развитие культуры волонтерства, формирование инфраструктуры поддержки волонтерства в России.

Просоциальный потенциал волонтерства позволяет считать его важным фактором социальной солидарности, условием социального доверия и, как следствие, социального благополучия. Волонтерство способствует формированию установки на реализацию способностей личности, мобилизацию социальной инициативы. Именно волонтерство, по утверждению А. В. Кисиленко, выступает в качестве основы для формирования солидарного сознания, активной гражданской позиции молодежи, специфической формы самоорганизации, способствующей осознанию пределов и возможностей саморегулирования в условиях нарастания неопределенности и риска, интенсификации и углублению процессов развития гражданского общества [12].

Осмысление понятия «волонтерская деятельность» в контексте философского знания позволяет понять природу, сущность и содержание данного феномена посредством обращения к категории «благо», «благополучие» [13]. На протяжении истории понятия блага, как источника добровольческой деятельности, и благополучия, как ее конечного результата, находили отражение в трудах философов. По Аристотелю, человек, обладая разумом, выстраивает дальнейший путь своего жизнесуществования в обществе в соответствии с нравственными нормами (уважение ближнего, благородные поступки во имя него и ради его благополучия и т.д.). Для каждого отдельного человека основной целью его жизнедеятельности является реализация способностей в обществе, где он живет, в нахождении своего места, на котором он наилучшим образом реализует свои способности. Оказание безвозмездной помощи может стать одним из способов достижения этой цели. 
Ученые эпохи гуманизма понимали под благом все то, что служит удовлетворению потребностей человека и его разностороннему развитию. При соблюдении принципа нравственности, по Канту, человек думает не только о своем благополучии, но и о благополучии ближнего, оказывая ему помощь и поддержку. В трудах русских и зарубежных философов содействие благу другого рассматривается как основа морали - высшего блага, вводится понятие «альтруизм». Волонтерская деятельность выступает условием формирования у человека таких качеств личности, ценностных ориентаций и установок, которые способствуют поддержанию гармоничного сосуществования с окружающим миром и собой, уважения к окружающим людям, культуре, традициям и ценностям. Таким образом, благо и состояние благополучия в аспекте просоциального поведения личности обретает не только индивидуальное содержание, но и общественное звучание. Оказание блага другому человеку и обществу позволяет личности обрести состояние собственного психологического благополучия.

Взаимосвязь психологического благополучия (счастья) и просоциального поведения показана в психологических, социологических и медицинских исследованиях.

L. Aknin c коллегами установили психологическую универсальность гедонистических преимуществ просоциальности (благотворительности), выраженных в форме эмоционального благополучия и счастья [14]. O. Curry с коллегами экспериментально доказали, что оказание помощи незнакомцу способствует повышению субъективного благополучия [15].

Благотворительность как форма общественно значимой деятельности и просоциального поведения позволяет проявить такие качества личности, как социальная ответственность, социальная взаимность, социальная справедливость, способность к сочувствию и готовность к оказанию помощи нуждающимся. Занимаясь благотворительностью, человек обретает самоуважение и чувство собственной значимости и полезности. В результате социологического опроса, проведенного в России, установлено, что счастливые люди значительно чаще оказывают помощь и занимаются благотворительностью. Среди респондентов с высоким уровенем счастья 
57 \% помогали другим людям за последний год. Среди тех, у кого уровень счастья низкий, благотворителей только 32 \% [16].

Согласно эвдемонистическому подходу благополучие человека достигается посредством позитивного психологического функционирования и развития. С эвдемонической точки зрения переживание благополучия рассматривается как процесс, ведущий людей к достижению определенных ценностей, которые позволяют индивидам расти, развивать свой потенциал; достигать самореализации и оставаться сосредоточенными на действиях, которые устраняют негативные аффекты или результаты [17]. Таким образом, психологическое благополучие представляет собой личностное состояние, в котором глубинные ценности ориентируют индивидов быть вовлеченными в действия, считающиеся важными для них $[17,18]$. Ryff предложил многомерную модель с шестью областями для измерения психологического благополучия. Это самопринятие, которое подразумевает хорошее самочувствие и позитивные отношения с другими, основанные на способности любить кого-то и иметь теплые и доверительные отношения с ним; автономию, которая включает в себя такие аспекты, как свобода и самоопределение; сосуществование с окружающей средой, которое представляет собой способность адаптировать окружающую среду таким образом, чтобы она соответствовала личным потребностям и ценностям; цель в жизни, которая в основном сводится к поиску смысла жизни; и, наконец, личностный рост, который представляет собой намерение развивать свой собственный потенциал $[17,19]$.

Психологическое благополучие означает не только хорошее самочувствие, оно ориентирует индивидов на достижение внутренних целей, ведущих к удовлетворенности жизнью. Согласно этому, просоциальное поведение приносит пользу не только тем людям, которые получают помощь, но и тем добровольцам, которые продвигают ее.

В кризисных же ситуациях просоциальное (помогающее) поведение может служить ресурсом сбережения психологического благополучия. Участие в просоциальном поведении является эффективной стратегией снижения воздействия стресса на психоэмоциональное состояние. P. Thoits и L. Hewitt установили, что люди, участвующие 
в социальных программах, более уверены в себе, склонны управлять собственной жизнью, обладают более высокой самооценкой и имеют хорошее здоровье (физическое и психическое). Как следствие, у этих людей формируется более высокая стрессоустойчивость.

Положительная связь между добровольчеством и психологическим благополучием подтверждена многочисленными исследованиями в различных странах. Chueng и Kwan показали, что добровольчество положительно влияет на самочувствие пожилых людей из Гонконга: повышает их самооценку, удовлетворенность жизнью и самооценку здоровья [20]. Кроме того, в США было установлено, что волонтерство - это социально ценная деятельность в свободное время, которая уменьшает негативные чувства [21].

По данным Всемирной организации здравоохранения (2009), психологическое благополучие выступает предиктором различных социально-психологических параметров, в том числе просоциального поведения. Когда люди чувствуют себя защищенными, они более открыты, обладают просоциальной ориентацией.

Волонтерство как социальная технология самоопределения и самоорганизации представителей молодого поколения, как форма организации серьезного досуга способно влиять на уровень благополучия молодежи. Установлено, что ценность безопасности является более значимой для студентов-волонтеров, чем для студентов, не имеющих опыт добровольческой деятельности. Атрибут и мотивационный центр этого вида ценности характеризуют психологическое благополучие просоциально активных студентов - это отсутствие опасности и угроз как в отношении физической и психологической целостности себя, так и окружающих людей, надежность, предсказуемость, социальный порядок, гармоничная целостность и стабильность межличностных, групповых и общественных отношений. Для студентов-волонтеров концепт «безопасность» как наиболее значимый на уровне нормативных идеалов согласуется с их индивидуальными приоритетами [22].

Добровольческая деятельность способна разрешить многие внутриличностные конфликты, так как волонтер получает возможность работать в команде, находит новых друзей и знакомых, отвлекается от обыденных проблем, получает удовольствие от нового занятия, 
получает возможность раскрыть свои таланты, воплотить в жизнь свои идеи, научиться любить себя, жить в состоянии душевного благополучия.

Y. Yang с соавторами обнаружили влияние психологического благополучия подростков на их просоциальное поведение в виртуальной среде. Выявляя зависимость между ориентацией на счастье (как смысложизненной ориентации) и субъективным благополучием, авторы исследуют косвенные эффекты просоциального поведения и поведения, вызывающего зависимость от интернета [23]. Оказалось, что просоциальное поведение опосредовало позитивную связь между смысложизненной ориентацией и субъективным благополучием. Аддиктивное же поведение в интернете разрушает эту позитивную связь. Изучая особенности просоциального поведения и поведения, вызывающего зависимость от интернета, среди китайских подростков, они также установили, что просоциальное поведение опосредовало позитивную связь между смысложизненными ориентациями и субъективным благополучием [23].

H. L. Schacter и G. Margolin показали, что участие подростков в просоциальных практиках позволяет удовлетворить социальные и эмоциональные потребности, повышая психологическое благополучие [24]. Р. Shaver с соавторами установили, что психологическая безопасность, обеспеченная чувством привязанности в браке, способствует развитию просоциального поведения [25].

S. Nelson с соавторами, проведя серию лонгитюдных исследований, доказали, что социальная ориентация на других, выраженная в просоциальном поведении человека (акты доброты по отношению к другим или миру), способствует увеличению у него положительных эмоций и, как следствие, обеспечению благополучия. В то время как самоцентрированное и нейтральное поведение не дает положительного эффекта [26].

C. Erving, исходя из теории социального обмена, обращает внимание на важность социальной поддержки волонтеров зрелого возраста для обеспечения их психологического благополучия, фокусируясь на самоуважении как глобальном отношении человека к самому себе, которое может помочь совладать с проблемами, справиться с негативными жизненными событиями, и мастерстве, 
позволяющем человеку почувствовать себя в состоянии контролировать то, что с ним происходит, обеспечить успешное выполнение задач или решением проблем [27]. Проведенные в последние годы исследования также позволили установить взаимообусловленность просоциального поведения и психологического благополучия обучающих образовательных организаций [28].

D. Son и L. Padilla-Walker в ходе лонгитюдного исследования «Благополучные семьи» установили, что просоциальное поведение старших подростков по отношению к друзьям (физическая помощь, обмен, защита, эмоциональная поддержка) положительно связано с качеством дружбы, психическим здоровьем и благополучием (тревога, удовлетворенность жизнью, депрессия) [29].

Мы провели два собственных исследования.

\section{Исследование 1}

Цель нашего исследования состояла в обосновании возможности обеспечения психологического благополучия (безопасности) учащейся молодежи посредством их вовлечения в просоциальную активность и формирования у них просоциальной мотивации.

Для определения взаимосвязи между просоциальностью и психологическим благополучием нами было проведено эмпирическое исследование.

В рамках исследования были тестированы 73 студента московского вуза в возрасте от 19 до 24 лет. Исследование проводилось в форме письменного опроса респондентов, в качестве методов были использованы следующие методики: «Шкала субъективного благополучия» (А. Перуэ-Баду, русскоязычная адаптация М.В. Соколовой); «Шкала альтруизма» (Ф. Раштон, русскоязычная адаптация Н. В. Кухтовой).

В табл. 1 представлены описательные статистики.

Результаты исследования показали, что по методике «Шкала субъективного благополучия» субъективное благополучие имеет низкие значения у $27 \%$ опрошенных, средние значения - у 50 \%, высокие значения - у $23 \%$. По методике «Шкала альтруизма» степень развития альтруистического качества имеет низкие значения у 13 \% опрошенных, средние значения - у 57 \%, высокие значения - 
Таблица 1

Описательная статистика методик

«Шкала субъективного благополучия», «Шкала альтруизма»

\begin{tabular}{l|c|c|c|c}
\hline \multicolumn{1}{c|}{ Шкала } & $\begin{array}{c}\text { Среднее } \\
\text { значение }\end{array}$ & $\begin{array}{c}\text { Стандарт- } \\
\text { ное откло- } \\
\text { нение }\end{array}$ & $\begin{array}{c}\text { Мини- } \\
\text { мальное } \\
\text { значение }\end{array}$ & $\begin{array}{c}\text { Макси- } \\
\text { мальное } \\
\text { значение }\end{array}$ \\
\hline Альтруизм & 43 & 3,9 & 31 & 50 \\
\hline $\begin{array}{l}\text { Субъективное благопо- } \\
\text { лучие }\end{array}$ & 65 & 13,1 & 31 & 92 \\
\hline $\begin{array}{l}\text { Напряженность и чувст- } \\
\text { вительность }\end{array}$ & 12 & 4,1 & 3 & 20 \\
\hline $\begin{array}{l}\text { Психоэмоциональная } \\
\text { симптоматика }\end{array}$ & 13 & 3,7 & 5 & 20 \\
\hline Изменения настроения & 7 & 2,8 & 2 & 13 \\
\hline $\begin{array}{l}\text { Значимость социального } \\
\text { окружения }\end{array}$ & 9 & 3,7 & 3 & 18 \\
\hline Самооценка здоровья & 8 & 2,6 & 2 & 12 \\
\hline $\begin{array}{l}\text { Удовлетворенность } \\
\text { повседневной деятель- } \\
\text { ностью }\end{array}$ & 12 & 3,3 & 6 & 18 \\
\hline
\end{tabular}

у 30 \%. Проведенный корреляционный анализ с применением коэффициента Пирсона позволил установить, что между альтруизмом и уровнем субъективного благополучия прослеживается слабая прямая корреляционная связь $(r=0,2 ; p<0,01)$.

\section{Исследование 2}

Второе исследование было связано с вторичным анализом данных Европейского социального исследования-2018 - ESS9 (табл. 2) [30]. В качестве социальной единицы в исследуемой базе данных были выбраны жители России, основной род занятий которых обучение (код вопроса F17c). В итоге была сформирована выборка из 116 респондентов в возрасте 17-26 лет $(M=20) ; 49 \%$ женщины, 51 \% - мужчины. Для каждой переменной более высокие баллы шкалы указывали на более высокие уровни конструкции. 
Для оценки психологического благополучия был выбран показатель самооценки счастья (от 0 - очень несчастлив до $10-$ очень счастлив; код вопроса $\mathrm{C} 1$ - «hарру»). Для оценки просоциальности были выбраны следующие показатели из модели ценностей Шварца: ценность оказания помощи окружающим людям (от $1-$ совсем не важно до 6 - очень важно; код вопроса H.L — «iphlppl»), ценность безопасности (от 1 - совсем не важно до 6 - очень важно; код вопроса H.E - «impsafe»); и дополнительно - восприятие окружающих людей как готовых помогать друг другу (от 0 - люди чаще заботятся только о себе до 10 - люди стараются помогать друг другу; код вопроса A6 - «pplhlp»). Второй и третий из названных показателей имеют косвенное отношение к просоциальности. Так, ранее нами показано, что в ситуациях, когда у людей актуализируется потребность в безопасности (стихийные бедствия, низкий уровень жизни, политические конфликты, религиозные конфликты и пр.), просоциальное поведение проявляется в большей степени [31]. Просоциальное поведение ориентировано на соблюдение норм (универсальных правил поведения), одной из которых является норма взаимности (помощь оказывается с расчетом на взаимность). Таким образом, если люди воспринимают окружающих как просо-

Таблица 2

Описательная статистика показателей психологического благополучия и просоциальности (по данным

Европейского социального исследования-2018)

\begin{tabular}{l|c|c|c|c}
\hline \multicolumn{1}{c|}{ Показатель } & $\begin{array}{c}\text { Сред- } \\
\text { нее } \\
\text { значе- } \\
\text { ние }\end{array}$ & $\begin{array}{c}\text { Стан- } \\
\text { дартное } \\
\text { отклоне- } \\
\text { ние }\end{array}$ & $\begin{array}{c}\text { Мини- } \\
\text { мальное } \\
\text { значение }\end{array}$ & $\begin{array}{c}\text { Макси- } \\
\text { мальное } \\
\text { значение }\end{array}$ \\
\hline Самооценка счастья & 6,8 & 2,02 & 1 & 10 \\
\hline $\begin{array}{l}\text { Восприятие окружающих } \\
\text { людей как готовых помо- } \\
\text { гать друг другу }\end{array}$ & 4,8 & 2,09 & 0 & 10 \\
\hline Ценность безопасности & 4,4 & 1,31 & 1 & 6 \\
\hline $\begin{array}{l}\text { Ценность оказания помо- } \\
\text { щи окружающим людям }\end{array}$ & 4,4 & 1,12 & 1 & 6 \\
\hline
\end{tabular}


циальных, то они, руководствуясь нормой взаимности, в большей степени будут демонстрировать просоциальное поведение.

Анализ данных показал, что по шкале «самооценка счастья» низкие значения выявлены у 6 \% респондентов, средние значения у 58 \%, высокие значения - у 36 \%. По шкале «ценность оказания помощи окружающим людям» низкие значения выявлены у 6 \% респондентов, средние значения - у 48 \%, высокие значения - у $46 \%$.

Проведенный корреляционный анализ с применением коэффициента Пирсона позволил установить, что между самооценкой счастья и восприятием окружающих людей как готовых помогать друг другу прослеживается слабая прямая корреляционная связь $(r=0,191 ; p<0,01)$. Также выявлена слабая прямая корреляционная связь $(r=0,202 ; p<0,01)$ между ценностями безопасности и оказания помощи окружающим людям.

\section{Обсуждение и выводы}

Важно, чтобы просоциальное воспитание способствовало развитию референтной значимости просоциальных норм, формированию чувства собственного достоинства при их принятии. В этом отношении позитивным моментом является тот факт, что наряду с эгоистическими мотивами (самореализация, нравится общаться с людьми) просоциального поведения у российской молодежи присутствуют и альтруистические: нравится помогать людям, значимость для развития страны, моральный долг [7].

В отечественной и зарубежной психолого-педагогической практике можно найти программы развития просоциальной мотивации у молодежи:

- кратковременный тренинг («просоциальная игра»), направленный на формирование просоциального поведения по отношению к незнакомцам посредством развития сострадания;

- обучающие упражнения и задания, направленные на формирование у студентов просоциального поведения, при выполнении которых студентам предлагается проанализировать различия между внутренними (например, самопринятие и чувство общности) и внешними (например, финансовый успех и имидж) целями в достижении благополучия; 
- программы индивидуального консультирования, реализуемые в школах и молодежных центрах и направленные на развитие просоциального поведения молодежи, в ходе которых делается акцент на развитие эмпатии, идентичности и межличностной близости как предикторов просоциального поведения.

Н.В. Кухтовой разработана и внедрена программа тренинга по коррекции асоциального поведения и формированию просоциальности у школьников подросткового возраста. Цель тренинга состоит в овладении альтернативными (социально приемлемыми) способами удовлетворения собственных потребностей подростков и взаимодействия с окружающими посредством научения формам просоциального поведения. Методологическую основу тренинга составляет теория социального научения Альберта Бандуры. Тренинг предполагает создание ситуаций, активизирующих эмоции, навыки, разнообразные стимулы-образы, проявления просоциального поведения в виде эмпатии, альтруизма, сотрудничества, готовности прийти на помощь другому человеку, основанных на социальных нормах, принятых в обществе [5].

Основными задачами тренинга Н. В. Молчановой и В. В. Гриценко, направленного на формирование просоциальной активности в условиях межкультурного взаимодействия, являются определение индивидуального стиля взаимодействия (поведения) в ситуации оказания помощи; развитие навыков, необходимых для актуализации просоциального поведения; выявление и осознание установок в отношении лиц другой национальности (культуры) в ситуации оказания помощи.

Однако следует помнить, что принудительное побуждение к нормам просоциального поведения может привести к развитию внешней, конвенциональной морали и их ситуативному соблюдению. Н. Вайнштейн и Р. Райан показали, что автономная мотивация просоциального поведения по сравнению с контролируемой в большей степени удовлетворяет психологические потребности помогающего и приносит пользу как помощнику, так и получателю.

Таким образом, вовлечение обучающихся в просоциальную практику, формирование у них просоциальной мотивации, актуализация когнитивных навыков и рефлексивных реакций могут 
стать действенным средством для обеспечения психологического благополучия и безопасности. С этой целью в процессе духовнонравственного развития и личностного становления целесообразно в рамках реализации гуманитарных дисциплин использовать тренинги и ситуативное моделирование, направленное на решение моральных дилемм, а также реализацию волонтерских практик и социально значимых проектов.

1. Безопасная образовательная среда: моделирование и развитие : учеб. пособие / под науч. ред. И. А. Баевой, С. В. Тарасова. СПб. : ЛОИРО, 2017. 265 c.

2. Кисляков П. А., Шмелева Е.А., Толстов С. Н. Обеспечение социальнопсихологической безопасности субъектов образования // Вопр. психологии. 2015. № 5. С. 46-55.

3. Zotova O. Yu., Karapetyan L. V. Psychological security as the foundation of personal psychological wellbeing (analytical review) // Psychology in Russia: State of the Art. 2018. Vol. 11, № 2. P. 100-113.

4. Идобаева О.А. Психолого-педагогическая модель формирования психологического благополучия личности : автореф. дис. ... д-ра психол. наук. М., 2013. 57 с.

5. Кухтова Н. В. Содержательные и динамические характеристики личности школьников подросткового возраста с просоциальной направленностью : монография. Витебск : УО «ВГУ им. П. М. Машерова», 2010. 195 с.

6. Аронсон Э., Уилсон Т., Эйкерт Р. Психологические законы поведения человека в социуме / пер. Л. Ордановой и др. М. : ОЛМА-Пресс ; СПб. : ЕВРОЗНАК, 2002. 557 с

7. Кисляков П. А., Шмелева Е. А., Говин О. Современное волонтерство в воспитании просоциального поведения личности // Образование и наука. 2019. Т. 21, № 6. С. 122-146.

8. Стратегия развития воспитания в Российской Федерации на период до 2025 года : распоряжение Правительства РФ от 29 мая 2015 г., № 996-р // Рос. газ. 2015. 8 июня.

9. Профессиональный стандарт педагога (концепция и содержания) [Электронный ресурc]. URL: http://минобрнауки.рф/документы/3071 (дата обращения: 25.12.2013). 
10. Об утверждении профессионального стандарта «Педагог (педагогическая деятельность в сфере дошкольного, начального общего, основного общего, среднего общего образования) (воспитатель, учитель)» : приказ Мин-ва труда и соц. защиты РФ от 18 окт. 2013 г. № 544н.

11. Волонтеры в РФ. Фонд «Общественное мнение» [Электронный pecypc]. URL: https://fom.ru/TSennosti/14039 (дата обращения: 03.02.2020).

12. Кисиленко А. В. Волонтерство: потенциал самоорганизации российской молодежи // Научный результат. Социология и управление. 2018. T. 4, № 1. С. 63-71.

13. Щербакова Н. В. Понятие «волонтерская деятельность» в контексте философского знания // Вестн. Забайк. гос. ун-та. 2012. № 11 (90). С. 98-103.

14. Aknin L. B., Barrington-Leigh C. P., Dunn E. W. et al. Prosocial spending and well-being: Cross-cultural evidence for a psychological universal // Journal of Personality and Social Psychology. 2013. № 104(4). P. 635-652.

15. Curry O. S., Rowland L.A., Van Lissa C. J. et al. Happy to help? A systematic review and meta-analysis of the effects of performing acts of kindness on the well-being of the actor // Journal of Experimental Social Psychology. № 76. Р. 320-329.

16. Счастливые люди чаще занимаются благотворительностью [Электронный ресурc]. URL: https://fom.ru/TSennosti/13926. (дата обращения: 03.02.2020).

17. Vásquez C., Hervás G., Rahona J. \& Gómez D. Bienestar psicológico y salud: Aportaciones desde la psicología positive // Anuario de Psicología Clínica y de la Salud. 2009. Vol. 5. P. 15-28.

18. Waterman A.S. Two conceptions of happiness: Contrasts of personal expressiveness (eudaimonia) and hedonic enjoyment // Journal of Personality and Social Psychology. 1993. Vol. 64. P. 678-691.

19. Ryff C., Keyes C. The structure of psychological well-being revisited // Journal of Personality and Social Psychology. 1995. Vol. 69. P. 719-727.

20. Chueng C., Kwan A. Inducting older adults into volunteer work to sustain their psychological well-being // Ageing International. 2006. Vol. 31, № 1. P. 44-58.

21. Mojza E., Sonnentag S., Bornemann C. Volunteer work as a valuable leisure-time activity: A day-level study on volunteer work, non-work experiences, and well-being at work // Journal of Occupational and Organizational Psychology. 2011. Vol. 84. P. 123-152. 
22. Руслякова Е. Е., Разумова Е. М., Шпаковская Е. Ю. Социально-психологические аспекты волонтерской деятельности студентов-психологов // Перспективы науки и образования. 2019. № 1 (37). С. 301-315.

23. Yang Y., Li P. P., Fu X. Y., Kou Y. Orientations to happiness and subjective well-being in chinese adolescents: the roles of prosocial behavior and internet addictive behavior // Journal of Happiness Studies. 2017. Vol. 18. P. 1747-1762.

24. Schacter H. L., Margolin G. When it feels good to give: depressive symptoms, daily prosocial behavior, and adolescent mood // Emotion. 2019. Vol. 19, № 5. P. 923-927.

25. Shaver P. R., Mikulincer M., Cassidy J. Attachment, caregiving in couple relationships, and prosocial behavior in the wider world // Current Opinion in Psychology. 2019. Vol. 25. P. 16-20.

26. Nelson S. K., Layous K., Cole S. W. Do Unto Others or Treat Yourself? The Effects of Prosocial and Self-Focused Behavior on Psychological Flourishing // Emotion. 2016. Vol. 6, № 16. P. 850-861.

27. Erving C.L., Amy Irby-Shasanmi. The effects of support exchanges on the psychological well-being of volunteers // Journal of sociology and social welfare. 2018. Vol. 3, № 45. P. 17-38.

28. Liu W., Su T., Tian L., Huebner E. S. Prosocial behavior and subjective well-being in school among elementary school students: the mediating roles of the satisfaction of relatedness needs at school and self-esteem [Electronic resource] // Applied Research in Quality of Life. 2020. https://doi.org/10.1007/ s11482-020-09826-1

29. Son D., Padilla-Walker L.M. Correction to: happy helpers: a multidimensional and mixed method approach to prosocial behavior and its effects on friendship quality, mental health, and well being during adolescence // Journal of Happiness Studies. 2020. № 21(5). P. 1705-1723.

30. ESS9-2018 [Электронный ресурc]. URL: https://www.europeansocialsurvey.org/data/download.html?r=9 (дата обращения: 03.02.2020).

31. Кисляков П. А. Системно-личностные детерминанты безопасного просоциального поведения личности // Системная психология и социология. 2019. № 4 (32). С. 79-91. 


\title{
НАРУЖНАЯ РЕКЛАМА \\ КАК ФАКТОР ИСКАЖЕНИЯ РЕАЛЬНОГО ОБРАЗА ГОРОДА \\ В ПРЕДСТАВЛЕНИИ МОЛОДЕЖИ*
}

\author{
E. 0. Мазурчук \\ H. И. Мазурчук
}

Сегодня в условиях урбанизации проблема формирования реального образа города как совокупности социального пространства и коллективной идентичности (А. К. Мокроусова), связанной с восприятием, опытом, окружением, ассоциациями (У.К. Линч) молодежи, становится предметом исследования в таких областях научного знания, как педагогика и психология. Педагогика затрагивает данную проблему в контексте культурного уровня молодежи как составляющей ее воспитанности. Психология же акцентирует внимание на образе города как продукте базового психического познавательного процесса - восприятия, являющегося основным источником информации для высшего психического процесса мышления [1-3].

Представители разных подходов, выбирая тот или иной аспект анализа особенностей данной социальной группы, обеспечивают таким образом многосторонность и комплексность ее изучения. В качестве объекта исследования в рамках ряда научных подходов молодежь (молодость) рассматривается следующим образом:

- как общность, определенная социально-демографическая и возрастная группа (стратификационный подход);

- социальный институт, молодежное движение: организация и функционирование молодого поколения, его отношение с другими поколениями; характер, формы и тенденции развития молодежного движения (институционально-функциональный подход);

- группа со своим специфическим образом жизни, стилем поведения, культурными нормами и ценностями (субкультурный подход);

Исследование выполнено при финансовой поддержке РФФИ в рамках научно-исследовательского проекта № 20-013-00830 А «Реальное и виртуальное пространство мегаполиса: стресс и девиации поведения городской молодежи». 
- проблемная стадия в развитии человека, характеризующаяся длящимся конфликтом между индивидом и обществом (конфликтологический подход) [4-10].

Исходя из вышесказанного, резюмируем, что в обобщенном понимании «молодежь» - это возрастная группа со своим специфическим образом жизни, стилем поведения, культурными нормами и ценностями, обусловленными определенной социальной средой [11].

Молодость - период начала вторичной социализации, когда, как правило, снижается роль родительской семьи в качестве агента социализации. Вторичная социализация молодежи протекает под влиянием других агентов, использующих различные способы воздействия на людей, в том числе и рекламу. С помощью рекламы они транслируют свои нормы и ценности, которые могут интериоризироваться молодыми людьми, а могут и отвергаться ими. Применяя разнообразные приемы и средства воздействия, агенты социализации способствуют адаптации молодых людей к условиям окружающей среды или, напротив, препятствуют ей. Так, реклама может стать стрессогенным фактором, под действием которого у молодежи снижается чувство безопасности, возрастает вероятность девиантных поступков.

Особую актуальность рассмотрению данной проблемы придает тот факт, что в современных городах-мегаполисах отчетливо прослеживается тенденция развития визуальных практик, характеризующихся стремительным ростом количества наружной рекламной продукции в городских публичных пространствах. Городские публичные пространства - это социально значимые элементы среды, культурные артефакты, создающие индивидуальное пространство для каждого, в котором значительное место отводится ценностной составляющей, выступающей ключевой для устройства жизни.

Указанные изменения обусловлены переходом российской экономики от государственного планирования к рыночному устройству, т. е. к развитию свободного предпринимательства и маркетинга [12].

В продуктах визуальных практик специалисты видят ресурсы, во-первых, для улучшения среды городского пространства как составляющей воспитывающей среды, так как, по мнению С. С. Толмачева, они выступают как продуктивный ресурс, развивающий 
и ориентирующий на моральные ценности и соответствующее поведение; во-вторых, для стимулирования активности разных социальных и возрастных групп; в-третьих, для экономического и культурного роста общества [13].

Наиболее распространенным способом использования городского публичного пространства становится наружная реклама, которая рассчитана преимущественно на визуальное восприятие, являющееся наиболее активным и основополагающим у молодежи в связи с возросшими объемами воспринимаемой информации и клиповостью мышления [14].

Как показывают исследования, проведенные в контексте изучения психологии рекламы, по широте информационного воздействия на молодежь наружная реклама является одним из самых распространенных, актуальных и эффективных методов продвижения продуктов и услуг.

Наружная реклама - это любой вид рекламы, размещенный на улице под открытым небом (билборды, афиши, плакаты, неоновая реклама на зданиях), которую может воспринимать каждый произвольно или непроизвольно [15].

Анализ научных исследований по психологии наружной рекламы позволил Е. Козыревой выделить ее эстетическую функцию. Наружная реклама, включенная в архитектуру городского публичного пространства, находит выражение в концепциях нейтрального и активного дизайна. Активные объекты рекламного дизайна ориентированы на формообразование, создание новых акцентов, нового образа архитектуры города. Наружная реклама, как правило, актуализирует непроизвольные процессы восприятия и внимания, что приводит к оценке объектов на подсознательном уровне. В случае появления интереса к объекту наружной рекламы срабатывает эффект сенсибилизации - повышение чувствительности нервных окончаний, которое происходит под воздействием внешних раздражителей, что повышает эффективность воздействия рекламы на формирование реального образа города у молодежи. Реклама, которая активно формирует архитектурный образ, не подчиняется существующей архитектуре фасадов и не имеет цели корректно 
вписаться в уже существующую систему городского публичного пространства.

В.И. Паллотта отмечает, что в определенных случаях наружная реклама может игнорироваться в городских публичных пространствах. Например, в столице Франции считается, что она способна отрицательно влиять на восприятие столетиями формировавшегося вида Парижа. В России реклама заняла свое место в городском публичном пространстве. Сегодня она формирует особый материальный и визуальный слой, отличный от реальной архитектуры города, и демонстрирует независимость, нередко граничащую с агрессивностью.

Все материальные объекты наружной рекламы, помимо воздействия на объемно-пространственную ситуацию, активно формируют реальный образ города у молодежи. За счет наружной рекламы городское публичное пространство наполняется текстами, которые считывает молодежь. Они эффективно воздействуют на ее сознание, потому как информация наружной рекламы распространяется посредством знаков, образующих текстовые структуры. Это не только письменность, но и картинка или эффект, понимаемые в качестве информационного посыла.

В связи с этим особого внимания заслуживает рассмотрение наружной рекламы как элемента национальной культуры и основного механизма ее формирования. Ряд авторов отмечают, что она возникает как феномен массовой культуры, однако оказывает влияние на духовную культуру отдельной личности, влияет на качественные характеристики ее восприятия и образы, которые формируются в результате него [1-3].

В течение длительного времени изучения особенностей восприятия рекламы целевыми и нецелевыми группами был зафиксирован феномен, который получил название «трансформация условных рекламных образов в нормы реального поведения потребителя рекламы» [16, с. 132]. Содержательно он заключается в том, что существует зависимость изображения, используемого в наружной рекламе, нарушающего этические нормы поведения в обществе, и возникновения деструктивных форм поведения людей, а также 
реального образа города особенно у молодежи $[15,17]$. Данный факт обусловлен их возрастными особенностями.

Учитывая позиции, рассмотренные выше, целесообразно заметить, что динамичность городских публичных пространств, насыщенных наружной рекламой, становится не просто признаком их существования, а фактором и результатом непрерывной трансформации, которая оказывает существенное влияние на психологическую безопасность и психологическое благополучие населения в целом и молодежи как основного потребителя информации, представленной наружной рекламой, в частности.

Психологическая безопасность как одна из составляющих национальной безопасности, включенная в категорию социальной безопасности, предполагает, что городские публичные пространства должны отвечать следующим требованиям:

- быть свободными от проявления психологического насилия;

- иметь референтную значимость для включенных в них субъектов (в плане положительного отношения к ней);

- характеризоваться преобладанием гуманистической центрации участников (т. е. центрации на интересах (проявлениях) своей сущности и сущности других людей);

- представлять собой среду взаимодействия, отражающегося в эмоционально-личностных и коммуникативных характеристиках ее субъектов.

Следовательно, психологически безопасная среда городского публичного пространства - это среда, сохраняющая, поддерживающая и развивающая психологическое здоровье и психологическое благополучие ее участников, которое, по мнению О.Е. Елисеевой, содержательно связано с эмоциональным равновесием и положительными эмоциями человека. Автор обосновано доказывает, что в структуру психологического благополучия входит:

- отношение человека к себе;

- чувство собственного достоинства;

- чувство непрекращающегося развития и самореализации;

- отношения с другими людьми, пронизанные заботой и доверием;

- эффективность межличностного взаимодействия. 
Отталкиваясь от понимания структурно-содержательной наполненности психологического благополучия, мы можем утверждать, что его сохранение возможно при условии совпадения реально существующей среды (городских публичных пространств) и образа этой среды, сформированного у молодежи, в том числе и под влиянием объектов наружной рекламы.

В рамках нашего исследования мы предприняли попытку проверить утверждение, что наружная реклама является фактором искажения реального образа города в представлении молодежи.

Исследование проводилось на базе федерального государственного бюджетного общеобразовательного учреждения высшего образования «Уральский государственный педагогический университет» (ФГБОУ ВО УрГПУ). В нем приняли участие студенты второго-шестого курсов в количестве 70 человек. В выборку вошло 35 мужчин и 35 женщин, возраст респондентов от 18 до 35 лет.

Данная группа, с одной стороны, уже несет в себе результаты влияния наружной рекламы как фактора, воздействующего на формирование образа города, а с другой - этот образ остается достаточно гибким, подверженным коррекции.

В процессе эмпирического исследования мы использовали метод анкетирования. Респондентам в дистанционном формате предлагалось ответить на ряд открытых и закрытых вопросов анкеты, позволяющих определить степень влияния наружной рекламы на формирование реального образа города в представлении молодежи. Полученные ответы обрабатывались с применением метода контент-анализа.

Анализ результатов исследования, полученных при ответе респондентов на закрытые вопросы анкеты, позволил зафиксировать, что представители молодежи - мужчины и женщины - по-разному оценивают влияние наружной рекламы на формирование реального образа города (табл. 1).

Так, большинство респондентов-женщин (58 \%) считают, что наружная реклама отрицательно влияет на образ города, 30 \% дали ей положительную оценку и $12 \%$-нейтральную, свидетельствующую об амбивалентном отношении или об отсутствии интереса к данной проблеме. В группе мужчин результаты распределились несколько 
иначе: среди мужчин-респондентов отрицательно оценивающих влияние наружной рекламы на образ города меньше, чем среди женщин (32\%), зато больше тех, кто дал положительную (40 \%) и нейтральную (28 \%) оценку. Полученные данные позволяют сделать вывод о том, что у женщин данной выборки преобладает отрицательная оценка влияние наружной рекламы на образ города, а среди мужчин больше тех, кто оценивает ее влияние положительно.

Следует заметить, что разница в оценке влияния наружной рекламы на формирование реального образа города в процессе первичной обработки данных была замечена и у представителей разных возрастов (табл. 2).

Данные, приведенные в табл. 2, дают основание утверждать, что среди респондентов в возрасте 18-23 лет тех, кто положительно оценивает влияние наружной рекламы на реальный образ города, больше, чем среди респондентов других возрастных категорий (58 \% против 35 \% в группе 24-29-летних и 29 \% среди 30-35-летних). У респондентов старшей возрастной группы, наоборот, наиболее выражена отрицательная оценка влияния наружной рекламы на реаль-

Таблица 1

Оценка влияния наружной рекламы на формирование реального образа города мужчинами и женщинами

\begin{tabular}{c|c|c|c}
\hline \multirow{2}{*}{ Пол } & \multicolumn{3}{|c}{ Оценка, \% } \\
\cline { 2 - 4 } & положительная & отрицательная & нейтральная \\
\hline Женский & 30 & 58 & 12 \\
\hline Мужской & 40 & 32 & 28 \\
\hline
\end{tabular}

Таблица 2

Оценка влияния наружной рекламы на формирование реального образа города респондентами разного возраста

\begin{tabular}{c|c|c|c}
\hline \multirow{2}{*}{ Возраст, лет } & \multicolumn{3}{|c}{ Оценка, \% } \\
\cline { 2 - 4 } & положительная & отрицательная & нейтральная \\
\hline $18-23$ & 58 & 30 & 12 \\
\hline $24-29$ & 35 & 30 & 35 \\
\hline $30-35$ & 29 & 45 & 26 \\
\hline
\end{tabular}


ный образ города (45 \% респондентов среди 30-35-летних, по 30 \% в группах 24-29 лет и 18-23 лет). Нейтральная оценка наиболее представлена у студентов в возрасте 24-29 лет (35\%), наименее у 18-23-летних (12\%). Среди респондентов 30-35 лет нейтрально относятся к влиянию наружной рекламы на реальный образ города $26 \%$. Таким образом, чем старше респонденты, тем более критично они относятся к наружной рекламе и тем меньше среди них тех, кто положительно оценивает ее влияние на образ города.

Однако, как показал контент-анализ открытых вопросов анкеты, молодые люди, принявшие участие в исследовании, как мужчины, так и женщины, относящиеся к разным возрастным группам, подчеркивают, что обращают внимание на наружную рекламу и задумываются о ее влиянии на изменения в образе города, возникающие из-за рекламных конструкций. Полученные данные дают основание утверждать, что наружная реклама является фактором искажения реального образа города, по мнению респондентов. Они отмечают, что при созерцании общего городского пространства именно наружная реклама становится для них объектом восприятия, а архитектура города - его фоном. Это приводит к появлению дисбаланса в образе города и снижению желания воспринимать городское пространство без наружной рекламы.

В процессе восприятия визуального образа (т. е. образа, который транслирует наружная реклама) молодежь принимает его за эталон, что может объясняться особенностью восприятия наглядной ситуации у данной возрастной группы.

Полученные результаты определили, на наш взгляд, необходимость выделить группы (кластеры) молодежи с разными оценками влияния наружной рекламы на формирование реального образа города для более дифференцированного рассмотрения изучаемого вопроса.

На первом этапе к имеющемуся массиву первичных данных был применен кластерный анализ (метод Уорда). Эта процедура позволила разделить выборку молодежи на несколько однородных групп.

В результате применения метода Уорда было зафиксировано четыре группы (кластера). 
В первую группу (кластер) вошли женщины в возрасте от 24 до 35 лет, негативно оценившие влияние наружной рекламы на формирование реального образа города. На наш взгляд, такие результаты обусловлены тем, что у женщин данной группы восприятие наружной рекламы как фактора искажения реального образа города определяется феминными качествами (зафиксированы с помощью контент-анализа текста ответов на открытые вопросы анкеты). Они обращают внимание на ее эмоционально насыщенные фрагменты, что отвлекает их от восприятия более значимых элементов городской среды. Именно поэтому наружная реклама получила у большей части женщин данной группы негативную оценку.

Во вторую группу (кластер) попали респонденты-мужчины от 18 до 29 лет с положительной оценкой влияния наружной рекламы на формирование реального образа города. Данный факт обусловлен тем, что мужчины рассматриваемой группы при восприятии наружной рекламы чаще анализируют ее содержание (маскулинные качества восприятия), поэтому проявляют сдержанность, что снижает вероятность понижения качества восприятия городской среды при формировании реального образа города.

Третья группа (кластер) представлена женщинами от 18 до 23 лет с позитивной оценкой влияния наружной рекламы на формирование реального образа города. Данная часть выборки, как показывает качественный анализ данных, обладает маскулинными качествами восприятия городской среды, что обусловливает содержательный, а не эмоциональный анализ наружной рекламы. Именно поэтому она не рассматривается как фактор искажения реального образа города.

Заключительная - четвертая группа (кластер) состоит из мужчин в возрасте от 30 до 35 лет с нейтральной и отрицательной оценкой влияния наружной рекламы на формирование реального образа города. Часть представителей данной группы рассматривают наружную рекламу как фактор искажения реального образа города, так как они в большей степени склонны к восприятию ее эмоционально насыщенных фрагментов, что отвлекает их от более значимых элементов городской среды. Вторая часть четвертой группы дает нейтральную оценку влиянию наружной рекламы на формирова- 
ние реального образа города, так как относящиеся к ней мужчины не имеют ярко выраженных признаков феминных или маскулинных качеств ее восприятия.

Полученные в ходе исследования данные подтверждают, что наружная реклама оказывает влияние на формирование реального образа города у респондентов как с феминным, так и с маскулинным типом ее восприятия. Наименее подвержены влиянию наружной рекламы те респонденты, у которых нет ярко выраженных феминных или маскулинных качеств ее восприятия. Однако это самая малочисленная группа респондентов.

Резюмируя вышесказанное, следует отметить, что:

- реальный образ города трактуется как обобщенная мысленная картина окружающего материального мира в сознании молодежи, имеющая ключевое значение в их жизни (У.К. Линч);

- в создании образа города участвуют различные элементы городских публичных пространств, основная роль среди которых отводится наружной рекламе, так как ее восприятие преимущественно происходит как произвольно, так и непроизвольно;

- наружная реклама оказывает чаще негативное влияние на формирование реального образа города в представлении молодежи, базируясь на активации непроизвольного внимания, вызывает определенное эмоциональное отношение, интерес, способствует формированию наглядного образа, транслируемого ей, как эталонного;

- образ наружной рекламы зачастую не способствует формированию адекватного образа городского пространства, приводит к существенным изменениям его восприятия молодежью.

Перечисленные особенности снижают уровень воспитанности молодежи, нацеливают ее на активное восприятие рекламной продукции, а не культурных объектов городской среды, что негативно сказывается на их психологическом благополучии, так как вызывает диссонанс между реальным образом города и образом, сложившимся у них.

1. Борисова Ю.В. Образ города как стратегия развития (на примере Иркутска) // Урбанистика. 2017. № 3. С. 81-92. 
2. Будник Е. А., Пантюшина А. Н. Учет гендерных особенностей при размещении наружной рекламы // Lingua mobilis. 2014. № 1 (47). C. 82-86.

3. Голова А. Г. Факторы, влияющие на потребительское поведение личности в мегаполисе // Журнал социологии и социальной антропологии. 2011. T. 14, № 5 (58). С. 304-312.

4. Вишневский Ю. Р., Шапко В. Т. Актуальная культура современного российского студенчества: методология исследования // Учен. зап. НТГСПА. Общественные науки : Актуальная культура современного российского студенчества : материалы межрегион. науч.-практ. конф. 2008. С. 8-13.

5. Вишневский Ю. Р., Шапко В. Т. Социология молодежи. Екатеринбург. 1997. $211 \mathrm{c}$.

6. Воецкая Т. В. Социализации и самореализация молодежи // XVI Уральские социологические чтения: Социальное пространство Урала в условиях глобализации - XX в. : материалы междунар. науч.-практ. конф. : в 3 ч. / отв. ред. С. Г. Зырянов. Челябинск, 2006. С. 161-167.

7. Запесоцкий А. И. Молодежь в современном мире: проблемы индивидуализациии социально-культурной интеграции. М., 2008.

8. Лисовский В. Т. Динамика социальных изменений: опыт сравнительных, социальных исследований российской молодежи // Социол. исслед. 1998. № 5. С. 98-104.

9. Социальный потенциал студенческой молодежи / Е. Сорокина [и др.] // Высшее образование в России. 2007. № 4. С. 108-110.

10. Стегний В. Н., Курбатова Л. Н. Социальный портрет современного студенчества // Высшее образование в России. 2010. № 2. С. 57-63.

11. Mazurchuk N.I., Mazurchuk E. O. Comparative analysis of value-semantic sphere of pedagogical students in russia and Ukraine // The European Proceedings of Social \& Behavioural Sciences EpSBS (IFTE $20184^{\text {th }}$ International Forum on Teacher Education).

12. Лебедев-Любимов А. Н. Психология в маркетинге. COOL-BRANDстратегия. СПб. : Питер, 2008.

13. Гуссер А. В., Белоусова Н. А. Влияние наружной рекламы на облик города // Научный альманах. 2016. № 2-1 (16). С. 140-143.

14. Выготский Л. С. Психология. М. : Наука, 2000. (Сер. : Мир психологии.) 
15. Лебедев-Любимов А. Н. Психология рекламы. 2-е изд. СПб. : Питер, 2007.

16. Юркина Л.В. К вопросу о развитии поведенческих норм в свете цивилизационных принципов // Философское осмысление судеб цивилизации. М., 2001. С. 91.

17. Salakhova V.B., Shulga T.I., Erofeeva M. A. et al. Dynamics of the value-motivation sphere under the influence of socio-psychological correction in a person prone to deviant behavior // Modern Journal of Language Teaching Methods. 2018. Vol. 8, № 12. P. 32-45. 


\title{
ЖЕСТОКОЕ ОБРАЩЕНИЕ С ДЕТЬМИ: ПОНЯТИЕ, ПОСЛЕДСТВИЯ И НАПРАВЛЕНИЯ ПРОФИЛАКТИКИ
}

\author{
Н. А. Томина \\ Н. Г. Церковникова
}

Проблематика насилия и жестокого обращения с детьми в современном российском обществе стала открыто обсуждаться сравнительно недавно. Современные социологические и психологические исследования убеждают, что данная проблема гораздо более масштабна, чем показывает официальная статистика. Физическое и психологическое насилие над детьми в России имеет исторические корни, и в современных российских семьях различные виды насилия по-прежнему распространены. Приведем некоторые статистические данные. Опрос 1500 респондентов из Архангельской, Брянской и Курганской областей, Республики Адыгея и Ямало-Ненецкого автономного округа в возрасте от 18 лет показал, что респонденты в детстве подвергались: физическому насилию $(64,4 \%)$, психологическому насилию (48,5 \%), сексуальному насилию (1,3\%), 10 \% респондентов столкнулись с пренебрежением родителями своими обязанностями [1].

Профилактика и при необходимости коррекция такого нежелательного явления, как насилие и жестокое обращение с детьми, становятся едва ли не приоритетной задачей профессиональной деятельности специалистов образовательных организаций, социально-реабилитационных центров для несовершеннолетних и других учреждений. При этом есть ряд специалистов (педагоги, психологи, воспитатели и др.), не умеющих распознавать признаки насилия и жестокого обращения, есть те, кто не знает, как правильно реагировать на выявленные признаки. Просветительская и профилактическая формы работы являются важными составляющими профессиональной деятельности специалистов на всех уровнях общего образования.

Неоднозначность точек зрения на то, что является насилием и жестоким обращением с несовершеннолетними, устойчивая и передающаяся из поколения в поколение культура физического 
наказания в российских семьях, трудности межведомственного взаимодействия при выявлении случаев жестокого обращения, да и вообще получения профессиональной поддержки делают проблему насилия и жестокого обращения в отношении детей актуальной. Считаем важным дать определения насилия и жестокого обращения в отношении детей, поскольку именно от правильного, однозначного понимания содержания понятий зависит адекватная реакция специалистов, ближайшего окружения ребенка.

Насилие, по определению Всемирной организации здравоохранения (ВО3), - это «преднамеренное применение физической силы или власти, действительное или в виде угрозы, направленное против себя, против иного лица, группы лиц или общины, результатом которого являются (либо имеется высокая степень вероятности этого) телесные повреждения, смерть, психологическая травма, отклонения в развитии или различного рода ущерб» [2, с. 5]. Понятие, используемое Всемирной организацией здравоохранения, подчеркивает преднамеренность и фактическое совершение акта насилия, независимо от его результата.

Как указывают И.А. Алексеева и И. Г. Новосельский, жестоким обращением с ребенком называется «причинение вреда физическому и психическому здоровью ребенка, угроза его развитию или жизни» [3, с. 19]. Авторы отмечают многообразие проявлений этого феномена: жестокое обращение, запущенность и пренебрежение потребностями и нуждами ребенка со стороны людей, которые должны опекать его и заботиться о нем.

Жестокое обращение с ребенком - это все многообразие действий или бездействие со стороны окружающих лиц, которые наносят вред физическому и психическому здоровью несовершеннолетнего, его развитию и благополучию, а также ущемляют его права или свободу.

Содержание понятий насилия и жестокого обращения лежит в одном смысловом поле и порой их используют как синонимы даже на законодательном уровне. В настоящее время существуют как международные, так и российские нормативно-правовые акты, регламентирующие права несовершеннолетних, права и обязанности родителей, законных представителей несовершеннолетних, а также 
определяющие ответственность родителей за последствия жестокого обращения с детьми, неисполнения обязанностей по воспитанию несовершеннолетнего.

Традиционно различают четыре категории жестокого обращения с детьми: «1) физическое насилие, 2) сексуальное насилие, 3) пренебрежение потребностями ребенка/отсутствие заботы, 4) эмоциональное насилие» [2, с. 64]. При этом в научной и методической литературе категорию эмоционального насилия часто называют психологическим.

Жестокое обращение всегда имеет последствия для личности. Они могут проявиться сразу после жестокого обращения и быть всем заметными. В этом случае у ребенка появляется шанс получить помощь. Последствия жестокого обращения могут быть невидимыми или хорошо скрываемыми «бомбами замедленного действия», которые взорвутся через какое-то время. Тогда окружающие не смогут связать их с причиной и оказать адекватную помощь, да и ребенок не всегда сможет увязать одно с другим. В некоторых случаях последствия жестокого обращения похожи на медленно действующий яд, который активно никак себя не проявляет, но медленно убивает. В других случаях - это, скорее, вирус, который проявляется или не проявляется и даже передается по наследству. Опыт жестокого обращения - это всегда травматический опыт, который меняет человека физически и/или психически в большей или меньшей степени.

Последствия жестокого обращения можно условно разделить на группы по разным основаниям: по видам и по времени их наступления. По видам последствия жестокого обращения с детьми могут быть физические и психологические. Под физическими последствиями понимается вред телу и его развитию, жизни и физическому здоровью, а под психологическими - неадекватная самооценка, искаженное представление о мире, иррациональные установки, нарушенная привязанность и т. д., вплоть до психических расстройств и болезней. В реальности физические и психологические последствия тесно связаны друг с другом, так как тело и психика неразрывно связаны друг с другом. 
К. Х. Бриш приводит результаты исследования, согласно которым опыт переживания жестокого обращения в детстве влияет на созревание отделов коры головного мозга, отвечающих за управление, интеграцию и модуляцию аффектов: «... жестокое обращение и/или травма в раннем детстве сильно изменяют развитие правого “невербального” полушария мозга, которое отвечает за различные аспекты привязанности и регуляцию аффектов» [4, с. 43-44]. С другой стороны, чрезмерная психическая боль способна вызывать психосоматические заболевания, стремление к самоповреждению, парасуицидальному и суицидальному поведению.

По данным Г. У. Виттхен, у многих детей, подвергавшихся жестокому обращению, отмечается снижение школьной успеваемости, способности к обучению [5]. Для детей типичны расстройства социального поведения. Так, ребенок, подражая взрослым, может быть агрессивным, драчливым и склонным к насилию в чрезвычайных обстоятельствах.

Вторым основанием для выделения последствий жестокого обращения можно считать время их наступления. В таблице представлены последствия жестокого обращения, которые разделяют на ближние и отдаленные [6].

Ближние последствия возникают здесь и сейчас либо в непосредственной близости к факту жестокого обращения, они непосредственно отражают нанесенный ущерб. Именно их описывают в качестве признаков, помогающих заметить жестокое обращение, которое имело место в недавнем прошлом. Ближние психологические последствия - это всегда попытка психики призвать на помощь, справиться с произошедшим, отреагировать и восстановиться.

Отсроченные последствия не всегда заметны, могут быть результатом накопленной травмы (травмы детского возраста могут проявить себя в более позднем возрасте). Последствия могут проявиться через много лет, даже если ближние последствия нашли свое воплощение, либо сопровождать человека всю жизнь (например, инвалидность, хроническое заболевание или психическое расстройство). 
Ближние и отдаленные последствия жестокого обращения с ребенком

\begin{tabular}{|c|c|}
\hline \multicolumn{2}{|c|}{ Последствия жестокого обращения с ребенком } \\
\hline $\begin{array}{l}\text { ближние (возникают сразу после } \\
\text { акта жестокого обращения) }\end{array}$ & $\begin{array}{l}\text { отдаленные (могут возникнуть че- } \\
\text { рез некоторое время после жестоко- } \\
\text { го обращения, проявиться в более } \\
\text { позднем возрасте или будут иметь } \\
\text { накопительный эффект) }\end{array}$ \\
\hline $\begin{array}{l}\text { Физические травмы, повреждения } \\
\text { Рвота } \\
\text { Головные боли } \\
\text { Потеря сознания } \\
\text { Кровоизлияния в глазные яблоки, } \\
\text { характерные для синдрома сотрясе- } \\
\text { ния, развивающегося у младенцев, } \\
\text { которых сильно трясут } \\
\text { Острые психические реакции } \\
\text { (ответная агрессия, возбуждение, } \\
\text { стремление сбежать, спрятаться, } \\
\text { глубокая заторможенность, апатия, } \\
\text { слезы, паника) } \\
\text { Захваченность сильными пережи- } \\
\text { ваниями страха, тревоги и гнева } \\
\text { Развитие тяжелой депрессии с чув- } \\
\text { ством собственной ущербности, } \\
\text { неполноценности } \\
\text { Суицидальные мысли и действия } \\
\text { сразу после акта жестокого обра- } \\
\text { щения }\end{array}$ & $\begin{array}{l}\text { Нарушения физического и психиче- } \\
\text { ского развития } \\
\text { Соматические заболевания } \\
\text { Личностные и эмоциональные на- } \\
\text { рушения Социальные последствия } \\
\text { Симптомы посттравматического } \\
\text { стрессового расстройства и травми- } \\
\text { рованной личности } \\
\text { Расстройства личности как резуль- } \\
\text { тат жестокого обращения }\end{array}$ \\
\hline
\end{tabular}

Опыт переживания насилия в детстве и юношестве может иметь фатальный исход для психологического самочувствия и общего развития личности. Часто дети и подростки, испытавшие насилие, ощущают себя соучастниками или виновниками. Наблюдаются расстройства эмоциональной сферы: необоснованная смена настроения, тревожность, депрессия, которые могут сопровождаться суицидальными попытками. Невротические симптомы сочетаются с нарушениями взаимоотношений с окружающими. Вследствие недоверия к миру появляются замкнутость, чувство одиночества. 
Среди отдаленных последствий насилия выделяют алкоголизм, аддиктивное и делинквентное поведение, попытки суицида [7].

Под профилактикой обычно понимают предупреждение, недопущение возникновения чего-либо неприятного или нежелательного. В нашем случае профилактика направлена на предупреждение жестокого обращения с детьми и пренебрежения их потребностями. Поскольку мы рассматриваем жестокое обращение и пренебрежение потребностями детей и подростков как результат взаимодействия между ребенком и взрослым в определенных, усугубляющих, нейтральных или облегчающих условиях, то можем выделить несколько основных направлений профилактических мер:

- меры, направленные на развитие облегчающих условий и минимизацию усугубляющих;

- меры, направленные на взрослых;

- меры, направленные на детей и подростков;

- меры, направленные на улучшение взаимодействия между ребенком и взрослым.

Отметим, что под усугубляющими условиями понимаются ситуативные, внешние и объективные условия жизни, которые способствуют жестокому обращению с детьми и насилию (например, отсутствие работы у родителей, экономический кризис, отсутствие возможности получить помощь, культурные установки типа «бьет значит любит» и т. д.). Облегчающие условия - это условия, позволяющие снизить риск жестокого обращения и/или минимизировать его последствия (например, доступность медицинской и психологической помощи, высокий уровень психологической грамотности, стабильная экономическая обстановка, культура ненасилия и т. д.).

При комплексном подходе профилактика должна проводиться по всем направлениям. Однако единичные меры также способны предотвратить жестокое обращение к конкретному ребенку в конкретном случае, а значит, дать шанс ребенку избежать травматизации.

Рассмотрим меры профилактики, направленные на взрослых. Данная группа мер предполагает работу с взрослыми: родителями, родственниками, специалистами и т. д. Взрослые уже сформировались как личности и активно участвуют в формировании личности 
ребенка, его представлений о том, как надо взаимодействовать с другими людьми и миром в целом.

Чем младше ребенок, тем важнее работа со взрослыми. Имея ограниченный ресурс, выбирая между работой с ребенком или взрослым, необходимо выбирать взрослого.

Цели пробилактической работы со взрослыми:

1) повышение осознанности поведения взрослого;

2) повышение эмоциональной компетентности взрослого;

3) повышение критического отношения взрослого к своему поведению;

4) информирование о деструктивных паттернах поведения и осознание взрослым собственных деструктивных паттернов поведения по отношению к ребенку и их возможных последствий;

5) расширение или формирование конструктивных паттернов взаимодействия с ребенком;

6) профилактика эмоционального выгорания взрослого;

7) пропаганда здорового образа жизни;

8) повышение жизнестойкости и стрессоустойчивости взрослого;

9) отделение собственных психологических сложностей и травм от ребенка и мотивирование на работу с ними;

10) повышение качества жизни взрослого.

Формы работы со взрослыми могут быть стихийными и специально организованными. К стихийным формам работы можно отнести разговор с родителем на детской площадке, оказание экстренной помощи, оказание первой психологической помощи, стихийно возникшую психологическую консультацию. К специально организованным формам работы с взрослыми относятся следующие:

- Открытые лекции и семинары по заранее заданной теме. Цель лекций и семинаров: повышение грамотности взрослых в вопросах психологии, педагогики, медицины, безопасности детей. Такие мероприятия проводятся на самые актуальные темы на разных площадках и разными организаторами. Например, родительский клуб в детском саду или в школе, на котором специалист излагает материал по теме и отвечает на вопросы участников. Информация, полученная на лекциях и семинарах воспитателями и учителями, 
может использоваться ими на родительских собраниях. При этом она должна быть понятной, интересно представленной и актуальной. Эффективность занятий с любой аудиторией возрастает при использовании демонстрационных материалов, заимствованных (примеры из фильмов, книг, сюжеты из реальной жизни) либо полученных в процессе выполнения участниками семинара-тренинга упражнения. При выборе упражнения важно учитывать резерв времени и возможные эмоциональные последствия для участников, способность специалиста оказать помощь.

- Конференции, «круглые столы» - это форма профилактики, предполагающая междисциплинарное взаимодействие специалистов и родителей, обсуждение вопросов с разных точек зрения. Цели могут быть разнообразны: от конкретной помощи здесь и сейчас до налаживания взаимодействия между участниками. Чем больше налаженных надежных связей между родителями и специалистами различных направлений, тем надежнее система профилактики и оказания помощи.

- Обучающие курсы, тренинги: школа приемных родителей, школа для будущих родителей, тренинг по развитию эмоционального интеллекта, тренинг по развитию саморегуляции, курсы повышения квалификации для специалистов, специализированные тренинги по работе с конкретной проблемой, курс по профилактике жестокого обращения с детьми и т. д. Цель курсов и тренингов развитие и отработка конкретных навыков, подготовка к сложным ситуациям профессионального взаимодействия. Очень важно, чтобы курсы, тренинги были безопасными и действительно включали профилактику насилия и жестокого обращения. Для подобных курсов должен быть предусмотрен отбор участников. В некоторых случаях подобные курсы/тренинги могут иметь противоположный эффект. Например, возможно провоцирование раскрытия травматического контейнера участника при прохождении курсов или тренингов. Без должного внимания к этому или информирования человека о месте получения квалифицированной помощи может произойти декомпенсация. Например, будущая мама, усвоившая правила кормления и пеленания новорожденного, как хорошая ученица может в будущем делать это насильно, без учета живого 
ребенка, как будто с куклой. К.Х. Бриш описывает профилактическую программу «SAFE - Программа надежности для родителей», которая включает видеотренинг. Исследования показали, что включение видеотренинга в эту программу повышает уровень критичности к собственному поведению и способствует развитию более чуткого отношения к младенцу в будущем. Подобный опыт возможно использовать и в других профилактических программах. В любом курсе или тренинге важно заложить время на работу с мотивацией и глубинными установками участников, отработку упражнений и их обсуждение, учитывать готовность участников к сложному материалу. От эмоциональной включенности каждого участника в работу будет зависеть эффект профилактики. Примером такой формы профилактики является проект АНО «Семья детям» по профилактике жестокого обращения с детьми в масштабах малого города.

Чем более тревожная тема, чем более она конфликтная и неоднозначная, тем больше необходимо включить ресурсных моментов в тренинг или курс и заложить больше времени на обсуждение чувств и размышлений участников.

- Киноклубы, читательские клубы (просмотр и обсуждение фильмов, книг, связанных с темой жестокого обращения). Цель киноклубов и читательских клубов - расширение представлений о возможных деструктивных формах поведения, их последствий и формирование культуры обсуждения тем насилия и жестокого обращения. Поскольку такие клубы имеют, как правило, добровольный формат участия и книги, фильмы анонсируются заранее, то вероятность ретравматизации или травматизации участников снижается, хотя не исключается полностью. Многое зависит от ведущего клуба, его способности оказать помощь. Плюсы данной формы профилактической работы с взрослыми заключаются в том, что присутствует элемент абстрагирования, формирование отношения человека к увиденному или прочтенному как к вымыслу, так как произведения (фильмы и книги) являются художественными. С одной стороны, это защищает личность от идентификации и позволяет обсуждать увиденное или прочитанное, с другой стороны, позволяет признать возможность существования подобного, т.е. 
снизить отрицание. Само обсуждение - это активное действие, которое препятствует травматизации.

- Интервизорские и супервизорские группы (как правило, регулярные закрытые небольшие группы с четкими правилами). Цель таких групп - разбор специалистами сложных случаев, повышение компетентности, нахождение путей решений в сложной ситуации. Обычно подобные формы применяются в профессиональных сообществах специалистов помогающих профессий. Самая известная форма - это Балинтовские группы. Иногда подобные группы могут создаваться специалистами для родителей. Наличие подобной группы является ресурсом и позволяет отложить немедленную реакцию на сложную ситуацию до момента встречи группы. В группе ситуация рассматривается всеми участниками с разных точек зрения, что позволяет расширить видение ситуации и найти разные пути выхода, а также получить эмоциональную поддержку и конструктивную критику в безопасных условиях.

- Консультации специалистов (супервизии). Цель консультаций - решение конкретного запроса. Консультации могут быть групповыми и индивидуальными. Чаще всего консультации назначаются заранее, хотя могут быть и стихийными (по ситуации и возможностям специалиста). Каждый специалист имеет свою специализацию, свою зону ответственности и компетенции. Четкое понимание, признание и этичное предъявление специалистом вовне этих ограничений также является профилактикой жестокого обращения с детьми. Этичное информирование взрослого о своих границах и границах возможной помощи наглядно демонстрирует взрослому, что, во-первых, границы могут быть; во-вторых, невозможно быть компетентным во всем; в-третьих, у взрослого есть возможность признать собственную некомпетентность и незнание, что не значит стать плохим, а значит получить шанс на помощь у компетентного специалиста; в-четвертых, реагировать на недовольство можно без последствий для всех (можно злиться и говорить про свою злость и недовольство и не быть брошенным). В консультациях профилактика осуществляется не столько за счет информирования взрослого, сколько за счет поведения специалиста, даже если задается вопрос: «Что делать?». 
- В любой коммуникации большая часть информации передается и воспринимается по невербальному каналу. В профилактике важно не столько, что говорится, сколько как говорится. В идеале «что» и «как» должны нести один смысл.

- Игры (социальные игры, коммуникативные игры, трансформационные игры, симуляции и т.д.). Цель проведения игр - дать возможность взрослому исследовать собственные паттерны поведения, увидеть последствия, расширить репертуар и попробовать новые способы коммуникации. Такая форма профилактики осуществляется в безопасных для личности условиях, возможен выбор ролей и формы игры. Можно взять готовые игры, подходящие под задачи профилактики, например, социальные игры Г. Хорна, игры «Лепешка» и «Договоримся», либо придумать игру самому. Например, взять ситуацию выполнения ребенком домашнего задания и проиграть ее с разными вариантами.

Для профилактики недостаточно просто проиграть ситуации, важен последующий их разбор и обсуждение. Должен быть ведущий, который находится вне игры и несет ответственность за процесс, тем самым обеспечивая его эффективность и безопасность.

- Спортивные и развлекательные мероприятия. Цель мероприятий - создание условий для снятия напряжения, получения радости и удовольствия; профилактика эмоционального выгорания. Напряжение имеет свойство накапливаться. Если его не отслеживать и не контролировать, то есть вероятность, что это напряжение начнет разряжаться в самый неожиданный момент или оно будет сниматься регулярно на окружении, в том числе на беззащитных детях. Физическая активность позволяет сбрасывать напряжение или расслабляться (каждому подходит свое) и таким образом восстанавливать душевное равновесие. Положительные эмоции позволяют восстановить баланс между негативом и позитивом.

Меры профилактики, направленные на детей и подростков. Основной целью профилактической работы с детьми и подростками является снижение риска их травматизации от жестокого обращения. Профилактическая работа ведется по следующим направлениям: 
1) формирование у детей и подростков представления о ценности каждого человека;

2) формирование представлений о собственных границах и границах других людей;

3) формирование и развитие представлений о правилах межличностного взаимодействия;

4) развитие эмоционального интеллекта, в том числе представлений об экологичных способах выражения негативных эмоций;

5) формирование представлений о правилах безопасности и способах самозащиты;

6) формирование стрессоустойчивости;

7) формирование и расширение репертуара копинг-стратегий;

8) формирование психологической устойчивости.

Меры профилактики реализуются в процессе естественной жизнедеятельности ребенка, его воспитания и обучения, причем выбор направлений и форм профилактики будет зависеть от актуального состояния ребенка, его возрастных и личностных особенностей, а также от возможностей взрослых и условий среды.

Рассмотрим основные направления и формы профилактической работы с детьми и подростками:

- Формирование надежной системы привязанности как форма профилактики жестокого обращения. Система привязанности начинает формироваться еще до рождения ребенка. Система привязанности - это биологически заложенная система, включающая чувства, ожидания и стратегии поведения ребенка, которые он вырабатывает в раннем детстве на основании опыта взаимодействия со значимыми другими, активизируется в ситуации опасности [4]. У ребенка формируется целая иерархия объектов привязанности. Надежная привязанность обеспечивает чувство безопасности, ощущение, что есть надежное убежище, где можно пережить любую ситуацию и залечить любые раны. Надежно привязанный ребенок в ситуации опасности, жестокого обращения с ним обращается к объекту привязанности за помощью, разъяснениями, утешениями и получает их, тем самым подтверждая надежность своего убежища. Дети с надежной привязанностью справляются быстрее даже с шоковой травмой. Дети с ненадежной привязанностью и снарушенной 
привязанностью недостаточно уверены в безопасности и надежности взрослых, поэтому не всегда ищут помощи, поддержки или делают это неочевидным образом (например, используя агрессию).

- Четкие правила и отсутствие двойных посланий как направление профилактики жестокого обращения с детьми. Для ребенка границы и правила обеспечивают также ощущение безопасности и понимание того, что можно делать, а что нельзя (как по отношению к нему, так и по отношению к другим). Например, «Если меня можно шлепать, то и мне можно шлепать других», «Если меня кусают, то и я кусаю». Многие правила взаимодействия не озвучиваются, а усваиваются на основании опыта. Проговаривание правил легализует их, делает более четкими, понятными и однозначными. Нарушение правил обязательно должно «маркироваться» взрослым и разбираться. Последствия нарушений могут быть разными: от разговора об этом нарушении с целью учета ребенком полученного опыта в дальнейшем до санкций. Последствия обязательно должны быть адекватны нарушению и способности ребенка их понять. Правила также должны соответствовать возрастным особенностям и возможностям ребенка. Все правила можно поделить на категории: позитивные («У нас так принято») и негативные («Нельзя!»). Должен быть соблюден баланс позитивных и негативных правил. Кроме этого можно разделить правила на группы:

- нельзя/можно всем,

- нельзя/можно ребенку,

- нельзя/можно взрослому,

- можно при определенных условиях,

- можно с определенного возраста.

Правила могут обезопасить ребенка от жестокого обращения не только дома, но и в других местах. Например, правила группы в детском саду, правила класса, секции, которые регулируют межличностное взаимодействие. Даже если ребенок подвергается насилию в домашних условиях, правила группы, направленные на профилактику жестокого обращения, дают ребенку представление, что может быть и по-другому.

- Развитие эмоциональной сферы ребенка. Необходимо специально уделять внимание развитию эмоциональной сферы ребенка, 
помочь ему понять ценность эмоций и переживаний в жизни человека, научить правильно выражать эмоции и понимать эмоции других людей, осознавать, что нет плохих эмоций, а есть неправильные способы их выражения. Разработаны специализированные программы по развитию эмоциональной сферы для детей разного возраста, книги и мультфильмы о разных эмоциях. Кроме этого можно акцентировать внимание ребенка на переживаниях разных героев сказок, фильмов, игр, других людей, и в первую очередь на переживаниях самого ребенка и его близких. Возможно также создание специальных условий для проживания особо тяжелых эмоций детьми. Например, «кресло обиды», в которое садится тот, кто обиделся и легально проживает свою обиду. Важно не манипулировать собственным эмоциональным состоянием во взаимодействии с ребенком, не спекулировать им. Подобного рода манипулирование относится к психологическому насилию.

- Прямое обучение поведению в различных ситуациях. Так же, как мы учим детей переходить дорогу, важно научить их правилам безопасного поведения, навыкам распознавания опасностей в обычной жизни, способам предотвращения и реагирования на опасности. Обучение должно проходить в игровой форме: тренинги, игры, в том числе специализированные компьютерные игры, целенаправленно подобранные книги и комиксы. Недостаточно прочитать эти правила, важно проиграть или обсудить - активно ассимилировать их. Такое обучение не должно сопровождаться повышенной тревогой взрослого, должно соответствовать возрастным и личностным особенностям ребенка и содержать варианты выхода из ситуации. Обучение не должно вызывать травму.

Меры профилактики, направленные на улучшение взаимодействия между ребенком и взрослым. В некоторых случаях жестокое обращение спровоцировано нарушенной коммуникацией между участниками взаимодействия. Процесс коммуникации - это процесс передачи информации, которая предварительно кодируется, затем передается от одного субъекта к другому по определенным каналам. Далее происходит последующая декодировка информации и обратная связь с тем человеком, который эту информацию 
изначально отправлял. Информация для обратной связи также кодируется, передается по каналу и декодируется.

Искажение коммуникативного процесса может происходить на любом этапе. Профилактика жестокого обращения с детьми в данном случае будет ориентирована на «маркировку» ошибок передачи информации, выявление коммуникативных барьеров и их последующее исправление. Цель данной группы мер профилактики - повышение качества коммуникации между родителями и детьми.

Рассмотрим основные причины снижения эффективности коммуникации между родителями и детьми и меры их профилактики:

1. Барьеры, возникающие в силу объективных причин (помехи, шумы, невозможность получить обратную связь по объективным причинам, отсутствие условий для обсуждения какой-либо темы). Повысить качество коммуникации в этом случае возможно различными способами: предложить отойти в сторону, назначить встречу в удобное для общающихся время и подходящем месте; создать для общения условия, оптимально пригодные для решения задач. Например, ребенок увлеченно смотрит мультфильм и не слышит то, что говорит мама. Вариант повышения качества коммуникации: мама дает ребенку досмотреть мультфильм (либо прерывает просмотр по ситуации), подходит к ребенку, опускается на уровень его глаз, доносит информацию и получает обратную связь от ребенка. Также можно маме попросить ребенка повторить то, что она попросила.

2. Трудности, обусловленные особенностями самих участников процесса (нарушение слуха, зрения, нечеткая дикция говорящего или другое нарушение речи). Повышение качества коммуникации связано с определением и применением адекватного способа компенсации возникшей сложности. Например, ребенок четырех лет с моторной алалией не может говорить словами, но выражает себя с помощью жестов и мимики. Вариантом повышения качества коммуникации в данном случае будет перевод эмоционально-жестового рассказа ребенка для остальных участников общения и обучение их тому, как ребенка можно понимать. При этом ребенок может поправлять неточности перевода взрослого. 
3. Неправильное кодирование информации. Для повышения качества коммуникации требуется выявление ошибок кодирования, их проверка с помощью обратной связи, замена неправильного кода на правильный, «маркирование» таких ошибок в дальнейшем и их устранение при обратной связи. Например, ребенок отрывается от родителя и перебегает дорогу перед автомобилем. Родитель перебегает дорогу следом и набрасывается на ребенка. При этом информация «Я за тебя испугался! Ты мне дорог!» ошибочно кодируется и воспринимается ребенком как «Ты плохой!». Вариант исправления такой ошибки: родитель приходит в состояние равновесия, справляется со своими чувствами, возвращается к произошедшему тогда, когда и ребенок готов воспринимать информацию от родителя. При этом родитель объясняет ребенку свои истинные чувства и договаривается с ним о приемлемом способе взаимодействия при переходе через дорогу. В следующий раз в аналогичной ситуации родитель сначала возвращается в состояние равновесия, а затем правильно кодирует свое состояние, требование к ребенку и может обсудить санкции за нарушение принятых правил на будущее. Учитывая опыт, взрослый учится предвосхищать подобные ситуации и принимать превентивные меры, параллельно обучая ребенка.

4. Неправильно выбранный канал передачи информации и неконгруэнтность передаваемой одновременно информации по разным каналам. Мы передаем информацию, используя сразу несколько каналов: вербально и невербально, лично и, используя средства связи (телефон, планшет, соседа, записки и т. д.). Одни каналы являются наиболее значимыми, удобными и достоверными, другие, наоборот, недостоверны, игнорируемы, неудобны. Повышение качества коммуникации видится нам в том, что человек должен понимать, какие каналы собеседник относит к первой категории, какие - ко второй. В зависимости от цели коммуникации человек должен отправлять информацию по нужному каналу, минимизировать расхождения информации, передаваемой одновременно по разным каналам. При этом если по разным каналам передается разная информация, то необходимо пояснить эту разницу. Например, возвратившись домой с работы, уставший и раздраженный родитель (информация передается невербально) говорит ребенку, что он его любит (информация 
передается вербально). Родитель при этом не отдает себе отчет в том, что дети дошкольного возраста воспринимают информацию преимущественно через невербальный канал. Повышение качества коммуникации становится возможным, если родитель объясняет, что его раздражение связано с усталостью, а не с ребенком, затем, придя в состояние эмоционального равновесия, повторяет ребенку свое послание о любви и на вербальном, и на невербальном уровне (обнимает ребенка и говорит ему: «Я тебя люблю!»), достигая таким образом конгруэнтности.

5. Нарушение декодирования. Повышение качества коммуникации связано с проверкой правильности декодирования с помощью обратной связи, «маркированием» и исправлением ошибок в системе декодирования. Например, родитель накричал на ребенка, после чего ребенок ушел в свою комнату. Родитель может декодировать этот поступок ребенка как обиду, безразличие, игнорирование, думать о том, что он травмировал ребенка, и это испортит их отношения навсегда. Однако нужно не приписывать ребенку свое видение его эмоционального состояния, а найти способ достоверно определить его. Только обратная связь в виде ответа ребенка на прямой вопрос родителя и распознавание его настроения в процессе диалога способны подтвердить или опровергнуть гипотезу декодирования.

Стоит отметить, что зачастую взрослые считают, что дети воспринимают происходящее так же, как они, и не понимают, что ребенок поступает, думает и чувствует иначе не из-за своей испорченности или зловредности, причина в другом: уровень развития психики ребенка, характерный для детского возраста эгоцентризм не позволяют ему понять, что у окружающих могут быть свои собственные потребности, представления и чувства. Поэтому профилактика жестокого обращения с детьми связана с освоением и использованием родителями адекватных детскому возрасту средств и приемов коммуникации.

Таким образом, профилактика - это важная часть работы специалистов по предотвращению травматизации детей. Существует достаточно широкий спектр мер профилактики жестокого обращения с детьми. Из них необходимо выбирать те, что соответствуют 
возможностям, компетенциям и ресурсам конкретной организации и специалиста.

Система профилактики должна быть направлена на предотвращение случаев жестокого обращения, поиск альтернативных, более эффективных и экологичных способов взаимодействия, поддержку детей и взрослых, при этом ребенок всегда должен оставаться в приоритете [8]. Эффективная система профилактики способна предотвратить травматизацию и/или минимизировать ущерб от шоковых травм у ребенка.

1. Беседина О.А. Распространенность жестокого обращения с детьми в российских семьях // Вестн. Тюм. гос. ун-та. Соц.-экон. и правов. исслед. 2016. Т. 2, № 3. С. 55-63.

2. Насилие и его влияние на здоровье : докл. о ситуации в мире : пер. с англ. / под ред. Этьенна Г. Круга и др. М. : Весь мир, 2003. 376 с.

3. Алексеева И. А., Новосельский И. Г. Жестокое обращение с ребенком. Причины. Последствия. Помощь. М. : Генезис, 2006. 256 с.

4. Бриш К. Х. Терапия нарушений привязанности: От теории к практике : пер. с нем. С. И. Дубинской. М. : Когито-Центр, 2012.316 с.

5. Виттхен Г. У. Энциклопедия психического здоровья. М. : Алетейа, 2006. 552 c.

6. Организация помощи детям, пострадавшим от насилия и жестокого обращения в рамках работы специалистов служб психолого-педагогического сопровождения : метод. рекомендации. Ханты-Мансийск, 2010. 140 с.

7. Сафонова Т.Я., Цьмбал Е.И. Жестокое обращение с детьми: сущность, причины, социально-правовая защита. М. : Психология и педагогика, 1993.27 с.

8. Об объявлении в Российской Федерации Десятилетия детства : Указ Президента РФ от 29.05.2017 г. № 240 [Электронный ресурс]. URL: http:// www.consultant.ru/document/cons_doc_LAW_288278/ (дата обращения: 14.03.2020). 


\section{Раздел 5 \\ МЕЖДИСЦИПЛИНАРНЫЕ ИССЛЕДОВАНИЯ \\ СОВРЕМЕННОГО ДЕТСТВА}

\section{ТРАНСФОРМАЦИЯ ПРЕДСТАВЛЕНИЙ О ШКОЛЕ У УЧАЩИХСЯ НА РАЗНЫХ ЭТАПАХ ШКОЛЬНОГО КУРСА ОБУЧЕНИЯ}

0. Ю. Зотова

Л. В. Тарасова

По мере того как развиваются знания о человеческом развитии и обучении, расширяются и возможности формирования более эффективных образовательных практик, необходимых для обеспечения благополучия детей и их здорового развития. Развитие и обучение детей формируется в результате взаимодействия между факторами окружающей среды, отношениями и возможностями обучения, наряду с физическими, психологическими, когнитивными, социальными и эмоциональными процессами $[1,2]$.

Активное изучение эффективности школьного образования началось в 70-х гг. прошлого века. Большое количество классических исследований способствовали дальнейшему, более глубокому изучению данной проблемы.

Так, Алан Одден определил следующие общие принципы эффективной школы: сильное руководство школы; высокие, но реалистичные ожидания; безопасная среда в школе; мониторинг успеваемости учащихся; согласование школьных академических целей или миссии; постоянное профессиональное развитие [3].

Немалое количество проведенных исследований показали, что школьный климат и восприятие учениками своего образования являются предикторами высокой успеваемости учащихся. Несколько исследований подтвердили связь между благоприятным школьным климатом и успехами в учебе. Например, школьный климат связан 
с мотивацией к обучению [4], общей успеваемостью в школе [5], средним баллом [6], вовлеченностью учеников [7], посещаемостью занятий [8].

Исследования изменений, происходящих с детьми на разных этапах обучения, показывают, что чем выше этап школьного курса обучения, тем менее благоприятными становятся характеристики школы, по мнению детей, а ученики проявляют все меньше стремлений к достижениям $[9,10]$. Исследования английских психологов продемонстрировали признаки плохого функционирования у учащихся после перехода в среднюю школу $[4,10,11]$. Мартин Майер и Кэрол Майдгли утверждают, что в старших классах все больше внимания уделяется оценке и эффективности, что заставляет учащихся чувствовать себя некомфортно [12]. Снижение комфортности пребывания в школе детей и подростков может повлиять на ряд результатов, таких как: академические результаты, самовосприятие, психическое здоровье, социальная компетентность, концентрация и мотивация [4, 13-17]. Снижение психологического благополучия учеников в процессе обучения в школе может быть связано с сокращением поддержки учителей, изменениями в размере школы, увеличением числа учителей, что затрудняет формирование тесных контактов между учителями и учеником [4].

Так, дети начальной школы в Норвегии демонстрировали более позитивное восприятие их среды обучения, чем учащиеся средних школ [18-20]. Учащиеся средних школ сообщали о меньшей удовлетворенности эмоциональной и академической поддержкой со стороны их учителей $[18,20]$.

С другой стороны, Кристофер Вейс и Питер Берман в 2007 г. пришли к выводу, что снижение привлекательности школы может быть связано с особенностями подросткового возраста, а не с ухудшением ситуации в средней и старшей школе [21]. Подростковый возраст - время гормональных и физических изменений, а также трансформации идентичности и саморефлексии [22, 23]. Когнитивное развитие ребенка повышает его способность размышлять о содержании учебных заданий и оценивать школьную деятельность. Это подразумевает, что ученики средней школы могут воспринимать школьную работу как менее значимую, чем дети младшего школьно- 
го возраста, потому что их когнитивное развитие сделало их более критичными, а не потому, что учебная программа менее актуальна.

Более того, предыдущие исследования показывают, что ученики в первые годы обучения не видят разницы между способностями и усилиями как причинами достижений [24-26]. Когда детям исполняется 9 лет, они уже могут приписывать результат исключительно усилию. С 10 лет школьники способны различать успеваемость в школе и усилия в школе, а с 12 лет разница между усилием и способностью понятна, и они признают способность как фактор, который ограничивает эффект от усилий. Признания способностей как фактора, который влияет на академические достижения, способствуют повышению чувствительности к обратной связи с преподавателем. Замечания и критические комментарии со стороны взрослых могут быть восприняты как отсутствие поддержки учителя.

Наконец, подростковый возраст характеризуется растущей потребностью в самоопределении и самостоятельности [27-29], что может привести к более негативному восприятию авторитетных фигур, таких как родители и учителя.

Сами ученики «являются лучшим источником информации для оценки ситуации внутри школы» [30, p. 486). Учитывая, что учителя и ученики не всегда одинаково воспринимают одну и ту же ситуацию [31], включение восприятия учащихся является критическим компонентом для оценки эффективности школьного образования. Кроме того, социально-экологическая теория предполагает, что восприятие людей, а не перспективы других или некоторая объективная реальность, имеют решающее значение для понимания их поведения [32-34]. Таким образом, собственные представления учеников следует учитывать при исследовании эффективности школьного образования.

Также важно признать, что восприятие учениками школы зависит от личных качеств и индивидуальных факторов, таких как пол, класс и этническая принадлежность [35-38]. Например, Кристин Кот и ее коллеги обнаружили, что мужчины и этнические студенты из числа меньшинств склонны демонстрировать менее позитивное представление о школе. Также ими было выявлено, что девочки бо- 
лее негативно воспринимают школу, чем мальчики [36]. Таким образом, изучение представлений о школе у учащихся может не только объяснить механизмы формирования благоприятного школьного климата, но и способствовать повышению академической успеваемости детей и подростков.

Цель исследования: изучить особенности представлений о школе у учащихся на разных этапах школьного курса обучения.

Выборка: учащиеся начальных классов $(n=53)$, средних классов $(n=26)$, старших классов $(n=30)$, а также студенты, обучающиеся на первом курсе вуза $(n=50)$.

\section{Методы исследования}

Методы: стандартный семантический дифференциал Ч. Осгуда, ассоциативный тест. Обработка проводилась при помощи факторного анализа (SPSS 20.0.), непараметрического критерия Краскела-Уоллиса, непараметрического критерия Манна-Уитни, контент-анализа.

\section{Результаты}

1. В целом образ школы носит более позитивный характер у учащихся начальных классов (2-3-е классы). На статистически достоверном уровне $(p<0,05)$ учащиеся начальных классов воспринимают школу как «радостную», «хорошую», «активную», «упорядоченную», «жизнерадостную», «любимую», «умную». Можно отметить линейное снижение степени позитивности восприятия школы по мере повышения образовательного этапа (рис. 1). То есть учащиеся средних классов значительно негативнее воспринимают образ школы, а учащиеся старших классов - еще более негативно. Все различия достоверны для $p<0,05$. Учащиеся первого курса вуза оценивают школу так же, как ученики старших классов, различия касаются лишь двух характеристик - школа в представлении учащихся первого курса является более «плохой» и при этом более «любимой» $(p<0,05)$.

2. В основе восприятия школы у учащихся разных ступеней образования лежит сходная система факторов: 
а) позитивные эмоции, связанные со школой («Позитивные эмоции»), появляются на этапе обучения в средней школе и сохраняются на протяжении последующих этапов обучения (любимый, родной, радостныци, жизнерадостныц и);

б) напряженность («Напряженность») как негативное переживание напряжения, описывающее образ школы, так же характерно для учащихся средней школы и последующих этапов обучения;

в) простота и легкость обучения («Простота/Легкость») в начальной школе воспринимается через упорядоченность: сложно то, в чем учащийся не может увидеть понятного ему порядка. То есть восприятие легкости связано с когнитивным процессом упорядочивания. На последующем же этапе обучения чувство легкости оказывается в тесной связи с переживанием позитивных или негативных эмоций: легкий - это радостный, а сложный - плохой;

г) более частные факторы - мягкость, чистота, скорость, свежесть связаны с изменением условий обучения: начало обучения в школе, переход из начальной школы в среднюю.

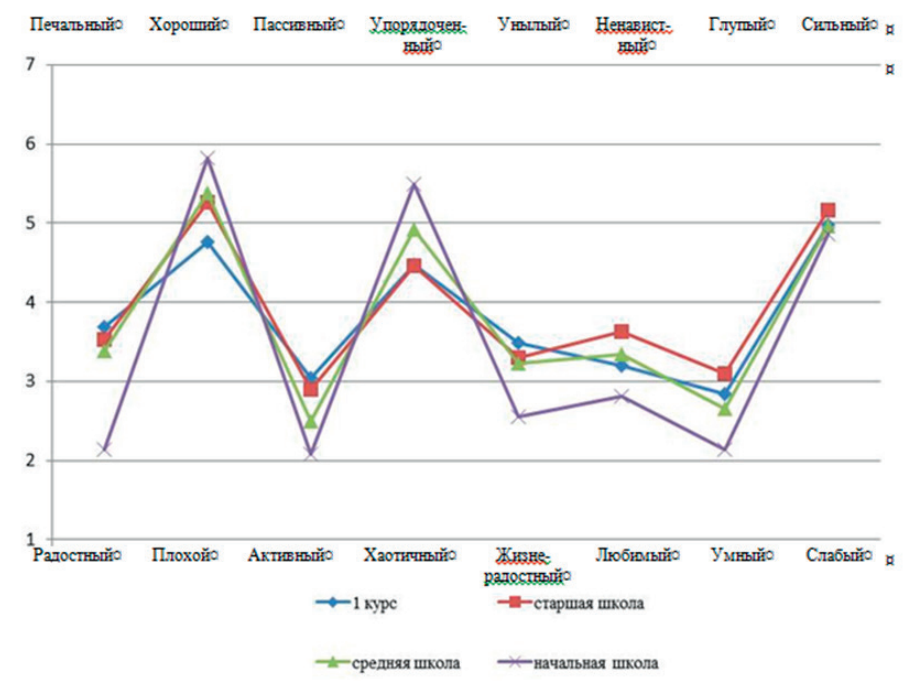

Рис. 1. Параметры образа школы в сознании учащихся разных этапов обучения 


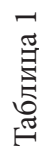

\begin{tabular}{|c|c|c|c|}
\hline 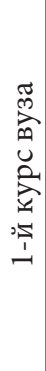 & 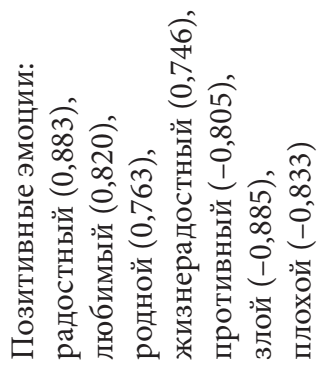 & 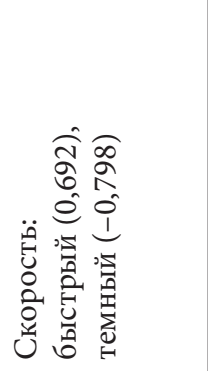 & 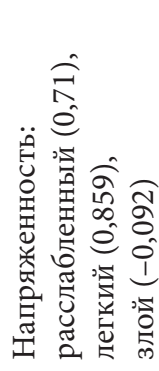 \\
\hline 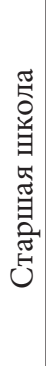 & 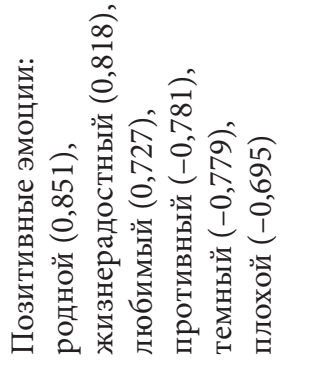 & 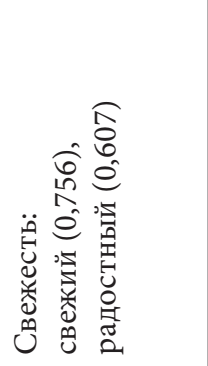 & 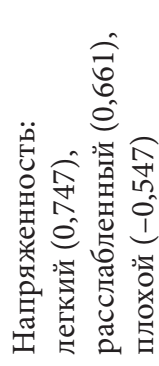 \\
\hline 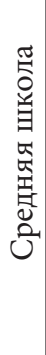 & 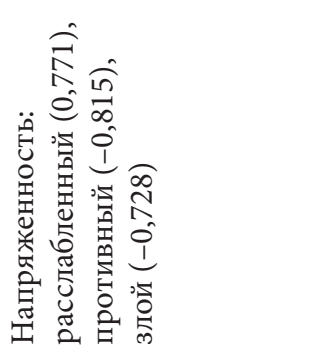 & 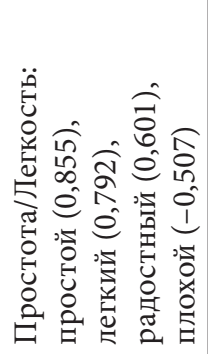 & 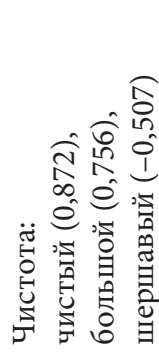 \\
\hline 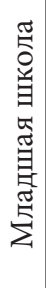 & 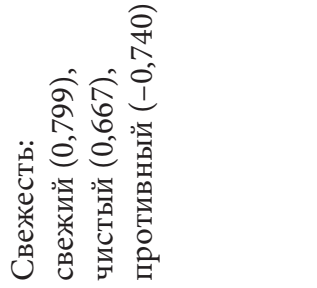 & 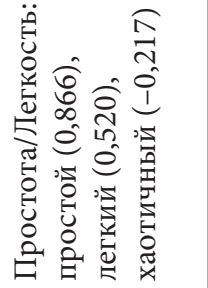 & 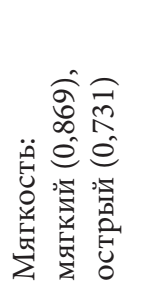 \\
\hline 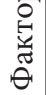 & $\neg$ & $\sim$ & $m$ \\
\hline
\end{tabular}




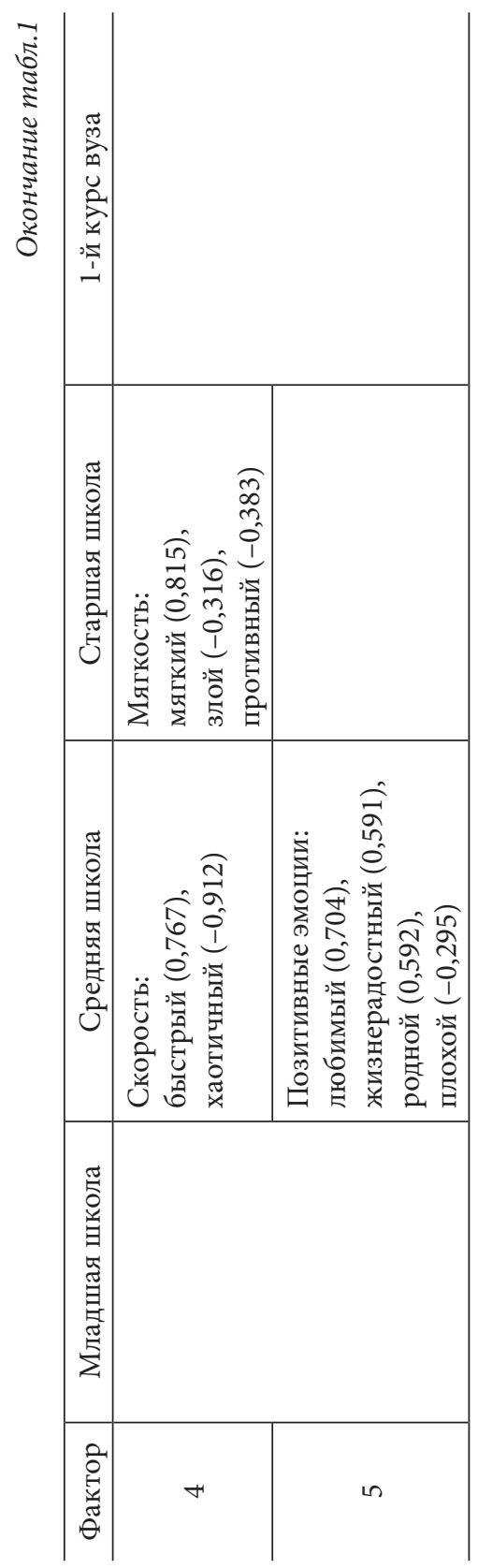


Факторная структура восприятия школы усложняется по мере обучения (количество факторов растет), а по завершении обучения - снова сводится к трем факторам (табл. 1).

3. Контент-анализ ассоциаций учащихся позволил выделить категории, через которые можно описать понятие школы (табл. 2):

a) предметные характеристики, отражающие непосредственно атрибуты обучения («учебники», «мел», «доска», «глобус», «пенал», «книги», «е-карта», «булки» и пр.);

б) характеристики процесса обучения («уроки», «знания», «учиться», «думать», «друзья», «обучение», «дискуссии», «приключение» и пр.);

в) результирующие характеристики обучения («оценки», «контрольные», «ЕГЭ», «экзамены» и пр.);

г) эмоциональные реакции и состояния, сопровождающие обучение. Данные состояния могут быть позитивными («ура», «веселье», «весело», «интерес», «радость», «яркая» и пр.) и негативными («не успею», «утомление», «стресс», «завал», «отсутствие сна», «одиночество», «ад», «волнение», «унижение» и пр.).

Таблица 2

Выраженность категорий, конкретизирующих образ школы

\begin{tabular}{|c|c|c|c|c|}
\hline \multirow[b]{2}{*}{ Категория } & \multicolumn{4}{|c|}{ Выраженность на этапах обучения, \% } \\
\hline & $\begin{array}{c}\text { начальная } \\
\text { школа }\end{array}$ & $\begin{array}{c}\text { средняя } \\
\text { школа }\end{array}$ & $\begin{array}{c}\text { старшая } \\
\text { школа }\end{array}$ & $\begin{array}{c}\text { 1-й курс } \\
\text { вуза }\end{array}$ \\
\hline $\begin{array}{l}\text { Предметные харак- } \\
\text { теристики }\end{array}$ & 38 & 18 & 8 & 12 \\
\hline $\begin{array}{l}\text { Характеристики } \\
\text { процесса }\end{array}$ & 52 & 24 & 16 & 22 \\
\hline $\begin{array}{l}\text { Характеристики } \\
\text { результата }\end{array}$ & 4 & 47 & 62 & 43 \\
\hline $\begin{array}{l}\text { Эмоциональные } \\
\text { реакции и состо- } \\
\text { яния: }\end{array}$ & 6 & 11 & 14 & 23 \\
\hline позитивные & 74 & 7 & 3 & 18 \\
\hline негативные & 26 & 93 & 97 & 82 \\
\hline
\end{tabular}




\section{Выводы}

Таким образом, по мере обучения сам процесс усвоения новых знаний, социализации в школе в сознании учащихся отходит на второй план и базовыми оказываются процедуры контроля результативности: «Школа - это контроль знаний, а не узнавание нового». Параллельно с этим все чаще отмечается наличие эмоций, сопровождающих обучение, что само по себе закономерно (как результат вовлечения в деятельность), но при этом необходимо отметить доминирование негативных переживаний. Вероятно, эти две тенденции (увеличение процедур контроля результата и негативные эмоциональные состояния) связаны, поскольку находят свое отражение и в результатах семантического дифференциала: появление фактора «Напряженность», содержащего эмоциональный компонент (напряженныц + злоц̆, противныц $)$.

1. Fischer K. W., Bidell T.R. Dynamic development of action, thought, and emotion // Theoretical models of human development, Handbook of child psychology / Eds. W. Damon, R. M. Learner. N. Y. : Wiley, 2006. Vol. 1. P. 319-399.

2. Rose T., Rouhani P., Fischer K. W. The science of the individual // Mind, Brain, and Education. 2013. Vol. 7(3). P. 152-158.

3. Odden A. Decentralized school management in Victoria, Australia. Washington : The World Bank, 1995.

4. Eccles J.S., Wigfield A., Midgley C. et al. Negative effects of traditional middle schools on students' motivation // Elementary School Journal. 1993. Vol. 93. P. 553-574.

5. Brookover W. B., Schweitzer J. H., Schneider J. M. et al. Elementary school social climate and school achievement // American Educational Research Journal. 1978. Vol. 15. P. 301-318.

6. Buckley M. A., Storino M., Sebastiani A. M. The impact of school climate: Variations by ethnicity and gender. Poster session presented at the annual meeting of the American Psychological Association. Toronto, ON, Canada, 2003.

7. Skinner E., Belmont M. Motivation in the classroom: Reciprocal effects of teacher behavior and student engagement across the school year // Journal of Educational Psychology. 1993. Vol. 85. P. 571-581. 
8. Gottfredson G. D., Gottfredson D. C. School climate, academic performance, attendance, and dropout // ERIC Document Reproduction Service No. ED 308225. 1989.

9. Barber B. K., Olsen J. A. Socialization in context: Connection, regulation, and autonomy in the family, school, and neighborhood, and with peers // Journal of Adolescent Research. 1997. Vol. 12(2). P. 287-315.

10. Galton M., Morrison I., Pell T. Transfer and transition in English schools // International Journal of Educational Research. 2000. Vol. 33(4). P. 341-363.

11. Galton M., Gray J., Ruddock J. The impact of school transitions and transfers on pupil progress and attainment. A DfEE Report. Norwich : Her Majesty's Stationary Office, 1999.

12. Maehr M. L., Midgley C. Transforming school cultures. Oxford and Boulder : Wiestview : Harper, 1996.

13. Eccles J. S., Early D., Frasier K. et al. The relation of connection, regulation, and support for autonomy to adolescents' functioning // Journal of Adolescent Research. 1997. Vol. 12(2). P. 263-286.

14. Little S. A., Garber J. Interpersonal and achievement orientations and specific stressors predict depressive and aggressive symptoms // Journal of Adolescent Research. 2004. Vol. 19(1). P. 63-84.

15. Ryan A. M., Patrick $H$. The classroom social environment and changes in adolescents' motivation and engagement during middle school // American Educational Research Journal. 2001. Vol. 38(2). P. 437-460.

16. Seidman E., Aber J.L., Allen L., French S. E. The impact of the transition to high school on the self-esteem and perceived social context of poor urban youth // American Journal of Community Psychology. 1996. Vol. 24(4). P. 489-515.

17. Seidman E., Allen L., Aber J. L., Mitchell C. The impact of school transitions in early adolescence on the self-system and perceived social context of poor urban youth // Child Development. 1994. Vol. 65(2). P. 507-522.

18. Byberg T. K. A., Tybring S. M. Læringsmiljø og konsentrasjon blant elever på barnetrinnet ( 5,6 og 7 trinn) og ungdomstrinnet [Learning environment and concentration among students in primary and secondary school in Norwegian]. Stavanger : University of Stavanger, 2004.

19. Sørlie M.-A., Nordahl T. Problematferd i skolen: hovedfunn, forklaringer og pedagogiske implikasjoner: hovedrapport fra forskningsprosjektet "Skole og 
samspillsvansker". [Problem behaviour in school: Main findings, explanations and educational implications: Main report from the project "Behavioural problems in schools"; in Norwegian]. Oslo : NOVA, 1998.

20. Thuen E., Bru E. Learning environment, meaningfulness of schoolwork and on-task orientation among Norwegian 9th grade students // School Psychology International. 2000. Vol. 21(4). P. 393-413.

21. Weiss C. C., Bearman P.S. Fresh starts: Reinvestigating the effects of the transition to high school on student outcomes // American Journal of Education. 2007. Vol. 113(3). P. 395-422.

22. Rutter M. Resilience: Some conceptual considerations // Journal of Adolescent Health. 1993. Vol. 14(8). P. 626-631.

23. Steinberg L., Morris A. Adolescent development // Annual Review of Psychology. 2001. Vol. 52. P. 83-110.

24. Folmer A. S., Cole D. A., Sigal A. B. et al. Age-related changes in children's understanding of effort and ability: Implications for attribution theory and motivation // Journal of Experimental Child Psychology. 2008. Vol. 99(2). P. 114-134.

25. Nicholls J.G. The development of the concepts of effort and ability, perception of academic attainment, and the understanding that difficult tasks require more ability // Child Development. 1978. Vol. 49(3). P. 800-814.

26. Nicholls J. G., Miller A. T. Reasoning about the ability of self and others: A developmental study // Child Development. 1984. Vol. 55(6). P. 1990-1999.

27. Allen J.P., Land D. Attachment in adolescence // Handbook of attachment: Theory, research, and clinical applications / Eds. J. Cassidy, P. R. Shaver. N. Y. : Guilford Press, 1999. P. 319-336.

28. Fuligni A. J., Barber B. L., Eccles J. S., Clements P. Early adolescent peer orientation and adjustment during high school // Developmental Psychology. 2001. Vol. 37(1). P. 28-36.

29. Steinberg L., Darling N.E., Fletcher A. C. et al. Authoritative parenting and adolescent adjustment: An ecological journey // Examining lives in context: Perspectives on the ecology of human development / Eds. P. Moen, K. Lüscher, G. H. Elder. Washington : American Psychological Association, 1995. P. 423-466.

30. Merrell K. W. Behavioral, social, and emotional assessment of children and adolescents. Mahwah: Erlbaum, 2003.

31. Mitchell M. M., Bradshaw C. P., Leaf P. J. Student and teacher perceptions of school climate: A multilevel exploration of patterns of discrepancy // Journal of School Health. 2010. Vol. 80. P. 271-279. 
32. Bronfenbrenner U. Contexts of child rearing: Problems and prospects // American Psychologist. 1979. Vol. 34. P. 844-850.

33. Haynes N. M., Emmons C., Ben-Avie M. School climate as a factor in student adjustment and achievement // Journal of Educational and Psychological Consultation. 1997. Vol. 8. P. 321-329.

34. Kuperminic G. P., Leadbeater B. J., Emmons C., Blatt S. J. Perceived school climate and difficulties in the social adjustment of middle school students // Applied Developmental Science. 1997. Vol. 1. P. 76-88.

35. Brookover W. B., Schweitzer J. H., Schneider J. M. et al. Elementary school social climate and school achievement // American Educational Research Journal. 1978. Vol. 15. P. 301-318.

36. Koth C. W., Bradshaw C. P., Leaf P. J. A multilevel study of predictors of student perceptions of school climate: The effect of classroom-level factors // Journal of Educational Psychology. 2008. Vol. 100. P. 96-104.

37. Thapa A., Cohen J., Guffey S., Higgins-D'Alessandro A. A review of school climate research // Review of Educational Research. 2013. Vol. 83. P. 357-385.

38. Wilson J., Pentecoste J., Bailey D. The influence of sex, age, teacher experience and race on teacher perception of school climate // Education. 1984. Vol. 104. P. 444-445. 


\section{ВЫБОР КАК ФАКТОР САМОРАЗВИТИЯ ЛИЧНОСТИ*}

И. В. Иванова

\section{Актуальность воспитания личности, готовой и способной к самостоятельному выбору, в контексте современного образования в РФ}

Для современной образовательной практики в России характерен ориентир на индивидуализацию процесса обучения, воспитания и развития детей, создание условий для раскрытия потенциальных творческих возможностей личности, при этом делается акцент на формирование свободной личности, способной к гибкому реагированию на стремительно меняющийся окружающий мир (реальный и виртуальный), готовой к постоянному саморазвитию и самосовершенствованию. Данный целевой ориентир отражен в основополагающих нормативно-правовых образовательных документах Российской Федерации: в Федеральном законе «Об образовании в РФ», Стратегии развития воспитания в Российской Федерации на период до 2025 года. Акцентируется внимание на том, что в современных социально-культурных условиях внимание должно уделяться воспитанию в детях умения совершать правильный выбор, формированию позитивных жизненных ориентиров и планов, которые выступают важными показателями саморазвития личности. Человек, который готов к свободному выбору и несет за него ответственность, способен самостоятельно меняться, а также вносить изменения в структуру общества, мира и всей планеты.

\section{Ретроспектива развития идей саморазвития, самовоспитания и свободы выбора}

в истории отечественной педагогической мысли

Идеи саморазвития не новы для отечественной педагогики. Мыслителей всегда волновала проблема саморазвития и самоопре-

* Исследование выполнено при финансовой поддержке РФФИ в рамках научного проекта № 20-013-00616 «Рефлексивно-ценностный подход как методологическая основа педагогического сопровождения саморазвития подростков в дополнительном образовании». 
деления человека, саморазвитие рассматривалось как способность строить себя, как одна из самых высоких потребностей и важнейших способностей человека. В работах отечественных ученых - представителей педагогической и философской мысли XIX в. (В.Г. Белинского, Н. А. Добролюбова, П.Ф. Лесгафта, Д. И. Писарева, Л. Н. Толстого, К. Д. Ушинского и других ученых) основательно разработаны некоторые вопросы теории и практики самообразования.

Л.Н. Толстой и К.Д. Ушинский, внесшие большой вклад в создание теоретических основ саморазвития личности в педагогической науке, рассматривали ориентацию образовательного процесса на потенциальные возможности личности и их реализацию как необходимое условие для любой системы образования. Исследователи утверждали, что главная цель педагогической деятельности помочь ребенку раскрыть свои способности.

Представители педагогической науки XX в. в России (С. Т. Шацкий, П. П. Блонский, А. С. Макаренко, В. А. Сухомлинский) стремились реализовать субъектный подход в обучении и воспитании детей. Саморазвитие личности через приобщение к творчеству в его различных проявлениях легло в основу педагогической концепции В.А. Сухомлинского. Ученый рассматривал социальное воспитание как фактор формирования готовности детей к саморазвитию.

В деятельности советских педагогов, создавших оригинальные образовательные системы, четко прослеживается идея развития внутренней активности и индивидуальной самостоятельности, формирования ответственности учащихся за свой личный выбор.

Развитие педагогики самовоспитания и самообразования продолжили Н. А. Бердяев, П.А. Кропоткин, Н. О. Лосский. Общая теория самовоспитания была создана учеными советского периода А. Я. Аретом, А. И. Кочетовым, Л. И. Рувинскими др.

Оригинальный подход к рассмотрению проблемы личностного развития найден в трудах представителей антрополого-гуманистического направления В. В. Вахтерова, П. Ф. Каптерева, П. П. Блонского, К. Н. Вентцеля. В научных трудах ученых широко представлена позиция, ориентированная на веру в силы и возможности творческой самореализации, сделан акцент на важности изучения интересов, потребностей и мотивов человека в процессе его образования и раз- 
вития. Ученые сосредоточились на том, что правильно организованная среда активизирует саморазвитие ребенка и обеспечивает развитие его индивидуальности.

В начале XX в. П.Ф. Каптерев определил и описал закономерности образовательного процесса, основанные на саморазвитии ребенка и совершенствовании его личности. Саморазвитие человека П. Ф. Каптерев рассматривал как сочетание саморазвития организма и самовоспитания, при этом воспитание определялось ученым как «систематическая помощь саморазвитию организма и всестороннее усовершенствование личности в мере ее сил и сообразно социальному идеалу» [1, с. 179].

Один из ключевых аспектов теории свободного воспитания К.Н. Венцеля - идея не формировать ребенка в соответствии с определенным идеалом человека, но помогать формированию индивидуального образа. Он отметил, что если учитель вместе со своими учениками разрабатывает учебную траекторию, план действий, эта траектория становится их коллективным результатом, в итоге ребенок чувствует себя полноправным участником образовательного процесса и может взять на себя ответственность за его проведение и осуществление [2].

В 1980-е гг. в России педагоги-новаторы (А.Н. Тубельский, В. А. Караковский, Ш. А. Амонашвили, Е. В. Бондаревская, И.П. Волков, Е. И. Ильина, С. И. Лысенкова, Б. П. Никитин, В.Ф. Шаталов, М. П. Щетинин, О.С. Газман, В.Ф. Шаталов и др.) провозгласили идеи педагогики сотрудничества, разработали авторские технологии обучения, рассматривающие ребенка в качестве субъекта саморазвития.

О. С. Газман, автор первой научной концепции оказания школьникам педагогической помощи в саморазвитии как жизненном самоопределении, основанной на идеях экзистенциальной философии и психологии, концепции педагогики свободы внес большой научный вклад в изучение проблемы саморазвития детей. Самоопределение, по его мнению, представляет собой процесс и результат осознанного выбора человеком позиции, целей и средств самореализации в конкретных условиях жизни, является основным механизмом получения внутренней свободы. Исходя из этого, 
педагогическая поддержка заключается в определении совместно с ребенком его интересов, целей, возможностей и путей преодоления препятствий (проблем), которые мешают ему сохранять человеческое достоинство и получать положительные результаты в обучении, самообразовании, общении и образе жизни. О.С. Газман считал, что педагогическая поддержка принадлежит к особой культуре воспитания, которая основывается на внутренней свободе, творчестве, демократии и гуманизме отношений между взрослым и ребенком.

Анализ литературы позволил прийти к выводам, что личностная свобода и ответственность перед собой, являясь критериями развития субъектности, входят в содержание таких характеристик личностного выбора, как:

1) сформированность представлений о множественности вариантов/альтернатив (А. А. Комлев, Н. В. Наумова и др.);

2) сформированность качественных характеристик выбора: значимость выбора, принятие на себя ответственности за выбор, наличие опыта самостоятельного выбора (Д. А. Леонтьев и др.);

3) процессуальная сторона выбора: оценка последствий принятия решения и выбора, удержание последствий выбора, соотнесение их с системой ценностей (этических представлений/ценностных ориентиров) ситуации «перепутья» в моральном выборе, примеривание на себя вероятностных последствий (Л.С. Выготский, И. Ялом и др.);

4) детерминанты выбора: наличие самостоятельности, свободы выбора, осознание своей жизненной, нравственной позиции в момент свершения выбора (Б. С. Братусь, Л. С. Выготский, Д. А. Леонтьев, Н.Ф. Наумова и др.);

5) наличие готовности к выьору: достижение эмоционального удовлетворения при осуществлении выбора, признание принятого решения наилучшим из возможных как основа самопринятия, способность и готовность к свершению самостоятельных выборов и несения за них ответственности (Д.А. Леонтьев и др.). 


\section{Современные идеи воспитания саморазвивающейся}

\section{личности, готовой к выбору и созданию проекта \\ собственного саморазвития}

Особое внимание стоит уделить концепции педагогики индивидуальности (О.С. Гребенюк и Т.Б. Гребенюк) и идеям экзистенциальной педагогики, содержащим концептуальные положения относительно механизмов воспитывающих воздействий (О.С. Гребенюк, Т. Б. Гребенюк, М.И. Рожков), основанным на принципах и концептуальных положениях экзистенциальной философии и экзистенциальной психологии.

Педагогические идеи О.С. Гребенюк и Т. Б. Гребенюк заложили основу для разработки методологии экзистенциальной педагогики, основными категориями которой являются индивидуальность, индивидуализация, саморазвитие, свобода выбора и экзистенциальная ответственность.

Основная идея экзистенциальной педагогики - формирование человека, способного к самопознанию, самореализации и самосовершенствованию на основе своего экзистенциального выбора, осознанного смысла своего существования и самореализации в соответствии с этим выбором [3].

Важные для понимания педагогического аспекта экзистенциализма концептуальные идеи высказал отечественный психолог, ученый В. Н. Дружинин, согласно которому «идеальной целью педагогики является формирование человека, умеющего прожить свою настоящую жизнь на основе сделанного им экзистенциального выбора, осознающего ее смысл и реализующего себя в соответствии с этим выбором» $[4$, с. 64]. Таким образом, смысл жизни реализуется через осознанно совершаемый экзистенциальный выбор и саморелизацию в соответствии с ним.

М.И. Рожков впервые выдвинул экзистенциальную цель воспитания: стимулировать личностное развитие ребенка на основе его рефлексивной оценки событий текущей жизни. Он раскрыл сущность саморазвития, описывая его как субъективный процесс самоизменения. Ученый рассматривает саморазвитие как реализацию ребенком собственного проекта совершенствования необходимых ему качеств [5]. 
Концепции экзистенциальной педагогики основаны на идеях философии экзистенциализма: понимании сущности, которая возникает после начала существования (Ж. П. Сартр); идее выбора как основы сущности человека (А. Камю); понимании свободы как свободы воли (Ю. Хабермас, К. Ясперс); идеях о свободе брать на себя ответственность за свою судьбу, свободе слушать свою совесть и принимать решения о своей судьбе (В. Франкл); на идеях экзистенциальной психологии о зависимости судьбы человека от отношения его к жизни и смерти, от разнообразия и типологии человеческих жизней (В.Н. Дружинин), а также на психологической теории преодоления, разработанной Р.Х. Шакуровым, основной категорией которой является барьер, преодолеваемый человеком и определяющий его развитие.

Саморазвивающаяся личность, согласно концепции экзистенциальной педагогики, обладает способностью строить свою судьбу и осуществлять собственный, индивидуальный выбор, умеет контролировать себя, свою жизнь, сознательно организует свое поведение и среду своей деятельности. Выбор, являясь экзистенциальной категорией, предполагает свободу и ответственность.

Рассуждая о свободе выбора, Н.Н. Михайлова и С. М. Юсфин указывают, что образовательный смысл категории «свобода» состоит в том, что данная категория может позиционироваться как механизм автономизации личности, заключающийся в присвоении ею права на уникальность. Речь идет о возможности существовать в собственном сознании и сознании других как нечто неповторимое, имеющее самоценность; о самореализации как выстраивании собственной жизненной траектории на основе самоопределения [6].

М.А. Фризен понимает природу саморазвития в плоскости трех экзистенций человеческого существования - духовности, свободы и ответственности - и дает следующее определение содержания этого процесса. Работа человека над самоизменением и самовоплощением является наиболее значимой и наиболее позитивной деятельностью для человека и общества. Человек становится уникальной смысловой вселенной только в том случае, если он пересекает пределы биологического и социального существования (свободы). 
Ответственность - это управление этими выходами за пределы, они должны быть направлены на благо человека и окружающих его людей, а также всего человеческого сообщества. Духовность рождается на стыке свободы и ответственности. Формирование системы нравственных ориентиров является одной из важнейших задач сознательного изменения личности. Через действия индивид вносит личный вклад в культуру (А.В. Петровский, В.А. Петровский) и, таким образом, несет ответственность как за характер своего бытия, так и за содержание культуры в целом [7].

Категория свободы выбора как личностной свободы «не от», а свободы «для» широко представлена в научных трудах О. С. Гребенюк, Т. Б. Гребенюк, Н. Н. Михайловой, С. М. Юсфина, М. И. Рожкова, В. И. Слободчикова и других ученых.

Свобода как показатель саморазвивающейся личности, по мысли Э. В. Ильенкова, понимается «в смысле развитой способности преодолевать препятствия, казалось бы, непреодолимые, в способности преодолевать их легко, изящно, артистично, а значит, в способности каждый раз действовать не только согласно уже известным эталонам, стереотипам, алгоритмам, но каждый раз индивидуально варьировать все общие вопросы действия применительно к индивидуально-неповторимым ситуациям...» [8, с. 234-235].

Понятие свободоспособности, раскрытое в трудах Н.Н. Михайловой и С. М. Юсфина, М.И. Рожкова и других ученых как неотъемлемый атрибут саморазвития личности, предопределяет действие рефлексивных механизмов, механизмов самоконтроля поведения и мысли, которые, в свою очередь, связаны с работой волевой функции сознания. Саморазвивающийся человек "создает себя», что подразумевает деятельность, невозможную без добровольных усилий. Интенциональные характеристики личности подчеркиваются в процессе самопринятия в ходе различных типов изменений в себе (своей личности, сущности) и преобразования мира.

Ученые (О. С. и Т.Б. Гребенюк, М.И. Рожков, В.П. Бедерханова, О.С. Газман, Н.Н. Михайлова, С. М. Юсфин и др.), рассуждая о свободе как характеристике саморазвивающейся личности, делают акцент на том, что неотъемлемым компонентом функционирования данного явления является экзистенииальный выбор. Как отмечает В.П. Бе- 
дерханова, свобода ощущается индивидом как субъектное явление, заключающееся в возможности самостоятельно делать выбор и нести за него ответственность (свобода выбора - свобода решения - свобода действий - свобода творчества и самовыражения). Самоконтроль - важный регулятор выбора, осуществленного человеком [9].

В трудах Л.И. Анцыферовой также имеется обращение к саморазвитию через осуществление личностью выборов. Ученый рассматривает человеческую жизнь как систему решений, основанную на времени. На протяжении всей жизни каждый человек должен принимать множество экзистенциальных решений, т. е. выборов в отношении характера своего существования. При необычных обстоятельствах он обнаруживает себя в новых системах социально-психологических связей, из материала которых ему приходится создавать свой новый, уникальный мир и осваивать новые образы жизни [10].

Для понимания того, как реализовывать экзистенциальную стратегию воспитания, важно знать ответ на вопросы: «На чем основан экзистенииальный выбор?», Какой психологический конгломерат выполняет роль регулятора саморазвития, определяет его вектор?».

В.И. Слободчиков и Е. И. Исаев пишут о саморазвитии как фундаментальной способности человека становиться и быть подлинным субъектом своей собственной жизни, а это означает, что в развитие человека включается важная детерминанта - ценностно-смысловая. Развитие для человека - это цель, ценность и смысл его жизни [11, c. 147].

Л. С. Выготский считал, что поведение и мыслетворчество регулируется, в первую очередь, мировоззрением. Для каждого человека индивидуальная система личностных смыслов определяет варианты его ценностных ориентаций. Личность создает индивидуально окрашенные ценностные ориентации, которые складываются на основе полученного жизненного опыта и определяют выбор линии поведения, которые он проецирует на свое будущее [12, с. 4-32].

Бесспорно, человек совершает экзистенциальный выбор, опираясь на сформированные на данный момент времени приоритетные ценности, имеющиеся смысложизненные ориентации, которые обеспечивают конструирование человеком образа смысла жизни, представление о своей стратегии жизни. 
Смысложизненные ориентации отвечают за осмысленность и ценность выборов, которые совершает человек, за способность влиять на ход жизненных событий и брать за них ответственность. Д. А. Леонтьев выделяет смысложизненные ориентации как одну из составляющих смысла жизни (наряду с локус-контролем, отражающим уверенность в способности влиять на ход собственной жизни, самостоятельно осуществлять жизненный выбор) и описывает их как «цели в жизни (переживание индивидом онтологической значимости жизни), эмоциональная насыщенность жизни и удовлетворенность самореализацией» [13, с. 158].

Приходим к выводу, что формирование смысложизненных ориентаций ученые определяют как одну из важных смыслорегулирующих основ саморазвития, и применительно к сфере образования оно выступает одной из ведущих задач, решение которой обеспечивает реализацию экзистенциальной стратегии воспитания.

Разработка рефлексивно-ценностного подхода как нового методологического подхода в педагогике (в рамках научной школы под руководством доктора педагогических наук, профессора, заслуженного деятеля науки РФ Михаила Иосифовича Рожкова). Выбор - сложная экзистенциальная задача для человека любого возраста. Особую актуальность приобретает задача формирования готовности личности к выбору в подростковом возрасте. Это объясняется рядом возрастно-психологических предпосылок:

1) подросток определяет свое место в социуме, у него формируется рефлексия, важными задачами развития становится самоопределение (профессиональное, личностное, социальное), а также самопознание (соотнесении «Я-реального» с «Я-идеальным»), складываются смысложизненные ориентации $[14,15]$;

2) имеется противоречивость поведения, отмечаются негативизм в сочетании с изменением в поведении под чьим-то влиянием, стремление к независимости и просьбы о помощи, энтузиазм в сочетании с пассивностью [16];

3) зачастую отмечается наличие способности делать выбор между равнозначно привлекаемыми альтернативами и одновременно сопротивляться искушениям и отвлекающим факторам [17]; 
4) выбор подростка осуществляется при недостаточном опыте, знаниях и возможностях [18].

Вместе с тем для формирования смысложизненных ориентаций важны принятые на этом этапе ценности и имеющийся событийный ряд, опыт выхода из проблемных ситуаций, связанный с самостоятельным выбором, анализом альтернатив выбора, рефлексией принятого рашения и его последствий. Речь идет о том, что в подростковом возрасте закладываются основы для формирования готовности к экзистенциальному выбору, которая при грамотном и своевременном сопровождении перейдет в качество личности, а самостоятельность и ответственность - в характеристику индивидуального стиля поведения.

Выбор всегда сопряжен с «выходом из зоны комфорта». Ситуация выбора, характерная для «выхода из зоны комфорта», порождает трудности и переживания, которые могут привести человека к следующим путям развития: становлению, саморазвитию, личностному росту или к регрессу, инволюции - остановке в развитии личности. Поэтому мы полагаем, что важно отдельное внимание уделить вопросу специбики педагогического сопровождения подростка в ситуации преодоления трудностей, порожденных необходимостью совершения самостоятельного выбора.

Обучение выбору приоритета рассматривается нами как ключевая задача педагогического сопровождения саморазвития личности. Мы в контексте разработанного нами рефлексивно-ценностного подхода, развивающего идеи экзистенциальной педагогики М.И. Рожкова, в качестве методики педагогического сопровождения, от которой зависит эффективность саморазвития подростков, рассматриваем стимулирующие реальные дилеммные ситуации, которые актуализируют экзистенииальный выбор человека, работают на определение иели и стратегии существования. Дилеммные ситуации, в отличие от проблемных ситуаций, не имеют однозначного решения, а предполагают свершение самостоятельного свободного выбора. В процессе анализа реальных дилеммных ситуаций разных видов активно задействована и активно развивается рефлексия (Почему я сделал этот выбор? Что делать дальше?), актуализируется экзистенциальный выбор человека. 
Опираясь на исследования О. С. и Т. Б. Гребенюк [3], мы предлагаем применять реальные дилеммные ситуации разных видов, выделяемые в соответствии с группой потребностей, в зоне которых возникла нехватка ресурсов, предопределившая дилемму:

1) реальные дилеммные ситуации в области интеллектуальной сферы;

2) реальные дилеммные ситуации в области эмоций;

3) реальные дилеммные ситуации в области мотивационной сферы;

4) реальные дилеммные ситуации в области волевой сферы;

5) реальные дилеммные ситуации в области рефлексии своего поведения;

6) реальные дилеммные ситуации в области предметно-практической сферы;

7) реальные дилеммные ситуации в области экзистенциальной сферы.

Ситуация преодоления трудностей, имеющаяся в реальной жизни или задаваемая дилеммой, созданной педагогом искусственно, рассматривается нами как основа для закрепления имеющихся и формирования новых ценностно-смысловых ориентиров личности, а сопровождение саморазвития подростка в ситуации преодоления трудностей выступает как механизм, обеспечивающий возможность перехода моральных (социальных) норм в нравственные (внутренние) нормы. В табл. 1 представлены характеристики, цели и основания для применения дилеммных ситуаций.

Приведем примеры дилеммных ситуаций для работы с подростками.

Дилеммная ситуация в области экзистенциальной сферы. Вы стали свидетелем того, как человек ограбил банк, но затем он передал деньги в детский дом. Эти деньги принесли большую пользу приюту, и он превратился из бедного в процветающий.

Вы: а) позвоните в полицию; б) ничего не сделаете, оставив в покое и грабителя, и детский дом.

Дилеммная ситуация в области эмоциональной сферы. Во время написания контрольной работы вы решили все задания и дал списать 


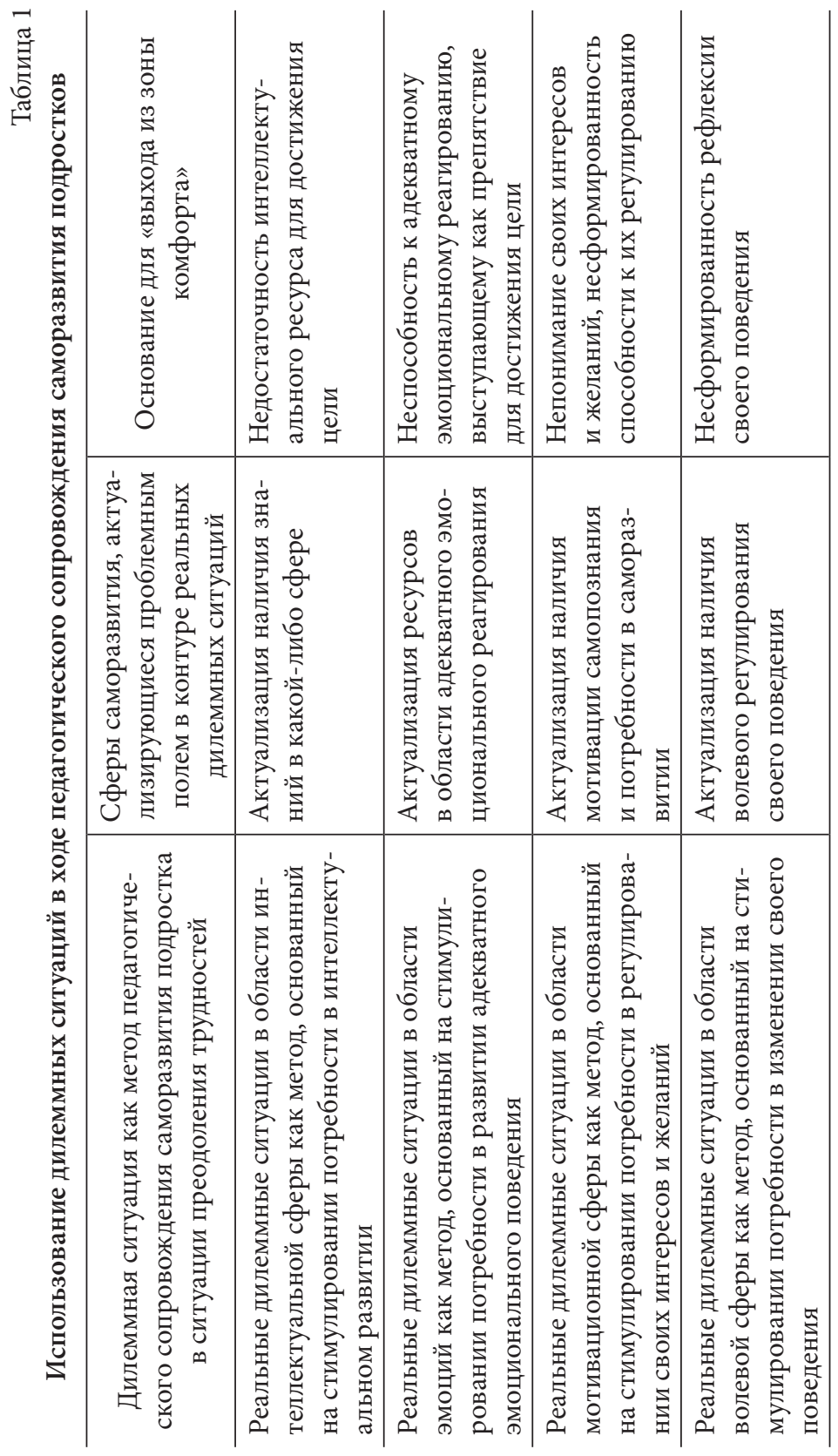




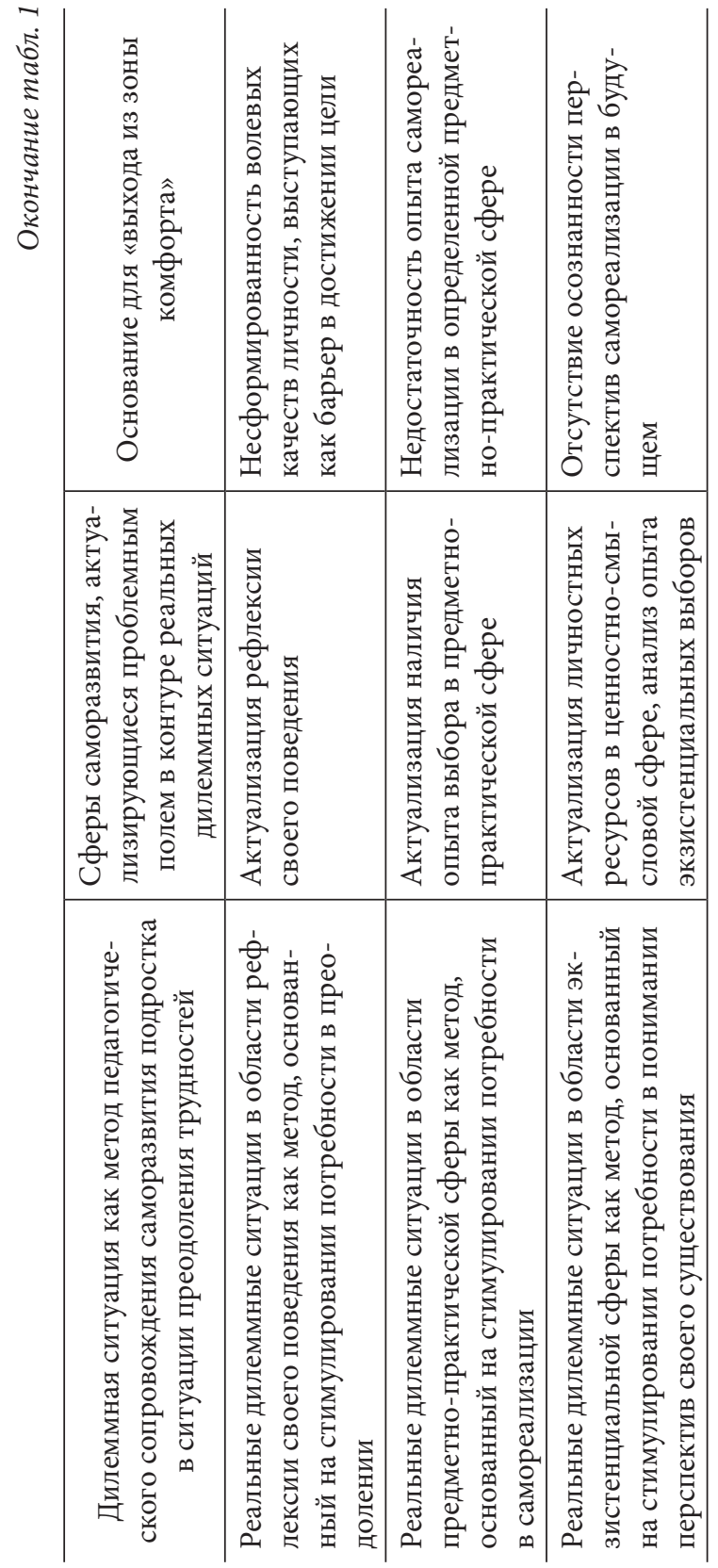


своему лучшему другу, по итогам он получил отметку «отлично», а вы получили «удовлетворительно», потому что списывали.

Вы: а) обратитесь к учителю с просьбой изменить оценку, так как именно вы решили все задания в полной мере и без ошибок и низкий балл получили незаслуженно; б) не станете обращаться к учителю.

Дилеммная ситуация в области рефлексии поведения. Александр работает в крупной компании, он ответственен за прием на работу сотрудников. Его друг Павел подал заявку на трудоустройство, но есть несколько человек, которые более квалифицированные, чем Павел, и обладают более высоким уровнем знаний и навыков. Александр хочет отдать эту позицию Павлу, однако чувствует себя виноватым, потому что должен быть беспристрастным. Он говорит себе, что в этом суть нравственности. Тем не менее вскоре он передумал и решил, что дружба дает моральное право быть пристрастным в некоторых вопросах. Таким образом, он отдает эту должность Павлу.

Вопрос: Прав ли Александр? Как бы вы поступили на его месте?

Рассматривая педагогическое сопровождение саморазвития подростков в рамках рефлексивно-ценностного подхода, отметим, что важную роль в выборе играет ценность, которая является привлекательной в данный момент времени для человека. То есть для принятия решения (в ходе решения реальных дилеммных ситуаций) подросток опирается на нравственную норму, интериоризированную в его сознании в данный момент времени.

Стимулирование подростков к рефлексии реальных дилеммных ситуаций является самостоятельным компонентом методики педагогического сопровождения саморазвития подростков в ситуации преодоления трудностей, позволяющим определять задачи последующих этапов взаимодействия подростка с референтными педагогами.

Метод стимулирующих реальных дилеммных ситуаций показывает свою эффективность при условиях:

а) их включения в естественную образовательную среду (например, в среду дополнительного образования детей);

б) их сочетания с включением подростков в социально активные виды деятельности, волонтерство, социальные проекты, 
позволяющие приобрести реальный опыт выборов и оценить их экологичность.

Решая дилеммы, подросток накапливает опыт самостоятельных выборов, рефлексирует по их поводу, учится предвидеть развитие событий в результате выбора той или иной альтернативы. Кроме того, решение дилемм может не только рассматриваться как воспитательный и развивающий метод, но и выступать как педагогический диагностический инструментарий.

В результате решения подростками различных видов дилеммных ситуаций определяется та сфера, которая выступает проблемной и требует развития. Иногда может быть определено конкретное личностное качество либо психологическая характеристика, влияющая на готовность к выбору и имеющая недостаточный уровень сформированности (рефлексия, волевые качества, запас знаний, опыт предметной деятельности, опыт самопознания, осознанность смысложизненных ориентаций и т. д.). Такие характеристики могут находиться в разных сферах.

В соответствии с обнаруженной проблемной доминантой в области готовности подростка к саморазвитию мы предлагаем организовывать индивидуально ориентированное педагогическое сопровождение саморазвития подростков по следующим маршрутам саморазвития: «Интеллектуальное обогащение»; «Эмоциональный баланс»; «Мои интересы и желания»; «Самоанализ как путь к успеху»; «Воля к победе»; «Опыт как путь к успеху»; «Увидеть свое будущее».

1. Индивидуальный марирут саморазвития «Интеллектуальное обогащение» направлен на решение задач формирования мотивации к саморазвитию в области интеллектуальной сферы, повышение веры в свои интеллектуальные возможности, создание условий для повышения самооценки. В качестве методов сопровождения применяются: анализ художественной, исторической и публицистической литературы, использование нравственной экспертизы содержания и результатов социальной практики, различные коуч-техники. Формами сопровождения могут быть: участие в олимпиадах, научно-практических конференциях, социальное проектирование, волонтерство, консультирование. 


\section{2. Индивидуальный марирут саморазвития «Эмоциональный}

баланс» решает задачи формирования мотивации подростка к саморазвитию в области эмоционально-волевой сферы, способности к адекватному эмоциональному поведению и рефлексии. Методами сопровождения выступают внушение и связанные с ним приемы аттракции, способствующие переживанию подростками совершенных поступков, арт-педагогические техники, коуч-техники. Формы сопровождения: тренинги эмоциональной гармонизации и личностного роста, социальное проектирование, волонтерство, консультирование.

\section{3. Индивидуальный маршрут саморазвития «Мои интересь} и желания». Задачи: формирование потребности в понимании своих интересов и желаний, потребности в их регулировании, формирование рефлексии. Методы сопровождения: создание ситуации успеха в социальной деятельности, поощрения (одобрение, похвала, поддержка); включение в практику решения проблемных ситуаций, позволяющих обнаружить истинные потребности, желания и интересы; коуч-техники; арт-педагогические техники. Формы сопровождения: тренинги самопознания и личностного роста, социальное проектирование, волонтерство, консультирование.

4. Индивидуальный маршрут саморазвития "Самоанализ как nуть к yспеху». Задачи: формирование потребности в приобретении рефлексивных качеств личности и рефлексии поведения. Используемые методы: упражнения в выдержке, самоконтроле, организованности, дисциплинированности, культуре общения; предъявление подростку требований, соответствующих общечеловеческим нормам, государственному законодательству, этническим особенностям; арт-педагогические техники. Формы сопровождения: тренинги самопознания и личностного роста, социальное проектирование, волонтерство, консультирование

\section{5. Индивидуальный марирут саморазвития "Воля к победе»} направлен на решение задачи формирования потребности в приобретении волевых качеств и рефлексии поведения. Применяются методы коррекции поведения, создающие условия для внесения подростками изменений в свой социальный характер и поведение (демонстрация способа решения аналогичной проблемы значимым 
для подростка персонажем или реальным человеком из числа социального окружения); коуч-техники, арт-педагогические техники.

6. Индивидуальньй маршрут саморазвития "Опьт как путь к yсnеху» направлен на решение задачи формирования потребности в приобретении опыта самореализации в определенной предметнопрактической сфере и накопление опыта выборов в предметно-практической сфере. В качестве методов сопровождения применяются: предоставление опыта социального взаимодействия, социальные пробы; воспитывающие ситуации; коуч-техники; арт-педагогические техники. Формы сопровождения: социальное проектирование, волонтерство, консультирование.

7. Индивидуальный марирут саморазвития «Увидеть свое будущее»» направлен на формирование потребности в самоопределении, понимание важности самоопределения, осмысленного самопознания и самопрогнозирования. Методами сопровождения могут выступить: метод дилемм; воспитывающие ситуации; социальные пробы; анализ художественной, исторической и публицистической литературы, нравственная экспертиза ее содержания и результатов; коуч-техники; арт-педагогические техники. Формами сопровождения являются: социальное проектирование, волонтерство, консультирование, тренинги самопрогнозирования.

Данные маршруты могут быть реализованы по отдельности, но возможно и их использование в комплексе. Комплексный маршрут индивидуального саморазвития формируется в соответствии с перечнем задач, подлежащих решению в рамках педагогического сопровождения.

Полагаем, что реализация индивидуальных маршрутов саморазвития возможна в системе дополнительного образования, поскольку они требуют высокого уровня вариативности, индивидуального подхода при построении и их реализации. Важной характеристикой дополнительного образования детей является то, что предлагаемая в данной системе образовательная среда построена на принципах, обеспечивающих возможности широкого удовлетворения потребностей, индивидуальных интересов и возможностей детей. 


\section{Выводы}

1. Исторически развивающаяся концепция саморазвития наполнена педагогическим содержанием и становится все более важной для современного гуманистического образовательного процесса. Личное развитие человека, главным фактором которого является выбор, теперь считается основной характеристикой целей, содержания и средств индивидуализации и личностно-ориентированного образования.

2. Саморазвивающаяся личность активна и инициативна. Большое значение для саморазвития имеет физическая, умственная и социальная активность, которая развивается в благоприятных условиях у каждого здорового индивида, личности. Саморазвивающаяся личность способна изменить себя и окружающий мир, при этом активный характер деятельности по самоизменению и изменению окружающего мира определяется множеством факторов: социальными установками, внутренней позицией личности («объективация», значимость, ответственность, притязания и другие мотивирующие факторы).

3. Самостоятельный выбор вершит судьбу человека, поэтому он должен быть осознанным и иметь характер предвидения, что невозможно без сформированных нравственных ориентиров как регуляторов поведения и сознания человека. Исходя из этого, важной задачей современного образования может выступать формирование у детей и подростков нравственных ценностных установок и на их основе проекта собственной жизни. Данная идея выступает ключевой в нашем научном исследовании, предметом которого является разработка рефлексивно-ценностного подхода как нового методологического подхода в педагогике, создаваемого в контексте экзистенциальной педагогики, в рамках научной школы под руководством М.И. Рожкова.

4. С позиции экзистенциального подхода считаем, что воспитание человека должно ориентировать воспитанника на его приближение к определенному образу, выбранному им с учетом сформированных смысложизненных ориентаций, представления о «Я-идеальном». Исходя из этого, важнейшей составляющей процесса воспитания свободного человека выступает педагогическое 
сопровождение его саморазвития, создающее условия для формирования ценностных ориентиров, не противоречащих нравственным нормам, принятым в обществе.

5. В контексте формирования готовности подростка к выбору особого внимания заслуживает реализации педагогического сопровождения саморазвития в ситуации преодоления трудностей (как реальных, так и специально созданных в целях воспитания и развития). Дилеммная ситуация предполагает включение сопровождаемого в диалог, в процессе которого он самостоятельно осознает и вербализирует внутриличностные противоречия, их причины, природу, анализирует имеющиеся ресурсы, намечает пути и средства решения возникших проблем.

6. Ситуация преодоления трудностей, имеющаяся в реальной жизни или задаваемая дилеммой, созданной педагогом искусственно, рассматривается нами как основа для закрепления имеющихся и формирования новых ценностно-смысловых ориентиров личности, а сопровождение саморазвития подростка в ситуации преодоления трудностей выступает как механизм, обеспечивающий возможность перехода моральных (социальных) норм в нравственные (внутренние) нормы. Исходя из этого, актуализация решения реальной дилеммной ситуации как искусственно созданной ситуации преодоления трудностей рассматривается нами в качестве целевой функции педагогического сопровождения саморазвития подростков.

7. Стимулирование подростков к рефлексии проблемных ситуаций, возникших трудностей и прогнозированию их разрешения является самостоятельным компонентом методики педагогического сопровождения саморазвития подростков в ситуации преодоления трудностей, позволяющим определять задачи последующих этапов взаимодействия подростка с референтными педагогами. Разработка индивидуальных маршрутов саморазвития, основанных на результатах решения подростком дилеммных ситуаций, является технологией, реализация которой видится наиболее рельефно в системе дополнительного образования детей, предполагающей широкие возможности реализации выбора (выбор творческого объединения, 
темпа и уровня освоения программы, детско-взрослой общности и т.п.).

1. Каптерев П. Ф. Педагогический процесс : избр. пед. соч. / под. ред. А. М. Арсеньева. М. : Педагогика, 1982.

2. Вентщель К. Н. Теория свободного воспитания и идеальный детский сад. М. : Амонашвили центр, 1999. 214 с.

3. Гребенюк О. С., Гребенюк Т. Ю. Основы педагогики индивидуальности : учеб. пособие. Калининград : Изд-во КГУ, 2000. 572 с.

4. Дружинин, В.Н. Варианты жизни: очерки экзистенциальной психологии [Электронный ресурс]. М. : ПЕР СЭ, 2005. 136 c. URL: http://biblioclub. ru/index.php? page=book\&id=233349.

5. Рожков М. И. Экзистенциальный подход к социально-педагогическому сопровождению детей // Ярослав. пед. вестн. 2013. Т. 2, № 4. С. 23-27.

6. Михайлова Н. Н., Юсфин С. М. Свободоспособность как результат развития субъектности ребенка в процессе педагогической поддержки // Вестн. Костром. гос. ун-та им. Н. А. Некрасова. Сер. : Педагогика. Психология. Социальная работа. Ювенология. Социокинетика. 2014. Т. 20 , № 2. С. 143-147.

7. Фризен М.А. Психологическая сущность и детерминанты саморазвития личности // Вестн. КРАУНЦ. Гуманитар. науки. 2011. № 2 (18). С. 24-33.

8. Ильенков Э. В. Что такое личность? С чего начинается личность. М. : Наука, 1979. 390 с.

9. Бедерханова В.П. В поисках гуманистической реальности // Сборник научных трудов / науч. ред. В. П. Бедерханова. Краснодар : КубГУ, 2007.

10. Анцыферова Л. И. Психологическое содержание феномена субъект и границы субъектно-деятельностного подхода. Проблема субъекта в психологической науке. М. : Акад. проект, 2000. 224 с.

11. Слободчиков В. И., Исаев Е. И. Психология развития человека: Развитие субъективной реальности в онтогенезе. М. : Школьная пресса, 2000. $416 \mathrm{c}$.

12. Выготский Л. С. Собрание сочинений : в 6 т. М. : Педагогика, 1982. T. $1.566 \mathrm{c}$.

13. Леонтьев А.Н. Деятельность. Сознание. Личность. М. : Смысл : Академия, 2005. 352 с. 
14. Bandura A., Ross D., Ross S. Transmission of aggression through imitation of aggressive models // The Journal of Abnormal and Social Psychology. 1961. № 63(3). P. 575-582. PMID 13864605. DOI: 10.1037/h0045925

15. Абульханова-Славская К.А. Стратегия жизни. М. : Мысль, 1991. 299 c.

16. Бернс Р. Т. Развитие Я-концепции и воспитание. М. : Прогресс, 1986. $420 \mathrm{c}$.

17. Harré $R$. The analysis of episodes // The context of social psychology. L. : Academic Press, 1972. P. 407-424.

18. Франкл В. Страдания от бессмысленности жизни. Актуальная психотерапия. Новосибирск : Сиб. унив. изд-во, 2015. 96 с. 


\section{ЭМОЦИОНАЛЬНО-ПОВЕДЕНЧЕСКИЕ ПРОБЛЕМЫ ПОДРОСТКОВ, ОБУЧАЮЩИХСЯ В РАЗЛИЧНЫХ ОБРАЗОВАТЕЛЬНЫХ СРЕДАХ}

М. М. Лобаскова

Ю. С. Измайлова

Закономерности психического развития детей и подростков следует изучать с учетом тех условий, которые сложились в образовательной среде [1]. Лицей или общеобразовательная школа? Такой вопрос нередко возникает перед родителями при выборе образовательного учреждения для своего ребенка. Общеобразовательная школа - это школа для всех. Школа-лицей - это учебное заведение, в котором обеспечены условия для развития определенных способностей обучающихся - гуманитарных, математических, эстетических и т.д. При поступлении в лицей проводится отбор детей в соответствии с профилем подготовки. Уровень требований к показателям интеллектуального развития детей выше, чем в общеобразовательной школе. Учебная нагрузка также отличается. В лицее больше учебных часов по профильным предметам, дополнительных занятий. Помимо этого использование рейтинговой системы и отчисление учеников с низкими результатами, с дисциплинарными взысканиями позволяет создать благоприятные условия для когнитивного развития детей и обеспечить высокий образовательный уровень в лицее. С одной стороны, обучение в лицее позволяет ребенку достичь высоких академических результатов, высокого уровня когнитивного развития, подготовиться к поступлению в высшее учебное заведение. С другой стороны, интенсивность психоэмоциональных нагрузок в лицее выше, что может оказать негативное влияние на здоровье учащихся, на их психологическое благополучие. В общеобразовательную школу принимают детей без тестирования, без дополнительных условий. Городские районы, где располагаются школы, отличаются контингентом населения, социально-экономическими условиями, демографическими особенностями, удаленностью от центра города и т.д. В общеобразовательных школах разный уровень преподавания, есть свой педагогический состав школы 
и дополнительные образовательные услуги. Во многих школах есть ученики из неблагополучных семей, некоторые учащиеся состоят на учете в связи с нарушением социально-правовых норм. Возникает необходимость изучения специфики эмоционально-поведенческих проблем подростков, обучающихся в различных образовательных условиях. Особого внимания требует подростковый период вследствие его противоречивости, сензитивности и уязвимости. В подростковом возрасте актуализируется задача обеспечения психологического благополучия процесса развития.

Многие исследования указывают на результативность изучения системы психологических особенностей в контексте средовых отношений $[2,3]$.

Поведенческие и эмоциональные проблемы, проявляющиеся в различных сферах жизни ребенка, могут блокировать нормальное развитие и ухудшать качество его жизни. В качестве маркеров эмоционально-поведенческих проблем были выбраны показатели тревожности, депрессивного настроения и агрессивного поведения. Наиболее широко количественный подход в исследовании отклонений в развитии представлен в работах Т. Ахенбаха, в его опросниках такие факторы проблемного поведения, как интернализация и экстернализация, включают в себя субшкалы. В интернализацию входят тревожность/депрессия, соматические проблемы, замкнутость, в экстернализацию - агрессия, делинквентное поведение [4].

В качестве одного из факторов, определяющих специфику возникающих отклонений, рассматривается темперамент. Большой вклад в разработку проблемы влияния темперамента на возникновение нарушений развития в детском возрасте внесли А. Томас и С. Чесс [5]. М.К. Ротбарт в психобиологической модели темперамента делает акцент на его качественных изменениях в ходе онтогенеза [6]. Развитие темперамента, по мнению авторов, включает развитие реактивных и саморегуляторных механизмов, которые позволяют адаптироваться к социальным нормам. Данные механизмы должны находиться в балансе, их несбалансированность может привести к нарушениям в развитии.

Для того чтобы определенное строение темперамента стало причиной расстройства, необходимо особого рода взаимодейст- 
вие между темпераментом ребенка и средой, в которой он живет. Одни приемы воспитания приводят к смягчению и устранению расстройств поведения, другие, напротив, к их усилению. Темперамент и среда не только взаимодействуют, но и взаимоизменяются. Некоторые черты темперамента ребенка могут оказывать влияние на формирование определенного отношения к ним родителей и окружения, с другой стороны, неправильные приемы воспитания могут привести к утрате ранее имевшихся у ребенка адаптивных способностей [7].

Изучение связи темперамента с эмоционально-поведенческими проблемами широко представлено в современных исследованиях. Так, в работе S. Thompson и др. выявлены связи темперамента с интернальными и экстернальными проблемами поведения, высокая негативная эмоциональность и низкий произвольный контроль являются предикторами нарушений в обоих векторах поведенческих проблем [8]. В лонгитюдном исследовании родителей и детей Эйвона (Великобритания) были изучены материнские пренатальные риски (психопаталогия, криминальное поведение, употребление психоактивных веществ), «бесстрашный» темперамент ребенка, измеренный в 2 года, особенности воспитания как предикторы «эмоциональной бесчувственности», рассматриваемой в качестве симптома поведенческих нарушений в подростковом возрасте. Авторами получены данные о прогностической связи «бесстрашного» темперамента, диагностированного в раннем детстве, пренатальных рисков и особенностей воспитания, измеренных в возрасте 4 лет, с эмоциональными проблемами в подростковом возрасте, при этом «бесстрашный» темперамент ребенка в большей мере связан с «эмоциональной бесчувственностью», чем другие показатели. Авторы выявили гендерную специфику «эмоциональной бесчувственности», связанную с темпераментом. У мальчиков «бесстрашный» темперамент проявляется как низкий уровень ответной реакции на наказание, а у девочек данная характеристика темперамента обнаруживает себя как смелость в новых, необычных ситуациях. Авторы предлагают использовать полученные результаты в программах вмешательства в работе с эмоциональными проблемами в подростковом возрасте [9]. Также в рамках данного проекта было 
проведено исследование связи темперамента, измеренного в 6 лет, и депрессии, измеренной в 18 лет. Была обнаружена связь между высокой негативной эмоциональностью в 6 лет и депрессией в 18 лет, что позволяет проводить адекватную профилактику депрессивных расстройств.

\section{Организация исследования}

В исследовании принимали участие 95 подростков г. Ижевска (девочек - 44, мальчиков - 51), обучающихся в 8-х классах (средний возраст 14,3 лет), из них учащихся лицея - 49 человек, учащихся общеобразовательной школы - 46 человек. Для оценки тревожности была использована методика Спилбергера - Ханина, для исследования депрессивного настроения, агрессивности и темперамента применялся опросник Ротбарт.

Методика Спилбергера - Ханина широко используется в отечественной психологии образования для выявления и изучения личностной и ситуативной тревожности учащихся. Шкала тревоги Спилбергера (State-Trait Anxiety Inventory - STAI) в модификации Ю. Л. Ханина позволяет оценить уровень ситуативной тревожности как состояния в данный момент и личностной тревожности - как устойчивой характеристики человека.

Опросник темперамента Ротбарт включает в себя шкалы, оценивающие 11 свойств темперамента, и шкалы социально-аффективного функционирования (агрессивное поведение и депрессивное настроение) [10].

\section{Шкаль темперамента}

1. Уровень активности (Activity Level): уровень общей моторной активности, включая темп и интенсивность передвижений.

2. Контроль активации (Activation control): способность выполнять действие при сильном желании избежать его.

3. Аффилиация (Affiliation): потребность в теплых отношениях и близости с другими независимо от застенчивости или экстраверсии.

4. Внимание (Attention): способность сосредотачивать и переключать внимание по мере необходимости. 
5. Страх (Fear): негативные эмоции, связанные с ожиданием неприятностей.

6. Фрустрация (Frustration): отрицательные эмоции, связанные с прерыванием текущей деятельности или невозможностью достижения цели.

7. Удовольствие от стимуляции высокой интенсивности (High Intensity Pleasure): удовольствие от действий, характеризующихся высокой интенсивностью или новизной.

8. Контроль торможения (Inhibitory control): способность планировать и подавлять несоответствующие реакции.

9. Перцептивная чувствительность (Perceptual Sensitivity): обнаружение или перцептивное осознание слабых, низко интенсивных воздействий окружающей среды.

10. Удовольствие от стимуляции низкой интенсивности (Pleasure Sensitivity): удовлетворение, связанное с действиями или стимулами, характеризующимися низкой интенсивностью, скоростью, сложностью, новизной и несовместимостью.

11. Застенчивость (Shyness): медленное или затрудненное приближение и/или дискомфорт в социальных ситуациях.

\section{Поведенческие икаль}

1. Агрессия (Aggression): враждебные и агрессивные действия, включая направленное на человека и предметы физическое насилие, прямую и косвенную вербальную агрессию и враждебную реактивность.

2. Депрессивное настроение (Depressive Mood): неприятные эмоции и пониженное настроение, потеря удовлетворенности и интереса к деятельности.

Полученные данные были проанализированы с помощью непараметрических статистических критериев.

\section{Результаты и их обсуждение}

При исследовании тревожности значимых различий между группами не выявлено, средние значения ситуативной и личностной тревожности подростков лицея составляют 37, 26 и 41,9 соответственно, подростков общеобразовательной школы $-41,9$ 
и 46, 3. В обеих группах часть подростков имеет высокие значения личностной тревожности, в лицее - 33 \%, в общеобразовательной школе - 59 \% подростков. Несмотря на то что в общеобразовательной школе большее количество детей склонно испытывать устойчивое состояние беспокойства, напряжения, тревоги, это, на наш взгляд, в большей степени связано с подростковым периодом, чем с особенностями образовательной среды. Однако следует отметить тенденцию к большему проявлению тревожности у подростков общеобразовательной школы по сравнению с лицеистами.

В ходе исследования были выявлены значимые различия уровня депрессивного настроения и агрессивности подростков различных образовательных систем. У подростков общеобразовательной школы в среднем выше показатели депрессивного настроения и агрессивности по сравнению с подростками-лицеистами. Особого внимания заслуживают данные о более высоком уровне депрессивного настроения и агрессивности девочек в сравнении с мальчиками. Результаты отражены в табл. 1.

Группа 8 - мальчики лицея

В исследовании депрессии и субдепрессии авторы едины во мнении о большей склонности девочек и женщин к возникновению тревожных и депрессивных расстройств [11-13]. Так, И.Е. Куприянова с соавторами отмечают, что из общего количества подростков

Таблица 1

Результаты исследования агрессивного поведения и депрессивного настроения подростков лицея и общеобразовательной школы

\begin{tabular}{|c|c|c|c|c|c|c|c|c|}
\hline \multirow{2}{*}{ Показатель } & \multicolumn{8}{|c|}{ Среднее значение } \\
\hline & 1 & 2 & 3 & 4 & 5 & 6 & 7 & 8 \\
\hline $\begin{array}{l}\text { Агрессивное } \\
\text { поведение }\end{array}$ & 2,6 & 2,26 & 2,35 & 2,53 & 2,82 & 2,01 & 2,48 & 2,34 \\
\hline $\begin{array}{l}\text { Депрессивное } \\
\text { настроение }\end{array}$ & 2,72 & 2,52 & 2,22 & 3,13 & 3,15 & 2,94 & 2,345 & 2,21 \\
\hline
\end{tabular}

Примечание. Значимые различия отмечены жирным шрифтом. 1-8 - группы подростков: 1 - подростки лицея; 2 - подростки общеобразовательной школы; 3 - мальчики; 4 - девочки; 5 - девочки общеобразовательной школы; 6 - девочки лицея; 7 - мальчики общеобразовательной школы. 
11-17 лет склонны к депрессивным переживаниям 25 \% мальчиков и $44 \%$ девочек [13]. В исследованиях половых различий агрессивности нет столь однозначной картины. Н.Д. Узлов не обнаружил половых различий у старших подростков, значимые различия были получены в группе студентов, показатели физической агрессии выше у мужчин, чем у женщин. Автором были выявлены возрастные особенности агрессивности - у студентов агрессия выше, чем у школьников [14]. В крупномасштабном исследовании A. Nivette и соавторов изучалась распространенность и вариативность половых различий в проявлениях физической агрессии, измеряемых частыми драками, среди 247909 подростков в 63 странах с низким и средним уровнем дохода. Результаты показывают, что в целом мужчины более чем в два раза чаще сообщали о частых драках в течение последних 12 месяцев, чем женщины. Авторы отмечают, что различия уменьшаются по мере уменьшения гендерного неравенства [15]. Мы полагаем, что большая выраженность агрессивного поведения девочек в нашем исследовании может быть связана, с одной стороны, с большей социальной активностью в рамках школьной деятельности, девочки склонны принимать более активное участие в различных школьных мероприятиях, с другой стороны, девочки опережают мальчиков в темпах полового созревания. Вероятно, также, что девочки чаще используют формы косвенной агрессии, проявление агрессивности девочек чаще имеет вербальный, скрытый характер. Мальчики более склонны к физической агрессии, проявления которой более очевидны и социально наказуемы.

Мы провели исследование темперамента подростков обеих образовательных систем (табл. 2) в связи с эмоционально-поведенческими проблемами. Были выявлены значимые различия между подростками двух школ в проявлении свойств темперамента «внимание» и «застенчивость».

Свойство темперамента «внимание» определяется как способность сосредоточивать и переключать внимание по мере необходимости, относится к фактору произвольного контроля. Факторная шкала «произвольный контроль» опросника Ротбарт включает три свойства темперамента: контроль активации, контроль торможения и контроль внимания. В данном случае внимание рассматривает- 
Таблица 2

Значимые различия свойств темперамента подростков лицея и общеобразовательной школы

\begin{tabular}{l|c|c|c}
\hline $\begin{array}{c}\text { Свойство тем- } \\
\text { перамента }\end{array}$ & $\begin{array}{c}\text { Среднее значение } \\
\text { (общеобразовательная } \\
\text { школа) }\end{array}$ & $\begin{array}{c}\text { Среднее зна- } \\
\text { чение } \\
\text { (лицей) }\end{array}$ & $\begin{array}{c}\text { Уровень до- } \\
\text { стоверности }\end{array}$ \\
\hline Внимание & 2,72 & 3,08 & $\boldsymbol{p} \leq \mathbf{0 , 0 5}$ \\
\hline Застенчивость & 3,04 & 2,54 & $\mathbf{p} \leq \mathbf{0 , 0 5}$ \\
\hline
\end{tabular}

ся как регуляторный компонент поведения. Сосредоточиваться и быстро переключать «внимание» лицеистам проще, чем детям из общеобразовательной школы, у лицеистов средние показатели выше, посторонние стимулы не мешают им выполнять какую-либо работу, они могут заниматься несколькими вещами одновременно, доводят свои дела до конца, внимательно выслушивают объяснения.

Застенчивость у подростков общеобразовательной школы выше, чем у лицеистов. Застенчивость как свойство темперамента - это медленное или затрудненное приближение и/или дискомфорт в социальных ситуациях, т.е. данная особенность отражает динамическую сторону социальной коммуникации. В этом случае подростки испытывают затруднения в установлении социальных контактов, им трудно познакомиться с новыми людьми, они стесняются ровесников противоположного пола.

Чем можно объяснить данные различия? С одной стороны, темперамент - конституциональная, наследственно обусловленная особенность поведения. В то же время темперамент развивается в онтогенезе и проявление его зависит от условий среды. Также стоит отметить, что в ходе обучения в лицее происходит отсев учеников. Родители лицеистов имеют высокий социоэкономический статус, оплачивают дополнительные образовательные услуги. Таким образом, лицей можно рассматривать как особую образовательную среду, где создаются благоприятные условия для учащихся со специфическими индивидуально-психологическими особенностями, в том числе с определенными свойствами темперамента.

Современные исследования отмечают роль взаимодействия интеракции и темперамента детей в формировании школьной успеш- 
ности, овладении социальными нормами $[16,17]$. Следовательно, структурирование образовательной среды требует учета индивидуально-психологических особенностей подростков, что позволит минимизировать неблагоприятные риски в ходе психического развития и поможет предотвратить возникновение эмоциональных и поведенческих проблем.

В представляемом нами пилотном исследовании мы проанализировали взаимосвязи темперамента и эмоционально-поведенческих проблем подростков в различающихся условиях образовательной среды. В ходе корреляционного анализа были выявлены значимые взаимосвязи свойств темперамента с тревожностью, депрессивным настроением и агрессивностью в группах мальчиков и девочек лицея и общеобразовательной школы, результаты представлены в табл. 3 .

Таблица 3

Значимые взаимосвязи темперамента и эмоционально-поведенческих проблем подростков лицея и общеобразовательной школы

\begin{tabular}{|c|c|c|c|c|}
\hline Показатель & $\begin{array}{c}\text { Депрессив- } \\
\text { ное настр-- } \\
\text { ение }\end{array}$ & $\begin{array}{c}\text { Ситуатив- } \\
\text { ная тре- } \\
\text { вожность }\end{array}$ & $\begin{array}{c}\text { Личност- } \\
\text { ная тре- } \\
\text { вожность }\end{array}$ & $\begin{array}{c}\text { Агрес- } \\
\text { сивное } \\
\text { поведение }\end{array}$ \\
\hline \multirow{4}{*}{ Контроль активации } & $-0,680^{\star *}$ & - & $-0,488^{*}$ & - \\
\hline & - & - & - & - \\
\hline & - & $-0,478^{\star}$ & $-0,503^{\star}$ & - \\
\hline & - & - & - & $-0,451^{\star}$ \\
\hline \multirow{4}{*}{$\begin{array}{l}\text { Контроль торможе- } \\
\text { ния }\end{array}$} & $0,597^{\star *}$ & - & $-0,597^{* *}$ & $-0,676^{* *}$ \\
\hline & - & - & - & $-0,522^{\star *}$ \\
\hline & - & - & $-0,383^{\star}$ & $-0,522^{\star \star}$ \\
\hline & - & - & & - \\
\hline \multirow{4}{*}{ Внимание } & $-0,537^{\star}$ & $-0,635^{\star *}$ & $-0,525^{\star}$ & - \\
\hline & - & - & - & - \\
\hline & - & $-0,518^{* *}$ & $-0,615^{\star *}$ & - \\
\hline & - & - & - & $-0,635^{\star *}$ \\
\hline \multirow{4}{*}{ Уровень активности } & $-0,477^{\star}$ & - & - & - \\
\hline & - & $-0,451^{\star}$ & - & - \\
\hline & - & - & $-0,450^{*}$ & - \\
\hline & - & - & - & $0,573^{\star *}$ \\
\hline
\end{tabular}


Окончание табл. 3

\begin{tabular}{|c|c|c|c|c|}
\hline Показатель & $\begin{array}{l}\text { Депрессив- } \\
\text { ное настро- } \\
\text { ение }\end{array}$ & $\begin{array}{c}\text { Ситуатив- } \\
\text { ная тре- } \\
\text { вожность }\end{array}$ & $\begin{array}{c}\text { Личност- } \\
\text { ная тре- } \\
\text { вожность }\end{array}$ & $\begin{array}{c}\text { Агрес- } \\
\text { сивное } \\
\text { поведение }\end{array}$ \\
\hline Фрустрация & $\begin{array}{c}- \\
- \\
0,537^{\star}\end{array}$ & $\begin{array}{l}- \\
- \\
-\end{array}$ & $\begin{array}{c}- \\
-0,417^{\star} \\
- \\
-\end{array}$ & $\begin{array}{c}- \\
- \\
0,824^{\star *}\end{array}$ \\
\hline Застенчивость & $\begin{array}{c}0,746^{\star *} \\
0,574^{\star *} \\
- \\
-\end{array}$ & $\begin{array}{c}0,713^{\star *} \\
- \\
- \\
-\end{array}$ & $\begin{array}{c}0,714^{\star *} \\
- \\
- \\
-\end{array}$ & $\begin{array}{l}- \\
- \\
-\end{array}$ \\
\hline $\begin{array}{l}\text { Удовольствие от вы- } \\
\text { сокоинтенсивных } \\
\text { стимулов }\end{array}$ & $\begin{array}{c}- \\
-0,424^{*} \\
- \\
-\end{array}$ & $\begin{array}{l}- \\
- \\
-\end{array}$ & $\begin{array}{l}- \\
- \\
-\end{array}$ & $\begin{array}{c}- \\
- \\
0,619^{* *}\end{array}$ \\
\hline $\begin{array}{l}\text { Удовольствие } \\
\text { от низкоинтенсивных } \\
\text { стимулов }\end{array}$ & $\begin{array}{l}- \\
- \\
-\end{array}$ & $\begin{array}{l}- \\
- \\
-\end{array}$ & $\begin{array}{c}- \\
- \\
-0,394^{\star} \\
-\end{array}$ & $\begin{array}{c}- \\
- \\
0,449^{*}\end{array}$ \\
\hline $\begin{array}{l}\text { Перцептивная чувст- } \\
\text { вительность }\end{array}$ & $\begin{array}{c}- \\
- \\
0,454^{\star} \\
-\end{array}$ & $\begin{array}{l}- \\
- \\
-\end{array}$ & $\begin{array}{l}- \\
- \\
-\end{array}$ & $\begin{array}{c}- \\
- \\
0,571^{\star *}\end{array}$ \\
\hline Страх & $\begin{array}{c}- \\
- \\
0,505^{\star}\end{array}$ & $\begin{array}{c}- \\
- \\
0,710^{* *}\end{array}$ & $\begin{array}{c}- \\
- \\
0,619^{* *}\end{array}$ & $\begin{array}{c}- \\
- \\
0,537^{\star}\end{array}$ \\
\hline
\end{tabular}

Примечание. В ячейках верхняя строка - группа «девочки-лицеисты», вторая строка - «девочки общеобразовательной школы», третья строка «мальчики-лицеисты», нижняя строка - «мальчики общеобразовательной школы»; ${ }^{*}-p<0,05,{ }^{* *}-p<0,01$.

Сравнивая коэффициенты корреляции в группах мальчиков и девочек лицея и общеобразовательной школы, мы можем отметить большее сходство в структуре взаимосвязей темперамента с маркерами эмоционально-поведенческого неблагополучия мальчиков и девочек лицея. Мы видим, что в отличие от подростков общеобразовательной школы в структуре взаимосвязей значимый 
вес имеет фактор произвольного контроля, включающий три шкалы - «контроль торможения», «контроль активации» и «внимание», причем данные свойства обратно пропорционально связаны с депрессивным настроением, агрессивным поведением и разными типами тревожности: чем выше показатели произвольного контроля, тем менее выражены эмоционально-поведенческие проблемы подростков.

В целом в выборке подростков наименьшее количество связей темперамента с эмоционально-поведенческими проблемами обнаружено в группе девочек общеобразовательной школы - всего 5 связей, в то же время у мальчиков общеобразовательной школы их 12 и характер их весьма специфичен.

Агрессивное поведение мальчиков общеобразовательной школы в сравнении с другими подростками выборки связано с большим количеством свойств темперамента. Так, чем выше перцептивная чувствительность и удовлетворенность от низкоинтенсивных стимулов, потребность в близких отношениях, тем вероятнее то, что агрессивное поведение мальчиков общеобразовательной школы возникает как защитный механизм. Также напрямую с агрессивным поведением в этой группе связаны высокие значения фрустрации и уровня активности, следовательно, двигательно активные подростки с высоким уровнем напряжения в большей степени склонны к агрессивному поведению. При высоких значениях контроля активации и внимания у мальчиков общеобразовательной школы агрессивность имеет низкие значения, в отличие от остальных групп подростков, у которых с агрессивным поведением обратно связан только контроль торможения, с другими свойствами темперамента связей агрессивного поведения не выявлено в группах лицеистов девочек и мальчиков. Далее обращает на себя внимание особое значение свойства темперамента «страх» в структуре взаимосвязей с эмоционально-поведенческими проблемами мальчиков общеобразовательной школы: чем выше значение данного свойства, тем выше уровень ситуационной, личностной тревожности, депрессивного настроения, агрессивного поведения, что также не обнаружено в других группах выборки. Чем выше склонность к переживанию 
страха, тем выше вероятность возникновения эмоционально-поведенческих проблем у мальчиков общеобразовательной школы.

В структуре взаимосвязей мальчиков и девочек общеобразовательной школы в отличие от лицеистов обнаружена связь свойств темперамента «удовольствие от высокоинтенсивных стимулов» и «перцептивная чувствительность» с депрессивным настроением у девочек и с агрессивным поведением у мальчиков. Если говорить о половых различиях, то следует отметить значимый вес свойства темперамента «застенчивость» в связях с тревожностью и депрессивным настроением у девочек, у мальчиков, в свою очередь, обнаружены значимые связи свойства темперамента «удовольствие от низкоинтенсивных стимулов» с личностной тревожностью (у лицеистов) и с агрессивным поведением (у мальчиков общеобразовательной школы).

Результаты различных исследований доказывают связь раннего темперамента с поведенческими проблемами в более старшем возрасте, что позволяет рассматривать темперамент как предиктор эмоционально-поведенческих проблем [18-22].

Психогенетические исследования, направленные на выявление роли генетических и средовых факторов, позволяют оценить механизмы связи темперамента и эмоционально-поведенческих проблем мальчиков и девочек в определенных условиях среды.

Soo Hyun Rhee с соавторами с помощью близнецового метода выявили половые различия в связи интернализации и экстернализации, общие факторы среды объясняют большую долю ковариации в связи с эмоциональностью и застенчивостью у мальчиков, у девочек только в связи с эмоциональностью. K. S. Lemery делает важный вывод: «Более ранний темперамент может объяснить генетическое влияние на симптомы проблем поведения, следует предпринять новые усилия по выявлению аспектов окружающей среды, которые приводят к расстройству» [22, с. 1]. Е. Д. Гиндина также указывает на то, что факторы общей среды вносят существенный вклад в индивидуальную вариативность эмоциональных и поведенческих проблем (тревожности/депрессии, социальной дезадаптации, деликвентности, интернализации, экстернализации и общей проблемности) в подростковом возрасте [23]. 


\section{Выводы}

В проведенном нами пилотном исследовании эмоциональноповеденческих проблем подростков лицея и общеобразовательной школы полученные результаты свидетельствуют о большей выраженности тревожности, депрессивного настроения и агрессивного поведения подростков общеобразовательной школы, при этом у девочек эти показатели выше, чем у мальчиков. Склонность к депрессивным переживаниям девочек согласуется с данными других авторов. Более высокие показатели агрессии мы связываем со спецификой агрессивного поведения девочек, например, с предпочтением косвенной агрессии, которая имеет более скрытый характер протекания.

Анализируя особенности темперамента подростков разных образовательных систем, мы обнаружили значимые различия между ними, что можно объяснить, как существующим в лицее отсевом детей, которые не справляются с высокой учебной нагрузкой, в том числе по причине слабой нервной системы, так и более благоприятными условиями для детей с особыми свойствами темперамента, включающими сочетание таких свойств как высокий произвольный контроль, низкая негативная эмоциональность, низкая перцептивная чувствительность и низкий уровень застенчивости.

Структура связей темперамента лицеистов и учащихся общеобразовательной школы имеет существенные отличия. Структура взаимосвязей мальчиков и девочек лицея более схожа, чем мальчиков и девочек общеобразовательной школы. Полученные нами предварительные результаты позволяют предположить, что образовательная среда лицея менее различается для мальчиков и девочек, что обусловливает большее сходство в структуре взаимосвязей темперамента подростков обоего пола, в отличие от условий общеобразовательной школы. Вероятно, здесь вариативность среды и ее дифференцированность выше, в то же время дисперсия исследуемых переменных в общеобразовательной школе может быть шире, что требует анализа на большей выборке испытуемых. В лицее образовательная среда благоприятно соответствует особенностям темперамента подростков, высокие требования и регламентация приводят к накоплению детей с определенными свойствами темперамента. 
В совокупности условия среды и индивидуальные особенности детей способствуют профилактике эмоционально-поведенческих проблем подростков лицея.

1. Баева И.А., Лактионова Е. Б. Экспертная оценка состояния образовательной среды на предмет комфортности и безопасности // Психологическая наука и образование. 2013. № 6. С. 5-12.

2. Zubizarreta A., Calvete E., Hankin B.L. Punitive parenting style and psychological problems in childhood: The moderating role of warmth and temperament // Journal of Child and Family Studies. 2019. Springer.

3. Schmidt N., Lemery-Chalfant K. \& Goldsmith, H. (n.d.). Wisconsin Twin Project Overview: Temperament and Affective Neuroscience // Twin Research and Human Genetics. № 1-6. doi: 10.1017/thg.2019.108.

4. Achenbach T.M. The classification of children's psychiatric symptoms: a factor-analytic study // Psychological Monographs: general and applied. 1966. Vol. 80(7). P. 1.

5. Thomas A., \& Chess S. Temperament and development. Oxford, England : Brunner/Mazel, 1977.

6. Rothbart M. K. Measurement of temperament in infancy // Child Development, 1981. № 52. P. 569-578.

7. Rothbart M. K., Bates J.E. Handbook of child psychology // Wiley Online Library. 2007.

8. Lengua L. J., Moran L., Zalewski M. et al. Relations of Growth in Effortful Control to Family Income, Cumulative Risk, and Adjustment in Preschool-age Children [Electronic resource] // J Abnorm Child Psychol. 2015. № 43. P. 705720. URL: https://doi.org/10.1007/s10802-014-9941-2

9. Barker E.D., Oliver B. R., Viding E. et al. The impact of prenatal maternal risk, fearless temperament and early parenting on adolescent callous-unemotional traits: a 14-year longitudinal investigation. First published: 16 March 2011 [Electronic resource]. URL: https://doi.org/10.1111/j.1469-7610.2011.02397.x

10. Лобаскова М.М. Природа индивидуальных различий темперамента в подростковом возрасте : дис. ... канд. психол. наук / Психол. ин-т РАО. M., 2006.

11. Albert P. R. Why is depression more prevalent in women? [Electronic resource] // Journal of Psychiatry \& Neuroscience: JPN. 2015. № 40(4). P. 219-221. URL: https://doi.org/10.1503/jpn.150205. 
12. Белова А. П., Мальх С. Б., Сабирова Е. З., Лобаскова М. М. Оценка депрессивности в подростковом возрасте // Вестн. Юж.-Урал. гос. ун-та. Сер. : Психология. 2008. № 32 (132). С. 10-18.

13. Куприянова И.Е., Дашиева Б. А., Карауш И. С. Клинические особенности подпороговой депрессии у подростков в зависимости от пола // Психиатрия, психотерапия и клиническая психология. 2019. Т. 10, № 2. C. 216-224.

14. Узлов Н. Д. Половые различия в склонности к агрессивным формам поведения и легитимизации насилия у старшеклассников и студентов вуза // Вестн. Удмурт. ун-та. 2018. Т. 28, вып. 4. С. 424-430.

15. Nivette A., Sutherland A., Eisner M., Murray J. Sex differences in adolescent physical aggression: Evidence from sixty-three low-and middle-income countries [Electronic resource] // Aggressive Behavior. 2019. № 45. P. 82-92. URL: https://doi.org/10.1002/ab.21799

16. Chen $X$. Culture, temperament, and social and psychological adjustment // Developmental Review. 2018. Vol. 50, pt. A, Dec. P. 42-53.

17. Roubinov D. S., Hagan M. J., Boyce W. T., Essex M. J. Child temperament and teacher relationship interactively predict cortisol expression: The prism of classroom climate // Development and Psychopathology. 2017. Vol. 29, Special iss. 5 (Biological and Behavioral Effects of Early Adversity on Multiple Levels of Development), Dec. P. 1763-1775.

18. Crescentini C., Garzitto M., Paschetto A. et al. Temperament and character effects on late adolescents' well-being and emotional-behavioural difficulties [Electronic resource] // Peer J. 2018. № 6: e4484. URL: https://doi.org/10.7717/ peerj. 4484

19. Checa P., Abundis-Gutierrez A. Parenting and Temperament Influence on School Success in 9-13 Year Olds // Front. Psychol. 2017. № 8. P. 543. doi: 10.3389/fpsyg.2017.00543

20. Петренко Е.Н., Козлова Е.А., Слободская Е. Р. Произвольная регуляция в дошкольном возрасте: связь с чертами личности и благополучием // Психология - наука будущего : материалы VII Междунар. конф. молодых ученых, 14-15 нояб. 2017 г., Москва / под ред. А. Л. Журавлева, Е. А. Сергиенко. М. : Изд-во «Институт психологии РАН», 2017.

21. Rhee S., Cosgrove V., Schmitz S. et al. Early Childhood Temperament and the Covariation Between Internalizing and Externalizing Behavior in School- 
Aged Children // Twin Research and Human Genetics. 2007. № 10(1). P. 33-44. doi:10.1375/twin.10.1.33

22. Lemery K. S. Exploring the etiology of the relationship between temperament and behavior problems in children // Dissertation Abstracts International. Section B : The Sciences and Engineering. 2000. № 61(2-B). P. 1112.

23. Гиндина Е. Д., Мальх С. Б., Лобаскова М. М. Генетические и средовые факторы поведенческих и эмоциональных трудностей у близнецов подросткового возраста // Психол. журн. 2006. Т. 27, № 5. С. 60-74. 


\title{
СВЯЗЬ СИМВОЛИЧЕСКОЙ И НЕСИМВОЛИЧЕСКОЙ ОЦЕНКИ КОЛИЧЕСТВА В УСЛОВИЯХ КОНТРОЛЯ ВИЗУАЛЬНЫХ ПАРАМЕТРОВ
}

\author{
Ю. А. Маракшина \\ А. О. Табуева \\ Ю. В. Кузьмина \\ М. М. Лобаскова
}

Многие данные свидетельствуют о том, что развитие математической компетентности основано на способности эффективно представлять информацию о числовой величине в символических форматах и приобретении символического чувства числа $[1,2]$. Символическое представление количества уникально для людей и требует способности точно представлять количество словесно в виде слов, обозначающих числа, или визуально в виде арабских числовых символов $[3,4,2]$. Тесная связь между оценкой количества в символической форме и математическими достижениями была подтверждена в нескольких исследованиях $[5,6,2]$. Поэтому важно понимать, как развивается символическое представление числа и как символы приобретают свое числовое значение.

Широко распространенная гипотеза утверждает, что символы обретают свое значение, будучи отображенными на ранее существовавшие несимволические представления количества, или приблизительное чувство числа (approximate number system, ANS). ANS обычно определяется как система, которая позволяет людям воспринимать и приблизительно оценивать количество без подсчета и использования символов [4]. Было высказано предположение, что способность представлять и оценивать количество в символическом формате существует только у людей, тогда как ANS является эволюционно древней и врожденной. Способность воспринимать количество в несимволическом формате была обнаружена у приматов и других животных [7]. У людей индивидуальные различия

* Исследование поддержано грантом РФФИ № 19-29-14138 «Когнитивные и психофизиологические механизмы чувства числа».

(с) Маракшина Ю. А., Табуева А. О., Кузьмина Ю. В., Лобаскова М. М., 2020 
в этой способности проявляются в раннем детстве и существуют уже у младенцев [8].

Несколько аргументов подтверждают идею о том, что символическая система оценки количества развивается у детей путем мэппинга (при отображении этих символов на приблизительные несимволические представления количества) [9]. Во-первых, было высказано предположение, что несимволические и символические представления величины соответствуют одним и тем же моделям поведения, которые известны как числовые эффекты расстояния и размера [10]. Было показано, что при оценке количества как в символическом, так и в несимволическом форматах люди менее точно и медленнее сравнивают числа или наборы объектов, которые более похожи друг на друга или когда существует большая пропорция между числами или наборами объектов (числовое расстояние или числовой эффект пропорции) [11]. Эффект размера проявляется в более низкой точности и увеличенном времени реакции при сравнении чисел и массивов объектов большего размера [10]. Второй аргумент предполагает, что несимволическое представление количества связано с математическими достижениями [11]. В частности, было показано, что несимволическая арифметика позволяет приобретать навыки символической арифметики [12]. Hyde et al. [13] показали, что оперирование несимволическими величинами улучшает последующую точную символическую арифметику у первоклассников. Некоторые авторы показали, что связь между ANS и символическими математическими навыками сильнее у детей с низким уровнем успеваемости, по сравнению с остальными [14]. Это может указывать на то, что связь между ANS и символическими навыками, вероятно, будет сильнее, когда символические навыки находятся на ранних стадиях развития.

Несмотря на обширные данные, предполагающие, что ANS может служить основой для приобретения символического представления о количестве и более сложных математических навыков, некоторые существующие результаты опровергают эту гипотезу [15]. Во-первых, был поставлен вопрос о том, связано ли несимволическое представление величины с математическими достижениями. В некоторых исследованиях не удалось обнаружить значительного 
влияния несимволического представления величины на достижения в математике [16]. Во многих исследованиях связь между представлением несимволической величины и математическими достижениями становилась незначимой или резко уменьшалась после контроля когнитивных способностей, таких как торможение [17].

Второй аргумент против гипотезы об ANS как основе для символического чувства числа базируется на исследованиях, демонстрирующих, что несимволические и символические представления величины представляют собой разные системы. В частности, было показано, что точность символических и несимволических представлений существенно не коррелирует и что обе они независимо влияют на успеваемость по математике, по крайней мере, у детей младшего школьного возраста [18]. Также было показано, что символические и несимволические эффекты отношения не коррелируют, что позволяет предположить, что две системы представления количества различаются [19].

Третий аргумент против гипотезы о том, что ANS служит основой для приобретения символического чувства числа, получен из нескольких лонгитюдных исследованиях, которые обнаружили, что символические представления предсказывают последующие несимволические представления, а не наоборот [20]. В частности, было показано, что в возрасте 3-4 лет знание детьми чисел в символической форме предсказывает последующую точность несимволических сравнений величин, тогда как связь в обратную сторону незначима [21]. Несколько исследований также показали, что формальное математическое образование и опыт работы с числами повышают точность несимволических сравнений $[20,22]$. Таким образом, многочисленные свидетельства опровергают гипотезу о том, что приобретение символической системы счисления происходит через отображение символов на ANS.

Следует отметить, что наличие или отсутствие связи между символическим и несимволическим чувством числа может быть связано с условиями, в которых осуществляется несимволическая оценка. Несимволическое чувство числа принято оценивать с использованием теста на несимволическое сравнение, к которым относится, например, тест сине-желтых точек. В этом тесте необходимо сравнить 
количество точек разного цвета и выбрать, точек какого цвета больше. Существует две предполагаемых подсистемы, обеспечивающих несимволическое сравнение: подсистема, функционирующая с опорой на оценку и сравнение визуальных параметров сравниваемых наборов точек (например, поверхностной и совокупной площадь, расстояния между точками), а также подсистема непосредственной оценки количества. Различия в точности каждой подсистемы проявляются в эффекте конгруэнтности - различии в точности между конгруэнтными заданиями (визуальные параметры положительно коррелируют с количественными параметрами) и неконгруэнтными заданиями (визуальные параметры отрицательно коррелируют с количественными). В неконгруэнтных заданиях для того, чтобы правильно сравнить наборы точек, необходимо оценить количество независимо от оценки визуальных параметров, в то время как для оценки количества в конгруэнтных заданиях достаточно правильно оценить и сравнить визуальные параметры.

Распознавание количества может осуществляться в условиях более доступного сравнения визуальных параметров (например, в ситуации, когда сравниваются одинаковые по форме фигуры, при этом сравниваемые наборы точек разных цветов отделены друг от друга), а также затрудненного доступа к сравнению визуальных параметров (например, когда надо сравнивать разные по форме фигуры, при этом фигуры разного цвета перемешаны). В условиях доступного сравнения визуальных параметров возникают большие различия в ответах на конгруэнтные и неконгруэнтные пробы. В конгруэнтных пробах точность значимо выше, чем в неконгруэнтных. В условиях затрудненного доступа эти различия становятся незначимыми или принимают обратное значение: в неконгруэнтных заданиях точность становится выше, чем в конгруэнтных. Это может говорить о том, что в условиях доступного сравнения визуальных параметров в большей степени задействована подсистема, функционирующая с опорой на визуальные параметры; в условиях затрудненного доступа в большей степени включена система непосредственной оценки количества [23].

Предыдущие исследования, направленные на исследование связи между несимволическим и символическим чувством числа, не учи- 
тывали возможные различия в силе связи двух подсистем несимволической оценки количества с символической репрезентацией количества. В данном исследовании ставится цель обнаружить связь между двумя подсистемами несимволической оценки количества (конгруэнтные/неконгруэнтные пробы) и символическим чувством числа у школьников разного возраста.

\section{Методика исследования}

Исследование было проведено с использованием данных, собранных у 1043 школьников 4-9-х классов из России и Кыргызстана. Из них: учащихся 4-х классов - 146, 5-х классов - 185, 6-х классов - 163, 7-х классов - 160, 8-х классов - 177, 9-х классов - 212. Исследование было одобрено этическим комитетом Психологического института Российской академии образования. Перед сбором данных было получено информированное и письменное согласие родителей. Согласие детей было получено устно.

Все участники были протестированы обученным экспериментатором в школьных помещениях. Все экспериментаторы использовали один и тот же протокол с инструкциями по проведению тестирования. Каждый участник сидел перед индивидуальным монитором и самостоятельно выполнял задания. Участники сидели примерно в 60 см от экрана.

Каждый участник выполнял новую версию теста «Сине-желтые точки» и тест «Числовая линия» на компьютере. Последовательность тестов была одинаковой.

\section{Тест «Числовая линия»}

Эта задача была запрограммирована и адаптирована в режиме онлайн на основе описания, полученного от Siegler and Opfer (2003) [24]. На экране была представлена линия с номером в верхней части экрана. Вертикальная метка высотой 11,5 пикселей обозначала начало и конец числовой строки. Левый конец строки был отмечен цифрой «0», а правый конец - цифрой «1000». Общая длина линии составляла 500 пикселей, что позволяло корректно отображать линию на экране компьютера. Центр числовой линии находился в центре экрана. Номер мишени имел высоту 0,4 см и располагался на 3 см выше центра числовой линии. 
Задача требовала, чтобы участники разместили число, отображаемое вдоль линии. Всего было оценено 22 числа, и эти числа были представлены всем участникам в одном порядке в разные моменты времени следующим образом: 246, 179, 818, 78, 722, 150, 366, 122, 738, $5,147,938,18,606,2,34,754,100,56,163,486$ и 725.

Каждый ученик мог перемещать мышь, чтобы отметить положение предполагаемого числа. Движение мыши совпадало с движением вертикальной красной линии (18,5 пикселей) на числовой линии. Когда участник решал дать ответ и отметить позицию, он щелкал левой кнопкой мыши. Точность ответа рассчитывалась как отклонение (в баллах) от правильной позиции, меньшее отклонение соответствовало лучшему показателю точности.

\section{Тест «Сине-желтые точки»}

В этой версии теста «Сине-желтые точки» участникам на короткое время (400 мсек) были представлены массивы желтых и синих фигур, которые различались по размеру и количеству. Участникам нужно было решать, фигур какого цвета больше, нажимая соответствующие клавиши на клавиатуре (клавишу «ж» для желтых фигур, клавишу «с» для синих фигур).

Стимулы включали 128 статических изображений. Стимулы сконструированы таким образом, чтобы проконтролировать эффект двух визуальных параметров: совокупной площади и поверхностной площади. По каждому из параметров стимулы могли быть конгруэнтными или неконгруэнтными, второй параметр при этом был одинаковым для двух наборов. В целом в тесте было 50 \% конгруэнтных заданий, в которых один из визуальных параметров положительно коррелировал с количественными параметрами, и $50 \%$ неконгруэнтных.

Для того чтобы учесть различия несимволического чувства числа в зависимости от условий доступности сравнения визуальных параметров, в половине заданий был использован смешанный формат предъявления, в другой половине - раздельный. В раздельном формате фигуры разного цвета находятся в разных частях экрана и не смешиваются. Также стимулы могли различаться по параметру гомогенности/гетерогенности. В 50 \% заданий необходимо было сравнить одинаковые фигуры (гомогенные условия), в другой по- 
ловине - разные фигуры (круги и треугольники) (гетерогенные условия). Таким образом, можно выделить четыре основных вида условий, различающихся по степени доступности сравнения визуальных параметров: 1) гомогенный/раздельный формат (наиболее простой для сравнения визуальных параметров); 2) гомогенный/ смешанный формат; 3) гетерогенный /раздельный формат; 4) гетерогенный/смешанный формат (наиболее сложный для сравнения визуальных параметров) [25].

По результатам проб рассчитывалась точность - количество правильных ответов для теста в целом, а также отдельно для конгруэнтных и неконгруэнтных заданий, как показатели точности двух подсистем несимволической оценки количества.

\section{Результаты}

В табл. 1 представлены результаты оценки несимволического чувства числа (тест «Сине-желтые точки») и символического чувства числа («Числовая линия») у 1043 учащихся 4-9-х классов.

Таблица 1

Среднее и стандартное отклонение результатов учащихся 4-9-х классов по тестам «Сине-желтые точки» и «Числовая линия»

\begin{tabular}{crrrr}
\multicolumn{1}{l}{$\begin{array}{l}\text { mean } \\
\text { "Сине-Желтые точки" }\end{array}$} & \multicolumn{2}{c}{ Числовая линия } & "Сине-Желтые точки" & Числовая линия \\
Класс & & & & \\
\hline 4 & 84.308219 & 73.697945 & 8.301695 & 67.652412 \\
\hline 5 & 81.351351 & 96.823784 & 10.713706 & 95.329820 \\
6 & 80.527607 & 86.884049 & 10.388926 & 78.628664 \\
7 & 82.868750 & 66.777500 & 10.595550 & 66.629727 \\
8 & 85.615819 & 58.675141 & 10.490222 & 63.041294 \\
9 & 85.037736 & 52.613208 & 12.928476 & 59.401365
\end{tabular}

Методом Спирмена с поправкой на множественные сравнения False Discovery Rate (FDR) была выявлена значимая для всех показателей отрицательная корреляционная связь между результатами теста «Числовая линия» и «Сине-желтые точки» (в конгруэнтных 
и неконгруэнтных условиях) у школьников разного возраста. В целом отрицательная связь указывает на то, что более точная символическая оценка числа (т. е. более низкие показатели ошибки в оценке позиции числа на числовой линии) связана с более точной несимволической оценкой. Размеры корреляционного эффекта $\rho$ для всех пар связей представлены на рисунке.

Отрицательная связь указывает на то, что более высокие показатели несимволической оценки количества связаны с меньшей погрешностью в символической оценке количества.

В табл. 2 представлены оценки уровня значимости $p$ для всех пар корреляционных связей.

Связь символического чувства числа и несимволического чувства числа у школьников 4-9-х классов остается стабильной, это относится к результатам теста в целом и неконгруэнтных условий. В то же время, связь между точностью в конгруэнтных заданиях и символическим чувством числа уменьшается к 9-му классу.

\section{Обсуждение}

Хотя большинство авторов согласны с тем, что тест «Числовая линия» является хорошим инструментом для измерения представлений символической величины, существует предположение, что данный тест измеряет навыки мэппинга (наложение символической

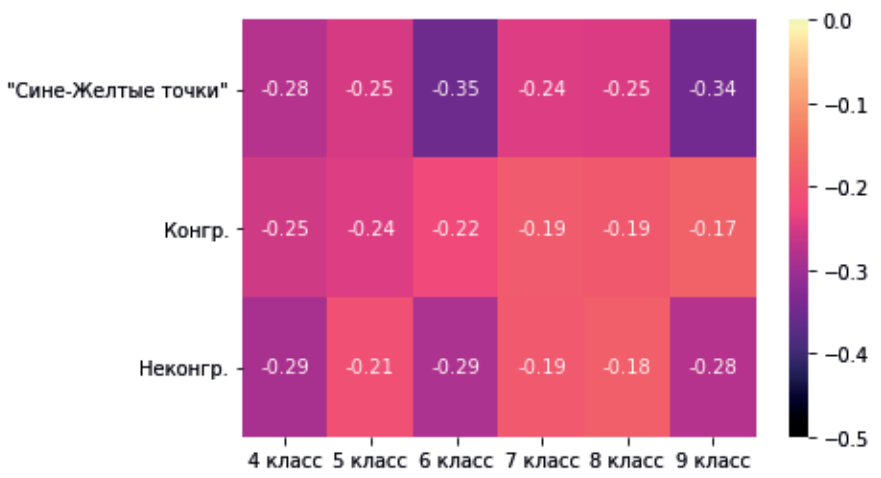

Размер $\rho$ корреляционной связи между баллами по тесту «Числовая линия» и оценками по тесту «Сине-желтые точки», в том числе в конгруэнтных и неконгруэнтных условиях 
обработки количества на приблизительную оценку количества с помощью несимволических представлений). Мэппинг рассматривается как модель, в соответствии с которой взрослые интуитивно отображают символические числа на соответствующие несимволические представления перед дальнейшей обработкой [24] Таким образом, результаты теста «Числовая линия» могут отражать как символические представления, так и навыки отображения. Кроме того, некоторые авторы утверждают, что между ANS и системами символического представления существуют взаимные отношения. $[25,27]$ В частности, Toll et al. [26] исследовали изменения в развитии несимволических и символических навыков сравнения и продемонстрировали, что существуют двунаправленные отношения. Goffin и Ansari [26] предположили возможность того, что природа и направление ассоциаций между символическими и несимволическими представлениями количества могут меняться в зависимости от возраста и опыта.

Считается, что в фило- и онтогенезе несимволическая форма репрезентации количества является более ранним образованием, чем символическая форма; в свою очередь, на фоне развития культурно обусловленной способности символической оценки несимволическое чувство числа уходит на второй план, что показано в нейровизуализационных исследованиях на примере активации соответствующих мозговых структур. [28, 29] Таким образом, положительная связь между способностями к символической и несимволической репрезентации количества у учащихся

Таблица 2

Уровни значимости $p$ с поправкой на множественные сравнения

FDR для всех пар корреляционных связей между оценками по тесту «Числовая линия» и оценками по тесту «Сине-желтые точки», в том числе в конгруэнтных и неконгруэнтных условиях

4 класс 5 класс 6 класс 7 класс 8 класс 9 класс

\begin{tabular}{rllllll}
\hline "Сине-Желтые точки" & 0.00187 & 0.00264 & 0.0000 & 0.01166 & 0.00726 & 0.00000 \\
Конгр. & 0.00387 & 0.00264 & 0.0079 & 0.03736 & 0.03630 & 0.02642 \\
Неконгр. & 0.00187 & 0.00913 & 0.0006 & 0.03736 & 0.03689 & 0.00016
\end{tabular}


средних классов, обнаруженная в нашем исследовании, может отображать особенностями закономерностей развития этих двух способностей.

Низкая согласованность результатов несимволических тестов, зависящая от различных способов, используемых для контроля визуальных параметров, ставит под сомнение способность обрабатывать несимволическое количество независимо от восприятия непрерывных визуальных свойств, таких как совокупная или поверхностная площадь двух наборов объектов [30]. Некоторые авторы предполагают, что повышение точности выполнения теста ANS объясняется увеличением точности оценки визуальных свойств, а не восприятием конкретного количества [31]. Другие авторы предполагают, что хотя в раннем возрасте на точность тестов ANS влияют визуальные свойства стимула, способность оценивать величину в несимволическом формате независимо от визуальных свойств увеличивается с возрастом [32]. Однако взаимосвязь между ANS и символическими числовыми навыками может частично объясняться визуально-пространственными способностями. Учитывая это, в данном исследовании мы предположили, что связь между символическим чувством числа и несимволическим чувством числа может различаться для двух подсистем несимволической оценки количества. Было обнаружено, что для обеих подсистем связь была значимой и положительной. Но для неконгруэнтных заданий, точность в которых обеспечивается работой подсистемы непосредственной оценки количества, связь остается стабильной от 4-го к 9-му классу. Для конгруэнтных заданий, в которых в большей степени задействована система с опорой на оценку визуальных параметров, связь между символическим и несимволическим чувством числа снижается от 4-го к 9-му классу. Одним из возможных объяснений данного эффекта является снижение вклада системы оценки визуальных параметров в символическое чувство числа.

Таким образом, две подсистемы оценки количества показывают разные паттерны взаимосвязи с символическим чувством числа в ходе развития. В то время как для подсистемы непосредственной оценки характерна стабильная связь от 4-го к 9-му классу, для подсистемы с опорой на оценку визуальных параметров выявлено снижение силы 
связи к 9-му классу. Возможно, что именно различиями в связи двух подсистем с символическим чувством числа могут объясняться имеющиеся противоречия в предыдущих данных относительно того, как связаны символическое и несимволическое чувство числа.

1. De Smedt B., Verschaffel L., Ghesquière P. The predictive value of numerical magnitude comparison for individual differences in mathematics achievement // Journal of Experimental Child Psychology. 2009. Vol. 103, № 4. P. 469-479.

2. Schneider M. et al. Associations of non-symbolic and symbolic numerical magnitude processing with mathematical competence: A meta-analysis // Developmental Science. 2017. Vol. 20, № 3. P. e12372.

3. Dehaene S., Cohen L. Towards an anatomical and functional model of number processing // Mathematical Cognition. 1995, Vol. 1, № 1. P. 83-120.

4. Feigenson L., Dehaene S., Spelke E. Core systems of number // Trends in Cognitive Sciences. 2004. Vol. 8, № 7. P. 307-314.

5. Sasanguie D. et al. Association between basic numerical abilities and mathematics achievement // British Journal of Developmental Psychology. 2012. Vol. 30, № 2. P. 344-357.

6. Rodic M. et al. Cross-cultural investigation into cognitive underpinnings of individual differences in early arithmetic // Developmental Science. 2015. Vol. 18, № 1. P. 165-174.

7. Emmerton J. Birds' judgments of number and quantity // Avian Visual Cognition. 2001.

8. Lipton J. S., Spelke E. S. Discrimination of large and small numerosities by human infants // Infancy. 2004. Vol. 5, № 3. P. 271-290.

9. Mundy E., Gilmore C. K. Children's mapping between symbolic and nonsymbolic representations of number // Journal of Experimental Child Psychology. 2009. Vol. 103, № 4. P. 490-502.

10. Dehaene S. Précis of the number sense // Mind \& language. 2001. Vol. 16, № 1. P. 16-36.

11. Halberda J., Feigenson L. Developmental change in the acuity of the "Number Sense": The Approximate Number System in 3-, 4-, 5-, and 6-year-olds and adults // Developmental Psychology. 2008. Vol. 44, № 5. P. 1457.

12. Gilmore C. K., McCarthy S. E., Spelke E. S. Symbolic arithmetic knowledge without instruction // Nature. 2007. Vol. 447, № 7144. P. 589-591. 
13. Hyde D. C., Khanum S., Spelke E. S. Brief non-symbolic, approximate number practice enhances subsequent exact symbolic arithmetic in children // Cognition. 2014. Vol. 131, № 1. P. 92-107.

14. Bonny J. W., Lourenco S. F. The approximate number system and its relation to early math achievement: Evidence from the preschool years // Journal of Experimental Child Psychology. 2013. Vol. 114, № 3. P. 375-388.

15. Reynvoet B., Sasanguie D. The symbol grounding problem revisited: A thorough evaluation of the ANS mapping account and the proposal of an alternative account based on symbol-symbol associations // Frontiers in Psychology. 2016. Vol. 7. P. 1581.

16. Inglis M., Attridge N., Batchelor S., Gilmore C. Non-verbal number acuity correlates with symbolic mathematics achievement: but only in children // Psychonomic Bulletin \& Review. 2011. Vol. 18. P. 1222-1229.

17. Lyons I. M., Beilock S. L. Numerical ordering ability mediates the relation between number-sense and arithmetic competence // Cognition. 2011. Vol 121. P. 256-261.

18. Fazio L. K. et al. Relations of different types of numerical magnitude representations to each other and to mathematics achievement // Journal of Experimental Child Psychology. 2014. Vol. 123. P. 53-72.

19. Lyons I. M., Nuerk H. C., Ansari D. Rethinking the implications of numerical ratio effects for understanding the development of representational precision and numerical processing across formats // Journal of Experimental Psychoogy. 2015. Vol. 144. P. 1021.

20. Kucian K., Grond U., Rotzer S. et al. Mental number line training in children with developmental dyscalculia // Special Issue. 2011. Vol. 57. P. 782-795.

21. Mussolin C. et al. Relationships between approximate number system acuity and early symbolic number abilities // Trends in Neuroscience and Education. 2012. Vol. 1, № 1. P. 21-31.

22. Guillaume M. et al. Differences in the acuity of the Approximate Number System in adults: The effect of mathematical ability // Acta Psychologica. 2013. Vol. 144, № 3. P. 506-512.

23. Кузьмина Ю. В., Захаров И.М, Исматуллина В. И. и др. Интуитивное чувство числа: две системы оценки количества // Теоретическая и экспериментальная психология. 2019. Т. 12, № 2. С. 19-38. 
24. Tosto M. G. et al. Development and Validation of a Mathematics-number sense Web-based Test Battery // Procedia-Social and Behavioral Sciences. 2013. Vol. 86. P. 423-428.

25. Dehaene $S$. The number sense: How the mind creates mathematics. OUP USA, 2011.

26. Toll S. W. M. et al. The development of (non-) symbolic comparison skills throughout kindergarten and their relations with basic mathematical skills // Learning and Individual Differences. 2015. Vol. 38. P. 10-17.

27. Goffin C., Ansari D. How are symbols and nonsymbolic numerical magnitudes related? exploring bidirectional relationships in early numeracy // Mind, Brain, and Education. 2019. Vol. 13, № 3. P. 143-156.

28. Ansari D. et al. Dissociating response conflict from numerical magnitude processing in the brain: an event-related fMRI study // Neuroimage. 2006. Vol. 32, № 2. P. 799-805.

29. Emerson R. W., Cantlon J.F. Continuity and change in children's longitudinal neural responses to numbers // Developmental Science. 2015. Vol. 18, № 2. P. 314-326.

30. Gebuis T., Reynvoet B. The interplay between nonsymbolic number and its continuous visual properties // Journal of Experimental Psychology: General. 2012. Vol. 141, № 4. P. 642.

31. Leibovich T., Henik A. Magnitude processing in non-symbolic stimuli // Frontiers in Psychology. 2013. Vol. 4. P. 375.

32. Szucs D. et al. Visual stimulus parameters seriously compromise the measurement of approximate number system acuity and comparative effects between adults and children // Frontiers in Psychology. 2013. Vol. 4. P. 444. 


\title{
ВЛИЯНИЕ СЕМЬИ НА САМООПРЕДЕЛЕНИЕ СОВРЕМЕННЫХ УЧАЩИХСЯ ПРИ ВЫБОРЕ СТЕМ-ПРОФЕССИИ В ЦИФРОВУЮ ЭПОХУ: КОНЦЕПТУАЛЬНЫЕ АСПЕКТЫ
}

\author{
Е.П.Масленникова \\ В.И. Исматуллина
}

В техноцентричном мире одним из вызовов современности является привлечение подростков к выбору STEM-карьеры (S - science, $\mathrm{T}$ - technology, E - engineering, $\mathrm{M}$ - mathematics). Возможность привлечения талантливых ребят, как и обеспечение доступности STEM-дисциплин на всех уровнях образования, являются приоритетами для системы образования в связи с необходимостью обеспечения базы для выбора данных специализаций. Изучение факторов, определяющих успешность в STEM, а также предикторов выбора STEM как области своей специализации, таким образом, становится не только теоретико-психологической задачей, но и прикладной проблемой, потенциально оказывающей влияние на глобальные экономические процессы.

Одним из важных факторов, обеспечивающих включенность подростков в STEM-области, является вклад родителей в выбор данных дисциплин в качестве будущей профессии своих детей. Влияние родителей, семьи явно прослеживается в процессах профессионального выбора, и это влияние сложно переоценить. Поколения семей, связанных одной профессиональной средой (профессиональным общением, передачей опыта, участием в общих проектах), существовавших в прошлом, становятся, увы, редким каналом воспроизводства инженерных и научных кадров, но и сегодня родители, наряду с иными «значимыми другими» (школьные учителя, ровесники), влияют на формирование жизненных и профессиональных стратегий школьников. Феномены, оказывающие

Исследование выполнено при финансовой поддержке РФФИ в рамках научного проекта № 19-29-14127 «Динамика гендерных различий в представлениях о естественно-научных и технических специализациях и их связь с когнитивномотивационными особенностями школьников в зависимости от уровня цифровизации школьной среды: кросскультурное лонгитюдное исследование». 
влияние на профессиональный выбор, являются комплексными и в большинстве случаев обусловлены не одной автономной причиной, а совокупностью взаимосвязанных причин.

Изучению влияния «значимых других», в частности родителей, на выбор технических наук и STEM-профессий в качестве карьеры как фактора, в значительной степени обусловливающего профессиональный выбор, посвящено множество исследований как зарубежных (J. M. Harackiewicz, C. S. Rozek, J.S. Hyde, L. Gabay-Egozi, Y. Shavit, M. Yaish, S. Ceci, W. Williams), так и отечественных авторов (М. М. Малышева, Е.А. Михайлова, О. Б. Савинская, О.А. Хасбулатова, И.Е. Калабихина, Е. А. Савостина, Е. В. Волобуева и И. Н. Смирнова).

Проблема гендерного неравенства, особенно актуальная в рамках выбора STEM-дисциплин, проявляется на всех этапах социализации молодежи и характеризуется снижением мотивации девочек к выбору профессий, традиционно считающихся мужскими. Объективные данные свидетельствуют, что распределение профессий в STEM между мальчиками и девочками неравномерно. Статистические данные показывают, что, например, в сфере IT среди специалистов с высшим образованием женщин $21 \%$, при этом их заработная плата составляет $82,6 \%$ от заработной платы мужчин, а среди техников женщин всего 24,2 \%, с уровнем заработной платы 68,3\% по сравнению с коллегами-мужчинами. Согласно статистическим отчетам, в России за 2015 г. доля женщин среди специалистов высшего уровня квалификации, занятых в сфере естественных и точных наук, составляет 29 \% (для сравнения: в сфере здравоохранения, биологии и сельского хозяйства $69 \%$ ); среди специалистов среднего уровня квалификации доля женщин, занятых в сфере физических и инженерных направлений деятельности, - 25 \%. Полоролевые модели в российском обществе приводят к формированию выраженных гендерных стереотипов относительно STEM-дисциплин, которые в итоге связаны с наблюдаемым в этих отраслях выраженным «гендерным разрывом» - значительным преобладанием лиц одного пола по сравнению с другим. Гендерные стереотипы, в свою очередь, влияют на мотивационные убеждения, находящиеся под влиянием правил и ролей, предписанных социальными контекста- 
ми, многие из которых относятся к полу. Установки о деятельности, соответствующей полу ребенка, которые транслируют родители, становятся также установками ребенка.

В статье L. Gabay-Egozi, Y. Shavit и M. Yaish показан процесс интериоризации гендерных ожиданий подростков, которые формируются в процессе взаимодействия со значимыми другими. Делая выбор относительно области дальнейшего образования, девочки и мальчики могут следовать общим представлениям о «подходящей» их полу профессии. Родители мальчиков чаще, чем родители девочек, поощряют выбирать сложные STEM-дисциплины (в Израиле в старших классах школы можно выбирать более или менее углубленное изучение предметов). Также родители мальчиков чаще поощряют дружбу со сверстниками, которые выбирают продвинутые STEM-дисциплины [1].

Гендерные роли воплощаются в набор стереотипных убеждений о том, какими должны быть женщины и мужчины и как они должны вести себя в разных сферах жизни [2]. Так, рассматривая свою будущую специальность, студентки не ассоциировали себя с теми, кто может успешно заниматься компьютерными науками, а студенты, в свою очередь, не видели себя среди тех, кто может углубленно заниматься английским языком [3]. Роль родителей, ближайшего семейного окружения в формировании этих гендерных ролей является ключевой - такие установки формируются гендерно различным воспитанием. Стиль общения родителей, их ценности - это условия, в которых начинается ранняя социализация, среда, которая во многом предопределяет дальнейший карьерный выбор. Так как социальные структуры базируются на гендерном разделении труда, то неизбежны и различия подходов в воспитании - они также становятся «гендерно-специфическими» [4].

О. Б. Савинская и Т. А. Мхитарян (2018) подчеркивают важность роли матери в формировании субъективной оценки достижений ребенка и влияния этой оценки на последующий профессиональный выбор. В данном исследовании использована регрессионная модель с эффектами взаимодействия, позволяющая выявить совокупности факторов, при которых школьницы отдают предпочтение или, наоборот, не выбирают STEM-дисциплины для будущей про- 
фессиональной реализации. Показано, что условия при которых сочетаются высокая субъективная оценка собственных достижений в математике, помощь родителей в выполнении домашних заданий, отсутствие разделения девочек и мальчиков на уроках труда в школе, приводят в итоге к выбору STEM-специализации для дальнейшего обучения [5].

В настоящее время расширяется возможность привлечения родителей к участию в выборе профессий подростками в области STEM посредством цифровых технологий. Доступность ресурсов, информирующих родителей о STEM-дисциплинах, выступает одним из необходимых шагов по привлечению подростков к этим областям. Так, экспериментальное исследование Harackiewicz и коллег (2012) показывает, что родители могут быть важным ресурсом (зачастую неиспользуемым) для повышения мотивации к выбору математических дисциплин в школе. Причем повысить мотивацию школьников к выбору курсов углубленного изучения математики в старших классах школы родители смогли, руководствуясь лишь информацией о потенциальной полезности выбора углубленного изучения математики в школе для будущей карьеры в STEM, разосланной в виде брошюр (также в материалах был доступ к веб-сайту с контентом о пользе STEM). Материалы, разосланные по почте родителям, содержали информацию о важности математики и естественных наук в повседневной жизни, важности выбора карьеры STEM, а также рекомендации о том, как говорить с подростком о связи между математикой, наукой и успехом в повседневной жизни. Это относительно простое вмешательство привело к тому, что ученики, родителям которых были предоставлены эти материалы, выбирали больше математических и естественно-научных курсов в последних классах школы [6].

В этом и в ряде других исследований $[7,8]$ было также показано, что образование родителей является предиктором образования их детей: дети высокообразованных родителей чаще выбирают математические и естественно-научные дисциплины. Однако эффект «мотивационного» вмешательства (материалы по почте для родителей) был почти таким же значимым, как влияние образования родителей. Дальнейшее исследование эффекта «мотивационного вмешательст- 
ва» Rozek и коллег (2015) ставило целью изучить его эффективность для различных групп (мальчиков и девочек с различным уровнем достижений). Оказалось, что информирование родителей наиболее эффективно для девочек с высоким уровнем достижений (оценками) и мальчиков с низким уровнем достижений [9].

Таким образом, влияние родителей на выбор академических дисциплин и профессиональное самоопределение имеет долгосрочную перспективу и играет причинно-следственную роль в выборе дисциплин и карьеры в области STEM. А изучение вклада родителей в профессиональный выбор и направление обучения школьников является важной научной проблемой, связанной с процессами построения успешной цифровой экономики в XXI в. Одной из задач, стоящих перед нашим исследованием по привлечению подростков в STEM-области, является разработка концепции, включающей информирование как подростков, так и их родителей о снижении числа школьников, выбирающих естественно-научные дисциплины в качестве своей будущей профессии, и существующем «гендерном разрыве» в этой области.

1. Gabay-Egozi L., Shavit Y., Yaish M. Gender differences in fields of study: The role of significant others and rational choice motivations // European Sociological Review. 2015. Vol. 31, № 3 P. 284-297.

2. Sagebiel F., Vázquez-Cupeiro S. Stereotypes and identity. Meta-analysis of gender and science research-Topic report 2010. 2010.

3. Cheryan S., Plaut V.C. Explaining underrepresentation: A theory of precluded interest // Sex Roles. 2010. Vol. 63, № 7-8. P. 475-488.

4. Bem S. L. Linzy gendera: transformacija vzgljadov na problemu neravenstva polov. Rosspèn, 2004.

5. Савинская О. Б., Мхитарян Т. А. Технические дисциплины (STEM) как девичий профессиональный выбор: достижения, самооценка и скрытый учебный план // Женщина в российском обществе. 2018. № 3 (88).

6. Harackiewicz J. M. et al. Helping parents to motivate adolescents in mathematics and science: An experimental test of a utility-value intervention // Psychological Science. 2012. Vol. 23, № 8. P. 899-906.

7. Jodl K. M. et al. Parents' roles in shaping early adolescents' occupational aspirations // Child Development. 2001. Vol. 72, № 4. P. 1247-1266. 
8. Simpkins S. D., Davis-Kean P. E., Eccles J. S. Math and science motivation: A longitudinal examination of the links between choices and beliefs // Developmental Psychology. 2006. Vol. 42, № 1. P. 70.

9. Rozek C.S. et al. Gender differences in the effects of a utility-value intervention to help parents motivate adolescents in mathematics and science // Journal of Educational Psychology. 2015. Vol. 107, № 1. P. 195. 


\title{
Раздел 6 \\ ПСИХОЛОГИЧЕСКИЕ АСПЕКТЫ РЕАЛИЗАЦИИ \\ ИНКЛЮЗИВНОГО ОБРАЗОВАНИЯ
}

\section{СОЦИАЛЬНО-ПСИХОЛОГИЧЕСКИЕ УСЛОВИЯ СТАНОВЛЕНИЯ СУБЪЕКТНОСТИ УЧЕБНЫХ ГРУПП (НА ПРИМЕРЕ ДЕФЕКТОЛОГИЧЕСКОГО ФАКУЛЬТЕТА)}

Н. А. Котелевцев

\begin{abstract}
Актуальность проблемы
В настоящий момент в связи с происходящими социально-экономическими изменениями в обществе особо остро стоит проблема формирования таких коллективов, которые отличаются самостоятельностью, наличием четкой внутренней регуляции среди участников, повышенным уровнем эффективности своей деятельности. Молодежные коллективы имеют широкую гамму социально-психологических качеств, среди которых наиболее значимым выступает способность группы быть субъектом отношений, общения и поведения.

Заметим, что проблема субъектности индивида и группы в отечественных и зарубежных исследованиях представлена достаточно широко, но тем не менее среди подходов к определению категориального аппарата существуют значительные различия. Так как мы работаем в рамках представлений курской психологической школы (Л.И. Уманского и А.С. Чернышева), то проблема определения социально-психологических условий формирования субъектности
\end{abstract}

Работа выполнена при поддержке гранта РФФИ (№ 19-013-00016 А, по договору № 19-013-00016\20) «Изучение социально-психологических условий становления субъектности учебных групп». 
учебных групп рассматривается через призму основных положений параметрической концепции развития коллектива и субъектно-деятельностного подхода. Так, по мнению А. С. Чернышева, развитие любой малой группы (в том числе и учебной) происходит в несколько этапов, где на начальном этапе группа выглядит как неорганизованная общность (диффузная группа, по Уманскому - Чернышеву), а наивысшей точкой развития является группа, способная проявлять субъектные качества (группа-коллектив, по Уманскому - Чернышеву) [1].

Для формирования субъектных качеств учебных групп перспективным представляется создание условий, которые по своим содержательным характеристикам превосходят социальные условия, присущие образовательной организации, но способствуют развитию и группы, и включенной в нее личности. Формирование таких условий происходит в социальных средах, которые изначально обладают более высоким уровнем организованности, благодаря чему включенные в них группы чаще проявляют субъектные качества. Такой средой является «социальный оазис», который, по А.С. Чернышеву, определяется как «...социум, отличающийся от обычной среды более высокими по содержанию и интенсивности характеристиками совместной деятельности и общения, эмоционально и интеллектуально насыщенной атмосферой сотрудничества и созидания» [2, c. 28]. Именно целенаправленное включение учебных групп в такой вид социальной среды позволяет не только преодолевать трудности, возникающие в процессе выполнения учебной деятельности, но и способствует развитию социально-ценных качеств личности.

В параметрической концепции Л. И. Уманского и А.С. Чернышева развитие группы происходит за счет трансформации таких параметров, как направленность активности, организованность, подготовленность, интеллектуальная и эмоциональная коммуникативность, волевая коммуникативность. Рассмотрим указанные параметры более подробно. В работах представителей курской психологической школы направленность группы рассматривается как системное качество, объединяющее в себе групповые цели, мотивы, нормы и ценности, которые выступают ядром группового сознания, возникающего на фоне формирования и развития систе- 
мы морально-нравственных эталонов группы (общения, отношения и взаимодействия), и в конечном итоге приводящее к повышению общей результативности как выполняемой группой деятельности, направленной на решение определенной задачи, так и внутригруппового взаимодействия индивидов. Такой процесс наблюдается в ходе сближения индивидуального и группового сознания, что неразрывно связано с включением группы в среду активно-деятельностного взаимодействия.

Организованность определяется как интегративный показатель самости группы, что раскрывается через способность членов группы в напряженных и экстремальных условиях, не поддаваясь сильному воздействию стрессогенных факторов, проявлять высокий уровень автономной самоорганизации. В решении конкретно поставленных задач параметр организованности позволяет определять степень общей согласованности членов группы как на внутреннем уровне (в ходе взаимодействия друг с другом), так и на внешнем (при взаимодействии с другими группами).

Подготовленность группы (индивида) - способность к эффективному включению в любой вид активности на основе учета общей специфики, сложности, формы и т. д. - отражает способность группы (индивида) к быстрой адаптации в условиях осуществления конкретной деятельности. Данный параметр наиболее выражен у групп-коллективов (или групп-субъектов), позволяя последним слаженно, четко и результативно включаться в любой вид деятельности (или в решение той или иной поставленной задачи).

Интеллектуальная коммуникативность - показатель способности членов группы к взаимопониманию, умению искать точки соприкосновения (на фоне различия индивидуальных мнений), разрабатывать и использовать паттерны наиболее прогрессивных моделей внутригруппового взаимодействия и взаимоотношений. По мнению А. С. Чернышева, интеллектуальная коммуникативность позволяет группам реализовать полноценный процесс межличностного восприятия как в ходе первичного познания членами группы друг друга, так и в ситуации повседневной жизнедеятельности [3].

Немаловажным фактором успешного развития группы как субъекта общения и отношений является эмоциональная ком- 
муникативность, отражающая способность ее членов выстроить позитивные эмоциональные взаимоотношения, установить межличностные связи, сформировать единый психоэмоциональный климат. В группах с высоким уровнем социально-психологической зрелости превалирует положительный настрой на деятельность, общение и отношения.

Волевая коммуникативность характеризуется обобщенным умением и способностью группы к преодолению трудностей, выступает в качестве показателя общей стрессоустойчивости, относительной целостности внутренней структуры и потенциала сохранения надежности. Данный компонент наиболее полно раскрывается в условиях экстремальной деятельности, в ситуациях неопределенности и напряженности, отражая тем самым способность группы проявлять себя субъектом самоорганизации.

Представленные параметры наиболее полно раскрываются и формируются в условиях развивающей социальной среды, так как именно в ней группы в активно-действенной форме приобретают и вырабатывают необходимые качества, тем самым проходя путь в континууме от диффузной группы до группы субъекта.

Исходя из нашего опыта, для успешного создания развивающих условий следует целенаправленно актуализировать следующие механизмы.

1. Формирование высокого уровня мотивации и готовности к включению в активную, социально значимую деятельность. Для реализации данного механизма необходимо целенаправленно включать обучающихся в такое молодежное движение, которое является более активным и продуктивным в сравнении с обычной жизнедеятельностью, тем самым позволяя включенным индивидам приобщиться к улучшенным жизненным идеалам, высоким нравственным целям и ценностям. Такая среда открывает обучающимся возможности для более глубокого познания собственного Я, идентификации, формируя, таким образом, триединую структуру (внутренняя «Яконцепция» - мнение других о собственном Я - принадлежность и причастность к ценностям референтной группы).

2. Включение педагогического состава в процесс создания, формирования и жизнедеятельности группы. Благодаря данному 
механизму коллектив педагогов выступает не как обособленное сообщество с декларативной формой взаимодействия с группами обучающихся, а как коллектив старших наставников, единомышленников, активно сотрудничающий с другими группами (в рамках социального оазиса). При этом следует отметить, что если коллектив педагогов проявляет более высокий уровень организованности, согласованности и социально-психологической зрелости, то для остальных групп он начинает выступать в качестве эталон-ориентира (как по своей структуре, системе взаимоотношений, так и по форме организации собственной деятельности).

3. Механизм соблюдения высокого темпоритма всех видов основной деятельности. Организация любых мероприятий и деятельности коллектива должна идти в более высоком темпе, соответствовать четкому ритму, с актуализацией всего многообразия форм организации совместной деятельности, по Л.И. Уманскому. В проводимых нами исследованиях установлено, что именно в среде, где все мероприятия группового характера имеют высокий темп, общий уровень организованности коллективов обучающихся повышается, так как последнее становится «жизненно важным» условием эффективной и продуктивной деятельности, конкурентоспособности. Такие условия вынуждают членов группы искать и вырабатывать наиболее оптимальные и быстрые стратегии решения тех или иных задач.

4. Обязательное введение четкой системы организационных норм и правил, обеспечивающих поддержание порядка и высокого уровня организованности. Такая система должна быть представлена в форме коллективно выработанных традиций и правил, имеющих свою историю создания. Следует заметить, что в процессе создания системы норм и правил (внутренних традиций коллектива и организации в целом) важно участие не только коллектива педагогов и руководителей, но и самих обучающихся, что, с одной стороны, создает чувство сопричастности к нормотворчеству, а с другой позволяет тем самым повысить уровень общей организованности (так как нормы и правила разрабатывались теми, кто согласен их соблюдать). В качестве примера можно привести такие варианты: создание эмблем команд, разработка гимнов, девизов, создание предметов единой атрибутики как команды, так и всей организации 
(с учетом особенностей каждого члена коллектива), которые будут отражать главные принципы и направленность группы в целом.

5. Создание условий, способствующих полноценному раскрытию творческого, спортивного, интеллектуального потенциала каждого члена группы. Для этого руководителями групп и педагогами должны внедряться совместные виды активностей, позволяющие актуализировать, развивать и держать в тонусе все разнообразные индивидуальные таланты, которые соответствуют интересам и направленностям членов коллектива.

6. Создание условий напряжения и экстремального состояния в ходе выполнения совместной деятельности. Для этого большая часть групповых мероприятий должны проходить в повышенном и высоком темпе, с четко заданным ритмом (это наиболее полноценно реализуется при организации профильных смен в детских оздоровительных лагерях), что, с одной стороны, порождает необходимость проявления высокого уровня сплоченности, организованности, активности, умения брать на себя ответственность и т. д., а с другой - выступает катализатором формирования навыка активного действия в условиях напряженности (с целью достижения положительного результата). Именно поэтому ограничение времени на выполнение задания, недостаток материальных средств (необходимых для выполнения поставленной задачи), обязательное представление результатов деятельности публично (в том числе в присутствии групп-конкурентов) позволяет актуализировать механизмы внутреннего развития социально-психологической зрелости группы и приводит к формированию субъектных качеств (как на групповом, так и на индивидуальном уровнях). Важно со стороны педагогического коллектива оказывать поддержку участникам и на первых этапах помогать сохранять положительный психологический климат в группе и мотивацию на выполнение деятельности.

7. Актуализация и внедрение широкого спектра совместной активности и деятельности. Следует учитывать, что разнообразные формы организации совместной деятельности следует внедрять не только на внутриколлективном уровне, но и при межгрупповом взаимодействии. 
Остановимся более подробно на формах организации совместной деятельности (далее - ФОСД), которые мы подразделили на 4 вида.

\section{Формы организации совместной деятельности}

Совместно-индивидуальный вид ФОСД. При данном варианте организации совместной деятельности в группах отмечается наименьшее количество контактов между участниками, но итоговый результат деятельности зависит от суммарного вклада всех членов группы (в данном случае вклад каждого из участников может варьироваться в диапазоне от минимального до максимального). При совместно-индивидуальном виде ФОСД межличностные контакты и взаимодействие между участниками могут отсутствовать или быть сведены к минимуму. Приведем пример совместно-индивидуального вида ФОСД: в образовательных организациях мы предлагали обучающимся задания, результатом выполнения которых является создание мультимедийного проекта. Членам группы давалось конкретизированное задание, с четкими правилами и сроками выполнения, каждый член группы отвечал за свой сектор выполняемого задания (кто-то собирал информацию, кто-то систематизировал ее, кто-то создавал иллюстрации и т. д.). В этом случае руководитель имеет возможность провести контроль степени индивидуального вклада каждого члена команды, управляя продуктивностью (при неспособности одних членов группы выполнить задание их обязанности могут быть переданы наиболее ответственным и активным). Важно в этом случае не полностью снимать ответственность с одного члена группа и перекладывать ее на другого, а менять их виды деятельности (если один не справляется с созданием иллюстраций, ему давали задание по поиску информации и т.д.). В рамках нашей работы мы использовали совместно-индивидуальный вид ФОСД еще и как инструмент практической диагностики, позволяющий выявлять наиболее актуальные варианты индивидуальных видов активностей для каждого студента, в дальнейшем моделируя ситуации, повышающие общую групповую результативность.

Совместно-последовательная ФОСД. Позволяет в бо́льшей степени отследить индивидуальные вклады участников групп в сов- 
местную деятельность с целью достижения некоторого результата. Следует отметить, что в данном варианте ФОСД степень успешности прохождения каждого отдельного этапа деятельности значительно влияет на конечный итог. По своей сути такой вид совместной деятельности напоминает работу конвейера, когда при переходе от одного участника к другому предмет деятельности изменяется, трансформируется и улучшается. Так, применительно к указанному выше примеру совместно-последовательный вид ФОСД реализовывался нами следующим образом: одному члену группы давалось задание найти информацию, после этого второй занимался ее редактированием, на основе работы второго третий добавлял графические примеры и т. д.

Совместно-распределенный вид формы организации совместной деятельности - это такой вид ФОСД, в ходе которого итог выполнения конкретного задания представляет из себя сумму индивидуальных вкладов каждого члена группы в общее «поле» деятельности. Такая деятельность может быть выполнена как на основе личного контакта, так и без него, тем не менее каждый член группы остается ответственен за свой объем работы и в ходе выполнения своей части задания может ориентироваться только на свое видение конечного результата или на уже выполненные другими членами группы части задания. Главным условием для такого вида ФОСД является задача руководителя четко распределить ответственность среди членов группы с последующим выполнением на общей площадке.

Примером может служить подготовка группой (отрядом) общей стенгазеты. При совместно-индивидуальной ФОСД каждый член группы выполняет посильное задание (один рисует, второй раскрашивает и т.д.). При совместно-распределенной ФОСД каждый член группы также выполняет посильные задания, но в процессе их выполнения участники более тесно контактируют друг с другом, и результат зависит от их объединенных усилий. При этом их роли распределены в рамках решения общей задачи: один рисует на ватмане название, второй готовит заметку и тут же размещает ее на том же самом ватмане, третий смешивает краски и т.д. Мы считаем, что такой вид ФОСД является промежуточным между совместно-индивидуальной и совместно-последовательной ФОСД, включая в себя еще 
и некоторые элементы взаимозависимого вида, отражая развитие процессов коммуникации и взаимодействия в группе.

Совместно-взаимозависимый вид ФОСД. Данный вид организации совместной деятельности отражает высокий уровень организованности и слаженности в работе коллектива и может выступать показателем развития его социально-психологической зрелости и субъектных качеств. Также данный вид формы организации совместной деятельности может применяться и в качестве своеобразного «тренажера» организованности, так как именно в коллективах с высоким уровнем проявления субъектных качеств данный вид деятельности присутствует в 95 \% случаев. Его общая характеристика состоит в том, что совместно-взаимозависимый вид ФОСД отличается высоким уровнем включенности членов группы в ее выполнение, повышенной интенсивностью усилий каждого участника, равноценным вкладом в общий результат деятельности (при этом если один или несколько участников снижают интенсивность своих усилий или выключаются из деятельности, то это приводит к снижению общего уровня результативности для всей группы). Получается, что при совместно-взаимозависимом виде ФОСД результат решения той или иной поставленной перед группой задачи напрямую зависит от посильного вклада каждого из участников, степени их согласованности, налаженных процессов межличностной коммуникации и взаимодействия, общего психологического климата в группе [4].

Следует отметить, что в участвовавших в нашем исследовании 2019-2020 гг. группах указанные варианты формы организации совместной деятельности в «чистом» виде встречались крайне редко, в то же время присутствовала некоторая вариативность в использовании комплекса ФОСД у разных групп в зависимости от степени развития их субъектных качеств. Чем ближе группа к своей субъектности как коллектива, тем чаще на всех уровнях взаимодействия (внутригрупповом и внешнегрупповом) применяется совместновзаимозависимый вид ФОСД.

Нами была разработана классификация групп субъектов, отражающая не только степень проявления группой субъектных качеств, но и общий уровень ее развития:

614 
- группы «собственно субъекты» - имеют высокий уровень развития социально-психологической зрелости, устойчивые динамические изменения в условиях эксперимента, отличаются стабильностью в проявлении таких параметров, как организованность, направленность активности, психологический климат, интеллектуальная и волевая коммуникативность; отличаются наличием четкой структуры групповых норм и ценностей, высокой степенью близости индивидуального и группового сознания;

- группы «потенциальные субъекты» - в своей структуре имеют неравномерное распределение общей развитости указанных выше параметров, в процессе развития могут проявлять общую неустойчивость. Динамические сдвиги в уровне развития социально-психологической зрелости группы могут носить как положительный, так и отрицательный характер, с возможностью смены своего вектора. Такое явление, как правило, не оказывает общего отрицательного влияния на ход становления и развития субъектных качеств группы и включенных в неё индивидов;

- группы «ситуационные субъекты» - отличаются тем, что проявление субъектных качеств в ходе выполнения совместной деятельности носит ситуационный и неустойчивый характер. В таких группах сценарий развития субъектности и проявления субъектных качеств может быть разнообразным: в одном случае группа может перейти на следующий этап развития, в другом, имея изначально высокие предпосылки к развитию субъектных качеств, показать отрицательную динамику (такой феномен мы наблюдали в 2014 г., когда группа «ситуационный субъект» вступила в жесткую конкуренцию и конфликт с группой «собственно субъектом», что для последней послужило толчком в развитии еще более проработанной системы ценностных ориентиров, а для первой группы - фактором, обусловившим откат в ее развитии).

Таким образом, использование ключевых положений параметрической концепции Л.И. Уманского и А.С. Чернышева и технологии создания развивающих социальных сред является одним из наиболее перспективных путей формирования субъектности и субъектных качеств как личности, так и группы. Так, если группа достигает своей высшей точки развития (становится коллективом) 
и приобретает качества субъекта деятельности, общения и отношений, то среди социально-психологических свойств группы наиболее полно реализуются такие интегративные показатели, как направленность членов коллектива, общий уровень организованности, подготовленность к выполнению совместной деятельности (в том числе и сложной), интеллектуальная коммуникативность, высокий уровень волевого контроля и положительный психологический климат. Отсюда следует, что изучение степени развития указанных параметров в группах позволяет установить общий уровень социально-психологической зрелости группы [3].

\section{Организация и содержание экспериментальной работы}

В рамках проводимого нами экспериментального исследования мы определили субъектность как психологическое свойство личности и группы, «которое позволяет аккумулировать энергетический потенциал всех психических процессов (а также высшей нервной деятельности), для достижения наиболее эффективных результатов решения задач на внутреннем и внешнем уровнях, с последующим их развитием» $[4$, с. 2]. В соответствии с данным подходом мы можем рассматривать субъектность личности и группы не как сумму отдельных психических свойств, а как новое интегративное свойство, которое в процессе реализации совместной деятельности позволяет определить общий уровень эффективности адаптационного поведения (как человека, так и группы) в меняющихся условиях (в том числе и экстремальных), сохраняя целостной структуру всех психических процессов. Такое интегративное свойство позволяет более успешно преодолевать возникающие жизненные трудности (повышая стрессоустойчивость и общие способности к социализации личности и группы).

Нами было выдвинуто предположение о том, что приобретение личностью и группой статуса субъекта совместной деятельности, общения и отношений обеспечивается комплексом внешних и внутренних условий, таких как:

- включение групп в социальные среды с большими воспитательными возможностями; 
- введение различных форм организации совместной деятельности (совместно-индивидуальная, совместно-последовательная, совместно-взаимозависимая);

- формирование устойчивой положительной мотивации включенности группы в другие социальные организации;

- наличие у группы установки на совершенствование совместной активности.

В качестве основных критериев развития учебной группы как субъекта мы выделяем:

- способность группы к организации и реализации эффективной совместной деятельности;

- общий уровень социально-психологического развития группы;

- степень соотношения индивидуального и группового сознания в исследуемых группах.

Формирование у групп субъектных качеств способствует, с одной стороны, развитию указанных выше параметров и общей социально-психологической зрелости, а с другой - развитию новых интегративных свойств личности (что отражается как на повышении мотивации в учебной деятельности, так и на общей успешности последней).

Для реализации экспериментального исследования нами на базе дефектологического факультета ФГБОУ ВО «Курский государственный университет» был создан психологический клуб «РsyLaboratorium», в котором для экспериментальных групп 1-4-го курса в 2018-2020 гг. проводились специальные тренинги, актуализирующие совместную деятельность среди обучающихся, что соотносится с ключевыми принципами построения развивающей социальной среды, по Уманскому - Чернышеву. Занятия в клубе проводились два раза в неделю. В ходе таких занятий двум группам предлагалось участвовать в различных видах совместной деятельности: спортивных эстафетах, творческих вечерах, интеллектуальных соревнованиях, разработке мероприятий факультета и т. д. Группы выступали в качестве организаторов и участников проводимых мероприятий. Результаты их деятельности оценивались независимой группой экспертов и освещались на факультете, что придавало им соревновательный характер. Всего в исследовании приняли участие 174 
студента бакалавриата (6 групп, 1-4-й курсы). Далее представлены методы и результаты экспериментального исследования в двух группах студентов 1-го курса (всего 47 человек).

\section{Методы исследования}

В качестве диагностического инструментария, позволяющего изучить уровень развития группы, мы использовали:

- карту-схему психолого-педагогической характеристики группы школьников Л. И. Уманского и А. С. Чернышева, позволяющую через изучение мнений и представлений членов группы определить уровень ее социально-психологической зрелости, а также степень включенности каждого члена группы в совместную деятельность [5];

- аппаратурную методику «Арка», разработанную группой сотрудников под руководством А. С. Чернышева, которая позволяет определить степень социально-психологической зрелости группы и настроя ее членов на совместную деятельность [Там же].

Карта-схема психолого-педагогической характеристики группы школьников Л. И. Уманского и А. С. Чернышева состоит из опросных листов, представляющих собой оценочную шкалу (пятибалльную), вмонтированную в набор качеств, характеризующих наиболее существенные свойства изучаемой группы, где испытуемому предлагается оценить степень выраженности одного из двух полярных суждений («5» ставится тогда, когда качество очень сильно и постоянно проявляется, «4»- проявляется постоянно, но не так сильно, «3» - не очень проявляется, «2»- проявляется противоположное отрицательное качество, «1» - сильно проявляется противоположное отрицательное качество). Карта-схема позволяет изучить такие параметры развития группы, как направленность активности, организованность, интеллектуальная коммуникативность, психологический климат. По итогам проведенного опроса среди всех членов группы для определения коэффициента показателя уровня социально-психологической зрелости группы подсчитывается $x$-среднее и полученный результат переводится в проценты (где интервал 0-22 \% - низкий уровень, 23-37\% - ниже среднего, 38-56 \% - средний, 57-72\% - выше среднего, 73-85\% - достаточно высокий, 86-100 \% - высокий) [3, 5]. 
Прибор-модель «Арка» представляет собой сборно-разборную конструкцию в виде арки, состоящую из 27 элементов, соединяющихся друг с другом в строгой последовательности, конструкция предназначена для выполнения практической совместной деятельности по её сборке в группе от 2 до 20 человек. Прибор-модель «Арка» позволяет через определение коэффициента эффективности деятельности группы изучить особенности протекания внутригрупповых процессов, общую степень социально-психологической зрелости группы, настрой членов группы на совместную деятельность, степень мотивации, а также степень согласованности взаимодействия членов группы в ходе выполнения совместной деятельности. В процессе работы группы экспериментатор фиксирует такие показатели взаимодействия, как сотрудничество, конкуренция, конфликт, степень ориентировки членов группы в условиях моделирования совместной деятельности, динамика лидерства и особенности его проявления в группе, общий стиль внутригруппового взаимодействия членов группы. В ходе выполнения экспериментальных проб в группе наиболее ярко начинают проявляться социально-психологические процессы (коммуникативные, эмоционально-волевые и т.д.). Экспериментальная проба представляет собой сбор материальной модели арки группой на время (засекается экспериментатором), после чего на основании проведенных экспериментальных проб рассчитывается коэффициент эффективности деятельности группы $L$ по формуле $L=T \_0 / T$, (где $T \_0-$ эталонное время для «Арки»; $T$ - время выполнения экспериментальной пробы группой) [5]. Более подробно о том, как проводится работа с прибором-моделью «Арка», можно ознакомиться в научных работах С. В. Сарычева и А.С. Чернышева $[2,5]$. Заметим, что данный метод применялся нами для диагностического изучения уровня развития (социально-психологической зрелости) коллектива в ходе осуществления экспериментальной работы в условиях естественного эксперимента. «Арка» позволяет изучить процессы формирования коллектива и особенности внутригруппового взаимодействия не на уровне мнений членов группы, а в ходе моделирования совместной деятельности. 
В процессе занятий обучающимся предлагаются новые формы активного взаимодействия, реализуется программа социального обучения, расширяется спектр совместной деятельности, что в конечном итоге способствует формированию пред-субъектных и собственно субъектных качеств личности и группы.

\section{Результаты и их обсуждение}

Диагностическое исследование проводилось нами дважды: до фактического изменения социально-психологических условий жизнедеятельности групп (сентябрь 2018 г.) и после включения групп в измененные социально-психологические (развивающие) условия (январь 2020 г.). В результате были получены следующие качественно-количественные данные:

- в двух экспериментальных группах были выявлены изменения, свидетельствующие о положительной динамике. Так, коэффициент уровня социально-психологической зрелости группы (в \%) до изменения условий составил в первой группе 18,7, во второй 17,2 , что соотносится с таким показателем развития, как «низкий». После включения групп в развивающие условия социальной среды изучаемые показатели претерпели следующие изменения: в первой группе коэффициент уровня социально-психологической зрелости составил 63,8, во второй - 54,2. Эти данные говорят о том, что уровень социально-психологической зрелости повысился и теперь соответствуют уровню развития «выше среднего». Заметим, что положительные сдвиги отмечаются и на качественном уровне: в экспериментальных группах заметно снижена частота конфликтных ситуаций, преобладает положительный социально-психологический климат, отмечается повышение уровня активности в учебной деятельности, заметно увеличение организованности и сплоченности в коллективах (что проявляется в слаженной работе в ходе организации широкого спектра мероприятий);

- экспериментальное изучение степени единства психологического настроя на совместную деятельность также проводилось дважды (до изменения условий и после). Уровень развития групповой мотивации на совместную деятельность определяет степень согласованности действий членов группы, отражает уровень ее ор- 
ганизованности и может служить показателем общей степени развития группы: чем ближе коэффициент эффективности деятельности группы $L$ к 1 , тем выше степень единства психологического настроя группы на реализацию совместной активности (см. таблицу).

Изучение уровня развития эффективности совместной деятельности на приборе-модели «Арка»

\begin{tabular}{|c|c|c|c|c|c|}
\hline \multirow{3}{*}{$\begin{array}{c}\text { № } \\
\Pi / \Pi\end{array}$} & \multirow{3}{*}{ Экспериментальная проба } & \multicolumn{4}{|c|}{$\begin{array}{c}\text { Коэффициент эффективно- } \\
\text { сти деятельности группы } L \\
(0,05<L \leq 1.0)\end{array}$} \\
\hline & & \multicolumn{2}{|c|}{ группа 1} & \multicolumn{2}{|c|}{ группа 2} \\
\hline & & до & после & до & после \\
\hline 1 & В обычных условиях & 0,23 & 0,72 & 0,15 & 0,70 \\
\hline 2 & $\begin{array}{l}\text { С отчетом времени через } 5 \text { секунд } \\
\text { (моделирует стрессовую ситуацию) }\end{array}$ & 0,15 & 0,67 & 0,12 & 0,71 \\
\hline 3 & С фиксацией ведущей руки & 0,18 & 0,70 & 0,22 & 0,77 \\
\hline 4 & Сборка «Безымянной арки» & 0,34 & 0,74 & 0,31 & 0,81 \\
\hline 5 & $\begin{array}{l}\text { Сборка в особо мотивированных } \\
\text { условиях (на рекорд) }\end{array}$ & 0,47 & 0,81 & 0,41 & 0,74 \\
\hline
\end{tabular}

Как видно из представленных в таблице результатов, в обеих группах отмечается положительная динамика изменения степени единства психологического настроя группы на реализацию совместной активности, что свидетельствует о развитии в исследуемых группах качеств субъектности. Такие изменения на качественном уровне отражаются в том, что члены групп приобретают способность к поиску эффективных решений в условиях напряженной деятельности; умение выходить из возникающих конфликтных ситуаций (в условиях коммуникативного взаимодействия); научаются сохранять положительный психологический климат (даже в ситуациях неопределенности и напряженности); проявляют более высокий уровень согласованности мнений; овладевают лидерскими и организаторскими компетенциями. 


\section{Выводы}

Оценивая имеющиеся данные (так как экспериментальное исследование продолжается), можно сделать следующие выводы.

Во-первых, в исследуемых группах наблюдаются положительные динамические сдвиги в уровне социально-психологической зрелости. На наш взгляд, они произошли благодаря изначально высокой включенности учебных групп дефектологического факультета в выполняемые виды деятельности и более высокой мотивации обучающихся (в то врем как в рамках проводимого нами грантового исследования в учебных группах других уровней образования спектр полученных результатов расположился в континууме от положительных изменений до явно регрессивных).

Во-вторых, мы отмечаем некоторые изменения у респондентов на уровне мнений и поведения. Более 58,8 \% обучающихся исследуемых групп не только стремятся к открытому и активному взаимодействию с другими членами группы, но и ситуационно проявляют лидерские и организаторские способности на фоне значительных изменений в общем уровне успешности учебной деятельности, в то время как у остальных студентов такие изменения носят несистемный характер.

Таким образом, проблема определения социально-психологических условий становления субъектности учебных групп в современном обществе с каждым годом становится все более актуальной, так как на фоне процессов глобализации значительная часть молодежи остается «за бортом» жизни, проявляя свою неспособность к успешной адаптации в изменяющихся условиях, что приводит к дезадаптивному поведению, в то время как развитие субъектных качеств, наоборот, формирует устойчивую личность и группу, способную выполнять любой вид деятельности даже в ситуации явного напряжения и экстремальности.

1. Уманский Л. И. Личность. Организаторская деятельность. Коллектив // Избранные труды. Кострома : КГУ им. Н. А. Некрасова, 2001. 208 с.

2. Социально одаренные дети: путь к лидерству (экспериментальный подход) / А. С. Чернышев, Ю. Л. Лобков, С. В. Сарычев, В. И. Скурятин. 2-е изд., испр. и доп. Воронеж : Кварта, 2007. 210 с. 
3. Психология лидерства: лидерство в социальных организациях : учеб. пособие для бакалавриата и магистратуры / под общ. ред. А. С. Чернышева. М. : Юрайт, 2018. 159 с.

4. Котелевцев Н. А. Современные представления о формах организации совместной деятельности в контексте субъектно-деятельностного подхода (на примере изучения временных молодежных коллективов детских центров Курской области) [Электронный ресурс] // Ученые записки : электрон. науч. журн. Курск. гос. ун-та. 2018. № 4 (48). URL: http://http:// scientific-notes.ru/pdf/053-041.pdf (дата обращения: 05.03.2020).

5. Чернышев А. С., Лунев Ю. А., Сарычев С. В. Аппаратурные методики психологической диагностики группы в совместной деятельности. М. : ИП РАН, 2005. 190 с. 


\section{ЗАНЯТИЯ В ИНКЛЮЗИВНОЙ КОРРЕКЦИОННО- РАЗВИВАЮЩЕЙ ГРУППЕ КАК СПОСОБ РАЗВИТИЯ КОММУНИКАТИВНЫХ НАВЫКОВ И НАВЫКОВ САМОРЕГУЛЯЦИИ У ДЕТЕЙ С ОГРАНИЧЕННЫМИ ВОЗМОЖНОСТЯМИ ЗДОРОВЬЯ (МЕНТАЛЬНЫЕ И ПОВЕДЕНЧЕСКИЕ НАРУШЕНИЯ)}

Ю. В. Мягкова

Современные реалии таковы, что все больше детей с ограниченными возможностями здоровья (OB3) начинают обучаться совместно с нормотипичными сверстниками, что кроме безусловных плюсов социализации и коммуникации в среде обычных ровесников влечет за собой и ряд сложностей. Статус «ребёнок с ОВЗ» предполагает, что дети имеют различные отклонения психического или физического характера, которые обусловливают нарушения общего развития и не позволяют им вести полноценную жизнь, а также препятствуют получению образования без создания специальных условий. К категории детей с ментальными и поведенческими нарушениями относятся дети с задержкой психического развития, расстройствами аутистического спектра, синдромом гиперактивности и дефицита внимания, нарушениями эмоционально-волевой сферы и поведения и др.

Несмотря на различные диагнозы и нарушения развития, можно определить ряд особенностей, наиболее характерных для детей с OB3, имеющих ментальные и/или поведенческие нарушения:

- низкий уровень развития восприятия, вследствие чего требуется более длительное время для приема и переработки информации, что, в свою очередь, становится причиной недостаточных знаний об окружающем мире;

- недостаточная сформированность пространственных представлений, что влечет за собой как проблемы чтения, письма, счета в учебной деятельности, так и неловкость, а часто и растерянность в подвижных играх с детьми;

- неустойчивость, рассеянность внимания, трудности переключения; 
- ограничения в объеме памяти: память преимущественно кратковременная, механическая и наглядная;

- бо́льшая развитость наглядно-действенного мышления по сравнению с наглядно-образным и словесно-логическим, вне зависимости от возраста;

- игровая деятельность сформирована недостаточно; сюжеты игры, способы игрового общения и сами игровые роли обеднены;

- нарушения речевых функций: трудности с пониманием сложных логико-грамматических конструкций, бедность словаря и фразеологической речи, нарушения звукопроизношения;

- неравномерность, дисгармоничность развития психических процессов и отдельных сторон познавательной деятельности, при этом из-за трудностей с самоконтролем и саморегуляцией часто детям не удается использовать свои сильные стороны;

- снижение работоспособности в результате повышенной истощаемости;

- несформированность произвольного поведения и, как следствие, недостаточно развитые навыки самоконтроля и недоразвитие чувства ответственности.

Эти особенности детей мешают не только получению и усвоению академических знаний, страдает и поведение на уроке, и выполнение домашних заданий. Чаще всего учителя предъявляют жалобы на отсутствие работы на уроке, особенно на невыполнение письменных заданий, выраженную отвлекаемость и несоблюдение фронтальных инструкций, которые педагог дает всему классу; родители сетуют на трудности с выполнением домашних заданий, связанные как с нежеланием детей, так и с необходимостью родителям дома повторно объяснять учебный материал, обсуждаемый на уроке в школе. Кроме того, часто дети с ОВЗ имеют и выраженные сложности во взаимодействии со сверстниками. У них не складывается дружба, часто возникают конфликты, порой в отношении них проявляется буллинг или, наоборот, сверстники игнорируют такого ребенка. Причиной такого отношения не всегда является только отсутствие толерантности со стороны других детей, часто оно связано с поведением самого ребенка с ОВЗ. Дети имеют достаточно стойкие и часто схожие проблемы коммуникативно-аффективной сферы, частично 
обусловленные речевыми нарушениями, а частично - незрелостью эмоционально-волевой сферы.

Согласно многим исследованиям и нашим наблюдениям, для детей с нарушениями коммуникативно-аффективной сферы характерны такие особенности личности как импульсивность, неумение поставить задачу, неполное выполнение задачи, поставленной перед ними, и неумение ориентироваться в условиях - все эти особенности проявляются при решении не только когнитивных задач, но и социально-коммуникативных. В коммуникации и социальном поведении отмечается незрелость $[1,2]$, проявляющаяся в ситуативности поведения, недостаточный уровень владения речевыми и неречевыми средствами общения с окружающими, что затрудняет процесс межличностного взаимодействия и подталкивает детей к аффективным проявлениям в коммуникациях, нарушает их социальную адаптацию. Дети, принимая и передавая информацию, нуждаются в активизации со стороны взрослого, им свойственны невнимательность к сообщению другого, поэтому смысл сообщения ускользает от них, дети могут выразить мысль только при помощи наводящих вопросов; предстоящее сообщение не планируют, высказывания носят ситуативно-импровизационный характер, во взаимодействии часто не обращают внимания на партнера. Также для таких детей характерна недостаточно сформированная схема тела, низкая телесная чувствительность, что, согласно многим исследованиям [3-5], коррелирует с алекситимией, проявления которой характерны для детей, имеющих когнитивную дефицитарность и/ или выраженные проблемы поведения либо дефицита внимания.

С целью формирования и закрепления желательных форм взаимодействия с окружающим миром и коррекции нежелательных в муниципальном автономном учреждении дополнительного образования детском оздоровительно-образовательном центре психолого-педагогической помощи «Семья и школа» были организованы групповые занятия коррекционно-развивающей направленности. Задачами данных занятий являются развитие коммуникативных навыков и эмоционального интеллекта, развитие групповых форм взаимодействия и адекватных форм поведения в социуме, разви- 
тие психических процессов и умения решать когнитивные задачи в процессе фронтальной работы.

Исходя из особенностей детей, была определена следующая структура занятия: коммуникативный блок, блок нейрогимнастики и познавательный блок.

Коммуникативный блок. Основными структурными элементами коммуникативного блока, рассчитанного на годовой курс занятий, являются следующие разделы: развитие парного взаимодействия; группового взаимодействия; навыков самоконтроля; эмоционального интеллекта и эмоциональной компетентности; навыков вербальной коммуникации; навыков невербальной коммуникации; умения выделять личностные качества коммуникативного партнера; развитие «Я-концепции» и умения нести ответственность за собственное поведение.

Курс начинается с работы в парах, затем в тройках, позже всей группой. На начальном этапе выполнения заданий задача детей договориться любым способом и выполнить задание совместно (нарисовать, перенести, построить и т.д.), затем появляются ограничивающие условия (например, один из участников работает с закрытыми глазами и действует только по вербальной инструкции или, наоборот, словесное общение запрещено, можно договариваться только невербально, стараться чувствовать партнера). Таким образом, начинают и продолжают развиваться в течение всего курса навыки вербальной и невербальной коммуникации у детей.

Вербальное взаимодействие развивается за счет отработки таких умений, как умение просить, соглашаться и отказывать, предлагать компромиссы, договариваться о совместной деятельности, предлагать игру и высказывать недовольство. Здесь большое значение имеют такие игры и упражнения, как «попроси игрушку» / «уговори поменяться игрушкой», а также «уговори сделать» что-то (выйти из круга, пустить в круг и т. д.). Кроме того, достаточно сложными для детей, но имеющими большой коррекционно-развивающий эффект являются упражнения, в которых необходимо только словесно дать описание процесса деятельности так, чтобы партнер, который не имеет возможности наблюдать за ней, смог повторить процесс и результат (например, сделать такую же постройку из конструк- 
тора, нарисовать такой же узор и т.д.). Результаты упражнений обязательно обсуждаются в форме обратной связи от детей (почему ты согласился или отказался; что мог бы сделать твой партнер по игре, чтобы ты согласился; чего тебе не хватило; понимал ли ты своего партнера, каких объяснений тебе не хватило; мог ли ты достаточно понятно объяснить сам и др.) и от ведущих, помогающих сделать выводы о значении интонации, высказываний, вызывающих интерес, точности формулировок, умения задать уточняющие вопросы, привлекательности предложения, фантазии и т.д. в ходе коммуникации.

Невербальное взаимодействие развивается за счет совместной деятельности в парах и группе в целом, где необходимый результат можно получить именно за счет слаженных совместных действий. В процессе выполнения упражнений дети учатся доступно доносить информацию, в том числе отрабатываются такие модели коммуникативного поведения, как взгляд на собеседника, приближение, прикосновения и т.д. Кроме того, предлагается много игр, в которых необходимо оказать и получить поддержку от партнера по общению (вариации на тему упражнения «Слепой и поводырь»). С детьми обсуждаются результаты выполнения заданий и причины успеха и неуспешности. И несмотря на особенности когнитивного развития, имеющиеся у многих детей, они в результате обсуждения способны понять, что каждому из них хочется быть ведущим и никому не нравится, когда управляют им, и сделать вывод о том, что если ты хочешь, чтобы слушались тебя, то необходимо и самому уметь уступать. Кроме того, развитие невербальной коммуникации происходит в процессе выполнения пластических этюдов, в которых детям предлагается представить и изобразить мимикой и жестами, без использования слов, те или иные действия или ситуации (ты поднимаешь тяжелый пакет; ты встретил друга). На начальных этапах работы над этими упражнениями участники выполняют задание индивидуально, а позже работают в парах (ты объясняешь иностранному другу, чем ты любишь заниматься в свободное время) или всей группой (уговори без слов группу агрессивно настроенных островитян-людоедов, чтобы тебя не съели, и докажи им свою полезность). Таким образом, дети учатся оказывать и принимать 
поддержку и помощь, появляется осознание правил коммуникации, личного вклада каждого в этот процесс.

Работа над развитием эмоционального интеллекта включает в себя формирование эмоционального самосознания (понимание собственных чувств и переживаний и причин, их вызвавших), навыков самоуправления (не игнорирование или подавление своих чувств, а способность с ними справляться, находить социально приемлемый способ выражения эмоций), эмпатии и социальной ответственности. Формирование социальной ответственности предполагает не только развитие умения принимать решения, нести за них ответственность, но и выстраивать коммуникацию так, чтобы всем участникам коммуникативного процесса было комфортно в нем находиться, уметь убеждать, соглашаться и отказывать, делая это в приемлемой для партнера форме и самому не испытывая при этом дискомфорта.

Работа над развитием эмоционального интеллекта начинается с игр и упражнений на знакомство с эмоциями. Дети учатся не только определять (глядя на пиктограммы, фотографии и мимику других участников группы) и изображать базовые эмоциональные состояния, но и рефлексировать собственные чувства, определять, какие из них помогают, а какие мешают при решении тех или иных задач. В процессе работы активно используются психологические этюды, анализ ситуаций, как приближенных к жизни или заданных участниками, так и возникших в ходе обсуждения терапевтических метафор или в процессе занятия. Разыгрывание психологических этюдов позволяет детям лучше понять собственные чувства и чувства другого человека в различных коммуникативных ситуациях, появляется возможность проиграть различные варианты взаимодействия, почувствовать себя комфортно/некомфортно, безопасно/небезопасно в различных коммуникативных ролях. В ходе обсуждения у детей развиваются рефлексия и эмпатия, появляется возможность оценить эмоциональное состояние, соответствующее каждой из ситуаций, и его причину, а также в безопасной ситуации принять и понять ответ других участников коммуникации. Кроме того, работа в группе помогает получить оценку и обратную связь 
со стороны детского коллектива, которая подкрепляется объяснениями психолога.

Здесь же отрабатываются навыки эмоциональной саморегуляции. Решению этой задачи помогают как работа над выразительностью движений и психологические этюды, так и тренинговые игры, предполагающие прямое управление своими чувствами (не засмеяться в ответ на попытки рассмешить, не рассердиться в ответ на обидные слова в свой адрес и т. д.). Навыки эмоциональной саморегуляции напрямую связаны с общей саморегуляцией поведения и кроме коммуникативного блока активно отрабатываются в блоке нейрогимнастики.

Еще одним важным структурным элементом коммуникативного блока является развитие «Я-концепции». Как показывает опыт нашей работы, даже высокофункциональные дети с ОВЗ имеют выраженные трудности в оценке собственных качеств, часто путают собственные умения и качества личности. Кроме свойственной всем детям «черно-белости» оценок и недостаточности словарного запаса для описания личностных черт, выраженную трудность представляет собственно анализ своей личности, ответ на вопрос «какой я?». Для развития «Я-концепции» активно используются ассоциативные упражнения (на какую игрушку ты похож и чем? на какой предмет мебели/цвет, предмет быта ты похож?), в ходе которых ведущие помогают участникам выделить личностные качества, а на более поздних этапах - дать им оценку (помогают или мешают тебе эти качества и почему/чем?). После того как у детей вырисовывается определенная вербализированная и осознанная картина своей личности, работа выходит на новый уровень - в процессе игр, а затем и последующих обсуждений с детьми анализируются качества личности через призму успешности и комфортности коммуникации и качества жизни. В ходе обсуждений делаются выводы о том, чем помогают или мешают те или иные личностные черты в процессе жизни, в общении с родителями и друзьями, достижении целей, учебе и т.д.

Вытекающим из самоанализа продолжением работы является сравнение себя как личности с другими членами группы, но не в парадигме «лучше - хуже», а через призму «чем я похож на партнера 
по общению, а чем от него отличаюсь», чему я могу научить партнера по коммуникации, а чему он может научить меня. В рамках этой работы интересно проходит упражнение по мотивам игры К. Фопеля «Волшебный базар». В процессе его выполнения дети должны сначала определить список своих сильны и слабых качеств, а точнее, проанализировать, чего у них в избытке, а чего не хватает, а затем среди участников группы найти тех, у кого нужного качества в избытке и кто может поделиться своими избыточными качествами с теми, кто испытывает в них дефицит. При обсуждении и анализе упражнения дети не только делятся своими чувствами от выполнения задания в плоскости «понравилось/не понравилось и почему», но и делают выводы о схожести и различии членов группы, учатся видеть собственные ресурсы и делают вывод о силе взаимоподдержки, а также ценности и полезности разных личностных качеств.

Блок нейрогимнастики, направленный на оптимизацию общего тонуса организма и развитие саморегуляции и самоконтроля, имеет определенную структуру: 1. Дыхательные упражнения - улучшают ритмирование организма, развивают самоконтроль и произвольное внимание. 2. Упражнения для глаз - повышают энергетизацию организма и способствуют расширению полей зрительного восприятия. 3. Растяжки, телесные упражнения - нормализуют гипер- и гипотонус и, как следствие, позволяют гармонизировать психическую и физическую активность, произвольность и переключаемость внимания. 4. Расслабление - позволяет более эффективно переключаться с одного вида деятельности на другой.

После освоения основных правил, последовательности упражнений (что является для детей тренировкой навыков саморегуляции) в программу добавляются упражнения и игры, направленные на элиминацию импульсивности, развитие межполушарного взаимодействия и пространственного (кинестического) фактора.

Способность ребенка к произвольной регуляции собственной деятельности является одним из важнейших условий его психического и социального развития, требования к которому резко возрастают с началом систематического обучения в школе. Формирование этой способности у детей с ОВЗ - одна из приоритетных 
задач их психолого-педагогического сопровождения в младшем школьном возрасте.

Дыхательные упражнения улучшают ритмирование организма, развивают самоконтроль и произвольность. Единственным ритмом, которым произвольно может управлять человек, является ритм дыхания и движения. Нейропсихологическая коррекция строится на автоматизации и ритмировании организма через базовые многоуровневые приемы. Следствием нарушений ритма организма является нарушение психического развития. Соответственно, умение произвольно контролировать дыхание развивает самоконтроль над поведением.

Глазодвигательные упражнения позволяют расширить поле зрения, улучшить восприятие. Однонаправленные и разнонаправленные движения глаз и языка развивают межполушарное взаимодействие и повышают энергетизацию организма.

Коррекционные движения тела и пальцев обеспечивают развитие межполушарного взаимодействия, снятие синкинезий и мышечных зажимов. Кроме того, развитие «чувствования» своего тела способствует обогащению и дифференциации сенсорной информации от самого тела. При регулярном выполнении реципрокных движений образуется и миелинизируется большое количество нервных путей, связывающих полушария головного мозга, что обеспечивает развитие психических функций. Медленное выполнение перекрестных движений способствует активизации вестибулярного аппарата и лобных долей мозга, что способствует формированию самоконтроля, повышает устойчивость внимания и адекватность поведения. Кроме того, выразительные движения являются неотъемлемым компонентом эмоциональной, чувственной сферы человека. В результате дети лучше чувствуют и осознают свое тело, свои чувства и переживания, могут более адекватно их выразить.

Заключительной частью работы в этом блоке занятия являются подвижные или настольные игры, способствующие развитию координации движений, пространственной ориентации, внимания, памяти, саморегуляции. В работе активно используются различные гимнастические снаряды, такие как мячи, ракетки, балансиры, скакалки и т.д. Кроме того, использование настольных игр не только 
позволяет развивать ловкость и внимательность, но и способствует воспитанию у детей творческого, совместного с другими членами семьи или друзьями проведения досуга. Благодаря подвижным играм, упражнениям и настольным играм дети учатся лучше владеть своим телом, развивается координация в системе «глаз - рука», в игровой форме отрабатываются навыки эмоциональной саморегуляции, в том числе эмоциональное переживание своей неудачи или, наоборот, победы. В то же время игра служит весомым поощрением при выполнении не всегда интересных, а порой и несколько монотонных дыхательных и глазодвигательных упражнений, растяжек.

Повторяя движения ведущего, подстраиваясь и координируя свои действия в зависимости от движений партнера (другого ребенка - члена группы или ведущего), дети усваивают и основы успешной коммуникации. Активные движения способствуют укреплению физического состояния детей - улучшается кровообращение, в том числе и кровоснабжение мозга, хорошо вентилируются легкие, мозг насыщается кислородом. Кроме того, двигательная активность активизирует вестибулярный аппарат, который, в свою очередь, стимулирует кору полушарий, отвечающую за интеллектуальные функции. Двигательные упражнения и подвижные игры заставляют детей сосредоточиваться на их выполнении, сложность упражнений постепенно возрастает, соответственно, развивается концентрация и произвольность внимания, снижается утомляемость, повышается способность к произвольному контролю.

Таким образом, блок нейрогимнастики выступает, с одной стороны, как подготовительная база для последующей части программы - блока развития когнитивной сферы, а с другой - выполняет самостоятельную функцию развития навыков самоконтроля и саморегуляции.

Познавательный блок представлен играми и упражнениями, направленными на развитие внимания и активного комплексного восприятия. Также большое внимание уделяется развитию пространственных и квазипространственных отношений, умений устанавливать закономерности и логические связи, действиям по аналогии и установлению логических связей по ассоциации. 
В силу особенностей коммуникативно-аффективного развития многим детям сложно удерживать активное внимание длительное время, трудно быть постоянно включенным в процесс, следить за деятельностью ведущего и других детей и контролировать свою, дожидаться своей очереди. В связи с этим определенное время на начальном этапе работы уделяется упражнениям в форме «посмотри и найди, кому подходит» (вариации на тему лото с зашумлением различной степени сложности). Практически у всех детей возникают сложности с выполнением заданий, в которых необходимо выделить существенные признаки, сделать выводы на основании полученной информации. С целью развития этих умений используются игры и упражнения на сравнение и выделение схожих и различных признаков, определение лишнего, деление на группы по различным основаниям, при этом ребенок должен сам определить те признаки, по которым формируется группа. Также используются различные упражнения на умение действовать по определенному правилу с учетом ряда ограничений, вариации упражнений на поиск недостающего (недостающих) элементов, в том числе простые судоку, задания на определение лишнего, неподходящего элемента, которые решаются как в наглядном, так и в устном варианте, работа с различными схемами и лабиринтами, решение логических задач, продолжение ряда на основании самостоятельно определенной закономерности, преобразование рисунка (набора фигур) согласно заданному правилу и ограничениям. Большое внимание уделяется и развитию речи. Эта работа идет как параллельно с выполнением остальных заданий (ребенок должен объяснить, что и почему он сделал, обосновать свой выбор), так и в качестве отдельных заданий, когда необходимо составить рассказ по серии картинок, угадать предмет по описанию, самостоятельно описать что-то, подробно рассказать о каком-то предмете или явлении.

Этот блок работы происходит за столом, что позволяет отрабатывать такие учебные умения, как самоорганизация в учебном процессе и выполнение фронтальной инструкции, удержание активного внимания в учебной деятельности. Эта часть занятия кроме своего прямого назначения - развития психических процессов также направлена на развитие саморегуляции и самоконтроля (необходи- 
мость организовать свое рабочее место, очередность высказываний, самостоятельное выполнение различных по уровню сложности заданий, необходимость распределять внимание при групповом выполнении задания), а также коммуникативных навыков (помощь одногруппнику, выражение поддержки, способность не демонстрировать своего превосходства в ситуации заметного различия уровня сложности выполняемых заданий).

Коррекционным эффектом обладает также сама специфика работы в инклюзивной группе, которая включает в себя не только детей с ОВЗ, но и нормотипичных детей с поведенческими или коммуникативно-аффективными сложностями. Дети с ОВЗ, входящие в состав группы, имеют различные диагнозы (задержка психического развития, тяжелые нарушения речи, расстройства аутистического спектра) и отличаются по возрасту. Коррекционный эффект при взаимодействии детей с ОВ3 и нормотипичных детей достигается за счет наблюдения за поведением более «сильных» членов группы и рефлексии (анализа своих чувств и поступков), возможности получения поддержки и обратной связи не только от ведущих, но и от других детей. Если для ребенка с ОВЗ этот эффект достаточно очевиден в виде «тянуться» за другими, при этом не чувствуя себя «не таким», то для нормотипичных детей, имеющих сложности в коммуникативной или эмоционально-волевой сфере, такая группа позволяет почувствовать себя в роли опекающего и поддерживающего, с одной стороны, и стимулирует повышение самоконтроля и саморегуляции, с другой. Отсутствие сравнения детей между собой со стороны ведущих и категорический запрет попыток показать свою значимость и умелость за счет более слабых одногруппников, а если такое случается, обсуждение ситуации и эмоций участников, позволяет каждому ребенку преодолевать собственные сложности, гордиться собственными результатами, тем самым повышая уверенность в себе и гармонизируя самооценку.

Коррекционная работа с детьми обязательно предполагает и работу психолога с родителями, которая начинается с консультации-знакомства. На этой встрече не только происходит сбор анамнеза и оценка уровня развития ребенка с целью индивидуализации коррекционно-развивающей деятельности, но и обсуждают- 
ся стратегии воспитания в семье, уточняется запрос, намечаются совместные действия по коррекционной работе с ребенком. Далее работа с родителями продолжается в форме обратной связи после каждого занятия - психологи, ведущие занятие, рассказывают о том, что было успешным, а что вызывало затруднения, обсуждают эмоциональную реакцию ребенка на те или иные задания, характер его взаимодействия с детьми. Особенности этого формата работы заключаются в том, что родители активно включены в процесс, обратная связь дается как общая для всех, так и индивидуальная. В формате общей обратной связи обсуждаются такие вопросы, как «что делали на занятии?», «какие задачи решали?», «как справлялись дети в целом с коммуникативным, познавательным блоком?», «как выполняли нейрогимнастику?». Родителям предлагаются вопросы для обсуждения значимых тем. Здесь же даются задания (как общие, так и индивидуальные), которые необходимо выполнить дома для более успешной дальнейшей работы и закрепления коррекционного эффекта. В формате индивидуальной обратной связи, которая не принимает форму полноценной индивидуальной консультации, а является ее экспресс-вариантом, обсуждаются причины того или иного поступка ребенка и его эмоциональных реакций, намечаются пути воспитательных воздействий дома. Кроме того, поднимаются вопросы, связанные с характерными для ребенка особенностями поведения в школе и дома, рассматриваются варианты решения возникших проблем. Часто психологам - ведущим группы приходится выступать в качестве модератора между семьей ребенка с ОВ3 и школой. В этом случае специалист либо передает рекомендации по взаимодействию с ребенком через родителей, либо напрямую связывается с педагогом (классным руководителем) ребенка и помогает найти оптимальные пути взаимодействия с этим ребенком.

Кроме обратной связи после занятий для родителей предлагаются индивидуальные консультации. Важным и, несомненно, системообразующим фактором для ребенка является семья, ее общий психологический климат, а не только воспитательные воздействия со стороны родителей (хотя их разумность и однозначность, единство требований, безусловно, необходимы). Соответственно важно, чтобы родители сумели найти собственные ресурсы, понять особен- 
ности своего ребенка не только через призму того, что он не может в силу ОВ3, но и его личностные качества, мотивы и стремления. Необходимо, чтобы семейное общение было комфортным для всех членов семьи. Часто решению этой задачи способствуют личные индивидуальные консультации психолога для родителей. Для некоторых родителей достаточно 1-2 таких консультаций, а некоторым требуется целая серия, порой граничащая с личной психотерапией.

\section{Индивидуальные консультации}

Основные сложности, которые испытывают семьи, воспитывающие ребенка с ОВ3, можно определить следующим образом:

1. Сужение круга общения в силу различных причин (особенности здоровья ребенка, нехватка времени, стеснение, трудности ребенка в коммуникации и/или нахождении в компании других людей и т.д.), что может привести к нарушениям в социализации ребенка.

2. Гиперопека и неконструктивная жалость со стороны родителей, которые дополнительно инвалидизируют ребенка, формируют инфантильный тип личности.

3. Возникающие у родителей негативные чувства (чувство вины, ущербности, стыда и т. д.) мешают выстраиванию нормальных взаимоотношений как внутри семьи, так и вне ее и, как следствие, социализации ребенка.

4. Недостаточная педагогическая компетентность родителей, нехватка специализированных знаний об особенностях воспитания и обучения особого ребенка мешают созданию необходимых условия для его развития дома.

Поэтому психологическая работа с семьями (родителями) детей с ОВ - одно из важных направлений в комплексной коррекционной работе.

Целью индивидуальных консультаций является повышение компетентности родителей в психолого-педагогических вопросах и помощь в социальной адаптации детей.

Задачи:

1. Консультирование родителей по вопросам детско-родительских отношений, воспитания и обучения детей. 
2. Обучение родителей методам и формам дополнительной работы с детьми в домашних условиях.

3. Работа с чувствами с использованием элементов танцевальнодвигательной психотерапии, квантовой психологии и т.д.

Результатом такой работы является повышение компетентности родителей в вопросах воспитания и успешного взаимодействия со всеми членами семьи, формирование активной родительской позиции и адекватной самооценки.

У всех детей, посещающих коррекционно-развивающие занятия, отмечается значительная положительная динамика как в когнитивном, так и в коммуникативно-аффективном развитии. Общим итогом коррекционно-развивающей работы, который достигается в результате групповых занятий со специалистом и индивидуальной работы с ребенком в семье, является коррекция неблагоприятных личностных особенностей (поведенческих и эмоциональных проблем), развитие когнитивных способностей (устранение учебной неуспешности), развитие межличностных взаимодействий и коммуникативных навыков. За счет инклюзивного состава группы участники получают новый опыт взаимодействия (толерантность и принятие для одних и умение договариваться и принимать приглашение или отказ в совместной деятельности для других). Также такая групповая работа позволяет научиться чувствовать свои и чужие личностные границы, управлять своим поведением в условиях группового взаимодействия, слышать фронтальную инструкцию. Именно инклюзивный состав и описанная выше структура занятий позволяют каждому ребенку в условиях работы в группе решать свои личные задачи и получать ту коррекционную помощь, которая ему необходима. Кроме того, отмечается улучшение микроклимата в семьях, повышение социальной адаптированности детей.

Согласно итоговой диагностике 26 детей в возрасте 7-10 лет, посещавших занятия в течение двух лет, и анкетированию родителей, в результате коррекционно-развивающей работы у $100 \%$ детей повысилась мотивация к обучению, возросла концентрация внимания как в учебной, так и в коммуникативной деятельности (у 80 \%), снизилась импульсивность (у 60 \%), 59 \% детей более успешно стали 
выполнять задания фронтально (в том числе за счет того, что они стали лучше слушать и понимать фронтальную инструкцию), у них увеличился темп деятельности. У 76 \% отмечается повышение адекватности поведения, 62 \% детей лучше стали понимать последствия своего поведения. Родители обратили внимание на то, что с детьми становится проще договариваться и появляется возможность передавать контроль за определёнными видами деятельности самим детям. Многие родители отмечают, что со стороны учителей поведение детей в школе вызывает меньше жалоб, они становятся более успешны в учебной деятельности. Вследствие появления ситуации успеха повышается мотивация достижения, снижаются негативные реакции на замечания и неудачи. Кроме того, родители замечают изменения в коммуникации детей со сверстниками: они проще знакомятся, ориентируются на личностные качества партнера по общению, меньше конфликтуют и самостоятельно, без помощи взрослых разрешают возникшие конфликты. Важным результатом работы, на который обращают внимание практически все родители как детей с ОВЗ, так и нормотипичных детей, посещающих группу, является расширение их словарного запаса. Дети легче и четче говорят о своих потребностях и чувствах, понятнее выражают свои мысли и, как следствие, становятся более успешны в коммуникации как дома, так и в социуме. Итоговая нейропсихологическая диагностика подтвердила повышение в два раза показателей уровня развития регуляции и контроля деятельности, кинетического, зрительного, пространственного механизмов у всех детей.

Родители отметили расширение знаний, умений в вопросах воспитания и обучения детей и освоение навыков саморегуляции, что способствует снижению их эмоционального напряжения, улучшению микроклимата в семье, достижению согласованности в выборе стилей семейного воспитания и в конечном счете гармонизации взаимоотношений между всеми членами семьи.

1. Семаго М. М., Семаго Н.Я. Типология отклоняющегося развития: Модель анализа и ее использование в практической деятельности. М. : Генезис, 2011. 400 с. 
2. Хаустов А. В. Практические рекомендации по формированию коммуникативных навыков у детей с аутизмом. М. : Изд-во Рос. ун-та дружбы народов, 2007.

3. Ересько Д. Б., Исурина Г. С., Койдановская Е. В. и др. Алекситимия и методы ее определения при пограничных психосоматических расстройствах : метод. пособие. СПб., 2009.

4. Калинин В.В. Алекситимия, мозговая латерализация и эффективность терапии ксанаксом у больных паническим расстройством // Социальная клиническая психиатрия. 2004. № 4. С. 96-103.

5. Карвасарский Б. Д. Клиническая психология / под ред. Б. Д. Карвасарского. СПб. : Питер, 2006. 


\section{МОДЕЛЬ ПСИХОЛОГО-ПЕДАГОГИЧЕСКОГО СОПРОВОЖДЕНИЯ СТУДЕНТОВ-ИНВАЛИДОВ В ПЕРИОД ИХ АДАПТАЦИИ К ОБУЧЕНИЮ В ВУЗЕ}

H. A. Cтепанова

Современные требования к системе высшего образования связаны с необходимостью создания психологически благоприятных условий для гармоничного развития личности обучающихся с различными образовательными потребностями и возможностями. Это актуализирует научный интерес к изучению проблемы адаптации студентов с ограниченными возможностями здоровья (OB3) и инвалидностью. Для исследования адаптации данной категории студентов к условиям обучения в вузе в настоящее временя созданы необходимые теоретические и практические предпосылки.

Качество процесса адаптации связано с целым рядом субъективных особенностей студентов с особыми образовательными потребностями, а также с объективными условиями организации психолого-педагогического сопровождения данного процесса.

Анализ существующего опыта образования студентов с ОВ3 позволяет выделить основные проблемы, затрудняющие их развитие и успешную социализацию (Э. В. Патраков, Л.В. Токарская, О.В. Гущин). К ним относится адаптация студентов-инвалидов к обучению в вузе.

С точки зрения Г.П. Максимовой, адаптация является предпосылкой активной деятельности студентов-инвалидов и требует создание условий, необходимых для ее эффективности. Так как уровень довузовской подготовки студентов различен, особое значение приобретают адаптационные способности, позволяющие им интегрироваться в новую среду [1].

Социальная адаптация, по мнению Л. В. Сафоновой, - это интегративный показатель состояния человека, отражающий его возможности для выполнения определенных биопсихосоциальных функций, таких как: 
- выстраивание системы общения и отношений с окружающими, а также проявление способности к труду, обучению, организации отдыха и досуга;

- адекватне восприятие собственного организма и окружающей действительности;

- адаптация поведения в соответствии с ожиданиями других [2].

Т.П. Браун отмечает, что если рассматривать процесс адаптации на основе взаимодействия студента (адаптанта) и образовательной среды, то успешность адаптационного процесса должна оцениваться двусторонне. Внешний критерий определяет приспособленность образовательной среды для обучения инвалидов и лиц с ОВЗ в соответствии с требованиями к ее организации. Внутренний критерий определяет удовлетворенность студента своей позицией, самочувствием, сохранением внутренних энергетических ресурсов, отсутствием напряжения и тревоги [3].

В.И. Никифоровым и А.И. Сурыгиным выделены три формы адаптации студентов с инвалидностью к вузу в процессе обучения:

- физиологическая, определяющая приспособление студента с инвалидностью к изменившимся условиям окружающей среды и жизнедеятельности;

- академическая - приспособление студентов с инвалидностью к условиям новой педагогической системы;

- социально-психологическая, состоящая в приспособлении психики студентов с инвалидностью к новым условиям жизнедеятельности [4].

Процесс адаптации, как отмечает Н.Н. Дарьенкова, должен охватывать все виды деятельности студентов, а это, в свою очередь, позволяет рассматривать адаптацию к воспитательному, учебному и учебно-профессиональному процессу [5].

М.Д. Коновалова выделила основную задачу социально-психологической адаптации, которая заключается в установлении межличностных контактов с одногруппниками, так как по-новому происходит статусное и ролевое распределение, и студенту приходится завоевывать и отстаивать свое положение. Неудовлетворенность существующим статусом внутри группы может привести к повышению тревожности, неуверенности в себе. Установление новых 
норм и ценностей в студенческой среде неизбежно влечет за собой изменение самооценки, личностных установок, которое может протекать на фоне стрессовых реакций организма [6].

Реакции на процесс адаптации могут усугубиться на фоне физических дефектов и хронических соматических заболеваний, которыми страдают студенты с инвалидностью.

Как отмечают И. Ю. Кулагина и Л.В. Сенкевич, при тяжелом хроническом заболевании, даже если оно не приводит к инвалидности, изменяются качество и стиль жизни человека. Больной человек вынужден пройти через этапы реабилитации (восстановительного лечения) и реадаптации, в том числе социальной, направленной на восстановление приспособленности к условиям профессиональной деятельности и быта. Эффективность реабилитации, реадаптации, а также адаптации зависит от общей позиции личности, использования имеющихся личностных ресурсов. Система личностных ресурсов, необходимых для преодоления критической ситуации тяжелого соматического заболевания, определяет реабилитационный потенциал личности [7].

Успешность процесса социально-психологической адаптации студентов-инвалидов определяется с помощью критериев, позволяющих оценить четыре основных ее компонента: когнитивный компонент, эмоционально-волевой, действенно-практической и мотивационный.

Когнитивный критерий определяет понимание студентами цели своего обучения в вузе, приобретение системы знаний о том, как можно достичь эту цель [8].

В данный компонент входят представления человека об отношениях с окружающими, своих способностях, социальных ролях, внешности, качествах личности, интересах, т. е. представления о себе реальном и о том, каким бы человек хотел быть, а также установки, связанные с представлениями о том, каким его видят другие.

В когнитивной теории личности адаптация выступает как осознаваемое позитивное когнитивно-эмоциональное соответствие внутренних возможностей и потребностей индивидуума, а также их соотношение с внешними социальными возможностями и требованиями. 
Эмоционально-волевой критерий позволяет оценить общее эмоциональное состояние человека и его отношение к изменившейся ситуации.

Эмоционально-волевой критерий характеризует личностное отношение студентов к характеру и результату обучения, их умения строить межличностные отношения, выявлять и преодолевать трудности, наличие у них положительных ценностных ориентаций и нравственных качеств. Данный критерий позволяет определить состояние студента, который попал из одной социальной среды в другую. От его взаимоотношений с однокурсниками, особенно внутри студенческой группы, с одной стороны, и от его отношения к учебному процессу в целом - с другой, зависит успешность обучения в вузе [8].

Эмоционально-волевой компонент адаптации отражает отношение человека к себе в целом, а также к отдельным сторонам собственной личности и деятельности, и проявляется в чувстве собственного достоинства, самоуважении, уровне притязаний и самооценке.

Действенно-практический критерий устанавливает степень самостоятельности деятельности студента в процессе социальнопсихологической адаптации. Он позволяет выявить наличие у обучающегося самостоятельности мышления, стремления достичь цели, опираясь на свои индивидуальные возможности и способности, определить степень их проявления [8].

Действенно-практический критерий определяет возможность саморегуляции человека, его способность принимать самостоятельные решения, контролировать свое поведение, управлять им, а также отвечать за свои поступки.

Действенно-практический компонент позволяет рассматривать адаптацию к новым условиям обучения как динамичный процесс, в ходе которого интеграция личности студента происходит не только в новую образовательно-воспитательную систему, но и в новый коллектив, в новую систему контроля и требований, а для многих и в совершенно новые условия жизнедеятельности.

Мотивационныцй критерий адаптации указывает, насколько адекватно студент воспринимает и оценивает себя и свои социаль- 
ные связи, соизмеряет свои потребности и возможности, осознает мотивы своего поведения в новой среде [9].

Реабилитационный потенциал - это та часть личностных ресурсов, которая непосредственно способствует реабилитации, реадаптации и адаптации в ситуации хронической болезни, она включает мотивационный, эмоциональный, самооценочный и коммуникативный компоненты, а также внутреннюю картину болезни [10]. Таким образом, мы можем предположить, что реабилитационный потенциал является общим основанием для оценки процесса социально-психологической адаптации студентов-инвалидов с применением вышеописанных критериев.

Н. А. Пешкова, Н. А. Степанова и С. К. Хаидов получили следующие данные по когнитивному компоненту социально-психологической адаптации студентов с инвалидностью: низкий уровень энергичности, средний уровень целеустремленности и инициативности, настойчивости и требовательности. Исследование эмоционального компонента показывает, что для студентов-инвалидов характерны снижение уровня самоинтереса, самоуважения, саморуководства и аутосимпатии, сформированность негативного самоотношения, при этом завышенная самооценка носит компенсаторный характер. При рассмотрении поведенческого компонента социально-психологической адаптации студентов-инвалидов обнаружены незначительная вера в свои силы и успех, преимущественно неудовлетворительные ожидания от жизни и других людей, средний уровень жизненной активности, преобладание мрачного и подавленного настроения. При изучении мотивационного компонента у студентов с инвалидностью отмечены низкие показатели по параметрам «справедливость мира» и «степень удачи», т.е. данные студенты убеждены, что мир настроен против них, что они сами мало что могут сделать со своей жизнью [10].

Исходя из этого, феномен адаптации можно рассматривать как состояние и как процесс. Адаптация как состояние представляет собой степень соответствия условий среды потребностям индивида. Адаптация как процесс (адаптирование) есть способ изменения среды и организма путем применения действий, соответствующих ситуации, для достижения равновесия между средой и организмом. 
Социальную адаптацию личности также определяют как одну из детерминант психологического благополучия. Неспособность приспосабливаться к новым условиям, к новому социальному статусу часто приводит к переживанию стресса, внутриличностному конфликту, фрустрации [11].

Для студентов с инвалидностью характерно сравнение своей успешности и уровня знаний с уровнем компетенции нормально развивающихся сверстников. Это вызывает реакцию неуверенности в себе, страхи, тревожность и в целом подрывает состояние благополучия студента. В то же время преодоление тех ситуаций, которые не являются трудными для нормально развивающихся студентов, у студентов с инвалидностью вызывает высокий эмоциональный подъем, способствующий повышению уровня их психологического благополучия. Индивид социально благополучен только тогда, когда произошло усвоение социального опыта и социальных ролей, сформированы навыки общения, а также существует интерес к окружающим и желание взаимодействовать с социумом. Следовательно, можно говорить о том, что психологическое благополучие студентов с инвалидностью - динамичное образование, причем эта динамика хаотична - периоды повышения психологического благополучия могут сменяться периодами его снижения, во время которых возрастает вероятность девиантного поведения и аффективных расстройств. Для сохранения чувства благополучия студенту-инвалиду необходимо сформировать аутопсихологическую компетентность. Помочь ему в этом - одна из задач психолого-педагогического сопровождения студентов-инвалидов в процессе их адаптации к обучению в вузе.

Как указывалось выше, выделяются три формы адаптации студентов с инвалидностью к процессу обучения в вузе: физиологическая, академическая и социально-психологическая. Разработанная нами модель психолого-педагогического сопровождения студентов-инвалидов в период их адаптации к обучению в вузе нацелена на помощь студентам с инвалидностью в социально-психологической адаптации.

В рамках данной модели возможны различные организационные решения, которые зависят от количества студентов с ин- 
валидностью. Психолого-педагогическое сопровождение может осуществляться специальным структурным подразделением вуза (если число обучающихся с инвалидностью достаточно велико). Деятельность по психолого-педагогическому сопровождению может быть организована в форме психолого-педагогического консилиума как постоянно действующего, скоординированного, объединенного общими целями коллектива специалистов, реализующих ту или иную стратегию сопровождения как обучающегося, так и образовательной среды.

Предполагаемая модель рассматривается как ресурсная составляющая процесса образования, система возможностей, необходимых для осуществления эффективной адаптации студентов с инвалидностью.

\section{Методы}

С целью разработки модели психолого-педагогического сопровождения студентов-инвалидов в ходе их адаптации к обучению в вузе нами было проведено исследование, которое проходило на базе факультета психологии Тульского государственного педагогического университета им. Л.Н. Толстого. В нем приняли участие 24 студента с инвалидностью в возрасте от 19 лет до 21 года (1-4-й курсы). Основные нозологии составляют нарушения опорно-двигательного аппарата и соматические заболевания.

Перед разработкой диагностической программы было осуществлено пилотажное исследование. Нами проведена анкета «Социальное самочувствие» [12] среди студентов с инвалидностью, целями которой являлось изучение их социального самочувствия, а также выбор дальнейшего направления диагностической работы.

Так как учебный процесс в вузе неотделим от взаимодействия студентов-инвалидов с преподавателями и одногруппниками, нами также был проведен сравнительный анализ данных об отношении преподавателей и студентов факультета психологии к лицам с ограниченными возможностями здоровья, полученных с помощью анкеты «Отношение к лицам с ограниченными возможностями здоровья» [13]. В анкетировании участвовали 23 преподавателя и 50 студентов. 
Исходя из особенностей психического развития студентов с инвалидностью, целей и задач психолого-педагогического сопровождения их адаптации к обучению в вузе, а также результатов анкетирования, была разработана и апробирована диагностическая программа, направленная на изучение адаптации к обучению в вузе студентов данной категории. Разработанная нами диагностическая программа направлена на исследование показателей студентов по основным компонентам адаптации в вузе и их оценки в соответствии с выделенными критериями:

1. Исследование когнитивного компонента адаптации. Показатель: самооценка представлений студентов с инвалидностью о сформированности значимых личностных характеристик.

2. Исследование эмоционально-волевого компонента адаптации. Показатель: проявление тревожности студентов.

3. Исследование поведенческого компонента адаптации. Показатели: адаптированность к учебной группе; адаптированность к учебной деятельности.

4. Исследование мотивационного компонента адаптации. Показатель: ведущие мотивы учебно-профессиональной деятельности студентов.

5. Реабилитационный потенциал. Показатель: выявление общего уровня реабилитационного потенциала личности.

Диагностическая программа включала следующие методики: «Оценочный лист личностных характеристик» (автор Н. В. Кузьмина); «Тревожность студентов», модификация опросника Дж. Тейлор; «Исследование адаптированности студентов в вузе» (авторы Т. Д. Дубовицкая, А.В. Крылова); «Изучение мотивации обучения в вузе» (автор Т.И. Ильина); «Реабилитационный потенциал личности» (авторы И.Ю. Кулагина, Л. В. Сенкевич).

\section{Обсуждение результатов}

По результатам анкетирования студентов-инвалидов установлено следующее: большинство респондентов считают, что к ним окружающие испытывают равнодушие. Свою жизнь они оценивают удовлетворительно. Многие обучающихся испытывают трудности в общении с посторонними людьми. При этом из беседы была полу- 
чена информация, что они часто вступают в конфликт с родителями и друзьями. Образование в жизни студентов-инвалидов определяет возможность получения профессии и знаний. Студенты отметили, что испытывают беспокойство по поводу своей будущей работы.

Согласно результатам, полученным по анкете «Отношение к лицам с ограниченными возможностями здоровья», имеются различия в отношении преподавателей и студентов к инвалидам в зависимости от их социальных ролей. Так, в большинстве случаев педагоги равнодушно относятся к инвалидам, если это сосед по дому, сосед по квартире, коллега по работе, подчиненный, одноклассник ребенка. Отрицательное отношение наблюдается, если инвалид - начальник, врач, учитель ребенка. Студенты же в большинстве случаев положительно относятся к инвалидам. Однако были выявлены редкие случаи, когда обучающиеся отрицательно относились к тому, что инвалид мог бы быть соседом по квартире, родственником, коллегой по работе, начальником, представителем органов власти, врачом, учителем ребенка.

По вопросу о необходимости льгот и государственной программы по трудоустройству инвалидов большинство преподавателей и студентов выразили обоюдное согласие.

Как видно из результатов анкетирования, не все педагоги и обучающиеся готовы к принятию студентов-инвалидов. Это свидетельствует о необходимости разработки системы мероприятий по формированию у педагогов и обучающихся позитивного отношения к данной категории студентов, содержащей психологическое просвещение, психопрофилактику, информационное просвещение преподавателей и студентов, а также другие виды деятельности психолога, создающие единую стратегию сопровождения студентов с ограниченными возможностями здоровья на этапе их обучения в вузе. Указанная система обеспечит выполнение необходимых условий для успешной адаптации студентов с инвалидностью к обучению в высшем учебном заведении.

Проведение диагностической программы позволило выявить особенности адаптации студентов-инвалидов.

Показатель «Проявление тревожности» завышен у 50 \% респондентов. Низкое значение данного показателя выявлено лишь у 12,5 \% 
обучающихся. Следовательно, эмоциональное состояние студентовинвалидов, связанное с обучением в вузе, нуждается в снижении уровня тревожности.

Показатель «Адаптированность» находится на низком уровне у 37,5 \% студентов с инвалидностью. Данные студенты с трудом осваивают учебные предметы и выполняют учебные задания. Им трудно выступать на занятиях, выражать свои мысли. При необходимости они не могут задать вопрос преподавателю. Также они испытывают трудности в общении с однокурсниками, проявляют сдержанность в отношениях. Для остальных студентов характерен средний уровень адаптированности, студентов с низким уровнем не выявлено. Высокий уровень адаптированности к учебной группе диагностирован у 25 \% респондентов. Высокий уровень адаптированности к учебной деятельности отмечен у 50 \% студентов-инвалидов, Таким образом, для данной выборки студентов необходима профилактическая работа по повышению уровней адаптированности к учебной группе и учебной деятельности.

По показателю «Ведущий мотив учебно-профессиональной деятельности» у 75 \% студентов с инвалидностью отмечается средний уровень мотивации к приобретению знаний, лишь у 25 \% студентов выявлен высокий уровень. Низкий уровень мотивации к овладению профессией отмечен у 25 \% испытуемых, у 50 \% выявлен средний уровень. Высокий уровень по данной категории диагностирован также у 25 \% респондентов. По мотиву учебно-профессиональной деятельности «Получение диплома» у 75 \% студентов с инвалидностью выявлен средний уровень, у 25 \% отмечен низкий уровень. Полученные результаты позволяют сделать вывод, что в данной группе необходимо провести профилактическую работу по повышению уровней мотивации по ведущим мотивам учебно-профессиональной деятельности «Приобретение знаний», «Овладение профессией».

По показателю «Общий уровень реабилитационного потенциала» получены следующие результаты: высокий уровень, способствующий реабилитации, реадаптации и адаптации в ситуации хронической болезни, выявлен у 50 \% студентов с инвалидностью. Средний уровень по данному показателю также отмечен у 50 \% студентов. По компоненту «Внутренняя картина болезни» средний уровень 
наблюдается у 62,5 \% студентов. Средний уровень мотивационного компонента выявлен у 75 \% респондентов, что говорит о недостаточной активности в решении учебных задач. Средний уровень эмоционального компонента отмечен у 62,5 \% студентов с инвалидностью. Низкий уровень по данному компоненту, свидетельствующий о негативном эмоциональном фоне студентов, обнаружен у 12,5 \% респондентов. Средний уровень по самооценочному компоненту выявлен у 37,5 \% студентов с инвалидностью. Коммуникативный компонент находится на среднем уровне у 62,5 \% испытуемых, что указывает на ограниченность коммуникации у студентов с инвалидностью. На основании вышеизложенного можно сделать вывод, что в данной группе необходимо провести профилактическую работу по повышению уровня реабилитационного потенциала.

На основе полученных на констатирующем этапе результатов нами составлена профилактическая программа, направленная на адаптацию студентов с инвалидностью к обучению в вузе. В целях эффективной адаптации к обучению в вузе студентов с инвалидностью проведение профилактических мероприятий целесообразно выстраивать в качестве модели психолого-педагогического сопровождения, в которую помимо педагога-психолога включены тьюторы, кураторы учебных групп, родители (лица, их заменяющие) и, конечно, сами студенты с инвалидностью.

Объектом психолого-педагогического сопровождения выступает процесс адаптации студентов-инвалидов к обучению в вузе.

Предметом психолого-педагогического сопровождения является разработка структуры и содержания психолого-педагогического сопровождения студентов-инвалидов в ходе их адаптации к обучению в вузе.

Предлагаемая нами модель психолого-педагогического сопровождения студентов с инвалидностью в процессе их адаптации к обучению в вузе включает в себя несколько этапов:

1. Диагностический этап.

Цель: исследование компонентов процесса адаптации у студентов с инвалидностью к обучению в вузе. 
Задачи:

- составление диагностической программы, направленной на изучение компонентов процесса адаптации студентов с инвалидностью к обучению в вузе;

- создание необходимых условий для проведения исследования;

- проведение диагностики и анализ ее результатов.

2. Организационный этап.

Цель: создание профилактической программы по адаптации студентов-инвалидов к обучению в вузе.

Задачи:

- определение направлений, цели и задач профилактической программы по адаптации студентов-инвалидов к обучению в вузе;

- проектирование и построение профилактической программы, основанной на полученных результатах диагностического этапа;

- подготовка просветительской лекции для преподавателей вуза об особенностях обучения студентов-инвалидов;

- разработка рекомендаций для родителей студентов с инвалидностью по снижению тревожности, связанной с обучением в вузе, повышению мотивации к обучению, повышению уровня общего реабилитационного потенциала.

3. Формирующий этап.

Цель: реализация профилактической программы по адаптации студентов-инвалидов к обучению в вузе.

Задачи:

- создание необходимых условий для реализации профилактической программы;

- проведение профилактической работы.

4. Контрольный этап.

Цель: диагностика сформированности компонентов процесса адаптации у студентов с инвалидностью к обучению в вузе.

Задачи:

- создание необходимых условий для проведения исследования;

- проведение повторной диагностики и анализ ее результатов.

5. Аналитический этап.

Цель: анализ эффективности проведенной профилактической работы по адаптации студентов-инвалидов к обучению в вузе. 
Задачи:

- анализ и сравнение полученных данных на констатирующем и контрольном этапах;

- оценка эффективности работы, проведенной специалистами психолого-педагогического сопровождения.

При составлении профилактической программы мы соблюдали следующие принципы:

1. Принцип системности коррекционных, профилактических и развивающих задач;

2. Принцип единства диагностики и коррекции;

3. Деятельностный принцип коррекции;

4. Принцип учета возрастно-психологических и индивидуальных особенностей;

5. Принцип комплексности методов психологического воздействия;

6. Принцип активного привлечения ближайшего социального окружения к участию в коррекционной программе;

7. Принцип возрастания сложности;

8. Принцип программированного обучения;

9. Принцип учета объема и степени разнообразия материала;

10. Принцип учета эмоциональной сложности материала [14].

В программу включены элементы группового психологического тренинга, что позволяет работать сразу с группой студентов, развивать необходимые умения, а учащимся получать обратную связь. На занятиях применялись следующие методы работы: дискуссия в группе, парная форма работы, наблюдение, метод игры (психотехника, имитационная и ролевая игры), аутотренинг, техники саморегуляции и рефлексия.

Задачи профилактической программы:

- снижение уровня тревожности;

- повышения уровня адаптированности к учебной группе и учебной деятельности;

- повышение уровня мотивации к приобретению учебных знаний;

- повышение уровня мотивации к овладению профессией;

- повышение уровня общего реабилитационного потенциала. 
Профилактическая программа рассчитана на 16 занятий, продолжительность одного занятия 60 минут. Занятия проводятся 1-2 раза в неделю. Каждое занятие имеет свои цели.

Профилактическую программу можно разделить на 4 блока:

Блок 1. Профилактическая работа, направленная на развитие свойств (показателей) когнитивного компонента адаптации и реабилитационного потенциала.

Блок 2. Профилактическая работа, направленная на развитие свойств (показателей) эмоционально-волевого компонента адаптации.

Блок 3. Профилактическая работа, направленная на развитие свойств (показателей) поведенческого компонента адаптации.

Блок 4. Профилактическая работа, направленная на развитие свойств (показателей) мотивационного компонента адаптации.

Форма проведения занятий: групповая.

Групповые правила проведения занятий: добровольное участие, искренность, уважение других учеников, внимательное слушание, активность на занятиях, открытая обратная связь, доверительность в общении, одобрение и взаимоподдержка друг друга.

Каждое занятие имеет следующую структуру:

1. Организационный момент. Включает в себя набор упражнений, способствующих активации участников группы, создает благоприятную атмосферу, повышает сплоченность.

2. Основная часть занятия. Эта часть включает в себя дискуссии, упражнения, игры, направленные на освоение цели программы

3. Заключительная часть (рефлексия занятия). В конце каждого занятия участники делятся своими впечатлениями.

Предложенная программа может быть рекомендована практическим психологам, педагогам-психологам, социальным педагогам и работникам, владеющим технологией проведения тренингов и коррекционных программ.

Сравнительный анализ показателей адаптации студентов-инвалидов к обучению в вузе до и после проведения занятий показал следующие изменения.

Уровень показателя «Проявления тревожности» снизился у $28,6 \%$ студентов с инвалидностью. Уровень адаптированности 
к учебной группе повысился у 42,8 \% испытуемых. Уровень адаптированности к учебной деятельности повысился у 14,3 \% обучающихся с инвалидностью. Уровень мотивации к приобретению знаний повысился у 28,6 \% студентов с инвалидностью. Уровень мотивации к овладению профессией повысился у 71,4 \% испытуемых. Общий уровень реабилитационного потенциала повысился у 14,3 \% студентов-инвалидов.

Для статистического анализа полученных данных был выбран $t$-критерий Стьюдента (см. таблицу).

Оценка эффективности с использованием $t$-критерия Стьюдента

\begin{tabular}{c|l|l|l|l|l}
\hline \multirow{2}{*}{$\begin{array}{c}\text { № } \\
\text { п/п }\end{array}$} & $\begin{array}{l}\text { Сравниваемый пока- } \\
\text { затель }\end{array}$ & $t_{\text {эмп }}$ & \multicolumn{2}{|c|}{$t_{\text {крит }}$} & \multirow{2}{*}{$\begin{array}{l}\text { Нахождение в зоне } \\
\text { значимости }\end{array}$} \\
\hline \multirow{2}{*}{1} & $\begin{array}{l}\text { Проявления тревож- } \\
\text { ности }\end{array}$ & 6,7 & 2,45 & 3,71 & $\begin{array}{l}\text { Находится в зоне } \\
\text { значимости }\end{array}$ \\
\hline \multirow{2}{*}{3} & $\begin{array}{l}\text { Адаптированность } \\
\text { к учебной группе }\end{array}$ & 3,8 & 2,45 & 3,71 & $\begin{array}{l}\text { Находится в зоне } \\
\text { значимости }\end{array}$ \\
\cline { 2 - 5 } & $\begin{array}{l}\text { Адаптированность } \\
\text { к учебной деятель- } \\
\text { ности }\end{array}$ & 4 & 2,45 & 3,71 & $\begin{array}{l}\text { Находится в зоне } \\
\text { значимости }\end{array}$ \\
\hline \multirow{2}{*}{4} & $\begin{array}{l}\text { Мотивация к прио- } \\
\text { бретению знаний }\end{array}$ & 4,5 & 2,45 & 3,71 & $\begin{array}{l}\text { Находится в зоне } \\
\text { значимости }\end{array}$ \\
\cline { 2 - 4 } & $\begin{array}{l}\text { Мотивация к овладе- } \\
\text { нию профессией }\end{array}$ & 4,6 & 2,45 & 3,71 & $\begin{array}{l}\text { Находится в зоне } \\
\text { значимости }\end{array}$ \\
\hline \multirow{2}{*}{4} & $\begin{array}{l}\text { Общий уровень } \\
\text { реабилитационного } \\
\text { потенциала }\end{array}$ & 5,9 & 2,45 & 3,71 & $\begin{array}{l}\text { Находится в зоне } \\
\text { значимости }\end{array}$ \\
\hline
\end{tabular}

При математико-статистическом анализе полученные эмпирические значения $t_{\text {эмп }}$ во всех расчетах по всем показателям оказались больше имеющегося $t_{\text {крит }}$. Поэтому полученные $t_{\text {эмп }}>t_{\text {крит }}$, что указывает на нахождение полученных результатов в зоне значимости. Это подтверждает их статистическую значимость.

\section{Выводы}

В результате апробации разработанной нами модели психолого-педагогического сопровождения студентов-инвалидов в период 
их адаптации к обучению в вузе, нацеленной на помощь студентам с инвалидностью в социально-психологической адаптации, была подтверждена ее эффективность.

Психолого-педагогическое сопровождение студентов-инвалидов в период их адаптации к обучению в вузе представляет собой целостную, комплексную, системно организованную деятельность специалистов различного профиля, действующих согласованно, в процессе которой создаются социально-психологические и педагогические условия для успешной адаптации студентов-инвалидов к обучению в вузе [15].

По мнению О.А. Козыревой, психолого-педагогическое сопровождение студентов с инвалидностью должно осуществляться центром инклюзивного образования, управлением воспитательной и внеучебной работы, социальными структурами и общественными организациями, научными центрами университета, деканатами факультетов [15].

Участниками модели сопровождения выступают педагог-психолог, тьютор, куратор учебной группы, где обучается студент с инвалидностью, родители студента (или лица, их заменяющие), сам студент с инвалидностью.

Модели сопровождения могут быть разными, однако процесс адаптации к обучению в вузе показал неотделимость рассматриваемых проблем студентов с инвалидностью от проблем всех студентов. Поэтому наиболее продуктивной будет организационная модель, предполагающая встраивание психолого-педагогического сопровождения студентов с инвалидностью как составной части в широкую систему психолого-педагогической поддержки обучающихся. Например, выделение сопровождения обучающихся с инвалидностью как относительно самостоятельного направления деятельности структурного подразделения, осуществляющего психологическую и педагогическую поддержку студентов вуза.

1. Максимова Г.П. Модернизация воспитания в высшей школе на основе интеграции педагогики и искусства в медиасреде : автореф. дис. ... д-ра пед. наук. Ростов-н/Д, 2007. 
2. Родонова С. Ю. Педагогические условия социальной адаптации иностранных студентов-стажеров к обучению на гуманитарном факультете российского вуза : дис. ... канд. психол. наук. Ярославль, 2002.

3. Браун Т.П. Адаптация студентов к обучению в вузе в условиях оптимизации образовательной среды : дис. ... канд. пед. наук. СПб., 2007.

4. Никифоров В. И., Сурыгин А.И. Теория и практика высшего профессионального образования : термины, понятия и определения. СПб. : Изд-во Политехн. ун-та, 2009.

5. Дарьенкова Н.Н. Адаптация студентов первого курса к обучению в техническом вузе в условиях информатизации образования : дис. ... канд. пед. наук. Н. Новгород, 2015.

6. Коновалова М. Д., Щетинина Е. Б. Психолого-педагогическое сопровождение студентов с ограниченными возможностями здоровья : учеб.-метод. пособие для студентов-магистрантов. Саратов : Изд-во Сарат. ун-та, 2013.

7. Кулагина И. Ю., Сенкевич Л. В. Реабилитационный потенциал личности при различных хронических заболеваниях // Культурно-историческая психология (М.). 2015. Т. 11, № 1. С. 50-60.

8. Пьянова Е.Н. Социально-психологическая адаптация студентов естественного профиля обучения регионального вуза : дис... канд. психол. наук. СПб., 2006. 130 с.

9. Горчакова А. А. Особенности процесса адаптации студента к учебно-профессиональной деятельности // Проблемы современной науки и образования. Иваново : Олимп, 2017. С. 88-90.

10. Пешкова Н. А., Степанова Н. А., Хаидов С. К. Изучение Я-концепции студентов с ограниченными возможностями здоровья // Я-концепция субъекта образовательной среды высшей школы : материалы Всерос. науч.-практ. конф. с междунар. участием / под общ. ред. В. И. Кошель. Ставрополь : Изд-во СтГМУ, 2017. С. 204-209.

11. Кузьмичева А. В., Водяха С.А. Взаимосвязь психологического благополучия с показателями социально-психологической адаптации студентов-физиков // Подготовка молодежи к инновационной деятельности в процессе обучения физике, математике, информатике : материалы междунар. науч.-практ. конф / отв. ред. Т.Н. Шамало. Екатеринбург : Урал. гос. пед. ун-т. 2014. С. 111-118. 
12. Фоминых Е. С. Психолого-педагогическое сопровождение девиктимизации студента-инвалида в профессионально-образовательной среде : дис. ... канд. психол. наук. Оренбург, 2012. 288 с.

13. Соловъев Н. Н. Социально-психологические факторы интеграции в общество детей с ограниченными возможностями здоровья: дис. ... канд. психол. наук. СПб., 2003. 206 с.

14. Осипова А.А. Введение в теорию психокоррекции. Воронеж : Модэк, 2002. 320 c.

15. Козырева О.А. Организация комплексного сопровождения студентов-инвалидов и студентов с ограниченными возможностями здоровья в процессе обучения в вузе [Электронный ресурс]. URL: https:/elibrary. ru/item.asp?id=27266505 (дата обращения: 15.02.2020). 


\title{
РАЗВИТИЕ ЖИЗНЕСТОЙКОСТИ У ЮНОШЕЙ И ДЕВУШЕК С ИНТЕЛЛЕКТУАЛЬНЫМИ НАРУШЕНИЯМИ В ОРГАНИЗАЦИЯХ ПРОФЕССИОНАЛЬНОГО ОБРАЗОВАНИЯ
}

\author{
Л. В. Токарская \\ М. Н. Черемных
}

Актуальность исследования. Жизнестойкость, являющаяся важнейшей личностной характеристикой современного человека, проявляет себя как способность успешно преодолевать трудности, неизбежно возникающие на жизненном пути. Личностные особенности, составляющие основу жизнестойкости, развиваются преимущественно в детском и частично в подростковом возрасте. Одним из ключевых кризисных периодов, бросающих вызов приспособительным ресурсам человека, является переходный этап от окончания обучения в школе к началу освоения будущей профессии. Вчерашние ученики, обретая статус студента, сталкиваются с неизбежными изменениями социальной ситуации, необходимостью освоения новых социальных ролей, новых правил поведения, иной учебной информации. Данный процесс может осложняться в ситуации наличия у студентов ограниченных возможностей здоровья. В связи с этим развитие качеств личности, способствующих более успешному преодолению описанных трудностей, является крайне важной задачей.

Нестабильность и постоянная изменчивость социальной ситуации, сопровождаемая отсутствием уверенности в завтрашнем дне, негативно сказывается как на физическом, так и на психологическом здоровье юношей и девушек, бросает вызов их адаптационным возможностям. Успешность преодоления возникающих трудностей оказывает непосредственное влияние на успешность их дальнейшего жизненного пути.

Изучая проблему личностных ресурсов, позволяющих справляться с трудными жизненными ситуациями, С. Мадди и С. Кобейса ввели понятие «hardiness», определив его как характеристику личности, являющуюся, по сути, системой представлений человека о самом себе, об окружающем его мире, и о месте, которое ему в этом мире 
отведено [1]. В отечественной психологии в исследованиях, посвященных изучению психологических факторов, способствующих успешному совладанию со стрессом, обычно используется понятие «жизнестойкость», предложенное Д.А. Леонтьевым. Жизнестойкость «характеризует меру способности личности выдерживать стрессовую ситуацию, сохраняя внутреннюю сбалансированность и не снижая успешность деятельности» [2, с. 3]. Уровень жизнестойкости личности определяется совокупностью уровней выраженности входящих в нее компонентов: вовлеченность, контроль и принятие риска [1].

В качестве интегральной характеристики уровня личностной зрелости Д.А. Леонтьев вводит понятие «личностный потенциал», которому, по мнению автора, лучше всего соответствует понятие «жизнестойкость», как система установок или убеждений, та базовая характеристика личности, «которая опосредует воздействие на ее сознание и поведение всевозможных благоприятных и неблагоприятных обстоятельств, от соматических проблем и заболеваний до социальных условий» [3].

Исследования С. Мадди и Д. А. Леонтьева легли в основу дальнейшего изучения ресурсов личности, позволяющих оценивать и прогнозировать успешность ее адаптации к трудным жизненным ситуациям. Под адаптацией понимается процесс нахождения оптимального соответствия личности окружающей среде, задача человека при этом сводится к осуществлению деятельности, направленной на удовлетворение актуальных потребностей и достижение значимых для него целей [4].

В научной литературе широко представлены исследования, посвященные жизнестойкости и другим личностным ресурсам, к которым относят физиологические и типологические характеристики личности, особенности развития когнитивной сферы, личностные качества, способности и жизненный опыт, ценностные системы и многое другое, при этом не последнее место уделяется навыкам управления ресурсами в трудных жизненных ситуациях [5]. Доказана связь жизнестойкости с возрастом [6], полом [7], копинг-стратегиями [8]. Подчеркивается идея динамичности жизнестойкости, ее неразрывная связь с биологической составляющей человека и его навыками [9]. 


\section{Исследование}

Особый интерес вызывают работы, раскрывающие особенности жизнестойкости лиц с ограниченными возможностями здоровья (ОВ3) [10-13]. При этом развитие личности в ситуации ограниченных возможностей здоровья рассматривается как нормальное личностное развитие в затрудненных условиях [14]. Подтверждением данного факта являются данные ряда исследований, указывающие, что по большому количеству переменных, характеризующих степень развитости личностных ресурсов, значимые различия между обучающимися с ОВЗ и обучающимися с нормативным развитием отсутствуют $[15,16]$. Таким образом, «ситуация инвалидности не может рассматриваться как однозначно детерминирующая проблемы адаптации, поскольку одни и те же физические и телесные особенности могут находиться в разном отношении к личности человека, по-разному встраиваться в структуру его жизнедеятельности [17].

Вариант развития будет определяться, в первую очередь, способностью личности принять вызов, обусловленный ограниченными возможностями здоровья, или отказаться от борьбы. При этом в психологии традиционно рассматривают три основных фактора, влияющих на ход и результаты развития $[14,18,19]$ :

1. Физиологические особенности индивида — та данность, с которой он рождается и/или живет.

2. Социальные особенности - среда, которая его окружает.

3. Психологические особенности - сама личность, ее позиция, отношение к ограниченным возможностям здоровья и активность [19].

Эти три фактора находятся в постоянном взаимодействии и могут либо способствовать развитию индивида, либо препятствовать ему. При этом «речь идет о характеристике именно условий, или предпосылок развития, но не самого развития». Реакция индивида на ограниченные возможности здоровья будет определяться степенью их выраженности, уровнем поддержки со стороны среды, а также готовностью, мотивированностью и способностью индивида к приложению интенсивных усилий для преодоления имеющихся ограничений. Решающим фактором, определяющим траекторию развития, является в конечном счете позиция личности по отношению к своей социальной ситуации [20]. 
Таким образом, активность самого субъекта, направленная на самостоятельное преодоление сложной жизненной ситуации, является важнейшей особенностью социальной поддержки [18], эта активность, готовность к изменениям, к движению навстречу оказываемой помощи является основной предпосылкой для эффективного преодоления имеющихся ограничений на пути к раскрытию своего потенциала. Существенное влияние на уровень жизнестойкости личности оказывает уровень развития эмоционального интеллекта, определяющего способность человека понимать эмоциональные состояния себя и других людей; умение формулировать и высказывать свои мысли; аргументированно отстаивать свою точку зрения; навык активного слушания и т. п. Эти компетенции расширяют диапазон возможностей человека, создают условия реализации своего личностного потенциала посредством более полного использования социальных ресурсов.

Так же, как и Д. А. Леонтьев [21], Б. Г. Ананьев [22] основным фактором жизнестойкости считал образование и умственный труд, подчеркивая при этом важность подкрепления ее такими составляющими, как действие режима жизни, питание и физический труд.

Если же картина мира у человека достаточно примитивна, то он не в состоянии, заняв рефлексивную позицию, переработать опыт, преодолеть трудные жизненные ситуации и продемонстрировать посттравматический рост [21]. Эта идея указывает на невозможность или затрудненность посттравматического роста для людей с невысоким образовательным и культурным уровнем и умственной отсталостью. В целом считается, что лица с интеллектуальными нарушениями не могут иметь высокий уровень жизнестойкости. В связи с этим работы, посвященные изучению жизнестойкости у данной категории лиц, практически не проводятся.

В настоящее время для типологизации умственной отсталости применяется медицинская классификация болезней десятого пересмотра [23], которая включает четыре степени умственной отсталости: легкая (F70), умеренная (F71), тяжелая (F72) и глубокая (F73) [24]. Степень выраженности нарушения зависит от тяжести перенесенной вредности, от ее локализации, а также от времени начала ее воздействия. Основную выборку испытуемых, принявших 
участие в нашем исследовании, составили обучающиеся, имеющие легкую умственную отсталость.

При легких формах умственной отсталости, как правило, не отмечается заметных изменений в физическом состоянии [25].

Недостатки психической деятельности при умственной отсталости составляют основу нарушения, при этом в первую очередь страдает мышление. Такие дети в подавляющем большинстве адекватно воспринимают окружающий мир, однако сам процесс восприятия малоактивен. Пониженная реактивность коры приводит к тому, что представления у этих детей обычно нечетки и малодифференцированы. Выработанные условные связи у них непрочны и быстро угасают. Обычно детали, второстепенные признаки предметов и явлений ими плохо или совсем не фиксируются, что вызывает значительные трудности при изучении нового материала, необходимость многократного повторения пройденного.

Вследствие нарушения восприятия и представлений, детям с умственной отсталостью бывает трудно найти сходство или различие между предметами по характерным признакам, высказать суждение о предмете, явлении, ситуации, самостоятельно оценить сложившуюся ситуацию и найти в ней свое место. Это зачастую является причиной неадекватных реакций и недостаточно осмысленных форм поведения.

У лиц с умственной отсталостью наблюдается значительное недоразвитие словесно-логического мышления при более сохранном наглядно-образном.

Развитие внимания существенно влияет на способности детей к обучению, при этом произвольное внимание у большинства из них отличается неустойчивостью - дети легко отвлекаются на любой посторонний раздражитель. Им трудно сосредоточить внимание на каком-то определенном предмете, что осложняет процесс обучения. Однако в ходе обучения и воспитания внимание становится более устойчивым, расширяется его объем. Этому способствует овладение навыками самообслуживания и трудовыми навыками.

У детей и подростков с умственной отсталостью отмечаются нарушения эмоционально-волевой сферы. Внешне это может выражаться в хаотичном поведении, преобладании движений и действий 
непроизвольного характера. Слабость воли у многих детей выражается еще и в том, что они легко подчиняются чужому влиянию, не проявляют настойчивости и инициативы в достижении цели. Их поведение зачастую носит импульсивный характер. У них могут наблюдаться сложности со сдерживанием чувств и влечений. Чувства таких детей малодифференцированы и бедны, однако в процессе развития сфера чувств значительно обогащается.

Одно из типичных нарушений даже при легкой умственной отсталости - это нарушение речи. Речь, как правило, формируется с задержкой; словарь накапливается медленно и никогда не достигает уровня, характерного для лиц, не имеющих нарушений. У многих детей нарушена структура слова (они не договаривают окончаний, допускают пропуски звуков и слогов, искажают или заменяют звуки), нарушен грамматический строй речи, зачастую ослаблен контроль за собственной речью.

Безусловно, лицам с умственной отсталостью свойственны индивидуальные особенности темперамента, характера и эмоциональных реакций. Они обладают и достаточными возможностями в отношении овладения некоторыми видами трудовой деятельности. В большей степени у них страдает познавательная деятельность, особенно способность к анализу, логическому обобщению, абстракции, т. е. то, что составляет основу интеллекта. Все это не дает данной группе детей возможности освоить программу общеобразовательной школы. Обучение детей с умственной отсталостью (интеллектуальными нарушениями) осуществляется в соответствии с адаптированными основными образовательными программами (АООП). По окончании школы выпускники с интеллектуальными нарушениями получают свидетельство об обучении и могут трудоустроиться или продолжить обучение в учреждениях начального и среднего профессионального образования по адаптированным программам.

В связи с тем, что период обучения в организации профессионального образования характеризуется необходимостью подготовки к дальнейшему самостоятельному трудовому и жизненному пути, именно он был выбран для уточнения особенностей и развития жизнестойкости у юношей и девушек с умственной отсталостью. 
Цель исследования - разработка и реализация психокоррекционной программы, направленной на развитие компонентов жизнестойкости у студентов с интеллектуальными нарушениями, анализ полученных результатов.

Гипотеза: жизнестойкость студентов с интеллектуальными нарушениями поддается развитию.

Выборка и методики исследования. В исследовании принимали участие студенты первого курса Государственного автономного профессионального образовательного учреждения Свердловской области «Екатеринбургский экономико-технологический колледж» (ГАПОУ СО «ЕЭТК»), обучающиеся по адаптированным программам начального профессионального образования «Швея» (в количестве 14 человек) и «Обувщик по ремонту обуви» (в количестве 13 человек). По этим программам обучаются студенты с легкой умственной отсталостью (F70).

В качестве испытуемых были выбраны группы разнополых учащихся, поскольку интересным представляется изучить половые различия проявлений жизнестойкости. Так, Т. В. Наливайко утверждает, что несмотря на традиционные взгляды на мужчин как на носителей таких личностных качеств, как агрессивность, решительность, целеустремленность, сильный характер, можно с уверенностью утверждать более высокий уровень выражения этих типологических качеств, соотносимых с понятием жизнестойкости, у представителей женской популяции [26].

В качестве основного инструментария был выбран опросник «Тест жизнестойкости» С. Мадди (в адаптации Е.Н. Осина и Е. И. Рассказовой) [27]. Надежность и достоверность результатов оценивались на основании методов математической статистики: для установления различий между показателями, полученными по шкалам опросника до и после реализации программы, применялся $t$-критерий Стьюдента.

\section{Описание программы «Развиваем жизнестойкость»}

При составлении плана и наполнении содержания программы занятий по развитию компонентов жизнестойкости учитывались личностно-психологические особенности учащихся, специфика 
осваиваемых ими профессий. Программа включала в себя три тематических занятия продолжительностью 40 минут каждое. Занятия проводились с интервалом в одну неделю. На первом и последнем занятиях проводилось контрольное тестирование.

Цель программы: повышение уровня жизнестойкости учащихся с интеллектуальными нарушениями.

Задачи программь:

1. Развитие у учащихся с интеллектуальными нарушениями (легкой умственной отсталостью) понимания необходимости более полного вовлечения в деятельность, участниками которой они являются.

2. Развитие убежденности учащихся в том, что они располагают внутренними ресурсами, позволяющими влиять на конечный итог разрешения трудностей, встречающихся на их жизненном пути.

3. Актуализация представлений учащихся о ценности опыта, извлекаемого в процессе преодоления жизненных трудностей, о его прямом влиянии на личностный рост и расширение представлений об окружающем мире.

4. Уточнение представлений о значимости наличия профессии и места работы.

При разработке содержания программы активно использовались медиаматериалы: презентации, мультфильмы, видеофрагменты, аудиозаписи, а также техники активной беседы, обеспечивающие максимальное привлечение внимания и включенность в работу. В качестве героев мультипликационных фильмов подбирались юноши и девушки, занятые в тех же профессиях, по которым обучались испытуемые. Занятия проводились отдельно в группах юношей и девушек.

\section{Описание хода проведения занятий}

На первом занятии решались задачи установления контакта с испытуемыми и выявления у них проявлений жизнестойкости.

В качестве наиболее доступных испытуемым средств использовались рассказ о швее и сапожнике, добившихся успеха в профессиональной деятельности; анимированные изображения, включенные в презентацию и мультипликационные фильмы. 


\section{Методы:}

1. Тест жизнестойкости С. Мадди, при этом учащимся пояснялось, что им могут быть интересны результаты и они смогут узнать о себе что-то новое. Необходимо, однако, отметить, что проявлявшиеся в начале занятия заинтересованность и любопытство сменились у испытуемых на сниженный эмоциональный фон и неудовольствие, когда они поняли, что нужно будет читать и писать. У испытуемых возник ряд вопросов на понимание смысла формулировок в опроснике, однако они смогли заполнить тест в полном объеме.

2. Беседа об авторе теории, основных компонентах жизнестойкости и способах преодоления жизненных трудностей. Так, понятие «вовлеченность» обсуждалось с помощью гиф-изображения кота, играющего в наперстки (с уточнением пользы вовлечения в деятельность на основе анализа конкретных жизненных ситуаций). Понятие «контроль» анализировалось через гиф-изображение кота за рулем автомобиля и пояснением важности проявления активности в деятельности и преодолении трудных жизненных ситуаций. Кроме того, кратко описывалась история жизни В. Франкла [28], для объяснения возможности переосмысления отношения к происходящему в случае невозможности на это повлиять. Понятие «принятие риска» объяснялось с помощью гиф-изображения умного котика и рассказа о важности приобретаемого опыта.

3. Обсуждение возможностей разрешения трудных ситуаций, вариантов построения плана их разрешения и перемен, которые происходят после преодоления трудностей.

4. Уточнение полноты понимания испытуемыми темы через серию вопросов и комментариев, а также перенос изучаемого материала на реальную жизнь и будущую профессиональную деятельность учащихся. Для этого девушкам демонстрировался мультфильм «Швея Элла», а молодым людям — «Маленький сапожник» и задавались вопросы о том, каким образом жизнестойкость проявляется в мультфильме, о помощи других героев, значимости поддержки окружения. Испытуемым предлагалось подумать о том, что помогло героям мультфильмов стать мастерами своего дела, и сделать вывод о том, чему учат данные истории. 
5. Подведение итогов, в ходе которого уточнялась роль жизнестойкости в жизни человека.

На втором занятии решалась задача уточнения содержания понятия «жизнестойкость» и его значимости для жизнедеятельности испытуемых.

Использовались те же средства, что и на первом занятии, только в презентации был удален практически весь текст, кроме заголовков и за счет этого увеличены изображения. Также демонстрировались мультипликационные фильмы.

\section{Методы:}

1. Уточняющая беседа с актуализацией остаточных знаний, которая показала. что испытуемые узнавали изображения и ключевые идеи, которые обсуждались на первом занятии.

2. Обсуждение мультфильмов «Жихарка» с девушками и «Шейдулла-лентяй» с юношами, особенностей проявления в них жизнестойкости, ценности социальной поддержи, а также опыта, который можно извлечь из этих фильмов, и того, что помогло героям выйти из сложной ситуации.

3. Подведение итогов занятия с групповым обсуждением компонентов жизнестойкости, проявленных героями мультфильмов.

Hа третьем занятии были поставлены задачи определения содержания и компонентов жизнестойкости, а также динамики проявлений жизнестойкости у испытуемых.

Средства: Тест жизнестойкости С. Мадди, мультипликационные фильмы.

\section{Методы:}

1. Беседа, включающая обсуждение основных компонентов жизнестойкости с опорой на подготовленную к предыдущему занятию презентацию.

2. Просмотр с девушками мультфильма «Маленькая Василиса», а с юношами - «Академик Иванов».

3. Обсуждение вопросов о коммуникативных навыках героев; важности социальной поддержки; активной жизненной позиции; приобретенного героями опыта; принципах жизнестойкости, проявленных героями мультфильмов. 
4. Заполнение теста жизнестойкости С. Мадди с обработкой результатов.

Результаты. Средние значения результатов, полученных в ходе проведения предварительного и итогового тестирования, приведены в таблице. Следует отметить, что заполнение бланков опросников вызвало затруднения у значительной части испытуемых, при этом пять испытуемых не смогли ответить на вопросы даже в условиях помощи педагогического коллектива и исследователей. Общее число студентов, сумевших заполнить опросник дважды, составило 22 человека.

Сравнительный анализ результатов предварительного и итогового тестирования по опроснику «Тест жизнестойкости С. Мадди» (в адаптации Е.Н. Осина и Е.И. Рассказовой)

\begin{tabular}{|c|c|c|c|}
\hline \multirow[b]{2}{*}{ Шкала } & \multicolumn{2}{|c|}{ Средние значения } & \multirow{2}{*}{$\begin{array}{c}\text { Уровень зна- } \\
\text { чимости } \leq\end{array}$} \\
\hline & $\begin{array}{c}\text { предварительное } \\
\text { тестирование }\end{array}$ & $\begin{array}{c}\text { итоговое тести- } \\
\text { рование }\end{array}$ & \\
\hline Вовлеченность & 17,8 & 21,8 &, 048 \\
\hline Контроль & 12,5 & 16,2 &, 010 \\
\hline Принятие риска & 8,8 & 10,3 & ,221 \\
\hline Жизнестойкость & 40,7 & 48,4 &, 014 \\
\hline
\end{tabular}

Обработка результатов предварительного и итогового тестирования с использованием $t$-критерия Стьюдента выявила значимые изменения уровня жизнестойкости у учащихся с интеллектуальными нарушениями по шкалам «вовлеченность», «контроль» и «общий уровень жизнестойкости». Безусловно, нельзя утверждать, что столь короткая программа могла дать выраженные результаты в отношении такого сложного психологического образования, как «жизнестойкость», тем не менее полученные данные требуют осмысления. Так, наиболее изменились показатели учащихся по шкале «контроль». Объяснить увеличение этого параметра можно характером вопросов, которые в большинстве своем были направлены на выявление пользы активной жизненной позиции героев мультфильмов. Наименее выраженными оказались различия по шкале «принятие риска», возможно, это связано с тем, что учащимся требовалось 
время для осмысления поведения героев мультфильмов, при этом им сложно анализировать, делать умозаключения, осуществлять прогностическую функцию в силу наличия интеллектуальных нарушений.

Тем не менее, согласно полученным результатам, после реализации программы у респондентов по всем шкалам повысились показатели жизнестойкости, следовательно, можно констатировать, во-первых, переосмысление ими своих возможностей, понимание важности активной совладающей позиции и осознание достигнутых с помощью специалиста ресурсов, помогающих в преодолении жизненных трудностей; во-вторых, актуализацию уже имеющихся представлений, переосмысление ранее полученного опыта через призму вновь полученной информации, что также стало возможным благодаря активному участию специалиста. Однако нельзя исключать и то, что полученные данные в определенной степени связаны с эмоционально положительной обстановкой во время проведения занятий и попыткой респондентов дать социально желательные ответы.

\section{Выводы}

Таким образом, удалось составить и реализовать психокоррекционную программу, учитывающую психолого-педагогические особенности учащихся с интеллектуальными нарушениями, а именно представить теоретический материал в простой и доступной для обсуждения форме, подобрать технологию работы, поддерживающую эмоциональную вовлеченность и интерес участников исследования, создать комфортный, благоприятный для работы психологический климат в учебном коллективе.

Получены интересные результаты, говорящие о возможности повышения жизнестойкости у учащихся с интеллектуальными нарушениями с помощью психокоррекционных занятий. Для работы с данным контингентом испытуемых был выбран верный формат занятий, включающих наглядные и запоминающиеся презентации, с изображениями-символами, несущими положительный, эмоционально насыщенный образ, а также мультфильмы, с героями ко- 
торых учащиеся могут отождествлять себя по профессиональному или половому статусу.

Данные результаты требуют дальнейшего обсуждения и проверки, однако они, на наш взгляд, представляют интерес, поскольку ранее исследования, указывающие на результативность психокоррекционных занятий (с использованием сказкотерапии и обсуждением литературных притч), направленных на развитие компонентов жизнестойкости у студентов, имеющих ограниченные возможности здоровья, проводились на группе студентов высшего учебного заведения, не имеющих выраженных интеллектуальных нарушений [29]. Проблема исследования жизнестойкости и ее компонентов у лиц с умственной отсталостью практически не привлекала внимания исследователей.

Необходимо отметить тот факт, что данная работа скорее ставит вопрос о возможности формирования способности к преодолению трудных жизненных ситуаций у данной категории учащихся. Кроме того, актуальным становится вопрос создания адаптированного теста жизнестойкости для лиц с интеллектуальными нарушениями.

Для получения более полных и точных данных о результативности разработанной программы требуется ее дальнейшая реализация в соответствующих учебных коллективах, в том числе в условиях совместных занятий с учащимися, не имеющими ограниченных возможностей здоровья.

1. Мадди С. Р. Теории личности: сравнительный анализ : пер. с англ. СПб., 2002. 567 c.

2. Леонтьев Д. А., Рассказова Е. И. Тест жизнестойкости. М. : Смысл, 2006. $63 \mathrm{c}$.

3. Леонтьев Д. А. Личностное в личности: личностный потенциал как основа самодетерминации [Электронный ресурc]. URL: https://www. psychology-online.net/articles/doc-1275.html

4. Методика многостороннего исследования личности: структура, основы интерпретации, некоторые области применения / Ф.Б. Березин, М. П. Мирошников, Е. Д. Соколова. 3-е изд. М. : Березин Феликс Борисович, 2011.318 с. 
5. Практикум по психологии здоровья / под ред. Г. С. Никифорова. СПб. : Питер, 2005.

6. Особенности формирования жизнестойкости и совладания с трудными жизненными и стрессовыми ситуациями несовершеннолетних в образовании : метод. пособие / под ред. Ю.Н. Денисова. Барнаул, 2014. $184 \mathrm{c}$.

7. Ершова И. А., Пермякова М.Е., Садкина Т. М. Связь жизнестойкости с самооценкой и копинг-стратегиями у юношей и девушек подросткового возраста // Педагогическое образование в России. 2019. № 4. С. 133-140.

8. Гуиунаева С. В. Копинг-стратегии подростков с различным уровнем жизнестойкости // Междунар. журн. прикладных и фундаментальных исслед. 2015. № 3-1. С. 92-95.

9. Щетинина Е. Б. Жизнестойкость студентов с ограниченными возможностями здоровья // Изв. Сарат. ун-та. 2015. Т. 4, № 4 (16). С. 111-114.

10. Горьковая И. А., Микляева А. В. Жизнестойкость и копинг-стратегии подростков с сенсорными и двигательными нарушениями // Изв. Рос. гос. пед. ун-та им. А. И. Герцена. 2018. № 187. С. 85-95.

11. Леонтьев Д. А., Александрова Л. А., Лебедева А. А. Развитие личности и психологическая поддержка учащихся с ОВЗ в условиях инклюзивного профессионального образования. М.: Смысл, 2017. 79 с.

12. Токарская Л. В., Григорьева Д. И. Сравнительный анализ жизнестойкости подростков с тяжелыми нарушениями речи и подростков с нормативным речевым развитием // Изв. Урал. федер. ун-та. Сер. 1 : Проблемы образования, науки и культуры. 2017. № 4. С. 89-95.

13. Tokarskaya L. Comparative Study of Hardiness Referring to Adolescents with Musculoskeletal Disorders and Adolescents with Normal Development // Lurian Approach in International Psychological Science : The Fifth International Luria Memorial Congress. KnE Life Sciences. 2018. P. 856-867. doi: 10.18502/ kls.v4i8.3343

14. Леонтьев Д. А. Развитие личности в норме и в затрудненных условиях // Культурно-историческая психология. 2014. Т. 10, № 3. С. 97-106.

15. Calhoun L. G., Tedeschi R. G. The foundations of posttraumatic growth: An expanded framework // Handbook of Posttraumatic Growth: Research and Practice. Mahwah : Lawrence Erlbaum, 2006. P. 3-23.

16. Суворов А. В. Уроки загорского эксперимента в контексте тифлосурдопсихологии // Дефектология. 2015. № 6. С. 3-16. 
17. Суворов А. В. Духовность как психическая способность и смысл жизни. 2015. 11 февр., 6 апр. [Электронный ресурс] // Колонка Александра Суворова. URL: http://tovievich.ru/news/6711kolonkaaleksandrasuvorovaduhovnostkakpsihicheskayasposobnostismysl zhizni.html (дата обращения: 01.05.2015).

18. Зейгарник Б. В. Патопсихология : учебник. М. : Эксмо, 2000.

19. Леонтьев Д.А. Психологические ресурсы преодоления стрессовых ситуаций: к уточнению базовых конструктов // Психология стресса и совладающего поведения в современном российском обществе : материалы II Междунар. науч.-практ. конф., Кострома, 23-25 сент. 2010 г. : в 2 т. / отв. ред.: Т. Л. Крюкова, М. В. Сапоровская, С. А. Хазова. Кострома : КГУ им. Н. А. Некрасова, 2010. Т. 2. С. 40-42.

20. Слободчиков В. И., Исаев Е. И. Основы психологической антропологии. Психология человека: введение в психологию субъективности : учеб. пособие для вузов. М. : Школа-Пресс, 1995.

21. Леонтьев Д.А. Удары судьбы как стимулы личностного развития: феномен посттравматического роста Д. А. Леонтьев // Жизнеспособность человека: индивидуальные, профессиональные и социальные аспекты / отв. ред. А.В. Махнач, Л. Г. Дикая. М. : Изд-во «Институт психологии РАН», 2016. С. $144-158$.

22. Ананьев Б. Г. Психология и проблемы человекознания / под ред. А.А. Бодалева. Москва : Изд-во «Институт практической психологии» ; Воронеж : НПО «МОДЭК», 1996. 384 с.

23. МКБ-10 [Электронный ресурc]. URL: https://мкб-10.com/F00-F99/ F70-F79_(дата обращения: 07.04.2019).

24. Маклаков А. Г. Личностный адаптационный потенциал: его мобилизация и прогнозирование в экстремальных условиях // Психол. журн. 2001. Т. 22, № 1. С. 16-24.

25. Обучение детей с нарушениями интеллектуального развития: (Олигофренопедагогика) : учеб. пособие для студентов высш. пед. учеб. заведений / Б. П. Пузанов, Н. П. Коняева, Б. Б. Горскин и др. ; под ред. Б. П. Пузанова. М. : Академия, 2001. 272 с.

26. Наливайко Т.В. Исследование жизнестойкости и ее связей со свойствами личности : автореф. дис. ... канд. психол. наук. Ярославль, 2006. $175 \mathrm{c}$. 
27. Осин Е.Н., Рассказова Е. И. Краткая версия теста жизнестойкости: психометрические характеристики и применение в организационном контексте // Вестн. Моск. ун-та. Сер. 14 : Психология. 2013. № 2. С. 147-165.

28. Франкл В. Экзистенциальный подход. Теория личности [Электронный ресурс]. URL: https://studfiles.net/preview/5132805/page:31/ (дата обращения: 15.02.2019).

29. Михальчи Е. В., Михальчи Е. Е. Формирование жизнестойкости у студентов с ОВЗ и инвалидностью // Вестн. Балт. федер. ун-та им. И. Канта 2018. № 2. С. 90-96. 


\section{КОММУНИКАТИВНОЕ ЕДИНСТВО ПЕДАГОГИЧЕСКОГО КОЛЛЕКТИВА В УСЛОВИЯХ ИНКЛЮЗИВНОГО ОБРАЗОВАНИЯ В ДЕТСКОМ САДУ}

С.Г. Шабас

В настоящее время перед дошкольным образованием стоят задачи, связанные с повышением качества образования, укреплением позитивного сотрудничества педагогов с семьями воспитанников, формированием командного профессионализма педагогов и созданием эмоционально благополучного климата в образовательном учреждении.

За последнее десятилетие наметился ряд тревожных тенденций, свидетельствующих о кризисных явлениях в жизни семьи, затрагивающих как супружеские, так и детско-родительские отношения. Эти неблагоприятные тенденции объясняются социально-экономическими условиями: нестабильностью социальной системы, низким материальным уровнем жизни, проблемами профессиональной занятости в большинстве регионов России, трансформацией традиционно сложившихся ролевой структуры семьи и распределения ролевых функций между супругами. Особенно значимыми эти тенденции становятся на фоне увеличения количества детей со спецификой психофизического развития и поведения.

В современных условиях увеличение количества детей с особыми образовательными потребностями и социально-психологические проблемы семей делают актуальным и необходимым организацию и поддержку ответственных и взаимозависимых отношений между специалистами, педагогами и родителями детей для создания условий эмоционального благополучия для каждого ребенка.

В связи с этим приоритетной иелью деятельности педагогического коллектива в условиях детского сада является применение инновационных методов для повышения психологической культуры родителей детей с особыми образовательными потребностями, создание условий, приводящих к оптимизации детско-родительских отношений, активное привлечение членов семьи ребенка к участию в воспитательно-образовательном процессе.

(C) Шабас С. Г., 2020

675 
Внедрение инклюзивного образования предполагает включение каждого ребенка вне зависимости от типа и степени выраженности нарушений в его психофизическом развитии в процесс обучения и воспитания с обычными сверстниками. Любой ребенок имеет право на получение и поддержание приемлемого уровня знаний, поэтому необходимо реализовывать образовательные программы с учетом широкого разнообразия детских особенностей и потребностей.

Семья является основой развития ребенка дошкольного возраста. Согласно статье 44 Закона «Об образовании», «...родители (законные представители) несовершеннолетних обучающихся имеют преимущественное право на обучение и воспитание детей перед всеми другими лицами. Они обязаны заложить основы физического, нравственного и интеллектуального развития личности ребенка» [1]. В основных принципах ФГОС дошкольного образования (1.4.) отмечена необходимость «сотрудничества Организации с семьей», а в пункте 1.3 говорится об обеспечении «психолого-педагогической поддержки семьи и повышения компетентности родителей (законных представителей) в вопросах развития и образования, охраны и укрепления здоровья детей» [2]. Кроме того, ФГОС дошкольного образования акцентирует внимание на том, что семья ребенка теперь приобретает новый социальный статус, и родители являются социальными партнерами детского образовательного учреждения.

В современной системе дошкольного образования дети с ограниченными возможностями здоровья обеспечены законодательным закреплением всех видов помощи, необходимой для полноценного развития, освоения образовательной программы и позитивной коммуникации со сверстниками и взрослыми. Психологическое, педагогическое, медицинское и другое сопровождение осуществляется в тесном взаимодействии всех специалистов дошкольных образовательных организаций и учреждений между собой.

Психолого-педагогическое сопровождение включает различные виды и формы, различающиеся по направленности, предмету и объекту: сопровождение семей воспитанников; сопровождение ребенка с различными образовательными потребностями (одаренного, гиперактивного, с трудностями в обучении, в критической 
ситуации и т. д.); сопровождение педагогов и специалистов в воспитательно-образовательном процессе; сопровождение детско-родительских отношений; сопровождение сотрудников и администрации детского сада.

Однако проблема заключается в том, что в работе по повышению эффективности деятельности специалистов и педагогов во взаимодействии с родителями слабо представлена диагностическая оценка потребности в психолого-педагогической деятельности в детском саду, основанная на системе сотрудничества всех участников воспитательно-образовательного процесса. Поэтому для эффективной реализации технологии сопровождения необходимо учитывать мотивацию администрации и заинтересованность родителей в сотрудничестве и позитивной коммуникации.

В процессе инклюзивного образования для обеспечения равного доступа к образованию всех обучающихся с учетом разнообразия особых образовательных потребностей и индивидуальных возможностей детей педагоги и специалисты испытывают значительные физические и психологические перегрузки. Это обстоятельство требует психологического сопровождения всего педагогического коллектива. Эмоциональное перенапряжение приводит к формированию синдрома профессионального выгорания и профессиональной деформации, что критически может сказываться на коммуникации педагогов и специалистов с детьми с ограниченными возможностями здоровья (ОВ3) и их родителями. Психологическое сопровождение должно быть направлено на формирование профессиональной готовности кадров к осуществлению инклюзивного образования.

Создание оптимальных психолого-педагогических условий для категории воспитанников с ОВЗ должно осуществляться в рамках единого подхода к воспитанию и при едином стиле педагогической деятельности. В связи с этим актуальной становится проблема общего понимания педагогическими работниками причин, условий формирования специфики психофизического развития ребенка с OB3, особенностей его поведения, путей коррекции и механизмов взаимодействия с семьей ребенка. 


\section{Деятельность педагогов и специалистов в процессе \\ осуществления инклюзивных практик}

Для реализации процесса инклюзии в детском саду необходимы особые условия для детей с ОВ3 разных категорий, специальная подготовленность педагогов и психологов образовательных организаций.

Развитие инклюзивной практики остро ставит вопрос о профессиональной, психологической и методической готовности педагогов работать в условиях инклюзии. Практика показывает, что часто в педагогических коллективах образовательных организаций существует проблемы недостатка профессиональной компетентности для работы в инклюзивной среде, наличие психологических барьеров и профессиональных стереотипов, которые влияют на качество предоставляемых образовательных услуг. Многие педагоги отмечают недостаток знаний и практического опыта в работе с особыми детьми, неготовность к сотрудничеству со специалистами службы сопровождения, проблемы, связанные с отсутствием полноценного оснащения материально-технической базы, недостаточным количеством методической литературы, недоступностью информационных ресурсов [3].

Профессиональная компетентность педагогов и специалистов дошкольных образовательных организаций (ДОО) обеспечивается совокупностью профессиональных качеств, необходимых для успешной педагогической деятельности в процессе осуществления инклюзивного образования детей дошкольного возраста. Однако педагоги нередко имеют недостаточный уровень представлений о специфике образования детей с особенностями развития, плохо знакомы с нормативно-правовой базой, регламентирующей права данного контингента воспитанников и их родителей, нечетко представляют себе особенности психомоторного и личностного развития детей с ОВ3 и инвалидностью, недопонимают специфику их образовательных потребностей и эмоциональных проблем. Часто отмечается недостаточный уровень толерантности к особым детям, неумение применять инновационные технологии и реализовывать образовательные программы в условиях комбинированных групп [4]. 
Гуманистическая направленность инклюзивного образования предполагает применение как общедидактических принципов организации воспитательно-образовательного процесса, определяемых ФГОС, так и специфических принципов образовательных отношений - принципа уважения, признания личности ребенка с особыми потребностями. Для педагогов и специалистов в таких условиях имеет значение наличие у них потребности к саморазвитию, готовности осваивать новые знания и образовательные технологии, высокий уровень профессиональной компетентности [5].

Одним из важных условий успешной социализации детей с OB3 является психологическое сопровождение всех членов семьи, воспитывающей таких детей. Технология сопровождения в образовании - это мультидисциплинарная научно-практическая деятельность целого ряда специалистов. Воплощая на практике идеи гуманистического и личностно-ориентированного инклюзивного обучения, технология сопровождения становится необходимой составляющей образовательной системы, позволяющей создать условия для полноценного развития детей с ОВЗ.

Технологии сопровождения ребенка с ОВЗ подразделяются на две основные группы:

1) технологии формирования базовых предпосылок учебной деятельности в соответствии с уровнем и особенностями психического развития ребенка и характером его нарушений;

2) технологии социальной адаптации ребенка в среде сверстников и в пространстве образовательного учреждения.

Применение соответствующих технологий позволяет создавать адекватное возрасту ребенка коррекционно-развивающее пространство, формировать и реализовывать релевантные потребностям ребенка стратегии воспитания, базирующиеся на конструктивных родительских установках и позициях по отношению к нему [6].

На личностное развитие ребенка с ОВЗ оказывают влияние выраженность и необратимость нарушений развития; специфика личности родителей и модели семейного воспитания; ценностные ориентации родителей в отношении ребенка и их зависимость от социально-культурного уровня; социальная среда, препятствующая или помогающая родителям в реализации их воспитательных задач. 
В связи с этим акцент коррекционного воздействия должен переноситься специалистами и педагогами на семью ребенка, причем внимание прежде всего должно уделяться влиянию родителей на установление позитивных детско-родительских отношений и создание благоприятной семейной атмосферы [7].

\section{Специфика взаимодействия детского сада и семьи в процессе реализации инклюзивного образования в детском саду}

Дети с ОВ3 могут обучаться в обычном детском саду, где в таком случае особое внимание должно уделяться проблеме отношений с родителями в процессе адаптации и социализации детей с нарушениями развития. Взаимодействие педагогов, специалистов и администрации с семьей в детском саду может рассматриваться как способ организации совместной деятельности на основе открытости и доверия с обеих сторон. В результате такого взаимодействия многие родители начинают занимать заинтересованную позицию, при которой между участниками образовательного процесса устанавливаются продуктивные субъект-субъектные отношения.

Данный вид взаимодействия может быть реализован через создание особой эмоциональной среды; индивидуальные и групповые формы работы; формирование активной субъектной позиции родителей в воспитательно-образовательном процессе [8].

Увеличение количества детей с особыми образовательными потребностями и социально-психологические проблемы семей делают необходимым организацию и поддержку ответственных и взаимозависимых отношений между специалистами, педагогами и родителями детей для создания условий эмоционального благополучия каждого ребенка.

Основной проблемой, имеющей важнейшее значение для воспитания ребенка с нарушениями в развитии, является отношение родителей к специфике этих нарушений. В соответствии с уровнем знаний, культуры, личностных особенностей родителей и ряда других факторов возникают различные типы реагирования, а соответственно, и поведения. Таким образом, проблемы семьи, воспитывающей ребенка с ограниченными возможностями здоровья, 
имеют множество аспектов психологического, социального и соматического характера [9].

В соответствии с профессиональным стандартом педагогический коллектив детского сада должен сотрудничать с семьей по вопросам воспитания и образования детей, проводить психолого-педагогическое просвещение для повышения родительской педагогический компетентности, а с родителями детей с ограниченными возможностями здоровья и детей-инвалидов психолого-педагогическое просвещение должно проводиться в русле коррекционного воздействия.

В зависимости от адекватности восприятия родителями состояния ребенка необходимо выделять группы родителей с высоким, средним и низким уровнем мотивации к полноценному сотрудничеству с детским садом. Часто родители детей с особыми образовательными потребностями имеют устоявшуюся собственную воспитательскую позицию, которая негативно влияет на возможность активизации и мобилизации потенциала семьи воспитанников [10].

Высокий уровень профессионализма педагогов и специалистов детского сада в условиях инклюзивного образования позволяет значительно оптимизировать работу педагогического коллектива, повышает качество воспитательно-образовательного процесса в работе с воспитанниками с ОВ3 и создает условия для оптимального социального партнерства с семьей каждого ребенка. Для повышения качества образования детей с особыми образовательными потребностями необходимо определение запросов и позитивных ресурсов семьи; мониторинг взаимодействия педагогов с семьей ребенка с ОВ3; определение уровня понимания родителями проблем, успехов и достижений их ребенка [11].

В условиях инклюзивного образования оптимальным вариантом организации взаимодействия детского сада и родителей детей с OB3 может стать разработка и внедрение Программы сотрудничества ДОО и семьи.

Данная программа помогает отразить достигнутый уровень работы с родителями; выявить преимущества и проблемы сотрудничества ДОО и семьи; определить цель работы; спрогнозировать стратегию и тактику перехода от достигнутых результатов к прогнозируемым. 
Сотрудничество ДОО и семьи осуществляется по следующим направлениям:

1) совместное определение целей деятельности;

2) совместное планирование предстоящей работы;

3) распределение сил, средств, предмета деятельности во времени в соответствии с возможностями каждого участника;

4) совместный контроль и оценка результатов работы;

5) кратковременное и долговременное прогнозирование результатов [12].

В условиях инклюзивного образования в отношении детей с ОВ3, которые получают образование совместно с типично развивающимися детьми, необходима разработка индивидуализированных образовательных целей; создание необходимых условий их поддержки; выстраивание командной стратегии сопровождения ребенка.

Особое значение имеет включение в команду родителей ребенка. Усилия педагогов по воспитанию и развитию детей с особыми образовательными потребностями будут эффективными только если они поддержаны родителями, понятны им и соответствуют потребностям семьи.

В инклюзивном образовательном процессе возрастает значимость сотрудничества родителей, педагогов и специалистов при согласовании целей и задач, приоритетов в развитии ребенка, планирования согласованных действий и методик работы с ним. Успешность обучения и воспитания ребенка в массовом учреждении зависит и от уровня психолого-педагогической компетентности родителей, от их активности, от установления конструктивного взаимодействия, уровня сотрудничества между родителями и специалистами образовательной организации.

Однако пока и родители, и педагоги, и специалисты недостаточно готовы к практической реализации полноценного и систематического взаимодействия. Поэтому, с одной стороны, необходима активизация профессиональной рефлексии педагогов и специалистов, с другой - проявление внутренней готовности родителей детей с ОВЗ к активному участию в реализации индивидуального маршрута воспитания и обучения особого ребенка [13]. 
Проблема низкой готовности педагогов к инклюзивному процессу и взаимодействию с родителями детей с ОВЗ связана с культурно-специфическими факторами, затрудняющими переход к инклюзивному образованию:

- традициями подготовки педагогов;

- спецификой системы общего и специального образования;

- существующими в обществе стереотипами восприятия людей с ограниченными возможностями здоровья;

- психологическими барьерами «страха вреда инклюзии» для других участников образовательного процесса;

- профессиональной неуверенностью педагогов в условиях комбинированных групп;

- негативными установками и предубеждениями;

- нежеланием педагогов меняться в соответствии с требованиями к специалистам, работающим с особыми детьми.

Особое значение для повышения качества инклюзивного образования имеет психологическая готовность педагогов, специалистов и администрации к осуществлению инклюзивных практик, включающая в себя, во-первых, эмоциональное принятие детей с различными видами нарушений; во-вторых, готовность включать данный контингент детей в полноценный воспитательно-образовательный процесс; в-третьих, удовлетворенность собственной педагогической деятельностью [14].

\section{Система коммуникативного единства педагогического} коллектива для работы в условиях инклюзивного образования

В муниципальном дошкольном образовательном учреждении «Детский сад № 26» Ленинского района г. Екатеринбурга создается система коммуникативного единства педагогического коллектива для работы в условиях инклюзивного образования. Это вызвано стремлением создать для воспитанников с ОВЗ условия для их эмоционального благополучия, необходимые для освоения ими образовательной программы, с использованием позитивного потенциала семьи и социального партнерства с дошкольным образовательным учреждением. 
Цель: создание условий психологической безопасности каждого воспитанника в условиях инклюзивного образования на каждом этапе педагогического процесса через разработку и реализацию системы коммуникативного единства всего педагогического коллектива.

В начале создания системы коммуникативного единства всему педагогическому коллективу МБДОУ «Детский сад № 26» было необходимо определить сферу деятельности узких специалистов и педагогов в совместной работе с родителями в детском саду по выстраиванию партнерского взаимодействия с семьями воспитанников. Использовались методы и средства психолого-педагогического просвещения, повышения педагогической компетенции, особенно в работе с родителями, имеющими детей с особыми образовательными потребностями, для повышения эффективности развивающей и коррекционной работы и психологической безопасности воспитанников.

Одной из главных задач системы совместной деятельности должна быть разработка плана общего взаимодействия всего педагогического коллектива, направленного на повышение эффективности образовательного процесса в условиях инклюзивного образования. В процессе работы были определены условия для формирования психологической безопасности воспитанников с опорой деятельности педагогического коллектива на позитивный потенциал семьи.

Педагогами и специалистами детского сада было определено, что психолого-педагогическое сопровождение семьи ребенка с ОВ3 и инвалидностью - это деятельность, основанная на актуализации коррекционно-развивающих ресурсов семьи, обеспечивающих эффективность ее функционирования, особенно в периоды кризисов, связанных с воспитанием и развитием особого ребенка.

Главными направлениями работы педагогического коллектива с детьми с особыми образовательными потребностями являются следующие:

1. Оказание соответствующих видов помощи всем участникам образовательно-воспитательного процесса - воспитанникам, сотрудникам, родителям и членам семьи дошкольника.

2. Осуществление психологического мониторинга образовательной среды детского сада. 
3. Обеспечение прав ребенка на развитие в соответствии с его потенциальными возможностями в реальных условиях его существования.

4. Содействие эффективной и полноценной адаптации воспитанников.

5. Составление общего плана коррекционных мероприятий, направленных на преодоление проблем в социально-психологическом развитии ребенка, для полноценного и систематического взаимодействия всех специалистов, педагогов и администрации ДОУ.

6. Повышение квалификации педагогического коллектива по проблемам социально-психологического развития ребенка дошкольного возраста и особенностям его взаимодействия с социальным окружением.

7. Обобщение и распространение опыта работы других дошкольных учреждений района, города и региона.

Спланированная и целенаправленная деятельность по выделенным направлениям ориентирована на формирование готовности всех членов педагогического коллектива к позитивному и плодотворному взаимодействию с детьми и их родителями, нацеленному на создание условий для успешного освоения воспитанниками образовательной программы с учетом их возрастных и личностных особенностей.

Система коммуникативного единства требует от каждого члена педагогического коллектива:

- систематического изучения и применения новых нормативно-законодательных актов по соблюдению прав детей с ОВЗ и их родителей в воспитательно-образовательном процессе;

- осуществления теоретико-практического исследования по специфике психолого-педагогического сопровождения детей с особыми образовательными потребностями в условиях дошкольного образования;

- насыщения развивающей предметно-пространственной среды психологическим содержанием с учетом индивидуальных особенностей детей;

- повышения профессиональной компетентности для осуществления инклюзивного образования; 
- сотрудничества с родителями для обогащения их воспитательных умений с учетом образовательных и социально-психологических потребностей семьи.

В связи с имеющимися значительными отклонениями в психофизическом и личностном развитии многих воспитанников и в соответствии с законодательно закрепленной ответственностью родителей за здоровье и развитие ребенка одной из основных задач педагогического коллектива МБДОУ № 26 является психолого-педагогическая поддержка семьи дошкольника, которая осуществляется через различные виды взаимодействия педагогов с родителями (информационно-просветительская, консультативная деятельность, формирование знаний, умений и навыков позитивного внутрисемейного взаимодействия для полноценного развития ребенка).

Эффективная работа с семьей ребенка с ОВЗ зачастую оказывается невозможной без предварительного формирования общей психологической культуры родителей, способствующей осознанию тесной связи культуры семьи с особенностями личности ребенка. Используя принципы и методы позитивного взаимодействия, детский сад помогает родителям конструктивно выстраивать общение с собственным ребенком, с педагогами и сотрудниками детского сада.

Анализ детско-родительских отношений выявил, что дети родителей, обладающих высоким уровнем психологической культуры, чаще всего уверены в собственной значимости; считают, что заслуживают уважения; имеют позитивную самооценку; принимают всех членов семьи и находят с ними общий язык; успешно усваивают роль и модель поведения родителя своего пола.

По результатам наблюдений систематическая работа в данном направлении позволяет многим молодым родителям, имеющим ребенка со спецификой развития, сознательно строить свои взаимоотношения с ребенком, адекватно реализовывать свой родительский потенциал, гармонично и конструктивно развивать детскородительские отношения, создавать позитивную внутрисемейную атмосферу.

В МБДОУ «Детский сад № 26» много лет функционирует система взаимодействия педагогического коллектива, администрации, медицинских работников и родителей (лиц, их заменяющих) с це- 
лью составления полноценного плана коррекционно-развивающих мероприятий для детей с ОВ3, инвалидностью или социально-психологическими проблемами.

Создание атмосферы сотрудничества детского сада с членами семьи ребенка, проведение бесед, анкетирования, консультаций, анализ запросов родителей, данных педагогов и специалистов позволяет создавать условия для развития и составлять подробный план работы с каждым воспитанником с учетом его текущего психолого-педагогического состояния. Медико-психолого-педагогическое и социально-правовое сопровождение данного контингента детей включает обязательный анализ следующих факторов развития дошкольника:

Физиологические факторы:

- наличие у ребенка различных нарушений психофизического здоровья;

- наличие у взрослых членов семьи проблем с психофизическим здоровьем;

- состояние ребенка во время медикаментозного лечения или сразу после его проведения.

- возможности и особенности регуляции поведения.

Психологические факторь:

- специфика психического статуса ребенка;

- уровень самооценки;

- степень развития коммуникативной функции;

- специфика мотивации для различных форм и видов деятельности;

- наличие интересов и склонностей.

Социальные факторь:

- нарушение внутрисемейных отношений - дисфункциональные, деструктивные или асоциальные семьи;

- нарушение детско-родительских отношений - снижение социально-психологической значимости ребенка, разрушение семейных ценностей, уменьшение эмоциональных контактов с ребенком, формирование депривационного синдрома;

- наличие у взрослых членов семьи социально-дезадаптивного поведения; 
- развитие ребенка в условиях стрессогенности - повышенные требования к ребенку, жестокое обращение, нарушение коммуникации со взрослыми, постоянная занятость родителей, оставление ребенка на других членов семьи и невротизация родителей;

- стили семейного воспитания и степень заинтересованности родителей в развитии и воспитании ребенка.

Формирование психологически безопасной образовательной среды в условиях инклюзивного образования основано на коммуникативном единстве педагогического коллектива и предполагает решение следующих задач:

1) организация воспитательно-образовательного процесса на основе безопасности и комфортности предметно-развивающей среды;

2) позитивное взаимодействие сотрудников с родителями;

3) использование различных форм и методов повышения квалификации педагогов и специалистов по проблемам инклюзивного образования;

4) профилактика синдрома профессионального выгорания педагогов.

Педагоги и специалисты доброжелательно и позитивно относятся ко всем детям, вовлекают их в различные виды совместной деятельности, стараются развивать у себя педагогическую наблюдательность для реагирования на специфические психофизические запросы каждого ребенка. Система взаимодействия всего педагогического коллектива направлена на укрепление эмоциональной устойчивости (самообладания) каждого ребенка, его возможности свободно проявлять свои эмоции и чувства. Особую значимость приобретает совместная работа по повышению у родителей детей с ОВЗ уровня доверия к педагогам, специалистам и администрации для повышения степени позитивного участия членов семьи ребенка в воспитательно-образовательном процессе.

В связи с изменением социально-психологического статуса педагога системы образования, повышенными стрессогенными условиями работы в процессе осуществления инклюзивных практик, необходимостью применения новых форм, методов и технологий работы в группах комбинированной направленности с совместным воспитанием и образованием детей с различными образовательны- 
ми потребностями, изменением статуса родителя на заказчика образовательных услуг педагоги и специалисты испытывают значительные физические и психологические перегрузки. Это обстоятельство обусловливает необходимость психологического сопровождения всего педагогического коллектива. Поэтому одной из составляющих коммуникативного единства педагогического коллектива в МБДОУ № 26 является психологическое сопровождение кадров, направленное на формирование их профессиональной готовности к осуществлению инклюзивного образования.

\section{Выводы}

Таким образом, создание коммуникативного единства педагогического коллектива позволяет соблюдать все правовые нормы и требования профессиональной этики для полноценной реализации прав всех воспитанников с ОВЗ в и их родителей, а также помогает осознанию необходимости постоянного повышения профессионализма для работы с семьей и ребенком с ОВЗ в условиях инклюзивного образования. Использование педагогами, специалистами и администрацией стратегий сотрудничества во взаимодействии с родителями в процессе инклюзивной практики является одним из главных условий успешности образования ребенка с особыми образовательными потребностями в детском саду.

1. Об образовании в Российской Федерации : федер. закон от 29.12.2012 № 273 [Электронный ресурс]. URL: http://www.consultant.ru/document/ cons_doc_LAW_140174/

2. Об утверждении федерального государственного образовательного стандарта дошкольного образования : приказ Минобрнауки Росси от 17.10.2013 № 1155 (ред. от 21.01.2019); зарегистрир. в Минюсте России 14.11.2013, № 30384) [Электронный pecypc]. URL: http://www.consultant.ru/ document/cons_doc_LAW_154637/

3. Болгова Н. Ю., Малиновская М. П. Проблемы и трудности педагогов дошкольного образования, реализующих инклюзивную практику // Вестн. пед. инноваций. 2019. № 2 (54). С. 113-119.

4. Емельянова И. Д., Маркова С. В., Подольская О. А. Профессиональная компетентность педагогов, реализующих инклюзивную практику в системе 
дошкольного образования, как условие социализации детей с ограниченными возможностями здоровья [Электронный ресурс] // Перспективы науки и образования. 2019. № 4 (40). C. 361-376. URL: https://pnojournal. files.wordpress.com/2019/09/pdf_190428.pdf. doi: 10.32744/pse.2019.4.28

5. Бичева И., Базаркина А.Н. Профессиональные компетенции педагога дошкольного образования в сфере осуществления инклюзивной практики [Электронный ресурс] // Проблемы современного педагогического образования. 2019. № 63-2. С. 66-69. URL: https://cyberleninka.ru/ article/n/professionalnye-kompetentsii-pedagoga-doshkolnogo-obrazovaniya-v-sfere-osuschestvleniya-inklyuzivnoy-praktiki

6. Психологическое сопровождение семьи ребенка с особыми возможностями здоровья в условиях инклюзивного образования : метод. рекомендации / сост. Н.А. Крушная. Челябинск : Изд-во Челяб. гос. пед. ун-та, 2018. 36 с. [Электронный ресурc]. URL: http://elib.cspu.ru/xmlui/bitstream/handle/123456789/1013/HA\%20Крушная.pdf?sequence $=1$ \&isAllowed=y

7. Ткачева В. В. Современные технологии психологической помощи семье ребенка с ограниченными возможностями здоровья [Электронный ресурс] // Современные проблемы науки и образования. 2016. № 4. C. 155-161 URL: https://science-education.ru/pdf/2016/4/24935.pdf

8. Шерайзина М. В., Александрова М. В., Новокшонова К. М. Продуктивное взаимодействие педагогов дошкольной образовательной организации и родителей детей с ограниченными возможностями здоровья [Электронный ресурс] // Проблемы современного педагогического образования. 2019. № 63-4. С. 262-265. URL: https://cyberleninka.ru/article/n/ produktivnoe-vzaimodeystvie-pedagogov-doshkolnoy-obrazovatelnoy-organizatsii-i-roditeley-detey-s-ogranichennymi-vozmozhnostyami

9. Арутюнян А. М. Проблемы семьи, воспитывающей ребенка с ограниченными возможностями здоровья [Электронный ресурс] // С.-Петерб. образоват. вестн. 2016. № 3 (3). C. 41-43. URL: http://cyberleninka.ru/article/n/ problemy-semi-vospityvayuschey-rebenka-s-ogranichennymi-vozmozhnostyami-zdorovya

10. Архипова Е. Ф. Партнерское взаимодействие с родителями в ДОО [Электронный ресурс] // Современное дошкольное образование. Теория и практика. 2016. № 9 (71). С. 52-58. URL: http://cyberleninka.ru/article/n/ partnerskoe-vzaimodeystvies-roditelyami-v-doo 
11. Шабас С. Г. Алгоритм профессионального взаимодействия педагогов детского сада с семьей ребенка с ОВ3 [Электронный ресурс] // Дошкольное воспитание. 2017. № 11. C. 79-84. URL: https://dovosp.ru/wpcontent/uploads/2017/11/shabas_DV-11-17.pdf

12. Заболтина В. В., Захарова Т. В. Взаимодействие специалистов дошкольной образовательной организации с родителями детей, имеющих ограниченные возможности здоровья, и детей-инвалидов в условиях инклюзивного образования [Электронный ресурс] // Проблемы современного педагогического образования. 2018. № 59-3. С. 291-294. URL: https:// cyberleninka.ru/article/n/vzaimodeystvie-spetsialistov-doshkolnoy-obrazovatelnoy-organizatsii-s-roditelyami-detey-imeyuschih-ogranichennye-vozmozhnosti

13. Сидоренко О.А., Хабарова И. В., Чиганова Е. А. Готовность педагогов и родителей детей с ограниченными возможностями здоровья к взаимодействию в условиях инклюзивного образования как проблема: психологический аспект [Электронный ресурс] // Педагогический имидж. 2019. Т. 13, № 2(43). C. 124-135. URL: https://journal.iro38.ru/files/SidorenkoOA-243.pdf. doi: 10.32343/2409-5052-2019-13-2-124-135. (дата обращения: 26.10.2019).

14. Першина Н.А., Кузьмина Ю. В., Шамардина М. В. Исследование психологической готовности участников образовательного процесса к инклюзивному образованию детей с ограниченными возможностями здоровья [Электронный ресурс] // Сиб. психол. журн. 2019. № 72. С. 180-191. URL: https://cyberleninka.ru/article/n/issledovanie-psihologicheskoy-gotovnosti-uchastnikov-obrazovatelnogo-protsessa-k-inklyuzivnomu-obrazovaniyu-detey-s-ogranichennymi. doi: 10.17223/17267080/72/10 


\section{АННОТАЦИИ}

\section{РАЗДЕЛ 1}

\section{Развитие самосознания и формирование социально зрелой личности как проблема психологии образования \\ Б. Ю. Берзин, В. А. Архипова}

Глава посвящена анализу таких понятий, как «самосознание личности», «социально зрелый человек», особенностям и этапам их становления и развития. Сегодня в связи с происходящими в мире изменениями, особенно в сфере массовых коммуникаций, становится актуальным исследование процессов, происходящих в сознании личности. Особую роль призвана сыграть психология образования, которая может стать эффективным средством формирования социально-культурных ценностей подрастающего поколения благодаря исследованию процессов развития самосознания, выявления его сущности и особенностей у детей и подростков, становления социальной зрелости. Методологической основой данного исследования послужили деятельностный и культурно-исторический подходы. В главе дается определение самосознания в его связанности с теорией отражения как внутреннего жизненного мира личности, как субъективной реальности, в которую погружен индивид. Выделяются общие и особенные признаки самосознания в сравнении с самоотражением и сознанием. Подчеркивается социальный характер самосознания, его субъектность и субъективность. Особое внимание уделяется категории «развитие», которое рассматривается как единство противоречивого - тождественного и нетождественного, устойчивого и изменяющегося. Авторы солидарны со сложившейся системой периодизации самосознания в возрастной психологии, но считают необходимым подчеркнуть важность изучения самосознания на всех этапах жизни человека. В современных условиях понятие «развитие» находит свое воплощение на практике в понятиях «формирование» и «воспитание». Особенности реализации методологии формирования и воспитания нашли отражения в приведенных примерах, полученных в ходе социально-психологического исследования выпускников школ в 2018-2019 гг.

Ключевые слова: сознание; самосознание; социальная зрелость; развитие; формирование; воспитание; личность; система образования 
Непрерывное образование: возрастной аспект проявлений Я (самооценка, самоотношение, самоактуализация) Н. С. Глуханюк, М. Н. Юртаева

В главе обсуждаются возможности и особенности развития проявлений Я в контексте непрерывного образования взрослого человека. Полученные результаты анализируются с учетом формирующего воздействия образовательной программы. Делаются следующие выводы: образовательная программа способна инициировать стремление человека к самоактуализации; механизмом данного инициирования выступает, с одной стороны, рост адекватной положительной самооценки и самоуважения, который основан на рефлексивности, внутренней «честности» и осознанности по отношению к себе, с другой - снижение напряженности защитного поведения в адрес Я. Результаты исследования эмпирически поддерживают представления о том, что самооценка, уважение и самоактуализация, доступны психологическому воздействию в процессе реализации образовательных программ для взрослых. Развитие образования взрослых связано с активизацией возможностей, выявлением потенциальных ресурсов и моделированием современных образовательных программ, обеспечивающих запуск механизмов саморазвития.

Ключевые слова: непрерывное образование; особенности проявлений Я взрослого обучающегося; самооценка; самоотношение; самоактуализация

\section{Психологические характеристики транспрофессиональных компетенций специалистов (на примере магистрантов - представителей социономических и технономических групп профессий) Э. Ф. Зеер, М. В. Зиннатова, Т. Д. Буковей}

В современном мире недостаточно быть профессионалом и обладать развитой профессиональной компетентностью. Сегодня становятся востребованы транспрофессионалы со сформированными транспрофессиональными компетенциями, которые отвечают реальным и будущим вызовам цифровой экономики, постиндустриального общества, цифровой индустриализации. Перед образовательным и профессиональным сообще- 
ствами закономерно встает проблема выделения сущностных характеристик транспрофессионала и транспрофессиональных компетенций. В главе предлагается авторское определение феномена транспрофессионализма, анализируется не просто состав транспрофессиональных компетенций, а их психологическая сущность; на основе теоретического анализа определены факторы-компоненты транспрофессионализма, способствующие его развитию в деятельности субъектной личности. Цель исследования: выявление и описание психологических характеристик транспрофессиональных компетенций специалистов. Глава построена на сравнительном и описательном анализе эмпирических данных выраженности транспрофессиональных компетенций. Методы исследования: теоретический анализ, опросный метод, методы математико-статистического анализа (описательный анализ, сравнительный анализ), методы интерпретации. В заключение обсуждаются ограничения, которые не снижают исследовательскую ценность проведенной работы.

Ключевые слова: транспрофессиональные компетенции; транспрофессионализм; специалисты

\title{
Постнеклассическая парадигма в образовании: возможности и ограничения
}

\author{
Л.В. Карапетян
}

Изменения, происходящие в нашей стране, неотвратимо оказывают влияние на все государственные сферы, в том числе и на сферу образования, поскольку ее основная функция - подготовка подрастающего поколения к жизни в соответствующих современных реалиях. При этом трансформационные изменения в обществе происходят весьма стремительно, тогда так система образования отличается малой подвижностью и относительной ригидностью. Очевидно, что парадигмы, определяющие ранее траекторию развития системы образования (классическая и неклассическая), не соответствуют современным тенденциям развития общества. Ученые предлагают новый методологический вектор развития образовательной системы, а именно ее ориентацию на постнеклассическую парадигму, которая в большей степени отражает окружающую действительность и отвечает вызовам социума. В статье анализируются прогрессивные тен- 
денции постнеклассической парадигмы, способные вывести отечественную систему образования на качественно новый уровень, соответствующий передовым результатам мировой педагогики, но специфичный для нашей страны, содержательно и стратегически отличающийся от западных моделей образования. Вместе с тем постнеклассическая парадигма имеет ряд ограничений, которые необходимо учитывать при ее внедрении. Научный и методический дискурс, разворачивающийся вокруг парадигмальной ориентации, оставляет открытым ряд актуальных вопросов. Актуальным является и то, что дискуссия о жизнеспособности новой методологической основы системы образования затягивается, и, возможно, в скором времени ей понадобятся новые методологические ориентиры.

Ключевые слова: система образования; методология; постнеклассическая парадигма

\title{
Онлайн-формат и традиционное обучение: сравнительный анализ психологических предикторов успешности студентов
}

\author{
М. В. Клименских, Ю. В. Лебедева, А. В. Мальиев, В. В. Савельев
}

Стремительное включение онлайн-обучения в практику высшей школы стало стимулом для разворачивания масштабных психолого-педагогических исследований. Представленные материалы - это сравнительный анализ данных академической успеваемости студентов на онлайн-курсах и в традиционном очном формате в связи с их индивидуально-психологическими характеристиками. Авторы приходят к выводу, что личностные особенности студентов не влияют на академический результат. Ключевой вывод данного исследования заключается в том, что успешный студент успешен в любом формате обучения. В связи с этим фокус научного поиска повышения путей эффективности онлайн-обучения должен быть сосредоточен не на психологических особенностях студентов, а на решении задач усовершенствования педагогического дизайна онлайн-курса.

Ключевые слова: массовые онлайн-курсы (МООК); интернет-курс; адаптивное обучение; индивидуальная образовательная траектория; психологические характеристики студенчества 


\section{Подходы к трактовке психолого-педагогических взаимодействий:}

\section{ретроспективный анализ}

Е. В. Коротаева

В каждой научной области время от времени наступает необходимость подведения некоторых итогов, сравнительного анализа, что позволило бы выделить определенные периоды, сущностные события, ключевую терминологию и т.д. Можно выделить четыре этапа в развитии и осмыслении психолого-педагогических взаимодействий. Первый этап может быть определен как этап реконструкции психолого-педагогической науки (1960-1980-е гг.). Второй этап характеризуется тенденцией к интеграции педагогики и психологии в рамках образовательного процесса (с конца 80-х гг. до 2000-х гг.). Данный этап отмечен вниманием к гуманистической составляющей психологии, что было особо значимо для педагогического процесса того времени. Третий этап связан с началом модернизации в российском образовании (первое десятилетие XXI в.), в процессе которого обнаружились разнонаправленность практики психолого-педагогических взаимодействий, и с принятыми в тот период нормативными документами, Четвертый этап «опережающей практики» начался с цифровой эпохи XXI в., в нем актуализировались новые, достаточно специфические аспекты психолого-педагогических взаимодействий. Очевидно, что они еще ждут своего анализа и методологического осмысления как в научной теории, так и в практике образовательного процесса.

Ключевые слова: психолого-педагогические взаимодействия: этапы трансформации подходов к трактовкам психолого-педагогических взаимодействий

\section{Аксиология цифрового образования: назад в будущее?}

\section{С. Н. Костромина}

Цифровая трансформация общества поставила перед образованием задачу смены «технологического уклада»: переход на цифровую систему управления, разработка цифровых образовательных ресурсов, открытый доступ в сеть, использование гаджетов, онлайн-технологий и т. д. В то же время образование продолжает оставаться основным механизмом соци- 
огенеза. В главе обсуждается проблема сохранения основной функции образования - становление и развитие личности в условиях цифровизации. Анализируются три основных образовательных подхода, имеющих место в отечественном образовании: академический, технологический (компетентностный) и антропологический. Каждый из подходов тем или иным образом транслирует определенные ценности и культуру: культуру элитарности, культуру полезности, культуру достоинства. В этом же контексте рассматриваются идеи цифрового образования. Индивидуализация образовательного процесса за счет цифровых средств ведет к его персонализации и адаптивности. При этом проблема формирования нравственно-ценностных основ личности, погружения в систему духовных координат общества, смысловыражения и смыслодвижения не решается. Открытость информационных ресурсов позволяет перейти к педагогике возможного, но требует переключения с режима детерминации на режим самодетерминированности (свобода выбора, «свобода поступления», рефлексия, самосознание, ответственность). Онлайн-коммуникация соединяет людей из отдаленных пространств, обеспечивая мобильность и гибкость взаимодействия, но не является форматом со-бытийности, где через сопричастность развиваются социальные ценности, реализуется активность человека в переживании. Следуя за технологиями, важно не утратить гуманистические ценности и перейти из идеологического прошлого к культуре достоинства в образовании, построенной на ценности личности, сотрудничестве, поддержке и уважении.

Ключевые слова: цифровое образование; личность; ценности; культура; технологии; смысл

\section{Навигационные характеристики цифровых текстов как фактор успешного информационного поиска обучающихся \\ Т. С. Леднева, А. И. Ковалев}

Цифровизация профессиональных и образовательных сфер трансформирует традиционные практики взаимодействия человека с текстовыми данными и требует наличия не только умений эффективного извлечения информации, но и создания оптимальных условий работы с цифровыми текстами. Важными параметрами, влияющими на эти процессы, являются 
динамические и навигационные характеристики цифровых текстов, различные сочетания которых облегчают или затрудняют процесс поиска информации. В данной главе была разработана и апробирована экспериментальная процедура определения влияния навигационных и динамических характеристик представления цифрового текста на цифровых устройствах на эффективность информационного поиска человеком. Для объективации успешности работы с текстами была использована методика регистрации движений глаз. Были созданы четыре типа среды для представления цифрового текста, различающиеся по способу динамического взаимодействия с текстом и по количеству навигационных подсказок. Навигация по тексту через прокручивание или постраничное перелистывание определила две большие группы сред по способу взаимодействия с текстом. Внутри каждая группа также была разделена на две подгруппы по признаку наличия или отсутствия возможности совершать обзор текста целиком. В эксперименте приняли участие 15 испытуемых. Было обнаружено, что значения длины пути перемещения взора по тексту и времени поиска ответа оказались значимо меньшими для сред с навигацией через прокручивание с возможностью совершения обзора всего текста через миниатюры страниц. Таким образом, разработанная процедура позволила выявить различия в навигационном поведении человека при чтении текстов, представленных в различных условиях взаимодействия с ними.

Ключевые слова: навигация в тексте; чтение; айтрекинг; цифровое образование

\section{Психологические механизмы развития правового самосознания личности: теоретико-методологические аспекты} Р.Р. Муслумов

Рассматриваются теоретико-методологические аспекты психологических механизмов в развитии правового самосознания личности. В правовом поведении существенная роль принадлежит самосознанию, которое представляет собой знание себя, отношение к себе, самооценку, мнение о себе как о личности. Правовое самосознание предопределяет характер правовых отношений человека, его правовую позицию, поступки и правовое поведение. В основе развития правового самосознания личности 
лежат психологические механизмы, представляющие динамическую психологическую систему, которая включает различные условия, факторы, средства, структуры, отношения, связи и другие психические явления, обеспечивающие становление, формирование, протекание и регуляцию этого процесса. В работе дана классификация основных психологических механизмов развития правового самосознания. Развитие правового самосознания является результатом деятельности всей системы психологических механизмов. В зависимости от конкретной ситуации и развития личности (ее возраста, психологических свойств и качеств, здоровья, социальной роли, межличностных отношений и пр.) значимость отдельных механизмов изменяется. Показана сущность психологических механизмов, рассмотрены история их изучения и структура. Раскрыта роль правовой социализации в правовом развитии личности. Особое внимание обращено на анализ фундаментальных психологических механизмов в развитии правового самосознания личности: мотивацию и рефлексию. В развитии правового самосознания личности психологические механизмы выполняют следующие основные функции: отражательную, побудительную, регулятивную и контролирующую.

Ключевые слова: правовое самосознание; психологический механизм; правовая социализация; мотивационный механизм; мотивы; ценностные ориентации; рефлексия; идентификация; функции психологических механизмов

\title{
РАЗДЕЛ 2
}

\section{Подходы к изучению психологического благополучия}

\author{
Г.И. Борисов
}

Проблема благополучия является актуальной для многих наук, в том числе для психологии. Такая востребованность привела к большому разнообразию видов, подходов и теорий благополучия. В главе представлена попытка анализа и рассмотрения видов, подходов и теорий благополучия. Рассмотрены такие виды благополучия, как эмоциональное, физическое, социальное, профессиональное, общественное, клиническое, сексуальное, отражающие удовлетворенность или успешность различными аспектами 
человеческой жизни. Психологическое благополучие рассматривается с позиций гедонистического и эвдемонического подхода, анализируются отечественные концепции благополучия.

Ключевые слова: благополучие; психологическое благополучие; счастье; образовательный процесс; профессиональное благополучие

\section{Психологическое благополучие студентов с позиции субъектно-ресурсного подхода (на примере студентов-психологов)}

Н. Е. Водопьянова

Исследование было направлено на оценку и сравнение психологического благополучия (ПБ) студентов первого (бакалавриат) и седьмого (магистратура) года обучения, выявление личностных предикторов (ресурсов) психологического ПБ как ориентиров для профессиональноличностного развития. Представлен теоретический анализ проблемы ПБ с позиций различных подходов. Эмпирическое исследование ПБ осуществлялось на основе субъектно-ресурсного подхода. Выявлены личностные предикторы ПБ обучающихся в бакалавриате и магистратуре (первый и седьмой год обучения по специальности «Психология»). Обнаружено, что у магистрантов по сравнению с первокурсниками показатели ПБ характеризуются более высокими значениями, имеют больше корреляционных связей с ресурсами разных уровней психической регуляции, а именно с показателями волевой регуляции (настойчивость, контроль, целеустремленность), ценностно-смысловой регуляции (перфекционизм, ориентированный на других, перфекционизм, ориентированный на себя), с ресурсами самоподдержки (самоэффективность), отраженного самоотношения (самоуверенность), самооценнностью, с жизнестойкостью. Полученные факты подтверждают предположение о том, что по мере взросления и профессиональной идентификации атрибуты субъектности (интра- и интеросубъектные ресурсы) оказывают все более сильное влияние на ПБ. Повышению ПБ старшекурсников сопутствует развитие волевых, ценностно-смысловых и когнитивно-оценочных ресурсов, что свидетельствует о расширении «ресурсной базы» для последующих этапов эффективной профессионализации специалистов-психологов. Очевидно, выявленные личностные предикторы ПБ должны учитываться при выборе психоразвивающих «мишений» профессионально-личностного развития 
с помощью системы психологического сопровождения субъектов обучения с учетом их возраста и этапа профессионализации.

Ключевые слова: психологическое благополучие; позитивное функционирование личности субъекты обучения; субъектно-ресурсный подход; ментальные ресурсы личности

\title{
Субъектность как предиктор психологического благополучия одаренных подростков
}

\author{
Е. Н. Волкова, И. В. Волкова
}

В статье представлены результаты исследования психологического благополучия и субъектности 563 одаренных подростков и подростков с нормативным уровнем способностей в возрасте 15-17 лет. Значимых различий по показателям как общего психологического благополучия, так и его структурных компонентов в сравниваемых группах не выявлено, кроме значения показателя «автономность»: у одаренных подростков способность вести себя независимо сформирована лучше, чем у их сверстников с нормативным уровнем способностей. Способность устанавливать позитивные, доверительные отношения у одаренных подростков выражена меньше (различия на уровне тенденции). Развитие субъектности у одаренных подростков-мальчиков происходит посредством развития способности к рефлексии и признания свободы выбора и ответственности за этот выбор, а у одаренных девочек - за счет развития представлений о собственной уникальности. Различные компоненты субъектности выступают предикторами психологического благополучия подростков сравниваемых групп: для одаренных мальчиков это активность, способность к рефлексии, возможность свободы выбора и ответственности за него; для одаренных девочек к этим компонентам добавляется осознание и переживание собственной уникальности; для подростков-мальчиков с нормативным уровнем способностей это активность, понимание и принятие другого человека; для подростков-девочек с нормативным уровнем способностей это способность к рефлексии, возможность свободы выбора и ответственности за него, понимание и принятие другого человека, саморазвитие. Дифференциация уровня психологического благополучия одаренных 
подростков и их сверстников связана со способностью к пониманию и принятию другого человека.

Ключевые слова: одаренные подростки; субъектность; психологическое благополучие

\title{
Здоровый образ жизни и жизнестойкость современных студентов
}

Д. А. Галочкина, М. Е. Пермякова

Обсуждается проблема таких жизненных ресурсов современного студента, как жизнестойкость и ведение здорового образа жизни. Представлены результаты исследования, проведенного на выборке студентов $(n=100)$ с целью выявления взаимосвязи жизнестойкости и здорового образа жизни. Установлено, что высокая жизнестойкость связана с ведением студентами здорового образа жизни и с их эрудированностью в вопросах ведения здорового образа жизни. Выявлена прямая взаимосвязь эрудированности студентов в вопросах здорового образа жизни с субъективной оценкой своего образа жизни и соматического здоровья, а также с такими составляющими профиля здорового образа жизни, как питание и межличностные отношения. Получены данные о том, что с возрастом у студентов снижается ответственность за здоровье. У девушек выявлено большее количество связей между компонентами жизнестойкости и параметрами здорового образа жизни, чем у юношей.

Ключевые слова: студенты; здоровый образ жизни; жизнестойкость; эрудированность в вопросах здорового образа жизни; профиль здорового образа жизни

\section{Вузовский этикет и этикетное поведение в вузе: современная ситуация и перспективы изучения}

\author{
О. Н. Даниленко
}

Цель главы - обосновать актуальность и наметить перспективные направления изучения вузовского этикета. Значимость вузовского этикета объясняется рядом причин. Наличие общепринятых правил, регулирующих формы взаимодействия студентов, преподавателей и работников 
администрации, способствует созданию оптимального психологического климата и является одним из условий эффективности процесса обучения. Опыт этикетного взаимодействия студента с преподавателями оказывает влияние на формирование личности молодого человека, создавая условия для укрепления позитивной идентичности учащегося вуза. Освоение этикетных моделей поведения в период обучения в вузе является предпосылкой их реализации в будущей профессиональной деятельности, а также повседневном общении. Традиционные правила вузовского этикета предписывали проявление статусного неравенства студентов и преподавателей при обязательном взаимном уважении. В настоящее время определенность и императивность традиционных правил вузовского этикета уменьшается. Этим обусловлена актуальность исследования вузовского этикета и этикетного поведения. В главе представлены перспективные направления таких исследований. Первое - изучение влияния радикальных изменений в организации деятельности вузов (включение вузов в сферу услуг, вовлечение студентов в совместные научные проекты и др.) на отношение студентов и преподавателей к традиционным моделям этикетного поведения. Второе - исследование коммуникативных практик, возникающих в связи с развитием информационных технологий и реализацией онлайн-общения преподавателей и студентов для решения образовательных и научных задач. Третье - изучение этикета как компонента организационной культуры вуза, претерпевающей значительные изменения в условиях рыночных отношений. Четвертое - поиски интрапсихических факторов, побуждающих субъекта к соблюдению или нарушению традиционных моделей вузовского этикета и их трансформации. Приводятся краткие сведения об авторских методиках, направленных на исследование психологии отношения к этикету, и полученных результатах. Обозначены перспективы внедрения намеченных и проведенных исследований в практику.

Ключевые слова: студенты и преподаватели вузов; этикет; вузовский этикет; этикетное поведение; этикетные модели поведения; статусные различия; организационная культура вуза; коммуникативная компетентность студентов 


\section{Конструктивное отношение к себе как профессионалу и благополучие личности \\ С. В. Духновский}

В главе с привлечением эмпирического материала обсуждаются вопросы благополучия субъектов образовательного процесса в контексте отношения к себе как профессионалу. Нашло свое подтверждение предположение о том, что конструктивное отношение к себе является условием благополучия личности, индикаторами выступают соответствующий кризисный профиль и удовлетворенность карьерой. Выборка исследования составила 97 чел. (преподаватели высших учебных заведений). В обследовании использовались авторские методики: «Определение отношения к себе профессионала», «Переживание кризиса личностью», «Шкала удовлетворенности карьерой», «Методика определения мотивационных типов». На основании эмпирических данных в зависимости от преобладающего кризисного профиля были выделены две группы субъектов образовательного процесса: 1) «благополучные» субъекты - с кризисным профилем «психологическое здоровье с благоприятным прогнозом»; 2) «неблагополучные» субъекты - с профилем «истощение с неопределенным прогнозом». Установлено, что в группе «благополучных» субъектов образовательного процесса с кризисным профилем «психологическое здоровье с благоприятным прогнозом» выражено конструктивное отношение к себе - респонденты обладают повышенным уровнем притязаний, установками на профессиональное саморазвитие и представлением о себе как профессионале, показатели принятия себя как профессионала и установки на должностное развитие выражены умеренно. Для них характерен повышенный уровень удовлетворенности карьерой и «профессиональный» тип трудовой мотивации. В группе «неблагополучных» субъектов с профилем «истощение с неопределенным прогнозом» преобладает деструктивное отношение к себе - пониженный уровень притязаний, принятия себя и представлений о себе как профессионале, слабая ориентация на профессиональное саморазвитие и должностное развитие в сочетании с пониженным уровнем удовлетворенности карьерой и «избегательным» типом трудовой мотивации.

Ключевые слова: профессионал; благополучие; кризисный профиль; конструктивное отношение к себе; удовлетворенность карьерой; трудовая мотивация

704 


\section{Личностные факторы адаптации студентов к новой социокультурной среде}

Е. А. Столярчук, М. А. Круглова

Рассмотрены особенности адаптации студентов, участвующих в международных обменах. Проанализированы основные теоретические концепции, объясняющие протекание процессов адаптации/дезадаптации к новой социокультурной среде; выделены этапы процесса адаптации визитеров; описана общетеоретическая интегративная модель кросскультурной коммуникации Ю. Кима, на основе которой был построен дизайн исследования. В эмпирическом исследовании изучались следующие показатели: адаптация к новым социокультурным условиям (методика Л. В. Янковского); социально-психологическая адаптация (методика К. Роджерса и Р. Даймонда в адаптации А. К. Осницкого); личностные факторы: готовность к переменам (методика Родник, Хезер, Голд, Хал в адаптации Н. А. Бажанова, Г. Л. Бардиер), толерантность к неопределенности (методика С. Баднер в адаптации Г. У. Солдатова) и локус контроля (методика Дж. Роттера). Для подтверждения степени обоснованности и достоверности результатов исследования были использованы методы математико-статистической обработки данных: сравнительный анализ с использованием критерия Манна - Уитни для выявления достоверности различий между показателями в зависимости от пола респондентов; корреляционный анализ с использованием коэффициента ранговой корреляции Спирмена для выявления взаимосвязей между показателями адаптации и личностными факторами; регрессионный анализ с целью выявления влияния личностных факторов на общий показатель адаптивности студентов. Было установлено, что от выраженности таких личностных факторов, как интолерантность к неопределенности, адаптивность и находчивость, зависит адаптация студентов к новой социальной среде.

Ключевые слова: адаптация; дезадаптация; культурный шок; образование; международный обмен; студенты 


\title{
Психологическое благополучие студентов Беларуси
}

\author{
Г. А. Фобанова
}

Психологическое благополучие студентов как субъективная оценка ими своего функционирования с точки зрения реализации своих потенциальных возможностей в прошлом, настоящем и будущем - одна из значимых составляющих успешного развития общества. В главе анализируется сущность феномена психологического благополучия в целом и благополучия студентов в частности; обосновывается важность постоянного мониторинга данного психологического параметра. Приводятся результаты эмпирического исследования психологического благополучия белорусских студентов различных курсов. Установлено, что только четверть опрошенных студентов имеют высокие показатели психологического благополучия. Такие показатели психологического благополучия, как «автономия» и «управление окружением», у студентов первого курса значимо ниже, чем у старшекурсников. Показатели шкалы «позитивные отношения с окружением» у юношей значимо ниже, чем у девушек. Полученные результаты во многом связаны со сложностями совладания с учебными, социальными, бытовыми, экономическими и психологическими вызовами, которые стоят перед студентами каждого курса. Однако показатели студентов первого курса вызывают наибольшую тревогу и требуют нахождения и разработки новых мероприятий по оптимизации их адаптации и развития личностных ресурсов. Предлагаются практические рекомендации (локальные и общесистемные) по повышению психологического благополучия студентов.

Ключевые слова: психологическое благополучие; социально-психологическая адаптация; студенты; психологическая служба университета; школьный психолог; психологическое сопровождение

\section{Активная жизненная позиция}

как фактор психологического благополучия студентов

\author{
Е. А. Хохолева, С. Д. Липатова
}

Рассматриваются теоретические и методологические аспекты жизненной позиции студентов вуза. Современная реальность демонстрирует личностно-ориентированный подход, в центре которого находится личность 
и ее интересы, активная жизненная позиция становится необходимой для успешной самореализации. Бизнес-среда требует от выпускников вузов сегодня не только профессиональной компетентности, но и способности проявлять активную жизненную позицию и адаптироваться к быстро меняющейся социально-экономической среде. Цель главы - обсуждение вопросов формирования активной жизненной позиции студенческой молодежи как фактора психологического благополучия. Представлена авторская типология видов жизненной позиции (активно-позитивная, активно-негативная, пассивно-негативная, пассивно-равнодушная). Исследование проходило в три этапа. На первом этапе с помощью авторской анкеты «Активная жизненная позиция» и опросника «Виды жизненной позиции» были определены особенности жизненной позиции студентов УрФУ. На втором этапе проведен эксперимент, формирующий активную жизненную позицию студентов в образовательной среде. На третьем этапе проанализированы изменения жизненной позиции студентов с использованием математических методов. Теоретический анализ показал, что большинство авторов предлагают активную жизненную позицию формировать через внеучебные воспитательные мероприятия. В главе описывается иной путь ее формирования - через активные методы обучения. В ходе эмпирического исследования было доказано, что применение активных методов в процессе обучения позволяет развивать активную жизненную позицию студентов. Сопоставление результатов уровня активно-позитивной жизненной позиции до и после коррекции с применением $T$-критерия Вилкоксона показало, что полученная величина $T=40$ попадает в зону значимости. Формирование принципов, мировоззрения, убеждений, моральных норм студентов с помощью использования активных методов обучения способствует развитию активной жизненной позиции и формирует психологическое благополучие обучающихся.

Ключевые слова: жизненная позиция; виды жизненной позиции; формы активной жизненной позиции; активные методы обучения; психологическое благополучие 


\section{Проблема профессиональной идентичности студентов-психологов в современном вузе \\ М. В. Чумаков, И. В. Васильева}

В исследовании рассматривается парадоксальная ситуация: с одной стороны, профессиональная идентичность традиционно понимается как характеристика, способствующая академической успешности студентовпсихологов, с другой - в реальной практике наблюдается последовательное снижение показателей профессиональной идентичности студентов-психологов. Не менее важным является то, что профессиональная идентичность - фактор субъективного благополучия человека. В исследовании участвовало 117 студентов-бакалавров, обучающихся по направлению «Психология», с 1-го по 4-й курс, а также студенты магистратуры. Метод сбора данных: опросник профессиональной идентичности студентов (У.С. Родыгиной). Расчет результатов методом дисперсионного однофакторного анализа показал, что профессиональная идентичность снижается в зависимости от курса, на котором учится студент: $F(32,385,13)=1,8065$, $p=0,005538$. Позитивные эмоции, связанные с удовлетворением потребностей в профессии, снижаются от начала к завершению обучения в вузе, а отрицательные, наоборот, растут. Позиция активного отношения студента к приобретаемой профессии снижается от начала к завершению обучения в вузе, позиция пассивного отношения растет, достигая максимума на 3-м курсе, и снижается к выпускному курсу. Полученные результаты поднимают значимую проблему: будущие психологи с ростом профессиональной квалификации становятся менее активными и испытывают все меньше позитивных эмоций от вовлечения в профессиональную психологическую деятельность. Таким образом, возникает необходимость пересмотра технологий обучения для сохранения профессиональной идентичности студентов-психологов, как с точки зрения активности, так и с точки зрения эмоционального реагирования.

Ключевые слова: студенты; профессиональная идентичность; психологическое благополучие; эмоции и активность в профессиональной деятельности 


\title{
Исследование толерантности к неопределенности у юношей и девушек старшего подросткового возраста в связи с их личностными особенностями
}

\author{
Е. П. Шаньгина, О. С. Виндекер
}

Представлены результаты исследования структуры толерантности к неопределенности у юношей и девушек в возрасте $14-17$ лет $(n=72 ; 45$ девушек и 27 юношей) в связи с мотивацией достижения, самоэффективностью и автономией. Предполагается, что уже в старшем подростковом возрасте проявляется гендерная специфика развития толерантности к неопределенности. Определено, что у юношей и девушек общая толерантность к неопределенности связана с возрастом - чем старше подросток, тем более выражены его возможности реагировать на сложные, неопределенные стимулы. Наблюдаются гендерные предпочтения по отношению к неопределенности. У юношей толерантность к неопределенности достоверно выше преимущественно благодаря открытости новому опыту и положительному отношению к ситуациям неопределенности. В отличие от девушек, у юношей принятие неопределенности и предпочтение трудных задач сопряжено с высокой мотивацией достижения. У девушек выбор трудных задач связан с автономностью и самоэффективностью в значимой для них деятельности, но при этом уровень их самоэффективности никак не связан с положительным отношением к ситуациям неопределенности. Результаты исследования могут быть учтены при разработке дополнительных образовательных программ для школьников, занимающихся проектной деятельностью, с учетом возраста и пола обучающихся.

Ключевые слова: толерантность к неопределенности; старший подростковый возраст; мотивация достижения; автономия; шкала самоэффективности 


\title{
РАЗДЕЛ 3
}

\section{Методика профессионально-ориентированного автобиографирования как средство сопровождения профессионального самоопределения студентов -} будущих педагогов

\author{
Е.Г. Белякова
}

Анализируются возможности нарративного подхода для сопровождения профессионального самоопределения студентов - будущих педагогов. Профессиональная идентичность, являющаяся важнейшим критерием профессионального самоопределения, рассматривается как продукт нарративной активности личности, разворачивающейся через создание авторских текстов с описанием индивидуального профессионального пути. Установлено, что свойства нарративной идентичности и закономерности ее развития, и прежде всего ее смысловая обусловленность, гибкость и возможность переконструирования, отвечают особенностям современной социокультурной ситуации «неопределенности - сложности - разнообразия» (А. Г. Асмолов). Соответственно, это позволяет опираться на положения нарративного подхода при разработке конкретных методик сопровождения профессионального самоопределения. Автобиографический нарратив как способ организации опыта воспроизводит в повествовании жизненную историю и социокультурный контекст ее порождения. В качестве особого типа нарративной активности проанализировано профессионально-ориентированное автобиографирование. Выделены его сущность (воссоздание целостной субъективной картины профессионального пути) и функции (смыслообразующая, диагностическая, развивающая/формирующая, мотивирующая, рефлексивная, проектировочная, интеграционная). Представлены конкретные варианты нарративных методик, разработанных в рамках авторской модели сопровождения профессионального самоопределения студентов-педагогов. Методики соотнесены с содержанием этапов сопровождения и позволяют активизировать процесс профессиональной самоидентификации через конструирование проспективной, актуальной и ретроспективной идентичностей, рефлексию опыта осуществления профессиональных проб, осмысление нового опыта и его интеграцию в целостное представление 
о себе как профессионале и своем профессиональном пути, через постановку новых целей профессионального развития.

Ключевые слова: профессиональное самоопределение; профессиональная идентичность; нарратив; методика профессионально-ориентированного биографирования; сопровождение профессионального самоопределения студентов-педагогов

\section{Развитие рефлексивной компетентности педагога общеобразовательного учреждения}

Т. И. Гречухина, А. В. Усачева

Проблема развития рефлексивной компетентности учителя связана с переходом российской системы общего образования на Федеральные государственные стандарты нового поколения и требованиями профессионального стандарта педагога. В современных условиях рефлексивная компетентность - основа возникновения инновационной среды в учреждении образования, которая создает возможности для профессионального развития и творчества. Необходимость развития рефлексивных способностей у педагогов как условия профессиональной деятельности не вызывает споров в профессиональном сообществе. Проектирование системы условий, средств, механизмов, способствующих профессиональному развитию педагогов, является развивающей функцией современной системы образования. В связи с этим актуальной является потребность образовательной практики в описании особенностей и содержания методик развития рефлексивной компетентности педагогов, выявлении эффективности их применения в реальном образовательном процессе общеобразовательного учреждения. Описание методик развития рефлексивной компетентности - задача не только педагогики, но и психологии, поскольку рефлексивная компетентность является феноменом, определяющим ценности и саморазвитие личности педагога. Авторы описывают рефлексивные методики (дидактические и технические средства), способствующие формированию рефлексивной среды, развитию компонентов рефлексивной компетентности педагогов в коллективных формах деятельности в условиях общеобразовательного учреждения. Полученные результаты показали, что в условиях рефлексивной среды общеобразова- 
тельного учреждения возможно формирование новых культурных норм деятельности, ее критический анализ. Проектирование системы условий и средств развития рефлексивной компетентности педагогов способствует положительной динамике профессионального развития (профессиональные качества субъекта и объекта), развитию компонентов рефлексивной компетентности (интеллектуальный, личностный, кооперативный, коммуникативный), ориентирует на коллективные формы профессионального взаимодействия.

Ключевые слова: рефлексивная компетентность; педагог; профессионализм; дидактический метод

\section{Проектирование карьерной стратегии современных педагогов в условиях цифровизации}

Е. М. Громова, Д. И. Беркутова, Т. А. Горшкова

Авторами обозначены проблемные точки и основные аспекты влияния проходящей сейчас очередной информационной революции, которая по оценкам большинства экспертов является одной из крупнейших в истории человеческой цивилизации, поскольку затрагивает глубинные основы того, как люди взаимодействуют друг с другом и окружающим миром. Сегодня цифровизация подвергла глобальной перестройке абсолютно все сферы нашей жизни. В исследовании сделана попытка проанализировать и переосмыслить систему профессионального образования педагогов в условиях цифровизации. Авторы подробно разбирают тезисы, обозначенные в ключевых документах, определяющих векторы трансформации профессионального образования в нашей стране: Указе Президента «О национальных целях и стратегических задачах развития Российской Федерации на период до 2024 года», нацпроектах «Образование» и «Цифровая экономика», ФГОС ВО. На основе данного анализа авторы убедительно доказывают, что рассматривать цифровизацию в профессиональном образовании педагогов нельзя лишь с позиции формирования цифровых компетенций, продиктованных новыми требованиями. Цифровизация в сфере профессионального образования - это гораздо более масштабное явление. Она изменяет и способы профессиональной деятельности педагога, и возможности для взаимодействия с другими участниками образо- 
вательного процесса (коллегами, учениками, их родителями), и процессы профессиональной идентификации за счет включения в формальные и неформальные сообщества в интернета и пр. Особо подчеркивается, что при проектировании карьеры в сфере образования зачастую наблюдается отсутствие перемещения в организационной иерархии образовательного учреждения («вертикальная карьера»). Но это не означает, что педагог не развивается. Как правило, в сфере образования карьерная стратегия выстраивается «внутри профессии» («горизонтальная карьера»), т. е. идет становление профессиональной идентичности. И сегодня педагогам необходимо помочь использовать положительные эффекты цифровизации для выстраивания своей карьерной стратегии, чтобы хоть немного нивелировать ее негативные последствия.

Ключевые слова: карьера педагога; цифровизация; профессиональная идентичность

\title{
Профессионализм педагога. Теория поколений: кому у кого учиться?
}

\author{
М. Н. Дудина
}

Теория поколений Нейла Хоува и Уильяма Штрауса почти неизвестна педагогам-профессионалам. В то же время даже на бытовом уровне заметна динамика потребностей цифрового детства, отрочества и юности, соответствующих поколенческих паттернов, что все чаще приводит к конфликту педагогов и обучаемых на всех уровнях образования. Развитие цифровизации информационного общества, доминирование культуры потребления привело к восприятию знаний как товара. Это влияет на все сферы жизни общества, трансформирует личность учащегося и педагога как участников образовательного процесса, с его целями, содержанием, технологиями и достигаемыми результатами. Обращаясь к основным положениям Л. С. Выготского (культурно-исторической теории развития высших психических функций), автор предлагает отказаться от традиционной образовательной модели и перейти к личностно-ориентированной, к использованию интерактивных инновационных технологий как средства достижения педагогического профессионализма, релевантного вызовам времени, преодолевающим отчуждение поколений от образования 
на этико-гуманистических путях психолого-педагогической фасилитации. Меняющаяся личность в меняющемся мире - проблема междисциплинарного характера - ориентирует систему образования на модернизацию целей, процесса, результата обучения и воспитание учащихся, креативно развитых, открытых к инновациям, готовых ими пользоваться во благо человека, природы и социума, способных создавать новое.

Ключевые слова: теория поколений; традиционная и инновационная дидактика; личностно-ориентированная образовательная модель; интерактивные методы обучения; педагог- фасилитатор

\section{Структурно-уровневая периодизация профессионального становления личности Ю. П. Поварёнков}

В главе определено понятие периодизации, которая рассматривается в качестве методического междисциплинарного приема деления процесса развития на этапы по формальным (временным) и содержательным (характеристика новообразований) основаниям. Зафиксированы ведущие типы периодизаций профессионального становления, сложившиеся в отечественной и зарубежной психологии, в качестве таковых выделены онтогенетические и профессионалогенетические. Показано, что формальным основанием для выделения стадий онтогенетических периодизаций является хронологический возраст профессионала, а для профессионалогенетических - профессиональный (карьерный) возраст. Дана развёрнутая характеристика сильных и слабых сторон каждой периодизации. Определено, что онтогенетические и профессионалогенетические периодизации опираются на разные методологические основания и поэтому противопоставляются психологами. Выделены и описаны два базовых уровня психологического анализа профессионального и карьерного развития личности, отражающих два аспекта целостного процесса профессионального становления личности, - трудовой и профессиональный путь. Раскрыто содержание трудового и профессионального пути, определены базовые понятия, используемые для их описания. Установлено, что онтогенетические периодизации описывают трудовой путь личности, профессионалогенетические - профессиональный путь. В главе дока- 
зывается, что адекватная периодизации должна учитывать оба уровня профессионального развития личности и поэтому она должна быть, как минимум, двухуровневой.

Ключевые слова: профессиональное и карьерное развитие; периодизация; трудовой путь личности; профессиональный путь личности

\title{
Особенности саморазвития педагогов и психологов с профессиональными деформациями
}

\author{
О. Б. Полякова
}

Выявлены особенности профессиональных деформаций педагогов и психологов: высокий уровень эмоционального истощения; выше среднего уровень деперсонализации, личностного отдаления, профессиональных деформаций вообще, психоэмоционального истощения, редукции личных достижений, редукции профессиональной мотивации. Определены особенности саморазвития педагогов и психологов с профессиональными деформациями: низкий уровень мотивационного компонента, способности к саморазвитию и самообразованию; ниже среднего уровень гностического компонента, готовности к профессиональному саморазвитию, готовности к саморазвитию, когнитивного компонента, оценки проекта профессиональной поддержки как возможности профессиональной реализации, саморазвития, способности к самоуправлению в профессиональной деятельности, стремления к саморазвитию; средний уровень коммуникативного компонента, нравственно-волевого компонента, организационного компонента, реализации потребностей в саморазвитии, самооценки личностных качеств, способствующих саморазвитию. Доказано, что высокое эмоциональное истощение педагогов и психологов приводит к снижению мотивационного компонента саморазвития и способности к саморазвитию и самообразованию. Установлено, что на снижение гностического компонента, готовности к профессиональному саморазвитию, готовности к саморазвитию, когнитивного компонента, оценки проекта профессиональной поддержки как возможности профессиональной реализации, саморазвития, способности к самоуправлению в профессиональной деятельности и стремления к саморазвитию влияет повышенная степень выраженности деперсонализации (личностного отдаления), психоэмоци- 
онального истощения, профессиональных деформаций вообще, редукции личных достижений и профессиональной мотивации.

Ключевые слова: мотивационный компонент саморазвития; профессиональные деформации; саморазвитие; способность к саморазвитию; эмоциональное истощение

\section{Социально-психологические аспекты развития кризиса утраты профессиональной деятельности у педагогов в период поздней зрелости \\ Э. Э. Сыманюк, А. А. Печеркина, Т. Д. Буковей}

Рассматриваются основные социально-психологические аспекты развития кризиса профессиональной деятельности педагогов в период поздней зрелости. Показано, что в рамках образовательной организации могут появляться педагогические конфликты, выступающие своеобразным продолжением конфликта поколений и основанные на принципиальных различиях в системах ценностей и мировоззрении, сформированном в процессе социализации. Динамика конфликта детерминирует возрастание негативных переживаний, усугубляя процесс преодоления кризиса утраты профессиональной деятельности. В качестве социально-психологических факторов кризиса утраты учителем профессии были выделены межпоколенческие конфликты, профессиональные деформации и социальные установки в обществе относительно людей в возрасте поздней зрелости. Исследование данных факторов позволит определить психологические механизмы для оказания социально-психологической поддержки педагогам в период переживания кризиса утраты профессии, а также будет способствовать повышению качества жизни в период поздней зрелости.

Ключевые слова: кризис; профессиональный кризис; кризис утраты профессии; учитель; социально-психологические аспекты кризиса утраты профессии 


\section{РАЗДЕЛ 4}

\section{Психологические особенности влияния кибербуллинга на молодежь \\ Е. В. Аверкиева}

По данным статистики, в развитых странах более 90 \% молодежи имеют доступ в интернет, при этом более трети детей 15-18 проводят в сети все свободное время. По данным различных исследований, именно коммуникативная функция интернета вышла на первый план для большинства пользователей. Тем не менее, как и в любом коммуникативном пространстве, в реальности человек может столкнуться в сети с проявлениями деструктивного поведения в общении. Отдельное внимание авторы уделяют кибербуллингу как примеру антисоциального поведения в интернете, упомянуты основные российские и зарубежные исследователи данной темы. Приводится определение феномена кибербуллинга, его характерные черты и распространенные формы. Представлены данные исследований последних лет о распространенности кибербуллинга как на территории России, так и за рубежом, указываются возможные причины расхождения в значениях. Рассматривается влияние кибербуллинга на различные аспекты жизни молодежи. Выделяются последствия психологического, социального, педагогического и физиологического характера. Отдельно рассмотрены гендерные и инструментальные различия в воздействии кибербуллинга на молодежь. Согласно результатам упомянутых исследований, подтверждается негативное воздействие кибербуллинга. Обосновывается необходимость дальнейшего исследования индивидуальных особенностей участников кибербуллинга в молодежной среде с целью выявления и внедрения эффективных стратегий совладания с данным феноменом.

Ключевые слова: молодежь; подростки; кибербуллинг; интернет-коммуникации; психологическое благополучие; стратегии совладания 


\title{
Малый город как пространство образования: \\ психологические аспекты
}

Т. Ю. Бистрова

Развивается взгляд на предметно-пространственную среду малого города как на образовательное пространство, хранящее историю места, его «дух» и идентичность. Показана недооценка жителями малых городов России городской среды и ее элементов, в том числе историко-архитектурных и историко-культурных объектов. Вовлечение в их актуализацию, соучастие процессам трансформации территорий (в том числе бывших индустриальных) прокомментированы с психологических позиций, с учетом ментальности и стереотипов жителей малых городов.

Ключевые слова: малый город; социокультурная среда города; российский город; психология горожан; стереотипы; «культурная травма»; вовлечение; участие; ментальность

\section{Проблема подросткового буллинга: актуальные направления современных исследований и организация помощи}

\author{
Е. Н. Волкова, А.А. Реан, И. В. Волкова
}

Результаты теоретических и экспериментальных исследований подросткового буллинга составляют основу для разработки программ его профилактики. Критериями идентификации буллинга выступают неоднократность и/или периодичность насильственных ситуаций; намеренность нанесения вреда; причинение физического или психологического вреда жертве; неравенство сил у обидчика и жертвы; невозможность для жертвы покинуть ситуацию буллинга. Для мониторинга и сравнительных исследований распространенности буллинга в образовании наиболее информативен реверсивный показатель, фиксирующий количество детей, не участвующих в травле, а не количество жертв или булеров. Организация профилактической работы в школе должна опираться на знание личностных и социальных особенностей обидчиков, жертв и свидетелей буллинга. Свидетели буллинга являются ключевыми адресатами профилактической работы. Семья, школа и школьная среда могут выступать провоцирующими и протективными факторами подросткового буллинга. Высокая опосредо- 
ванность буллинга факторами культуры и одновременно недостаточная изученность подросткового буллинга в условиях российского образования определяет высокую актуальность научных исследований этого направления для разработки программ профилактики буллинга в школе.

Ключевые слова: подростковый буллинг; критерии выявления; распространенность; обидчики; жертвы; свидетели; семья; образовательная среда

\section{Просоциальное поведение и психологическое благополучие учащейся молодежи П. А. Кисляков, Е. А. Шмелева}

Проведен анализ и обоснована взаимосвязь просоциального поведения и психологического благополучия молодежи. В рамках исследования проведен обзор публикаций отечественных и зарубежных авторов, тестирование студентов одного из московских вузов $(n=73)$ в возрасте от 19 до 24 лет в форме письменного опроса. Использовались следующие методики: «Шкала субъективного благополучия» (А. Перуэ-Баду, в адаптации М.В. Соколовой); «Шкала альтруизма» (Ф. Раштон, в адаптации Н.В. Кухтовой). Был проведен вторичный анализ данных Европейского социального исследования - 2018 (ESS9). В качестве социальной единицы в исследуемой базе данных были выбраны жители России в возрасте $17-26$ лет $(M=20)$, основной род занятий которых обучение $(n=116)$; 49 \% - женщины, 51 \% - мужчины. Полученные эмпирические данные обрабатывались с помощью анализа процентных соотношений, корреляционного анализа Пирсона. Расчеты производились на базе пакета статистических программ SPPS 22.

Проведенное исследование показало, что среди большинства студентов субъективное благополучие проявляется на достаточном уровне. Большая часть респондентов продемонстрировала средний уровень развития альтруизма. Установлено, что между альтруизмом и уровнем субъективного благополучия студентов существует корреляционная связь. Через участие в просоциальной активности и формирование просоциальной мотивации студентам удается обеспечить состояние психологического благополучия (безопасности). Выявлено наличие взаимосвязи также между самооценкой счастья и восприятием окружающих людей как готовых помогать 
друг другу, а также между ценностями безопасности и оказания помощи окружающим людям. Выявленные взаимосвязи позволяют прогнозировать уровень психологического благополучия личности в зависимости от ее просоциальной активности. В процессе духовно-нравственного развития и личностного становления целесообразно в рамках реализации гуманитарных дисциплин использовать тренинги и ситуативное моделирование, направленное на решение моральных дилемм, а также реализацию волонтерских практик и социально значимых проектов.

Ключевые слова: волонтерство; психологическое благополучие; безопасность; просоциальная активность; молодежь; ценности; помощь; альтруизм

\section{Наружная реклама как фактор искажения реального образа города в представлении молодежи \\ Е. О. Мазурчук, Н. И. Мазурчук}

Исследование наружной рекламы как фактора искажения реального образа города в представлении молодежи проведено в рамках актуального для современной науки направления - сохранение психологической безопасности и психологического благополучия населения. Аргументировано доказано, что данным фактором может выступать наружная реклама, оказывающая существенное влияние на уровень воспитанности молодежи (педагогический аспект), и особенность восприятия молодежью реального образа города (психологический аспект). Вместе с тем авторами акцентируется внимание на том, что наружная реклама, как правило, способствует формированию неадекватного образа города, приводит к его искажению в сознании молодых людей, чем оказывает негативное влияние на их психологическое здоровье. В тексте с позиции различных подходов рассматривается основополагающее понятие «молодежь», дается содержательное описание наиболее эффективного и распространенного метода продвижения товаров и услуг, а также элемента национальной культуры и основного механизма ее формирования - наружной рекламы. Для исследования данной проблемы применялся комплекс обзорно-аналитических, теоретических, эмпирических методов и методов обработки и интерпретации результатов. По результатам анкетирования молодежи (обучающихся в ФГБОУ ВО «Уральский государственный педагогический 
университет») была зафиксирована разница в отношении к наружной рекламе в зависимости от пола и возраста респондентов. С помощью метода математической статистики выделено четыре группы (кластера) испытуемых, имеющих разные характеристики восприятия наружной рекламы как фактора искажения реального образа города. Вместе с тем в процессе описания групп (кластеров) были зафиксированы феминные качества восприятия и маскулинные качества восприятия наружной рекламы у респондентов, вошедших в выборку. Подтверждение совокупного влияния пола, возраста и качества восприятия молодежью наружной рекламы определило научную новизну результатов. Материалы исследования могут стать источником теоретических и практических знаний для специалистов, занимающихся поиском и формированием модели городских публичных пространств, обусловливающих сохранение психологического здоровья и благополучия молодежи.

Ключевые слова: молодежь; наружная реклама; реальный образ города; феминные качества восприятия; маскулинные качества восприятия

\section{Жестокое обращение с детьми: понятие, последствия и направления профилактики \\ Н. А. Томина, Н. Г. Церковникова}

Актуальность рассмотрения вопросов жестокого обращения с ребенком и необходимости разработки и применения мер профилактики данной проблемы не вызывает сомнения. Приведены ссылки на немногочисленные статистические данные в России по данной проблеме. В главе рассмотрены понятия жестокого обращения и насилия в отношении детей. Отмечаются различные формы жестокого отношения к детям: действие и бездействие, насилие и пренебрежение потребностями ребенка. Акцентируется внимание на травматичном характере различных форм жестокого обращения с детьми. Также описываются физические и психологические виды последствий жестокого обращения с ребенком, а также ближние и отдаленные последствия. Обоснована необходимость профилактической работы, которая направлена на предупреждение жестокого обращения с детьми и пренебрежения их потребностями. Обозначены цели и формы профилактической работы со взрослыми, детьми и подростками, 
а также представлены меры профилактики, направленные на улучшение взаимодействия между ребенком и взрослым. Раскрыты направления профилактики жестокого обращения с детьми, которые могут быть использованы в образовательной организации. Система профилактики жестокого обращения с детьми направлена на поиск выходов и нахождение альтернативных, более эффективных и экологичных способов взаимодействия, поддержание взрослых и детей в различных ситуациях. Система профилактики жестокого обращения с детьми ориентируется на ценности детства, семьи и воспитания в ней.

Ключевые слова: ребенок; жестокое обращение; насилие; профилактика; просвещение

\title{
РАЗДЕЛ 5
}

\section{Трансформация представлений о школе} у учащихся на разных этапах школьного курса обучения

\author{
О. Ю. Зотова, Л. В. Тарасова
}

Исследования изменений, происходящих с детьми на разных этапах обучения, показывают, что чем выше этап школьного курса обучения, тем менее благоприятными становятся характеристики школы, по мнению детей, а ученики проявляют все меньше стремлений к достижениям. Снижение комфортности пребывания в школе детей и подростков может повлиять на академические результаты, самовосприятие, психическое здоровье, социальную компетентность, концентрацию и мотивацию. Ученики являются лучшим источником информации для оценки ситуации внутри школы, поэтому включение восприятия учащихся является критическим компонентом для оценки эффективности школьного образования. Целью исследования являлось изучение особенностей представлений о школе у учащихся на разных этапах школьного курса обучения. Выборка: учащиеся начальных классов $(n=53)$, средних классов $(n=26)$, старших классов $(n=30)$, а также студенты, обучающиеся на первом курсе вуза $(n=50)$. По результатам исследования было выявлено, что по мере обучения сам процесс усвоения новых знаний, социализации в школе в сознании учащихся отходит на второй план и базовыми оказываются процедуры контроля 
результативности: «Школа — это контроль знаний, а не узнавание нового». Параллельно с этим все чаще отмечается наличие негативных переживаний, сопровождающих обучение.

Ключевые слова: социальные представления; учащиеся; образ школы

\title{
Выбор как фактор саморазвития личности
}

\author{
И. В. Иванова
}

Глава посвящена вопросу изучения выбора (личностного, социального, экзистенциального), осуществляемого личностью на протяжении всей жизни. Выбор рассматривается в качестве фактора саморазвития, а готовность к самостоятельному и осознанному выбору, наряду с готовностью нести за него ответственность, выступает как важный показатель саморазвития. Категории саморазвития, выбора, ответственности, самостоятельности, субъектности традиционно выступают ведущими в философских, психологических и педагогических концепциях и теориях, основанных на экзистенциализме. Исторически развивающаяся концепция саморазвития наполнена педагогическим содержанием и становится все более важной для современного гуманистического образовательного процесса. В контексте современного образования особую популярность получает концепция экзистенциальной педагогики, разработанная О.Г. Гребенюк и М.И. Рожковым, основной идеей которой является формирование человека, способного к самопознанию, самореализации и самосовершенствованию на основе сделанного им выбора, осознающего смысл своего существования и реализующего себя в соответствии с выбором. В контексте рефлексивно-ценностного подхода как нового методологического подхода в педагогике, разработанного нами в рамках научной школы под руководством доктора педагогических наук, профессора РФ И. М. Рожкова, воспитание человека основывается на понимания им своей свободы и желания стать таким, каким он себя представляет. Исходя из данной идеи, важнейшей составляющей процесса воспитания свободного человека выступает педагогическое сопровождение его саморазвития. В контексте формирования готовности подростка к выбору особого внимания заслуживает реализации педагогического сопровождения саморазвития в ситуации преодоления трудностей. Актуализация решения реальной 
дилеммной ситуации рассматривается нами в качестве целевой функции педагогического сопровождения саморазвития подростков. Разработка индивидуальных маршрутов саморазвития, основанных на результатах решения подростком дилеммных ситуаций, является технологией, реализация которой видится наиболее рельефно в системе дополнительного образования детей, предполагающей широкие возможности реализации выбора.

Ключевые слова: экзистенциализм; экзистенциальная педагогика; свобода; ответственность; выбор; самостоятельность; саморазвитие

\section{Эмоционально-поведенческие проблемы подростков, обучающихся в различных образовательных средах М. М. Лобаскова, Ю. С. Измайлова}

Представлены результаты исследования эмоционально-поведенческих проблем в связи с темпераментом подростков, обучающихся в лицее и общеобразовательной школе. Нами выявлено, что у подростков общеобразовательной школы выше уровень депрессивного настроения и агрессивного поведения по сравнению с лицеистами. Высокий уровень ситуационной и личностной тревожности чаще встречается у подростков общеобразовательной школы. В ходе корреляционного анализа обнаружены различия в структуре связей эмоционально-поведенческих проблем и свойств темперамента подростков лицея и общеобразовательной школы. Значимый вес имеет фактор произвольного контроля в группе подростков-лицеистов, чем выше показатели контроля торможения, контроля активации и внимания, тем ниже проявления эмоционально-поведенческих проблем. В группе подростков общеобразовательной школы структура взаимосвязей значительно отличается как количественно, так и качественно. Мы пришли к выводу, что для лицеистов в меньшей степени характерно проявление эмоционально-поведенческих проблем по нескольким причинам. С одной стороны, в лицее организованы более благоприятные условия среды не только для когнитивного, но и для личностного развития подростков. С другой стороны, в лицее происходит «накопление» учеников с определенными свойствами темперамента. В целом можно говорить о благоприятном взаимодействии природных особенностей (темперамента) и соответству- 
ющих условий среды, что является одним из факторов психологического благополучия подростков.

Ключевые слова: эмоционально-поведенческие проблемы; темперамент; подростки; образовательная среда

\section{Связь символической и несимволической оценки количества} в условиях контроля визуальных параметров

Ю. А. Маракшина, А. О. Табуева, Ю. В. Кузьмина, М. М. Лобаскова

Способность к символической оценке количества развивается на основе ранее существовавшего несимволического представления количества. Наличие или отсутствие связи между символическим и несимволическим чувством числа может быть связано с условиями, в которых осуществляется несимволическая оценка, в частности, с нагрузкой на оценку визуальных параметров. На 1043 учащихся 4-9-х классов была продемонстрирована монотонная положительная связь несимволической оценки количества с символической оценкой количества. В частности, было продемонстрировано, как при несимволической оценке в конгруэнтных условиях (облегченного доступа к визуальным параметрам) эта связь уменьшается в процессе онтогенетического развития. Одним из объяснений наблюдаемого эффекта может служить уменьшение роли несимволического чувства числа в задачах на символическую оценку количества с возрастом.

Ключевые слова: символическое чувство числа; несимволическое чувство числа; школьный возраст

\section{Влияние семьи на самоопределение современных учащихся при выборе STEM-профессии в цифровую эпоху: концептуальные аспекты \\ Е. П. Масленникова, В. И. Исматуллина}

Экономический рост и социальное развитие общества обеспечиваются достаточным количеством специалистов высокого уровня в естественнонаучных и технических сферах, сокращенно обозначаемых акронимом STEM ( $\mathrm{S}$ - science, $\mathrm{T}$ - technology, E - engineering, $\mathrm{M}$ - mathematics). 
Спрос работодателей на выпускников с такой квалификацией и навыками растет и будет расти в будущем. Проблема гендерного неравенства, которая особенно актуальна в рамках выбора дисциплин STEM, проявляется на всех этапах социализации молодежи и характеризуется снижением мотивации девушек к выбору профессий, традиционно считающихся мужскими. Отношение к деятельности, соответствующей полу ребенка, которое транслируется родителями, также становится установкой ребенка. Феномены, оказывающие влияние на профессиональный выбор, являются комплексными и в большинстве случаев обусловлены не одной автономной причиной, а совокупностью взаимосвязанных причин. Влияние родителей на выбор академических дисциплин и профессиональное самоопределение имеет долгосрочную перспективу и играет причинно-следственную роль в выборе академических дисциплин и карьеры области STEM. Изучение вклада родителей в профессиональный выбор и направление обучения школьников является важной научной проблемой, связанной с процессами построения успешной цифровой экономики в XXI в.

Ключевые слова: STЕМ-области; вклад родителей; цифровые технологии

\title{
РАЗДЕЛ 6
}

\section{Социально-психологические условия становления субъектности учебных групп (на примере дефектологического факультета)}

\author{
Н. А. Котелевиев
}

Рассматриваются социально-психологические условия становления субъектности учебных групп на примере групп обучающихся дефектологического факультета. Раскрывается особенность изучения субъектности групп в контексте параметрической концепции развития коллектива, по Л. И. Уманскому и А. С. Чернышеву. Дается определение категорий «субъект» и «субъектность». Применение технологии построения развивающих социальных сред (социальных оазисов) в учебных группах в условиях высшего учебного заведения способствует формированию в них более высокого уровня социально-психологической зрелости, согласованности и сплоченности, как критериев проявления субъектных качеств. Становление учебных групп дефектологического факультета 
как субъектов деятельности, общения и отношений происходит через расширение вариантов совместной деятельности, в которую включаются группы, что обусловливает в последующем сближение индивидуального и группового сознания, способствует развитию внутригрупповых процессов коммуникации, формированию устойчивого благоприятного психологического климата. Представлены результаты проведенного среди обучающихся дефектологического факультета диагностического исследования по изучению условий становления субъектности учебных групп. В выводах описывается уровень проявляемых субъектных качеств групп, дается сравнительная характеристика полученных диагностических данных до включения групп в развивающую социальную среду и расширения веера совместной деятельности и после.

Ключевые слова: субъектность; развивающая социальная среда; учебная группа; совместная деятельность

\title{
Занятия в инклюзивной коррекционно-развивающей группе
} как способ развития коммуникативных навыков и навыков саморегуляции у детей с ограниченными возможностями здоровья (ментальные и поведенческие нарушения)

\author{
Ю. В. Мягкова
}

Данная статья раскрывает возможности помощи детям с ОВ3 с ментальными и поведенческими (коммуникативно-аффективными) нарушениями в условиях центра дополнительного образования в рамках работы в инклюзивной группе. Описывается содержание и организация коррекционно-психологической помощи детям, структура и содержание групповых коррекционно-развивающих занятий, а также работа с родителями. Автор раскрывает эффективные формы и методы коррекционной работы, в процессе которой формируются коммуникативные навыки и навыки эмоциональной саморегуляции.

Ключевые слова: дети с ОВ3; саморегуляция; самоконтроль; коммуникативные навыки; инклюзия; групповая работа 


\title{
Модель психолого-педагогического сопровождения студентов- инвалидов в период их адаптации к обучению в вузе
}

\author{
Н. А. Степанова
}

Рассматривается проблема адаптации студентов с ограниченными возможностями здоровья и инвалидностью в вузе. Отмечается взаимная зависимость процесса адаптации от ряда субъективных особенностей студентов данной категории и объективных условий организации психолого-педагогического сопровождения данного процесса. Социальная адаптация рассматривается как интегративный показатель состояния человека, отражающий его возможности для выполнения определенных биопсихосоциальных функций. Описывается процесс социально-психологической адаптации студентов-инвалидов, который определяется четырьмя основными критериями: когнитивным, эмоционально-волевым, действенно-практическим и мотивационным. Когнитивный критерий определяет понимание студентами цели своего обучения в вузе, приобретение системы знаний о том, как можно достичь эту цель. Эмоционально-волевой критерий характеризуется наличием личностного отношения студентов к характеру и результату обучения, их умениями строить межличностные отношения. Эмоционально-волевой компонент отражает отношение к себе человека, как в целом, так и к отдельным сторонам собственной личности и деятельности. Действенно-практический критерий определяет возможность саморегуляции человека, его способность принимать самостоятельные решения, контролировать свое поведение и отвечать за свои поступки. Мотивационный критерий адаптации указывает, насколько адекватно студент воспринимает и оценивает себя и свои социальные связи, осознает мотивы своего поведения. Успешная социальная адаптация определяет психологическое благополучие личности. Психологическое благополучие как многоуровневый критерий психологического состояния и социального статуса индивида, являющийся динамичным образованием, имеет хаотический характер, что требует организации сопровождения в университете студентов с инвалидностью.

Ключевые слова: социально-психологическая адаптация; критерии социально-психологической адаптации; студенты с ограниченными возможностями здоровья; психологическое благополучие 
Развитие жизнестойкости у юношей и девушек с интеллектуальными нарушениями в организациях профессионального образования

Л. В. Токарская, М. Н. Черемных

Рассматриваются результаты реализации психокоррекционной программы, направленной на развитие жизнестойкости у юношей и девушек с легкой умственной отсталостью (интеллектуальными нарушениями), получающих образование в условиях учреждения среднего профессионального образования. Испытуемые обучаются по адаптированным программам в отдельных группах учреждения, где кроме них обучаются студенты, не имеющие ограниченных возможностей здоровья. Содержание программы включало представленную в доступной для лиц с интеллектуальными нарушениями форме информацию о жизнестойкости, ее компонентах и значимости данного феномена для жизни человека. До и после обучения по программе проводилось обследование с использованием опросника «Тест жизнестойкости С. Мадди» (в адаптации Е.Н. Осина и Е.И. Рассказовой), продемонстрировавшее повышение показателей жизнестойкости у испытуемых. Всего выборку составили 13 юношей и 14 девушек. Исследование показало возможность развития жизнестойкости у данной категории лиц, несмотря на то, что в их отношении, как правило, данный феномен не рассматривается, поскольку важным фактором жизнестойкости считается образование, умственный труд и развитый эмоциональный интеллект (Б. Г. Ананьев, Д. А. Леонтьев и др.). Таким образом, данная работа открывает новые грани для проведения исследований жизнестойкости, в первую очередь в отношении лиц с интеллектуальными нарушениями.

Ключевые слова: жизнестойкость; интеллектуальные нарушения; умственная отсталость; юноши; девушки

\section{Коммуникативное единство педагогического коллектива в условиях инклюзивного образования в детском саду \\ С. Г. Набас}

Законодательное закрепление у детей с ограниченными возможностями здоровья всех видов помощи, необходимой для их полноценного развития, обязывает педагогические коллективы в системе дошкольного 
образования налаживать совместную деятельность и сотрудничество с семьей по вопросам воспитания и образования воспитанников. Важное значение для развития детей с особыми образовательными потребностями имеет отношение родителей к проблемам ребенка и уровень их мотивации к полноценному сотрудничеству с детским садом. Анализируется опыт создания в МБДОУ «Детский сад № 26» Ленинского района г. Екатеринбурга системы коммуникативного единства всего педагогического коллектива с опорой на позитивный потенциал семьи как основу психологической безопасности воспитанников в условиях инклюзивного образования. Общее понимание причин, условий и путей коррекции проблем в развитии ребенка дошкольного возраста педагогами, специалистами и родителями помогает решать актуальные и перспективные задачи индивидуального личностного развития каждого воспитанника. Для решения проблем инклюзивного образования представлены различные виды совместной деятельности педагогического коллектива и взаимодействия с родителями детей с ОВ3, выделены параметры психологически безопасной среды.

Ключевые слова: коммуникативное единство; инклюзивное образование; детский сад 


\title{
ABSTRACTS
}

\author{
SECTION 1
}

\section{Development of self-consciousness and formation of a socially mature personality as a problem of psychology of education}

Boris Y. Berzin, Viktoriya A. Arkhipova

The article is devoted to the analysis of such concepts as "personality self-awareness", "socially mature person", the characteristics and stages of their formation and development. Today, in connection with the changes taking place in the world, especially in the field of mass communications, it becomes relevant to study the processes taking place in the consciousness of an individual. The psychology of education is called upon to play a special role, which can become an effective means of forming the socio-cultural values of the younger generation through the study of the development of self-awareness, identifying its essence and characteristics in children and adolescents, and the formation of social maturity. The methodological basis of this research was the activity and cultural-historical approaches. The article gives a definition of self-consciousness in its connection with the theory of reflection as the inner life world of the individual, as a subjective reality in which the individual is immersed. General and special signs of self-awareness are highlighted in comparison with self-reflection and consciousness. The social character of self-awareness, its subjectivity and subjectivity is emphasized. Noting the dynamic nature of self-consciousness, personality maturity, special attention is paid to the category of "development", which is considered as the unity of the contradictory - identical and non-identical, stable and changing. The author agrees with the existing system of periodization of self-awareness in developmental psychology, but considers it necessary to emphasize the importance of studying self-awareness at all stages of a person's life. In modern conditions, the concept of "development" finds its embodiment in practice in the concepts of "formation" and "education". The peculiarities of the implementation of the methodology of formation, upbringing were reflected in the examples given, obtained in the course of a socio-psychological study of school graduates in 2018-2019.

Keywords: consciousness; self-awareness; social maturity; development; formation; upbringing; personality; education system 


\section{Life-long education: the age aspect of self manifestations (self-esteem, self-attitude, self-actualization) \\ Natalya S. Glukhanyuk, Marina N. Iurtaeva}

The chapter discusses the possibilities and features of the development of manifestations of the Self in the context of lifelong education for adults. The results obtained are analyzed taking into account the formative impact of the educational program. The analysis of changes to the completion of the program allowed us to draw the following conclusions: the educational program is capable of initiating a person's desire for self-actualization; the mechanism of this initiation is, on the one hand, the growth of adequate positive self-esteem and self-respect, based on reflexivity, internal "honesty" and awareness in relation to oneself, on the other, - a decrease in the tension of protective behavior towards the self. The research results empirically support the idea of the fact that self-esteem, respect and self-actualization are available to psychological impact in the process of implementing educational programs for adults.

The development of adult education is associated with the activation of opportunities, the identification of potential resources and the modeling of modern educational programs that ensure the launch of self-development mechanisms.

Keywords: lifelong education; features of manifestations of the self of an adult learner; self-esteem; self-attitude; self-actualization

\section{Psychological characteristics of transpofessional competences of employees (on the example of masters, representatives of socionomic and technonomic profession groups) Evald F. Zeer, Mariya V. Zinnatova, Tatiana D. Bukovey}

In the modern world, it is not enough to be a professional and have a developed professional competence. Today, transprofessionals with developed transprofessional competencies that meet the real and future challenges of the digital economy, post-industrial society, and digital industrialization are becoming in demand. The educational and professional communities are naturally faced with the problem of identifying the essential characteristics of the transprofessional and transprofessional competences. The paper offers the author's definition of the phenomenon of transprofessionalism, analyzes not 
just the composition of transprofessional competencies, but their psychological essence; based on the theoretical analysis, the factors - components of transprofessionalism that contribute to its development in the activity of the subject personality are determined. The aim of the research is to identify and describe the psychological characteristics of transprofessional competencies of employees. The work is based on a comparative and descriptive analysis of empirical data on the expression of transprofessional competencies. Research methods: theoretical analysis, survey method, methods of mathematical and statistical analysis (descriptive analysis, comparative analysis), methods of interpretation. In conclusion, we discuss the limitations of the article, which do not reduce the research value of the work.

Keywords: transprofessional competencies; transprofessionalism; employees

\title{
Post-non-classical paradigm in education: opportunities and limitations
}

\author{
Larisa V. Karapetyan
}

The changes taking place in our country inevitably have an impact on all public spheres, including education, since its main function is to prepare the younger generation for life in the relevant modern realities. At the same time, transformational changes in society occur very rapidly, while the education system is characterized by low mobility and relative rigidity. It is obvious that the paradigms that previously determined the trajectory of development of the education system (classical and non-classical) correspond to modern trends in the development of society. Scientists propose a new methodological vector for the development of the educational system, namely its orientation to the post-non-classical paradigm, which more closely reflects the surrounding reality and meets the challenges of society. The article analyzes the progressive trends of the post-non-classical paradigm that can bring the domestic education system to a qualitatively new level, corresponding to the best results of world pedagogy, but specific to our country, meaningfully and strategically different from Western models of education. However, the post-non-classical paradigm has a number of limitations that must be taken into account when implementing it. The scientific and methodological discourse that unfolds around the paradigm orientation leaves open a number of topical issues. It is also relevant that the dis- 
cussion about the viability of a new methodological framework for the education system is being delayed, and it may soon need new methodological guidelines.

Keywords: education system; methodology; post-non-classical paradigm

\section{The online format and face-to-face education: comparative analysis of psychological predictors of academical success of students \\ Marina V. Klimenskikh, Julia V. Lebedeva, Alexey V. Maltsev, Vladimir V. Savelev}

The rapid integration of online learning into higher school practice has stimulated the development of psychological and pedagogical researches. The paper presents a comparative analysis of students' academic success in online courses and in the traditional face-to-face format in relation to their individual psychological characteristics. The authors conclude that students' personal characteristics do not affect academic results. The key conclusion of this study is that a successful student is successful in any training format. In this regard, the focus of the scientific search for ways to improve the effectiveness of online learning should not be focused on the psychological characteristics of students, but on solving the problems of improving the pedagogical design of an online course.

Keywords: Mass online courses (MOOC); e-learning; adaptive learning; individual educational trajectory; psychological characteristics of students

\section{Approaches to the interpretation of psychological and pedagogical interactions: a retrospective analysis \\ Elena V. Korotaeva}

In each scientific field, from time to time there is a need to sum up some results, comparative analysis, which would allow us to identify certain periods, essential events, key terminology, etc. in Relation to the scientific field of psychological and pedagogical interactions, we can distinguish four stages in the development and understanding of this direction. The first stage can be defined as the stage of reconstruction of psychological and pedagogical science that occurred in the 1960s and 1980s. The second stage is characterized by a tendency to integrate pedagogy and psychology in the educational process (from 
the late 80 's to the two thousandth years). This stage is marked by attention to the humanistic component of psychology, which was particularly significant for the pedagogical process of that time. The third stage is associated with the beginning of modernization in Russian education (the first decade of the XXI century), during which the practice of psychological and pedagogical interactions and the normative documents adopted at that time were revealed to be multidirectional.the Fourth stage of "advanced practice" began with the digital era of the XXI century, and new, rather specific aspects of psychological and pedagogical interactions were updated. It is obvious that they are still waiting for their analysis and methodological understanding both in scientific theory and in the practice of the educational process.

Keywords: psychological and pedagogical interactions; stages of transformation of approaches to interpretation of psychological and pedagogical interactions

\section{Axiology of digital education: back to the future? Svetlana N. Kostromina}

The digital transformation of society has set the task of changing the "technological order" in education: the transition to a digital management system, the development of digital educational resources, open access to the network, the use of gadgets, online technologies, etc. At the same time, education continues to be the main mechanism of sociogenesis. The article discusses the problem of preserving the main function of education - the formation and development of personality in the context of digitalization. The article analyzes three main paradigms (educational approaches) in domestic education: academic, technological (competence-based) and anthropological. Each of the approaches translates certain values and culture: a culture of elitism, a culture of usefulness, a culture of dignity. The ideas of digital education are considered in the same context. Individualization of the educational process through digital means leads to its personalization and adaptability. At the same time, without solving the problem of forming the moral and value foundations of the individual, immersion in the system of spiritual coordinates of society, meaning expression and meaning movement. The openness of information resources makes it possible to switch to the pedagogy of the possible, but it requires switching from the mode of determination to the mode of self-determination: freedom 
of choice, "freedom of admission", reflection, self-awareness, responsibility. Online communication connects people from distant spaces, providing mobility and flexibility of interaction, but it is not a format of co-existence, where social values are developed through participation, human activity in experience is realized. Following technology, it is important not to lose humanistic values, and to move from the ideological past to a culture of dignity in education, built on the value of the individual, cooperation, support and respect.

Keywords: digital education; personality; values; culture; technology; meaning

\section{Navigational characteristics of digital texts as a factor of the successfulinformation search}

Tatyana S. Ledneva, Artem I. Kovalev

The digitalization of professional and educational spheres is transforming the traditional approach to interaction with textual data and requires from people not only new skills of effective information extraction, but also the creation of optimal conditions for working with digital texts. The dynamic and navigational characteristics of digital texts are important parameters influencing these processes. Various combinations of these characteristics facilitate or obstruct information retrieval process. In this work, an experimental procedure was developed and tested to examine the effect of navigation and dynamic characteristics of the presentation of text on digital devices on the effectiveness of information search. The eye-tracking technique was also use to estimate the eye-movement parameters during reading texts in different forms. Four types of setups of digital text presentation were create, varying in the way they allowed to interact dynamically with the text and in the number of navigation cues. Navigating through text by scrolling or paging has defined two large groups of setups in terms of the way they allow to interact with text. Each group was also divide into two subgroups varying with the ability to review the entire text. The experiment involved 15 subjects. Their task was to read the text and find answers to some questions. It was found that the gazepath length and the searching time turned out to be significantly smaller for setup with scrolling type of navigation combined with miniatures. Thus, the developed procedure made it possible to identify differences in the navigational behaviour of a person while working with textual information in various setups.

Keywords: text navigation; eye-tracking; digital education 


\section{Psychological mechanisms for the development of the legal self-awareness of the personality}

Rustam R. Muslumov

The article discusses the theoretical and methodological aspects of psychological mechanisms in the development of legal identity of the individual. In legal behavior, an essential role belongs to self-awareness, which is knowledge of oneself, attitude towards oneself, self-esteem, an opinion about oneself as a person. Legal identity predetermines the nature of human legal relations, his legal position, actions and legal behavior. The development of a person's legal self-awareness is based on psychological mechanisms that represent a dynamic psychological system, which includes various conditions, factors, means, structures, relationships, connections and other mental phenomena that ensure the formation, formation, flow and regulation of this process. The work provides a classification of the main psychological mechanisms for the development of legal self-awareness. The development of legal consciousness is the result of the activity of the entire system of psychological mechanisms. Depending on the specific situation and development of the individual (her age, psychological properties and qualities, health, social role, interpersonal relations, etc.), the significance of individual mechanisms changes. The essence of psychological mechanisms is shown, the history of their study is briefly considered, the structure is revealed. The role of legal socialization in the legal development of an individual is revealed. Particular attention is paid to the analysis of the fundamental psychological mechanisms in the development of legal identity of the individual: motivation and reflection. In the development of a person's legal self-awareness, psychological mechanisms perform the following main functions: reflective, incentive, regulatory and controlling.

Keywords: legal self-awareness; psychological mechanism; legal socialization; motivational mechanism; motives; value orientations; reflection; identification; functions of psychological mechanisms 


\section{SECTION 2}

\section{Approaches to the study of psychological well-being}

Georgy I. Borisov

Well-being is a topical issue for many sciences, including psychology. Nevertheless, this demand has led to a wide variety of species, approaches, theories of well-being. This article presents an attempt to analyze and consider the species, approaches, well-being. The article will consider such types of well-being as emotional, physical, social, professional, social, clinical, sexual. As reflecting satisfaction or success in various aspects of a person's life. Psychological well-being will be considered separately. Psychological well-being is considered from the standpoint of a hedonistic and eudemonic approach will be considered. Domestic concepts of well-being will also be considered.

Keywords: well-being; psychological well-being; happiness; educational process; professional well-being

\section{Psychological well-being in students from subjective and resource-based view (via students of Department of Psychology) Nataliya Ye. Vodopyanova}

The aim of the study is the assessment and comparison of the psychological well-being (PWB) in students of the first (bachelor's) and seventh (master's) years of education, and testing personality predictors (resources) of PWB as guidelines for professional and personal development. The paper presents a theoretical analysis of the PWB problem from the standpoint of various approaches. An empirical study of PWB uses subjective and resource-based view. The article shows personal PWB predictors in bachelor and graduate students (first and the seventh year of study in Psychology). The PWB indicators of graduate students against the firstyear students demonstrate higher values and correlations with resources of different levels of mental regulation, i. e. volition (perseverance, control, determination), value and semantic management (perfectionism to others, self-perfectionism), self-support resources (self-efficacy), reflected self-reliance (self-confidence, selfworth, vitality). The obtained facts confirm that growing-up and professional identity of the subjectivity attributes (intro- and inter-subject resources) have 
an increasing effect on the PWB. The rise of PWB in graduate students shows the volitional, value-semantic and cognitive-evaluative resources development and indicates the expansion of the resource base for the subsequent stages of the psychologists' professional development. Obviously, the identified personality predictors of PWB should be used in choosing psycho-developmental targets for professional and personal growth through a system of psychological support for training subjects in the context of their age and stage of professionalization.

Keywords: psychological well-being; positive activity of training person; subjective and resource-based view; personal mental resources

\section{Subjectivity as a predictor of psychological well-being of gifted adolescents}

Elena N. Volkova, Irina V. Volkova

The article presents the results of a study of the psychological well-being and subjectivity of 563 gifted adolescents and adolescents with a standard level of abilities at the age of 15-17 years. There were no significant differences in indicators of both general psychological well-being and its structural components in the compared groups, except for the value of the indicator "Autonomy". Gifted adolescents have a better ability to behave independently than their peers with a normative level of abilities. The ability to establish positive, trusting relationships among gifted adolescents is less pronounced (differences at the level of tendencies). The development of subjectivity in gifted adolescent boys occurs through the development of the ability to reflect and recognition of freedom of choice and responsibility for this choice, and in gifted girls - through the development of ideas about their own uniqueness. Various components of subjectivity are predictors of psychological well-being of adolescents in the compared groups. For gifted boys, this is activity, the ability to reflect, the possibility of freedom of choice and responsibility for it. For gifted girls, awareness and experience of their own uniqueness are added to these components. For adolescent boys with a normative level of ability, this is activity, understanding and acceptance of another person. For adolescent girls with a normative level of abilities, this is the ability to reflect, the possibility of freedom of choice and responsibility for it, understanding and acceptance of another person, self-development. Differ- 
entiation of the level of psychological well-being of gifted adolescents and their peers is associated with the ability to understand and accept another person.

Keywords: gifted adolescents; subjectivity; psychological well-being

\section{Healthy lifestyle and resilience of modern students}

Dariya A. Galochkina, Margarita E. Permyakova

In this article the problem of such life resources of the modern student as resilience and healthy lifestyle is discussed. Presented are the results of the study conducted on a sample of students $(n=100)$ with the purpose to determine the relationship between resilience and healthy lifestyle. It's established that the high resilience is correlated with students' practice of healthy lifestyle and their knowledge about healthy lifestyle. Direct correlation was established of the students knowledge about healthy lifestyle and their subjective measure of own lifestyle and somatic health, and also with such elements of healthy lifestyle profile as nutrition and interpersonal relationships. The data indicating that responsibility for their own health declines with age of the students was obtained. More connections between elements of resilience and the parameters of healthy lifestyle were identified in females.

Keywords: students; healthy lifestyle; resilience; knowledge of healthy lifestyle; healthy lifestyle profile

\section{University etiquett and etiquett behaviour in the university: modern situation and study perspectives \\ Olga I. Danilenko}

The purpose of the article is to substantiate the relevance and outline promising areas of university etiquette. The significance of university etiquette can be explained by a number of reasons. The presence of generally recognized rules regulating the forms of interaction between students, lecturers and administrative officers facilitates the creation of optimum psychological climate and is the one of preconditions for the efficiency of the process of study. The experience of etiquette interaction between student and lecturers influence the formation of the personality of the young person, creating the conditions for the strengthening of the positive identity of a student of the university. The digestion of etiquette 
models in the period of study is prerequisite for their implementation in future professional activities, as well as in the everyday communication. Traditional rules of high education institution university etiquette prescribed the demonstration of status inequality of students and lecturers with obligatory mutual respect. At present, the definiteness and the imperativeness of traditional university etiquette are decreasing. And that is the reason of the topicality of study of the university etiquette and etiquette behavior. The article presents prospective fields of such studies. The first one is the study of the influence of radical changes in the organization of universities' activities (inclusion of universities to the services' sector, involvement of students in joint scientific project, etc.). The second is the study of communicative practices arising in connection with the development of information technologies and the implementation of online communication between teachers and students for solving educational and scientific problems. The third is the study of etiquette as a component of the organizational culture of the university, which is undergoing significant changes in the conditions of market relations. Fourth - the search for intra-psychic factors which motive a person to observe or to violate traditional models of university etiquette and of their transformations. Provides brief information about the author's methods aimed at studying the psychology of attitudes towards etiquette and the results obtained. Prospects for the implementation of the planned and conducted research into practice are outlined.

Keywords: university students and lecturers; etiquette; university etiquette; etiquette behavior; etiquette models of behavior; status differences; organizational culture at the university; communicative competence of students

\section{Constructive attitude towards yourself as a professional and well-being of the individual Sergey V. Dukhnovsky}

The article discusses, through empirical material, the well-being of educational actors in the context of treating themselves as a professional. The assumption that a constructive attitude towards itself is a condition of well-being of the individual was confirmed, indicators of which are the corresponding crisis profile and career satisfaction. The sample of the study was 97 teachers of higher education institutions. In the survey the author's methods were used: "Determination of attitude 
to himself of a professional," Experience of crisis by personality, "Scale of career satisfaction," Methodology of determination of motivational types. "On the basis of empirical data depending on the prevailing crisis profile two groups of subjects of educational process were allocated: 1) 'safe' subjects - with the crisis profile 'psychological health with the favorable forecast', 2) 'unsuccessful' subjects - with the 'exhaustion with the uncertain forecast' profile. It is established that in group of 'safe' subjects of educational process with the crisis profile 'psychological health with the favorable forecast', the constructive attitude towards itself - is expressed respondents have the increased level of claims, installations on professional self-development and idea of themselves as the professional, indicators of acceptance of as professional and installation on official development are expressed moderately. They are characterized by an increased level of career satisfaction and a 'professional' type of labour motivation. In group of 'unsuccessful' subjects with the 'exhaustion with the uncertain forecast' profile the destructive attitude towards itself - the lowered level of claims, acceptance of and ideas of itself as the professional, weak orientation to professional self-development and official development in combination with the lowered level of satisfaction with career and 'izbegatelny" type of labor motivation prevails.

Keywords: professional; well-being; crisis profile; constructive attitude towards yourself; career satisfaction; labor motivation

\section{Personal factors of students' adaptation to the new socio-cultural environment Elena A. Stolyarchuk, Marina A. Kruglova}

The article discusses the features of adaptation of students participating in international exchanges. We discussed the key theoretical concepts explaining the flow of processes of adaptation/maladaptation to a new sociocultural environment; the stages of process of adaptation of visitors; describes the General theoretical integrative model of cross-cultural communication, Y. Kim, on which was built the design of the study. In an empirical study, the following indicators were studied: adaptation to new socio-cultural conditions (the method of L. V. Yankovsky); social and psychological adaptation (K's method Rogers and R. Diamond in the adaptation of A. K. Osnitsky); personal factors: readiness for change (the method of Rodnik, Heather, gold, Hal in the adaptation 
of N. A. Bazhanov, G. L. Bardier), tolerance to uncertainty (the method of S. Badner in the adaptation of G. U. Soldatov) and the locus of control (the method of J. The rotter). To confirm the degree of validity and reliability of the research results, methods of mathematical and statistical data processing were used: comparative analysis using the Mann-Whitney criterion to identify the reliability of differences between indicators depending on the gender of respondents; correlation analysis using Spearman's rank correlation coefficient to identify relationships between adaptation indicators and personal factors; regression analysis to identify the influence of personal factors on the overall adaptability of students. It was found that students' adaptation to the new social environment depends on the severity of such personal factors as tolerance to uncertainty, adaptability and resourcefulness.

Keywords: adaptation; maladaptation; culture shock; education; international exchange; students

\section{Psychological well-being of students in Belarus}

\section{Galina A. Fofanova}

Psychological well-being of students as a subjective assessment of their functioning from the point of view of realizing their potential in the past, present and future is one of the most important components of the successful development of society. The essence of the phenomenon of psychological well-being in general, and of students, in particular, is analyzed in the article; the importance of constant monitoring of this psychological parameter is substantiated. The results of an empirical study of the psychological well-being of Belarusian students of various courses are presented. It was found that only a quarter of the surveyed students are characterized by high indicators of psychological well-being. Such indicators of psychological well-being as "autonomy" and "environmental management" among first-year students are significantly lower than among senior students. The indicators of the "positive relationship with the environment" scale among boys are significantly lower than among girls. The results obtained are largely related to the difficulties of coping with the educational, social, economic, psychological challenges and household calls that students of each course face. However, the indicators of first-year students cause the greatest concern and require finding and developing new measures to optimize their adaptation and 
the development of personal resources for further successful development. Practical recommendations (local and system-wide) for improving the psychological well-being of students are offered in the article.

Keywords: psychological well-being; socio-psychological adaptation; students; psychological service of the university; school psychologist; psychological support

\section{Active life position as a factor of psychological well-being of students} Evgeniya A. Khokholeva, Svetlana D. Lipatova

The article discusses the theoretical and methodological aspects of the life position of University students. Modern reality demonstrates a personality-oriented approach, in the center of which are the person and personal interests, an active life position becomes necessary for successful self-realization. The business environment requires University graduates today not only to have professional competence, but also the ability to take an active life position and adapt to a rapidly changing socio-economic environment. The purpose of the publication is to discuss the formation of an active life position of students as a factor of psychological well-being. The article presents the author's typology of forms of life position (active-positive, active-negative, passive-negative, passive-indifferent). The study was conducted in three stages. At the first stage, the features of the life position of URFU students were determined using the author's questionnaire "Active life position" and the questionnaire "Types of life position". At the second stage, an experiment was conducted that forms an active life position of students in the educational environment. At the third stage, changes in the life position of students are analyzed using mathematical methods. Theoretical analysis has shown that most authors offer an active life position to form through extracurricular educational activities. The article describes a different way-formation through active learning methods. In the course of an empirical study, it was proved that the use of active methods in the learning process allows students to develop an active life position. Comparison of the results of the level of active-positive life position before and after correction using the Wilcoxon $\mathrm{T}$-test showed that the obtained value $\mathrm{T}=40$ falls into the zone of significance. The formation of principles, worldview, beliefs, and moral standards of students, through active teaching methods, contributes to the development of an active life position and forms the psychological well-being of students. 
Keywords: life position; types of life position; forms of active life position; active teaching methods

\section{The problem of professional identity of students of psychology in a modern university \\ Mikhail V. Chumakov, Inna V. Vasileva}

The study examines a paradoxical situation, on the one hand, professional identity is traditionally understood as a characteristic that contributes to the academic success of student psychologists, and on the other hand, in real practice, a consistent decrease in the professional identity of student psychologists is observed. Equally important is that professional identity is a factor in the subjective well-being of a person. The study involved 117 undergraduate student studying psychology, from 1 to 4 courses, as well as graduate students. Data collection method: student professional identity questionnaire (U.S. Rodygina). The calculation of the results by the method of variance one-factor analysis showed that professional identity decreases depending on the course at which the student is studying $F(32,385.13)=1.8065$, $p=0.005538$. Positive emotions associated with meeting the needs of the profession are reduced from the beginning to the end of studies at the university, and negative ones, on the contrary, are growing. The position of the student's active attitude towards the acquired profession decreases from the beginning to the end of studies at the university, the position of the passive attitude grows, reaching a maximum in the 3rd year, and decreases to the graduation course. The obtained results raise a significant problem: future psychologists with the growth of professional qualifications become less active and experience less and less positive emotions from involvement in professional psychological activities. Thus, there is a need to revise learning technologies to preserve the professional identity of students of psychologists, both in terms of activity and in terms of emotional response.

Keywords: students; professional identity; subjective well-being; emotions and activity in professional activities 


\section{Tolerance for ambiguity in connection with personality traits and gender in adolescence \\ Elena P. Shangina, Olga S. Vindeker}

The article is devoted to investigation of correlation between gender role and tolerance for ambiguity of 14-17-years old teenagers. An empirical research has been established relationship between tolerance for ambiguity and achievement motivation, autonomy and self-efficacy of adolescence. It is assumed that gender-specific development of tolerance for ambiguity is manifested in adolescence. It is determined that boys and girls have a general tolerance to uncertainty associated with age: then older the teenagers, the more pronounced their ability to respond to uncertain stimuli. Gender preferences in relation to ambiguity are observed. Boys have a significantly higher tolerance for ambiguity, mainly due to their openness to new experiences and positive attitude to situations of uncertainty and ambiguity. In contrast to girls, boys with high achievement motivation are more tolerant to ambiguity and prefer difficult tasks. For girls, the choice of difficult tasks is associated with autonomy and self-efficacy in activities that are important to them, but their level of self-efficacy is not related to a positive attitude to situations of ambiguity. The results of the study can be taken into account when developing additional educational programs for high school students engaged in project activities, taking into account the age and gender.

Keywords: tolerance for ambiguity; adolescents; achievement motivation; autonomy; self-efficacy scale

\section{SECTION 3}

\section{Professional-oriented autobiography methodology as an instrument of supporting professional self-determination student-future teachers Evgeniya G. Belyakova}

The possibilities of the narrative approach to support the professional self-determination of students - future teachers are analyzed. Professional identity, which is the most important criterion for professional self-determination, is viewed as a product of a person's narrative activity, which unfolds through 
the creation of copyright texts describing an individual professional path. It has been established that the properties of narrative identity and the patterns of its development, and, above all, its semantic conditioning, flexibility and the possibility of re-engineering, correspond to the peculiarities of the modern socio-cultural situation of "uncertainty - complexity - diversity" (A. G. Asmolov). Accordingly, this makes it possible to rely on the provisions of the narrative approach in the development of specific techniques for supporting professional self-determination. Autobiographical narrative as a way of organizing experience reproduces in the narrative the life story and the socio-cultural context of its generation. Professionally oriented autobiography is analyzed as a special type of narrative activity. Highlighted its essence (recreation of an integral subjective picture of the professional path) and functions (sense-forming, diagnostic, developmental / formative, motivating, reflective, design, integration). Specific variants of narrative techniques developed within the framework of the author's model of supporting the professional self-determination of student teachers are presented. The techniques are correlated with the content of the support stages and make it possible to activate the process of professional self-identification through the construction of prospective, relevant and retrospective identities, reflection of the experience of professional trials, comprehension of new experience and its integration into a holistic idea of oneself as a professional and one's professional path, through setting new goals of professional development.

Keywords: professional self-determination; professional identity; narrative; professionally oriented biography methodology; accompaniment of professional self-determination of student teachers

\section{Development of teacher's reflexive competence general educationalinstitution}

Tatiana I. Grechuhina, Alena V. Usacheva

The problem of developing the teacher's reflexive competence is related to the transition of the Russian system of General education to the Federal state standards of the new generation and the requirements of the professional standard of the teacher. In modern conditions, reflexive competence is the basis for the emergence of an innovative environment in an educational institution, which creates opportunities for professional development and creativity. The need to de- 
velop reflexive abilities in teachers as a condition of professional activity does not cause disputes in the professional community. Designing a system of conditions, tools, and mechanisms that contribute to the professional development of teachers is a developing function of the modern education system. In this regard, the need for educational practice is urgent in describing the features and content of methods for developing reflexive competence of teachers, and identifying the effectiveness of their application in the real educational process of a General education institution. Description of methods for developing reflexive competence is a task not only of pedagogy, but also of psychology, since reflexive competence is a phenomenon that determines the values and self-development of the teacher's personality. The article describes reflexive methods (didactic and technical means) that contribute to the formation of a reflexive environment, the development of components of reflexive competence of teachers in collective forms of activity in a General education institution. The results obtained showed that in the conditions of the reflexive environment of a General education institution, it is possible to form new cultural norms of activity and its critical analysis. Designing a system of conditions and means for developing teachers' reflexive competence contributes to the positive dynamics of professional development (professional qualities of the subject and object), the development of components of reflexive competence (intellectual, personal, cooperative, communicative), and focuses on collective forms of professional interaction.

Keywords: reflexive competence; teacher; professionalism; didactic method

\section{Designing modern teachers career strategy in the context of digitalization}

Ekaterina M. Gromova, Diana I. Berkutova, Tatyana A. Gorshkova

The authors identify the problem points and the main aspects of the impact of the current information revolution, which, according to most experts, is one of the largest in the history of human civilization, since it affects the deep foundations of how people interact with each other and the world around them. Today, digitalization has subjected absolutely all areas of our life to a global restructuring. The study attempts to analyze and rethink the system of professional education of teachers in the conditions of digitalization. The authors analyze in detail the theses outlined in the key documents that define the vectors of trans- 
formation of professional education in our country: the presidential Decree "on national goals and strategic objectives for the development of the Russian Federation for the period up to 2024", the national projects "Education" and "Digital economy", the Federal state educational system. Based on this analysis, the authors convincingly prove that it is impossible to consider digitalization in professional education of teachers only from the position of forming digital competencies dictated by new requirements. The digitalization in the field of vocational education is a much more extensive phenomenon. It changes the ways of professional activity of a teacher, the opportunities for interaction with other participants in the educational process (colleagues, students, their parents), and the processes of professional identification by including them in formal and informal communities on the Internet, and so on. The authors emphasize that when designing a career in education, there is often no movement in the organizational hierarchy of an educational institution ("vertical career"). But this does not mean that the teacher does not develop in his career. Generally, in the field of education, the career strategy is built "inside the profession" ("horizontal career"), i. e., the formation of a professional identity is underway. And today, teachers need help in using the positive effects of digitalization to build their career strategy, in order to even out its negative consequences a little.

Keywords: teacher career; digitalization; professional identity

\section{Professionalism of the teacher. Generational theory: who to learn from whom? Margarita N. Dudina}

Generational theory by Neil Hove and William Strauss is almost unknown to the professionals in education. At the current moment, it is noticeable even in everyday life that there is dynamics of the needs of digital childhood, adolescence and youth, as well as changes in the corresponding generational patterns. They result in growing numbers of conflicts between teachers and students at all levels of education. The development of the digitalization of the information society, the dominance of consumer culture has led to the adoption of knowledge as a commodity. This affects all spheres of society, transforms the personality of the student and teacher as participants in the educational process with its goals, content, technologies and achieved results. Turning to the main provisions 
of L. S. Vygotsky (cultural-historical theory of the development of higher mental functions), the author offers to abolish the traditional educational model and master personality-oriented approach in education. This model implies the use of interactive innovative technologies as a mean for achieving professionalism in pedagogy. They attune to the challenges of today and help to overcome the alienation of younger generations from education through the ethical-humanistic paths of psychological and pedagogical facilitation. A changing personality in a changing world - an interdisciplinary problem orientes the education system to the modernization of the goals, process, learning outcomes and education of students who are creatively developed, open to innovations, willing to use them for the benefit of man, nature and society, capable of creating new things.

Keywords: generation theory; traditional and innovative didactics; personality-oriented educational model; interactive teaching methods; teacher as a facilitator

\section{Structural-level approach to periodization of professional personalization of personality}

Yuri P. Povarenkov

The article defines the concept of periodization, which is considered as a methodological interdisciplinary method for dividing the development process into stages on formal (temporary) and substantive (characterization of new formations). The leading types of periodizations of professional formation that have developed in domestic and foreign psychology are fixed: ontogenetic and professional-genetic. It is shown that the formal basis for ontogenetic periodizations is the chronological age of the professional, and for professional-genetic ones, the professional (career) age. A detailed description of the strengths and weaknesses of each periodization is fixed. It is revealed that ontogenetic and professional-genetic periods are based on different methodological foundations and therefore are opposed by psychologists. Two basic levels of psychological analysis of professional and career development of a personality, which reflect two aspects of the holistic process of professional development of a personality, are highlighted and described. They are named the labor and professional path. The contents of the labor and professional paths are disclosed, the basic concepts used to describe them are defined. It has been established that ontogenetic 
periodizations describe the individual's labor path, professional-genetic ones describe the professional path. The article proves that an adequate periodization should take into account both levels of professional development of a person and therefore it should be at least two-level.

Keywords: professional and career development; periodization; labor path of an individual; professional path of an individual

\section{Features of self- development of teachers and psychologists with professional deformations}

Olga B. Polyakova

The features of professional deformations of teachers and psychologists are revealed: a high level of emotional exhaustion; higher than average level of depersonalization, personal estrangement, professional deformations in general, psychoemotional exhaustion, reduction of personal achievements, reduction of professional motivation. The features of the self-development of teachers and psychologists with professional deformations are determined: a low level of motivational component, the ability to self-development and self-education; below the average level of the gnostic component, readiness for professional self-development, readiness for self-development, cognitive component, evaluation of the project of professional support as an opportunity for professional realization, self-development, self-management ability in professional activity, desire for self-development; the average level of the communicative component, the moral-volitional component, the organizational component, the realization of the needs for self-development, self-esteem of personal qualities that contribute to self-development. It is proved that high emotional exhaustion of teachers and psychologists leads to a decrease in the motivational component of self-development and the ability to self-development and self-education. It has been established that the decrease in the gnostic component, readiness for professional self-development, readiness for self-development, cognitive component, assessment of the project of professional support as an opportunity for professional realization, self-development, the ability to self-govern in professional activities and the desire for self-development is affected by a higher degree of severity of depersonalization (personal estrangement), psychoemotional exhaustion, 
professional deformations in general, reduction of personal achievements and professional motivation.

Keywords: motivational component of self-development; professional deformations; self-development; ability to self-development; emotional exhaustion

\section{Socio-psychological aspects of the development of the crisis of loss of professional activity in teachers in late adulthood} Elvira E. Symanyuk, Anna A. Pecherkina, Tatiana D. Bukovey

The article deals with the main socio-psychological aspects of the development of the crisis of professional activity of teachers of late maturity. Within an educational organization, pedagogical conflicts may appear that act as a kind of continuation of the generational conflict and are based on fundamental differences in the systems of values and worldview formed in the process of socialization. The dynamics of conflict determines the increase in negative experiences, aggravating the process of overcoming the crisis of loss of professional activity. Intergenerational conflicts, professional deformations, and social attitudes in society relative to people in late adulthood were identified as socio-psychological factors of the crisis of loss of a teacher's profession. The study of these factors will determine the psychological mechanisms for providing socio-psychological support to teachers during the crisis of losing their profession, and will also contribute to improving the quality of life in late adulthood.

Keywords: crisis; professional crisis; crisis of loss of profession; teacher; socio-psychological aspects of the crisis of loss of profession.

\section{SECTION 4}

\section{Psycological aspects of cyberbullying impact on adolescents} Elizaveta V. Averkieva

According to statistics, about $90 \%$ of youth in developed countries have access to internet, along with that, about one third of children aged 15-18, spend most of their free time online. According to various researches, the communicative function of internet is particularly valued by the majority of users. 
Nevertheless, as with communication in real life, a person can become a victim of destructive socialization patterns online. This article is deducated to cyberbullying as an example of antisocial behavior in internet, most known Russian and foreign researchers of this subject are indicated. The definition of cyberbullying is given, along with its characteristic features and common forms. The data on cyberbullying prevalence in Russia and foreign countries is represented in this article, with possible explanations of divergence in numbers are suggested. The impact of cyberbullying on various aspects of life of youth is considered. The consequences of psychological, social, pedagogical and physiological nature are marked. Separately, gender and instrumental differences of cyberbullying impact upon youth are considered. According to the results of the mentioned research negative impact of cyberbullying is confirmed. The necessity of futher research of individual factors of persons involved in cyberbullying is justified in order to clarify and integrate the most effective coping strategies for this phenomena.

Keywords: youth; adolescents; cyberbullying; online communication; mental health; coping strategies

\section{A small town as a space of education: psychological aspects}

\section{Tatiana Y. Bystrova}

The view on the material-spatial environment of a small town as an educational space that stores the history of a place, its "spirit" and identity, is being developed. The underestimation of the urban environment and its elements, including historical-architectural and historical-cultural objects by inhabitants of small towns in Russia is shown. Involvement in their actualization, participation in the processes of territory transformation (including former industrial ones) are commented on from a psychological point of view, taking into account the mentality and stereotypes of residents of small towns.

Keywords: small town; socio-cultural environment of the city; Russian city; psychology of citizens; stereotypes; "cultural trauma"; involvement; participation; mentality 


\section{The problem of adolescent bullying: current directions of research and aid organization \\ Elena N. Volkova, Artur A. Rean, Irina V. Volkova}

The results of theoretical an $\neq \mathrm{d}$ experimental studies of adolescent bullying is the basis for the development of programs for its prevention. The criteria for identifying bullying are the frequency of violent situations; intentional harm; causing physical or psychological harm to a victim; power inequality between offender and victim; the inability for the victim to leave the bullying situation. For monitoring and comparative studies of the prevalence of bullying in education, the most informative indicator is a reversible indicator that records the number of children who do not participate in bullying, rather than the number of victims or offenders. The organization of preventive work in schools should be based on knowledge of the personal and social characteristics of the offenders, victims and witnesses of bullying. Bullying witnesses by key targets of prevention work. Family, school and school environment can be provocative and protective factors in adolescent bullying. The high mediation of bullying by cultural factors and, at the same time, insufficient knowledge of adolescent bullying in the context of Russian education determines the high relevance of scientific research in this area for the development of programs for the prevention of bullying in schools.

Keywords: adolescent bullying; criteria of identification; prevalence; offenders; victim; family; educational environment

\section{Prosocial behavior and psychological well-being of students Pavel A. Kislyakov, Elena A. Shmeleva}

The article analyzes and substantiates the relationship between prosocial behavior and psychological well-being of young people. As part of the study, a review of publications by domestic and foreign authors, testing of students $(n=73)$ aged 19 to 24 years in the form of a written survey was conducted. The following methods were used: "Scale of subjective well-being" (A. Perue-Badu, adapted by M. V. Sokolova); "Scale of altruism” (F. Rushton, adapted by N. V. Kuhtova). A secondary analysis of data from the European Social Survey 2018 (ESS9) was conducted. Russian residents whose main occupation is education $(n=116)$ at the age of $17-26$ years $(M=20)$ were selected as a social unit in the studied 
database; $49 \%$ were women, $51 \%$ were men. The obtained empirical data were processed using percentage analysis and Pearson correlation analysis. Calculations were made on the basis of the statistical software package SPPS 22 . The study showed that among the majority of students, subjective well-being is shown at a sufficient level. Most of the respondents showed an average level of altruism development. It is established that there is a correlation between altruism and the level of subjective well-being of students. Through participation in Pro-social activity and the formation of Pro-social motivation, students manage to ensure a state of psychological well-being (security). There is also a correlation between the self-esteem of happiness and the perception of people around them as ready to help each other, as well as between the values of security and helping others. The identified relationships allow us to predict the level of psychological well-being of an individual depending on its prosocial activity. In the process of spiritual and moral development and personal formation, it is advisable to use trainings and situational modeling aimed at solving moral dilemmas, as well as the implementation of volunteer practices and socially significant projects within the framework of the Humanities.

Keywords: volunteering; psychological well-being; security; prosocial activity; youth; values; help; altruism

\section{Outdoor advertising as a factor of distortion of the real image of the city in the representation of youth Ekaterina O. Mazurchuk, Nina I. Mazurchuk}

The study of outdoor advertising as a factor of distortion of the real image of the city in the view of young people was carried out within the framework of the current direction for modern science - the preservation of psychological security and psychological well-being of the population. It is argued that this factor can be outdoor advertising, which has a significant impact on the level of education of young people (pedagogical aspect), and the peculiarity of the perception of the real image of the city by young people (psychological aspect). At the same time, the authors emphasize that outdoor advertising, as a rule, contributes to the formation of an inadequate image of the city, leads to its distortion in the minds of young people, which has a negative impact on their psychological health. The text considers the fundamental concept of "youth" from the position 
of various approaches, provides a meaningful description of the most effective and widespread method of promoting goods and services, as well as an element of national culture and the main mechanism for its formation - outdoor advertising. To study this problem, a set of review-analytical, theoretical, empirical methods and methods for processing and interpreting the results was used. According to the results of a survey of young people (students of the Ural state pedagogical University), a difference in attitude to outdoor advertising was recorded, depending on the gender and age of the respondents. Using the method of mathematical statistics, four groups (clusters) of subjects with different characteristics of perception of outdoor advertising as a psychological and pedagogical factor of distortion of the real image of the city are identified. At the same time, in the process of describing groups (clusters), feminine perception qualities and masculine perception qualities of outdoor advertising were recorded in the respondents included in the sample. Confirmation of the combined influence of gender, age and quality of perception of outdoor advertising by young people determined the scientific novelty of the results. The research materials can become a source of theoretical and practical knowledge for specialists engaged in the search and formation of a model of urban public spaces that determine the preservation of psychological health and well-being of young people.

Keywords: youth; outdoor advertising; real image of the city; feminine qualities of perception; masculine qualities of perception

\section{Child abuse: the concept, consequences and directions of prevention Nadezhda A. Tomina, Natalya G. Tserkovnikova}

The relevance of considering child abuse and the need to develop and apply preventive measures for this problem is beyond doubt. The links are given to a few statistics in Russia on this issue. The article discusses the concepts of child abuse and violence against children. Various forms of the child abuse are described: action and inaction, violence and neglect of the needs of the children. The attention is focused on the harmfulness of various forms of child abuse. The physical and psychological effects of child abuse are also described, as well as immediate and long-term effects. This article substantiates the need for preventive work, which is aimed at preventing child abuse and neglect of children's need. The article outlines the goals and forms of preventive work with adults, 
teenagers and children, also presents preventive measures aimed at improving interaction between the child and the adult. The directions of the prevention of child abuse that can be used in an educational organization are disclosed. The child abuse prevention system is aimed at finding ways out and finding alternative, more effective and harmless ways of interacting, supporting adults and children in various situations. The child abuse prevention system focuses on the values of childhood, family and parenting.

Keywords: child; abuse; violence; prevention; education

\section{SECTION 5}

\section{Transformations of school perceptions in students at different stages of the school curriculum Olga Yu. Zotova, Lyudmila V. Tarasova}

The research into changes occurring to children in different stages of schooling shows that the higher the stage of schooling is, the less favorable characteristics the school enjoys in students' opinion, and students themselves are increasingly reluctant to show ambitions for achievement. A lower comfort of children and teenagers' stay in school can affect academic progress, self-perception, mental health, social competence, concentration, and motivation. Schoolers are the best source for assessing the domestic school situation, that is why incorporating schoolers' perceptions is a crucial component to measure the effectiveness of school education. The study aimed to examine specific features of school perceptions shared by schoolchildren at different stages of the school curriculum. The sample involved primary schoolchildren $(n=53)$, middle schoolers $(n=26)$, upper schoolers $(n=30)$, and first-year university students $(n=50)$. The results show as students progress up the education system, the very process of learning, socialization in school takes a back seat in schoolers' minds while the procedures of progress monitoring come to the fore - "School is more academic performance rating than knowledge acquisition". In parallel, there have been increasing reports on negative experiences accompanying education.

Keywords: social representations (perceptions); schoolers; the image of the school 


\title{
Choice as a factor of personal development
}

\author{
Irina $V$. Ivanova
}

The section of the monograph is devoted to the study of the choice (personal, social, existential) carried out by a person throughout his life. The choice is considered as a factor of self-development, and the readiness for independent and conscious choice, along with the readiness to bear responsibility for it, acts as an important indicator of self-development. The categories of self-development, choice, responsibility, independence, subjectivity are traditionally leading in philosophical, psychological and pedagogical concepts and theories based on existentialism. The historically developing concept of self-development is filled with pedagogical content and becomes more and more important for the modern humanistic educational process. In the context of modern education, the concept of existential pedagogy, developed by O. G. Grebenyuk and M. I. Rozhkov, the main idea of which is the formation of a person capable of self-knowledge, self-realization and self-improvement on the basis of his choice, realizing the meaning of his existence and realizing himself in accordance with the choice. In the context of the reflexive-value approach as a new methodological approach in pedagogy, developed by us within the framework of a scientific school under the guidance of Doctor of Pedagogy, Professor of the Russian Federation I. M. Rozhkov, the upbringing of a person is based on his understanding of his freedom and the desire to become what he represents himself. Based on this idea, the most important component of the process of educating a free person is the pedagogical support of his self-development. In the context of the formation of a teenager's readiness to choose, special attention should be paid to the implementation of pedagogical support for self-development in a situation of overcoming difficulties. We consider the actualization of the solution to a real dilemma situation as the target function of pedagogical support for self-development of adolescents. The development of individual routes of self-development based on the results of solving dilemma situations by a teenager is a technology, the implementation of which is seen most vividly in the system of additional education for children, which implies ample opportunities for making a choice. The study was carried out with the financial support of the Russian Foundation for Basic Research within the framework of scientific project No. 20-013-00616.

Keywords: existentialism; existential pedagogy; freedom; responsibility; choice; independence; self-development 


\section{Emotional and behavioral problems in adolescents studying in regular schools and lyceums \\ Marina M. Lobaskova, Julia S. Izmailova}

We present the results of a study of the relationship between emotional and behavioral problems and temperament traits in adolescents studying in regular schools and lyceums (specialized schools). We have observed that adolescents in regular schools have higher levels of depressive mood and aggressive behavior compared to lyceum students. A high level of situational and personal anxiety is more common among regular school students. A correlation analysis revealed differences in the structure of the relationships of temperament traits and emotional and behavioral problems between the two groups of adolescents. For lyceum students, higher inhibitory, activation and attention control are related to lower levels of emotional and behavioral problems, and the overall factor of effortful control can be extracted from their data in a meaningful way. We came to the conclusion that emotional and behavioral problems are less common in lyceum students for several reasons. On the one hand, a lyceum boasts favorable environmental conditions for both cognitive and personal development of adolescents. On the other hand, lyceums attract a certain audience that may be significantly different from the overall population in terms of temperament traits. In general, we put forth that the psychological wellbeing of adolescents is related to both favorable neurobiological traits and a nurturing environment.

Keywords: emotional and behavior problems; temperament; adolescence; school environment

\section{Relationships between symbolic and non-symbolic number sense undtr control of visual parameters Julia A. Marakshina, Anna O. Tabueva, Yulia V. Kuzmina, Marina M. Lobaskova}

The capacity for symbolic numerosity representation develops on the basis of a pre-existing non-symbolic numerosity representation. Relationships between the symbolic and non-symbolic number sense can be related to the conditions in which the non-symbolic numerosity representation is carried out, in particular, with the load on the assessment of visual parameters. For 1043 pupils in grades 
4-9, a monotonous relationship between non-symbolic and symbolic numerosity representation was demonstrated. In particular, it was demonstrated that this relationship decreases during ontogenetic development for non-symbolic numerosity representation in congruent conditions (facilitated access to visual parameters). One of the explanations for the observed effect can be a decreased role of the non-symbolic number sense in tasks on the symbolic number sense with age.

Keywords: symbolic number sense; non-symbolic number sense; school age

\section{The influence of parents upon adolescents' choice of STEM pathways in the digital age. Conceptual aspects Ekaterina P. Maslennikova, Victoria I. Ismatullina}

Economic growth and social development of society is provided by a sufficient number of high-level specialists in natural science and technical fields or abbreviated as STEM-areas ( $\mathrm{S}$ - science, T - technology, E - engineering, $\mathrm{M}$ - mathematics). Employers' demand for graduates with such qualifications and skills is growing and will continue to grow in future. The problem of gender inequality, which is especially relevant in the framework of the choice of STEM disciplines, manifests itself at all stages of youth socialization and is characterized by a decrease in the motivation of girls to choose professions that are traditionally considered male. The attitudes about the activity corresponding to the child's sex, which are broadcast by the parents, also become the attitudes of the child. The phenomena that influence professional choice are complex and in most cases are caused not by one autonomous cause, but by a set of interrelated causes. The influence of parents on academic choices and professional self-determination has a long-term perspective and plays a causal role in academic choices and STEM careers. Studying the influence of parents on the professional choice and direction of education of schoolchildren is an important scientific problem associated with the processes of building a successful digital economy in the $21^{\text {st }}$ century.

Keywords: STEM-region; the contribution of the parents; the digital technology 


\section{SECTION 6}

\section{Socio-psychological conditions of formation of the subject of teaching teaches of studying defectological faculty}

Nikolay A. Kotelevtsev

The article discusses the socio-psychological conditions for the formation of subjectivity of educational groups on the example of groups of students of the defectology department. A feature of studying the subjectivity of groups in the context of the parametric concept of collective development is revealed, according to L. I. Umansky and A.S. Chernyshev. The definition of the categories "subject" and "subjectivity" is given. The use of technology to build developing social environments (social oases) in educational groups in a higher educational institution, according to the author, contributes to the formation of a higher level of socio-psychological maturity, coherence and cohesion as criteria for the manifestation of subjective qualities. The formation of the study groups of the defectology faculty as subjects of activity, communication and relations takes place through the expansion of options for joint activities, which include groups, which subsequently leads to the convergence of individual and group consciousness, contributes to the development of intra-group communication processes, the formation of a stable favorable psychological climate. The results of a diagnostic study conducted among students of the Faculty of Defectology to study the conditions of the formation of subjectivity of educational groups are presented. The conclusions describe the level of manifest subjective qualities of groups, give a comparative description of the obtained diagnostic data before the inclusion of groups in the developing social environment and the expansion of the fan of joint activity and after.

Keywords: subjectivity; developing social environment; study group; joint activities 


\section{Classes in an inclusive correctional-developing group as a way to develop communication and self-regulation skills in children with disabilities (mental and behavioral disorders) \\ Julia V. Myagkova}

This article reveals the possibilities of helping children with disabilities with mental and behavioral (communicative-affective) disorders in the conditions of a center for additional education in the framework of work in an inclusive group. The content and organization of correctional and psychological assistance to children, the structure and content of group correctional and developmental classes, as well as work with parents are described. The author reveals effective forms and methods of corrective work, in the process of which communication skills and skills of emotional self-regulation are formed.

Keywords: children with disabilities; self-regulation; self-control; communication skills; inclusion; group work

\section{Success of adaptation to university of disabled students as an indicator of psychological welfare Nataliya A. Stepanova}

In the article the problem of adaptation of students with disabilities and disability at the University. It is noted the mutual dependence of adaptation process from a number of subjective characteristics of students in this category and the objective conditions of the organization of psychological and pedagogical support of the process. Social adaptation is considered as an integrative indicator of the state of man, reflecting his ability to perform specific biopsychosocial features. Describes the process of socio-psychological adaptation of students with disabilities, which is defined by four main criteria: cognitive, emotionally-strong-willed, effective and motivational. Cognitive test determines the students' understanding of the purpose of their University education, acquisition of knowledge about how to achieve this goal. Emotional-volitional criterion is characterized by the personal relations of the students to the nature and result of the training, their skills to build interpersonal relationships. Component of the emotional-volitional reflects the attitude of the person as a whole and to individual parties own personality and activities. Effective test determines 
the ability of self-regulation, ability to accept independent decisions, to control their behaviour and to take responsibility for their actions. Motivational adaptation criterion specifies how well the student perceives and evaluates themselves and their social context, aware of the motives of his conduct. Successful social adaptation determines psychological well-being of the individual. Psychological well-being as a multi-level criterion of the psychological state and social status of the individual, as a living entity which has a chaotic nature, which requires support for University students with disabilities.

Keywords: socio-psychological adaptation; criteria for socio-psychological adaptation; students with disabilities; psychological well-being

\section{Growth of hardiness in adolescent}

\section{with intellectual disorders in vocational education organizations}

\section{Ludmila V. Tokarskaya, Maksim N. Cheremnih}

The article discusses the results of the implementation of a psychocorrectional program aimed at developing hardiness in adolescent with mild mental retardation (intellectual disabilities) who are educated in secondary vocational education institutions. Subjects are trained according to adapted programs in separate groups of the institution, where, in addition to them, students who have no limited health abilities are trained. The content of the program included information on hardiness, its components and the significance of this phenomenon for human life, presented in an accessible form for people with intellectual disabilities. Before and after training under the program, a survey was conducted using the questionnaire "Test of hardiness S. Muddy" (adapted by E. N. Osin and E. I. Rasskazova), which demonstrated an increase in the vitality indicators of the subjects. In total, the sample consisted of 13 young men and 14 young women. The study showed the possibility of developing hardiness in this category of people, despite the fact that, as a rule, this phenomenon is not considered in their relation, since education, mental work, and developed emotional intelligence are considered an important factor in hardiness (B. G. Ananyev, D. A. Leontiev et al.). Thus, this work opens up new facets for conducting hardiness studies, primarily in relation to persons with intellectual disabilities.

Keywords: hardiness; intellectual disabilities; mental retardation; adolescent 


\section{Communication harmony of the teaching staff in conditions of inclusive education at a childcare center}

Svetlana G. Shabas

The legislative consolidation of all types of aid for children with disabilities, which is necessary for their healthy development, stipulates the need for implementing joint activities and cooperating with families in the field of bringing-up and education for the teaching staff in the system of preschool education. The parents' attitude to the child's problems and the level of their motivation for the full-scale cooperation with the childcare center is essential for development of the children with special educational needs. This article analyzes the experience of the creation of the system of the communication harmony of the entire teaching staff supported by the positive potential of the family as a basis for the psychological safety of pupils in conditions of inclusive education in childcare center No. 26 MBPEI (Municipal Budgetary Preschool Educational Institution) of Leninsky District, the city of Ekaterinburg. The teachers, specialists and parents' common idea of the reasons, conditions, and ways of correcting problems in the development of the preschooler helps to solve current and future tasks of the individual personal development of each pupil. With the aim of solving the problems of inclusive education, the research presents different types of joint activities of the teaching staff and cooperation with the parents of the children with disabilities, as well as defines the parameters of the psychologically safe environment.

Keywords: communication harmony; inclusive education; childcare center 


\section{АВТОРСКИЙ КОЛЛЕКТИВ}

Аверкиева Елизавета Вячеславовна, магистр психологии, департамент психологии, Уральский гуманитарный институт, Уральский федеральный университет имени первого Президента России Б. Н. Ельцина, Екатеринбург, Россия.

eli.averkieva@gmail.com

Архипова Виктория Александровна, аспирант кафедры теории и социологии управления, Уральский институт управления - филиал Российской академии народного хозяйства и государственной службы при Президенте Российской Федерации, Екатеринбург, Россия. v.arkhipova95@mail.ru

Белякова Евгения Гелиевна, доктор педагогических наук, доцент, профессор кафедры общей и социальной педагогики Института психологии и педагогики, Тюменский государственный университет, Тюмень, Россия. e.g.belyakova@utmn.ru

Берзин Борис Юрьевич, доктор философских наук, профессор, профессор кафедры общей и социальной психологии, Уральский федеральный университет имени первого Президента России Б. Н. Ельцина, Екатеринбург, Россия.

berzinb@yandex.ru

Беркутова Диана Искандеровна, кандидат педагогических наук, доцент, доцент кафедры методик математического и информационно-технологического образования, Ульяновский государственный педагогический университет им. И.Н. Ульянова, Ульяновск, Россия. diana820329@mail.ru

Борисов Георгий Игоревич, старший преподаватель кафедры общей и социальной психологии, Уральский федеральный университет имени первого Президента России Б.Н. Ельцина, Екатеринбург, Россия. georgy.borisov@urfu.ru

Буковей Татьяна Дмитриевна, аспирант, Уральский федеральный университет имени первого Президента России Б. Н. Ельцина, Екатеринбург, Россия.

t.d.bukovey@urfu.ru 
Быстрова Татьяна Юрьевна, доктор философских наук, профессор, профессор кафедры культурологии и дизайна, Уральский федеральный университет имени первого Президента России Б. Н. Ельцина, Екатеринбург, Россия.

taby27@yandex.ru

Васильева Инна Витальевна, доктор психологических наук, доцент, профессор кафедры общей и социальной психологии, Тюменский государственный университет; профессор кафедры философии, иностранных языков и гуманитарной подготовки сотрудников ОВД, Тюменский институт повышения квалификации сотрудников МВД России, Тюмень, Россия.

i.v.vasileva@utmn.ru

Виндекер Ольга Сергеевна, кандидат психологических наук, доцент, доцент кафедры педагогики и психологии образования, Уральский федеральный университет имени первого президента России Б. Н. Ельцина, Екатеринбург, Россия.

o.s.vindeker@urfu.ru

Водопьянова Наталия Евгеньевна, доктор психологических наук, доцент, профессор кафедры психологического обеспечения профессиональной деятельности, Санкт-Петербургский государственный университет, Санкт-Петербург, Россия.

vodop@mail.ru

Волкова Елена Николаевна, доктор психологических наук, профессор, ведущий научный сотрудник Института психологии, Российский государственный педагогический университет им. А. И. Герцена, СанктПетербург, Россия.

envolkova@yandex.ru

Волкова Ирина Владимировна, главный аналитик лаборатории Центра междисциплинарных исследований в сфере наук об образовании, Российская академия образования, Москва, Россия.

atrila@mail.ru

Галочкина Дария Александровна, магистр психологии, Уральский федеральный университет имени первого Президента России Б.Н. Ельцина, Екатеринбург, Россия.

daria_galochkina@mail.ru 
Глуханюк Наталья Степановна, доктор психологических наук, профессор, профессор кафедры управления персоналом и психологии, Уральский федеральный университет имени первого Президента России Б.Н. Ельцина, Екатеринбург, Россия. profi.n@mail.ru

Горшкова Татьяна Анатольевна, кандидат педагогических наук, доцент, доцент кафедры методик математического и информационно-технологического образования, Ульяновский государственный педагогический университет им. И.Н. Ульянова, Ульяновск, Россия. uln75@mail.ru

Гречухина Татьяна Ивановна, кандидат педагогических наук, доцент, доцент кафедры педагогики и психологии образования, Уральский федеральный университет имени первого Президента России Б.Н. Ельцина, Екатеринбург, Россия. grechuhinati@yandex.ru

Громова Екатерина Михайловна, кандидат педагогических наук, доцент, доцент кафедры методик математического и информационно-технологического образования, Ульяновский государственный педагогический университет им. И.Н. Ульянова, Ульяновск, Россия. gromova_ek@mail.ru

Даниленко Ольга Ивановна, доктор культурологии, доцент, профессор кафедры общей психологии факультета психологии, Санкт-Петербургский государственный университет, Санкт-Петербург, Россия. danilenko.olga@gmail.com

Дудина Маргарита Николаевна, доктор педагогических наук, профессор, профессор кафедры педагогики и психологии образования, Уральский федеральный университет имени первого Президента России Б.Н. Ельцина, Екатеринбург, Россия.

mndudina@yandex.ru

Духновский Сергей Витальевич, доктор психологических наук, профессор Гуманитарного института североведения, Югорский государственный университет, Ханты-Мансийск, Россия. dukhnovskysv@mail.ru

Зеер Эвальд Фридрихович, доктор психологических наук, профессор, профессор кафедры психологии образования и профессионального 
развития, Российский государственный профессионально-педагогический университет, Екатеринбург, Россия.

zeer.ewald@yandex.ru

Зиннатова Мария Владимировна, кандидат психологических наук, доцент, доцент кафедры педагогики и психологии образования, Уральский федеральный университет имени первого Президента России Б. Н. Ельцина, Екатеринбург, Россия.

mashaperv@rambler.ru

Зотова Ольга Юрьевна, доктор психологических наук, доцент, профессор кафедры общей и прикладной психологии, Гуманитарный университет, Екатеринбург, Россия.

oiambusheva@mail.ru

Иванова Ирина Викторовна, кандидат психологических наук, доцент, доцент кафедры социальной адаптации и организации работы с молодежью, Калужский государственный университет им. К. Э. Циолковского, Калуга, Россия.

IvanovaDIV@yandex.ru

Измайлова Юлия Сергеевна, педагог-психолог ГБОУ СОШ 57, Севастополь, Россия. izmaylova_62_94@mail.ru

Исматуллина Виктория Игоревна, кандидат психологических наук, ведущий научный сотрудник лаборатории возрастной психогенетики, Психологического института Российской академии образования, Москва, Россия.

ismatullina.v@pirao.ru

Карапетян Лариса Владимировна, доктор психологических наук, доцент, доцент кафедры общей и социальной психологии, Уральский федеральный университет имени первого Президента России Б. Н. Ельцина, Екатеринбург, Россия.

karapetyanl@mail.ru

Кисляков Павел Александрович, доктор психологических наук, доцент, заведующий кафедрой психологии труда и специальной психологии, Российский государственный социальный университет, Москва, Россия. pack.81@mail.ru

Клименских Марина Владимировна, кандидат педагогических наук, доцент, доцент кафедры педагогики и психологии образования, Ураль- 
ский федеральный университет имени первого Президента России Б.Н. Ельцина, Екатеринбург, Россия.

marina.klimenskikh@mail.ru

Ковалев Артем Иванович, кандидат психологических наук, доцент факультета психологии, Московский государственный университет имени М. В. Ломоносова, Москва, Россия.

artem.kovalev.msu@mail.ru

Коротаева Евгения Владиславовна, доктор педагогических наук, профессор, Уральский государственный педагогический университет, Екатеринбург, Россия.

e.v.korotaeva@yandex.ru

Костромина Светлана Николаевна, доктор психологических наук, профессор, заведующий кафедрой психологии личности, Санкт-Петербургский государственный университет, Санкт-Петербург, Россия. s.kostromina@spbu.ru

Котелевцев Николай Александрович, кандидат психологических наук, доцент кафедры специальной психологии и коррекционной педагогики, Курский государственный университет, Курск, Россия. apv-78@yandex.ru

Круглова Марина Анатольевна, кандидат психологических наук, доцент, доцент кафедры эргономики и инженерной психологии, Санкт-Петербургский государственный университет, Санкт-Петербург, Россия. marakruglova@mail.ru

Кузьмина Юлия Владимировна, кандидат психологических наук, научный сотрудник лаборатории возрастной психогенетики, Психологический институт Российской академии образования, Москва, Россия. papushka7@gmail.com

Лебедева Юлия Владимировна, кандидат психологических наук, доцент, доцент кафедры педагогики и психологии образования, Уральский федеральный университет имени первого Президента России Б.Н. Ельцина, Екатеринбург, Россия.

ljulia1@rambler.ru

Леднева Татьяна Сергеевна, магистрант факультета психологии, Московский государственный университет имени М. В. Ломоносова, Москва, Россия.

t.kozak@mail.ru 
Липатова Светлана Дмитриевна, кандидат педагогических наук, доцент кафедры управления персоналом и психологии, Уральский федеральный университет имени первого Президента России Б. Н. Ельцина, Екатеринбург, Россия.

LipatovaSD@mail.ru

Лобаскова Марина Михайловна, кандидат психологических наук, старший научный сотрудник лаборатории возрастной психогенетики, Психологический институт Российской академии образования, главный аналитик Российской академии образования, Москва, Россия. lobaskovamm@gmail.com

Мазурчук Екатерина Олеговна, кандидат психологических наук, старший преподаватель кафедры психологии образования, Уральский государственный педагогический университет, Екатеринбург, Россия.

MazurchukE@yandex.ru

Мазурчук Нина Ивановна, кандидат педагогических наук, доцент, доцент кафедры педагогики, Уральский государственный педагогический университет, Екатеринбург, Россия.

Mazurchuk-nina@rambler.ru

Мальцев Алексей Владимирович, кандидат биологических наук, доцент, доцент кафедры общей и социальной психологии, Уральский федеральный университет имени первого Президента России Б. Н. Ельцина, Екатеринбург, Россия.

A.V.Maltsev@urfu.ru

Маракшина Юлия Александровна, кандидат психологических наук, научный сотрудник лаборатории возрастной психогенетики, Психологический институт Российской академии образования, Москва, Россия. retalika@yandex.ru

Масленникова Екатерина Павловна, ведущий аналитик лаборатории нейростимуляции Центра междисциплинарных исследований в сфере наук об образовании, Российская академия образования, Москва, Россия. bayan-sulu@mail.ru

Муслумов Рустам Рафикович, кандидат психологических наук, доцент, доцент кафедры педагогики и психологии образования, Уральский федеральный университет имени первого Президента России Б. Н. Ельцина, Екатеринбург, Россия.

mrr82@yandex.ru 
Мягкова Юлия Владимировна, кандидат психологических наук, педагогпсихолог, Муниципальное автономное учреждение дополнительного образования «Центр “Семья и школа”», Екатеринбург, Россия. yulla-11@yandex.ru

Пермякова Маргарита Евгеньевна, кандидат психологических наук, доцент, доцент кафедры общей и социальной психологии, Уральский федеральный университет имени первого Президента России Б.Н. Ельцина, Екатеринбург, Россия. pme8@mail.ru

Печеркина Анна Александровна, кандидат психологических наук, доцент, заведующий кафедрой педагогики и психологии образования, Уральский федеральный университет имени первого Президента России Б. Н. Ельцина, Екатеринбург, Россия.

a. a.pecherkina@urfu.ru

Поварёнков Юрий Павлович, доктор психологических наук, профессор, профессор кафедры общей и социальной психологии, Ярославский государственный педагогический университет им. К. Д. Ушинского Ярославль, Россия.

y.povarenkov@yspu.org

Полякова Ольга Борисовна, кандидат психологических наук, доцент, доцент кафедры социальной, общей и клинической психологии, Российский государственный социальный университет; доцент кафедры педагогики и психологии, Открытый гуманитарно-экономический университет, Москва, Россия.

pob-70@mail.ru

Реан Артур Александрович, доктор психологических наук, профессор, академик Российской академии образования, заведующий лабораторией профилактики асоциального поведения Института образования, Национальный исследовательский университет «Высшая школа экономики», Москва, Россия.

arean@hse.ru

Савельев Владимир Вадимович, старший преподаватель кафедры клинической психологии и психофизиологии, Уральский федеральный университет имени первого Президента России Б. Н. Ельцина, Екатеринбург, Россия.

bbsav91@gmail.com 
Степанова Наталия Анатольевна, кандидат психологических наук, доцент, декан факультета психологии, Тульский государственный педагогический университет имени Л. Н. Толстого, Тула, Россия.

Stepanova_na@inbox.ru

Столярчук Елена Анатольевна, старший преподаватель кафедры психологического обеспечения профессиональной деятельности, Санкт-Петербургский государственный университет, Санкт-Петербург, Россия. estol@yandex.ru

Сыманюк Эльвира Эвальдовна, доктор психологических наук, профессор, заведующий кафедрой общей и социальной психологии, Уральский федеральный университет имени первого Президента России Б. Н. Ельцина, Екатеринбург, Россия.

e.e.symaniuk@urfu.ru

Табуева Анна Олеговна, младший научный сотрудник лаборатории возрастной психогенетики, Психологический институт Российской академии образования, Москва, Россия.

anntabueva@gmail.com

Тарасова Людмила Владимировна, кандидат психологических наук, доцент, доцент кафедры общей и прикладной психологии, Гуманитарный университет, Екатеринбург, Россия.

tarasovagu@mail.ru

Токарская Людмила Валерьевна, кандидат психологических наук, доцент, Уральский федеральный университет имени первого Президента России Б. Н. Ельцина, Екатеринбург, Россия.

liydmil@mail.ru

Томина Надежда Анатольевна, старший преподаватель кафедры клинической психологии и психофизиологии, Уральский федеральный университет имени первого Президента России Б. Н. Ельцина, Екатеринбург, Россия.

nadtoma@gmail.com

Усачева Алена Вячеславовна, кандидат исторических наук, доцент кафедры педагогики и психологии образования, Уральский федеральный университет имени первого Президента России Б.Н. Ельцина, Екатеринбург, Россия.

alenausacheva@mail.ru 
Фофанова Галина Александровна, кандидат психологических наук, доцент, доцент кафедры психологии, Белорусский государственный университет, Минск, Беларусь.

rugfofanova@gmail.com

Хохолева Евгения Аркадьевна, старший преподаватель кафедры управления персоналом и психологии, Уральский федеральный университет имени первого Президента России Б.Н. Ельцина, Екатеринбург, Россия. e.a.hoholeva@urfu

Церковникова Наталья Геннадьевна, кандидат психологических наук, доцент кафедры профессиональной педагогики и психологии, Российский государственный профессионально-педагогический университет, Екатеринбург, Россия.

ppp_ts@mail.ru

Черемных Максим Николаевич, психолог, МБУ «Центр социально-психологической помощи детям и молодежи “Форпост”», Екатеринбург, Россия.

22626max@gmail.com

Чумаков Михаил Владиславович, доктор психологических наук, доцент, заведующий кафедрой психологии, Курганский государственный университет, профессор кафедры общей и социальной психологии, Уральский федеральный университет имени первого Президента России Б.Н. Ельцина, Курган, Россия. mihailchv@mail.ru

Шабас Светлана Георгиевна, кандидат психологических наук, доцент факультета социальной психологии, Гуманитарный университет, Екатеринбург, Россия.

shabassv@rambler.ru

Шаньгина Елена Петровна, педагог-психолог, Муниципальное автономное общеобразовательное учреждение «Средняя общеобразовательная школа № 200 с углубленным изучением отдельных предметов», Екатеринбург, Россия.

elena_shangina@list.ru

Шмелева Елена Александровна, доктор психологических наук, доцент, профессор кафедры психологии и социальной педагогики, Ивановский государственный университет; профессор кафедры иностранных 
языков и профессиональных коммуникаций, Ивановская пожарноспасательная академия ГПС МЧС России, Иваново, Россия. noc_shmeleva@mail.ru

Юртаева Марина Николаевна, кандидат психологических наук, доцент кафедры управления персоналом и психологии, Уральский федеральный университет имени первого Президента России Б. Н. Ельцина, Екатеринбург, Россия. myurtaeva_82@mail.ru 


\section{CONTRIBUTORS}

Arkhipova Viktoriya Aleksandrovna, Postgraduate Student of the Department of Theory and Sociology of Management, Ural Institute of Management branch of the Russian Academy of National Economy and Public Administration under the President of the Russian Federation, Yekaterinburg, Russia. v.arkhipova95@mail.ru

Averkieva Elizaveta Vyacheslavovna, Master of Psychology, Ural Institute for Humanities, Ural Federal University named after the first President of Russia B. N. Yeltsin, Yekaterinburg, Russia.

eli.averkieva@gmail.com

Belyakova Evgeniya Gelievna, Doctor of Pedagogy, Associate Professor, Professor of the Department of General and Social Pedagogy, Institute of Psychology and Pedagogy, University of Tyumen, Tyumen, Russia.

e.g.belyakova@utmn.ru

Berkutova Diana Iskanderovna, Candidate of Pedagogical Sciences, Associate Professor, Associate Professor of the Department of Mathematical Methods and Technological Education, Ulyanovsk State Pedagogical University named after I. N. Ulyanov, Ulyanovsk, Russia. diana820329@mail.ru

Berzin Boris Yurievich, Doctor of Philosophy Sciences, Professor, Professor of the Department of General and Social Psychology, Ural Federal University named after the first President of Russia B. N. Yeltsin, Yekaterinburg, Russia. berzinb@yandex.ru

Borisov Georgy Igorevich, Senior Lecturer at the Department of General and Social Psychology, Ural Federal University named after the first President of Russia B. N. Yeltsin, Yekaterinburg, Russia. georgy.borisov@urfu.ru

Bukovey Tatiana Dmitrievna, Postgraduate Student, Ural Federal University named after the first President of Russia B. N. Yeltsin, Yekaterinburg, Russia. t.d.bukovey@urfu.ru 
Bystrova Tatiana Yurievna, Doctor of Philosophy, Professor, Professor of the Department of Cultural Studies and Design, Ural Federal University named after First President of Russia B. N. Yeltsin, Ekaterinburg, Russia. taby27@yandex.ru

Cheremnih Maksim Nikolaevich, Psychologist, Center for Social and Psychological Assistance to Children and Youth "Forpost", Yekaterinburg, Russia. 22626max@gmail.com

Chumakov Mikhail Vladislavovich, Doctor of Psychological Sciences, Associate Professor, Head of the Department of Psychology, Kurgan State University; Professor of the Department of General and Social Psychology, Ural Federal University named after the first President of Russia B. N. Yeltsin, Kurgan, Russia.

mihailchv@mail.ru

Danilenko Olga Ivanovna, PhD in Culturology, Associate Professor, ProfessorDepartment of General Psychology, Faculty of Psychology, Saint Petersburg State University, St. Petersburg, Russia.

danilenko.olga@gmail.com

Dudina Margarita Nikolaevna, Doctor of Pedagogical Sciences, Professor of the Department of Pedagogy and Educational Psychology at The faculty of Psychology, Ural Federal University named after the first President of Russia B. N. Yeltsin, Yekaterinburg, Russia.

mndudina@yandex.ru

Dukhnovsky Sergey Vitalyevich, Doctor of Psychological Sciences, Professor of Institute of Humanities (Northern studies) Yugra State University, Khanty-Mansiysk, Russia.

dukhnovskysv@mail.ru

Fofanova Galina Alexandrovna, Candidate of Psychological Sciences, Associate Professor, Associate Professor of the Department of Psychology, Belarusian State University, Minsk, Belarus.

gfofanova@gmail.com

Galochkina Dariya Alexandrovna, Master of Psychology, Ural Federal University named after First President of Russia B. N. Yeltsin, Ekaterinburg, Russia. daria_galochkina@mail.ru

Glukhanyuk Natalya Stepanovna, Doctor of Psychological Sciences, Professor, Professor of the Department of Human Resource Management and 
Psychology, Ural Federal University named after the first President of Russia B. N. Yeltsin, Yekaterinburg, Russia.

profi.n@mail.ru

Gorshkova Tatyana Anatolievna, Candidate of Pedagogical Sciences, Associate Professor, Associate Professor of the Department of Mathematical Methods and Technological Education, Ulyanovsk State Pedagogical University named after I. N. Ulyanov, Ulyanovsk, Russia. uln75@mail.ru

Grechuhina Tatiana Ivanovna, Candidate of Pedagogic Sciences, Associate Professor of Pedagogy and Psychology of Education, Ural Federal University named after the first President of Russia B. N. Yeltsin, Yekaterinburg, Russia. grechuhinati@yandex.ru

Gromova Ekaterina Mikhailovna, Candidate of Pedagogical Sciences, Associate Professor, Associate Professor of the Department of Mathematical Methods and Technological Education, Ulyanovsk State Pedagogical University named after I. N. Ulyanov, Ulyanovsk, Russia. gromova_ek@mail.ru

Iurtaeva Marina Nikolayevna, Candidate of Psychological Sciences, Associate Professor of the Department of Human Resource Management, Ural Federal University named after the first President of Russia B. N. Yeltsin, Yekaterinburg, Russia.

myurtaeva_82@mail.ru

Ivanova Irina Viktorovna, Candidate of Psychological Sciences, Associate Professor, Associate Professor, Department of Social Adaptation and Organization of Work with Youth, Tsiolkovskiy Kaluga State University, Kaluga, Russia. IvanovaDIV@yandex.ru

Ismatullina Victoria Igorevna, $\mathrm{PhD}$, Leading Researcher, Laboratory of Developmental Genetics FSBSI "Psychological Institute" of the Russian Academy of Education, Moscow, Russia. ismatullina.v@pirao.ru

Izmailova Julia Sergeevna, Educational Psychologist of State Budgetary Educational Institution - Secondary School, Sevastopol, Russia. izmaylova_62_94@mail.ru

Karapetyan Larisa Vladimirovna, Doctor of Psychological Sciences, Associate Professor, Associate Professor of General and Social Psychology, Ural 
Federal University named after the first President of Russia B. N. Yeltsin, Yekaterinburg, Russia.

karapetyanl@mail.ru

Khokholeva Evgeniya Arkad'evna, Senior Lecturer of the Department of Personnel Management and Psychology, Ural Federal University named after the first President of Russia B. N. Yeltsin, Yekaterinburg, Russia.

e.a.hoholeva@urfu.ru

Kislyakov Pavel Aleksandrovich, Doctor of Psychological Sciences, Associate Professor, Head of the Department of Labor Psychology and Special Psychology, Russian State Social University, Moscow, Russia. pack.81@mail.ru

Klimenskikh Marina Vladimirovna, Candidate of Pedagogic Sciences, Associate Professor, Department of Psychology, Ural Federal University, Yekaterinburg, Russia.

marina.klimenskikh@mail.ru

Korotaeva Evgeniya Vladislavovna, Candidate of Pedagogic Sciences, Professor, Ural State Pedagogical University, Yekaterinburg, Russia.

e.v.korotaeva@yandex.ru

Kostromina Svetlana Nikolayevna, Doctor of Psychological Sciences, Professor, Head of the Department of Personality Psychology, Saint-Petersburg State University, Saint-Petersburg, Russia.

s.kostromina@spbu.ru

Kotelevtsev Nikolay Alexandrovich, Candidate of Psychological Sciences, Associate Professor, Department of Special Psychology and Correctional Pedagogy, Kursk State University, Kursk, Russia.

apv-78@yandex.ru

Kovalev Artem Ivanovich, Candidate of Psychological Sciences, Associate Professor, Department of Psychology, Lomonosov Moscow State University, Moscow, Russia.

artem.kovalev.msu@mail.ru

Kruglova Marina Anatolievna, Associate Professor at the Department of Ergonomics and Engineering Psychology, Saint Petersburg State University, Saint-Petersburg, Russia.

marakruglova@mail.ru 
Kuzmina Yulia Vladimirovna, PhD, Research Associate of the Laboratory of Developmental Behavioural Genetics of Psychological Institute of Russian Academy of Education, Moscow, Russia. papushka7@gmail.com

Lebedeva Julia Vladimirovna, Candidate of Psychological Sciences, Associate Professor, Department of Psychology, Ural Federal University named after the first President of Russia B. N. Yeltsin, Yekaterinburg, Russia. ljulia1@rambler.ru

Ledneva Tatyana Sergeevna, Master of Psychology, Department of Psychology, Lomonosov Moscow State University, Moscow, Russia. t.kozak@mail.ru

Lipatova Svetlana Dmitrievna, Candidate of Pedagogic Sciences, Associate Professor of the Department of Personnel Management and Psychology, Ural Federal University named after the first President of Russia B. N. Yeltsin, Yekaterinburg, Yekaterinburg, Russia.

LipatovaSD@mail.ru

Lobaskova Marina Mikhailovna, PhD, Senior Researcher of the Laboratory of Developmental Behavioural Genetics of Psychological Institute of Russian Academy of Education, Chief analyst of the Russian Academy of education, Moscow, Russia.

lobaskovamm@gmail.com

Maltsev Alexey Vladimirovich, Candidate of Biological Sciences, Associate Professor of the Department of Psychology, Ural Federal University named after the first President of Russia B. N. Yeltsin, Yekaterinburg, Russia. A.V.Maltsev@urfu.ru

Marakshina Julia Alexandrovna, PhD, Research Associate of the Laboratory of Developmental Behavioural Genetics of Psychological Institute of Russian Academy of Education, Moscow, Russia. retalika@yandex.ru

Maslennikova Ekaterina Pavlovna, Leading Analyst, Neurostimulation Laboratory, Center for Interdisciplinary Research in Educational Sciences "Russian Academy of Education", Moscow, Russia.

bayan-sulu@mail.ru 
Mazurchuk Ekaterina Olegovna, Candidate of Psychological Sciences, Chief Lecturer of the Department of Educational Psychology, Ural State Pedagogic University, Yekaterinburg, Russia.

MazurchukE@yandex.ru

Mazurchuk Nina Ivanovna, Candidate of Pedagogical Sciences, Associate Professor, Associate Professor of the Department Pedagogy, Ural State Pedagogical University, Yekaterinburg, Russia.

Mazurchuk-nina@rambler.ru

Muslumov Rustam Rafikovich, Candidate of Psychological Sciences, Associate Professor of Department of Pedagogy and Psychology of Education, Ural Federal University named after the first President of Russia B. N. Yeltsin, Yekaterinburg, Russia.

mrr82@yandex.ru

Myagkova Julia Vladimirovna, Candidate of Psychological Sciences, Psychologist, Municipal Autonomous Institution of Continuing Education Center "Family and School", Yekaterinburg, Russia.

yulla-11@yandex.ru

Pecherkina Anna Aleksandrovna, Candidate of Psychological Sciences, Associate Professor, Head of the Department of Pedagogy and Psychology of Education, Ural Federal University named after the first President of Russia B. N. Yeltsin.

a.a.pecherkina@urfu.ru

Permyakova Margarita Evgen'evna, Candidate of Psychological Sciences, Associate Professor, Associate Professor of the Department General and Social Psychology, Ural Federal University named after First President of Russia B. N. Yeltsin, Ekaterinburg, Russia.

pme8@mail.ru

Polyakova Olga Borisovna, Candidate of Psychological Sciences, Associate Professor, Associate Professor of Department of Social, General and Clinical Psychology, Russian State Social University; Associate Professor of Department of Pedagogy and Psychology, Open University of Humanities and Economics, Moscow, Russia.

pob-70@mail.ru 
Povaryonkov Yuri Pavlovich, Doctor of Psychological Sciences, Professor, Professor of the Department of General and Social Psychology, Yaroslavl State Pedagogical University named after K. D. Ushinsky, Yaroslavl, Russia. y.povarenkov@yspu.org

Rean Artur Aleksandrovich, Doctor of Psychological Sciences, Professor, Academician of the Russian Academy of Education, Head of Laboratory of Prevention of Antisocial Behaviour of HSE, Moscow, Russia. arean@hse.ru

Savelev Vladimir Vadimovich, Senior Lecturer of the Department of Psychology, Ural Federal University named after the first President of Russia B. N. Yeltsin, Yekaterinburg, Russia. bbsav91@gmail.com

Shabas Svetlana Georgievna, Candidate of Psychological Sciences, Associate Professor of the Social Psychology Department, University of the Humanities, Yekaterinburg, Russia.

shabassv@rambler.ru

Shangina Elena Petrovna, School Psychologist, Municipal Autonomous Educational Institution Secondary School № 200 with Profound Studying of Some Subjects, Yekaterinburg, Russia.

elena_shangina@list.ru

Shmeleva Elena Aleksandrovna, Doctor of Psychological Sciences, Associate Professor, Professor of the Department of Psychology and и Social Pedagogy, Ivanovo State University; Professor of the Department of Foreign Languages and Professional Communications, IFRA of SFS of EMERCOM of Russia, Ivanovo, Russia.

noc_shmeleva@mail.ru

Stepanova Nataliya Anatolievna, Candidate of Psychological Sciences, Associate Professor, Tula State Lev Tolstoy Pedagogical University, Dean of the Department of Psychology, Tula, Russia.

Stepanova_na@inbox.ru

Stolyarchuk Elena Anatolievna, Senior Teacher, Department of Psychological Support of Professional Activity, Saint Petersburg State University, Saint Petersburg, Russia. estol@yandex.ru 
Symanyuk Elvira Evaldovna, Doctor of Psychological Sciences, Professor, Head of the Department of General and Social Psychology, Ural Federal University named after the first President of Russia B. N. Yeltsin, Yekaterinburg, Russia. e.e.symaniuk@urfu.ru

Tarasova Lyudmila Vladimirovna, Candidate of Psychological Sciences, Associate Professor, Associate Professor at General and Applied Psychology Chair, Liberal Arts University - University for Humanities, Yekaterinburg, Russia. tarasovagu@mail.ru

Tabueva Anna Olegovna, Junior Researcher of the Laboratory of Developmental Behavioural Genetics of Psychological Institute of Russian Academy of Education, Moscow, Russia.

anntabueva@gmail.com

Tokarskaya Ludmila Valerievna, Candidate of Psychological Sciences, Associate Professor of Psychological Department, Ural Federal University named after the first President of Russia B. N. Yeltsin, Yekaterinburg, Russia. liydmil@mail.ru

Tomina Nadezhda Anatolyevna, Senior Lecturer of the Department of Clinical Psychology and Psychophysiology, Ural Federal University named after the first President of Russia B. N. Yeltsin, Yekaterinburg, Russia. nadtoma@gmail.com

Tserkovnikova Natalya Gennadyevna, Candidate of Psychological Sciences, Associate Professor of the Department of Psychology and Physiology, Russian State Vocational Pedagogical University, Yekaterinburg, Russia.

ppp_ts@mail.ru

Usacheva Alena Vyacheslavovna, Candidate of Historical Sciences, Associate Professor of Pedagogy and Psychology of Education, Ural Federal University named after the first President of Russia B. N. Yeltsin, Yekaterinburg, Russia. alenausacheva@mail.ru

Vasileva Inna Vitalievna, Doctor of Psychological Sciences, Associate Professor, Professor of the Department of General and Social Psychology, Professor of the Department of Philosophy, Foreign Languages and Humanity Training of Law Enforcement Officers, Tyumen, Russia.

i.v.vasileva@utmn.ru

Vindeker Olga Sergeevna, Candidate of Psychological Science, Associate Professor, Department of Pedagogy and Educational Psychology, Ural Federal 
University named after the First President of Russia B. N. Yeltsin, Yekaterinburg, Russia.

o.s.vindeker@urfu.ru

Vodopyanova Nataliya Yevgenyevna, Doctor of Psychological Sciences, Associate Professor, Department of Psychological Support for Professional Activities, Saint Petersburg State University, Saint-Petersburg, Russia. vodop@mail.ru

Volkova Elena Nikolayevna, Doctor of Psychological Sciences, Professor, Leading Researcher of Institute of Psychology of the Herzen State Pedagogical University of Russia, Saint Petersburg, Russia.

envolkova@yandex.ru

Volkova Irina Vladimirovna, Senior Analyst of the Center for Interdisciplinary Research in Education of Russian Academy of Education, Moscow, Russia. atrila@mail.ru

Zeer Evald Fridrihovich, Doctor of Psychological Sciences, Professor, Professor of the Department of Psychology of Education and Professional Development, Russian State Vocational Pedagogical University, Yekaterinburg, Russia. zeer.ewald@yandex.ru

Zinnatova Mariya Vladimirovna, Candidate of Psychological Sciences, Associate Professor, Associate Professor of the Department of Pedagogy and Psychology of Education, Ural Federal University named after the first President of Russia B. N. Yeltsin, Yekaterinburg, Russia. mashaperv@rambler.ru

Zotova Olga Yurievna, Doctor of Psychological Sciences, Associate Professor, Professor of the Department of General and Applied Psychology, Liberal Arts University - University for Humanities, Yekaterinburg, Russia. oiambusheva@mail.ru 


\section{СОДЕРЖАНИЕ}

Предисловие (А. А. Печеркина)

Раздел 1

\section{МЕТОДОЛОГИЧЕСКИЕ АСПЕКТЫ ПСИХОЛОГИИ ОБРАЗОВАНИЯ}

Развитие самосознания и формирование социально зрелой личности как проблема психологии образования

(Б. Ю. Берзин, В.А. Архипова)

Непрерывное образование: возрастной аспект проявлений «Я»

(самооценка, самоотношение, самоактуализация)

(Н. С. Глуханюк, М. Н. Юртаева)

Психологические характеристики транспрофессиональных

компетенций специалистов (на примере магистрантов -

представителей социономических и технономических групп

профессий) (Э. Ф. Зеер, М. В. Зиннатова, Т. Д. Буковей).

Постнеклассическая парадигма в образовании: возможности

и ограничения (Л. В. Карапетян)

Онлайн-формат и традиционное обучение: сравнительный анализ психологических предикторов успешности студентов (М. В. Клименских, Ю. В. Лебедева, А. В. Мальцев, В. В. Савельев).......76

Подходы к трактовке психолого-педагогических взаимодействий:

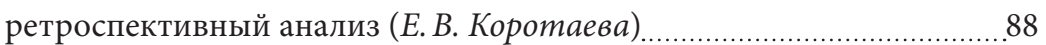

Аксиология цифрового образования:

назад в будущее? (С. Н. Костромина) ...................................................... 98

Навигационные характеристики

цифровых текстов как фактор успешного информационного

поиска обучающихся (Т. С. Леднева, А. И. Ковалев).

Психологические механизмы развития

правового самосознания личности:

теоретико-методологические аспекты (Р. Р. Муслумов) 


\section{Раздел 2 \\ ПСИХОЛОГИЧЕСКОЕ БЛАГОПОЛУЧИЕ \\ СУБЪЕКТОВ ОБРАЗОВАНИЯ}

Подходы к изучению психологического благополучия (Г. И. Борисов)...157 Психологическое благополучие студентов с позиции субъектно-

ресурсного подхода (на примере студентов-психологов)

(Н.Е. Водопьянова)

Субъектность как предиктор психологического благополучия

одаренных подростков (Е.Н. Волкова, И. В. Волкова).

Здоровый образ жизни и жизнестойкость современных студентов

(Д. А. Галочкина, М. Е. Пермякова).

Вузовский этикет и этикетное поведение в вузе: современная

ситуация и перспективы изучения (О. И. Даниленко).

Конструктивное отношение к себе как профессионалу

и благополучие личности (С. В. Духновский)

Личностные факторы адаптации студентов к новой

социокультурной среде (Е. А. Столярчук, М. А. Круглова) 258

Психологическое благополучие студентов Беларуси (Г.А. Фофанова)...277 Активная жизненная позиция как фактор психологического благополучия студентов (Е.А. Хохолева, С. Д. Липатова) 294

Проблема профессиональной идентичности студентов-психологов

в современном вузе (М. В. Чумаков, И. В. Васильева). 307

Исследование толерантности к неопределенности у юношей

и девушек старшего подросткового возраста в связи с их личностными особенностями (Е. П. Шаньгина, О. С. Виндекер).

Раздел 3

\section{ПСИХОЛОГИЯ ПРОФЕССИОНАЛЬНОГО РАЗВИТИЯ ПЕДАГОГА}

Методика профессионально-ориентированного

автобиографирования как средство сопровождения

профессионального самоопределения студентов -

будущих педагогов (Е. Г. Белякова). 
Развитие рефлексивной компетентности

педагога общеобразовательного учреждения

(Т. И. Гречухина, А. В. Усачева) 356

Проектирование карьерной стратегии современных

педагогов в условиях цифровизации (Е. М. Громова,

Д. И. Беркутова, Т.А. Горшкова).

Профессионализм педагога. Теория поколений:

кому у кого учиться? (М. Н. Дудина).

Структурно-уровневая периодизация профессионального

становления личности (Ю. П. Поварёнков).

Особенности саморазвития педагогов и психологов

с профессиональными деформациями (О. Б. Полякова).

Социально-психологические аспекты развития кризиса утраты

профессиональной деятельности у педагогов в период поздней

зрелости (Э. Э. Сыманюк, А. А. Печеркина, Т. Д. Буковей)

Раздел 4

\section{ПРОБЛЕМЫ ПСИХОЛОГИЧЕСКОЙ БЕЗОПАСНОСТИ ОБРАЗОВАТЕЛЬНОЙ СРЕДЫ}

Психологические особенности влияния кибербуллинга на молодежь

(Е. В. Аверкиева)

Малый город как пространство образования: психологические аспекты (Т. Ю. Быстрова). 468

Проблема подросткового буллинга: актуальные направления

современных исследований и организация помощи

(Е. Н. Волкова, А. А. Реан, И. В. Волкова)

Просоциальное поведение и психологическое благополучие

учащейся молодежи (П.А. Кисляков, Е. А. Шмелева). 491

Наружная реклама как фактор искажения реального образа города

в представлении молодежи (Е. О. Мазурчук, Н. И. Мазурчук). 508 Жестокое обращение с детьми: понятие, последствия и направления профилактики (Н.А. Томина, Н. Г. Церковникова) 520 


\section{Раздел 5 \\ МЕЖДИСЦИПЛИНАРНЫЕ ИССЛЕДОВАНИЯ СОВРЕМЕННОГО ДЕТСТВА}

Трансформация представлений о школе у учащихся на разных

этапах школьного курса обучения (О. Ю. Зотова, Л. В. Тарасова)....538

Выбор как фактор саморазвития личности (И. В. Иванова)

Эмоционально-поведенческие проблемы подростков, обучающихся

в различных образовательных средах (М. М. Лобаскова,

Ю. С. Измайлова).

Связь символической и несимволической оценки количества

в условиях контроля визуальных параметров (Ю. А. Маракшина,

А. О. Табуева, Ю. В. Кузвмина, М. М. Лобаскова)

Влияние семьи на самоопределение современных учащихся

при выборе STEM-профессии в цифровую эпоху: концептуальные

аспекты (Е. П. Масленникова, В. И. Исматуллина) 600

\section{Раздел 6 \\ ПСИХОЛОГИЧЕСКИЕ АСПЕКТЫ РЕАЛИЗАЦИИ ИНКЛЮЗИВНОГО ОБРАЗОВАНИЯ}

Социально-психологические условия становления субъектности учебных групп (на примере дефектологического факультета) (Н.А. Котелевцев) 606

Занятия в инклюзивной коррекционно-развивающей группе как способ развития коммуникативных навыков и навыков саморегуляции у детей с ограниченными возможностями здоровья (ментальные и поведенческие нарушения) (Ю. В. Мягкова). 624

Модель психолого-педагогического сопровождения студентовинвалидов в период их адаптации к обучению в вузе (Н.А. Степанова) 641

Развитие жизнестойкости у юношей и девушек с интеллектуальными нарушениями в организациях профессионального образования (Л.В. Токарская, М. Н. Черемных). 
Коммуникативное единство педагогического коллектива в условиях инклюзивного образования в детском саду (С. Г. Шабас)

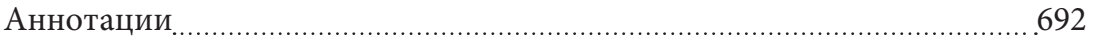

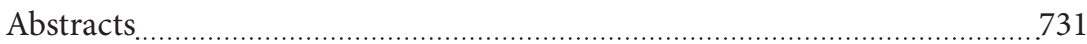

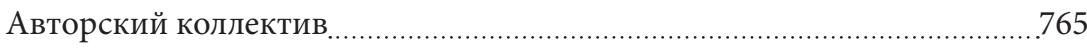

Contributors 


\section{ПСИХОЛОГИЯ ОБРАЗОВАНИЯ: СОВРЕМЕННЫЙ ВЕКТОР РАЗВИТИЯ}

Редактор H. B. Чапаева

Корректор Н. В. Чапаева

Компьютерная верстка В. К. Матвеев 


\section{Электронное сетевое издание размещено в архиве УрФу http://elar.urfu.ru}

Подписано 17.11.2020. Формат $60 \times 841 / 16$. Уч.-изд. л. 40,3. Объем данных 7,04 Мб.

Гарнитура Minion Pro, Myriad Pro.

Издательство Уральского университета 620000 , Екатеринбург-83, ул. Тургенева, 4

Тел.: +7 (343) 358-93-06, 350-90-13, 358-93-22, 350-58-20

Факс: +7 (343) 358-93-06

E-mail: press-urfu@mail.ru

http://print.urfu.ru 


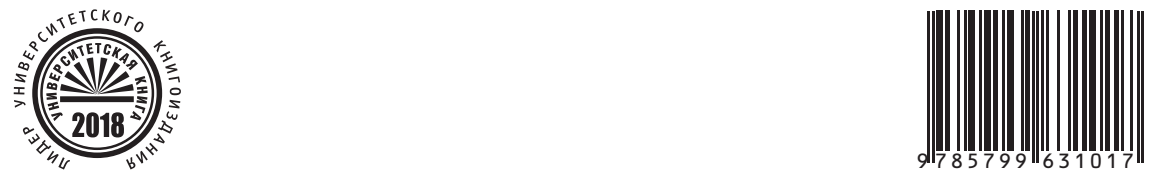